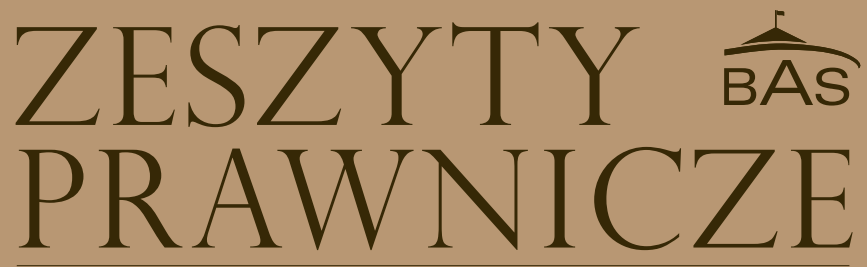

Biura Analiz Sejmowych Kancelarii Sejmu

Instytucja i-votingu w wybranych krajach

Możliwość prowadzenia przez partie polityczne kampanii społecznych

Ocena wniosku dotyczącego praworządności w Polsce (art. 7 Traktatu o Unii Europejskiej)

Możliwość podjęcia interwencji poselskiej u komornika sądowego 


\section{ZESZYTY \\ PRAWNICZE}

BIURA ANALIZ SEJMOWYCH

ROK XV • 1 (57) - 2018 


\section{Rada programowa}

dr Ziemowit Cieślik, UKSW - przewodniczący - $\operatorname{dr}$ Piotr Czarny, UJ - dr Adam Łazowski, University of Westminster (London) - prof.zw. dr hab. Cezary Mik, UKSW - prof. zw. dr hab. Krzysztof Skotnicki, Ut . dr hab. Adam Szafrański, UW - prof.zW. dr hab. Andrzej Szmyt, UG - prof. dr hab. Marek Szydło, UWr

\section{Zespół redakcyjny}

dr Wojciech Arndt, Akademia Ignatianum - redaktor naczelny - Justyna Stegner-Gurecky - sekretarz redakcji - dr Piotr Chybalski, UKSW - dr Ewelina Gierach, UKSW - dr hab. Robert Jastrzębski, UW dr Adam Karczmarek, UKSW - dr Krzysztof Kozłowski, UJ - Bartosz Pawłowski - dr hab. Jadwiga Potrzeszcz, KUL - drPrzemysław Sobolewski, UW - dr Zofia Szpringer - drhab. Michał Warciński, UW

\section{Redakcja tematyczna}

dr Ewelina Gierach - prawo konstytucyjne - dr Przemysław Sobolewski - prawo cywilne i handlowe - dr Zofia Szpringer - prawo finansowe

\section{Redakcja językowa i korekta}

Teresa Muś

\section{Skład}

Janusz Świnarski

\section{Fotografia na okładce}

„Sprawiedliwość" - płaskorzeźba Aleksandra Żurakowskiego w Sali Posiedzeń Sejmu, fot. Mariusz Wideryński

\section{Kontakt z redakcja}

e-mail: justyna.stegner@sejm.gov.pl

Biuro Analiz Sejmowych Kancelarii Sejmu

00-441 Warszawa, ul. Zagórna 3

tel. (+48 22) 6941845

faks (+48 22) 6941865

e-mail: punkt_konsultacyjny@sejm.gov.pl

e-mail:wydawnictwo_BAS@sejm.gov.pl

(c) Copyright by Kancelaria Sejmu

Warszawa 2018

Wszelkie prawa zastrzeżone. Żadna część ani całość opracowania nie może być bez zgody wydawcy - Kancelarii Sejmu - reprodukowana, użyta do innej publikacji oraz przechowywana w jakiejkolwiek bazie danych.

ISSN 2082-064X

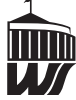

Wydawnictwo Sejmowe 


\section{SPIS TREŚCI}

1 ARTYKUŁY

Jarosław Zbieranek

Głosowanie przez internet (i-voting) w wybranych państwach $\ldots \ldots \ldots \ldots$

Magdalena Musiał-Karg

Analiza doświadczeń związanych $\mathrm{z}$ wykorzystaniem głosowania internetowego (i-voting) $\mathrm{w}$ wybranych państwach $\ldots \ldots \ldots \ldots \ldots$

\section{OPINIE BAS}

A ZAGADNIENIA PRAWA KONSTYTUCYJNEGO

\section{Krzysztof Skotnicki}

Instytucja $i$-votingu w wybranych krajach $\ldots \ldots \ldots \ldots \ldots$

Piotr Chybalski

Wykładnia art. 184 ust. 2 regulaminu Sejmu - przedmiot wniosku formalnego .

Piotr Czarny

Możliwość prowadzenia przez partie polityczne kampanii społecznych $\ldots .$. .

B ZAGADNIENIA PRAWA MIĘDZYNARODOWEGO I EUROPEJSKIEGO

\section{Cezary Mik}

Ocena uzasadnionego wniosku, zgodnie z art. 7 Traktatu o Unii Europejskiej, dotyczącego praworządności w Polsce, wraz z projektem decyzji Rady w sprawie stwierdzenia wyraźnego ryzyka poważnego naruszenia przez Rzeczpospolitą Polską zasady praworządności . . . . . . . . . . . . . . . . . . . .

\section{Paweł Bachmat, Marek Jaśkowski}

Ocena rządowego projektu ustawy o dokumentach publicznych (druk sejmowy nr 2153)

\section{Tomasz Jaroszyński, Mirosław Sobolewski}

Ocena rządowego projektu ustawy o szczególnych rozwiązaniach związanych z organizacją sesji Konferencji Stron Ramowej Konwencji Narodów Zjednoczonych w sprawie zmian klimatu w Rzeczypospolitej Polskiej (druk sejmowy nr 2120) . . . . . . . . . . . . . . . . . . . . . . .

\section{Paweł Bachmat}

Przekroczenie granic obrony koniecznej - w sprawie propozycji nowelizacji art. 25 Kodeksu karnego . . . . . . . . . . . . . . . . . . . . . . . 
D SPRAWY POSELSKIE

Wojciech Odrowąż-Sypniewski

Znaczenie wyrażenia „obowiązki poselskie” - wykładnia art. 22 ust. 1 regulaminu Sejmu . . . . . . . . . . . . . . . . . . . . . . . . .

Joanna M. Karolczak

Możliwość podjęcia interwencji poselskiej u komornika sądowego . . . . . . . .

Wojciech Odrowąż-Sypniewski

Tryb zwoływania posiedzeń komisji sejmowych $\ldots \ldots \ldots \ldots \ldots \ldots$

E VARIA

\section{Henryk Dzwonkowski}

Dopuszczalność uznania środków finansowych pobieranych przez wojewódzką stację sanitarno-epidemiologiczną z tytułu zawartych umów z innymi wojewódzkimi stacjami sanitarno-epidemiologicznymi na wykonywanie badań porównawczych za dochód budżetu państwa . . . . . . . . . . . . . .

\section{Wioleta Wasil}

Ocena petycji w sprawie zmiany ustawy o ujawnianiu informacji o dokumentach organów bezpieczeństwa państwa z lat 1944-1990 oraz treści tych dokumentów

\section{Piotr Czarny}

Ocena art. 25 ustawy o finansowaniu zadań oświatowych . . . . . . . . . .

Henryk Dzwonkowski

Prawnofinansowa ocena art. 25 ustawy o finansowaniu zadań oświatowych . . .

\section{STANOWISKA SEJMU W SPRAWACH} PRZED TRYBUNAŁEM KONSTYTUCYJNYM

\section{Andrzej Pogłódek}

Dopuszczalność dowodów - wniosek Rzecznika Praw Obywatelskich (sygn. akt K 27/16) dotyczący ustawy - Kodeks postępowania karnego . . . . . . . . . . .

\section{Jolanta Bucińska}

Zgodność z Konstytucją niektórych przepisów ustawy o planowaniu rodziny, ochronie płodu ludzkiego i warunkach dopuszczalności przerywania ciąży . . . 


\section{CONTENTS}

1 ARTICLES 7

Jarosław Zbieranek

Voting over the Internet (i-voting) in selected countries $\ldots \ldots \ldots \ldots$. . . . .

Magdalena Musiał-Karg

Analysis of experiences related to the use of voting over the Internet (i-voting). Selected examples . . . . . . . . . . . . . . . . . .

2 OPINIONS OF THE BUREAU OF RESEARCH (BAS)

A CONSTITUTIONAL LAW ISSUES

Krzysztof Skotnicki

I-voting in selected countries $\ldots \ldots \ldots \ldots \ldots \ldots$

Piotr Chybalski

Interpretation of Article 184 par. 2 of the Standing Orders of the Sejm - subject matter of a point of order $\ldots \ldots \ldots \ldots \ldots$

Piotr Czarny

Admissibility of running social campaigns by political parties $\ldots \ldots \ldots \ldots$

B EUROPEAN AND INTERNATIONAL LAW ISSUES

\section{Cezary Mik}

The assessment of the justified application, in accordance with Article 7 of the Treaty on European Union, concerning the rule of law in Poland, together with the draft Council decision on stating the clear risk of a serious violation of the rule of law by the Republic of Poland . . . . . . . . . . . . . . . . . . .

\section{LEGISLATIVE OPINIONS}

\section{Paweł Bachmat, Marek Jaśkowski}

Evaluation of the government bill on public documents (Sejm's paper no. 2153)

\section{Tomasz Jaroszyński, Mirosław Sobolewski}

Evaluation of the government bill on specific solutions related to the organization of the sessions of the Conference of the Parties to the United Nations Framework Convention on Climate Change in Republic of Poland (Sejm's paper no. 2120) . . . . . . . . . . . . . . . . . . . . . .

\section{Pawel Bachmat}

Exceeding the boundaries of necessary defense - regarding the petition concerning amendment of Article 25 of the Criminal Code . . . . . . . . . . . . . 
D DEPUTIES' AFFAIR

Wojciech Odrowąż-Sypniewski

The meaning of the term "Deputies' duties" - interpretation of Article 22 para. 1 of the Standing Orders of the Sejm . . . . . . . . . . . . .

Joanna M. Karolczak

Possibility of taking Deputies' intervention in a court bailiff . . . . . . . . . .

Wojciech Odrowąż-Sypniewski

The procedure for convening sittings of Sejm committees . . . . . . . . . .

E MISCELLANEA

\section{Henryk Dzwonkowski}

Admissibility of recognizing, as an income of the state budget, financial resources charged by the Voivodship Sanitary and Epidemiological Station under contracts concluded with other Voivodship Sanitary and Epidemiological Stations (VSES) for conducting comparative tests . . . . . . . . . . . . . . . . .

\section{Wioleta Wasil}

Evaluation of the petition regarding the amendment of the act on disclosure of information on documents of state security autorities from 1944-1990 and the content of these documents . . . . . . . . . . . . . . . .

Piotr Czarny

Evaluation of Article 25 of the Act on Financing Educational Tasks . . . . . .

\section{Henryk Dzwonkowski}

Legal and financial evaluation of Article 25 of the Act on Financing of Educational Tasks . . . . . . . . . . . . . . . . . . . . . . . . .

\section{THE SEJM'S POSITIONS ON CASES} BEFORE THE CONSTITUTIONAL TRIBUNAL

Andrzej Pogłódek

Admissibility of evidence - request of the Ombudsman (K 27/16) regarding the Act - Code of Criminal Procedure . . . . . . . . . . . . . . .

\section{Jolanta Bucińska}

Compliance with the Constitution of some provisions of the Act on Family Planning, Protection of the Human Fetus and Conditions of Acceptability of Termination of Pregnancy $\ldots \ldots \ldots \ldots \ldots \ldots \ldots \ldots \ldots \ldots$ 


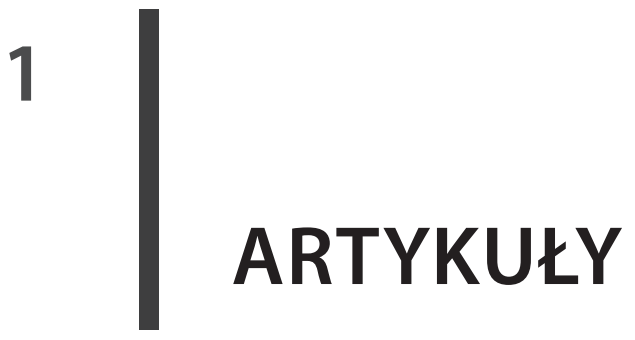





\title{
Głosowanie przez internet (i-voting) w wybranych państwach
}

\begin{abstract}
Voting over the Internet (i-voting) in selected countries: The author of the article presents the so-called i-voting as one of alternative voting procedures and examples of introducing it in several countries. Many researchers consider i-voting as one of the ways to meet voters expectations. Potential benefits and risks of Internet voting are widely discussed. The initial, strong assumption that there is a direct relation between applying i-voting (as the alternative voting procedure) to voters and increasing voter turnout, seems to be highly problematic. There is no unequivocal proof that such a link exists. Research results suggest that in this respect i-voting provides, above all, an additional opportunity to participate in the vote. The fact that one takes advantage of it it does not result from any necessity, but is primarily a consequence of a freely made decision, influenced by other factors, such as convenience or curiosity about changing the usual way of participating in the vote. On the other hand, opponents regard i-voting as a serious threat of basic principles of elections. Potential implications of this form of voting on security, transparency and integrity of voting are stressed.
\end{abstract}

\author{
Keywords: elections | Internet | voting \\ Słowa kluczowe: wybory | internet | głosowanie
}

Doktor nauk prawnych, ekspert w Zespole Prawa Konstytucyjnego, Międzynarodowego i Europejskiego Biura Rzecznika Praw Obywatelskich, współpracownik Centrum Studiów Wyborczych Uniwersytetu Mikołaja Kopernika w Toruniu; zbieranek@o2.pl.

\section{Wprowadzenie}

W systemach prawa wyborczego i referendalnego wielu państw funkcjonują od lat tzw. alternatywne procedury głosowania. Są to konstrukcje, które umożliwiają wyborcom oddawanie głosu w inny sposób niż tradycyjnie w lokalu wyborczym. Wyróżnia się najczęściej cztery zasadnicze alternatywne procedury głosowania: głosowanie przez pełnomocnika, głosowanie korespondencyjne, głosowanie elektroniczne (zdalne), a także przy wykorzystaniu tzw. mobilnej urny wyborczej ${ }^{1}$.

1 Szerzej kwestie te przedstawiam w: J. Zbieranek, Alternatywne procedury głosowania w polskim prawie wyborczy - gwarancja zasady powszechności wyborów czy mechanizm zwiększania frekwencji wyborczej?, Warszawa 2013. 
W niniejszym artykule uwaga zostanie skierowana przede wszystkim na alternatywną procedurę: głosowania elektronicznego zdalnego - z wykorzystaniem internetu (i-voting) ${ }^{2}$. Aby uporządkować rozważania, należy zaznaczyć, że jest to jedna z kilku technik, którą obejmuje szersza kategoria, jaką stanowi głosowanie elektroniczne (e-voting). Zgodnie z definicją e-voting zakłada użycie technologii elektronicznych w procedurach związanych z wyborami, przy czym muszą one obejmować co najmniej akt oddawania głosu3 ${ }^{3}$ W literaturze spotkać można kilka podziałów w obrębie tej procedury. Renomowany Instytut IDEA proponuje podział e-votingu na: a) systemy oparte na maszynach do głosowania (DRE - direct recording electronic voting machines); b) systemy oparte na systemach skanerów umożliwiających odczytanie karty ze wskazaną przez wyborców preferencją (OMR - optical mark recognition); c) systemy oparte na drukarkach głosów elektronicznych - zbliżonych do maszyn do głosowania, umożliwiających wydruk kart lub oznaczeń zawierających preferencje wyborcy, które są przygotowane do odczytu (EBPs - electronic ballot printers); oraz d) systemy głosowania $\mathrm{z}$ wykorzystaniem internetu ( $i$-voting, Internet voting) ${ }^{4}$. W najprostszym podziale można wyróżnić natomiast, w zależności od umiejscowienia aktu głosowania ${ }^{5}$ a) techniki oddawania głosu w lokalu wyborczym (DRE, inne maszyny elektroniczne); b) procedury zdalne, umożliwiające oddanie głosu poza lokalem wyborczym (w tym $i$-voting) ${ }^{6}$. Należy podkreślić, że, co do zasady, korzystanie z elektronicznych maszyn do głosowania stanowi jedynie odmienną technicznie formę udziału w głosowaniu, która wymaga udania się do lokalu wyborczego. Ich stosowanie ma miejsce w tzw. środowisku kontrolowanym, a więc pod ścisłym nadzorem organów organizujących wybory (organów wyborczych) ${ }^{7}$. Nie stanowią one w takim ujęciu alternatywnej procedury głosowania. Obecnie jest to najczęściej używana technika e-votingu. Dużo większym wyzwaniem jest stosowanie głosowania elektronicznego zdalnego $\mathrm{z}$ wykorzystaniem internetu. W państwach, w których jest stosowana, procedura $i$-votingu opiera się przede

2 W niniejszym artykule zaprezentowane zostaną ustalenia oraz osobiste opinie autora.

3 Tak w dokumencie Rady Europy, Council of Europe, Reccommendation on Legal, Operational and Technical Standards for E-voting, Rec(2004)11, wrzesień 2004 r. Również m.in.: Factsheet. Electronic voting - The first real practice [w:] B. Kaufmann, R. Buchi, N. Braun, Guidebook to direct democracy. In Switzerland and beyond, Marburg 2010, s. 130.

4 Introducing Electronic Voting: Essential Considerations, IDEA, Stokholm 2011, s. 9-11.

5 O.O. Okediran i in., A framework for a multifaceted electronic voting system, „International Journal of applied science and technology” 2011, vol. 1, no 4, s. 135.

6 P. Norris, Will new technology boots turnout? Experiments in e-Voting and all-postal voting in British local elections [w:] Voter turnout in Western Europe since 1945, Stockholm 2004, s. 42.

7 O.O. Okediran i in., A framework for a multifaceted electronic voting system, op. cit., s. 135. 
wszystkim na wykorzystaniu komputera osobistego połączonego $\mathrm{z}$ internetem. Jest to technika umożliwiająca oddawanie głosu poza lokalem (lub zorganizowanym punktem, kioskiem) wyborczym i dlatego stanowi alternatywną procedurę głosowania.

Po ustaleniu kwestii definicji warto zwrócić uwagę na szersze tło rozwoju procedur $i$-votingu. $\mathrm{W}$ związku $\mathrm{z}$ występującym $\mathrm{w}$ wielu państwach spadkiem zainteresowania obywateli uczestniczenia w mechanizmach demokratycznych ${ }^{8}$, w tym w wyborach i referendach, wielu badaczy zaczęło postrzegać ogromną szansę na zmianę tego stanu rzeczy w rozwoju demokracji elektronicznej. Wiąże się to $\mathrm{z}$ upowszechnieniem się łatwo dostępnego medium, jakim jest szerokopasmowy internet. Wskazywano na realną szansę odbudowy zaangażowania obywateli w procesy decyzyjne przez tworzenie zupełnie nowych kanałów i procedur partycypacji?.

W literaturze przedmiotu schyłku XX i początku XXI wieku odnaleźć można rozbudowane wizje różnorodnych zmian (również społecznych) związanych z zamysłem wprowadzenia oraz upowszechnienia głosowania przez internet. Wskazywano, że procedura taka szybko zbuduje zupełnie nową formułę uczestnictwa w procesach decyzyjnych, włączając do nich grupy wyborców, które dotychczas nie brały w nich udziału ${ }^{10}$. Łatwość stosowania procedury głosowania za pośrednictwem internetu w połączeniu z jej dostępnością miała doprowadzić do znacznego zniwelowania organizacyjnych "kosztów” uczestniczenia w wyborach, jakie ponosi wyborca. To zaś powinno wpływać wymiernie i (jak zakładano) trwale na wzrost poziomu uczestnictwa $\mathrm{w}$ wyborach ${ }^{11}$. Warto odnotować, że rozwiązanie to miało przeciwdziałać - zauważalnemu w wielu państwach zjawisku zdecydowanie mniejszego uczestnictwa w głosowaniach najmłodszych wyborców ${ }^{12}$. Co ważne, oprócz procedury oddawania głosu w sposób zdalny obywatele uzyskać mieli dzięki internetowi również możliwość łatwego dostępu do najważniejszych informacji dotyczących kwestii publicznych, umożliwiających im, dzięki pogłębionej wiedzy, wybór swoich przedstawicieli w sposób bardziej świadomy ${ }^{13}$.

8 D. Boshel, Can Internet voting increase participation? Remote electronic voting and turnout in the Estonian 2007 parliamentary elections, Paper for the conference Internet and Voting, Fiesole, 3-4 czerwca 2010 r., s. 1.

9 Szerzej zob. B. Bimber, The Internet and citizen communication with government: Does the medium matter?, „Political Communication” 2001, vol. 4, nr 16, s. 409-429.

10 D. Boshel, Can Internet voting increase participation?, op. cit., s. 4.

11 D. Mider, Głosowanie przez Internet a demokracja, „Studia Politologiczne” 2011, t. 20, s. 240.

12 Szerzej zob. J.S. Stratford, J. Stratford, Computerized and networked government information, „Journal of Government Information” 2001, No 28, s. 297-301.

13 P. Norris, E-voting as a magic ballot? [w:] Electronic Voting and Democracy, red. N. Kersting, H. Baldersheim, Palgrave 2004, s. 221. 
Warto podkreślić, że w debacie publicznej nie był przedstawiany jako priorytetowy potencjalny wpływ głosowania elektronicznego zdalnego na zapewnienie gwarancji korzystania z praw wyborczych np. przez grupy zagrożone wykluczeniem (osoby z niepełnosprawnością, w zaawansowanym wieku, podróżujące) ${ }^{14}$. Jest to o tyle zrozumiałe, że pionierami użycia mechanizmów głosowania przez internet były państwa, w których już od wielu lat stosowano i oferowano wyborcom różnorodne procedury alternatywne - „analogowe”15 (głosowanie przez pełnomocnika, głosowanie korespondencyjne). Działania mające na celu zapewnienie możliwości oddawania głosów najbardziej potrzebującym grupom obywateli, zmarginalizowanym z przyczyn trudności organizacyjnych $\mathrm{w}$ procesie wyborczym, zostały więc już podjęte wcześniej.

Większe zainteresowanie problematyką alternatywnych procedur głosowania, w tym głosowania za pomocą internetu, spowodowały, że w wielu dokumentach o charakterze międzynarodowym znalazły się ważne odniesienia i standardy ich stosowania. Bardzo ważne ustalenia zawiera dokument przygotowany przez Komisję Wenecką Rady Europy: Kodeks dobrych praktyk w sprawach wyborczych ${ }^{16}$. Dokument ten miał m.in. wpływać na kierunki zmian prawa wyborczego i umożliwiać skuteczne monitorowanie wyborów ${ }^{17}$. Odnosił się do wielu kwestii o kardynalnym znaczeniu, formułując wnioski w np. zakresie zasady powszechności prawa wyborczego, zasady równości, wolności wyboru, zwalczania nadużyć wyborczych, bezpieczeństwa procesu wyborczego czy finansowania kampanii wyborczych. Kodeks odnosił się również bezpośrednio do alternatywnych procedur głosowania - wymieniając i opisując cztery z nich: głosowanie korespondencyjne, głosowanie przez pełnomocnika, głosowanie elektroniczne (w szerszym ujęciu) i głosowanie z wykorzystaniem mobilnej urny wyborczej.

Należy podkreślić, że w Kodeksie pozytywnie oceniano stosowanie alternatywnych procedur głosowania w procesie wyborczym, przedstawiając jednocześnie warunki oraz kryteria, jakie procedury takie powinny wypełniać, by mogły być uznane za zgodne $\mathrm{z}$ demokratycznymi standardami. W dokumencie wskazano, że: wyborcy musza mieć zawsze możliwość głosowania w lokalu wyborczym, jednoznacznie uznając tę procedurę za podstawową. Dopiero bo-

14 O.O. Okediran i in., A framework for a multifaceted electronic voting system, op. cit., s. 136.

15 Szerzej zob. J. Zbieranek, Alternatywne procedury głosowania, op. cit.

16 Code of good practice in electoral matters. Guidelines and explanatory report, Adopted by the Venice Commission at its $52^{\text {nd }}$ session (Venice, 18-19 October, 2002), opinion no 190/2002.

17 J. Jaskiernia, Alternatywne sposoby głosowania w świetle prac instytucji systemu Rady Europy [w:] Międzynarodowa Konferencja Naukowa nt. Alternatywne sposoby głosowania a aktywizacja elektoratu, Rzeszów 26-27 marca 2007 r., red. S. Grabowska, R. Grabowski, Rzeszów 2007, s. 195. 
wiem po tym zastrzeżeniu wymieniono również „inne procedury”, wskazując, że są one dopuszczalne i: moga być zaakceptowane po spełnieniu określonych warunków.

Omawiany dokument dopuszcza stosowanie głosowania elektronicznego w szerokim znaczeniu, jednak z ważnymi zastrzeżeniami odnoszącymi się do zapewnienia bezpieczeństwa i wiarygodności mechanizmu oddawania głosu. Podkreślono w nim, że niezmiernie istotne jest zachowanie w całej procedurze zasady tajności. Wskazano również, że wyborca powinien uzyskać możliwość potwierdzenia oddania głosu, a także skorygowania głosu błędnie oddanego. „Elektroniczna karta" do głosowania powinna być zaprojektowana w przejrzysty sposób, treści w niej zawarte powinny być jasne i czytelne. Wskazano, że konieczne są również rozbudowane procedury umożliwiające, w razie konieczności, wcześniejsze zweryfikowanie i sprawdzenie działania systemu głosowania elektronicznego. Liczne wymogi postawiono w zakresie zapewnienia bezpieczeństwa całego systemu - przede wszystkim uniknięcia ingerencji w jego działanie z zewnątrz. Podkreślono również konieczność zapewnienia jego niezawodności i transparentności działania.

Pewną kontynuacją przedstawionych wyżej działań podjętych przez Komisję Wenecką (ale i sposobu postrzegania i oceny alternatywnych procedur głosowania) były prace Komitetu Ministrów Rady Europy, który przygotował w 2004 r. dokument bezpośrednio odnoszący się do głosowania elektronicznego (w szerszym ujęciu obejmujący również głosowanie elektroniczne zdalne): Zalecenia Komitetu Ministrów dla państw członkowskich $w$ sprawie prawnych, praktycznych $i$ technicznych standardów głosowania elektronicznego ${ }^{18}$. Warto podkreślić, że odzwierciedla on ważne tendencje, jakie pojawiały się wówczas w wielu państwach, a także odnosi się do oczekiwań, jakie formułowano w odniesieniu do nowej procedury głosowania.

$\mathrm{Na}$ wstępie dokumentu podkreślono, że wobec rozwijających się technik informatycznych i komunikacyjnych, które mają zastosowanie w codziennym życiu, władze muszą brać je również pod uwagę, projektując procedury udziału w procesach demokratycznych. W dalszej części dokumentu wymieniono różne przyczyny wprowadzenia nowych procedur w państwach je wdrażających. W kontekście dalszych rozważań warto je przywołać. Autorzy dokumentu stwierdzają: niektóre $z$ państw członkowskich już obecnie stosują lub rozważaja stosowanie głosowania elektronicznego, mając na uwadze różne zadania, w tym: umożliwienie wyborcom oddania głosu $z$ miejsca innego niż lokal wyborczy w ich obwodzie głosowania, ułatwienie oddania głosu przez wyborcę; ułatwienie udziału $w$ wyborach i referendach wszystkim tym, którzy sa uprawnieni do głosowania, w szczególności obywatelom przebywającym lub mieszkającym za granicą; rozszerzenie dostępu do głosu wyborcom niepełnosprawnym lub tym, którym fizyczna

18 Council of Europe, Reccommendation on Legal, op. cit. 
obecność w punkcie wyborczym i korzystanie z udostępnionych tam urządzeń sprawia trudności; zwiększenie frekwencji wyborczej poprzez udostępnienie dodatkowych sposobów głosowania; dostosowania głosowania do postępu społecznego i rozwijajacego się zastosowania nowych technologii jako środków porozumiewania się i obywatelskiego zaangażowania $w$ demokrację; ograniczanie, z czasem, ogólnych kosztów ponoszonych przez organy władzy organizujące wybory na prowadzenie wyborów i referendów; bardziej wiarygodne i szybsze przedstawianie wyników wyborów, oraz zapewnienie głosującym lepszej obsługi, poprzez oferowanie różnych sposobów głosowania ${ }^{19}$.

W Zaleceniach Komitetu Ministrów zaakcentowano przede wszystkim kwestie zasad dotyczących bezpieczeństwa i pewności nowej procedury. Wyraźnie podkreślono, że jedynie takie systemy głosowania elektronicznego, które są bezpieczne, wiarygodne, skuteczne, sprawne technicznie, otwarte na niezależną weryfikację oraz łatwo dostępne dla głosujących, będą budowały zaufanie publiczne. Jest ono bowiem podstawowym warunkiem przeprowadzania głosowania elektronicznego ${ }^{20}$.

W ostatnim czasie uznano, że powyższy dokument wymaga pewnego uzupełnienia (z uwzględnieniem późniejszych doświadczeń). Dlatego też Komitet Ministrów Rady Europy ustanowił w roku 2017 Zalecenia Komitetu Ministrów dla państw członkowskich $w$ sprawie standardów głosowania elektronicznego ${ }^{21}$.

W dokumencie tym sformułowano liczne wymogi dotyczące wypełniania przez procedurę głosowania elektronicznego podstawowych zasad prawa wyborczego (powszechności, równości, tajności i wolnych wyborów). Wskazano m.in. konieczność zapewnienia czytelnej dla wyborców formuły oddawania głosu w ramach głosowania elektronicznego. Podkreślono, że procedura głosowania elektronicznego zdalnego (a więc również $i$-voting) nie może być jedyną procedurą oddawania głosu, a powinna być traktowana jako alternatywna, dodatkowa. Zwrócono jednocześnie uwagę na konieczność odpowiedniego uczulenia wyborców, że głosowanie elektroniczne zdalne ma w pełni realny wpływ na wynik wyborów (lub referendów). W dalszej części szczegółowo wskazano i wymieniono gwarancje proceduralne związane z przejrzystością, weryfikowalnością procesu oddawania głosu, a także jego wiarygodnością. Podkreślono też konieczność uzyskania przez wyborcę potwierdzenia oddania głosu w sposób skuteczny. Wyraźnie widać troskę autorów dokumentu o bezpieczny przebieg wyborów, w których dostępna jest możliwość głosowania z wykorzystaniem procedury elektronicznej. Państwa członkowskie są w tym zakresie zobowiązane do spełnienia bardzo konkretnych wymogów technicznych i organizacyjnych.

19 Ibidem.

20 Ibidem.

21 Recommendation CM/Rec(2017)5' of the Committee of Ministers to member States on standards for e-voting, czerwiec $2017 \mathrm{r}$. 
Dotyczą one m.in. tajności głosowania (na każdym szczeblu) - w szczególności podkreślono konieczność uniemożliwienia odtworzenia głosu konkretnego wyborcy (i powiązania z nim).

W dokumencie zalecono państwom wprowadzanie procedury głosowania elektronicznego stopniowo, zgodnie z przygotowanymi wcześniej regulacjami prawnymi i mechanizmami organizacyjnymi i technicznymi. Organy odpowiedzialne za przeprowadzanie wyborów przede wszystkim powinny przejąć odpowiedzialność i kontrolę nad systemem głosowania elektronicznego ( $w$ tym zakresie sformułowane zostały dokładne wymogi).

\section{Doświadczenia z wdrażania i stosowania i-votingu w wybranych państwach}

Problematyka głosowania elektronicznego jest od kilkudziesięciu lat na świecie uznawana za istotną, dlatego stanowi przedmiot licznych badań i analiz. W wielu państwach wprowadzono możliwość głosowania elektronicznego w lokalach wyborczych (z pomocą maszyn elektronicznych, EMB) lub kiosków umożliwiających oddanie głosu. Jest to obecnie niewątpliwie najpopularniejsza i sprawdzona organizacyjnie forma powszechnego głosowania elektronicznego, z której korzystają w wyborach i referendach miliony wyborców.

Jak już zostało wspomniane, w ostatnich latach duże zainteresowanie zostało skierowane na procedury głosowania elektronicznego zdalnego, a w szczególności głosowanie za pomocą internetu ( $i$-voting). $\mathrm{W}$ wielu państwach podjęto rozbudowane projekty badawcze i wdrożeniowe. Przeprowadzono liczne działania o charakterze pilotażowym. Zebrano cenne doświadczenia i obserwacje, które pozwoliły na zweryfikowanie założeń oraz dokonanie oceny nowej procedury. Ustalenia są $\mathrm{w}$ tej mierze bardzo zróżnicowane: $\mathrm{w}$ niektórych państwach po przeprowadzeniu rozbudowanych działań pilotażowych podjęto decyzję o rezygnacji z wdrażania $i$-voting $u$ (Wielka Brytania, Norwegia). $\mathrm{W}$ innych projekt jest kontynuowany, lecz wprowadzona procedura skierowana jest do ograniczonej liczby wyborców z uwagi na kryterium terytorialne (Kanada, Szwajcaria) lub/ oraz kryteria dotyczące konkretnych grup wyborców (Stany Zjednoczone, Francja, Australia). Jedynym państwem, które obecnie stosuje głosowanie elektroniczne jako procedurę powszechną, skierowaną do wszystkich obywateli, jest Estonia.

Warto zauważyć, że w wielu państwach procedury głosowania elektronicznego są rozważane łącznie - dlatego różnorodne komplikacje oraz kontrowersje związane z wcześniejszym stosowaniem maszyn elektronicznych mają również wpływ na potencjalne wprowadzania głosowania za pomocą internetu (Holandia, Niemcy).

Zamysł głosowania przez internet spotyka się z zasadniczo dobrymi ocenami wyborców, którzy w wielu państwach formułują swoje konkretne oczekiwania odnośnie do tej procedury. Dlatego tematyka ta jest obecna w debacie publicznej, 
powstają opracowania i raporty naukowe, jednak wciąż jest to relatywnie początkowe stadium badań, obejmujące rozważania teoretyczne (Rumunia, Mołdawia, Bułgaria $^{22}$, Dania ${ }^{23}$, Polska $^{24}$ ).

W dalszej części analizy przedstawione będą przykłady różnorodnych działań związanych $\mathrm{z}$ wdrażaniem $i$-votingu podejmowanych w wybranych państwach z uwzględnieniem ich specyfiki, wyzwań, zastosowanych rozwiązań technicznych oraz efektów - w szczególności w odniesieniu do zakładanych celów.

22 W Bułgarii 25 października 2015 r. przeprowadzone zostało referendum, w którym zadano wyborcom pytanie: „Czy popierasz koncepcje przyznania wyborcom prawa do głosowania za pośrednictwem internetu poza lokalem wyborczym w wyborach i referendach?”. Większość głosujących $(69,5 \%)$ odpowiedziała twierdząco.

23 W 2008 r. burmistrzowie ośmiu największych gmin miejskich w Danii skierowali do Ministerstwa Spraw Społecznych (odpowiadającemu wówczas za kwestie organizowania i przeprowadzania wyborów) stanowisko, w którym wnioskowali o podjęcie kroków mających na celu przygotowanie działań pilotażowych związanych z wprowadzeniem e-votingu. Nowa procedura miała polegać na zastosowaniu procedur elektronicznych w toku głosowania w lokalach wyborczych (non-remote voting). Strona rządowa podniosła jednak wiele problemów organizacyjnych związanych z zapewnieniem bezpieczeństwa oraz przejrzystości tej procedury, przywołując również przykłady komplikacji, jakie występowały w innych państwach. Rozważano też podjęcie prac mających na celu wdrożenie głosowania zdalnego, z wykorzystaniem internetu ( $i$-votingu). Debatę na ten temat podjęto m.in. przy okazji opracowywania i wprowadzania mechanizmu elektronicznego rejestru wyborców. Strona rządowa po analizach podniosła jednak poważne zastrzeżenia związane z zapewnieniem przy i-votingu gwarancji zasady bezpośredniości głosowania, tajności (która zgodnie z duńskim ustawodawstwem jest obowiązkiem, a nie prawem wyborcy) oraz bezpieczeństwa. Dlatego też uznano, że nie ma podstaw dla podjęcia w Danii działań mających na celu wprowadzenie głosowania przez internet, co spotkało się z poparciem partii parlamentarnych. Stanowisko takie - wyrażające obawy przed stosowaniem e-votingu - zostało również w 2015 r. przedstawione Misji OBWE analizującej m.in. procedury głosowania w Danii. Więcej zob. w: The Parliamentary Electoral System in Denmark, Kopenhaga 2011, s. 32-33; Denmark Early General Elections, 18 czerwca 2015 r., OSCE/ODIHR Needs Assessment Mission Report, s. 6.

24 Szerzej kwestie te przedstawiam w: J. Zbieranek, Alternatywne procedury głosowania, op. cit. Wyniki badań opinii społecznej zob. B. Roguska, J. Zbieranek, Polacy o proponowanych zmianach $w$ prawie wyborczym. Komunikat $z$ badań, Warszawa 2014. Należy zauważyć, że w 2016 r. została złożona i rozpatrywana była przez Sejm RP petycja obywatela dotycząca m.in. wprowadzenia możliwości głosowania przez internet (sygn. BKSP-145-126/16). 


\section{Przykłady działań pilotażowych}

\section{- Norwegia}

Debata nad wprowadzeniem do procedury wyborczej możliwości głosowania za pomocą internetu (zdalnie) trwa w Norwegii od kilkunastu lat. Warto zauważyć, że poważny niepokój wzbudzało w tym czasie zjawisko zmniejszającej się frekwencji wyborczej, kiedy to ze średniego uczestnictwa w wyborach około $75 \%$ uprawnionych w latach 70. XX wieku, wielkość ta osiągnęła średnią około 60\% (58\% w 2003 r.) ) $^{25}$. Norweskie Ministerstwo Rozwoju Regionalnego (organ odpowiedzialny za przeprowadzanie wyborów zarówno na szczeblu lokalnym, jak i krajowym) w 2004 r. powołało specjalny roboczy komitet, który miał za zadanie opracowanie procedur głosowania elektronicznego. W działaniach tych założono opracowanie platformy do głosowania internetowego, która stosowana równolegle do obecnych metod głosowania, po pierwsze, zwiększyłaby dostęp norweskich wyborców do dogodnych dla nich procedur wyborczych, a po drugie, pozwoliłaby na bardziej efektywne przeprowadzenie wyborów, w szczególności liczenie głosów. Choć problematyka zakładanego podniesienia frekwencji wyborczej była niezmiernie ważna na początkowym etapie inicjowania i opracowywania założeń $i$-votingu w Norwegii, to w późniejszym czasie w oficjalnych dokumentach już jej nie wymieniano. W toku prac zespołu rozważano różnorodne zagadnienia związane m.in. z kwestiami zabezpieczeń takiej procedury, szczególnie w kontekście zapewnienia zasady tajności głosowania.

W sierpniu 2008 r. Ministerstwo Rozwoju Regionalnego zainicjowało program „E-elections 2011” i zdecydowało o przeprowadzeniu pilotażu głosowania przez internet w wyborach samorządowych, które odbyły się 12 września $2011 \mathrm{r}$. Ustalono wówczas, że głosowanie to będzie zorganizowanie wśród ograniczonej liczby wyborców - mieszkańców wybranych gmin, a jego wyniki zostaną uwzględnione w ustalaniu ogólnych wyników wyborów. Warto wspomnieć, że norweskie ustawodawstwo wyborcze dopuszcza możliwość przeprowadzania działań pilotażowych skierowanych do ściśle określonych grup wyborców, natomiast przeważająca większość przepisów dotyczących głosowania przez internet została uregulowana w sposób ramowy aktami podustawowymi - wydawanymi przez Ministra Rozwoju. Z jednej strony starano się tak skonstruować regulację, by była ona zgodna ze standardami międzynarodowymi dotyczącymi głosowania elektronicznego (w szczególności formułowanymi przez Radę Europy), z drugiej jednak starano się pewne kwestie pozostawić nieuregulowane (np. część procedur technicznych, zabezpieczenie). Takie założenie miało umożliwić większą elastyczność przeprowadzonego testu, a następnie - swobodniejsze opracowanie regulacji z uwzględnieniem jego wyników i doświadczeń. Wiele dokumentów

25 J. Saglie, S.B. Segaard, Internet voting in Norway 2011: Democratic and Organisational Experiences, XXII IPSA World Congress of Political Science Paper, s. 3-4. 
(np. instrukcje) związane z przeprowadzanym pilotażem publikowano na bieżąco na stronie internetowej projektu ${ }^{26}$.

Wystosowano apel do gmin o zgłaszanie gotowości do udziału w projekcie i zamiar uczestniczenia w pilotażu. Aplikacje zgłoszeniowe przeanalizowano i wytypowano 11 gmin ( $\mathrm{z}$ uwzględnieniem różnorodnych kryteriów, np. lokalizacji).

Warto wskazać na kontrowersje, jakie wzbudzały opisywane działania. Plan przeprowadzenia pilotażu głosowania przez internet był krytykowany przez część ekspertów, a grupa norweskich parlamentarzystów podniosła kwestie braku zabezpieczeń procedur głosowania i starała się zablokować w parlamencie dalsze prace. Ostatecznie decyzją większości parlamentarnej zdecydowano o kontynuowaniu projektu. Władze dwóch gmin zrezygnowały jednak z udziału w pilotażu, w związku z czym po dołączeniu jednej gminy, która aplikowała wcześniej - liczba gmin objętych pilotażem została ostatecznie ustalona na 10 (z 429), w których łącznie zamieszkiwało 168066 osób.

Przeprowadzono m.in. cykliczne badania opinii publicznej. Trzeba podkreślić, że Norwegowie prezentowali bardzo wysoki poziom zaufania do głosowania przez internet. W badaniach realizowanych w 2011 r. ufność w tę procedurę deklarowało $76 \%$ badanych ${ }^{27}$. Zwolennikami głosowania za pomocą internetu były w przeważającej większości kobiety, ankietowani posiadający wyższe wykształcenie oraz wyższe dochody. Wyraźnie zauważalne było większe zainteresowanie i akceptacja dla procedury wśród młodych, podczas gdy osoby starsze preferowały raczej tradycyjne procedury głosowania. Badacze podkreślają jednocześnie specyficzne rozumienie zasady tajności głosowania przez Norwegów - w badaniach prezentują oni bowiem dość dużą akceptację dla możliwości poznania preferencji wyborczych przez inne osoby ${ }^{28}$.

Pilotaż przeprowadzony w 2011 r. charakteryzował się kilkoma ważnymi założeniami. Przede wszystkim ustalono, że procedura głosowania przez internet jest tylko uzupełniającą procedurą i nie może oznaczać w żadnym razie wyłączenia dla grupy wyborców możliwości skorzystania $\mathrm{z}$ innych procedur głosownia. Wyborca głosujący za pośrednictwem i-votingu mógł oddać głos w dłuższym okresie poprzedzającym dzień wyborów. Czynił to w ramach głosowania przedterminowego, które trwało od 9 sierpnia do 9 września 2011 r. $^{29}$. Co ważne, w tym okresie mógł dokonać dowolnej zmiany swojej preferencji. W dzień wyborów możliwe było jednak już tylko głosowanie w tradycyjnej procedurze. Co

26 Norway Internet Voting Pilot Project Local Government Elections, 12 September 2011, OSCE/ODIHR Election Expert Team Report, Warszawa, s. 1-4.

27 A. Trechsel, Potential and challenges of E-Voting in the European Union, Bruksela 2016, s. 25.

28 Ibidem.

29 W tym czasie wyborcy mogli głosować tradycyjnie, oddając swój głos w urzędach publicznych (ratuszu, urzędach gmin itp.). 
bardzo istotne - oddanie głosu przez wyborcę w lokalu wyborczym unieważniało w każdym przypadku głos oddany wcześniej w procedurze $i$-votingu.

W Norwegii obowiązywał jeden system głosowania elektronicznego, na który składała się aplikacja umożliwiająca oddawanie głosu, program przechowywania danych o wyborcach i ich weryfikacji, serwer do gromadzenia głosów oddanych i serwery do unieważnienia głosów w przypadku ponownego głosowania w lokalu wyborczym, usługi dotyczące szyfrowania głosów ${ }^{30}$.

W procedurze głosowania elektronicznego wyborca za pośrednictwem przeglądarki internetowej na komputerze osobistym korzystał z pomocy profilu wykorzystywanego do usług w ramach elektronicznej administracji ${ }^{31}$ (MinID), logując się do tego portalu na podstawie dotychczasowego osobistego hasła. W kolejnym etapie, by zalogować się do systemu głosowania zdalnego, wyborca otrzymywał na swój telefon komórkowy dodatkowo jednorazowe hasło dostępu. Po jego wprowadzeniu w systemie ukazywała się użytkownikowi lista komitetów wyborczych wraz z kandydatami. Warto zauważyć, że portal był dostosowany do potrzeb wyborców z dysfunkcją wzroku, zawierał też możliwości skorzystania z różnych wersji językowych (m.in. w języku polskim ${ }^{32}$ ). Wyborca wskazywał swoją preferencję i zatwierdzał wybór, co powodowało przesłanie zaszyfrowanego głosu na serwer. Należy podkreślić bardzo ciekawy mechanizm weryfikacji oddanego głosu. Każdy wyborca przed wyborami otrzymywał bowiem tradycyjną pocztą kartę z listą kandydatów i przypisanymi im kodami. W trakcie weryfikacji głosu po zatwierdzeniu wyboru wyborca otrzymywał wiadomość tekstową (SMS) na swój telefon komórkowy z informacją o wyborze dokonanym na kandydata (odpowiedni kod). Po sprawdzeniu przez wyborcę kodu zawartego w wiadomości z kartą otrzymaną pocztą, można było stwierdzić, czy głos był oddany właściwie (a jeśli nie, dokonać ewentualnej korekty, nie później jednak niż w przeddzień wyborów).

Warto dodać, że dużą rolę w odkodowywaniu przesyłanych głosów odegrała Rada Wyborcza - ciało składające się z przedstawicieli ugrupowań politycznych, które wzięły udział w wyborach (w Norwegii nie funkcjonuje Komisja Wyborcza, a zadania związane z przeprowadzaniem wyborów są realizowane, jak już zostało wspomniane, przez Ministerstwo Rozwoju Regionalnego). Członkowie Rady wyposażeni zostali w klucze kodowe umożliwiające deszyfrowanie głosów oddanych w trakcie głosowania elektronicznego.

Wyniki wyborów samorządowych w roku 2011 wskazały, że w gminach objętych pilotażem z głosowania za pomocą internetu skorzystało 27554

$30 \quad$ Szerzej zob. J. Rzucidło, Referendum w obliczu głosowania za pośrednictwem Internetu - doświadczenia Estonii, Norwegii I Szwajcarii [w:] Instytucje demokracji bezpośredniej w praktyce, red. O. Hałub, M. Jabłoński, M. Radajewski, Wrocław 2016, s. 293-295.

31 J. Saglie, S.B. Segaard, Internet voting in Norway 2011, op. cit., s. 3-4.

32 Norway Internet Voting Pilot Project Local Government Elections, op. cit., s. 9. 
osób $^{33}$, a więc $26,4 \%$ wyborców uprawnionych, biorących udział w głosowaniu (w poszczególnych gminach odsetek ten wahał się od 19,8\% w Mandal do 31,6\% w Tynset). Należy zauważyć, że głosowali wyborcy nie tylko z terenu Norwegii, ale łącznie SMS wysłane zostały na telefony komórkowe wyborców w 35 innych państwach $^{34}$. W przypadku 519 głosów wyborcy, którzy zagłosowali wcześniej za pomocą internetu, udali się do lokali wyborczych i zagłosowali jednak tradycyjnie (co unieważniało wcześniejszy wybór) ${ }^{35}$.

Z uwzględnieniem doświadczeń z pilotażu w wyborach samorządowych podjęto decyzję o kontynuowaniu prac nad rozwojem procedur i-votingu, a w szczególności o przeprowadzeniu kolejnego pilotażu w wyborach parlamentarnych, które były zaplanowane na 9 września $2013 \mathrm{r}^{36}$. Ustalono, że uprawnionymi do oddania głosu przez internet będą wyborcy zamieszkali na terenie 12 gmin, łącznie blisko 250159 osób (a więc około 7\% ogółu uprawnionych). Głosowanie odbywało się w sposób zbliżony do tego przeprowadzonego w roku $2011^{37}$. Wyborcy mogli zagłosować za pomocą internetu w okresie od 12 sierpnia do 6 września 2013 r. Mogli zmieniać swoje preferencje, a jeśli zdecydowali się na oddanie głosu w lokalu wyborczym, głos ten unieważniał wybór drogą elektroniczną. Warto podkreślić, że nad głosowaniem czuwał specjalnie powołany Komitet ds. Wyborów Przeprowadzanych w Internecie, w skład którego wchodzili przedstawiciele komitetów wyborczych, wyborców, a także eksperci. Większość regulacji związanych z głosowaniem przygotowało natomiast Ministerstwo Rozwoju Regionalnego.

Pilotaż przeprowadzony w 2013 r. poprzedziła akcja informacyjna oraz cykl szkoleń poświęconych zasadom bezpieczeństwa i-votingu. Odsetek uprawnionych wyborców, który skorzystał z procedury głosowania przez internet, był nieco większy niż w 2011 r. i wyniósł 36,4\% spośród wyborców biorących udział w wyborach. Jak zauważyła w swoim raporcie Misja OBWE, w toku głosowania elektronicznego wykryto błąd w oprogramowaniu, który mógł spowodować mniejszy stopień zabezpieczenia głosów. Usunięto go bezzwłocznie ${ }^{38}$.

33 Ibidem, s. 16. W dokumentach OBWE podawana jest również liczba 27557 wyborców. Liczba 27554 przytaczana jest m.in. w: M. Jabłoński, J. Rzucidło, Głosowanie za pośrednictwem Internetu $w$ Królestwie Norwegii - założenia i realizacja programu E-VALG2011, „Studia Wyborcze” 2012, t. XIV, s. 70.

Ibidem, s. 9.

35 Ibidem, s. 10.

36 Nie obyło się jednak bez kontrowersji, bowiem zamysł przeprowadzenia pilotaży był bardzo mocno krytykowany przez część parlamentarzystów, którzy podkreślali zastrzeżenia odnośnie do bezpieczeństwa $i$-votingu (jako procedury odbywającej się w niekontrolowanym środowisku). Więcej zob. Norway Parliamentary Elections, 9 września 2013 r., OSCE/ODIHR Election Assessment Mission Final Report, s. 7.

37 J. Saglie, S.B. Segaard, Internet voting in Norway 2013, XXIII IPSA World Congress of Political Science Paper, s. 6.

38 Norway Parliamentary Elections, op. cit., s. 8. 
Jakkolwiek w oficjalnych dokumentach związanych z pilotażami przeprowadzonymi w Norwegii nie wskazywano na oczekiwany skutek w postaci zwiększenia frekwencji wyborczej, zagadnienie to było szeroko przywoływane przez media, stało się także przedmiotem licznych badań naukowych, $\mathrm{w}$ tym badań opinii społecznej.

Wnioski $\mathrm{z}$ analizy poziomu frekwencji wyborczej zarówno $\mathrm{w}$ pilotażu z 2011 r., jak i 2013 r. nie dają podstaw do wskazania, że nowa procedura przyczyniła się do jej zwiększenia. Zauważono, że w 2011 r. frekwencja w objętych pilotażem gminach była nieco wyższa (o około 3\%) od frekwencji zanotowanej w poprzednich wyborach, ale o taki sam poziom wzrosła frekwencja wyborcza w całym kraju (z 61,7\% w 2007 r. do 64,5\% w 2011 r.). Dokładne badania opinii społecznej przeprowadzone $\mathrm{w}$ gminach ukazały również, że jakkolwiek nową możliwość głosowania oceniono bardzo dobrze jako prostą i wygodną ${ }^{39}$, to jednak nie spowodowała ona mobilizacji poszczególnych grup wyborców (np. młodych ${ }^{40}$. W bardzo niewielkim odsetku respondenci wskazywali na kwestie organizacyjne i problemy techniczne w głosowaniu, które ta procedura mogłaby usunąć. Zbliżone wnioski wynikały również z pilotażu przeprowadzonego w 2013 r. - kiedy to poziom frekwencji był porównywalny. W konkluzji można stwierdzić, że przykład norweski potwierdził tylko ustalenia badaczy w innych państwach, że nowa procedura jest oceniana przez wyborców pozytywnie jako użyteczna, nowoczesna (co powoduje jej upowszechnianie), jednakże korzystają z niej w przeważającej większości osoby, które wzięłyby udział w wyborach również wtedy, gdyby procedury tej nie było.

Po przeprowadzeniu dwóch głosowań pilotażowych w roku 2011 oraz w roku 2013 rząd Norwegii postanowił w 2014 r. zakończyć projekt i przerwać dalsze działania mające na celu wprowadzenie procedury głosowania za pośrednictwem internetu. Podkreślono przy tym, że wbrew początkowym oczekiwaniom procedura ta nie spowodowała zwiększenia frekwencji wyborczej, a odwołując się do ustaleń norweskiego instytutu badań społecznych, wskazano, że i-voting nie przyczynił się do aktywizacji nowych grup wyborców, np. młodych. Jednocześnie wskazywano na ogromne wyzwania związane z zabezpieczeniem nowej procedury, które musi spełniać bardzo wysokie standardy ${ }^{41}$.

\section{- Wielka Brytania}

Ważne doświadczenia $\mathrm{z}$ zastosowania zdalnego głosowania elektronicznego z wykorzystaniem internetu zyskała również Wielka Brytania, choć podobnie jak w opisanym przypadku Norwegii, były to działania o charakterze pilotażowym.

39 Potwierdził to również przebieg głosowania - kiedy to na specjalną infolinię odebrano jedynie 691 telefonów z pytaniami od wyborców.

40 J. Saglie, S.B. Segaard, Internet voting in Norway 2011, op. cit., s. 11-14.

${ }^{41}$ A. Trechsel, Potential and challenges of E-Voting in the European Union, op. cit., s. 29. 
W związku z poważnym spadkiem frekwencji wyborczej i wyraźnym zmniejszeniem zainteresowania obywateli wyborami, Brytyjska Komisja Wyborcza (Electoral Commission) przeprowadzała od początku XXI wieku zakrojony na dużą skalę program badawczy ${ }^{42}$. W jego ramach zaprojektowano liczne próby, testy i pilotaże związane z zastosowaniem różnorodnych procedur głosowania (często stosowanych równolegle). W pakiecie rozwiązań postanowiono również zaproponować części wyborców możliwość oddawania głosu za pomocą internetu. Należy podkreślić, że wyborcy brytyjscy co do zasady pozytywnie odnosili się do propozycji wprowadzenia takiej procedury głosowania (w badaniach przeprowadzonych $2001 \mathrm{r}$. popierało ją 66\% użytkowników internetu ${ }^{43}$ ).

Pierwszy, szeroki pilotaż miał miejsce w Wielkiej Brytanii w maju 2002 r., kiedy to w 30 wybranych okręgach wyborczych w różnych częściach kraju blisko 2,5 mln wyborców mogło skorzystać z nowych procedur głosowania. W 16 z nich przewidziano możliwość oddawania głosu drogą elektroniczną ${ }^{44}$. Warto podkreślić, że zaplanowano stosowanie różnych „pakietów” nowych procedur obok głosowania za pomocą internetu wyborcy brytyjscy w niektórych okręgach mogli głosować za pomocą telefonu komórkowego, kiosku itp. Całkowity budżet projektu w 2002 r. wyniósł 4,1 mln funtów ${ }^{45}$.

W 2003 r. przeprowadzono łącznie głosowania pilotażowe w 59 gminach, z których w 18 umożliwiano zagłosowanie z użyciem procedur elektronicznych (budżet przedsięwzięcia wynosił 18,5 mln funtów).

W konkluzjach raportu z pilotażowego wdrażania głosowania z wykorzystaniem internetu w Wielkiej Brytanii wskazano, że grupa wyborców, którzy nie biorą udziału w wyborach $\mathrm{z}$ powodu niedostosowania procedur głosowania do ich potrzeb i różnych barier instytucjonalnych głosowania, jest niewielka ${ }^{46}$. Dzieje się tak m.in. $\mathrm{z}$ uwagi na wachlarz innych alternatywnych procedur, które są dla nich dostępne. Jak zauważyła Pippa Norris: E-voting powinien być rozumiany jako analogiczne ułatwienie głosowania, jak głosowanie korespondencyjne ${ }^{47}$. Procedura głosowania elektronicznego miała być natomiast poprzez nowoczesną, atrakcyjną formułę adresowana przede wszystkim do osób, które z własnej woli nie głosują (np. młodych wyborców), i je zaktywizować. Ostatecznie jednak tego celu nie osiągnięto: $z$ powodu występowania innych czynników wpływających na

42 United Kingdom of Great Britain and Northern Ireland General Election, OSCE/ ODIHR Election Assessment Mission Report, Warsaw 2010; J. Zbieranek, Alternatywne procedury głosowania, op. cit., s. 49.

43 The implementation of electronic voting in the UK. Research summary, London 2002, s. 5.

44 Elections Canada, A Comparative Assessment of Electronic Voting, Part IV: European Trials, http://www.elections.ca/content.aspx? section=res\&dir=rec/tech/ivote/comp\& document=euro\&lang=e [dostęp 12 października 2017 r.].

45 Ibidem.

46 The implementation of electronic voting in the UK, op. cit., s. 5.

47 P. Norris, E-voting as a magic ballot?, op. cit., s. 1. 
brak uczestnictwa $w$ wyborach - np. rozpowszechnionej postawy kwestionujacej obowiązek obywatelski zwiazany $z$ udziałem $w$ wyborach ${ }^{48}$. Konkludując, stwierdzono, że: e-voting samodzielnie jest niezdolny do wplywania na większy stopień zaangażowania $w$ demokracje $e^{49}$. Wnioski te bardzo mocno rozczarowały reformatorów, podważając cele i zakładane funkcje nowych procedur ${ }^{50}$.

Kolejny pilotaż przeprowadzono w 2007 r. w wyborach samorządowych (możliwość głosowania $\mathrm{z}$ zastosowaniem internetu przewidziano $\mathrm{w}$ pięciu jednostkach samorządu). Pozwolił on na zebranie ważnych spostrzeżeń dotyczących m.in. wpływu samej konstrukcji procedury na korzystanie z niej przez wyborców. Zasady głosowania elektronicznego w poszczególnych gminach różniły się $\mathrm{w}$ wielu szczegółach. W analizie funkcjonowania procedury zwrócono uwagę na dzień oddawania głosu przez wyborcę w ramach i-votingu. W gminach, w których możliwe było oddawanie głosu zdalnie tylko w okresie poprzedzającym wybory $\mathrm{z}$ wykluczeniem jednak samego dnia wyborów, blisko dwukrotnie mniej wyborców $(3,4-8,5 \%$ ogółu) skorzystało z tej procedury niż w miejscowościach, w których taka możliwość była dostępna również w dniu wyborów (16,3-17,7\%). Okazało się też, że w gminach, gdzie głosowanie elektroniczne było zabronione w dzień wyborów - wielu wyborców, mimo deklaracji, nie skorzystało z tej metody w ogóle, natomiast (co było możliwe) stawiali się wówczas w lokalu wyborczym i brali udział w „klasycznej” procedurze oddawania głosu.

Warto przywołać przykład głosowania pilotażowego do Rady Miejskiej w Sheffield. Wyborcy mogli skorzystać z procedury $i$-voting $u$ w okresie czterech dni przed dniem wyborów (jako rodzaj głosowania przedterminowego). Aby skorzystać z niej, wyborca był zobowiązany do zgłoszenia takiego zamiaru w urzędzie miasta. Każdy wyborca otrzymał z odpowiednim wyprzedzeniem urzędowe pismo wraz z opisem procedury głosowania elektronicznego oraz szablonem formularza zgłoszeniowego. Formularz, zawierający m.in. wybrany kod i podpis wyborcy, był następnie weryfikowany. W dalszym kroku wyborca otrzymywał unikalny numer identyfikacyjny (VIN) ${ }^{51}$. Głosujący przez internet logował się do portalu, używając wybranego wcześniej kodu, daty urodzenia oraz numeru VIN i dokonywał wyboru swojej preferencji. Była ona jeszcze raz potwierdzana (wyborca mógł skorygować swój wybór), a następnie procedura kończyła się. Szyfrowany głos był autoryzowany przez urzędnika wyborczego i ostatecznie zliczony wraz z innymi głosami w dzień wyborów.

Warto podkreślić, że obok $i$-votingu $\mathrm{w}$ ramach omawianego pilotażu stosowana była również procedura głosowania $\mathrm{z}$ wykorzystaniem telefonu komór-

48 Ibidem, s. 4.

49 Ibidem.

50 P. Norris, Will new technology boots turnout?, op. cit., s. 46.

51 The Electoral Commission, Electoral pilot scheme evaluation. Sheffield City Council. August 2007 electoral pilot schemes, London 2008, s. 9. 
kowego. Wyborca mógł wybrać jedną z tych procedur, a z uwagi na ich podobieństwo (wchodziły w zakres głosowania elektronicznego - zdalnego), były one statystycznie - przedstawiane łącznie. Podsumowując przeprowadzony pilotaż, podkreślano, że spośród osób głosujących elektronicznie zdalnie zdecydowana większość skorzystała z głosowania przez internet, natomiast tylko co piąty z telefonu komórkowego. Łącznie jednak procedury elektroniczne nie spotkały się z większym zainteresowaniem wyborców. Na 374328 uprawnionych skutecznie skorzystało $\mathrm{z}$ nich 4621 osób $^{52}$, a więc 1,23\% uprawnionych (3,43\% spośród biorących udział w głosowaniu).

Koszt pilotażu, który został przeprowadzony w Sheffield, wyniósł ponad 760 tys. funtów (wliczając w to wszelkie wydatki, także kampanię informacyjną). $\mathrm{Na}$ jednego wyborcę uprawnionego do głosowania koszt więc wyniósł 1, 83 funta, ale w innym ujęciu - każdy głos oddany drogą elektroniczną kosztował ponad 147 funty $^{53}$.

Kompleksowa analiza wszystkich pilotaży przeprowadzonych w 2007 r. wykazała, że liczba wyborców, którzy skutecznie skorzystali z procedury $i$-votingu, była relatywnie niewielka. Podobnie jak we wcześniejszych projektach wskazano w konkluzjach Electoral Commission, że nie jest możliwe ustalenie rzeczywistego wpływu nowej procedury na wzrost uczestnictwa wyborców w głosowaniu ${ }^{54}$. Z przeprowadzonych w poszczególnych gminach badań opinii publicznej wynikało, że zdecydowana większość użytkowników i-votingu na pewno głosowałaby nawet, gdyby tej procedury nie było ${ }^{55}$. Natomiast wśród wyborców, którzy skorzystali z nowych rozwiązań, pozytywnie oceniła je przeważająca większość (87\%). Uznano ją za prostą i deklarowano zamiar korzystania z niej w kolejnych wyborach. Wyniki te wprost korespondują z ustaleniami badaczy, że powszechne alternatywne procedury mają niewielki wpływ na pozyskiwanie nowych wyborców spośród tych, którzy z własnej woli (z przeróżnych przyczyn) rezygnują z udziału w wyborach ${ }^{56}$. Stanowią więc li tylko dodatkową możliwość oddawania głosu dla wyborców, którzy i tak by głosowali (czyli tzw. przekonanych).

Procedura głosowania z wykorzystaniem internetu budziła jednak bardzo poważne obawy związane z jej bezpieczeństwem, szczególnie w kontekście gwarantowania zasady tajności głosowania. Wskazywano na liczne poważne niedoskonałości - m.in. w zakresie przejrzystości liczenia głosów ${ }^{57}$. Brak skutecznych

52 Początkowo zamiar taki zgłosiło 13642 wyborców, z których przeważająca większość zagłosowała jednak tradycyjnie.

53 Electoral Commission, Electoral pilot scheme evaluation, op. cit., s. 27-28.

54 Electoral Commission, Electronic voting. May 2007 electoral pilot schemes. Summary, London 2008, s. 5.

55 Ibidem, s. 4.

56 R.M. Stein, G. Vonnahme, Engaging the unengaged voter: vote centers and voter turnout, Rice University, 2007, s. 20.

57 Elections Canada, A Comparative Assessment of Electronic Voting, op. cit. 
gwarancji bezpieczeństwa spowodował też znaczne zmniejszenie liczby gmin, które wyraziły zamiar uczestniczenia w pilotażu w 2007 r. Przygotowywanie różnych nowych procedur głosowania w tym samym czasie uniemożliwiło przeprowadzenie odpowiednio wcześniej testów oprogramowania itp. związanych $\mathrm{z} i$-votingiem. System nie działał właściwie, co spowodowało wystąpienie nieprawidłowości oraz błędów. Ostatecznie działania pilotażowe zostały po wyborach w 2007 r. zawieszone przez Electoral Commission, a w 2008 r. rząd brytyjski ogłosił wycofanie się z planów wprowadzenia głosowania z wykorzystaniem internetu.

\section{Przykłady państw stosujących i-voting}

\section{- Szwajcaria}

Szwajcaria jest federacją składającą się z kantonów, a każdy z nich ustanawia własne regulacje dotyczące procedur wyborczych. Warto podkreślić, że obywatele tego państwa mają możliwości udziału w wyborach lub referendach nawet kilka razy w roku (najczęściej jest ich od czterech do sześciu). Szwajcaria ma bardzo duże wieloletnie doświadczenie we wprowadzeniu alternatywnych procedur głosowania. Już w połowie XX wieku niektóre kantony dopuściły do prawa wyborczego możliwość głosowania korespondencyjnego ${ }^{58}$. Zostały nią początkowo objęte ściśle określone grupy obywateli, których uznawano za mających poważne trudności w realizowaniu swoich praw wyborczych (m.in. osoby z niepełnosprawnościami). Z czasem, po pozytywnych doświadczeniach z zastosowaniem procedury w praktyce, rozszerzono możliwość głosowania korespondencyjnego, adresując procedurę do wszystkich wyborców. Ostatecznie do 2005 r. każdy kanton w Szwajcarii wprowadził możliwość głosowania korespondencyjnego przez wszystkich wyborców bez konieczności zgłaszania uprzednio takiego zamiaru (przesyłki z materiałami wyborczymi przesyłane są automatycznie). Wdrożenie procedury głosowania korespondencyjnego było więc etapowe, rozłożone na wiele lat, co skutkowało jej niezawodnością, zaufaniem społecznym oraz bardzo dużą popularnością (korzysta z niej około $85 \%$ głosujących) ${ }^{59}$. Należy jednak wyraźnie podkreślić, że mimo dużych oczekiwań towarzyszących upowszechnianiu głosowania korespondencyjnego w kantonach - zastosowanie nowej procedury nie przełożyło się na istotne zwiększenie frekwencji wyborczej ${ }^{60}$.

Niejako naturalną kontynuacją rozwoju alternatywnych procedur głosowania w Szwajcarii było podjęcie w drugiej połowie lat 90. ubiegłego wieku prac

58 Szersza analiza zob. J. Zbieranek, Alternatywne procedury głosowania, op. cit., s. 40-42.

59 Swiss Confederation Federal Assembly Elections, 23 October 2011, OSCE/ODIHR Election Assessment Mission Report, Warsaw 2011, s. 13-15.

60 P. Funk, Modern voting tools, social incentives and voter turnout: theory and evidence, Working paper, Barcelona 2006, s. 32; J. Zbieranek, Alternatywne procedury głosowania, op. cit., s. 42. 
koncepcyjnych mających na celu wprowadzenie do prawa wyborczego mechanizmów głosowania za pomocą internetu. Od 1998 r. przygotowywano projekty umożliwiające w ten sposób głosowanie zdalne. W działaniach tych prym wiodły władze trzech kantonów (Genewa ${ }^{61}$, Zurych ${ }^{62}$ i Neuchatel ${ }^{63}$ ), z czasem zostały one nazwane kantonami „założycielskimi” - swoistymi pionierami i-votingu w Szwajcarii. W kantonach tych przeprowadzano liczne testy i działania pilotażowe. Warto podkreślić, że dotyczyły one zarówno wyborów, jak i referendów (pierwszy pilotaż głosowania internetowego został przeprowadzony w Anieres/ kanton Genewa w 2003 r. właśnie przy okazji referendum lokalnego ${ }^{64}$. Z czasem wyróżnione zostały modele $i$-votingu stosowane w tych kantonach ${ }^{65}$, gdzie kanton Neuchatel charakteryzuje „przyłączenie” procedury głosowania do szerszego portalu usług administracji elektronicznej (niektórzy polscy autorzy porównują go do polskiego e-Puapu ${ }^{66}$ ). Natomiast rozwiązania wypracowane w kantonach Genewa i Zurych są podobne i zakładają możliwość korzystania przez wyborcę z osobnej aplikacji do głosowania stosowanej z bezpośrednim wykorzystaniem przeglądarki internetowej. Taka różnorodność systemów stanowi charakterystykę $i$-votingu w Szwajcarii. Z czasem rozpoczęto rozważania nad upowszechnieniem nowej procedury w innych kantonach, a także w skali całego państwa. Liderem i koordynatorem prac na poziomie ogólnokrajowym jest Kancelaria Federalna, a w badania włączona została m.in. Politechnika Berneńska, zapewniająca projektowi $i$-votingu wsparcie eksperckie. Stopniowo liczba kantonów zaangażowanych w projekt powiększała się. Jak zauważono w raporcie z obserwacji wyborów federalnych przygotowanym przez OBWE w 2012 r., projekt wdrażania i-votingu jest w Szwajcarii realizowany powoli, etapami (step-by-step) $)^{67}$, a jednocześnie konsekwentnie i rozważnie ${ }^{68}$. Co warte podkreślenia, założono, że wprowadzanie $i$-votingu jest zarówno projektem technologicznym, jak i społecznym $^{69}$, dlatego zaangażowani w jego przygotowanie zostali także m.in. eksperci

${ }_{61}$ Szerzej zob. M. Chevallier, The Geneva Internet voting system, Geneva 2011.

62 G.E.G. Beroggi, E-voting through the Internet and with mobile phones, Zurich 2009, http://unpan1.un.org/intradoc/groups/public/documents/unpan/unpan030950.pdf [dostęp 12 października $2017 \mathrm{r}$.].

63 A. Trechsel, E-voting and electoral participation [w:] Dynamics of Referendum Campaigns - An International Perspective, red. C. de Vreese, London 2007, s. 159.

65 Ibidem.

66 Szerzej zob. J. Rzucidło, Referendum w obliczu głosowania, op. cit.

67 M. Solvak, K. Vassil, E-voting in Estonia: Technological Diffusion and Other Developments Over Ten Years (2005-2015), University of Tartu \& Estonian National Electoral Committee, Tartu 2016, s. 48.

68 Swiss Confederation Federal Assembly Elections, 23 October 2011, OSCE/ODIHR Election Assessment Mission Report, Warszawa 2011, s. 15.

69 Szerzej zob. J. Zbieranek, Alternatywne procedury głosowania, op. cit., s. 57-58. 
z dziedziny nauk społecznych z Uniwersytetu w Genewie. W ramach projektu prowadzone są rozbudowane i wielopłaszczyznowe badania nad głosowaniem elektronicznym, przygotowano analizy socjologiczne (dotyczące zaufania obywateli do nowej procedury) i prawnych. We wnioskach do tych analiz podkreślano konieczność rozłożenia (podobnie jak w przypadku procedury głosowania korespondencyjnego) procesu wdrażania $i$-votingu na lata, przygotowanie kilkunastoletniego planu działań i konsekwentne jego realizowanie.

Początkowo planowano w toku reform podejmowanych w Szwajcarii zastąpienie głosowania korespondencyjnego przez elektroniczne. Takie rozwiązanie miało, wykorzystując nowoczesną formułę, stanowić dodatkowy impuls dla aktywizacji wyborców i spowodować zwiększenia frekwencji wśród Szwajcarów, szczególnie zaś aktywizować i włączać w procesy decyzyjne młodych wyborców $^{70}$. Minister spraw wewnętrznych kantonu Zurych Markus Notler podkreślał w kontekście prac nad i-votingiem: to kamień milowy w szwajcarskiej demokracji, otwarcie wyborów dla dzisiejszego społeczeństwa informacyjnego ${ }^{71}$. Z czasem jednak skorygowano ten pogląd, biorąc pod uwagę ówczesne doświadczenia z zastosowania w Szwajcarii powszechnego głosowania korespondencyjnego, które, podobnie jak w innych państwach, wykazały, że alternatywne procedury głosowania nie mają większego wpływu na frekwencję wyborczą ${ }^{72}$. W nowym ujęciu uznano, że głównym celem działań zmierzających do wprowadzenia głosowania elektronicznego jest zwiększenie wygody wyborców. Po analizach i pilotażach uznano, że nowa procedura powinna wzmocnić w szczególności te sfery głosowania, w których wyborcy wciąż napotykają problemy techniczne i organizacyjne. Dlatego uznano, że priorytetem w pierwszym etapie działań będzie umożliwienie korzystania z procedury głosowania elektronicznego Szwajcarom zamieszkałym poza granicami kraju, gdzie istnieją poważne bariery techniczne w korzystaniu z głosowania korespondencyjnego.

Analizując przykład Szwajcarii, należy zwrócić szczególną uwagę na problematykę zastosowania i-votingu w wyborach federalnych do Rady Państwa (Narodu). Trzeba podkreślić, że już w 2002 r. została zmieniona szwajcarska federalna ustawa o prawach politycznych, w której wprowadzono przepisy umożliwiające poszczególnym kantonom przeprowadzanie pilotażowego i-votingu za zgodą Rady Federalnej w wyborach federalnych. Wskazano również ważne zastrzeżenie, zgodnie z którym $\mathrm{w}$ projekcie pilotażowym nie może uczestniczyć więcej niż $10 \%$ uprawnionych wyborców. Regulacja formułowała liczne kwestie związane $\mathrm{z}$ weryfikacją wyborcy, zapewnieniem tajności głosowania (szyfrowaniem danych itp.), a także bezpieczeństwem systemu informatycznego. Jak jednak

70 E.G. Beroggi, E-voting through the Internet and with mobile phones, op. cit., s. 1.

71 M. Chevallier, Internet Voting, turnout and deliberation: a study, „Electronic Journal of e-Government" 2009, vol. 7, No. 1, s. 34.

72 Szerzej zob. J. Zbieranek, Alternatywne procedury głosowania, op. cit., s. 57-58. 
zauważyło w swoich raportach OBWE ${ }^{73}$, w aktach prawnych zabrakło ważnych kwestii związanych ze standardami prowadzenia pilotaży, a niektóre rozwiązanie były fragmentaryczne.

Władze czterech kantonów przygotowały w wyborach federalnych $2011 \mathrm{r}$. pilotaż skierowany wyłącznie do swoich wyborców, którzy przebywają poza granicami kraju. Trzeba podkreślić, że kantony te zmieniały przed pilotażem poszczególne regulacje wyborcze, jednak wciąż nie zawarły w nich szczegółowych regulacji dotyczących procedur $i$-votingu, co zostało podkreślone przez OBWE $\mathrm{w}$ raporcie $\mathrm{z}$ obserwacji $\mathrm{i}^{74}$.

Należy zauważyć, że w omawianym pilotażowym głosowaniu zastosowano równocześnie dwa odmienne systemy zarządzania głosowaniem przez internet. Jeden z nich był zarządzany przez firmę prywatną (zastosowały go trzy kantony), jeden natomiast był zarządzany bezpośrednio przez instytucję publiczną - kanton „pionierski” Genewa (i był on oparty na wspomnianym wcześniej modelu).

Ustalono, że wyborcy będą mieć dostęp do systemu głosowania elektronicznego przez swoje osobiste komputery, z wykorzystaniem przeglądarki internetowej i dostępu do publicznego internetu. Co ważne, do skutecznego oddania głosu w procedurze $i$-votingu, w celu identyfikacji wyborcy niezbędne było wprowadzenie kodu, który był wysyłany do wyborcy wcześniej - tradycyjną pocztą. System umożliwiał oddanie głosu przez cztery tygodnie przed dniem wyborów (był więc głosowaniem przedterminowym). Należy podkreślić, że wyborca po oddaniu głosu nie mógł go już zmienić (odmiennie od rozwiązania norweskiego), system uniemożliwiał również oddanie głosu nieważnego (także intencjonalnie). Wyborcy mieli możliwość sprawdzenia poprawność oddania głosu (preferencji), ale podobnie jak w procedurze głosowania korespondencyjnego nie mieli możliwości uzyskania pełnego potwierdzenia, czy ich głos został skutecznie zliczony i wzięty pod uwagę przy ustalaniu końcowych wyników wyborów.

Ostatecznie w pilotażu przeprowadzonym w trakcie wyborów 2011 r. spośród ponad 22000 uprawnionych do głosowania wyborców przebywających poza granicami kraju zagłosowała $\mathrm{z}$ wykorzystaniem internetu blisko połowa ${ }^{75}$ (inni wyborcy głosowali korespondencyjnie). Jak już zostało wspomniane, wybory te, w szczególności w kontekście głosowania elektronicznego, były monitorowane przez Misję OBWE, która pozytywnie oceniła przedsięwzięcie. Doświadczenia

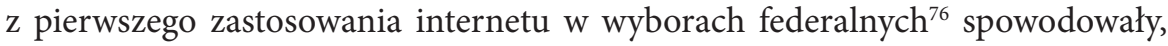
że postanowiono kontynuować rozwój tej procedury. Skorygowano priorytety,

73 Swiss Confederation Federal Assembly Elections, 23 October 2011, op. cit., s. 13-15.

74 Szerzej zob. J. Zbieranek, Alternatywne procedury głosowania, op. cit., s. 57-58.

75 Swiss Confederation Federal Assembly Elections, 23 October 2011, op. cit., s. 15-16.

76 Warto podkreślić, że do października 2015 r. w 12 kantonach przeprowadzano łącznie 229 testów i pilotaży o charakterze lokalnym - w odniesieniu do wyborów i referendów, Swiss Confederation Federal Assembly Elections, 18 October 2015, OSCE/ODIHR Election Expert Team Final Report, s. 3. 
ustalając, że i-voting nadal będzie kierowany do grupy wyborców przebywających poza granicami kraju, ale docelowo rozważone zostanie wprowadzenie w poszczególnych kantonach jako procedury powszechnej, dla wszystkich wyborców, równolegle z procedurą głosowania korespondencyjnego.

W kolejnych wyborach o charakterze federalnym, które odbyły się 18 października 2015 r., zgodnie z powyższymi założeniami przygotowano następny pilotaż. W jego ramach uprawnionymi do oddania głosu przez internet byli wszyscy wyborcy z czterech kantonów przebywający poza granicami kraju (34 293 osoby), a także ograniczona liczba wyborców z dwóch - spośród czterech - kantonów, którzy przebywali w kraju (97 841 wyborców). Należy zauważyć, że w odpowiedzi na rekomendacje OBWE poważnie rozbudowano regulacje dotyczące zasad głosowania przez internet. W szczególności został przyjęty dekret o głosowaniu elektronicznym regulujący kwestie związane $\mathrm{z}$ tajnością głosowania, w tym: wymogi bezpieczeństwa, audyt, a także zasady odpowiedzialności osób zaangażowanych $\mathrm{w}$ organizację wyborów, jak również zadania związane m.in. z edukacją wyborców.

Ostatecznie z liczby 132134 wyborców uprawnionych do głosowania przez internet (łącznie uprawnionych było do głosowania 5283556 obywateli), głos oddało 13370 osób (a więc około 10\%). Odsetek korzystających z i-votingu różnił się w poszczególnych kantonach i wahał się od 7\% uprawnionych w kantonie Genewa do $18 \%$ w kantonie Lucerna ${ }^{77}$.

Techniczne aspekty oddawania głosów były bardzo zbliżone do obowiązujących w wyborach w $2011 \mathrm{r}$. W szczególności wyborcy nie mogli oddawać głosu nieważnego ani zmieniać preferencji już po oddaniu głosu. Możliwe było sprawdzenie, czy system właściwie go zapisał. Wciąż jednak nie było możliwości pełnego zweryfikowania przez wyborcę, czy jego głos został skutecznie wzięty pod uwagę $\mathrm{w}$ trakcie ostatecznego ustalania wyników wyborów. Zmiana tego stanu rzeczy i wprowadzenie technicznej możliwości weryfikacji skuteczności oddania głosu za pomocą i-votingu stanowi jeden z najważniejszych postulatów zgłaszanych przez władze kantonów po zakończeniu głosowania 2015 r. i uwzględnionych w planach na lata $2016-2017^{78}$.

Warto poruszyć również kwestie kosztów związanych z wdrażaniem e-votin$g u$. W literaturze przedmiotu wskazuje się, że jest on wysoki i obejmuje m.in. zbudowanie i utrzymanie całej infrastruktury, a także zatrudnienie wysoko wyspecjalizowanych ekspertów do jej obsługi. Dla przykładu można podać, że przygotowanie pierwszych pilotażowych głosowań tylko w kantonie Zurych w latach 2004-2006 kosztowało 7,9 mln franków szwajcarskich, a każda gmina, która włączyła się do programu, musiała liczyć się z kosztem $0,5 \mathrm{mln}$ franków. Dodatkowo obsługa systemu w okresie pilotaży wiązała się z kosztem 3,2 mln franków,

77 Ibidem.

78 Ibidem. 
co oznaczało łączny koszt 11,2 mln franków ${ }^{79}$. Koszty są w poszczególnych kantonach zróżnicowane - zależą m.in. od tego, czy wypracowują swój model, czy też korzystają z już wypracowanych (a więc wykupują licencję). Szacowany koszt wdrożenia procedury $i$-votingu w całej Szwajcarii na tej podstawie wstępnie szacowano na od 400 do 600 mln franków szwajcarskich ${ }^{80}$.

Z informacji uzyskanych z Kancelarii Federalnej wynika, że w latach 20002005 Kancelaria przekazała na rozwój projektu i-votingu 7,5 mln franków, a w latach 2006-2012 - 2,5 $\mathrm{mln}^{81}$.

Wdrażanie $i$-votingu w Szwajcarii jest obecnie oceniane pozytywnie, podkreślane jest stopniowe, ale konsekwentne rozwijanie tej procedury. Efekty są uznawane za bardzo obiecujące ${ }^{82}$.

- Estonia

Władze Estonii od lat intensywnie i konsekwentnie rozwijały szeroki pakiet e-usług i e-administracji, oferując obywatelom cały wachlarz usług publicznych świadczonych drogą elektroniczną. Jednocześnie podjęto starania na rzecz upowszechnienia dostępu do sieci internetowej wśród obywateli oraz o zaopatrzenie ich w instrumentarium techniczne, które umożliwia korzystanie z usług elektronicznej administracji ${ }^{83}$. Prowadzono również liczne akcje i projekty społeczne, które miały zachęcać do korzystania z narzędzi elektronicznych w życiu publicznym i systematycznie budowano zaufanie do procedur realizowanych za pośrednictwem internetu ${ }^{84}$. Działania te okazały się niewątpliwie skuteczne - jako przykład można podać, że już w 2005 r. blisko 75\% obywateli Estonii złożyło swoje zeznanie podatkowe drogą elektroniczną ${ }^{85}$. Wzrastało społeczne oczekiwanie na wprowadzenie procedury głosowania elektronicznego. Zgodnie z badaniami opinii publicznej przeprowadzonymi w 2004 r. zwolennikami głosowania przez internet było 64\%, a w 2005 r. już 73\% ankietowanych ${ }^{86}$.

79 B. Giampiero, P. Moser D. Bierer, Evaluation der EVoting Testphase im Kanton Zürich 2008-2011, 2011 [za:] E-Voting in Switzerland, University Fribourg paper, 2012, s. 24-25. E-Voting kostet bis zu 600 Millionen Franken, https://www.swissinfo.ch/ger/e-voting-kostet-bis-zu-600-millionen-franken/596492 [dostęp 19 października 2017 r.]. Korespondencja autora z Kancelarią Federalną (mail z 20 października 2017 r.).

82 A. Trechsel, Potential and challenges of E-Voting in the European Union, op. cit., s. 27.

83 Szerzej zob. http://merlin.obs.coe.int/iris/2000/5/article21.en.html [dostęp 12 października 2017 r.].

84 A. Hildebrandt, Estonia - informatyczny tygrys Europy, „Pomorski Przegląd Gospodarczy" 2008, nr 1 (36), http://www.ppg.gda.pl/index.php/pol/wydawnictwo/okno_ na_swiat/estonia_informatyczny_tygrys_europy [dostęp 13 października 2017 r.]. D. Boshel, Can Internet voting increase participation?, op. cit., s. 2.

86 Internet Voting at the Elections of Local Government Councils on October 2005, Tallin 2005, s. 24-26. 
Dysponując rozwiniętą infrastrukturą techniczną, postanowiono wprowadzić narzędzia elektroniczne również do procedury wyborczej. Na początku XXI wieku rozpoczęto prace nad powszechnym głosowaniem elektronicznym, które docelowo miało być skierowane do ogółu wyborców. Do 2005 r. w toku licznych działań, testów oraz konsultacji opracowano dokładne założenia i procedury $i$-votingu. Warto podkreślić, że w ramach prac przygotowawczych założono wykorzystanie wdrożonych dla większości obywateli Estonii dokumentów tożsamości, które umożliwiały ich pełną weryfikację (konieczny był czytnik). Dodatkowo, w późniejszym okresie możliwe było użytkowanie odpowiednika takiego dokumentu w formie karty SIM (w formacie umożliwiającym zastosowanie jej w telefonie komórkowym, który stawał się przez to jednocześnie dowodem osobistym i czytnikiem kart) ${ }^{87}$. Koszty są trudne do oszacowania (ponieważ składają się na nie koszty pośrednie i bezpośrednie). Ocenia się, że około 50-60 tys. euro wynosić ma każdorazowy koszt unowocześnienia systemu przed wyborami ${ }^{88}$, a w latach 2005-2017 na działania związane bezpośrednio z i-votingiem przekazane zostało około $1 \mathrm{mln}$ euro ${ }^{89}$.

Ustalono, że każdy wyborca jest zobowiązany do pobrania na swój komputer aplikacji, dzięki której może elektronicznie oddać swój szyfrowany głos. Przewiduje się również wykorzystanie serwerów dedykowanych operacjom przekazywania głosów, a także ich magazynowania. Ważnym elementem systemu i-votingu jest również aplikacja mająca na celu zliczenie głosów oddanych drogą elektroniczną. Warto podkreślić, że przewiduje się podwójne szyfrowanie głosów - na podstawie klucza prywatnego (wykorzystywanego w procedurze obliczania głosów) i publicznego. Po odbiorze przez komisję wyborczą przesłanej drogą elektroniczną karty wyborczej podpis elektroniczny jest usuwany.

Od 2011 r. procedura głosowania elektronicznego przewiduje, że wyborca powinien pobrać specjalną aplikację ze strony internetowej Komisji Wyborczej. Koniecznym krokiem jest również umieszczenie dokumentu tożsamości w czytniku kart podłączonym do komputera ${ }^{90}$, a także wpisanie osobistego numeru identyfikacyjnego (PIN). W kolejnym etapie możliwy jest wybór właściwego kandydata, co jest autoryzowane wprowadzeniem kolejnego kodu PIN. W toku

87 Estonia Parliamentary Elections, 1 March 2015, OSCE/ODIHR Election Experts Team Report, Warszawa 2016, s. 3.

88 S. Pârvu, Paper vs Internet: is electronic voting a solution for Romania, marzec 2015 r., s. 5.

89 Korespondencja autora z Państwowym Biurem Wyborczym Estonii (mail z 27 października 2017 r.).

90 Początkowo czytnik taki musiał zakupić wyborca we własny zakresie (koszt to równowartość około 20 dolarów US) lub korzystać z czytników umieszczonych w urzędach, publicznych bibliotekach. Wraz z wprowadzeniem kart - czytnikami stać się mogły np. telefony komórkowe, Feasibility study on Internet Voting for the Central Electoral Commission of the Republic of Moldova, Chisinau 2016, s. 11. 
dalszych operacji podpis elektroniczny rozpatrywany jest osobno w odniesieniu do wskazanej przez wyborcę preferencji (które są zliczane przy ustalaniu wyników wyborów). Mechanizm ten zapewniający anonimowość wyboru na-

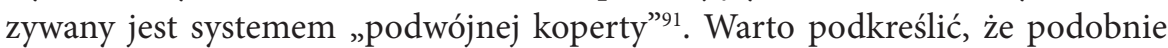
jak w przypadku rozwiązań stosowanych w Norwegii, wyborca, który dysponuje kilkoma dniami na oddanie głosu, może jeszcze zmienić swoją preferencję (oddając kolejny raz głos za pomocą internetu, ale również głosując w lokalu wyborczym $)^{92}$.

Podczas wyborów lokalnych w 2005 r., kiedy to po raz pierwszy Estończycy mieli możliwość zagłosowania za pomocą internetu, z nowej procedury skorzystało 9317 wyborców, co stanowiło 0,9\% wszystkich uprawnionych do głosowania. Jednak w kolejnych wyborach liczba osób głosujących elektronicznie stale rośnie. W wyborach parlamentarnych 2007 r. było to 30275 (3,4\% uprawnionych wyborców); w wyborach do Parlamentu Europejskiego 2009 r. - 58669 (6,5\%); w wyborach samorządowych 2009 r. - 100413 (9,5\%); w wyborach parlamentarnych 2011 r. - 140846 (15,4\%); w wyborach lokalnych 2013 r. - 133808 (12,3\%); w wyborach do Parlamentu Europejskiego - 103151 (11,4\%); wyborach parlamentarnych 2015 r. - $176491(19,6 \%)^{93}$.

Warto zauważyć, że w Estonii stosowane są od lat alternatywne procedury głosowania kierowane do konkretnych grup obywateli, którzy tradycyjnie uważani są za napotykających trudności w dotarciu do lokali wyborczych. Procedury te stanowią w tym kontekście konieczne gwarancje wypełniania zasady powszechności wyborów. Jako przykład można podać, że głosowanie z wykorzystaniem mobilnej urny wyborczej jest adresowane do wąskiego, ściśle określonego kręgu wyborców - osób, które z powodu stanu zdrowia, wieku bądź niemożności dotarcia do lokalu z innych przyczyn wnioskują o głosowanie w domu. Wyborcy przebywający poza granicami Estonii mają możliwość głosowania (oprócz osobi-

91 Ibidem, s. 4. Szerzej zob. J. Rzucidło, Referendum w obliczu głosowania, op. cit.

92 Kwestia ta była przedmiotem kontrowersji w kontekście zasady równości. Ostatecznie wypowiedział się Sąd Najwyższy, który stwierdził, że wyborcy tacy nie są w lepszej, nierównej sytuacji względem innych wyborców, bowiem nadal mają oni do dyspozycji jeden głos. Warto podkreślić, że Sąd Najwyższy przywołał w tym zakresie (wspomniane już) Zalecenia Komitetu Ministrów dla państw członkowskich w sprawie prawnych, praktycznych i technicznych standardów głosowania elektronicznego, z których wynika, że techniczne kwestie głosowania elektronicznego i „tradycyjnego" w lokalu wyborczym nie muszą być przy tym takie same. Więcej zob. M. Więcek, Estonia: wyrok Sądu Najwyższego Republiki Estonii (Izba Kontroli Konstytucyjności) z dnia 1 września 2005 r. dotyczący problemów związanych $z$ głosowaniem $w$ wyborach za pośrednictwem Internetu (sygn. 3-4-1-13-05), „Przegląd Sejmowy” 2008, nr 2, s. 325-330; M. Rulka, Orzecznictwo dotyczące konstytucyjności regulacji umożliwiajacych głosowanie elektroniczne (Niemcy, Austria, Estonia, Indie), „Przegląd Sejmowy” 2015, nr 6, s. 217-228.

93 S. Pârvu, Paper vs Internet, op. cit., s. 4-5. 
stego w lokalu wyborczym utworzonym w placówce dyplomatycznej) również za pomocą poczty. Dodatkowo wyborcy mogą skorzystać z trybu głosowania osobistego przedterminowego - we wskazanych punktach wyborczych ${ }^{94}$.

Wprowadzenie powszechnie dostępnego głosowania elektronicznego zdalnego stanowiło nową ofertę i zmianę przede wszystkim dla grup wyborców nieobjętych jeszcze dotychczas wdrożonymi alternatywnymi procedurami. W Estonii dokonano tym samym ważnego kroku, w istotny sposób liberalizując kryteria i adresując nową procedurę do każdego wyborcy, bez względu na przyczynę korzystania z niej.

W przeżywającej kryzys uczestnictwa w wyborach Europie i wielu państwach na całym świecie zaczęto bacznie obserwować i rozpatrywać doświadczenia estońskie w kontekście zwiększania frekwencji wyborczej; podobnie przyglądano się szwajcarskim, brytyjskim i amerykańskim doświadczeniom w zakresie powszechnego stosowania głosowania korespondencyjnego. Oczekiwano, że zwiększy się uczestnictwo w wyborach szczególnie młodych obywateli.

Nowa procedura zyskała bez wątpienia w Estonii popularność i korzysta z niej coraz większa grupa wyborców.

Warto zwrócić uwagę na problematykę frekwencji wyborczej. W pierwszych i kolejnych wyborach, w których zastosowanie znalazła powszechna procedura $i$-votingu, zanotowano następujący jej poziom: w wyborach lokalnych $2005 \mathrm{r}$. frekwencja wynosiła 47,4\%; w parlamentarnych 2007 r. - 61,9\%; w wyborach do Parlamentu Europejskiego 2009 r. - 43,9\%; w wyborach lokalnych 2009 r. 60,6\%; w wyborach parlamentarnych 2011 r. - 63,5\%; w wyborach lokalnych 2013 r. - 58,0\%, w wyborach do Parlamentu Europejskiego 36,5\%; w wyborach parlamentarnych 2015 r. $-64,2 \%{ }^{95}$.

W literaturze przedmiotu pojawiają się opinie wskazujące, że zaobserwowany w Estonii relatywny wzrost frekwencji wyborczej można bezpośrednio łączyć $\mathrm{z}$ wykorzystaniem procedury $i$-voting $u^{96}$. Opierając się na rozbudowanych symulacjach, wzrost taki szacowany jest na około 2-3\% (np. szacunek dla wyborów samorządowych w 2009 r. to $2,6 \%{ }^{97}$ ). Teza o wpływie e-votingu na znaczne podwyższenie frekwencji wyborczej wydaje się trudna do udowodnienia ${ }^{98}$. Czynniki oddziałujące na frekwencję wyborczą są zbyt złożone, by wzrost wiązać można było bezpośrednio z zastosowaniem nowej techniki oddawania głosu. Jako efekt wdrożenia nowej procedury wskazuje się raczej zmianę techniki oddawania gło-

94 Estonia Parliamentary Elections, 6 March 2011, OSCE/ODIHR Election Assessment Mission Report, Warsaw 2011, s. 11-12.

95 S. Pârvu, Paper vs Internet, op. cit., s. 4-5.

96 Powszechnym błędem jest również bezpośrednie interpretowanie wzrostu frekwencji wyborczej na podstawie wyłącznie wzrostu (bezwzględnej) liczby wyborców korzystających z procedury $i$-votingu.

97 R. Verbij, Dutch E-Voting opportunities, Twerne 2014, s. 40.

98 D. Boshel, Can Internet voting increase participation?, op. cit., s. 20. 
su wśród osób, które zwykle uczestniczą w wyborach, a nie pozyskanie nowych wyborców wśród grupy wyborców dotychczas stale niegłosujących. Nowsze dane z wyborów z lat 2013 i 2015 wskazują również, że procedura nie trafiła do wyborców najmłodszych ${ }^{99}$.

Warto jednak pamiętać, że w Estonii kwestia barier organizacyjnych w dostępie obywateli do głosowania została w dużej mierze rozwiązana poprzez wachlarz innych procedur - zarówno alternatywnych, jak i oferujących wydłużony czas głosowania (głosowanie przedterminowe w lokalu wyborczym) ${ }^{100}$.

\section{- Stany Zjednoczone}

Warto poddać szerszej analizie rozwiązania przyjęte w Stanach Zjednoczonych. W każdym ze stanów procedury wyborcze regulowane są oddzielnie, co powoduje występowanie dość dużych różnic w zakresie technik oddawania głosu, ale i umożliwia zebranie różnorodnych doświadczeń z ich stosowania. Dość szeroko wykorzystywana jest procedura głosowania przedterminowego, w ramach której wyborca może oddać głos nawet na kilkadziesiąt dni przed właściwym dniem wyborów.

Należy podkreślić, że rozwiązanie umożliwiające głosowanie przedterminowe skierowane było początkowo do grup obywateli, którzy napotykali duże trudności z dotarciem do lokali wyborczych, a więc osób niepełnosprawnych, starszych, chorych bądź - w niektórych przypadkach - podróżujących w dniu wyborów. W latach 80 . XX wieku rozpoczęto stopniowe rozszerzanie kręgu osób uprawnionych do tej procedury, wprowadzając m.in. na szerszą skalę możliwość głosowania przedterminowego bez konieczności podania przez wyborcę przyczyny korzystania z tej procedury. Niektóre stany (Kansas i Washington) wprowadziły we wczesnych latach 90. ubiegłego wieku możliwość zarejestrowania się przez wyborce jako stały „wyborca przedterminowy”, co powodowało przesyłanie automatyczne materiałów pocztą przy okazji każdych kolejnych wyborów.

99 Dane za stroną Elections Canada: https://www.canada.ca/en/democratic-institutions/ services/reports/online-voting-path-forward-federal-elections.html\#toc27 [dostęp 22 października 2017 r.].

100 Przeprowadzane (m.in. przy okazji wyborów parlamentarnych 2007 r.) badania opinii społecznej wskazały, że z głosowania przez internet skorzystała m.in. grupa osób, które dzielił dość duży dystans do lokali wyborczych, a po nowej procedurze spodziewały się (i najczęściej osiągnęły) oszczędność czasu. Co ważne, grupa ta nie obejmowała wyborców spełniających przesłanki do skorzystania z innych procedur alternatywnych, a więc np. osoby obłożnie chore czy niepełnosprawne. W tym wypadku procedura doprowadzała do realnego ułatwienia i uproszczenia uczestniczenia w wyborach. Grupa ta jedna nie była liczna i stanowiła nie więcej niż około 2-3\% ogółu głosujących. Szerzej zob. M. Solvak, K. Vassil, E-voting in Estonia: Technological Diffusion, op. cit., s. 106-114; S. Pârvu, Paper vs Internet, op. cit., s. 15. 
W ramach głosowania przedterminowego w wielu stanach stosowane są procedury zdalne, w szczególności głosowanie korespondencyjne ${ }^{101}$. Rozważane jest również możliwie szerokie wykorzystanie internetu w procedurach głosowania ${ }^{102}$. Należy podkreślić, że wprowadzono już bardzo interesujące rozwiązania w tym zakresie. Przede wszystkim mają one na celu istotne usprawnienie procedur głosowania przedterminowego, zdalnego w sytuacjach, kiedy głosowanie korespondencyjne nie gwarantuje wyborcom w pełni skutecznego oddania głosu w wyznaczonym terminie. Dlatego też na mocy federalnego prawa (Uniformed and Overseas Citizens Absentee Voting Act, UOCAVA) przewiduje się możliwość przekazywania kart do głosowania z wykorzystaniem technik elektronicznego komunikowania się. Procedura taka jest przede wszystkim adresowana do członków sił zbrojnych przebywających poza granicami kraju. Rozwiązania w poszczególnych stanach różnią się, ale co do zasady przewiduje się w tej procedurze wykorzystanie e-maila (karta staje się załącznikiem w formacie pdf) lub dedykowanego portalu internetowego ${ }^{103}$. Na początku roku 2017 pięć stanów umożliwia lub umożliwiało (pilotaż) przesyłanie głosów za pomocą portalu, natomiast dwadzieścia jeden - za pomocą e-maila (lub faksu) ${ }^{104}$. Dwadzieścia pięć stanów nie przewiduje wciąż żadnej możliwości przekazywania głosu z wykorzystaniem internetu (choć spośród nich siedem dopuszcza możliwość wykorzystania faksu).

Warto podkreślić odmienny od doświadczeń europejskich kontekst opisanej wyżej procedury, która stanowi przede wszystkim techniczne uzupełnienie i rozwinięcie głosowania przedterminowego (korespondencyjnego) stosowane w wyjątkowych sytuacjach, dla ściśle ograniczonej grupy wyborców. Głosowanie $\mathrm{z}$ wykorzystaniem internetu $\mathrm{w}$ takim ujęciu nie jest więc procedurą z precyzyjnie wypracowanymi zasadami bezpieczeństwa, a raczej swobodnym, uproszczonym wykorzystaniem istniejących możliwości komunikacji. Budzi to ogromne

101 W obrębie tej procedury również badane są różne warianty. Często przywoływanym przykładem stosowania głosowania korespondencyjnego jest stan Oregon. W stanie tym już w latach 80. w niektórych lokalnych wyborach stosowano głosowanie wyłącznie za pomocą poczty (all-mail). Natomiast inne procedury były stopniowo wyłączane (w tym również głosowanie w lokalu wyborczym). Po pozytywnych rezultatach stosowania nowej procedury w ograniczonym wymiarze, w 1995 r. zdecydowano się na przeprowadzenie głosowania wyłącznie korespondencyjnego na poziomie całego stanu Oregon. Szerzej zob. J. Zbieranek, Alternatywne procedury głosowania, op. cit., s. 45.

102 Między innymi w 2000 r. przeprowadzono głosowania pilotażowe, jednak działania te nie były szerzej kontynuowane. Szerzej zob. https://www.canada.ca/en/democratic-institutions/services/reports/online-voting-path-forward-federal-elections. html\#toc27 [dostęp 14 października 2017 r.].

103 Również za pomocą faksu (należy zauważyć, że procedura ta opierać się może na wykorzystaniu sieci telefonicznej, ale także internetu).

$104 \mathrm{Http} / /$ www.ncsl.org/research/elections-and-campaigns/internet-voting.aspx [dostęp 13 października 2017 r.]. 
zastrzeżenia m.in. z uwagi na brak właściwych zabezpieczeń dla zasady tajności, możliwość ingerencji z zewnątrz w treść głosu czy też praktyczny brak możliwości weryfikacji przez wyborcę skuteczności oddania głosu ${ }^{105}$. Właśnie z powyższych przyczyn, mimo zainteresowania i testów, procedura ta przez dłuższy czas nie została wprowadzona $\mathrm{w}$ niektórych stanach, np. stanie Connecticut. Inne stany, które ją dopuszczają, wprowadziły dodatkowe ograniczenia (przebywanie wyborcy w szczególnie niebezpiecznych rejonach) lub wymogi (wysłanie również wypełnionej karty do głosowania tradycyjną pocztą).

Warto jednak przywołać przykład rozwiązań przyjętych w stanie Alaska. Z uwagi na trudności wynikające z rozproszenia wyborców i trudnych warunków naturalnych, władze stanu zdecydowały o umożliwieniu przekazywania głosów w opisany sposób wszystkim wyborcom, a nie tylko osobom objętym UOCAVA. Wprowadzono jednocześnie specjalne procedury bezpieczeństwa. Wyborca powinien w określonym terminie zgłosić zamiar głosowania przedterminowego, zdalnego właściwej komisji wyborczej, wskazując preferowany sposób przesłania swojego głosu (może to uczynić e-mailem, z wykorzystaniem portalu internetowego lub faksem). Warto podkreślić, że wyborca chcący skorzystać z portalu internetowego i oddać w ten sposób głos, musi dodatkowo wydrukować certyfikat wyborcy oraz kartę identyfikacyjną (konieczne jest również potwierdzenie przez jednego świadka). Następnie dokumenty powinny zostać zeskanowane i przesłane elektronicznie wraz z oddawanym elektronicznie głosem. Przesłany przez wyborcę głos jest przez komisję drukowany oraz dołączany do pozostałych (papierowych) głosów oddanych w danych wyborach i liczony na ogólnych warunkach.

Po wielu krytycznych komentarzach związanych z bezpieczeństwem wprowadzono nowe zabezpieczenia, a system jest poddawany stałemu monitoringowi i okresowym ocenom ${ }^{106}$.

W kilku innych stanach rozszerzono grupę wyborców, którzy są uprawnieni do oddania głosu z wykorzystaniem e-maila, m.in. na wyborców z niepełnosprawnościami $^{107}$.

\section{- Inne państwa}

Głosowanie $\mathrm{z}$ wykorzystaniem internetu opracowywano i testowano we Francji (już od 2002 r.). Przyjęto, że $i$-voting będzie stosowany jako procedura skierowana do obywateli przebywających poza granicami kraju (równocześnie z innymi procedurami głosowania- korespondencyjnym, przez pełnomocnika oraz oso-

105 Szerzej zob. N. Hastings, R. Peralta, S. Popoveniuc, A. Regenscheid, Security Considerations for Remote Electronic UOCAVA Voting, Waszyngton 2011.

106 Procedura ta opisana dokładnie na stronie Elections Alasca, http://www.elections.alaska.gov/Core/votingbyonline.php [dostęp 12 października 2017 r.].

107 Przegląd różnych rozwiązań zob. http://www.businessinsider.com/22-states-that-allow-you-to-vote-online-2016-9?IR=T/\#colorado-3 [dostęp 22 października 2017 r.]. 
bistym głosowaniu w lokalu wyborczym). Zgodnie z przyjętymi rozwiązaniami wyborca powinien zamiar głosowania zgłosić do konsula. Następnie otrzymuje on za pośrednictwem poczty login oraz e-mailem - hasło, pozwalające na w pełni skuteczne oddanie głosu na dedykowanym portalu ${ }^{108}$.

Głos jest wielokrotnie szyfrowany. W wyborach parlamentarnych $2012 \mathrm{r}$. w obu turach zagłosowało w ten sposób po około 120000 wyborców $^{109}$.

W marcu 2017 r. rząd francuski ogłosił, że wycofuje się z planów umożliwienia w czerwcowych wyborach głosowania za pomocą internetu przez wyborców przebywających poza granicami kraju. Decyzję motywowano brakiem możliwości zapewnienia bezpieczeństwa i sygnałami o możliwości dokonania cyberataków na system głosowania ${ }^{110}$.

Warto przywołać bardzo ciekawe doświadczenia z zastosowania głosowania z wykorzystaniem internetu, jakie zostały zebrane w Australii. Badania i próby przeprowadzane były w poszczególnych stanach. W 2010 r. Tasmania umożliwiła niewielkiej grupie wyborców przebywających poza miejscem zamieszkania ( $w$ tym poza granicami kraju) na skorzystanie z procedury tzw. Express voting. $\mathrm{Na}$ życzenie wyborcy - otrzymywał on e-mailem (lub faksem) kartę do głosowania oraz formularz deklaracji wyborcy. Po wypełnieniu - przesyłał on oba dokumenty również z wykorzystaniem e-maila, faksu lub klasycznej poczty (procedura nawiązywała więc do rozwiązań stosowanych w Stanach Zjednoczonych w ramach UOCAVA). W taki sposób głosowało 754 wyborców, z czego 576 głosów zostało skutecznie oddane (termin) ${ }^{111}$.

W 2011 r. Komisja Wyborcza Nowej Południowej Walii wprowadziła system o nazwie iVote, umożliwiający oddawanie głosów za pomocą internetu lub telefonu. $\mathrm{Z}$ nowego systemu mogli korzystać wyborcy z niepełnosprawnością, zamieszkali w dużej odległości od lokalu wyborczego oraz wszyscy wyborcy przebywający poza terytorium stanu. Głos mogli oddać w okresie tzw. głosowania przedterminowego, po uprzednim zgłoszeniu zamiaru. Z nowej możliwości skorzystało 46864 wyborców, których głosy zostały wydrukowane i dołączone do głosów oddanych w sposób tradycyjny ${ }^{112}$. Uruchomienie i obsługa systemu iVote kosztowała blisko 3,5 mln dolarów australijskich, co dawało kwotę około 74 dolarów na jeden głos (średni koszt oddanego głosu metodami tradycyjnymi w tych wyborach to 8 dolarów).

108 R. Verbij, Dutch E-Voting opportunities, op. cit., s. 42.

109 Republic of France Parliamentary Elections 10 and 17 June 2012, OSCE/ODIHR Election Assessment Mission Final Report, s. 13.

110 Https://www.reuters.com/article/us-france-election-cyber/france-drops-electronic-voting-for-citizens-abroad-over-cybersecurity-fears-idUSKBN16D233 [dostęp 18 października 2017 r.].

111 Internet voting in Australian election systems, Australian Electoral Commission (AEC), 2013, s. 23-24.

112 Ibidem, s. 24. 
W wyborach 2015 r. system iVote został już poważnie zmodyfikowany, skorzystało z niego skutecznie 286000 wyborców, z których zdecydowana większość (97\%) wyraziła bardzo pozytywne oceny. Funkcjonowanie systemu wiązało się z kosztem 1,2 miliona dolarów australijskich ${ }^{113}$.

W Kanadzie prowadzone są rozbudowane badania nad $i$-votingiem, w szczególności na szczeblu wyborów lokalnych. Działania te charakteryzuje duże natężenie, ale również rozproszenie i różnorodność stosowanych systemów. Od 2003 r. głosowanie z wykorzystaniem internetu przeprowadzono blisko 200 razy, a uprawnionych do skorzystania $\mathrm{z}$ tej procedury było blisko 4,5 mln wyborców (dla przykładu w 2014 r. w wyborach lokalnych w Ontario uprawnionych było 2,2 mln obywateli). Wśród powodów podjęcia prac nad wprowadzeniem głosowania elektronicznego wymienia się zwiększenie dostępu wyborców do procedur głosowania, wpłynięcie na frekwencję wyborczą oraz zwiększenie wygody. $\mathrm{Z}$ drugiej jednak strony podnoszone są poważne zastrzeżenia związane $\mathrm{z}$ zapewnieniem bezpieczeństwa. $Z$ tego też powodu zauważyć należy działania władz centralnych mające na celu ograniczanie możliwości wprowadzania procedur $i$-votingu przez poszczególne jednostki samorządu terytorialnego (obecnie jest to możliwe tylko w wybranych prowincjach). Warto odnotować również, że przyjęte rozwiązania mogą poważnie różnić się - i-voting może być stosowany bowiem wraz z inną alternatywną procedurą głosowania (np. przez pełnomocnika) i/ lub tradycyjną metodą udziału w głosowaniu w lokalu wyborczym.

Jakkolwiek procedura głosowania $\mathrm{z}$ wykorzystaniem internetu spotyka się z bardzo pozytywnym przyjęciem wśród wyborców i jest coraz bardziej popularna (stopniowo „wypierając” inne procedury głosowania), to nie przekłada się w sposób jednoznaczny na istotne zwiększenie frekwencji wyborczej. Nie ma również poważnych podstaw dla wskazania wpływu na aktywizację grupy wyborców najmłodszych (co było jednym z zakładanych celów wprowadzania nowej procedury) ${ }^{114}$.

\section{Wnioski}

Głosowanie przez internet od kilkunastu lat budzi poważne zainteresowanie $\mathrm{w}$ wielu państwach na całym świecie. Zastosowanie $i$-votingu w wyborach i referendach jest jednak wciąż ograniczone. Obecnie przepisy przewidujące stosowa-

113 Feasibility study on Internet Voting for the Central Electoral Commission of the Republic of Moldova, op. cit., s. 17-19.

114 N. Goodman, R. Smith, Internet Voting in Sub-National Elections: Policy Learning in Canada and Australia [w:] The International Conference on Electronic Voting. E-Vote-ID 2016, red. R. Krimmer i in., http://www.regeringen.ax/sites/www.regeringen. ax/files/attachments/page/international-conference-e-voting-2016-proceedings.pdf [dostęp 17 października 2017 r.]. 
nie tej procedury funkcjonują jedynie ${ }^{115}$ w Australii, Armenii, Estonii, Kanadzie, Francji, Indiach ${ }^{116}$, Meksyku ${ }^{117}$, Panamie, Szwajcarii oraz Stanach Zjednoczonych. Co ważne, tylko w Estonii głosowanie za pomocą internetu jest procedurą powszechną - adresowaną do wszystkich wyborców. W pozostałych państwach zastosowanie i-votingu jest ograniczone do ściśle określonych grup wyborców (najczęściej przebywających poza granicami kraju, personelu wojskowego itp.) lub z uwzględnieniem podziału terytorialnego (Kanada, Szwajcaria). W wielu państwach po przeprowadzeniu głosowań pilotażowych ostatecznie zdecydowano o wycofaniu się ze stosowania procedury głosowania przez internet (Wielka Brytania, Norwegia), w innych takie decyzje są poważnie rozważane (Francja). O pewnym konsekwentnym, udanym rozwoju stosowania procedury można mówić przede wszystkim w przypadku Szwajcarii.

W większości państw głosowanie za pośrednictwem internetu zostało wprowadzone jako kolejna alternatywna procedura głosowania - obok istniejących ułatwień (np. głosowania korespondencyjnego, przez pełnomocnika). Wcześniejsze doświadczenia $\mathrm{z}$ wprowadzaniem oraz stosowaniem tych procedur były bez wątpienia bardzo pomocne we wdrażaniu $i$-votingu. Dotyczy to kwestii organizacyjnych, społecznych, a także konstytucyjno-prawnych (zgodność z zasadami prawa wyborczego, które są interpretowane w sposób zbliżony do głosowania korespondencyjnego).

Z wprowadzeniem głosowania przez internet wiązano oczekiwania poważnego zwiększenia frekwencji wyborczej. Należy podkreślić jednak, że sposób określania takiego wpływu jest niezmiernie trudny ${ }^{118}$, bowiem zjawisko frekwencji wyborczej charakteryzuje się ogromną złożonością ${ }^{119}$, a na podjęcie decyzji o udaniu się do lokalu wyborczego wpływa (obok kwestii technicznych) wiele

115 Ibidem.

116 W 2010 r. w sześciu gminach został przeprowadzony pilotaż głosowania z wykorzystaniem internetu. Obejmował niewielką grupę wyborców - łącznie uprawnionych do głosowania było 387 osób. Organizacyjnie procedura była dość skomplikowana: tożsamość wyborcy potwierdzał urzędnik wyborczy, następnie do tak zweryfikowanych i wpisanych do rejestru wyborców przesyłany był login (e-mailem), a następnie hasło za pomocą SMS. Ostatecznie w ten sposób zagłosowało 124 wyborców (a więc co trzeci), R. Verbij, Dutch E-Voting opportunities, op. cit., s. 50.

117 W 2012 r. przeprowadzony został pilotaż głosowania z wykorzystaniem i-votingu w ramach wyborów gubernatora Mexico City. Uprawnionymi do skorzystania z nowej procedury byli wyborcy mieszkający poza granicami kraju. Spośród 7911 wyborców uprawnionych do głosowania w ten sposób zagłosowała 1/3, R. Verbij, Dutch E-Voting opportunities, op. cit., s. 50.

118 Szerzej zob. B. Geys, Explaining voter turnout: a review of aggregate-level research, „Electoral Studies” 2006, No 25, s. 637-663.

119 P. Gronke, E. Galanes-Rosenbaum, P.A. Miller, Early voting and turnout, Political Science \& Politics, 2007, s. 639. 
czynników związanych m.in. z istotą kampanii wyborczej, ofertą polityczną, znajomością kandydatów czy też postaw wobec samych wyborów ${ }^{120}$. Nie ma więc podstaw, by uznać, że $i$-voting samodzielnie jest w stanie wpłynąć np. na zmianę postaw obywateli wobec systemu politycznego, oceny bieżącej polityki i innych kwestii warunkujących w dużej mierze decyzje o udziale w wyborach oraz oddaniu głosu ${ }^{121}$.

Nowa procedura głosowania miała w założeniu aktywizować do udziału w głosowaniach grupy biernych wyborców ${ }^{122}$. W szczególności wskazywano, że i-voting może zachęcić do wyborów i referendów młodszych wyborców. Nie można odmówić takiemu oczekiwaniu podstaw $-\mathrm{z}$ badań opinii publicznych (również w Polsce) wynika, że $i$-voting to zdecydowanie najbardziej preferowana i oczekiwana procedura głosowania. Popularność (przynajmniej w deklaracjach osób ankietowanych) procedury elektronicznego głosowania wśród młodych wyborców wynikać jednak może z powszechnego pojmowania jej jako skrajnie prostej i niewymagającej większego zaangażowania, co rozmija się jednak z rzeczywistością, bowiem korzystanie z tej techniki łączy się z koniecznością podjęcia wcześniej konkretnych czynności (w zależności od przyjęcia rozwiązań technicznych, obejmujących najczęściej złożenie wniosku w określonej formie i w określonym terminie, obsługę oprogramowania, odbiór przesyłki pocztowej zawierającej hasło itp.). Doświadczenia większości państw wskazują wyraźnie, że w praktyce $i$-voting nie wpływa na zwiększenie uczestnictwa w wyborach osób młodych.

Badania wskazują, że w państwach stosujących głosowanie przez internet stopniowo rośnie jego popularność (i liczba osób korzystających z tej możliwości), to jednak wciąż odnosi się w dużej mierze do tej samej grupy aktywnych wyborców, którzy są zdecydowani do udziału w wyborach i referendach bez względu na to, czy będą mogli korzystać z tej procedury. Głosowanie za pomocą internetu jest związane ze swobodną decyzją uwarunkowaną takimi czynnikami, jak wygoda czy ciekawość związana z odmianą od dotychczasowego sposobu udziału w głosowaniu.

Pewien, relatywnie ograniczony wpływ na zwiększenie możliwości udziału w głosowaniu grupy biernych wyborców $i$-voting może mieć jedynie w odniesieniu do obywateli, którzy napotykają techniczne i organizacyjne problemy z głosowaniem, ale tylko wtedy, kiedy inne udogodnienia i ułatwienia (w tym

120 Szerzej zob. P. Norris, Will New Technology Boost Turnout? [w:] Electronic Voting and Democracy: A Comparative Analysis, red. N. Kersting, H. Baldersheim, London 2005, s. 193-225; The implementation of electronic voting in the UK, op. cit.

121 P. Gronke, E. Galanes-Rosenbaum, P.A. Miller, Early voting and turnout, op. cit., s. 639.

122 C. B. Mann, G. Mayhew, Multiple voting methods, Multiple mobilization opportunities? Voting behavior, institutional reform and mobilization strategy, Prepared for the University of Maryland American Politics Workshop, February 17, 2012, s. 5. 
inne alternatywne procedury głosowania, jak głosowanie korespondencyjne) nie zapewniają skutecznie udziału w wyborach w referendach. Dotyczy to w szczególności grup wyborców z niepełnosprawnościami czy przebywających poza granicami kraju itp.

Procedura $i$-votingu jest, co do zasady, zgodna $\mathrm{z}$ najważniejszymi zasadami prawa wyborczego. W sferze praktycznej jednak może powodować pewne niebezpieczeństwa dla ich skutecznego przestrzegania. W szczególności, głosowanie za pomocą internetu jest zgodne z zasadą bezpośredniości (w takim znaczeniu, że wyborcy nie wybierają elektorów, którzy dopiero w ich imieniu - wybierają kandydatów). Preferencję bowiem wskazuje wyborca i przekazuje ją za pomocą procedury elektronicznej. I-voting w założeniu jest zgodny również z zasadą równości (formalnej), stanowiącą, że każdy wyborca dysponuje jednym głosem. Należy podkreślić zgodność $i$-votingu z zasadą powszechności. W tym kontekście wymaga zauważenia, że głosowanie przez internet powinno być stosowane jako alternatywna procedura głosowania - przy równoczesnym zachowaniu możliwości skorzystania przez wyborcę również z procedury oddawania głosu w lokalu wyborczym. Tylko takie rozwiązanie nie spowoduje bowiem negatywnych efektów związanych z wykluczeniem cyfrowym, a więc sytuacji, w której część z wyborców z uwagi na brak dostępu do internetu/oprzyrządowania lub kompetencji/umiejętności byłaby wykluczona $\mathrm{z}$ udziału w wyborach ${ }^{123}$. W niektórych okolicznościach głosowanie przez internet wzmacnia gwarancję zasady powszechności (o czym była mowa wyżej), zastosowanie tej procedury umożliwia bowiem oddanie głosu wyborcom, którzy napotykają w tym zakresie bariery techniczne i organizacyjne. Rozpatrując zgodność $i$-votingu z zasadą tajności, należy podkreślić, że w poszczególnych państwach tajność rozpatrywana jest różnie: bądź jako prawo wyborcy (z którego nie musi korzystać), bądź jako obowiązek (na taką interpretację wskazuje m.in. przywołany wcześniej Kodeks dobrych praktyk $w$ sprawach wyborczych). Od przyjętych mechanizmów (w tym bezpieczeństwa) zależy całkowite zapewnienie gwarancji tej zasady, dlatego kwestia ta ma ogromne znaczenie ${ }^{124}$.

Z wprowadzeniem i-votingu wiążą się poważne zagrożenia dla bezpieczeństwa procesu wyborczego. W szczególności procedura ta jest podatna na różnego rodzaju nieuprawnione ingerencje do systemu z zewnątrz (m.in. cyberataki), co może bezpośrednio wpłynąć na zniekształcenie wyników wyborów czy referendów. Co ważne, dane zbierane są najczęściej na kilku serwerach, a to skupienie umożliwia wpływ jednorazowo na większą liczbę głosów. Dlatego niezmiernie

123 Ważną kwestią jest również dostępność procedury głosowania przez internet dla wszystkich uprawnionych, co nie zawsze jest praktykowane. Dla przykładu procedura $i$-votingu w Estonii nie zawiera wersji rosyjskojęzycznej, mimo że część obywateli porozumiewa się głównie w tym języku.

124 Szerzej zob. M. Rulka, E-Voting a zasady prawa wyborczego, op. cit., s. 81-82. 
istotne jest stworzenie odpowiednich, skutecznych zabezpieczeń, co wydaje się zadaniem niezmiernie trudnym i wymagającym ciągłego rozwoju mechanizmów.

Wspomniane wyżej cyberataki, inne nieprawidłowości, ale również błędy i awarie w funkcjonowaniu systemu głosowania elektronicznego mogą również skutkować zmniejszonym zaufaniem obywateli do procedur wyborczych i referendalnych.

Procedurę $i$-votingu charakteryzuje problematyczna przejrzystość, w szczególności w kontekście uczestniczenia w procesie wyborczym i referendalnym obserwatorów (w tym obywateli, organizacji społecznych).

Wprowadzanie $i$-votingu związane jest z relatywnie dużymi kosztami dla budżetu związanymi z zaprojektowaniem, testami, a także nakładami na bieżące utrzymanie i konserwację systemu, co jest niezbędne dla zapewnienia jego niezawodności i bezpieczeństwa. Tylko w części są one równoważone mniejszymi kosztami organizacyjnymi (np. liczenia głosów). Niezwykle ważne są także akcje informacyjne skierowane do wyborców, co również jest elementem wydatków, jakie są ponoszone na funkcjonowanie $i$-votingu. Szacuje się, że głos oddany za pośrednictwem internetu to koszt nawet kilka razy większy niż w tradycyjnej procedurze oddawania głosu.

\section{Podsumowanie}

Alexander Trechsel wskazał, że w wielu państwach po pełnym nadziei „starcie” głosowania przez internet na początku XXI wieku nastąpił okres stagnacji, rozczarowań, kiedy stało się jasne, że procedura ta nie tylko szybko nie zastąpi tradycyjnych technik, ale nierzadko pojawiają się zbyt poważne problemy techniczne, prawne, wreszcie polityczne, aby mogła zostać w ogóle wdrożona. Jednak na podstawie konsekwentnych działań podejmowanych m.in. w Szwajcarii, Estonii czy Kanadzie, które przynoszą pozytywne efekty (a z pewnością brak jest negatywnych), badacz ten formułuje tezę o odbywającej się właśnie „drugiej wiośnie" $i$-votingu ${ }^{125}$. Wydaje się, że jest to zbyt daleko idący wniosek. W kilkanaście lat po rozpoczęciu prac nad wprowadzeniem głosowania za pomocą internetu wciąż jest to procedura stosowana w nielicznych państwach, w bardzo ograniczonym zakresie lub z wykorzystaniem bardzo kontrowersyjnych, prowizorycznych wręcz mechanizmów (Stany Zjednoczone). Należy zauważyć ogromne wyzwania związane z zapewnieniem bezpieczeństwa, przy jednoczesnym bardzo problematycznym wpływie procedury na takie zjawiska, jak niska frekwencja wyborcza czy bierność młodych wyborców, a także dyskusyjnej wygodzie. Stawia to wiele państw przed poważnym dylematem i koniecznością dokonania bilansu zysków i strat związanych $\mathrm{z}$ wprowadzeniem $i$-votingu.

125 A. Trechsel, Potential and challenges of E-Voting in the European Union, op. cit., s. 6. 


\section{Bibliografia}

Beroggi G.E.G., E-voting through the Internet and with mobile phones, Zurich 2009, http:// unpan1.un.org/intradoc/groups/public/documents/unpan/unpan030950.pdf.

Bimber B., The Internet and citizen communication with government: Does the medium matter?, „Political Communication” 2001, vol. 4, nr 16, https://doi.org/10.1080/ 105846099198569.

Boshel D., Can Internet voting increase participation? Remote electronic voting and turnout in the Estonian 2007 parliamentary elections, Paper for the conference Internet and Voting, Fiesole, 3-4 czerwca 2010 r., https://doi.org/10.1108/00012530310486557.

Chevallier M., Internet Voting, turnout and deliberation: a study, „Electronic Journal of e-Government" 2009, vol. 7, No. 1.

Chevallier M., The Geneva Internet voting system, Geneva 2011.

Code of good practice in electoral matters. Guidelines and explanatory report, Adopted by the Venice Commission at its 52nd session (Venice, 18-19 October, 2002), opinion no 190/2002.

Elections Canada, A Comparative Assessment of Electronic Voting, Part IV: European Trials, http://www.elections.ca/content.aspx?section=res\&dir=rec/tech/ivote/ comp\&document=euro\&lang=e.

Electoral Commission, Electronic voting. May 2007 electoral pilot schemes. Summary, London 2008.

Factsheet. Electronic voting - The first real practice [w:] B. Kaufmann, R. Buchi, N. Braun, Guidebook to direct democracy. In Switzerland and beyond, Marburg 2010.

Funk P., Modern voting tools, social incentives and voter turnout: theory and evidence, Working paper, Barcelona 2006.

Geys B., Explaining voter turnout: a review of aggregate-level research, „Electoral Studies” 2006, No 25, s. 637-663, https://doi.org/10.1016/j.electstud.2005.09.002.

Giampiero B., Moser P., Bierer D., Evaluation der EVoting Testphase im Kanton Zürich 2008-2011, 2011 [za:] E-Voting in Switzerland, University Fribourg paper, 2012.

Goodman N., Smith R., Internet Voting in Sub-National Elections: Policy Learning in Canada and Australia [w:] The International Conference on Electronic Voting. E-Vote-ID 2016, red. R. Krimmer i in., https://doi.org/10.1007/978-3-319-52240-1_10.

Gronke P., Galanes-Rosenbaum E., Miller P.A., Early voting and turnout, Political Science \& Politics, 2007, https://doi.org/10.1017/s1049096507071028.

Hastings N., Peralta R., Popoveniuc S., Regenscheid A., Security Considerations for Remote Electronic UOCAVA Voting, Waszyngton 2011, https://doi.org/10.6028/nist.ir.7770.

Introducing Electronic Voting: Essential Considerations, IDEA, Stokholm 2011.

Jabłoński M., Rzucidło J., Głosowanie za pośrednictwem Internetu w Królestwie Norwegii założenia i realizacja programu E-VALG2011, „Studia Wyborcze” 2012, t. XIV.

Jaskiernia J., Alternatywne sposoby głosowania w świetle prac instytucji systemu Rady Europy [w:] Międzynarodowa Konferencja Naukowa nt. Alternatywne sposoby głosowania a aktywizacja elektoratu, Rzeszów 26-27 marca 2007 r., red. S. Grabowska, R. Grabowski, Rzeszów 2007. 
Mann C. B., Mayhew G., Multiple voting methods, Multiple mobilization opportunities? Voting behavior, institutional reform and mobilization strategy, Prepared for the University of Maryland American Politics Workshop, February 17, 2012.

Mider D., Głosowanie przez Internet a demokracja, „Studia Politologiczne” 2011, t. 20.

Norris P., E-voting as a magic ballot? [w:] Electronic Voting and Democracy, red. N. Kersting, H. Baldersheim, Palgrave 2004, https://doi.org/10.2139/ssrn.336542.

Norris P., Will New Technology Boost Turnout? [w:] Electronic Voting and Democracy: A Comparative Analysis, red. N. Kersting, H. Baldersheim, London 2005, https://doi. org/10.1057/9780230523531_12.

Norris P., Will new technology boots turnout? Experiments in e-Voting and all-postal voting in British local elections [w:] Voter turnout in Western Europe since 1945, Stockholm 2004, https://doi.org/10.2139/ssrn.437140.

Okediran O.O. i in., A framework for a multifaceted electronic voting system, „International Journal of applied science and technology" 2011, vol. 1, no 4.

Pârvu S., Paper vs Internet: is electronic voting a solution for Romania, marzec 2015.

Roguska B., Zbieranek J., Polacy o proponowanych zmianach w prawie wyborczym. Komunikat $z$ badań, Warszawa 2014.

Rulka M., E-Voting a zasady prawa wyborczego, „Przegląd Sejmowy” 2017, nr 3.

Rulka M., Orzecznictwo dotyczące konstytucyjności regulacji umożliwiajacych głosowanie elektroniczne (Niemcy, Austria, Estonia, Indie), „Przegląd Sejmowy” 2015, nr 6.

Rzucidło J., Referendum w obliczu głosowania za pośrednictwem Internetu - doświadczenia Estonii, Norwegii I Szwajcarii [w:] Instytucje demokracji bezpośredniej w praktyce, red. O. Hałub, M. Jabłoński, M. Radajewski, Wrocław 2016.

Saglie J., Segaard S.B., Internet voting in Norway 2011: Democratic and Organisational Experiences, XXII IPSA World Congress of Political Science Paper.

Saglie J., Segaard S.B., Internet voting in Norway 2013, XXIII IPSA World Congress of Political Science Paper.

Solvak M., Vassil K., E-voting in Estonia: Technological Diffusion and Other Developments Over Ten Years (2005-2015), University of Tartu \& Estonian National Electoral Committee, Tartu 2016.

Stein R.M., Vonnahme G., Engaging the unengaged voter: vote centers and voter turnout, Rice University, 2007, https://doi.org/10.1017/s0022381608080456.

Stratford J.S., Stratford J., Computerized and networked government information, „Journal of Government Information" 2001, No 28, https://doi.org/10.1016/s1352-0237(01)00274-x.

The Electoral Commission, Electoral pilot scheme evaluation. Sheffield City Council. August 2007 electoral pilot schemes, London 2008.

The implementation of electronic voting in the UK. Research summary, London 2002.

Trechsel A., E-voting and electoral participation [w:] Dynamics of Referendum Campaigns - An International Perspective, red. C. de Vreese, London 2007, https://doi. org/10.1057/9780230591189_8.

Trechsel A., Potential and challenges of E-Voting in the European Union, Bruksela 2016. 
Więcek M., Estonia: wyrok Sądu Najwyższego Republiki Estonii (Izba Kontroli Konstytucyjności) z dnia 1 września 2005 r. dotyczący problemów związanych z głosowaniem $w$ wyborach za pośrednictwem Internetu (sygn. 3-4-1-13-05), „Przegląd Sejmowy” 2008, nr 2 .

Zbieranek J., Alternatywne procedury głosowania w polskim prawie wyborczy - gwarancja zasady powszechności wyborów czy mechanizm zwiększania frekwencji wyborczej?, Warszawa 2013. 


\section{Analiza doświadczeń związanych z wykorzystaniem głosowania internetowego (i-voting) w wybranych państwach ${ }^{1}$}

Analysis of experiences related to the use of voting over the Internet (i-voting). Selected examples: In contemporary states there appear more and more opinions on crisis of democracy and lowering of turnout in general elections. So, many experts state that in times of dynamic development of ICT tools traditional ways of voting should be supplemented by alternative methods of voting, including electronic voting. The aim of this article is to analyze experiences related to the implementation and use of internet voting (as a form of electronic voting) in selected countries. The considerations in this text will lead to answer the following research questions: which countries have implemented internet voting and if / how this form of voting affects voter turnout? In which countries (and why) the endeavors on the introduction of i-voting were suspended? What are the i-voting procedures in individual countries? What are the most important risks (threats) and benefits of voting over the Internet? What are the costs of the implementation of internet voting in certain countries?

Keywords: elections | Internet | voting over internet | i-voting

Słowa kluczowe: wybory | internet | głosowanie przez internet | i-głosowanie

\section{Wstęp}

W dobie dynamicznego rozwoju technologii informacyjnych i komunikacyjnych, szczególnie internetu, coraz częściej pojawiają się opinie mówiące, że tradycyjne sposoby uczestnictwa i głosowania w wyborach (w lokalu wyborczym) ze względu na utrudniony udział wielu uprawnionych (osób starszych, niepełnospraw-

\footnotetext{
Artykuł powstał w ramach projektu „E-voting jako alternatywna procedura głosowania w elekcjach państwowych. Doświadczenia wybranych państw a perspektywy wdrożenia e-głosowania w Polsce" - finansowanego przez NCN (konkurs OPUS, UMO-2014/15/B/HS5/0135).
} 
nych ruchowo, przebywających za granicą) winny być uzupełnione m.in. o formy głosowania elektronicznego. Stanowiska te są uzasadniane także poglądami na temat kryzysu demokracji, przejawiającego się głównie w obniżającym się poziomie frekwencji wyborczej. W związku z tym w wielu państwach podjęto kroki, by wprowadzić dodatkowe rozwiązania umożliwiające wyborcom udział w głosowaniu (np. advance voting) czy też alternatywne sposoby głosowania (głosowanie korespondencyjne, głosowanie przez pełnomocnika), a w innych wprowadzono lub rozważa się wprowadzenie do systemów głosowania innowacyjnych sposobów uczestnictwa opartych na elektronicznych środkach komunikacji.

Celem niniejszego artykułu jest analiza doświadczeń związanych $\mathrm{z}$ wdrożeniem i wykorzystaniem głosowania internetowego (jako formy głosowania elektronicznego) w wybranych państwach, gdzie głosowanie przez internet funkcjonuje lub gdzie wykorzystywano tę formę uczestnictwa w głosowaniach powszechnych. W opracowaniu postarano się udzielić odpowiedzi na następujące pytania badawcze: jakie państwa wdrożyły głosowanie internetowe i czy/jak ta forma głosowania wpływa na frekwencję wyborczą, w jakich państwach i dlaczego wstrzymano prace nad wprowadzeniem $i$-votingu, jakie są najważniejsze ryzyka (zagrożenia) i korzyści związane z głosowaniem przez internet? Postanowiono skoncentrować się na analizie doświadczeń pięciu państw, które wdrożyły lub zamierzały wdrożyć i-voting. Są to: Estonia, Szwajcaria, Stany Zjednoczone, Norwegia i Austria. Zaznaczyć przy tym należy, że dwa pierwsze państwa zdołały wprowadzić w życie głosowanie przez internet, dlatego poświęcono im najwięcej miejsca.

\section{Głosowanie internetowe}

Elektroniczne głosowanie (określane jako e-voting) jest jednym z tzw. alternatywnych sposobów głosowania i należy do narzędzi demokracji elektronicznej². E-voting w najprostszym ujęciu: oznacza głosowanie za pomoca środków elektronicznych ${ }^{3}$.

2 R. Krimmer, E-voting as a New Form of Voting, [w:] Explorations in eGovernment \& eGovernance. Volume 2: Selected proceedings of the Second International Conference on eGovernment and eGovernance, red. A. Balci, C. Can Actan, O. Dalbay, Antalya 2010, s. 148; M. Musiał-Karg, E-voting (as a form of E-democracy) in the European Countries [w:] Explorations in eGovernment \& eGovernance. Volume 2: Selected proceedings of the Second International Conference on eGovernment and eGovernance, red. A. Balci, C. Can Actan, O. Dalbay, Antalya 2010, s. 156-157.

3 A. Kaczmarczyk, R. Czajkowski, E-Głosowanie - niezbędny element elektronicznej platformy do obsługi procedur $w$ demokracji w społeczeństwie informacyjnym. E-vote an essential element of electronic platform for services for democratic procedures in the Information Society, referat prezentowany na konferencji „Tworzenie mechanizmów i struktur rozwoju elektronicznej gospodarki w Polsce”, Warszawa, 12 czerwca 2001 r., 
Technologiami wykorzystywanymi w procesach głosowania są przede wszystkim internet, telefonia, telewizja, platformy cyfrowe ${ }^{4}$.

Pod względem zastosowanych rozwiązań systemy e-głosowania można podzielić na cztery typy:

- maszyny do głosowania (Direct recording electronic voting machines, DRE) bez możliwości lub z możliwością druku potwierdzenia oddanego głosu (voter-verified paper audit trail, VVPAT); maszyny DRE z opcją VVPAT dostarczają fizycznych dowodów oddania głosu,

- systemy OMR (Optical Mark Recognition systems) bazują na wykorzystaniu specjalnych skanerów, które rozpoznają głosy oddane przez wyborców na specjalnych kartach do głosowania (dostosowanych do odczytu przez skanery); systemy OMR mogą funkcjonować jako:

- centralne systemy liczenia głosów - wówczas karty do głosowania są skanowane i liczone w specjalnych centrach przeliczania głosów, oraz jako

- systemy skanowania optycznego (precinct count optical scanning systems, PCOS) - wówczas skanowanie i przeliczanie kart do głosowania odbywa się w lokalu wyborczym, bezpośrednio po wprowadzeniu karty do głosowania (oddaniu głosu),

- drukarki głosów elektronicznych (Electronic ballot printers, EBPs) - urządzenia podobne do maszyn do głosowania, za pomocą których drukowane są specjalne karty (czytelne dla maszyn) lub znaczniki zawierające informację o wyborze dokonanym przez głosującego; takie głosy są dostarczane do skanowania i automatycznie przeliczane,

- systemy głosowania internetowego, w których głosy za pośrednictwem internetu przekazywane są do centralnego serwera zliczającego głosy; głosy oddawane mogą być zarówno z komputerów publicznych (maszyn do głosowania), tzw. kiosków wyborczych, jak i z dowolnego komputera z dostępem do internetu ${ }^{5}$.

W literaturze specjalistycznej głosowanie internetowe dzieli się najczęściej na dwie kategorie: głosowanie w lokalu wyborczym (Internet Voting at the Polling Place) lub głosowanie zdalne (Remote Internet Voting). W tym pierwszym wyborcy oddają głos w specjalnie do tego przygotowanym kiosku wyborczym z wykorzystaniem kanału, jakim jest internet. Natomiast Remote Internet Voting jest zdalnym sposobem oddawania głosu, dzięki któremu wyborca głosuje bądź

s. 50, http://www.logistyka.net.pl/images/articles/1375/Ref-Czajkowski.doc [dostęp 13 października 2017 r.].

4 M. Nowina-Konopka, Elektroniczna urna, http://www.rpo.gov.pl/pliki/12066058070. pdf [dostęp 15 września 2012 r.].

5 Introducing Electronic Voting: Essential Considerations, International Institute for Democracy and Electoral Assistance (International IDEA), Policy Paper, December 2011, s. 10-11. 
to z kiosku wyborczego (tyle że znajdującego się poza lokalem wyborczym), bądź $\mathrm{z}$ dowolnego komputera podłączonego do internetu. Internetem przesyłane są dane do centralnej bazy danych z każdego z wymienionych typów stanowisk.

Na rysunku 1 przedstawiono wybrane mocne i słabe strony trzech sposobów głosowania przez internet: głosowania internetowego za pomocą maszyn do głosowania umiejscowionych w lokalu wyborczym, za pomocą kiosku wyborczego znajdującego się poza lokalem wyborczym oraz za pomocą zdalnego głosowania online ( $\mathrm{z}$ komputera lub telefonu komórkowego).

Pierwszy sposób głosowania internetowego - w lokalu wyborczym - gwarantuje wysoki poziom kontroli, zapewnia duży stopień bezpieczeństwa, ale jednocześnie $\mathrm{w}$ porównaniu z dwiema pozostałymi formami jest mniej dostępną metodą dla elektoratu (wyborca, żeby zagłosować, musi pójść do konkretnego lokalu wyborczego). W przypadku zdalnego głosowania z kiosku wyborczego zapewniony jest umiarkowany poziom kontroli (mniejszy niż w lokalu wyborczym), wysoki poziom bezpieczeństwa, a dodatkowo - kiosk wyborczy jest nieco bardziej dostępny dla przeciętnego wyborcy. Nadmienić warto, że sposób ten może generować więcej problemów technicznych w porównaniu z i-głosowaniem w lokalu wyborczym.

\section{Rysunek 1. Sposoby głosowania internetowego}

- wysoki poziom kontroli

- bardzo wysoki poziom zabezpieczenia

Głosowanie internetowe w lokalu wyborczym Polling Place Internet Voting

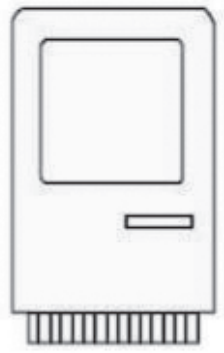

niska dostępność
- umiarkowany poziom kontroli

- wysoki poziom zabezpieczenia

Zdalne głosowanie internetowe w kiosku Remote Kiosk Internet Voting

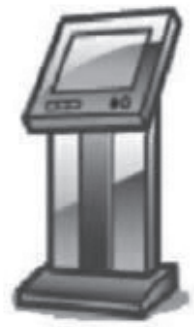

umiarkowana dostępność
- niski poziom kontroli

- umiarkowany poziom zabezpieczenia

Zdalne głosowanie internetowe; głosowanie telefoniczne Remote Internet Voting /Mobile Phone Voting

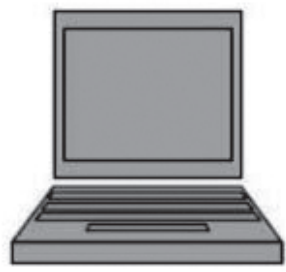

duża dostępność res\&dir=rec/tech/ivote/comp\&document=description\&lang=e\#fg1 [dostęp 11 października 2017 r.]. 
Zdalne głosowanie internetowe przeprowadzone za pomocą komputera czy telefonu komórkowego wydaje się być sposobem mniej narażonym na różnego rodzaju problemy techniczne (choćby z powodu małej liczby użytkowników jednego urządzenia - głosowanie za pośrednictwem komputera czy telefonu przeprowadza zwykle jego właściciel). Takie głosowanie z perspektywy wyborcy może być dokonane o dowolnej porze $\mathrm{z}$ dowolnego miejsca ${ }^{6}$. Zauważyć należy, że Remote Internet Voting gwarantuje jednocześnie o wiele niższy poziom kontroli, co z kolei może negatywnie przekładać się na poziom bezpieczeństwa (narażenie komputera osobistego na ataki hakerskie).

Głosowane internetowe może być wykorzystane przy wyborach (i-wybory/ i-election) oraz w referendach (i-referendum), co odpowiada rozróżnieniu między formami demokracji przedstawicielskiej i bezpośredniej. Pod względem technologicznym ten drugi rodzaj głosowania wydaje się mniej skomplikowany do zastosowania - głównie ze względu na zwykle dwie możliwe odpowiedzi w głosowaniu („Tak” lub „Nie”). W przypadku wyborów karta do głosowania jest najczęściej bardziej skomplikowana i obszerniejsza co do treści niż karta referendalna.

Rozpatrując wprowadzenie dowolnej formy e-głosowania (także $i$-voting), należy uwzględnić fakt, że w zależności od wybranej formuły głosowanie może być przeprowadzone w tzw. środowisku kontrolowanym lub niekontrolowanym.

O i-głosowaniu w środowisku kontrolowanym mówi się wówczas, gdy oddawanie głosów następuje w lokalu wyborczym, kiosku wyborczym lub innym miejscu nadzorowanym przez personel reprezentujący organ zarządzający wyborami. Oznacza to, że tzw. administracja wyborcza może w dużym stopniu kontrolować procedury wyborcze, warunki, w jakich wyborcy oddają swoje głosy, oraz same technologie głosowania. Głosowanie internetowe w środowisku kontrolowanym może być zatem uznane za odpowiednik tradycyjnego głosowania na papierowych kartach wyborczych w lokalu wyborczym. Z kolei głosowanie internetowe $\mathrm{w}$ środowisku niekontrolowanym polega na oddaniu głosu w warunkach bez nadzoru przedstawicieli administracji wyborczej jak i bez kontroli urządzeń, za pomocą których oddawane są głosy. Wyborca może zatem oddać głos z dowolnego komputera lub z innego urządzenia przenośnego (smartfon, tablet), mającego dostęp do internetu ${ }^{7}$.

Obawy związane z głosowaniem w niekontrolowanym środowisku dotyczą przede wszystkim kwestii zagwarantowania tajności głosowania, oddawania głosów za kogoś z rodziny, zastraszania wyborców, kupowania głosów. Jednym $\mathrm{Z}$ argumentów przeciwników takich form głosowania jest także utrata rytuałów

6 A Comparative Assessment of Electronic Voting, http://www.elections.ca/content. aspx? section=res\&dir=rec/tech/ivote/comp\&document=description\&lang=e\#fg1 [dostęp 11 października 2017 r.].

7 Introducing Electronic Voting: Essential, op. cit., s. 10-11. 
związanych z dniem wyborczym. Ponadto wysuwane są argumenty, mówiące o negatywnym wpływie na wybory przepaści cyfrowej (digital divide) i technicznego oddzielenia tożsamości wyborcy od karty do głosowania.

I-głosowanie może być wprowadzone jako jedyny kanał głosowania dostępny dla wyborców lub może być oferowany jako dodatkowy sposób głosowania. Głosowanie za pomocą internetu jest powszechnie wprowadzane jako kanał alternatywny, podczas gdy maszyny głosujące są najczęściej wprowadzane jako jedyny kanał głosowania dostępny dla wyborców w lokalu wyborczym.

\section{Państwa, które mają doświadczenia związane z i-votingiem}

Zgodnie z danymi Competence Center for Electronic Voting and Participation (E-Voting.CC $\mathrm{GmbH}$ ) tylko kilka państw na świecie stosuje (lub jest na bardzo zaawansowanym etapie wdrażania) tzw. Remote Internet Voting. Zaznaczyć należy, że we wszystkich przypadkach $i$-voting stanowi dodatkową, alternatywną wobec głosowania tradycyjnego i korespondencyjnego formę uczestnictwa w wyborach oraz referendach.

\section{Estonia}

Światowym liderem, jeśli chodzi o wykorzystanie elektronicznego głosowania w wyborach, jest Estonia. Obywatele tego małego państwa od 2005 r. mają możliwość głosowania za pomocą internetu ${ }^{8}$.

Na szczeblu rządowym dyskusja o implementacji elektronicznego głosowania w Estonii rozpoczęła się w 2001 r. Rok później estoński parlament - Zgromadzenie Państwowe (Riigikogu) - stworzył podstawy prawne do przeprowadzenia głosowania przez internet ${ }^{9}$. Latem 2003 r. Państwowa Komisja Wyborcza w Estonii zaczęła wdrażać projekt systemu i-głosowania ${ }^{10}$. W styczniu 2000 r. weszła

8 M. Musiał-Karg, Internetowe głosowanie w E-stonii na przykładzie wyborów w latach 2005-2009, „Przegląd Politologiczny” 2011, nr 3, s. 98-111.

9 Digital Signature Act 2002 - ustawa pozwala obywatelom używać przyjętych podpisów elektronicznych w celu potwierdzania tożsamości w transakcjach online, a także w głosowaniu; N. Goodman, J.H. Pammett, J. DeBardeleben, J. Freeland, A Comparative Assessment of Electronic Voting, Strategic Knowledge Cluster Canada-Europe Transatlantic Dialogue, Carlton University, February 2010, s. 33, https://www.elections.virginia.gov/Files/Media/SB11Workgroup/SB11DraftSept3v1-APPX.pdf [dostęp 10 października 2017 r.].

10 E. Maaten, Towards remote e-voting: Estonian case, Elections Departament. Chancellery of the Riigikogu (Parliament), Tallin 2004, materiały konferencyjne $\mathrm{z}$ The International Workshop on Electronic Voting in Europe, Bregenz/Austria, 7-9 lipca 2004 r., s. 83, https://pdfs.semanticscholar.org/ff4d/0a77e7561e62fd0258280c0baa02 d8256a03.pdf [dostęp 10 października 2017 r.]. 
w życie ustawa dotycząca nowych dowodów osobistych (Identity Documents Act), wprowadzając od 2002 r. obowiązek posiadania eID-card ${ }^{11}$. Takie dowody osobiste, wydawane przez rząd Estonii od 2002 r., mają dwojakie funkcje: oprócz tego, że są dokumentami identyfikacyjnymi, służą również do potwierdzania tożsamości elektronicznej.

Aby oddać głos przez internet, estoński wyborca potrzebuje: dowodu osobistego nowej generacji z ważnymi certyfikatami (odnawianymi na stronie www), kodów PIN (wydawanych razem z kartami eID) oraz komputera wyposażonego w czytnik kart eID (wraz z odpowiednim oprogramowaniem - instalacja installer.id.ee/), połączenia $\mathrm{z}$ internetem oraz systemu operacyjnego Windows, MacOS lub Linux ${ }^{12}$. Od 2011 r. do uwierzytelnienia możliwe są także rozwiązania mobilne - Mobile-ID solution.

Jedną z najważniejszych kwestii ustalonych przy wdrażaniu systemu i-głosowania był fakt, że głosowanie elektroniczne musi być tak podobne do głosowania tradycyjnego jak to tylko możliwe. Oprócz tego warunkiem wprowadzenia w życie $i$-votingu była zgodność głosowania z prawem i zasadami wyborów, a także to, by i-głosowanie było co najmniej w takim stopniu bezpieczne jak oddawanie głosów w sposób tradycyjny ${ }^{13}$.

Zgodnie $\mathrm{z}$ estońskim prawem wyborczym ${ }^{14}$ i-głosowanie odbywa się od 10 . do 4. dnia przed dniem wyborów. Taki rozkład w czasie, tzw. advance voting, jest potrzebny, by zagwarantować czas niezbędny do wyeliminowania podwójnych głosów do dnia wyborów. By zapewnić wyborcy oddanie głosu zgodnego z jego wolą, wyposaża się go w możliwość zmiany głosu elektronicznego przez ponowne zagłosowanie (jeszcze przed dniem wyborów) lub przez zagłosowanie w lokalu wyborczym (również przed dniem wyborów).

System i-głosowania w Estonii oparty jest na „metodzie podwójnej koperty” wykorzystywanej zwykle w głosowaniu korespondencyjnym (rysunek 2).

Jak wspomniano, w Estonii istnieje możliwość ponownego elektronicznego głosowania w wyborach - wyborca w czasie advance voting może oddać głos po raz kolejny, a poprzednio oddany głos zostaje wówczas anulowany. W tym kontekście niezwykle istotna jest zasada traktowania głosowania tradycyjnego jako priorytetowego. Gdy wyborca, który zagłosował wcześniej elektronicznie,

11 W 2005 r. posiadacze nowych eID cards stanowili około 900 tys.; Estonian National Electoral Committee, http://www.vvk.ee/index.php?id=11178\&tpl=1062 [dostęp 10 października 2017 r.].

12 Ibidem.

13 E-Voting System. General Overview, Estonian National Electoral Committee, Tallin 2005-2010, s. 7.

14 Riigikogu Election Act, Local Government Council Election Act, Referendum Act and European Parliament Election Act - wszystkie ustawy zawierają podobne warunki e-głosowania. 


\section{Rysunek 2. Metoda podwójnej koperty w i-głosowaniu w Estonii}

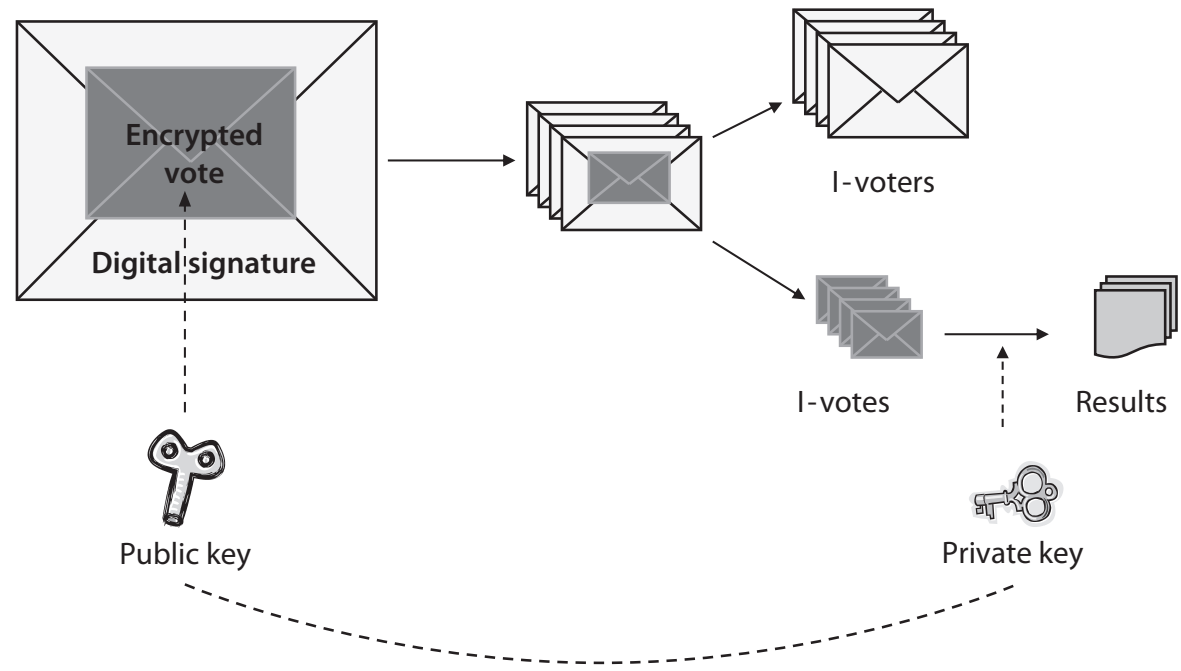

Źródło: T. Martens, Internet Voting in Estonia, National Electoral Committee, Prezentacja PPT, https:// www.valimised.ee/sites/default/files/uploads/eng/EH_Overiview_03-11.pdf [dostęp 11 października 2017 r.].

w dniu głosowania tradycyjnego pójdzie do lokalu wyborczego i tam odda głos, jego elektroniczny głos zostaje anulowany.

Z technicznego punktu widzenia wymagane jest, by system elektronicznego (internetowego) głosowania w Estonii był tak prosty jak to tylko możliwe, a także tak transparentny, by specjaliści od tego typu przedsięwzięć mogli sprawdzać jego funkcjonowanie. Zgodnie z przyjętymi w Estonii założeniami system i-głosowania musi być także przeznaczony do wielokrotnego stosowania - chodzi o to, by przy kolejnych wyborach nie istniała potrzeba opracowywania nowego systemu opartego na metodach elektronicznych ${ }^{15}$.

Warto zwrócić także uwagę na motywacje wdrożenia i-głosowania w Estonii. Jako najważniejsze przyczyny wymienić należy: udostępnienie dodatkowego i wygodnego kanału oddawania głosu, a przez to unowocześnienie głosowania,

15 Jeśli chodzi o sam akt wyborczy, to należy pamiętać, że zaangażowane w niego są zawsze dwie strony: wyborca oraz odbiorca głosu. W głosowaniu elektronicznym natomiast tymi stronami są komputer wyborcy oraz serwery prowadzone przez Państwową Komisję Wyborczą (National Electoral Committee, NEC) i pod jej nadzorem. Najsłabszym ogniwem procedury e-głosowania jest zapewne będący własnością wyborcy - komputer, nad którym nie ma kontroli. Mimo że serwery NEC mogą być kontrolowane, to pojawiające się błędy czy ataki mogą wpłynąć na dużą liczbę głosów jednocześnie. System e-głosowania traktuje te kwestie bardzo poważnie, E-Voting System. General Overview, op. cit., s. 8. 
a także umożliwienie bardziej wydajnego wykorzystania istniejącej infrastruktury (cyfrowe platformy oraz elektroniczne eID-karty). W przeciwieństwie do licznych stwierdzeń pojawiających się w opinii publicznej, zwiększenie frekwencji wyborczej nie było celem wdrożenia $i$-votingu w Estonii. Jednak w wielu pracach dotyczących i-głosowania zwraca się uwagę na kwestie jego wpływu na poziom frekwencji w wyborach.

Tabela 1. I-wybory w Estonii - zestawienie wybranych danych

\begin{tabular}{|c|c|c|c|c|c|c|c|c|}
\hline Wybory & 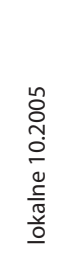 & 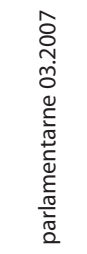 & 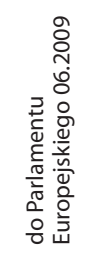 & 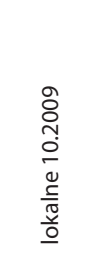 & 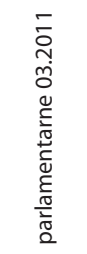 & 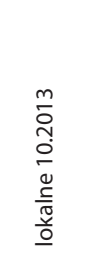 & 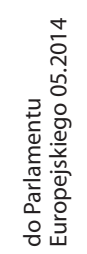 & 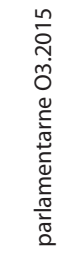 \\
\hline Frekwencja (\%) & 47,43 & 61,91 & 43,88 & 60,6 & 63,5 & 58,0 & 36,5 & 64,2 \\
\hline $\begin{array}{l}\text { I-frekwencja (\%), i-głosy } \\
\text { w stosunku do wszystkich } \\
\text { uprawnionych }\end{array}$ & 0,91 & 3,46 & 6,54 & 9,5 & 15,4 & 12,3 & 11,4 & 19,6 \\
\hline $\begin{array}{l}\text { Udział i-głosów w stosunku } \\
\text { do wszystkich oddanych } \\
\text { głosów (\%) }\end{array}$ & 1,85 & 5,44 & 14,68 & 15,74 & 24,3 & 21,2 & 31,3 & 30,5 \\
\hline $\begin{array}{l}\text { I-głosy wśród wszystkich } \\
\text { głosujących przed dniem } \\
\text { wyborów (advanced voting) }\end{array}$ & 7,2 & 17,6 & 45,4 & 44 & 56,4 & 50,5 & 59,2 & 59,6 \\
\hline $\begin{array}{l}\text { l-głosy z zagranicy w stosun- } \\
\text { ku do wszystkich i-głosów }\end{array}$ & b.d. & $\begin{array}{c}2 \% \\
51 \\
\text { państw }\end{array}$ & $\begin{array}{l}3 \% \\
66 \\
\text { państw }\end{array}$ & $\begin{array}{c}2,8 \% \\
82 \\
\text { państwa }\end{array}$ & $\begin{array}{l}3,9 \% \\
105 \\
\text { państw }\end{array}$ & $\begin{array}{l}4,2 \% \\
105 \\
\text { państw }\end{array}$ & $\begin{array}{l}4,69 \% \\
89 \\
\text { państw }\end{array}$ & $\begin{array}{l}5,71 \% \\
116 \\
\text { państw }\end{array}$ \\
\hline Okres i-głosowania & $3 \mathrm{dni}$ & $3 \mathrm{dni}$ & $7 \mathrm{dni}$ & $7 \mathrm{dni}$ & $7 \mathrm{dni}$ & $7 \mathrm{dni}$ & $7 \mathrm{dni}$ & $7 \mathrm{dni}$ \\
\hline
\end{tabular}

Źródło: na podstawie danych Estonian National Electoral Committee, http://www.vvk.ee/voting-methods-in-estonia/engindex/statistics [dostęp 10 października 2017 r.].

Analizując wyniki kolejnych wyborów w Estonii (lokalnych, parlamentarnych czy wyborów do Parlamentu Europejskiego), łatwo dojść do wniosku, że i-głosowanie zyskuje na popularności i coraz więcej wyborców uczestniczących w poszczególnych elekcjach decyduje się na oddanie głosów za pośrednictwem internetu. Dowodzą tego dane zaprezentowane w tabeli 1.

Przyglądając się skali udziału Estończyków w wyborach, zauważyć można, że o ile w wyborach do Parlamentu Europejskiego frekwencja wyborcza istotnie zmalała, o tyle w wyborach lokalnych wzrost partycypacji od roku 2005 jest zauważalny. W przypadku zaś wyborów parlamentarnych odnotowano wzrost frekwencji odpowiednio o 2\% w roku 2011 (w stosunku do pierwszego i-głosowania w 2007 r.) oraz o 1\% w 2015 (w stosunku do wyniku z 2011 r.). Trudno jednak formułować jednoznaczną opinię, że i-głosowanie przekłada się na wzrost frekwencji. Odnotowuje się wzrost udziału obywateli w wyborach lokal- 
nych i parlamentarnych, jednak specjaliści są ostrożni w formułowaniu wniosków w tym obszarze ${ }^{16}$.

Podsumowując, stwierdzić należy, że na sukces w zakresie wdrożenia i funkcjonowania i-głosowania w Estonii miały wpływ następujące czynniki:

- porozumienie na szczeblu politycznym co do implementacji i-głosowana,

- współpraca sektora prywatnego i publicznego w zakresie opracowania syste$\mathrm{mu}$,

- szerokie wykorzystanie ID-kart (wraz z bezpiecznym uwierzytelnieniem),

- odpowiednie koszty: rozwój i implementacja w ciągu 4 lat - 400 tys. euro (koszty wdrożenia $i$-votingu w stosunku do całego budżetu wyborczego (20\% w 2005 r. i $6 \%$ w 2007 r. $)^{17}$.

\section{Szwajcaria ${ }^{18}$}

Szwajcaria jest kolejnym przykładem państwa europejskiego, które jako jedno z pierwszych rozpoczęło proces zmierzający do implementacji głosowania opartego na wykorzystaniu nowych technologii. Helwecki rząd rozpoczął proces wdrażania e-voting $u^{19}$ (a precyzyjniej - i-votingu) w roku $1998^{20}$.

Do 2015 r. w Konfederacji Szwajcarii wdrażane były trzy projekty pilotażowe - Genewa, Neuchâtel i Zurych ${ }^{21}$. Kluczowy jest fakt, że Vote électronique (bo taka jest oficjalna nazwa całego projektu) był wspólnym projektem Konfederacji i kantonów. Pierwsze próby z i-votingem rozpoczęły się w 2003 r. w Genewie, a następnie w Neuchâtel i Zurychu. W 2008 r. głosowanie online zostało rozszerzone na obywateli szwajcarskich mieszkających za granicą, najpierw w Genewie, a potem w pozostałych kantonach ${ }^{22}$. Do 2015 r. łącznie 13 kantonów (tworząc konsorcja) testowało trzy szwajcarskie systemy. Na krótko przed wyborami parlamentarnymi w 2015 r. system Zurychu nie przeszedł audytu bezpieczeństwa.

16 M. Solvak, K. Vassil, E-voting in Estonia: Technological Diffusion and Other Developments Over Ten Years (2005-2015), University of Tartu \& Estonian National Electoral Committee, Tartu 2016.

17 P. Vinkel, Internet Voting in Estonia, http://www.eis.fi/tapahtumat/2008/Seminaari200809/Finnish_delegation_Internet_voting.pdf [dostęp 10 października 2017 r.].

18 Szerzej na temat e-votingu w Szwajcarii zob. M. Musiał-Karg, Elektroniczne referendum w Szwajcarii. Wybrane kierunki zmian helweckiej demokracji bezpośredniej, Poznań 2012.

19 W związku z tym, że projekty szwajcarskie w swoich oficjalnych nazwach miały słowo „e-voting”, autorka w przypadku szwajcarskich doświadczeń używa zamiennie określeń e-głosowanie oraz i-głosowanie.

20 D. Braendli, The scope of e-voting in Switzerland, E-Voting and Electronic Democracy: Present and the Future - An International Conference, Seoul, South Korea, March 17-18 2005, s. 2.

${ }^{21}$ Projekty w różnym zakresie uwzględniają wykorzystanie nowoczesnych technologii. Umożliwiają głosowanie w wyborach i referendach m.in. za pomocą internetu, ale i SMSa.

22 M. Musiał-Karg, Elektroniczne referendum w Szwajcarii, op. cit., s. 188-228. 
Dziewięć kantonów, które wybrało Zurych E-voting System, rozwiązało konsorcjum i zawiesiło dalsze prace nad wdrażaniem tego systemu ${ }^{23}$.

Funkcjonujące w Szwajcarii trzy systemy głosowania elektronicznego (internetowego) - Zurych, Genewa, Neuchâtel - różniły się między sobą strukturą, jednak najważniejsze kroki (etapy) przy oddawaniu głosów za pośrednictwem tych systemów wyglądały bardzo podobnie. Dysponując dokumentem uprawniającym do głosowania (na którym zamieszczone są dane do głosowania elektronicznego), wyborca po wpisaniu swojego identyfikatora (ID użytkownika) lub numeru karty do głosowania wybierał właściwą odpowiedź na pytanie referendalne, następnie wpisywał z karty do głosowania elektronicznego kod PIN i utajnione pod „zdrapką” hasło, a na końcu wysyłał głos. Procedurę kończyło otrzymanie informacji, potwierdzającej oddanie głosu.

Pierwszoplanowym celem wprowadzania $e$-votingu w Konfederacji Szwajcarskiej było dostarczenie uprawnionym obywatelom dodatkowej platformy do oddawania głosów w referendach i wyborach oraz umożliwienie w przyszłości składania tzw. elektronicznego podpisu przy okazji składania wniosków związanych $\mathrm{z}$ inicjatywą ludową, referendum czy zgłaszaniem kandydatów przed wyborami parlamentarnymi. Za najważniejszą grupę wyborców potencjalnie zainteresowanych wprowadzaniem e-votingu uznano ludzi młodych korzystających $\mathrm{z}$ internetu (wcześniej zazwyczaj nieuczestniczących w głosowaniach) oraz wyborców, którzy nie są zdolni do uczestnictwa w głosowaniach (ze względu np. na ograniczenia natury fizycznej). Ważną grupę docelową stanowią obywatele Szwajcarii, którzy przebywają poza granicami państwa.

Dodać należy, że każdy z wdrażanych w Szwajcarii projektów udostępniał demonstracyjną wersję procedury głosowania. Po wejściu na odpowiednie strony internetowe: systemu genewskiego - www.ge.ch.evoting, systemu zuryskiego - www. evotingdemo.zh.ch, systemu Neuchâtel - www.guichetunique.ch, kierując się instrukcjami podawanymi na stronie internetowej, można przejść całą procedurę głosowania.

W Geneva E-voting System ${ }^{24}$ głosowanie internetowe odbywa się w czterech etapach.

- Aby uzyskać dostęp do serwera wyborczego, wyborca musi wpisać do systemu 16-cyfrowy numer ważnej karty do głosowania ${ }^{25}$.

23 U. Serdült, The Swiss Experience with Internet Voting, The Centre for E-Democracy, 2016, http://www.centreforedemocracy.com/wp-content/uploads/2016/10/Policy_ Brief_Uwe_Serduit.pdf [dostęp 11 października 2017 r.].

24 A. Weber, G. Taglioni, Swiss Elections to the National Council: First trials with e-voting in elections at federal level, Dagstuhl-Seminar 11281: Verifiable Elections and the Public (10-15.07.2011), s. 3, http://arxiv.org/ftp/arxiv/papers/1109/1109.2489.pdf [dostęp 12 listopada 2012 r.].

25 Warto nadmienić, że karta do głosowania podzielona jest na dwie części: lewa strona służy do głosowania online, natomiast strona prawa - do głosowania tradycyjnego lub korespondencyjnego. 


\section{Rysunek 3. Kolejne etapy głosowania elektronicznego}

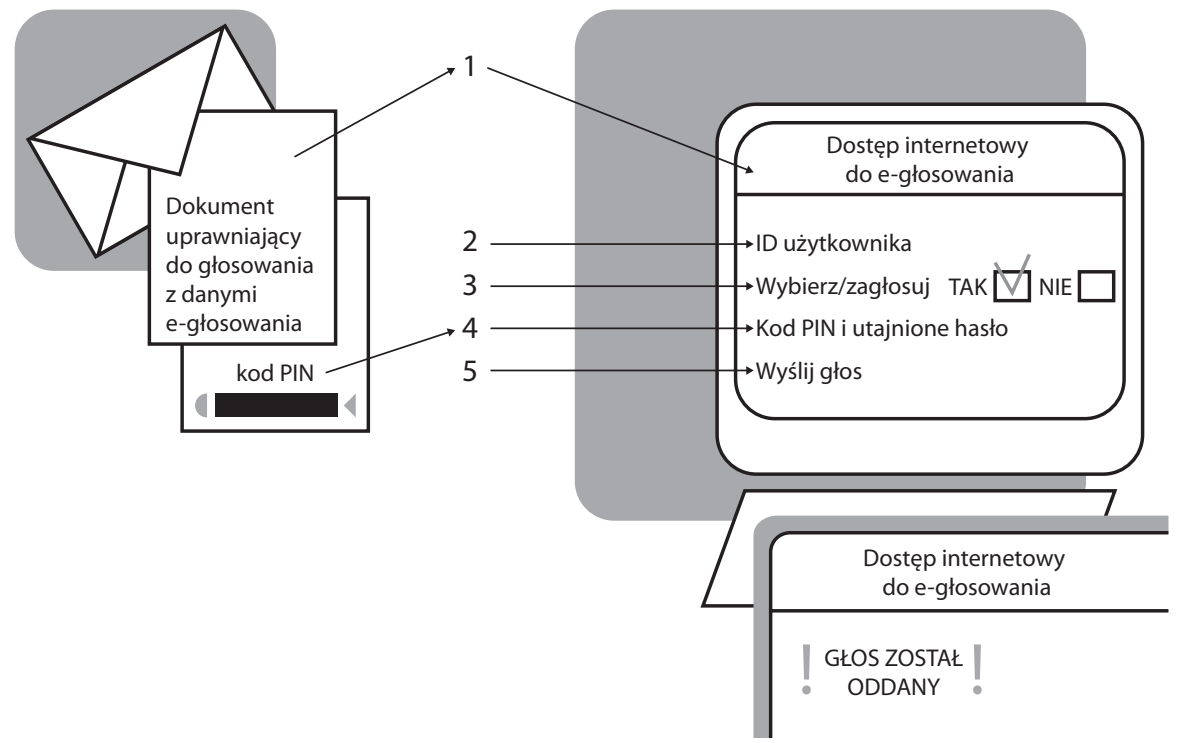

Źródło: E-voting. Wspólny projekt federalno-kantonalny, broszura informacyjna nt. e-votingu, Bundeskanzler, Berno 2012, s. 12-13.

\section{Rysunek 4. Głosowanie za pośrednictwem Geneva E-voting System}

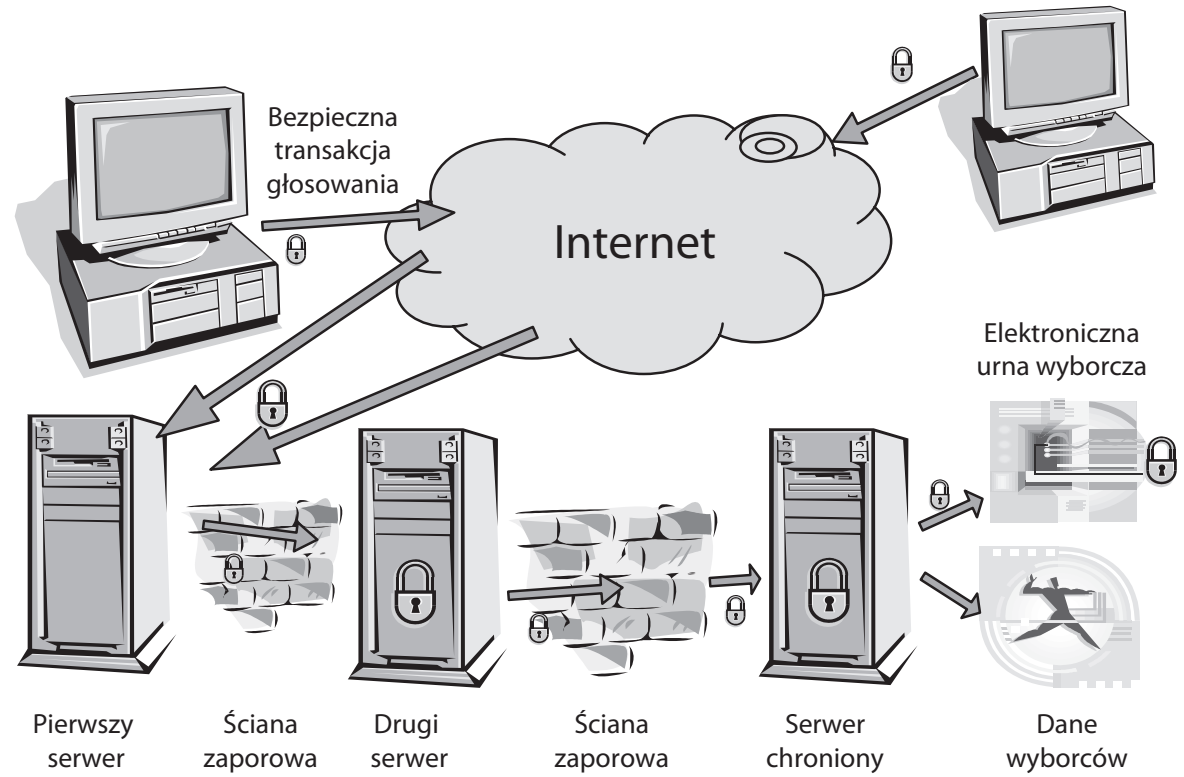

Źródło: M. Chevalier, Internet voting: Status, Perspectives and Issues, prezentacja podczas warsztatów ITU E-Government, Genewa, lipiec 2003 r., http://www.itu.int/itudoc/itu-t/workshop/e-gov/e-gov010.pdf [dostęp 11 października 2017 r.]. 


\section{Grafika 1. Karta do głosowania}

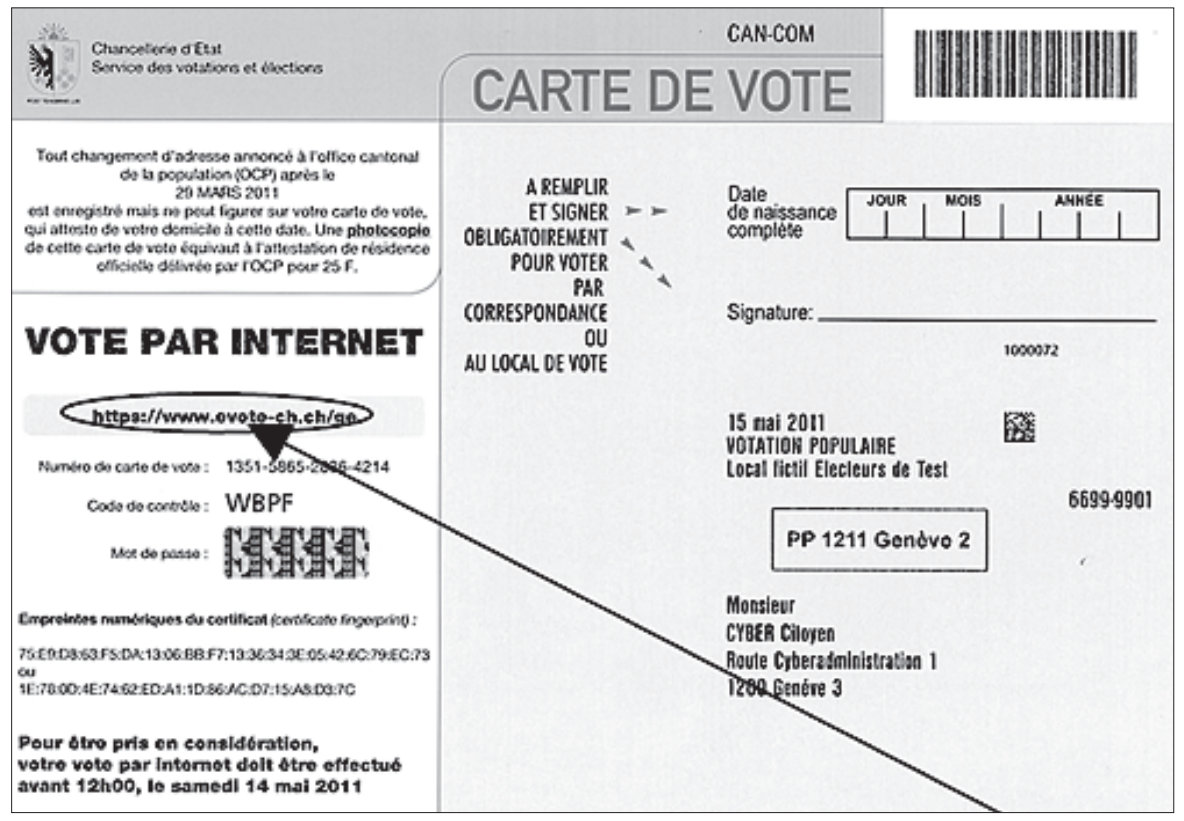

Źródło: E-voting, Republique et Canton de Geneve, http://ge.ch/vote-electronique/actualites/votation-8-mars-vote-electronique-electeurs-prennent-controle [dostęp 13 października 2017 r.].

- Wyborca oddaje głos, zaznaczając kwadrat z odpowiedzią „Tak” lub „Nie”.

- System wymaga od wyborcy potwierdzenia dokonanych wyborów. Za pomocą kodu kontrolnego wyborca może sprawdzić, czy jego głos został uwzględniony $\mathrm{w}$ systemie. Następnie wyborca jest proszony o dokonanie uwierzytelnienia przez wpisanie daty urodzenia, miejsca pochodzenia, kodu identyfikacyjnego z karty wyborczej (który ukryty jest pod tzw. zdrapką ${ }^{26}$ ).

- System potwierdza, że zarejestrował głos (informacja z datą i godziną rejestracji) ${ }^{27}$.

Schemat głosowania w kantonie Zurych przedstawiono na rysunku 5. Właścicielem oprogramowania stosowanego w Zurich E-voting System był kanton Zurych, natomiast przedsięwzięcie od strony technicznej obsługiwała firma zewnętrzna ${ }^{28}$.

26 Zdrapka to technika pokrywania papieru lub kuponu specjalną warstwą ochronną. Powierzchnia do zdrapania zakrywa kod lub symbol, który nie jest możliwy do odczytu bez usunięcia warstwy ochronnej.

27 State Council's Report to the Grand Council on the Geneva electronic voting project, Republic and Canton of Geneva, State Chancellery, 2007, s. 21-22.

28 A. Weber, G. Taglioni, Swiss Elections to the National, op. cit., s. 3. 


\section{Rysunek 5. Głosowanie za pośrednictwem Zurich E-voting System}

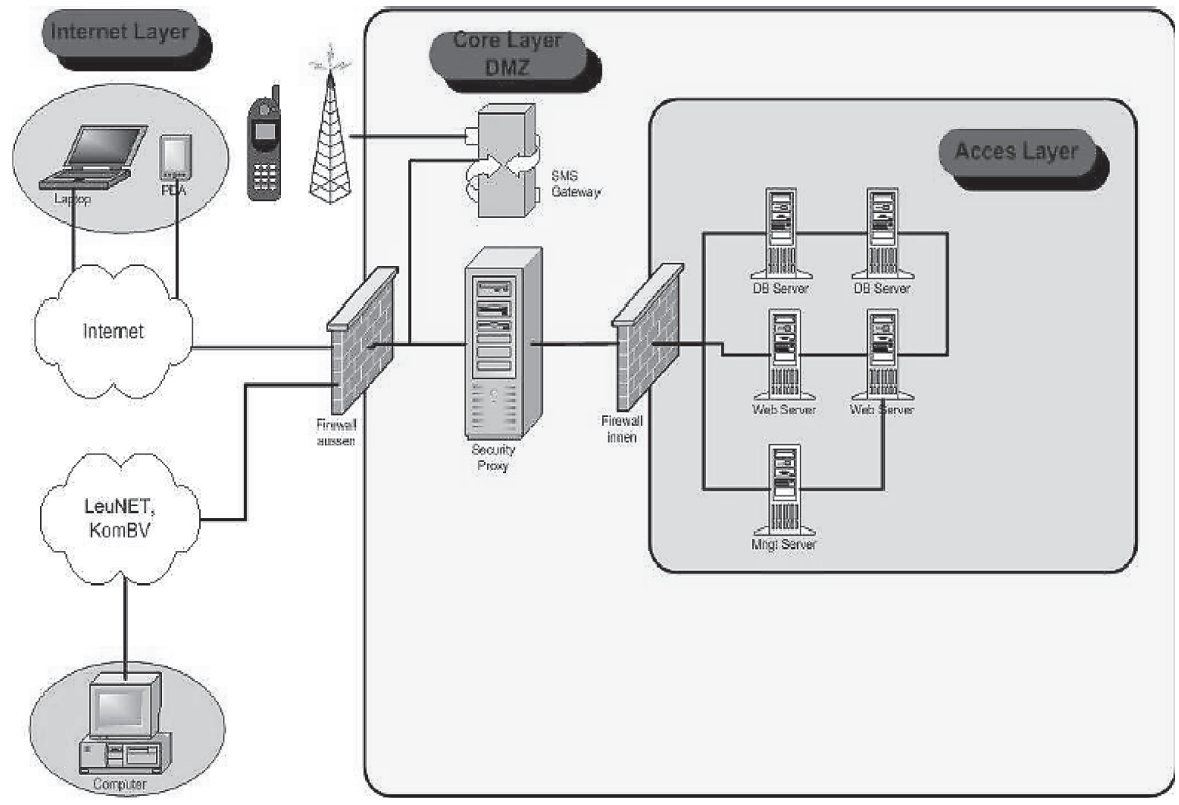

Źródło: Statistiches Amt des Kantons Zürich.

Z punktu widzenia wyborcy procedura głosowania elektronicznego w kantonie Zurych jest bardzo zbliżona do tej z kantonu Genewa. Dodać warto, że początkowo w pakiecie wyborczym znajdowało się również zestawienie kodów SMS, które mogły być wykorzystane przy głosowaniu za pośrednictwem telefonu komórkowego. Z głosowania telefonicznego zrezygnowano ze względu na małe zainteresowanie wyborców.

Cały proces pilotażu zaplanowany został na około cztery lata. Głosowania pilotażowe, wykorzystujące internet, zostały zakończone sukcesem wiosną roku 2006. Swisscom Solutions, szwajcarska wiodąca firma telekomunikacyjna, wprowadzała system oraz prowadziła wewnętrzny audyt pod względem bezpieczeństwa głosowań. Kancelaria Federalna równolegle prowadziła oddzielny audyt.

Koszt całego przedsięwzięcia wyniósł 3,7 mln dolarów: 1,9 mln dolarów wydano na planowanie i opracowanie, a 1,8 mln dolarów przeznaczono na implementację systemu. Niezmiernie istotny wydaje się fakt, że coroczne koszty operacyjne związane z e-votingiem szacowane są na kwotę 400 tys. dolarów, co w przeliczeniu daje 0,5 dolara na jeden elektronicznie oddany głos ${ }^{29}$.

Zaznaczyć należy, że procedura e-głosowania w ramach platformy internetowej Guichet unique - podobnie jak w pozostałych kantonach - zbliżona była do

29 G.E.G. Beroggi, Secure and Easy Internet Voting, „Computer” 2008, t. 41, nr 2, s. 52. 
systemu bankowości internetowej. Cały system $e$-voting w Neuchâtel pod względem różnego rodzaju zabezpieczeń (kryptografii i certyfikatów) podobny jest do projektu wdrażanego w kantonie Genewa ${ }^{30}$.

Po problemach z zapewnieniem bezpieczeństwa w systemie $i$-votingu kantonu Zurych wstrzymano także prace nad systemem Neuchâtel. Na poziomie Konfederacji postanowiono dalej pracować nad systemem genewskim oraz nad nowym systemem e-głosowania oferowanym przez Swiss Post $^{31}$.

Obecnie sześć kantonów prowadzi testy i-głosowania. W trzech kantonach e-voting jest oferowany tylko wyborcom szwajcarskim zamieszkałym za granicą. Kantony Genewa i Neuchâtel umożliwiają i-głosowanie także części wyborców mieszkających w kraju. W kantonie Bazylea-Stadt - od dnia 5 czerwca 2016 r. nie tylko Szwajcarzy mieszkający za granicą, ale także osoby niepełnosprawne mieszkające w kantonie mogą korzystać z i-głosowania

Podsumowując, stwierdzić należy, że do tej pory 14 kantonów w różnym czasie umożliwiało Szwajcarom mieszkającym za granicą internetowe głosowanie. Trzy kantony (Neuchâtel, Genewa i Bazylea-Stadt) prowadziły systemy głosowania elektronicznego dla mieszkańców Szwajcarii. Statystyki wskazują, że około $60 \%$ obywateli, którzy mieli prawo głosować drogą elektroniczną, skorzystało $\mathrm{z}$ tej możliwości.

Obecnie szwajcarskie prawo stawia ograniczenia liczbowe co do i-głosowania: dopuszcza się umożliwienie składania maksymalnie 10\% i-głosów w referendach i 30\% w przypadku głosowań powszechnych nad poprawkami konstytucyjnymi. Obecnie Swiss Post i kanton Genewa oferują i testują systemy głosowania internetowego, które mogłyby być wykorzystane w Szwajcarii ${ }^{32}$.

\section{USA}

Idea przeprowadzenia wyborów całkowicie za pośrednictwem internetu w najbliżej przyszłości nie jest rozważana w Stanach Zjednoczonych.

Jednak w wielu stanach umożliwiono wyborcom nieobecnym w dniu wyborów odsyłanie głosu w sposób elektroniczny (internetowy). Wysyłanie kart wyborczych - przez e-mail lub fax - jest najczęściej zarezerwowane dla obywateli podlegających federalnej ustawie Uniformed and Overseas Citizens Absentee Vo-

30 D. Cavadini, L. Cimasoni, Case Studies on E-Voting, Seminar work on E-government, University of Fribourg, 2007, s. 10, http://diuf.unifr.ch/is/studentprojects/pdf/reports/eGov_HS07_Case_Studies_on_E-Voting_\%28DanieleCavadini_LorenzoCimasoni\%29.pdf [dostęp 14 października 2017 r.].

31 Swiss Post's e-voting solution. Electronic voting and elections for Switzerland, https:// www.post.ch/en/business/a-z-of-subjects/industry-solutions/swiss-post-e-voting [dostęp 11 października 2017 r.].

32 Swiss e-voting poised for expanded roll-out, 5 kwietnia 2017 r., https://www.swissinfo.ch/eng/politics/digital-democracy_swiss-e-voting-poised-for-expanded-roll-out/43087404 [dostęp 13 października 2017 r.]. 
ting Act (UOCAVA) ${ }^{33}$. Motywacją do wprowadzenia takiej możliwości były przede wszystkim trudności w terminowym otrzymywaniu i odsyłaniu kart wyborczych do komisji wyborczej (co szczególnie dotykało osoby przebywające za granicą).

W dwudziestu jeden stanach oraz dystrykcie Kolumbia możliwe więc jest odsyłanie kart wyborczych e-mailem lub faksem ${ }^{34}$. W sześciu stanach amerykańskich możliwe jest odsyłanie głosów faksem ${ }^{35}$. Tylko w pięciu stanach - Alabama, Alaska, Arizona, Dakota Północna i Missouri - możliwe jest głosowanie internetowe przez specjalny portal przeznaczony do głosowania.

W Missouri umożliwiono głosowanie wojskowym, którzy przebywają poza granicami państwa „w strefie wroga”, a w Alabamie głosowanie za pośrednictwem internetu możliwe jest wyłącznie dla wyborców podlegających pod ustawę UOCAVA i to tylko w formie pilotażowej. Dakota Północna i Arizona umożliwiają i-głosowanie wszystkim wyborcom UOCAVA, a na Alasce każdy wyborca może głosować za pośrednictwem portalu internetowego. W osiemnastu amerykańskich stanach nie ma możliwości przesyłania głosów elektronicznie ${ }^{36}$. Wyborcy mogą odesłać swoje karty do głosowania za pośrednictwem zwykłej poczty ${ }^{37}$.

Ostrożność i sceptycyzm wobec $i$-votingu jest związana $z$ faktem, że oddawanie głosu za pośrednictwem internetu (w przeciwieństwie do wysyłania kart do głosowania jako załącznika w poczcie elektronicznej) niesie za sobą duży poziom zagrożenia bezpieczeństwa. Zdaniem Alexa Haldermana, specjalisty w zakresie bezpieczeństwa komputerowego z Uniwersytetu Michigan: [t]echnologia nie jest przygotowana do bezpiecznego głosowania przez Internet ${ }^{38}$. Zaznaczyć należy, iż większość ekspertów, porównując odsyłanie głosów e-mailem lub faksem z i-głosowaniem, twierdzi, że głosy internetowe są masowo narażone na ataki hakerskie, podczas gdy odesłanie głosu pocztą elektroniczną lub faksem naraża tylko jeden głos (w załączniku). Pojawiają się też opinie, że $i$-voting jest bardziej skomplikowany niż bankowość online, do której często porównywane są portale do głosowania internetowego ${ }^{39}$.

33 Electronic Transmission of Ballots, 16 stycznia 2017 r., http://www.ncsl.org/research/ elections-and-campaigns/internet-voting.aspx [dostęp 10 października 2017 r.].

34 Colorado, Delaware, District of Columbia, Hawaii, Idaho, Indiana, Iowa, Kansas, Maine, Massachusetts, Mississippi, Montana, Nebraska, Nevada, New Jersey, New Mexico, North Carolina, Oregon, South Carolina, Utah, Washington i West Virginia.

35 California, Florida, Louisiana, Oklahoma, Rhode Island, Texas.

36 Arkansas, Connecticut, Georgia, Illinois, Kentucky, Maryland, Michigan, Minnesota, New Hampshire, New York, Ohio, Pennsylvania, South Dakota, Tennessee, Vermont, Virginia, Wisconsin i Wyoming.

37 Electronic Transmission, op. cit.

38 Internet Voting - Not Ready for Prime Time?, http://www.ncsl.org/research/elections-and-campaigns/the-canvass-february-2013.aspx\#Internet [dostęp 12 października 2017 r.].

39 Ibidem. 


\section{Norwegia}

Analizując doświadczenia europejskie związane z i-głosowaniem, wspomnieć można także o Norwegii, gdzie odbyły się dwie próby związane z $i$-votingem. Pierwsza z nich miała miejsce przy wyborach lokalnych w 2011 r. i obejmowała 10 gmin $^{40}$. Dwa lata później w wyborach parlamentarnych $i$-voting wykorzystano w 12 gminach. W obu przypadkach - w 2011 r. i w 2013 r. - i-głosowanie było dodatkowym sposobem głosowania względem tradycyjnego. W 2013 r. powyżej 250 tys. uprawnionych mogło skorzystać z głosowania za pomocą internetu. Głosowanie za pośrednictwem internetu możliwe było przedterminowo - w okresie od 12 sierpnia do 6 września. W dniu głosowania można było głosować wyłącznie w lokalu wyborczym. Głosowanie internetowe - szczególnie przez opozycję postrzegane było jako bardzo kontrowersyjne, przede wszystkim ze względów bezpieczeństwa. Po zwycięstwie przez te ugrupowania wyborów parlamentarnych w 2013 r., w czerwcu 2014 r. ogłoszono, że próby z i-głosowaniem zostały wstrzymane ${ }^{41}$.

Zgodnie z raportem dotyczącym i-głosowania w 2013 r. z możliwości i-votingu skorzystało około 70 tys. Norwegów, reprezentujących 38\% spośród 250 tys. uprawnionych. Z raportu wynikało również, że nie ma dowodów na to, że i-głosowanie wpływa na zwiększenie frekwencji wyborczej czy też mobilizuje nowe grupy wyborców (np. ludzi młodych) do głosowania ${ }^{42}$.

\section{Austria}

Próby głosowania za pośrednictwem internetu przeprowadzone były także w 2009 r. w Austrii w wyborach do Austriackiej Federacji Studentów (Hochschülerinnen und Hochschülerschaftswahlen). Pierwsza próba implementacji i-głosowania w Austrii okazała się technicznie skuteczna. Prawie 1\% (2161) uprawnionych studentów oddało swoje głosy drogą elektroniczną między 18 a 22 maja 2009 r. Do identyfikacji i uwierzytelnienia wykorzystano dowód osobisty (austriacki model inteligentnej karty z podpisem cyfrowym) oraz odpowiedni czytnik kart. Anonimowość została zagwarantowana przy użyciu protokołu kryptograficznego w fazie post-voting i była ona podobna do te samej procedury

40 S.B. Segaard, H. Baldersheim, J. Saglie, The Norwegian Trial with Internet Voting: Results and Challenges, Revista General de Derecho Público Comparado 2013, http://79.125.117.151/Publikasjoner/Bok-og-tidsskriftsartikler/2013/2013-031 [dostęp 14 października 2017 r.].

${ }_{41}$ J. Saglie, S.B. Segaard, Internet voting and the secret ballot in Norway: principles and popular understandings, „Journal of Elections, Public Opinion and Parties” 2016, t. 26, nr 2, s. 155-156.

42 E-voting experiments end in Norway amid security fears, 27 czerwca 2014 r., http:// www.bbc.com/news/technology-28055678 [dostęp 10 października 2017 r.]. 
przy głosowaniu korespondencyjnym ${ }^{43}$. Zaznaczyć trzeba, że głosowanie zostało unieważnione orzeczeniem austriackiego Trybunału Konstytucyjnego z 13 grudnia $2011 \mathrm{r}^{44}$.

\section{Głosowanie przez internet - argumenty zwolenników i przeciwników ${ }^{45}$}

Rozważania nad zagadnieniem wdrażania i-głosowania prowadzą do analizy motywów oraz potencjalnych korzyści i zagrożeń związanych z i-votingem ${ }^{46}$.

Najkorzystniejszą zmianą, jaką może przynieść $i$-voting, jest zwiększenie mobilności wyborców. Taki system głosowania umożliwia bowiem oddanie głosu w dowolnym miejscu i w dowolnym czasie (w granicach określonych prawem) nawet gdy wyborca pozostaje poza miejscem swojego zamieszkania. Ponadto dzięki nowym technologiom zwiększa się komfort oddawania głosów - wyborca już nie musi wychodzić $\mathrm{z}$ domu do lokalu wyborczego (lub na pocztę w przypadku głosowania korespondencyjnego), by tam oddać lub wysłać swój głos. Głosowanie internetowe przynosi także korzyści osobom niepełnosprawnym, które często mają trudności z dotarciem do lokali wyborczych.

Z punktu widzenia administracji głosowanie elektroniczne może przyspieszyć oraz zwiększyć dokładność przeliczania oddanych w wyborach czy referendach głosów. W tym kontekście zwraca się przede wszystkim uwagę na wyeliminowanie prawdopodobieństwa popełnienia błędu przez urzędników wyborczych oraz manipulacje w lokalach wyborczych. Ponadto wprowadzenie elektronicznego systemu rejestru wyborców mogłoby wyeliminować zdarzające się czasami przypadki wielokrotnego głosowania, a w państwach, gdzie jeszcze nie wprowadzono e-głosowania, elektroniczny centralny rejestr wyborców mógłby być zapewne pierwszym etapem na drodze do wprowadzenia $i$-voting $u^{47}$.

Systemy i-głosowania, gdzie funkcjonuje elektroniczny centralny rejestr wyborców, mogą przyczynić się do redukcji kosztów związanych z organizacją wy-

43 R. Krimmer, A. Ehringfeld, M.Traxl, The Use of E-Voting in the Austrian Federation of Students Elections 2009, s. 33, https://subs.emis.de/LNI/Proceedings/Proceedings167/33.pdf [dostęp 13 października 2017 r.].

44 E-Voting Pilot in Austria Cancelled by Constitutional Court, https://www.wu.ac.at/en/ evoting/news-details/detail/e-voting-pilot-in-austria-cancelled-by-constitutional-court/ [dostęp 15 października 2017 r.].

45 Szerzej zob. M. Musiał-Karg. Elektroniczne referendum w Szwajcarii, op. cit., s. 173176.

46 R. Krimmer, E-Voting in Austria. Current Status in and around Austria, 11 marca 2010 r., IECEG Conference, Belek, Turcja.

47 A. Rakowska, M. Rulka, Centralny elektroniczny rejestr wyborców podstawa reform prawa wyborczego, Instytut Spraw Publicznych, Warszawa 2011, s. 14. 


\section{Tabela 2. Mocne i słabe strony elektronicznego głosowania}

\begin{tabular}{|c|c|}
\hline Mocne strony elektronicznego głosowania & Słabe strony elektronicznego głosowania \\
\hline 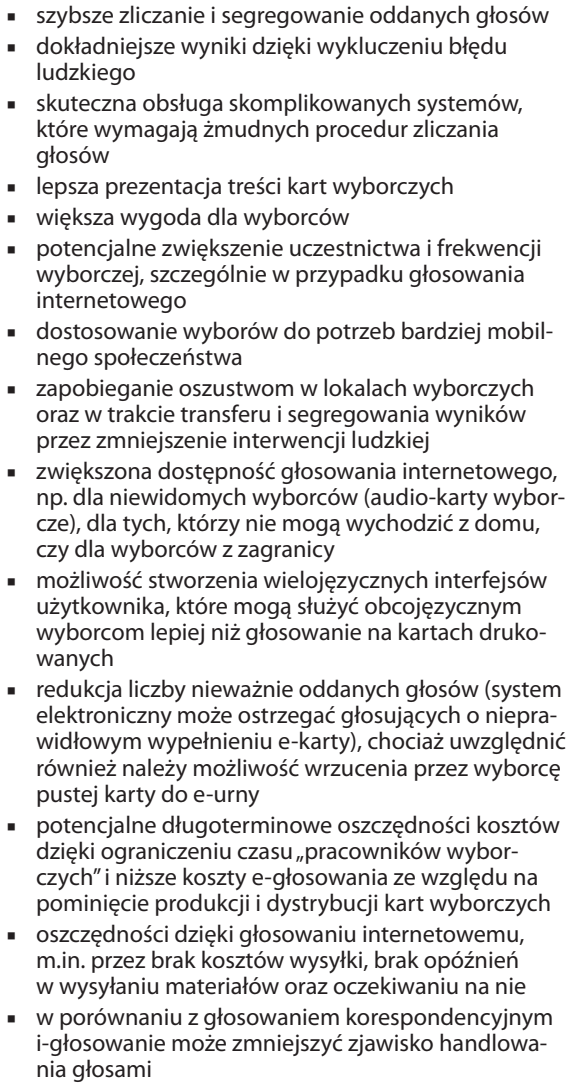 & $\begin{array}{l}\text { - } \text { brak przejrzystości } \\
\text { - } \text { ograniczona otwartość i zrozumienie systemu dla } \\
\text { - brak uzgodisodnionych standardów dla systemów e- } \\
\text { głosowania } \\
\text { - możliwość naruszenia tajności głosowania, zwłasz- } \\
\text { cza w systemach, w których odbywa się zarówno } \\
\text { uwierzytelnianie wyborców, jak i głosowanie } \\
\text { - ryzyko manipulacji przez tzw. insiderów (administra- } \\
\text { torów, obsługę systemów) z szerszym dostępem do } \\
\text { systemu lub przez hakerów z zewnątrz } \\
\text { - zwiększone koszty zarówno w przypadku zakupu, } \\
\text { jak i utrzymania systemu e-głosowania } \\
\text { - zwiększone wymogi bezpieczeństwa, jeśli chodzi } \\
\text { o ochronę systemu głosowania w czasie wyborów } \\
\text { i między wyborami, w tym podczas transportu, } \\
\text { - składowania i konserwacji } \\
\text { - zmniejszony poziom kontroli przez administrację } \\
\text { wyborczą } \\
\text { - możliwości ponownego liczenia głosów } \\
\text { - potrzebne dodatkowe kampanie edukujące wybor- } \\
\text { - ców } \\
\text { - możliwy konflikt z istniejącymi przepisami prawnymi } \\
\text { - możliwy brak zaufania wyborców wobec wyborów } \\
\text { elektronicznych, co jest skutkiem wskazanych wyżej } \\
\text { słabych stron }\end{array}$ \\
\hline
\end{tabular}

Źródło: Introducing Electronic Voting: Essential Considerations, International Institute for Democracy and Electoral Assistance, Policy Paper, December 2011, s. 8-9.

borów czy referendów. Argument ten jest uzasadniany tym, że przy okazji i-głosowania nie ma potrzeby angażowania do pracy w lokalach wyborczych dużej liczby urzędników wyborczych, którzy są niezbędni, gdy wybory organizowane są tradycyjnie (przy urnach wyborczych).

Wprowadzenie internetu do wyborów wywołuje dyskusję na temat słabych stron i-głosowania. Potwierdzeniem tego jest m.in. fakt, że wiele państw wyraziło zaniepokojenie, iż głosowanie elektroniczne może doprowadzić do masowych oszustw wyborczych.

Innym ważnym problemem jest identyfikacja wyborców. Z jednej strony należy przyznać, że hasło i podpis elektroniczny są pomocne na etapie głosowania, ale $\mathrm{z}$ drugiej strony trzeba brać także pod uwagę, że dane te mogą być wykorzystane nie przez wyborcę, ale przez osoby trzecie. 
Systemy głosowania za pomocą internetu narażone są ponadto na wiele problemów technicznych. Mogą być bowiem przedmiotem ataków, które z kolei mogą doprowadzić do istotnych zakłóceń procesu głosowania. Dlatego też serwery, systemy, komputery czy kioski do głosowania powinny być tak zabezpieczone, aby nie mogły być naruszone lub zainfekowane wirusami.

Analizując literaturę poświęconą elektronicznemu głosowaniu, można wskazać najczęściej pojawiające się mocne i słabe strony i-votingu. Większość ze wskazywanych cech została ujęta w tabeli 2, która stanowi podsumowanie jednej z części raportu szwedzkiego International Institute for Democracy and Electoral Assistance pt. Introducing Electronic Voting: Essential Considerations.

\section{Koszty głosowania internetowego, wybrane przykłady}

Jeśli chodzi o koszty związane z wdrożeniem $i$-votingu, to trzeba zauważyć, że opracowanie, przygotowanie i samo wdrożenie systemu i-głosowania w krótkiej perspektywie czasu wiąże się z wysokimi kosztami, które - jak argumentują zwolennicy e-głosowania - będą znacznie mniejsze w długim okresie.

Austria (Internet voting, wybory do rady studenckiej)

- 3,8 euro na zarejestrowanego (403 euro/wyborcę),

- 870 tys. euro na 230 tys. zarejestrowanych, 2161 wyborców ${ }^{48}$.

\section{Estonia (Internet voting)}

- 1-5 euro na wyborcę lub 0,1-0,5 euro na zarejestrowanego,

- 500 tys. euro ustanowienie systemu (bez systemu uwierzytelniania); koszty bieżące 100 tys. euro na 100 tys. wyborców lub $1 \mathrm{mln}$ zarejestrowanych.

Szwajcaria (Internet voting)

- 0,3 euro/wyborcę (zakładając trzy elekcje rocznie),

- utrzymanie: $10 \mathrm{mln}$ euro w okresie 10 lat dla $1 \mathrm{mln}$ wyborców.

Powyższe zestawienie ${ }^{49}$ opracowane przez International Institute for Democracy and Electoral Assistance przedstawia szacunki i koszty wdrożenia głosowania za pomocą internetu. Nadmienić należy, że koszty wdrożenia systemu i-votingu zależne są od zastosowanych technologii, a także uwarunkowań implementacji takich rozwiązań (liczba wyborców, liczba wyborów).

48 BM für Wissenschaft und Forschung. Anfragebeantwortung, http://www.parlament. gv.at/PAKT/VHG/XXIV/AB/AB_02562/fnameorig_166607 [dostęp 13 października 2017 r.].

49 Introducing Electronic Voting: Essential Considerations, International Institute for Democracy and Electoral Assistance, Policy Paper, December 2011, s. 31-32. 


\section{Wnioski}

Prowadzone w niniejszym artykule rozważania skłaniają do sformułowania kilku wniosków, które przedstawiono poniżej.

- Głosowanie za pośrednictwem internetu staje się coraz bardziej dyskutowanym/rozważanym sposobem głosowania w wyborach i referendach. Dowodem tego jest fakt, że w ostatnich latach w wielu państwach toczy się dyskusja na temat wdrożenia i-głosowania, a także przeprowadzane są/były głosowania testowe i pilotażowe, by sprawdzić funkcjonalność $i$-votingu.

- Państwem, któremu udało się z sukcesem wdrożyć głosowanie internetowe, jest Estonia, gdzie od 2005 r. można głosować za pośrednictwem internetu w wyborach lokalnych, parlamentarnych oraz w wyborach do Parlamentu Europejskiego. Estonia jest jedynym państwem na świecie, gdzie i-głosowanie dostępne jest dla każdej osoby uprawnionej do głosowania. Drugim państwem, w których głosowanie internetowe zostało już mocno rozwinięte i przetestowane, jest Szwajcaria. Po problemach z zabezpieczeniem głosowania za pośrednictwem Zurych E-voting System, postanowiono zawiesić dalsze testy tego systemu, a przedsięwzięcie przekazano Swiss Post. Obecnie systemy $i$-votingu w Szwajcarii wdrażane są przy wykorzystaniu systemu kantonu Genewa oraz Swiss Post. Mimo prób wdrożenia i-głosowania w wielu innych państwach (USA, Norwegia, Austria) system Remote Internet Voting nie działa w takim zakresie jak w Estonii.

- Procedury oddawania głosów za pośrednictwem i-votingu są zróżnicowane. Większość z systemów podobna jest do bankowości elektronicznej. Głosy oddaje się na specjalnie przygotowanych portalach internetowych. W Estonii niezbędne jest wykorzystanie eID-card lub Mobile-ID do oddania głosu za pośrednictwem internetu. W szwajcarskim systemie kantonu Genewa niezbędne jest posiadanie karty do głosowania, na której umieszczone są odpowiednie kody, umożliwiające uwierzytelnienie wyborcy.

- Za wcześnie jest, by formułować wnioski dotyczące wpływu wykorzystania i-votingu na frekwencję wyborczą. Widoczny jest pewien umiarkowany wpływ na partycypację w wyborach lokalnych i w minimalny sposób w wyborach parlamentarnych w Estonii, jednak trudno jest jednoznacznie to stwierdzić. Istnieje potrzeba, by wraz ze wzrostem liczby elekcji z wykorzystaniem i-głosowania pogłębiać badania nad wpływem $i$-votingu na frekwencję. Dodać należy, że w Szwajcarii, gdzie przeprowadzono wiele prób i-votingu, nie odnotowano praktycznie żadnej zmiany, jeśli chodzi o frekwencję.

- Najważniejsze ryzyko związane z wykorzystaniem $i$-votingu w elekcjach jest natury technicznej. Najczęściej wysuwanym argumentem przeciwników głosowania internetowego jest narażenie systemów $i$-votingu na ataki hakerskie. Oprócz tego pojawiają się zarzuty zmniejszonego poziomu kontroli nad i-wyborami przez administrację wyborczą, co wynika z tego, że głosowanie odby- 
wa się w tzw. niekontrolowanym środowisku. Głównym atutem i-głosowania pojawiającym się w dyskusjach jest zwiększenie wygody wyborców, którzy $\mathrm{z}$ dowolnego miejsca i w dowolnym czasie wyznaczonym przez komisję wyborczą mogą oddać głos z komputera osobistego podłączonego do internetu. Ma to szczególne znaczenie dla osób niepełnosprawnych ruchowo lub dla tych, którzy w dniu głosowania przebywają za granicą.

- Analiza kosztów wdrożenia głosowania internetowego pozwala sformułować wniosek, że są one zróżnicowane - w zależności od państwa, systemu, liczby wyborców. Specjaliści od wdrażania systemów i-głosowania argumentują jednak, że mimo wysokich kosztów na początku wdrażania systemu, w dłuższym okresie są one zdecydowanie niższe (brak potrzeby drukowania kart wyborczych, angażowania administracji wyborczej, zmniejsza się liczba lokali wyborczych itp.).

\section{Bibliografia}

Braendli D., The scope of e-voting in Switzerland, E-Voting and Electronic Democracy: Present and the Future - An International Conference, Seoul, South Korea, March 17-18 2005.

Cavadini D., Cimasoni L., Case Studies on E-Voting, Seminar work on E-government, University of Fribourg, 2007, http://diuf.unifr.ch/is/studentprojects/pdf/reports/ eGov_HS07_Case_Studies_on_E-Voting_\%28DanieleCavadini_LorenzoCimasoni\%29.pdf.

Kaczmarczyk A., Czajkowski R., E-Głosowanie - niezbędny element elektronicznej platformy do obstugi procedur $w$ demokracji $w$ społeczeństwie informacyjnym. E-vote an essential element of electronic platform for services for democratic procedures in the Information Society, referat prezentowany na konferencji „Tworzenie mechanizmów i struktur rozwoju elektronicznej gospodarki w Polsce", Warszawa, 12 czerwca 2001 r., http://www.logistyka.net.pl/images/articles/1375/Ref-Czajkowski.doc.

Krimmer R., Ehringfeld A., Traxl M., The Use of E-Voting in the Austrian Federation of Students Elections 2009, https://subs.emis.de/LNI/Proceedings/Proceedings167/33. pdf.

Krimmer R., E-voting as a New Form of Voting, [w:] Explorations in eGovernment \& eGovernance. Volume 2: Selected proceedings of the Second International Conference on eGovernment and eGovernance, red. A. Balci, C. Can Actan, O. Dalbay, Antalya 2010.

Krimmer R., E-Voting in Austria. Current Status in and around Austria, 11 marca 2010 r., IECEG Conference, Belek, Turcja.

Maaten E., Towards remote e-voting: Estonian case, Elections Departament. Chancellery of the Riigikogu (Parliament), Tallin 2004.

Musiał-Karg M., Elektroniczne referendum w Szwajcarii. Wybrane kierunki zmian helweckiej demokracji bezpośredniej, Poznań 2012. 
Musiał-Karg M., E-voting (as a form of E-democracy) in the European Countries [w:] Explorations in eGovernment \& eGovernance. Volume 2: Selected proceedings of the Second International Conference on eGovernment and eGovernance, red. A. Balci, C. Can Actan, O. Dalbay, Antalya 2010.

Musiał-Karg M., Internetowe głosowanie w Estonii na przykładzie wyborów w latach 20052009, „Przegląd Politologiczny” 2011, nr 3.

Nowina-Konopka M., Elektroniczna urna, http://www.rpo.gov.pl/pliki/12066058070.pdf.

Rakowska A., Rulka M., Centralny elektroniczny rejestr wyborców podstawa reform prawa wyborczego, Instytut Spraw Publicznych, Warszawa 2011.

Saglie J., Segaard S. B., Internet voting and the secret ballot in Norway: principles and popular understandings, „Journal of Elections, Public Opinion and Parties” 2016, t. 26, nr 2, https://doi.org/10.1080/17457289.2016.1145687.

Segaard S. B., Baldersheim H., Saglie J., The Norwegian Trial with Internet Voting: Results and Challenges, Revista General de Derecho Público Comparado 2013, http://79.125.117.151/Publikasjoner/Bok-og-tidsskriftsartikler/2013/2013-031.

Serdült U., The Swiss Experience with Internet Voting, The Centre for E-Democracy, 2016, http://www.centreforedemocracy.com/wp-content/uploads/2016/10/Policy_Brief_ Uwe_Serduit.pdf.

Solvak M., Vassil K., E-voting in Estonia: Technological Diffusion and Other Developments Over Ten Years (2005-2015), University of Tartu \& Estonian National Electoral Committee, Tartu 2016.

Vinkel P., Internet Voting in Estonia, http://www.eis.fi/tapahtumat/2008/Seminaari200809/Finnish_delegation_Internet_voting.pdf.

Weber A., Taglioni G., Swiss Elections to the National Council: First trials with e-voting in elections at federal level, Dagstuhl-Seminar 11281: Verifiable Elections and the Public (10.-15.07.2011), http://arxiv.org/ftp/arxiv/papers/1109/1109.2489.pdf. 
\begin{tabular}{l|l}
2 & OPINIE BAS
\end{tabular}

\begin{tabular}{l|l} 
A & \\
ZAGADNIENIA PRAWA \\
KONSTYTUCYJNEGO
\end{tabular} 



\title{
Instytucja i-votingu w wybranych krajach ${ }^{1}$
}

\begin{abstract}
I-voting in selected countries: The author states that the number of countries in which $\mathrm{i}$-voting is applied is not large, while there are discussions on this subject in many countries., There is also a tendency to give up this method of voting. Although more and more voters use i-voting, it does not significantly increase voter turnout during elections. In the opinion of the author, there are many dangers arising from the introduction of i-voting, but the most important one seems to be the lack of confidence of voters in this way of voting and the belief in falsifying of voting and election results. The lack of universal access to computers and the Internet is also significant.
\end{abstract}

Keywords: elections | internet | i-voting

Słowa kluczowe: wybory | internet | i-głosowanie

Profesor doktor hab. nauk prawnych, Uniwersytet Łódzki, ekspert ds. legislacji BAS; KSkotnicki@wpia.uni.lodz.pl.

\section{Przedmiot opinii}

Przedmiotem opinii jest $i$-voting rozumiany jako głosowanie $\mathrm{w}$ wyborach lub podczas referendum za pomocą internetu, $\mathrm{z}$ uwzględnieniem następujących kwestii:

- wskazania państw na świecie, w którym stosowany jest $i$-voting,

- procedury głosowania $w$ ramach $i$-votingu,

- danych dotyczących frekwencji, a więc głosujących w ten sposób,

- zabezpieczenia,

- potencjalnego ryzyka związanego z $i$-votingiem,

- kosztów jednorazowych wprowadzenia systemu obsługującego głosowanie przez internet oraz związanych z jego utrzymaniem.

1 Opinia prawna na temat instytucji i-votingu $w$ wybranych krajach sporządzona 26 września 2017 r. na zlecenie wicemarszałka Sejmu; BAS-WAKiU 1715/17. 


\section{Państwa, w których stosowany jest internet}

Gwałtowny rozwój nowoczesnych technologii, w tym w szczególności komputeryzacja, powoli acz systematycznie wkracza również w świat polityki. Cyberdemokracja staje się też faktem w przypadku przeprowadzania wyborów i referendów. Dążeniu do wprowadzenia nowych rozwiązań także w tym obszarze trudno się dziwić - zwłaszcza wybory są centralnym punktem demokracji, poprzez który społeczeństwo najpełniej wyraża swój udział w życiu politycznym. Nowe technologie mają ułatwić tę partycypację, unowocześnić proces głosowania oraz usprawnić sam przebieg wyborów czy referendów.

Trzeba pamiętać, że cyberdemokracja jest złożona i niejednorodna, można też budować wiele jej klasyfikacji. Szczególne miejsce zajmuje w niej e-voting. Jest to określenie używane w dwóch znaczeniach:

- szerokim, odnoszącym się do kwestii technicznych, takich jak np. elektroniczne sporządzanie list wyborców czy elektroniczne udzielanie pełnomocnictwa do głosowania,

- wąskim, odnoszącym się wyłącznie do różnorodnych technik głosowania, mającym przy tym dwie podstawowe formy: a) wykorzystania maszyn wyborczych, tzw. głosomatów, ustawianych w lokalach wyborczych bądź nawet poza nimi (np. w hipermarketach, na stacjach kolejowych, lotniskach); b) wykorzystania internetu (co określane jest mianem $i$-votingu) bądź też telewizji kablowej, sieci telefonii komórkowej itd. ${ }^{2}$.

Wykorzystywanie nowoczesnych elektronicznych technik głosowania jest w świecie stosunkowo powszechne i jest to zjawisko niezwykle dynamiczne, czego jednak nie należy rozumieć jako systematycznie rozwijające, znajdujące zastosowanie w coraz większej liczbie państw. Wyraźnie dowodzą tego wyniki badań prowadzonych przez Competence Center for Electronic Voting and Participation, które co pewien czas zamieszcza mapę ukazującą ten proces. Ostatnia pochodzi z 2015 r. (mapa 1), zaś wcześniejszą z 2010 r. odnaleźć można w artykule Michała Czakowskiego pt. E-voting na przykładzie Estonii i Brazylii ${ }^{3}$.

Wyraźnie widać na załączonej mapie, że państw, w których istnieje możliwość głosowania za pośrednictwem internetu, nie jest wiele, dosyć popularne jest natomiast wykorzystywanie głosomatów. Z powszechnie toczonej na świecie dyskusji na temat możliwości wykorzystania elektronicznych technik głosowa-

2 Zob. K.W. Czaplicki, Alternatywne sposoby głosowania (Zarys problemów) [w:] Międzynarodowa Konferencja Naukowa nt. Alternatywne sposoby głosowania a aktywizacja elektoratu, Rzeszów 26-27 marca 2007 roku, red. S. Grabowska, R. Grabowski, Rzeszów 2007, s. 32; M. Giżyńska, D. Lis-Staranowicz, E-voting: blaski i cienie elektronicznego głosowania [w:] Ksiegga dedykowana prof. dr hab. Bogusławowi Banaszakowi, s. 440 , w druku.

3 „Studia BAS” 2011, nr 3(27), s. 124 [Wybrane problemy systemów wyborczych, red. D. Dziewulak]. 

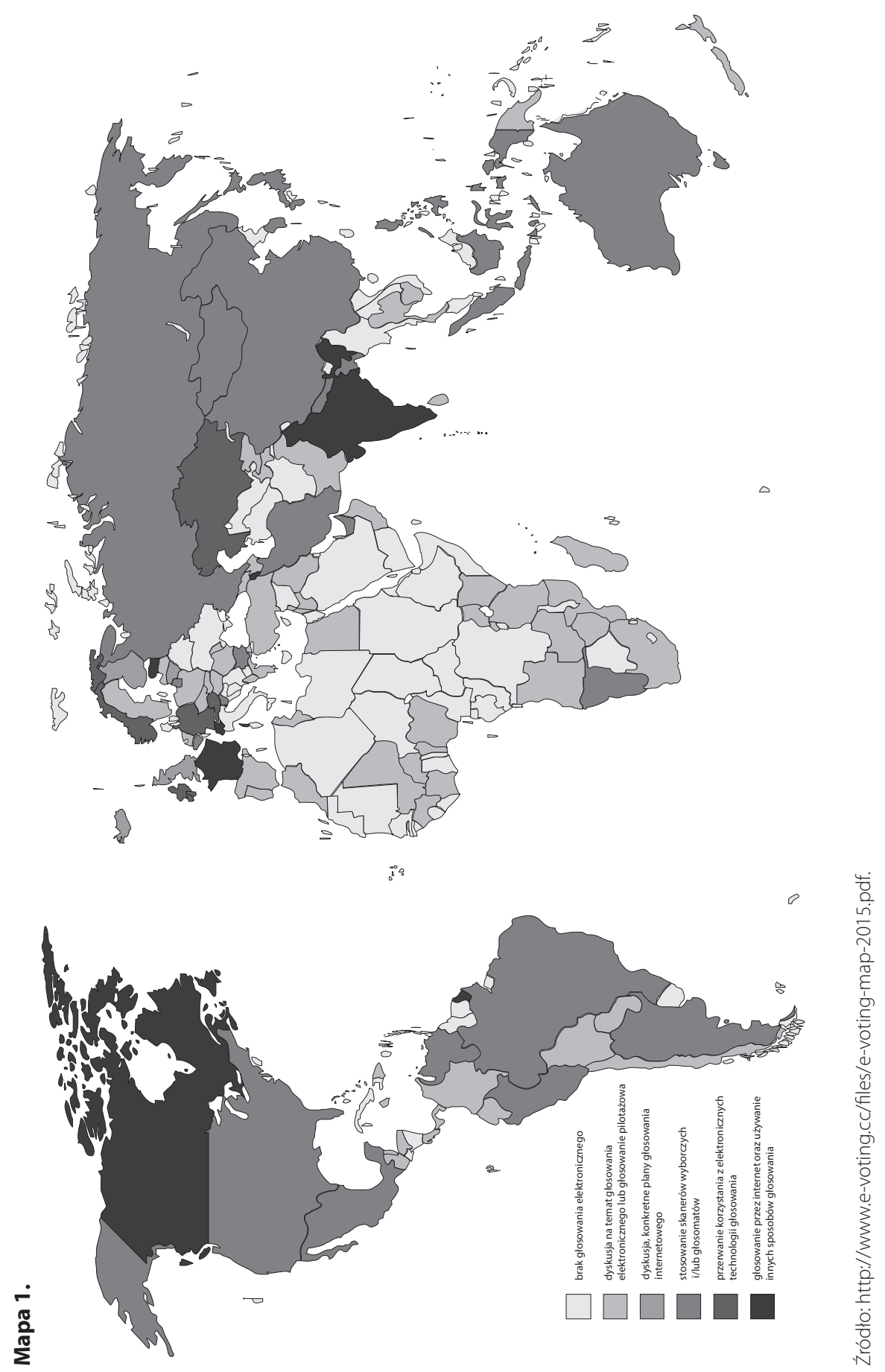
nia wynika, że łatwo daje się zauważyć tendencję do odchodzenia od takiej możliwości głosowania.

Pierwsze próby wykorzystywania elektronicznych systemów głosowania odbyły się już w połowie lat 90. ubiegłego wieku. Bodaj pierwszy: przypadek takiego głosowania miał miejsce podczas amerykańskich wyborów parlamentarnych z 4 listopada 1997 r., na co zezwoliło prawo wyborcze stanu Teksas, gdzie mieszka większość amerykańskich kosmonautów. W NASA opracowano w tym celu specjalny program komputerowy. Procedura tego głosowania wygladała $w$ ten sposób, że przewodniczacy komisji wyborczej w miejscu zamieszkania kosmonauty przesłał do amerykańskich kontrolerów lotu w moskiewskim centrum lotów kosmicznych kartę do głosowania, która następnie została przez nich przekazana na laptop kosmonauty. Ten po jej wypetnieniu zwrócił ja ta sama droga do przewodniczacego komisji przed zakończeniem głosowania ${ }^{4}$. Trudno nie odnieść wrażenia, że w tym wypadku od rzeczywistego znaczenia samego głosowania większą wagę przywiązywano do wydźwięku propagandowego tego wydarzenia.

Pod koniec XX wieku niewątpliwie najbardziej popularne było wykorzystywanie podczas wyborów głosomatów, co miało miejsce w Brazylii, w której w 2000 r. skorzystało z nich podczas wyborów 110 mln wyborców. W polskiej literaturze przedmiotu wskazuje się, że po raz pierwszy i-voting został zastosowany w 2000 r. w stanie Arizona w USA, podczas próbnych wyborów zorganizowanych przez Partię Republikańską (uczestniczyło w nich 35 tys. osób), gdzie wyborcy oddawali głos: za pomoca strony internetowej, a każdy oddany $w$ ten sposób głos był zaszyfrowany i opatrzony cyfrowym podpisem ${ }^{5}$. Na przełomie XX i XXI wieku eksperymentowano z nim również we Francji oraz Szwecji, Holandii 1 Wielkiej Brytanii, przy czym tylko w tym ostatnim państwie były to powszechne wybory lokalne, natomiast w innych krajach były to wybory w mniejszych gremiach, np. studenckich ${ }^{6}$.

National Democratic Institute podaje, że z i-votingiem eksperymentowało łącznie 14 państw, ale tylko w czterech: Estonii, Francji, Kanadzie i Szwajcarii przybrało to bardziej powszechny charakter, w pozostałych pozostaje on nadal w fazie prób, albo nawet od takiej metody odstąpiono; Estonia jest przy tym jedynym krajem, w którym stworzono możliwość powszechnego dostępu do tego alternatywnego sposobu głosowania ${ }^{7}$.

4 Zob. K. Skotnicki, Zasada powszechności wyborów. Zagadnienia teorii i praktyki, Łódź 2000, s. 261-262.

5 Zob. K. Duda, E-voting jako forma demokracji bezpośredniej. Dotychczasowe doświadczenia $i$ ich konsekwencje, „Refleksje” 2011, nr 4, s. 159.

6 Zob. A. Preisner, e-Voting - przyszłość e-demokracji? (Szkic kilku niełatwych kwestii) [w:] Międzynarodowa Konferencja Naukowa nt: Prawo wyborcze do parlamentu w wybranych państwach europejskich, Rzeszów 3-4 kwietnia 2006 roku, red. S. Grabowska, R. Grabowski, Rzeszów 2006, s. 206.

7 Https://www.ndi.org/e-voting-guide/internet-voting [dostęp 20 września 2017 r.]. 
Analiza wykorzystania głosowania za pośrednictwem internetu w innych państwach pokazuje, że polem doświadczalnym, podczas którego pilotażowo testowany jest ten sposób głosowania, są najczęściej wybory lokalne; tak było np. w Paragwaju, Szwajcarii czy Wielkiej Brytanii ${ }^{8}$. Z testowaniem elektronicznego systemu głosowania mieliśmy również do czynienia w Holandii, Belgii, Szwajcarii, Włoszech, Hiszpanii i Niemczech. Uczyniono tak również w państwie, które - przynajmniej w Europie - wskazywane jest jako najlepszy wzór wykorzystywania takiego sposobu głosowania, czyli w Estonii. Możliwość wprowadzenia podczas wyborów lokalnych głosowania przez internet dopuszczono tam już w 2005 r. Natomiast podczas wyborów parlamentarnych w 2007 r. w Szwajcarii możliwość głosowania za pośrednictwem internetu dopuszczona była w kilkunastu kantonach ${ }^{10}$.

Na marginesie warto również przypomnieć, że w Polsce pilotażowe głosomaty wypróbowywano podczas wyborów w 2005 r. w dwóch lokalach wyborczych w Warszawie i Sopocie ${ }^{11}$.

Niewątpliwie najbardziej znanym i opisanym w Polsce przykładem państwa, w którym stosowany jest $i$-voting, jest Estonia, o czym decyduje nie tylko to, że jest to kraj młodej demokracji postsowieckiej i bliskość, ale przede wszystkim pozytywne doświadczenie i znaczna liczba głosujących w ten sposób wyborców. Należy przypomnieć, że możliwość głosowania za pomocą internetu pojawiła się tam w 2002 r. na poziomie samorządowym, a pierwszy raz głosowano w praktyce $2005 \mathrm{r}^{12}$. Warto też dodać, że po uchwaleniu ustawy stwarzającej możliwość głosowania za pośrednictwem internetu prezydent odmówił jej podpisania i skierował ją do zbadania zgodności z konstytucją. Sąd uznał jednak, że do naruszenia zgodności z ustawą zasadniczą - o czym szerzej piszę w dalszej części opinii - w tym przypadku nie dochodzi.

Doświadczenie estońskie jest też dlatego interesujące, że nie jest prawdą, iż z tego sposobu głosowania korzystają przeważnie młodzi wyborcy (osób w wieku ponad 55 lat głosowało w tym państwie dwukrotnie więcej niż osób w wie-

8 Zob. K.W. Czaplicki, Głosowanie elektroniczne (e-voting) - wybrane zagadnienia [w:] Demokratyczne standardy prawa wyborczego Rzeczypospolitej Polskiej. Teoria i prakty$k a$, red. F. Rymarz, Warszawa 2005, s. 39-41.

9 Zob. A. Preisner, e-Voting, op. cit., s. 208.

10 Zob. M. Musiał-Karg, Alternatywne metody głosowania na przykładzie głosowania korespondencyjnego oraz e-votingu w Szwajcarii, „Białostockie Studia Prawnicze” 2016, z. 20/A.

11 Zob. A. Preisner, e-Voting, op. cit., s. 209.

12 Szerokie omówienie tej procedury zawiera obszerna monografia: M. Solvak, K. Vassil, E-voting in Estonia: Technological Diffusion and Other Developments Over Ten Years (2005-2015), University of Tartu \& Estonian National Electoral Committee, Tartu 2016, http://skytte.ut.ee/sites/default/files/skytte/e_voting_in_estonia_vassil_solvak_ a5_web.pdf [dostęp 15 września 2017 r.]. 
ku do 24 lat), co nawet przy strukturze demograficznej „starego” społeczeństwa skłania do refleksji o obiegowej tezie, że internet to domena ludzi młodych.

Powyższej tezy dowodzi również przykład Norwegii. Przygotowania do zastosowania tego systemu głosowania trwały od 2004 r., a po raz pierwszy pilotażowo i-voting został wykorzystany w dziesięciu gminach (Bodø, Bremanger, Hammerfes, Mandal, Radøy, Re, Sandnes, Tynset, Vefsn, Ålesund) podczas wyborów samorządowych w 2011 r. Zakładano przy tym, że docelowo do powszechnego zastosowania tego sposobu głosowania dojdzie podczas wyborów parlamentarnych w $2017 \mathrm{r}^{13}$. Mimo pewnych drobnych problemów pierwsze pilotażowe głosowanie przez internet w 2011 r. ocenione zostało umiarkowanie pozytywnie i w konsekwencji eksperyment ten został powtórzony w 2013 r. w dwunastu miastach. Ostatecznie jednak rząd norweski w czerwcu 2017 r. zrezygnował z tego sposobu głosowania, zaś Norweski Urząd ds. Modernizacji stwierdził, że mimo pragnienia politycznego dyskusja w parlamencie pokazała, że liczba obaw o naruszenie demokratycznych procedur i problemów technicznych przeważyła o podjęciu takiej decyzji ${ }^{14}$.

\section{Procedury głosowania w e-votingu}

I-voting to jeden z rodzajów e-votingu. Składają się na niego trzy elementy: urządzenie, $\mathrm{z}$ którego oddawany jest głos, internet oraz serwer, na którym zbierane są poszczególne głosy i ustalany jest wynik głosowania, a czasem również wyborów. Głos może być przy tym oddany z takich urządzeń, jak: komputer osobisty, laptop, smartfon, telefon komórkowy, ale również każde inne urządzenie, które ma możliwość połączenia się z internetem, jak telewizor czy nawet konsola do gier ${ }^{15}$. Serwer może natomiast w czasie głosowania przez wyborców działać w trybie online (tryb ciągły), być włączany okresowo lub w trybie offline, a więc być włączany dopiero po zamknięciu lokali wyborczych.

Kiedy rozważamy kwestię procedury w przypadku $i$-votingu, należy pamiętać, że nie można mówić o jednej uniwersalnej, zawsze stosowanej procedurze, gdyż jest ich wiele. Najlepszym dowodem na to są różne procedury, które są stosowane w Szwajcarii. W Estonii sposób głosowania za pomocą internetu zmieniał się i początkowo wyglądał inaczej niż obecnie.

W Estonii w procedurze tej wykorzystywane są dowody elektroniczne oraz kody $\mathrm{PIN}^{16}$. Specyfika $i$-votingu polega na tym, że odbywa się ono przed dniem/

13 Szerzej zob. M. Jabłoński, J. Rzucidło, Głosowanie za pośrednictwem Internetu w Królestwie Norwegii - założenia i realizacja programu e-VALG2011, „Studia Wyborcze” 2012, t. XIV, s. 57.

14 Www.bbc.com/news/technology-28055678 [dostęp 9 września 2017 r.].

15 Szerzej zob. A. Preisner, e-Voting, op. cit., s. 201-202.

16 Zob. M. Czakowski, E-voting, op. cit., s. 125. 
dniami głosowania w lokalach wyborczych. W Estonii jest to od dziesiątego dnia do czwartego dnia przed dniem tradycyjnego głosowania podczas wyborów i od szóstego do czwartego dnia przez dniem referendum państwowego. Podczas pierwszego głosowania $\mathrm{w}$ ten sposób wyborca, poza dostępem do internetu, musiał dysponować odpowiednią kartą identyfikacyjną, w którą był wyposażony w mikroprocesor dowód osobisty lub prawo jazdy. Musiał też zainstalować w komputerze odpowiedni program (Internet Explorer) i zakupić specjalny czytnik. Koszt takiego urządzenia wynosił początkowo około 20 euro ${ }^{17}$, a obecnie jest obniżony do mniej niż 10 euro i można go kupić w sklepach internetowych, a nawet w supermarketach. Wyborca umieszczał dowód w czytniku, otwierał stronę internetową, za pośrednictwem której głosował, następnie pobierał i otwierał stosowną aplikację. Po zweryfikowaniu na podstawie kodu PIN, głosował, co potwierdzał drugim specjalnym kodem PIN i otrzymywał potwierdzenie oddania głosu ${ }^{18}$. Sposób ten był zastosowany jednorazowo. Podczas następnych wyborów do identyfikacji służył specjalny dokument elektroniczny, który mógł być wykorzystany jedynie za pośrednictwem internetu. Podczas wyborów w $2011 \mathrm{r}$. po raz pierwszy była też możliwość głosowania za pomocą telefonu komórkowego wyposażonego w specjalną kartę SIM (Mobile-ID card); posiadanie tej karty jest niezbędne, bez niej nie da się zagłosować. Głosowanie odbywa się na stronie Państwowej Komisji Wyborczej. Najpierw wyborca jest identyfikowany na podstawie certyfikatu cyfrowego umożliwiającego uwierzytelnienie. Po jego weryfikacji wyświetla mu się lista kandydatów, na której zaznacza swój wybór (głos) i potwierdza cyfrowym podpisem za pomocą certyfikatu zgodnego z ustawą o podpisie elektronicznym. Co ciekawe, wyborca może w tej samej procedurze zmienić swój głos. Rozwiązanie to, jako naruszające zasadę równości obywateli, zaskarżył jako niekonstytucyjne prezydent Estonii, według którego stawia ono w uprzywilejowanej sytuacji głosujących w ten sposób wyborców, podczas gdy głosujący w lokalu wyborczym swojej decyzji już zmienić nie mogą. Sąd Państwowy, pełniący m.in. funkcję sądu konstytucyjnego, uznał jednak, że skoro wszyscy wyborcy mają możliwość głosowania przez internet i wyłącznie od nich zależy, z jakiego sposobu głosowania skorzystają, to nie można mówić o naruszeniu zasady równości. W przypadku zmienienia przez wyborcę treści głosu oddanego za pośrednictwem internetu pod uwagę brany jest zawsze głos oddany najpóźniej. Sąd uznał również, że trudno jest mówić o naruszeniu tajności głosowania, nawet bowiem w sytuacji, w której na wyborcy głosującym elektronicznie

17 Zob. J. Lewandowska, M. Matusiak, Wady i zalety e-votingu jako alternatywnej metody głosowania [w:] Wyzwania współczesnego prawa wyborczego, red. A. Pyrzyńska, P. Raźny, J. Wojciechowska, R. Zych, Toruń 2014, s. 141.

18 Dlatego w estońskiej literaturze uznaje się ten system głosowania/zabezpieczenia za system dwóch kopert i porównuje do głosowania korespondencyjnego z tradycyjną papierową kartą do głosowania; zob. M. Solvak, K. Vassil, E-voting, op. cit., s. 8. 
została wymuszona treść jego głosu, to może on go później zmienić lub nawet udać się do lokalu wyborczego i oddać głos w sposób tradycyjny na papierowej karcie do głosowania. Po zakończeniu głosowania w sposób elektroniczny sporządzane są listy głosujących w ten sposób wyborców, które przekazywane są do właściwych komisji w lokalach wyborczych i tam odnotowywane w spisie wyborców. Wyborca w dniu głosowania może jednak udać się do lokalu wyborczego i głosować w sposób tradycyjny; w takim wypadku przy ustalaniu wyniku głosowania uwzględniony jest głos oddany na papierowej karcie do głosowania, a głos oddany przez internet nie jest uwzględniany ${ }^{19}$. Po zakończeniu głosowania w lokalach wyborczych głosy oddane wyłącznie za pomocą internetu są przez system informatyczny przetwarzane w ten sposób, że następuje oddzielenie głosu od podpisu, dzięki czemu dochowana jest zasada tajności głosowania ${ }^{20}$.

W Szwajcarii i-voting stosowany jest w następujących kantonach: Argowia, Bazylea-Miasto, Berno, Fryburg, Genewa, Gryzonia, Lucerna, Neuchâtel, Szafuza, Soluta, Sank Galle, Turgowia i Zurych. Z uwagi na jej federalną strukturę oraz specyfikę (odmienność) poszczególnych jej podmiotów pozostawiono kantonom daleko idącą swobodę w kształtowaniu wielu rozwiązań, stąd też stosowane są trzy systemy głosowania elektronicznego: większość kantonów korzysta z Zurich E-voting System (Argowia, Fryburg, Gryzonia, Szafuza, Soluta, Sank Galle, Turgowia i Zurych), mniej z Geneva E-voting System (Genewa, Bazylea-Miasto, Berno, Lucerna), a najmniej popularny jest Neuchâtel E-voting System, który wykorzystywany jest jedynie w kantonie Neuchâtel, ale służy też do wielu usług administracyjnych (wielowymiarowa platforma Guichet unique). Jak podaje Magdalena Musiał-Karg, systemy te: różnią się między sobą strukturą, jednak najważniejsze kroki (etapy) przy oddawaniu głosów za pośrednictwem tych systemów wygladaja bardzo podobnie. Dysponujac dokumentem uprawniającym do głosowania (na którym zamieszczone sa dane do głosowania elektronicznego), wyborca po wpisaniu swojego identyfikatora (ID użytkownika) lub numeru karty do głosowania, wybiera właściwa odpowiedź na pytanie referendalne, następnie wpisuje z karty do głosowania elektronicznego kod PIN i utajnione pod „zdrapka” hasło, a na końcu wysyła głos. Na koniec procedury otrzymuje informacje, potwierdzajaca oddanie głosu ${ }^{21}$.

Niewątpliwie kwestie związane z głosowaniem przez internet powinny być szczegółowo dopracowane. Pomocne mogą być w tym wypadku przyjęte przez Komitet Ministrów Rady Europy w dniu 30 września 2004 r. „Zalecenia Komitetu Ministrów dla państw członkowskich w sprawie prawnych, operacyjnych i technicznych standardów głosowania elektronicznego", które zostały opracowane na

19 Szerzej i bardziej szczegółowo zob. M. Czakowski, E-voting, op. cit., s. 130-132.

20 Zob. I. Dyś-Branicka, E-voting jako alternatywna procedura głosowania na przykładzie Estonii - szanse i zagrożenia [w:] Instytucje demokracji bezpośredniej w praktyce, red. O. Hałub, M. Jabłoński, M. Radajewski, Wrocław 2016, s. 263.

21 M. Musiał-Karg, Alternatywne metody, op. cit., s. 20. 
podstawie standardów dla głosowania elektronicznego przygotowanych przez Europejską Komisję na rzecz Demokracji przez Prawo, czyli tzw. Komisję Wene$\mathrm{ckąc}^{22}$. Nie omawiając ich szerzej, warto podkreślić, że wskazują one, iż w sytuacji, w której system głosowania elektronicznego nie jest powszechny, może być on stosowany jedynie jako dodatkowy, uzupełniający sposób oddawania głosu. Zaznaczono jednocześnie, że powinien być on przejrzysty, zrozumiały i dostępny dla wszystkich, $\mathrm{w}$ tym dla osób z niepełnosprawnościami. Niezmiernie ważne jest również, aby wyborcy pozostawiono możliwość oddania pustego głosu.

\section{Dane dotyczące frekwencji}

W literaturze przedmiotu podaje się, że podczas wyborów samorządowych w Estonii w 2005 r. z głosowania za pomocą internetu skorzystało ponad 9 tys. osób, czyli $1 \%$ uprawnionych do głosowania ${ }^{23}$. W kolejnych latach podczas wyborów do różnych organów procentowy udział głosujących w ten sposób wyborców systematycznie wzrastał i wynosił odpowiednio: 5,5\% podczas wyborów do Riigikogu (parlamentu) w 2007 r.; 14,7\% podczas wyborów do Parlamentu Europejskiego w 2009 r.; 15,8\% podczas wyborów lokalnych w 2009 r.; 24,3\% podczas wyborów parlamentarnych w $2011 \mathrm{r}$. i 30,5\% podczas wyborów parlamentarnych w 2015 r. ${ }^{24}$. Co niezwykle istotne, ten wzrost liczby głosujących za pośrednictwem internetu nie przekłada się jednak na ogólne zwiększenie frekwencji podczas wyborów. W wyborach w $2007 \mathrm{r}$. wynosiła ona 61,9\% uprawnionych do głosowania, a w 2011 r. - 64,2\%, a w ostatnich wyborach parlamentarnych w 2015 r. - 64,2\%. Nieco lepiej przedstawia się to $\mathrm{w}$ wyborach lokalnych $-47,4 \%$ podczas wyborów w 2005 r. i 58\% podczas wyborów w 2013 r. Już jednak podczas wyborów do Parlamentu Europejskiego frekwencja zmalała z 43,9\% w 2009 r. do 36,5\% w $2014 \mathrm{r}^{25}$. Dlatego można stwierdzić, że gdyby nie było możliwości głosowania przez internet, osoby, które oddały w ten sposób głos, i tak uczestniczyłyby w głosowaniu, udając się do lokalu wyborczego bądź korzystając z innego alternatywnego sposobu głosowania.

W Norwegii próbne głosowania za pośrednictwem internetu odbyły się w 2011 r. i w 2013 r. W 2013 r. z możliwości głosowania elektronicznego, które miało miejsce w 12 miastach, skorzystało około 70 tys. Norwegów, to znaczy

22 Są one opublikowane jako załącznik do artykułu K.W. Czaplickiego, Głosowanie elektroniczne (e-voting) - wybrane zagadnienia [w:] Demokratyczne standardy prawa wyborczego Rzeczypospolitej Polskiej. Teoria i praktyka, red. F. Rymarz, Warszawa 2005, s. 49-96; ich omówienie zawarte jest również w pracy G. Kryszenia, Standardy prawne wolnych wyborów parlamentarnych, Białystok 2007, s. 232-233.

23 Zob. A. Preisner, e-voting, op. cit., s. 207.

24 Zob. M. Czakowski, E-voting, op. cit., s. 126; I. Dyś-Branicka, E-voting, op. cit., s. 261.

25 Ibidem, s. 264. 
około 38\% spośród 250 tys. uprawnionych do głosowania. Mimo to podjęto decyzję o wycofaniu się z tego sposobu głosowania. Zadecydowało o tym, po pierwsze, to, że $i$-voting nie spowodował zwiększenia frekwencji podczas wyborów. Po drugie, co nie mniej istotne, nie stwierdzono, aby i-voting spowodował zwiększenie aktywności wyborczej młodych wyborców. Dlatego też rząd norweski postanowił wycofać się z głosowania w ten sposób. Odwołano się przy tym do raportu norweskiego Instytutu Badań Społecznych, w którym wskazano, że nie ma pewności odnośnie do swobody oddania głosu przez wyborcę oraz podano, że 0,75\% ogółu wyborców głosowało w 2013 r. dwukrotnie, tzn. online i w lokalu wyborczym ${ }^{26}$.

Odnosząc się do kwestii korzystania z możliwości głosowania przez internet, należy przywołać także ocenę jej stosowania w Szwajcarii. M. Musiał-Karg zasadnie, moim zdaniem, twierdzi, że ten sposób głosowania jedynie zmodyfikował głosowanie korespondencyjne w tym państwie, a nie je zrewolucjonizował, co jest o tyle istotne, że głosowanie korespondencyjne jest w tym kraju dominującym sposobem głosowania ${ }^{27}$.

Za szybkim wprowadzeniem $i$-votingu opowiada się natomiast przewodnicząca Komisji Wyborczej w Wielkiej Brytanii, której zdaniem tylko w ten sposób da się zaktywizować młodych wyborców.

\section{Zabezpieczenia}

Co do kwestii zabezpieczeń, to pragnę jedynie zwrócić uwagę na następujące podstawowe rozwiązania prawne: głosowanie powinno być podobne do głosowania tradycyjnego na papierowej karcie do głosowania, należy dążyć do samodzielnego i tajnego głosowania, konieczna jest wreszcie dbałości o jednokrotne liczenie głosu wyborcy, co jest szczególnie ważne w przypadku możliwości zmieniania treści oddawanego głosu do momentu zakończenia czasu głosowania przez internet.

\section{Potencjalne ryzyka}

W przypadku głosowania przez internet niewątpliwie najłatwiej jest mówić o ryzykach, jakie niesie za sobą możliwość jego wprowadzenia.

Niewątpliwie za najpoważniejsze uważam zwiększenie i tak już w niemałej części polskiego społeczeństwa przeświadczenia o manipulowaniu i fałszowaniu wyników głosowania i wyborów, co jedynie pogłębi nieufność do klasy po-

26 Www.bbc.com/news/technology-28055678 [dostęp 3 września 2017 r.].

27 Zob. M. Musiał-Karg, Alternatywne metody, op. cit., s. 14. 
litycznej jako takiej, a nawet do całego ustroju politycznego ${ }^{28}$. W Polsce można, w moim przekonaniu, mówić o powszechnym braku zaufania zarówno do instytucji (także niezależnych), jak i ekspertów. Zjawisko, o którym piszę, najlepiej zdaje się oddawać dowcip, którego autorstwo przypisywane jest P. Waglowskiemu: obywatel zagłosował za partia X, głosomat zmienił na partie Y, operator systemu postanowi jednak wesprzeć $Z$, co mu się nie udało, bo ktoś $w$ centrali „przez przypadek” wyłaczył system, a po jego „podniesieniu” wyszło, że oddano głosy na partię Q. Podając oficjalne wyniki wyborów, komisja ogłosiła, że wygrała partia $R$ (która akurat nie startowała $w$ tych wyborach, ale sukces wyborczy przyjęła $z$ satysfakcją) ${ }^{29}$. Korupcja wśród twórców oprogramowania i osób obsługujących system (administratorów, urzędników itd.) jest oczywiście możliwa, ale przychylam się do poglądu, że zdecydowanie mniejsza niż wśród tysięcy członków komisji wyborczych (komisji do spraw przeprowadzenia referendum) liczących głosy oddane w tradycyjny sposób w lokalu wyborczym ${ }^{30}$. Należy również pamiętać, że jednym z celów $i$-votingu jest dążenie do zwiększenia frekwencji. Nie może prowadzić to jednak do sytuacji, w której aktywizacji młodych wyborców towarzyszyć będzie narastający sceptycyzm starszego pokolenia, które z dużym dystansem podchodzi do wszelkich nowinek technicznych i które niewątpliwie będzie niezmiernie trudno przekonać do głosowania w inny sposób niż znane im dotychczasowe karty do głosowania ${ }^{31}$.

Inne ryzyko związane jest $\mathrm{z}$ faktem, że - mimo wielu obiegowych twierdzeń - nie wydaje się, aby można było mówić w Polsce o powszechnym dostępie do komputerów. Posiadają je i korzystają z nich przede wszystkim osoby młode i w średnim wieku, natomiast wśród osób starszych generalnie jest to zjawisko zdecydowanie rzadsze i malejące wraz z wiekiem. Trzeba również pamiętać, że dostęp do internetu nadal nie jest powszechny i to mimo wysiłków, zwłaszcza władz lokalnych. Eksperci podnoszą to od lat ${ }^{32}$.

Opisane fakty sprawiają, że możliwość głosowania za pośrednictwem internetu będzie w praktyce dostępna nie powszechnie, lecz jedynie tylko dla pewnej, wprawdzie systematycznie powiększającej się, ale tylko grupy wyborców. Dlatego nie przypadkowo w literaturze przedmiotu wskazuje się, że prawne stworzenie

28 Pisałem na ten temat w pracy: Możliwość wykorzystania alternatywnych sposobów głosowania podczas wyborów samorządowych [w:] Wybory i referenda lokalne. Aspekty prawne i politologiczne, red. M. Stec, K. Małysa-Sulińska, Warszawa 2010, s. 123.

29 Podaję za: R. Balicki, A. Preisner, E-voting - szanse, możliwości, zagrożenia [w:] Międzynarodowa Konferencja Naukowa nt. Alternatywne sposoby głosowania a aktywizacja elektoratu, Rzeszów 26-27 marca 2007 r., red. S. Grabowska, R. Grabowski, Rzeszów 2007, s. 73.

30 Zob. np. A. Preisner, e-Voting, op. cit., s. 204.

31 Szerzej pisałem o tym w: Prawne problemy ustanowienia w Polsce alternatywnych sposobów głosowania, „Przegląd Wyborczy. Biuletyn Informacyjny” 2009, nr 9-10, s. 31.

32 Zob. I. Dyś-Branicka, E-voting, op. cit., s. 266. 
możliwości głosowania przez internet będzie prowadzić do naruszenia konstytucyjnej zasady równości wyborów, gdyż taka możliwość głosowania zostanie stworzona dla niektórych spośród nich, bogatszych grup socjoekonomicznych ${ }^{33}$. Należy jednak pamiętać, że praktyka dowodzi, iż młodzi wyborcy niekoniecznie korzystają z możliwości głosowania w taki sposób. O ile bowiem w Szwajcarii chętnie głosowali oni za pośrednictwem internetu, to w Wielkiej Brytanii taki sposób głosowania absolutnie nie spowodował wzrostu aktywności wyborczej tej grupy obywateli.

Jeszcze inne ryzyko wiąże się z bardzo często podnoszonym niebezpieczeństwem naruszenia zasady tajności głosowania, a w szczególności z potencjalną możliwością tzw. głosowania rodzinnego, w którym głowa rodziny (osoba z najsilniejszym autorytetem, nie musi to być ojciec, również np. dominujące we wpływie na domowników dziecko) będzie narzucać innym członkom rodziny głosowanie na listę kandydatów bądź kandydata, na którą/którego ona głosuje. Nie jestem przekonany o zasadności tego zarzutu, gdyż niebezpieczeństwo takie zachodzi również w szczególności w przypadku głosowania korespondencyjnego, gdy wręcz istnieje możliwość, iż wyborca nie będzie widzieć swojej karty do głosowania. Istotnym problemem technicznym jest dlatego powiązanie konkretnego głosu z konkretnym wyborcą bez możliwości ustalenia tego przez kogokolwiek.

Niewątpliwym zagrożeniem dla $i$-votingu jest zawodność systemu, a w szczególności możliwość popełnienia przypadkowych błędów. Dowodzi tego zresztą praktyka i „liczenie głosów z powietrza” w Holandii ${ }^{34}$. Dlatego też organizacje międzynarodowe zajmujące się ochroną praw człowieka oczekują większej transparentności od wyborów estońskich i przedstawienia przez władze tego państwa ekspertyz technicznych potwierdzających sprawność i niezawodność stosowanego systemu ${ }^{35}$.

Kolejne zagrożenie stwarza działalność hakerów, którzy mogą zniekształcać zarówno treść oddawanych głosów, jak i obliczanie wyników głosowania i wyborów czy referendów. Jest to zawsze groźne, jednak szczególnie w przypadku takich działań ze strony służb obcych państw. Na niebezpieczeństwo takie wskazują specjaliści od bezpieczeństwa komputerowego.

Nie ulega wątpliwości, że do czasu, kiedy głosowanie za pomocą internetu będzie jedynym sposobem oddania głosu podczas wyborów bądź referendów, oczywiste jest, że wynik głosowania uzyskany wyłącznie w drodze $i$-votingu może mocno różnić się od ostatecznego, gdyż obecnie głosować w ten sposób będą jedynie bogatsze i bardziej wykształcone grupy socjoekonomiczne ${ }^{36}$.

33 Zob. K. Wojtyczek, Konstytucyjne regulacje systemu wyborczego III Rzeczypospolitej, [w:] 10 lat demokratycznego prawa wyborczego Rzeczypospolitej Polskiej (1990-2000), red. F. Rymarz, Warszawa 2000, s. 121-123; K.W. Czaplicki, Głosowanie elektroniczne, op. cit., s. 45; G. Kryszeń, Standardy, op. cit., s. 231.

34 Zob. M. Czakowski, E-voting, op. cit., s. 123.

35 Zob. I. Dyś-Branicka, E-voting, op. cit., s. 263.

36 Zob. A. Preisner, e-Voting, op. cit., s. 204. 
$\mathrm{Na}$ koniec wskazywania potencjalnych zagrożeń wynikających z $i$-votingu pragnę wreszcie podnieść, iż absolutnie nie podzielam zarzutu, że ten sposób głosowania narusza zasadę bezpośredniości głosowania. Wątku tego nie rozwijam, gdyż uważam, że w wystarczającym stopniu przesądza o tym wyrok Trybunału Konstytucyjnego z 20 lipca 2011 r. w sprawie o sygn. akt K 9/11 odnośnie do głosowania korespondencyjnego i głosowania przez pełnomocnika.

\section{Koszty jednorazowego wprowadzenia systemu obsługującego głosowanie przez internet i związane z jego utrzymaniem}

Nie mogę odpowiedzieć na pytanie o koszt jednorazowego wprowadzenia systemu obsługującego głosowanie za pośrednictwem internetu ani o wysokości wydatków związanych z jego utrzymaniem, gdyż jako prawnik nie dysponuję taką wiedza.

Uważam jednak, że odnosząc się do tej kwestii nie można pominąć faktu, iż przy jej ocenie należy brać pod uwagę oszczędności wynikające z obniżenia kosztów druku, dystrybucji, zbierania i liczenia głosów kart do głosowania, w tym diet dla członków komisji wyborczych.

\section{Podsumowanie}

Przeprowadzona analiza pokazuje, że mimo stosowania $i$-votingu w kilku państwach, jak i dosyć powszechnej dyskusji na ten temat w świecie, do tego sposobu głosowania podchodzi się z dużą ostrożnością, a w niektórych krajach nawet się z niego rezygnuje. Doświadczenie pokazuje bowiem, że mimo przeświadczenia, że przyczyni się ono do zwiększenia udziału wyborców w wyborach i referendach, w praktyce wcale się tak nie dzieje. Procedury głosowania są bardzo zróżnicowane, nawet w jednym państwie, czego przykładem jest Szwajcaria. Jest wiele niebezpieczeństw płynących z wprowadzenia $i$-votingu, ale najważniejszy wydaje się brak zaufania wyborców do tego sposobu głosowania oraz przeświadczenie o dokonywaniu dzięki niemu fałszowania wyników głosowania i wyborów. Nie bez znaczenia jest też brak powszechnego dostępu do komputerów i internetu. Nie sposób odpowiedzieć na pytanie odnoszące się do kosztów wprowadzenia i utrzymania $i$-votingu.

W Polsce od lat toczy się dyskusja na ten temat. Propozycja ustanowienia w Kodeksie wyborczym głosowania elektronicznego znalazła się w rekomendacji Instytutu Spraw Publicznych ${ }^{37}$. Jednocześnie zgodnie podkreśla się, że wymaga

37 Zob. L. Kolarska-Bobińska, J. Zbieranek, W stronę reformy prawa wyborczego $w$ Polsce [w:] Prawo wyborcze. Analizy. Interpretacje. Rekomendacje, red. J. Zbieranek, Warsza- 
to stworzenia absolutnie pewnego systemu, który umożliwi zachowanie tajności głosowania oraz do minimum ograniczy niebezpieczeństwo błędów, a tym bardziej fałszerstw ${ }^{38}$. Niezwykle istotne jest też pytanie, czy korzyści płynące $\mathrm{z}$ tego sposobu głosowania przewyższą koszty poniesione w związku z ich wprowadzeniem i utrzymaniem ${ }^{39}$.

\section{Bibliografia}

Balicki R., Preisner A., E-voting - szanse, możliwości, zagrożenia [w:] Międzynarodowa Konferencja Naukowa nt. Alternatywne sposoby głosowania a aktywizacja elektoratu, Rzeszów 26-27 marca 2007 r., red. S. Grabowska, R. Grabowski, Rzeszów 2007.

Czakowski M., E-voting na przykładzie Estonii i Brazylii, „Studia BAS” 2011, nr 3(27).

Czaplicki K.W., Alternatywne sposoby głosowania (Zarys problemów) [w:] Międzynarodowa Konferencja Naukowa nt. Alternatywne sposoby głosowania a aktywizacja elektoratu, Rzeszów 26-27 marca 2007 roku, red. S. Grabowska, R. Grabowski, Rzeszów 2007.

Czaplicki K.W., Głosowanie elektroniczne (e-voting) - wybrane zagadnienia [w:] Demokratyczne standardy prawa wyborczego Rzeczypospolitej Polskiej. Teoria i praktyka, red. F. Rymarz, Warszawa 2005.

Duda K., E-voting jako forma demokracji bezpośredniej. Dotychczasowe doświadczenia i ich konsekwencje, „Refleksje” 2011, nr 4.

Dyś-Branicka I., E-voting jako alternatywna procedura głosowania na przykładzie Estonii szanse i zagrożenia [w:] Instytucje demokracji bezpośredniej w praktyce, red. O. Hałub, M. Jabłoński, M. Radajewski, Wrocław 2016.

Giżyńska M., Lis-Staranowicz D., E-voting: blaski i cienie elektronicznego głosowania [w:] Ksiega dedykowana prof. dr hab. Bogusławowi Banaszakowi, w druku.

Gwarancje korzystania $z$ czynnego prawa wyborczego przez osoby starsze $i$ osoby $z$ niepetnosprawnościami. Analiza i zalecenia, red. J. Zbieranek, „Zasada Równego Traktowania. Prawo i Praktyka" 2012, nr 4.

Jabłoński M., Rzucidło J., Głosowanie za pośrednictwem Internetu w Królestwie Norwegii założenia i realizacja programu e-VALG2011, „Studia Wyborcze” 2012, t. XIV.

wa 2009, s. 16; podobnie: Gwarancje korzystania z czynnego prawa wyborczego przez osoby starsze i osoby z niepetnosprawnościami. Analiza i zalecenia, „Zasada Równego Traktowania. Prawo i Praktyka" 2012, nr 4, s. 96.

38 Zob. G. Kryszeń, Standardy, op. cit., s. 232; J. Rzucidło, Perspektywy głosowania za pośrednictwem Internetu w RP, „Studia Wyborcze” 2013, t. XV, s. 89; P. Uziębło, Prawne gwarancje zasady powszechności wyborów a wyzwania współczesności [w:] Aktualne problemy prawa wyborczego, red. B. Banaszak, A. Bisztyga, A. Feja-Paszkiewicz, Zielona Góra 2015, s. 451.

39 Zob. M. Zieliński, Racja bytu głosowania elektronicznego [w:] Aktualne problemy prawa wyborczego, red. B. Banaszak, A. Bisztyga, A. Feja-Paszkiewicz, Zielona Góra 2015, s. 481. 
Kolarska-Bobińska L., Zbieranek J., W stronę reformy prawa wyborczego w Polsce [w:] Prawo wyborcze. Analizy. Interpretacje. Rekomendacje, red. J. Zbieranek, Warszawa 2009.

Kryszeń G., Standardy prawne wolnych wyborów parlamentarnych, Białystok 2007.

Lewandowska J., Matusiak M., Wady i zalety e-votingu jako alternatywnej metody głosowania [w:] Wyzwania wspótczesnego prawa wyborczego, red. A. Pyrzyńska, P. Raźny, J. Wojciechowska, R. Zych, Toruń 2014.

Musiał-Karg M., Alternatywne metody głosowania na przykładzie głosowania korespondencyjnego oraz e-votingu w Szwajcarii, „Białostockie Studia Prawnicze” 2016, z. 20/A. https://doi.org/10.15290/bsp.2016.20a.01.

Preisner A., e-Voting - przyszłość e-demokracji? (Szkic kilku niełatwych kwestii) [w:] Międzynarodowa Konferencja Naukowa nt: Prawo wyborcze do parlamentu w wybranych państwach europejskich. Rzeszów 3-4 kwietnia 2006 roku, red. S. Grabowska, R. Grabowski, Rzeszów 2006.

Rzucidło J., Perspektywy głosowania za pośrednictwem Internetu w RP, „Studia Wyborcze” 2013, t. XV.

Skotnicki K., Możliwość wykorzystania alternatywnych sposobów głosowania podczas wyborów samorzadowych [w:] Wybory i referenda lokalne. Aspekty prawne i politologiczne, red. M. Stec, K. Małysa-Sulińska, Warszawa 2010.

Skotnicki K., Prawne problemy ustanowienia w Polsce alternatywnych sposobów głosowania, „Przegląd Wyborczy. Biuletyn Informacyjny” 2009, nr 9-10.

Skotnicki K., Zasada powszechności wyborów. Zagadnienia teorii i praktyki, Łódź 2000.

Solvak M., Vassil K., E-voting in Estonia: Technological Diffusion and Other Developments Over Ten Years (2005-2015), University of Tartu \& Estonian National Electoral Committee, Tartu 2016, http://skytte.ut.ee/sites/default/files/skytte/e_voting_in_estonia_ vassil_solvak_a5_web.pdf.

Uziębło P., Prawne gwarancje zasady powszechności wyborów a wyzwania współczesności [w:] Aktualne problemy prawa wyborczego, red. B. Banaszak, A. Bisztyga, A. Feja-Paszkiewicz, Zielona Góra 2015.

Wojtyczek K., Konstytucyjne regulacje systemu wyborczego III Rzeczypospolitej, [w:] 10 lat demokratycznego prawa wyborczego Rzeczypospolitej Polskiej (1990-2000), red. F. Rymarz, Warszawa 2000.

Zieliński M., Racja bytu głosowania elektronicznego [w:] Aktualne problemy prawa wyborczego, red. B. Banaszak, A. Bisztyga, A. Feja-Paszkiewicz, Zielona Góra 2015.

\section{Strony internetowe}

Http://www.e-voting.cc/files/e-voting-map-2015.pdf.

Www.bbc.com/news/technology-28055678.

Https://www.ndi.org/e-voting-guide/internet-voting.

Http://skytte.ut.ee/sites/default/files/skytte/e_voting_in_estonia_vassil_solvak_a5_web. pdf. 


\section{Piotr Chybalski}

\section{Wykładnia art. 184 ust. 2 regulaminu Sejmu - przedmiot wniosku formalnego ${ }^{1}$}

Interpretation of Article 184 par. 2 of the Standing Orders of the Sejm - subject matter of a point of order: The discussed Article specifies the acceptable subject matter of points of order. The assumption that they may concern matters being the subject of orders of the day and the course of sittings means that the subject matter of the point of order cannot become a matter to be considered in the future, i.e. during any of subsequent sittings. In the author's opinion, it is in principle unacceptable to submit pro futuro points of order. Article 184 para. 2 of the Standing Orders of the Sejm refers only to the subject of the point of order and not to the motives of the motion submitted by the applicant. This means that, on justifying the point of order, a Deputy may rely on external circumstances, i.e. not related to a group of matters considered by the Sejm during a given sitting.

Keywords: point of order | Standing Orders | sitting of the Sejm Słowa kluczowe: wniosek formalny | regulamin Sejmu | posiedzenie Sejmu

\section{Przedmiot opinii}

Przedmiotem niniejszej opinii jest wykładnia art. 184 ust. 2 regulaminu Sejmu, który stanowi, że: [w] nioski formalne moga dotyczyć wyłącznie spraw będących przedmiotem porzadku dziennego i przebiegu posiedzenia.

\section{Uwagi ogólne}

Uregulowana w art. 184 regulaminu Sejmu, a także w niektórych innych przepisach regulaminu (zwłaszcza art. 188 ust. 1), instytucja wniosków formalnych

1 Opinia prawna $w$ sprawie wykładni art. 184 ust. 2 regulaminu Sejmu sporządzona 31 października 2017 r. na zlecenie zastępcy Szefa Kancelarii Sejmu; BAS-WAKiU 2085/17. 
należy do klasycznych instytucji prawa parlamentarnego, występujących zarówno w Sejmie, Senacie (art. 48 regulaminu Senatu), jak w parlamentach państw obcych (np. jako tzw. points of order w parlamencie brytyjskim). Istotę pojęcia „wniosku formalnego" stanowi jego przedmiot. Zgodnie z art. 184 ust. 2 regulaminu Sejmu wnioski formalne mogą dotyczyć wyłącznie spraw będących przedmiotem porządku dziennego i przebiegu posiedzenia. Nie chodzi tu jednak o merytoryczne wpływanie na sposób rozstrzygnięcia przez Sejm owych spraw (co stanowi domenę wniosków określanych w piśmiennictwie konstytucyjnym mianem materialnych, służących „wprost realizacji kompetencji Sej$\mathrm{mu}^{2 \prime}$, a więc np. poprawki czy wniosku o odrzucenie projektu), lecz o sam sposób procedowania.

W polskim parlamentaryzmie wnioski formalne przewidziane były już $\mathrm{w}$ pierwszym regulaminie parlamentarnym przyjętym po odzyskaniu niepodległości, tj. w Tymczasowym regulaminie obrad Sejmu Ustawodawczego Rzeczypospolitej Polskiej z 14 lutego 1919 r. (art. 30). Co ciekawe, specyfika polskich regulacji regulaminowych odnoszących się do wniosków formalnych wyraża się $\mathrm{w}$ tym, iż w kolejnych regulaminach zawierano w założeniu wyczerpujące listy tych wniosków, tworząc zamknięte katalogi wniosków formalnych. Taki stan rzeczy odróżnia omawianą instytucję od jej odpowiednika z obrad komisyjnych, czyli tzw. wniosków w sprawach proceduralnych (art. 163a ust. 1 regulaminu Sejmu), przewidzianych w regulaminie od wejścia w życie noweli z 19 grudnia 2008 r. (M.P. 2009, nr 2, poz. 9). Regulamin nie zawiera bowiem nawet przykładowej, otwartej listy wniosków w sprawach proceduralnych.

\section{Kształtowanie się art. 182 ust. 2 regulaminu Sejmu}

Mimo zarysowanego wyżej utrwalonego charakteru instytucji wniosków formalnych w polskim prawie parlamentarnym we wcześniej obowiązujących regulaminach Sejmu, Senatu czy dwóch sejmów ustawodawczych nie występował odpowiednik art. 184 ust. 2 regulaminu Sejmu. Przepis ten pojawił się dopiero w pierwotnej wersji obecnego regulaminu Sejmu, z tym że pierwotnie oznaczony był jako art. 109 ust. 2. Co ciekawe, nie występował on w projekcie regulaminu ${ }^{3}$, lecz został wprowadzony $\mathrm{w}$ drugim czytaniu projektu w wyniku poprawki zgłoszonej przez jednego z wicemarszałków w imieniu Prezydium Sejmu ${ }^{4}$. W pier-

2 P. Sarnecki, Uwaga nr 1 do art. 184 [w:] Komentarz do regulaminu Sejmu, red. A. Szmyt, Warszawa 2018, s. 832.

3 Zob. druk sejmowy nr 116/I kad.

4 Zob. wypowiedź wicemarszałka Sejmu J. Zycha, Sprawozdanie stenograficzne z 21. posiedzenia Sejmu I kadencji, 22 lipca 1992 r., System Informacyjny Sejmu [dostęp 30 października 2017 r.]. 
wotnej wersji omawiany przepis miał stanowić, iz: $[\mathrm{w}]$ nioski formalne moga dotyczyć wyłącznie spraw będących przedmiotem porządku dziennego obrad, lecz w wyniku wysuwanych w toku debaty wątpliwości interpretacyjnych jego treść z inicjatywy jednego z posłów uzupełniono o frazę „i przebiegu posiedzenia”. W takiej wersji ówczesny art. 109 ust. 2 został przyjęty przez Sejm.

Warto dodać, że w toku obowiązywania regulaminu treść analizowanego przepisu nie podlegała jakimkolwiek modyfikacjom - oczywiście poza zmianą numeracji ${ }^{6}$.

\section{Wykładnia art. 184 ust. 2 regulaminu Sejmu}

Jakkolwiek problematyka wniosków formalnych nie należy do często omawianych w piśmiennictwie konstytucyjnym - nawet w opracowaniach poświęconych prawu parlamentarnemu - można odnotować dwie wypowiedzi poświęcone wykładni art. 184 ust. 2 regulaminu Sejmu, przy czym, co istotne, są one ze sobą zbieżne. Przede wszystkim należy przywołać uwagi P. Sarneckiego. Autor ten zauważył, że przyjęcie wniosku formalnego dotyczącego przebiegu posiedzenia: oznacza ingerencję i z reguły skorygowanie toku obrad nad poszczególnymi punktami porzadku dziennego, odejście od toku wzorcowego, który polega na swobodzie kierowania obradami przez Marszałka Sejmu ${ }^{7}$. Istotniejsza wydaje się jednak uwaga odnosząca się do wyrażenia „sprawy będące przedmiotem porządku dziennego”. Zdaniem P. Sarneckiego oznacza ono, że: stosowne rozstrzygnięcia Sejmu podjęte na ich podstawie odnosza się wyłacznie do konkretnej sprawy porzadku dziennego i nie posiadaja żadnego szerszego znaczenia, wykraczającego poza tę sprawę . $^{8}$.

Drugim autorem, który odniósł się do art. 184 ust. 2 regulaminu Sejmu, jest M. Stębelski. Omawiając przewidziane w art. 184 ust. 3 pkt 1 regulaminu Sejmu wnioski formalne o przerwanie i odroczenie posiedzenia, stwierdził, że w świetle art. 184 ust. 2: zarówno wniosek o przerwanie, jak i odroczenie posiedzenia, zgłoszony na podstawie art. 184 ust. 3 pkt 1 regulaminu Sejmu może się odnosić wyłącznie do toczacego sie już posiedzenia. Nie jest natomiast możliwe, aby dotyczyt on, co prawda zwołanego, ale jeszcze nierozpoczętego posiedzenia ${ }^{9}$. Stanowisko

5 Zob. wystąpienia posłów J. Szymańskiego i S. Szańkowskiego, Sprawozdanie stenograficzne z 22. posiedzenia Sejmu I kadencji, 30 lipca 1992 r., System Informacyjny Sejmu [dostęp 30 października 2017 r.].

6 Tzw. przenumerowania przepisów regulaminu Sejmu dokonano na mocy art. 3 noweli regulaminu z 14 lutego 2002 r., M.P. nr 9, poz. 162.

P. Sarnecki, Uwaga nr 1 do art. 184, op. cit.

8 Ibidem.

9 M. Stębelski, Wniosek formalny o przerwanie (odroczenie) posiedzenia Sejmu [w:] Regulamin Sejmu w opiniach Biura Analiz Sejmowych, t. II, red. W. Odrowąż-Sypniewski, Warszawa 2010, s. 461. 
wydaje się w pełni korespondować z założeniem przyświecającym inicjatorom uwzględnienia $\mathrm{w}$ regulaminie analizowanego przepisu. W debacie nad projektem regulaminu, toczącej się w 1992 r. podczas I kadencji Sejmu (1991-1993) wyrażono pogląd, że przyjęcie rozwiązania zawartego w obecnym art. 184 ust. 2 regulaminu Sejmu oznacza, iż: nie będzie można składać wniosków formalnych dotyczących następnego dnia obrad czy też na przykład porządku obrad następnego posiedzenia ${ }^{10}$.

Podzielając przedstawione wyżej stanowiska, należy stwierdzić, że analizowany przepis dookreśla dopuszczalny przedmiot wniosków formalnych. Przesądzenie, że mogą one dotyczyć spraw będących przedmiotem porządku dziennego i przebiegu posiedzenia, oznacza, że przedmiotem wniosku formalnego nie może stać się sprawa, która ma być rozpatrywana w przyszłości, tj. na którymś z kolejnych posiedzeń. Przykładowo niedopuszczalny byłby wniosek formalny o zmianę w sposobie prowadzenia dyskusji (art. 184 ust. 3 pkt 8 regulaminu Sejmu) nad którymś z punktów porządku obrad (bądź też kilku punktów) posiedzenia Sejmu następującego po posiedzeniu, podczas którego wniosek został zgłoszony. Ponadto równie niedopuszczalny byłby wniosek, który odnosiłby się do wszystkich przyszłych posiedzeń, choćby wniosek formalny o odroczenie posiedzenia (art. 184 ust. 3 pkt 1 regulaminu Sejmu), które zostało wstępnie zaplanowane ( $w$ ramach ustalenia tzw. tygodni posiedzeń przez Prezydium Sejmu, zob. art. 12 pkt 2 regulaminu Sejmu) w określonym terminie.

Co więcej, w moim przekonaniu konieczne jest zastrzeżenie, że co do zasady niedopuszczalne jest zgłaszanie wniosków formalnych pro futuro. Uwzględniając fakt, że wnioski formalne można podzielić na dwa podstawowe typy, tj. a) odnoszące się do całokształtu posiedzenia Sejmu (w szczególności wnioski formalne o przerwanie, odroczenie lub zamknięcie posiedzenia - art. 184 ust. 3 pkt 1 regulaminu Sejmu) oraz b) związane z danym punktem porządku obrad (np. wnioski formalne o zamknięcie listy mówców - art. 184 ust. 3 pkt 3 regulaminu Sejmu, zamknięcie dyskusji - art. 184 ust. 3 pkt 4 regulaminu Sejmu, czy zmianę w sposobie prowadzenia dyskusji - art. 184 ust. 3 pkt 8 regulaminu Sejmu), oznaczałoby to, że niewystarczające jest przesądzenie, iż temporalną granicę dopuszczalnego zakresu wniosków stanowi zakończenie posiedzenia Sejmu, podczas którego są one zgłaszane. Należałoby przyjąć, że przedmiotem wniosków formalnych związanych z danym punktem porządku obrad (oznaczone wyżej literą b) może być wyłącznie sposób procedowania Sejmu w tym punkcie obrad. Nie byłoby więc dopuszczalne, aby izba, przyjmując wnioski for-

10 Zob. wystąpienie posła-sprawozdawcy B. Twaroga prezentującego sprawozdanie Komisji Regulaminowej i Spraw Poselskich o projekcie uchwały - regulamin Sejmu Rzeczypospolitej Polskiej (druki sejmowe nr 116/I kad. i 360/I kad.), Sprawozdanie stenograficzne z 22. posiedzenia Sejmu I kadencji, 30 lipca 1992 r., System Informacyjny Sejmu [dostęp 30 października 2017 r.]. 
malne, niejako „organizowała” sobie przebieg całego posiedzenia, np. ustalając na początku posiedzenia sposób prowadzenia dyskusji odnośnie do wszystkich punktów porządku obrad.

Powyższy wniosek wynika z przekonania, że wnioski formalne co do zasady stanowią szczególne, wyjątkowe rozwiązania proceduralne, modyfikujące ogólne przepisy regulaminu (np. wniosek formalny o zmianę w sposobie prowadzenia dyskusji umożliwia ingerencję izby w przewidzianą w art. 181 ust. 1 regulaminu Sejmu kompetencję Prezydium Sejmu, wykonywaną po zasięgnięciu opinii Konwentu Seniorów, do zaproponowania Sejmowi propozycji przeprowadzenia debaty w ramach limitów czasowych przysługujących klubom i kołom poselskim). Stąd, w myśl dyrektywy wykładni exceptiones non sunt extendendae zasadne jest opowiedzenie się za ścisłą interpretacją zakresu wniosków formalnych. Ponadto przedstawiona wyżej teza wydaje się znajdować uzasadnienie w wynikającej implicite $\mathrm{z}$ art. 184 regulaminu Sejmu zasadzie niezwłocznego rozstrzygania przez Sejm wniosków formalnych ${ }^{11}$. Dodatkowo w art. 184 ust. 4 regulaminu Sejmu o wymienionych w tym przepisie wnioskach formalnych Sejm rozstrzyga większością głosów obecnych posłów, a więc bez konieczności zachowania kworum wynoszącego połowę ustawowej liczby posłów (zob. art. 120 Konstytucji RP). Przyjęcie stanowiska odmiennego od zaprezentowanego wyżej (czyli dopuszczenia wniosków formalnych dotyczących dowolnego punktu porządku obrad danego posiedzenia Sejmu) skutkowałoby możliwością stosowania swego rodzaju „trików proceduralnych” przez posłów, nawet reprezentujących mniejszość parlamentarną. Można byłoby bowiem, korzystając z nieobecności na sali posiedzeń większości posłów, przy wykorzystaniu art. 184 ust. 4 regulaminu Sejmu dezorganizować całe posiedzenie, np. zamykając - wbrew woli większości - dyskusję nad wszystkimi punktami porządku dziennego (art. 184 ust. 4 w związku $\mathrm{z}$ art. 184 ust. 2 pkt 4 regulaminu Sejmu).

W uzupełnieniu rozważań dotyczących wykładni art. 184 ust. 2 regulaminu Sejmu trzeba doprecyzować, że przepis ten odnosi się wyłącznie do przedmiotu wniosku formalnego (treści żądania zawartego we wniosku), nie zaś do jego osnowy, czyli przedstawionych przez wnioskodawcę motywów zgłoszenia wniosku. Oczywiście znaczna część wniosków formalnych może być z natury rzeczy motywowana wyłącznie aktualną sytuacją w izbie (np. przewidziany w art. 184 ust. 3 pkt 11 regulaminu Sejmu wniosek o stwierdzenie kworum jedynie obawą inicjatora wniosku, iż w danym momencie kworum nie jest zachowane). Z drugiej strony niektóre wnioski, np. o przerwę, odroczenie czy zamknięcie posiedzenia, mogą być uzasadniane okolicznościami zewnętrznymi, tj. niezwiązanymi z grupą spraw rozpatrywanych przez Sejm podczas danego posiedzenia. Przyję-

11 Szerzej na ten temat P. Chybalski, Opinia prawna w sprawie trybu udzielania głosu w celu zgłoszenia wniosku formalnego, z 30 października 2017 r., sygn. BAS-WAKiU 2068/17, niepubl. 
cie przeciwnego stanowiska mogłoby de facto pozbawić te wnioski formalne racji bytu. Przykładowo należałoby uznawać za niedopuszczalny wniosek formalny o przerwę umotywowany jakąś istotną uroczystością, w której przynajmniej część posłów chciałaby wziąć udział.

\section{Podsumowanie}

W podsumowaniu należy przedstawić kilka wniosków.

- W art. 184 ust. 2 regulaminu Sejmu dookreśla się dopuszczalny przedmiot wniosków formalnych. Przesądzenie, że mogą one dotyczyć spraw będących przedmiotem porządku dziennego i przebiegu posiedzenia, oznacza, że przedmiotem wniosku formalnego nie może stać się sprawa, która ma być rozpatrywana w przyszłości, tj. na którymś z kolejnych posiedzeń. Przykładowo niedopuszczalny byłby wniosek formalny o zmianę w sposobie prowadzenia dyskusji (art. 184 ust. 3 pkt 8 regulaminu Sejmu) nad którymś z punktów porządku obrad (bądź też kilku punktów) posiedzenia Sejmu następującego po posiedzeniu, podczas którego wniosek został zgłoszony. Ponadto również niedopuszczalny byłby wniosek, który odnosiłby się do przyszłych posiedzeń, choćby wniosek formalny o odroczenie posiedzenia (art. 184 ust. 3 pkt 1 regulaminu Sejmu), które zostało wstępnie zaplanowane (w ramach ustalenia tzw. tygodni posiedzeń przez Prezydium Sejmu, zob. art. 12 pkt 2 regulaminu Sejmu) w określonym terminie.

- Co więcej, należałoby uznać, że co do zasady niedopuszczalne jest zgłaszanie wniosków formalnych pro futuro. Oznacza to, że przedmiotem wniosków formalnych związanych $\mathrm{z}$ danym punktem porządku obrad (np. wniosku o zamknięcie dyskusji - art. 184 ust. 3 pkt 4 regulaminu Sejmu) może być wyłącznie sposób procedowania Sejmu w tym punkcie obrad. Nie byłoby więc przykładowo dopuszczalne, aby izba, przyjmując wnioski formalne, niejako "organizowała" sobie przebieg całego posiedzenia, np. ustalając na początku posiedzenia sposób prowadzenia dyskusji odnośnie do wszystkich punktów porządku obrad.

- Artykuł 184 ust. 2 regulaminu Sejmu odnosi się wyłącznie do przedmiotu wniosku formalnego (treści żądania zawartego we wniosku), nie zaś do jego osnowy, czyli przedstawionych przez wnioskodawcę motywów zgłoszenia wniosku. Oznacza to, że uzasadniając wniosek formalny, poseł może powoływać się na okoliczności zewnętrzne, tj. niezwiązane z grupą spraw rozpatrywanych przez Sejm podczas danego posiedzenia. Przykładowo dopuszczalny byłby wniosek o przerwę umotywowany jakąs istotną uroczystością, w której przynajmniej część posłów chciałaby wziąć udział. Oczywiście należy nadmienić, że znaczna część wniosków formalnych nie może być z natury rzeczy motywowana okolicznościami zewnętrznymi, lecz wyłącznie aktualną sytua- 
cją w izbie (np. przewidziany w art. 184 ust. 3 pkt 11 regulaminu Sejmu wniosek o stwierdzenie kworum jedynie obawą inicjatora wniosku, że w danym momencie kworum nie jest zachowane).

\section{Bibliografia}

Sarnecki P., Uwaga nr 1 do art. 184 [w:] Komentarz do regulaminu Sejmu, red. A. Szmyt, Warszawa 2018.

Stębelski M., Wniosek formalny o przerwanie (odroczenie) posiedzenia Sejmu [w:] Regulamin Sejmu w opiniach Biura Analiz Sejmowych, t. II, red. W. Odrowąż-Sypniewski, Warszawa 2010. 


\section{Możliwość prowadzenia przez partie polityczne kampanii społecznych ${ }^{1}$}

Admissibility of running social campaigns by political parties: Political parties may legitimately undertake public activities (including the so-called social campaigns) aimed at encouraging citizens to provide financial support, in the form of pecuniary donations, to monetary works aimed at the implementation of a specific activity of a party within the framework of "influencing with democratic methods the state policy" and statutory goals of a given party. Such activities cannot take the form of a public collection, i.e. involve the collection of funds in cash or in kind in public places or encourage such activities. Payments to political parties made in connection with a specific purpose (e.g. preparation of a bill) are subject to the subjective and quota restrictions set out in the Act on Political Parties.

Keywords: political party | donation | public collection

Słowa kluczowe: partia polityczna | darowizna | zbiórka publiczna

Doktor nauk prawnych, starszy wykładowca na Uniwersytecie Jagiellońskim, ekspert ds. legislacji BAS; piotr.czarny@neostrada.pl.

\section{Zagadnienia wstępne}

Przedmiotem niniejszej opinii prawnej jest odpowiedź pytanie: czy partie polityczne w Polsce - w świetle obowiązujących przepisów prawa - mogą legalnie prowadzić kampanie społeczne (poprzez np. publikacje plakatów/ogłoszeń) zachęcające obywateli do finansowego wsparcia w tworzeniu danego projektu ustawy?

Niniejsza opinia ma charakter ogólny i nie odnosi się wprost do konkretnej sytuacji. Została sporządzona przede wszystkim na podstawie przepisów ustawy z 27 czerwca 1997 r. o partiach politycznych (t.j. Dz.U. 2017, poz. 876) oraz prze-

1 Opinia prawna w sprawie prowadzenia przez partie polityczne kampanii społecznych sporządzona 13 listopada 2017 r. na zlecenie Klubu Parlamentarnego Prawo i Sprawiedliwość; BAS-WAKiU 2137/17. 
pisów tytułu XXXIII księgi trzeciej Kodeksu cywilnego (t.j. Dz.U. 2017, poz. 459; dalej: k.c.).

Ze względu na odrębnie określone cele i zasady działania europejskich partii politycznych tezy i ustalenia niniejszej opinii nie odnoszą się do tego rodzaju organizacji.

\section{Uzasadnienie i ustalenia szczegółowe}

1. Należy na początku ustalić, co oznacza pojęcie „kampania społeczna”. Nie jest to termin prawnie zdefiniowany. Ogólnie przyjmuje się, że: [k]ampania społeczna jest forma działań społecznie zaangażowanych organizacji, obok akcji czy programu społecznego. Jest to medialna kampania realizowana najczęściej przy współpracy różnych podmiotów, majaca na celu rozwiązanie jakiegoś problemu społecznego, promocję wartości lub zmianę postaw; umożliwia różne typy wsparcia - finansowe, rzeczowe, usługowe. W innym ujęciu określenie to rozumiane jest: jako zestaw różnych działań zaplanowanych w konkretnym czasie, skierowanych do określonej grupy docelowej, której celem jest doprowadzenie do wzrostu wiedzy, zmiany myślenia, zachowania wobec określonego problemu społecznego lub prowadzi do rozwiązywania problemu społecznego blokującego osiaganie dobra wspólnego zdefiniowanego jako dany cel marketingowy. Kampania społeczna może stosować narzędzia i techniki reklamowe oraz $P R^{2}$.

Niezależnie od tego, jak dokładnie definiować kampanie społeczne, stwierdzić należy ogólnie, że dopuszczalność ich prowadzenia przez partie polityczne wynika z art. 11 Konstytucji RP, który poręcza m.in. wolność działania partii politycznych. Organizacja tego typu może w swojej działalności wykorzystywać różnorodne środki i sposoby, o ile mieszczą się one w szeroko pojętych ramach działania w celu: wpływania metodami demokratycznymi na kształtowanie polityki państwa. Jak się wskazuje w literaturze: [u]strojodawca wskazał w ten sposób na wielość i różnorodność działań, za pomoca których partia może wpływać na kształt polityki państwa. Tak zakreślony cel nie ogranicza działalności partyjnej do udziału w wyborach czy dązenia do zdobycia władzy. Wpływ na kształt polityki państwa partie wywierać powinny przez angażowanie opinii publicznej do debaty nad polityka państwa, profesjonalizacje polityki (np. przez wykorzystywanie funduszów eksperckich), rozmaite procedury kontrolne (np. interpelacyjne), ocene prowadzonej polityki czy proponowanie własnych rozwiązańn ${ }^{3}$. Niewątpliwie ini-

2 B. Tarczydło, Kampania społeczna $w$ teorii i praktyce, https://www.ue.katowice.pl/ fileadmin/_migrated/content_uploads/19_B.Tarczydlo_Kampania_spoleczna_w_ teorii_i_praktyce.pdf [dostęp 6 listopada 2017 r.].

3 J. Sułkowski, Uwaga 39 do art. 11 [w:] Konstytucja RP, t. I, Komentarz do art. 1-86, red. M. Safjan, L. Bosek, Warszawa 2016, s. 361. 
cjowanie i prowadzenie kampanii społecznej w sprawie przygotowania projektu ustawy mieści się w pojęciu angażowania opinii publicznej, jak również związane jest z proponowaniem własnych rozwiązań.

Należy oczywiście zgłosić zastrzeżenie, że działania partii politycznych również w zakresie kampanii społecznych nie mogą naruszać art. 13 Konstytucji. Temat prowadzonej kampanii nie może zatem: odwoływać się do totalitarnych metod i praktyk działania nazizmu, faszyzmu i komunizmu, oraz zakładać albo dopuszczać nienawiści rasowej i narodowościowej. Wykluczone jest także stosowanie przemocy. Niezależnie od tego, za naruszenie prawa należałoby również uznać takie określenie celu i założeń kampanii społecznej, które stanowiłoby przestępstwo, np. publiczne nawoływanie do wszczęcia wojny napastniczej lub pochwałę takiej wojny (art. $117 \S 3$ Kodeksu karnego) czy też publiczne nawoływanie do popełnienia przestępstwa albo publiczną pochwałę przestępstwa (art. 255 Kodeksu karnego).

Z zasady wolności działania partii politycznych wynika, że wszelkie ograniczenia w tej dziedzinie wynikać powinny wyraźnie z przepisów Konstytucji RP lub ustaw. Co do „publikacji” plakatów zwrócić trzeba uwagę, że zgodnie z art. 63 $\$ 1$ Kodeksu wykroczeń legalne umieszczanie w miejscu publicznym do tego nieprzeznaczonym ogłoszeń, plakatów, afiszów, apeli, ulotek, napisów lub rysunków albo ich wystawianie na widok publiczny w innym miejscu wymaga zgody zarządzającego tym miejscem.

2. Jeśli chodzi o majątkowy aspekt prowadzenia przez partię polityczną kampanii społecznej, tj. o różne metody zachęcania do wsparcia finansowego określonych zamierzeń (celów), to na początku stwierdzić należy, że zgodnie z art. 24 ust. 1 ustawy o partiach politycznych majątek tego typu organizacji: powstaje ze składek członkowskich, darowizn, spadków, zapisów, $z$ dochodów z majątku oraz $z$ określonych ustawami dotacji i subwencji. Do darowizn, spadków i zapisów wobec braku ich bliższego zdefiniowania w ustawie o partiach politycznych - zastosowanie znajdują przepisy Kodeksu cywilnego ${ }^{4}$. Darowizną w świetle art. 888 $\$ 1$ k.c. jest nieodpłatne świadczenie na rzecz obdarowanego kosztem majątku darczyńcy. Finansowe wsparcie partii politycznej w sytuacji, gdy osoba go dokonująca nie ma otrzymać od partii żadnego świadczenia o charakterze majątkowym, które byłoby „ekonomicznym ekwiwalentem” dokonanego „wsparcia”, kwalifikować należy pod względem prawnym jako darowiznę. Oczywiste jest, że cel wsparcia finansowego w postaci przygotowania („stworzenia”) projektu nie jest tego rodzaju działaniem, które zmieniałoby ocenę prawną wpłat na rzecz partii politycznych. Ponieważ darowizny na rzecz partii politycznych są - choć pod pewnymi warunkami - dopuszczalne, to nie można uznać, że zwracanie się o nie również do nieokreślonego imiennie kręgu osób, a więc w formie tzw.

4 M. Dębska, Ustawa o partiach politycznych. Komentarz, 2013, LexisNexis, uwaga 4 do art. 24. 
kampanii społecznej - jest czymś zabronionym. W rozumieniu prawa cywilnego zachęcanie do wpłat na rzecz partii politycznych poprzez ogłoszenia i inne informacje stanowi prawnie dopuszczalne zaproszenie do zawarcia umowy, a konkretnie umowy darowizny (art. 71 k.c.).

Partie mogą zwracać się o darowizny na ich rzecz zarówno w zakresie swojej „ogólnej” działalności statutowej, jak i „pomoc” tego rodzaju w realizacji konkretnych zamierzeń. Kwestia, na jaki konkretnie cel darczyńca dokonuje świadczenia na rzecz obdarowanego, nie należy bowiem do konstytutywnych elementów umowy darowizny. Jak stwierdził Sąd Najwyższy w wyroku z 6 października 2017 r. sygn. akt II CK 39/045: [o] drębną kwestia sa natomiast-niestanowiace już warunku prawnego bytu umowy [darowizny - dopisek P.C.] - osobiste motywy dokonania darowizny, która może służyć rozmaitym celom indywidualnym i społecznym. Pobudka doprowadzająca do zawarcia umowy może być chęć wyrażenia uczucia przywiąania lub wdzięczności, wyświadczenia przysługi lub niesienia pomocy, uzyskania przyjaźni lub odpowiedniego postępowania osoby obdarowanej bądź przysłużenia się oznaczonym celom podjętym $w$ interesie ogółu. Partie polityczne mogą wskazywać potencjalnym darczyńcom również określone zamierzenia o charakterze publicznym, które mają skłonić tych ostatnich do dokonania darowizny, a więc odwoływać się do potencjalnych pobudek ewentualnych darczyńców.

Poza tym z art. 893 k.c. wynika, że darczyńca może włożyć na obdarowanego obowiązek oznaczonego działania lub zaniechania, nie czyniąc nikogo wierzycielem (polecenie). Nie wnikając w szczegóły, stwierdzić należy, że darczyńca może również wskazać partii politycznej (jako obdarowanemu) określone zamierzenie, które powinna ona podjąć lub dążyć do jego realizacji. Trzeba przyjąć, że także ten element może być ujęty w „zaproszeniu do zawarcia umowy” (umowy darowizny), jakim - co już wspomniano - mogą być ogłoszenia (plakaty) i inne informacje upowszechniane przez partie polityczne.

3. Ustawa o partiach politycznych wprowadza zakaz przeprowadzania przez partie polityczne zbiórek publicznych (art. 24 ust. 6). Zgodnie z art. 1 ust. 1 ustawy z 14 marca 2014 r. o zasadach prowadzenia zbiórek publicznych (t.j. Dz.U. 2017, poz. 1223) zbiórką publiczną jest: zbieranie ofiar w gotówce lub $w$ naturze $w$ miejscu publicznym na określony, zgodny z prawem cel pozostający $w$ sferze zadań publicznych, o których mowa $w$ art. 4 ust. 1 ustawy z 24 kwietnia 2003 r. o działalności pożytku publicznego i o wolontariacie (Dz. U. z 2016 r. poz. 1817 i 1948 oraz z 2017 r. poz. 60 i 573), oraz na cele religijne. Oznacza to m.in., że formy zachęcania do wpłat na rzecz partii politycznych nie mogą mieć cech konstytutywnych zbiórki publicznej, tj. polegać na uzyskiwaniu środków finansowych w gotówce lub naturze w miejscach publicznych. Odnosząc się do postawionego we wstępie pytania, stwierdzić należałoby, że ewentualna kampania społeczna,

$5 \quad$ LEX nr 1448701. 
mająca na celu uzyskanie przez partię polityczną finansowego wsparcia obywateli nie powinna przewidywać działań charakterystycznych dla zbiórki publicznej, tj. odbywać się poprzez wskazywanie miejsc publicznych, w których możliwe jest dokonywanie wpłat na określony cel w gotówce lub też w formie rzeczowej.

4. Ustawa o partiach politycznych zawiera ponadto ograniczenia podmiotowe oraz (względne i bezwzględnie) ograniczenia kwotowe dotyczące wpłat na rzecz partii politycznych. Zgodnie z art. 25 ust. 1: [p]artii politycznej moga być przekazywane środki finansowe jedynie przez obywateli polskich majacych stałe miejsce zamieszkania na terenie Rzeczypospolitej Polskiej, z zastrzeżeniem przepisów art. 24 ust. 4 i 7, art. 28 ust. 1 oraz przepisów ustaw dotyczących wyborów do Sejmu Rzeczypospolitej Polskiej i do Senatu Rzeczypospolitej Polskiej oraz wyborów do Parlamentu Europejskiego w zakresie dotacji podmiotowej. W myśl art. 25 ust. 4: łączna suma wpłat od osoby fizycznej na rzecz partii politycznej, z wyłaczeniem składek członkowskich $w$ kwocie nieprzekraczającej $w$ jednym roku minimalnego wynagrodzenia za pracę, ustalanego na podstawie odrębnych przepisów, obowiązującego w dniu poprzedzającym wpłatę, oraz wpłat na Fundusz Wyborczy partii politycznej, nie może przekraczać w jednym roku 15-krotności minimalnego wynagrodzenia za prace, ustalanego na podstawie odrębnych przepisów, obowiazującego $w$ dniu poprzedzającym wpłatę. Poza tym art. 25 ust. 5 przewiduje, że: jednorazowa wpłata kwoty przekraczajacej minimalne wynagrodzenie za prace, ustalane na podstawie odrębnych przepisów, obowiąujące $w$ dniu poprzedzajacym wpłatę, może być dokonywana na rzecz partii politycznej jedynie czekiem rozrachunkowym, przelewem lub kartą płatniczą. Przyjąć należy, że ograniczenia powyższe dotyczą również darowizn na rzecz partii politycznych ${ }^{6}$. Powoduje to, że partia polityczna w ramach tzw. kampanii społecznej nie powinna upowszechniać informacji, które mogłyby wprowadzać potencjalnych darczyńców w błąd jeśli chodzi o dopuszczalność darowizny, np. przez prowadzenie kampanii wśród obywateli polskich zamieszkałych za granicą, sugerowanie wpłat przekraczających ustawowe limity. Stanowić by to mogło naruszenie art. $286 \$ 1$ Kodeksu karnego (wprowadzenie w błąd w celu osiągnięcia korzyści majątkowej).

\section{Podsumowanie}

- Partie polityczne mogą zgodnie z prawem podejmować publicznie działania (również tzw. kampanie społeczne) zmierzające do zachęcenia obywateli do finansowego wsparcia w formie darowizn pieniężnych prac mających na celu realizację konkretnego zamierzenia partii mieszczącego się $\mathrm{w}$ ramach $w p \not y$ wania metodami demokratycznymi na kształtowanie polityki państwa i statutowych celów danej partii (np. przygotowania określonego projektu ustawy).

6 M. Dębska, Ustawa o partiach, op. cit. 
W sensie cywilnoprawnym działania takie stanowią dopuszczalne zaproszenie do zawarcia umowy (umowy darowizny).

- Opisane wyżej działania nie mogą mieć charakteru zbiórki publicznej, tj. polegać na zbieraniu środków finansowych w gotówce lub w naturze w miejscach publicznych ani też zachęcać do takich działań.

- Wpłaty na rzecz partii politycznych dokonywane w związku z określonym zamierzeniem (np. przygotowaniem projektu ustawy) podlegają ograniczeniom podmiotowym i kwotowym określonym w ustawie o partiach politycznych. W działaniach zachęcających do wpłat partie powinny unikać przekazywania takich informacji, które wprowadzałyby potencjalnych darczyńców w błąd co do dopuszczalności przekazywania darowizn.

\section{Bibliografia}

Dębska M., Ustawa o partiach politycznych. Komentarz, 2013, LexisNexis.

Sułkowski J., Uwaga 39 do art. 11 [w:] Konstytucja RP. Kometarz, t. I, Art. 1-86, red. M. Safjan, L. Bosek, Warszawa 2016.

Tarczydło B., Kampania społeczna $w$ teorii i praktyce, https://www.ue.katowice.pl/fileadmin/_migrated/content_uploads/19_B.Tarczydlo_Kampania_spoleczna_w_teorii_i_ praktyce.pdf. 
\begin{tabular}{l|l}
2 & \\
& OPINIE BAS
\end{tabular}

B

ZAGADNIENIA PRAWA MIĘDZYNARODOWEGO I EUROPEJSKIEGO 



\title{
Ocena uzasadnionego wniosku, zgodnie z art. 7 Traktatu o Unii Europejskiej, dotyczącego praworządności w Polsce, wraz z projektem decyzji Rady w sprawie stwierdzenia wyraźnego ryzyka poważnego naruszenia przez Rzeczpospolitą Polską zasady praworządności ${ }^{1}$
}

\begin{abstract}
The assessment of the justified application, in accordance with Article 7 of the Treaty on European Union, concerning the rule of law in Poland, together with the draft Council decision on stating the clear risk of a serious violation of the rule of law by the Republic of Poland: Having assessed the EU documents, the author states that the proposed decision does not have social, economic or financial consequences. When assessing documents legally, the author states that the recommendations and the determination of a clear risk are two separate acts of the Council, the recommendations of which are a an act adopted prior to the one concerning the identification of the clear risk. Consequently, the recommendations cannot be part of the statement of a clear risk. The defective nature of the Commission's proposed decision makes it difficult to assess the impact. The contradiction of this decision with the TEU should be challenged by the European Parliament during the consent procedure or by the Court of Justice in the course of the follow-up procedure.
\end{abstract}

Keywords: European Union | protection of the rule of law | Poland

Słowa kluczowe: Unia Europejska | ochrona praworządności | Polska

1 Opinia na temat uzasadnionego wniosku zgodnie z art. 7 Traktatu o Unii Europejskiej dotyczącego praworządności w Polsce, wraz z projektem decyzji Rady w sprawie stwierdzenia wyraźnego ryzyka poważnego naruszenia przez Rzeczpospolita Polska zasady praworządności (COM(2017) 835 final) sporządzona 8 lutego 2018 r. na zlecenie przewodniczącej Komisji ds. Unii Europejskiej; BAS-WAPM 78/18. 


\section{Opinia merytoryczna}

\section{Przedmiot dokumentów UE}

\section{- Treść dokumentów UE}

Opiniowany dokument został sformułowany w trybie art. 7 ust. 1 Traktatu o Unii Europejskiej (TUE). Składa się z pięciu części i dołączonego projektu decyzji Rady Unii Europejskiej w sprawie stwierdzenia wyraźnego ryzyka poważnego naruszenia przez Rzeczpospolitą Polską zasady praworządności (2017/0360, NLE). Uzasadniony wniosek (powinno być: uzasadniona propozycja ${ }^{2}$ ) rozpoczyna się wprowadzeniem, w którym m.in. nawiązuje się do pojmowania zasady praworządności (pkt 2), a zatem wzorca oceny dokonanej przez Komisję, krótkiego opisu art. 7 ust. 1 TUE i podstawowych obaw Komisji związanych z sytuacją w Polsce.

W części drugiej Komisja charakteryzuje okoliczności faktyczne i przebieg postępowania, którego zwieńczeniem jest opiniowany uzasadniony wniosek. Jest to stosunkowo najbardziej rozbudowany fragment wniosku. Komisja wskazała, że rozwój wypadków w Polsce związanych z zasadą praworządności Komisja śledzi i podejmuje odpowiednie działania od listopada 2015 r. Jako podstawę swojej aktywności wskazała komunikat skierowany do Parlamentu Europejskiego i Rady z 11 marca 2014 r. pt. Nowe ramy UE na rzecz umocnienia praworządności $i^{3}$. W dokumencie tym ustanowiła trójetapową procedurę dotyczącą, w jej rozumieniu, dialogu z państwem członkowskim. Procedura ta obejmuje: a) ocenę Komisji; b) zalecenie w sprawie praworządności; c) działania następcze w stosunku do zalecenia w sprawie praworządności. W części drugiej Komisja scharakteryzowała także działania władz polskich, w szczególności parlamentu i Prezydenta RP, przede wszystkim w odniesieniu do Trybunału Konstytucyjnego i sądownictwa. Przedstawiła też działania, jakie Komisja i inne podmioty (Parlament Europejski, europejskie zrzeszenia organów sądowych czy palestry, ale także Komisja Wenecka Rady Europy i inne organy Rady, inne podmioty międzynarodowe, zwłaszcza związane z ONZ, OBWE, niektóre polskie organy państwowe, jak Sąd Najwyższy czy Rzecznik Praw Obywatelskich, a także inne zainteresowane podmioty) podejmowały wobec sytuacji w Polsce w zakresie poszanowania zasady praworządności. Komisja skoncentrowała uwagę na swojej opinii na sprawie praworządności w Polsce z 1 czerwca 2016 r., a zwłaszcza na

2 Tłumaczenia traktatów są wadliwe w zakresie, w jakim termin „proposal”, „proposition” tłumaczą jako wniosek, a nie propozycja (ewentualnie projekt), ponieważ termin „wniosek” w polskim języku prawnym i prawniczym nie obejmuje projektów aktów czy propozycji legislacyjnych lub politycznych. Podobnie zresztą w prawie Unii Europejskiej „wniosek” (motion) odnosi się do działań proceduralnych. Tymczasem "propozycja” jest odniesiona wyłącznie do działań w postaci aktów prawnych.

$3 \operatorname{COM}(2014) 158$ final. 
trzech dotychczasowych zaleceniach z lat 2016-2017, które były publikowane w Dzienniku Urzędowym Unii Europejskiej4. Komisja przypomina w tym kontekście różne działania i akty władz polskich, które oceniła krytycznie.

W tym kontekście wskazała dwie grupy uchybień w sferze praworządności. Pierwsza z nich dotyczy braku niezależnej i zgodnej z prawem kontroli zgodności z Konstytucją RP. Naruszenia zaliczone do tej grupy stanowią część trzecią opinii. Koncentrują się one wokół Trybunału Konstytucyjnego (TK). Komisja wymienia m.in.: niedopuszczenie do objęcia funkcji sędziego przez trzech wybranych przez Sejm poprzedniej kadencji sędziów, włączenie do składu TK sędziów wadliwie wybranych, wadliwe wybory prezesa i wiceprezesa TK, zmiany w składach orzekających. Komisja uznała wręcz, że te działania spowodowały: całkowita zmiane składu TK poza zwyktym konstytucyjnym procesem powoływania sędziów. Następnie Komisja wskazała postępowanie wobec Trybunału (nieopublikowanie i niewykonanie niektórych wyroków TK), które spowodowało, że utracił on swoją legitymację i że: nie można już zagwarantować zgodności polskich przepisów prawa $z$ ustawa zasadniczą, co ma szczególne znaczenie w związku z jednoczesnym uchwaleniem przez Sejm ustaw we wrażliwych dziedzinach (s. 20). Komisja podkreśla, że nie zostały wykonane żadne z działań zalecanych przez Komisję.

Część czwartą uzasadnionego wniosku wypełniają ustalenia dotyczące zagrożeń dla niezależności sądów powszechnych (w gruncie rzeczy wymiaru sprawiedliwości). Mowa tutaj zwłaszcza o uchybieniach, jakie w rozumieniu Komisji popełniły władze polskie w stosunku do Sądu Najwyższego (SN), tj. obniżenie wieku emerytalnego i odwołanie i obowiązkowe przeniesienie w stan spoczynku obecnych około 37\% sędziów SN, prawo Prezydenta RP do przedłużenia kadencji sędziego na wniosek zainteresowanego, wprowadzenie skargi nadzwyczajnej, wprowadzenie szczególnego postępowania dyscyplinarnego, ustanowienie dwóch nowych izb do SN, o szczególnej względem pozostałych pozycji ustrojowej i budżetowej, Krajowej Rady Sądownictwa (KRS), tj. skrócenie kadencji członków KRS, nowy sposób wyboru jej członków, i sądów powszechnych, tj. obniżenie wieku emerytalnego, upoważnienie Ministra Sprawiedliwości do przedłużania kadencji, uprawnienia Ministra Sprawiedliwości w zakresie odwoływania i powoływania prezesów sądów powszechnych, możliwość stosowania przez Ministra Sprawiedliwości dyscyplinującego okresowego obniżenia dodatku funkcyjnego prezesom sądów powszechnych. Ponadto Komisja zwróciła uwagę na niepokojące, jej zdaniem, zmiany w odniesieniu do Krajowej Szkoły Sądownictwa i dopuszczenia asesorów do orzekania, prokura-

4 Zalecenia nr 2016/1374 z 27 lipca 2016 r. (Dz.Urz. UE L 217, s. 53); nr 2017/146 z 21 grudnia 2016 r. (Dz.Urz. UE L 22, s. 65); nr 2017/1520 z 26 lipca 2017 r. (Dz.Urz. UE L 228, s. 19). Podstawą tych zaleceń był art. 292 Traktatu o funkcjonowaniu Unii Europejskiej. 
tury, łącznie ze sprawą połączenia stanowiska Ministra Sprawiedliwości i Prokuratora Generalnego.

Ostatnia, piąta część uzasadnionego wniosku zawiera argumentację na rzecz stwierdzenia istnienia wyraźnego ryzyka poważnego naruszenia zasady praworządności. Komisja wskazała, że mimo zaleceń sytuacja stale ulega pogorszeniu. Zmiany w TK i działania z nim związane podważyły, w jej ujęciu, niezależność i legitymację TK i wykluczyły skuteczną kontrolę konstytucyjności prawa w Polsce. Ustawodawstwo i działania dotyczące SN z kolei doprowadziły do: strukturalnego osłabienia niezawisłości sędziów Sądu Najwyższego, budzą zastrzeżenia dotyczące zasady podziału władz (zwłaszcza w powiązaniu z równoległą reformą KRS), a w zakresie wprowadzenia skargi nadzwyczajnej podważają zasady pewności prawa i podziału władz. W przypadku sądów powszechnych Polska uchybiła zasadzie nieusuwalności sędziów, która jest podstawowym elementem zasady niezawisłości sędziów, a przez swobodne powoływanie i odwoływanie prezesów sądów także zasadzie niezależności władzy sądowniczej. Zasady te naruszono również w związku ze zmianami dotyczącymi KRS. Komisja podkreśliła w kontekście tych zarzutów, że władze polskie nie wykorzystały okazji, aby uwzględnić obawy Komisji i innych podmiotów, co dowodzi braku dobrej woli z ich strony. Wreszcie Komisja stwierdziła, że działania władz polskich powodują poważne konsekwencje: a) brak możliwości skutecznego skontrolowania konstytucyjności nowego „wrażliwego” ustawodawstwa; b) naruszanie zasady praworządności uniemożliwia należyte wypełnianie praw i obowiązków traktatowych, a także podważa wzajemne zaufanie przedsiębiorstw i organów krajowych do systemów prawnych; c) zakłócenia w zakresie należytego funkcjonowania praworządności są szkodliwe dla rynku wewnętrznego i działań obszaru wolności, bezpieczeństwa i sprawiedliwości (niezależne sądownictwo to warunek współpracy sądów $\mathrm{z}$ różnych państw członkowskich).

W zakończeniu uzasadnionego wniosku Komisja stwierdza, że jest gotowa w każdej chwili ponownie go rozważyć, jeżeli władze polskie wykonają działania, które Komisja wskazała w wydanym jednocześnie z wnioskiem zaleceniu, w terminie w nim określonym, tj. 3 miesięcy od daty otrzymania tego zalecenia (pkt 49) $)^{5}$.

Ostatnim elementem uzasadnionego wniosku jest projekt decyzji Rady w sprawie stwierdzenia wyraźnego ryzyka poważnego naruszenia przez Rzeczpospolitą Polską zasady praworządności. Komisja referuje w nim w skrótowy sposób przyczyny, jakie, jej zdaniem, doprowadzają Radę do przyjęcia decyzji, a w części operatywnej formułuje dwa przepisy. W pierwszym z nich stwierdza wystąpienie wyraźnego ryzyka poważnego naruszenia zasady praworządności przez Polskę, a w drugim zaleca, aby Polska podjęła następujące działania w terminie trzech miesięcy od daty notyfikacji decyzji:

5 Zalecenie nr 2018/103 z 20 grudnia 2017 r., Dz.Urz. UE L 17 z 2018 r., s. 50. 
- przywróciła niezależność i legitymację Trybunału Konstytucyjnego jako gwaranta Konstytucji RP przez zapewnienie, aby prezes, wiceprezes oraz sędziowie Trybunału byli wybierani i powoływani zgodnie z prawem, oraz przez pełne wykonanie wyroków TK z 3 i 9 grudnia 2015 r., zgodnie z którymi stanowiska sędziów TK ma objąć trzech sędziów wybranych zgodnie z prawem przez Sejm poprzedniej kadencji w październiku 2015 r., a trzech sędziów wybranych przez Sejm nowej kadencji bez ważnej podstawy prawnej nie może orzekać, dopóki nie zostaną wybrani zgodnie z prawem,

- opublikowała i w pełni wykonała wyroki TK z 9 marca 2016 r., 11 sierpnia 2016 r. $i 7$ listopada 2016 r.,

- zagwarantowała, aby ustawa o Sądzie Najwyższym, ustawa - Prawo o ustroju sądów powszechnych, ustawa o Krajowej Radzie Sądownictwa oraz ustawa o Krajowej Szkole Sądownictwa zostały zmienione w taki sposób, aby zapewniono ich zgodność z wymogami w zakresie niezależności sądów i niezawisłości sędziów, podziału władz i pewności prawa,

- zagwarantowała, aby wszelka reforma sądownictwa była przygotowywana w ścisłej współpracy z przedstawicielami sądownictwa i wszystkimi zainteresowanymi stronami, w tym z Komisją Wenecką,

- powstrzymała się od działań i oświadczeń publicznych, które naruszają legitymację TK, SN, sądów powszechnych, sędziów, zarówno konkretnych osób, jak i sędziów ogółem, oraz wymiaru sprawiedliwości jako całości.

Wymienione zalecenia są zbieżne z zaleceniem Komisji z 20 grudnia 2017 r. (pkt 47).

\section{- Geneza dokumentów UE}

Komisja przedstawiła uzasadniony wniosek po dwóch latach od rozpoczęcia procedury praworządności, jaką przeprowadziła zgodnie z komunikatem z 2014 r., w przekonaniu, że: $w$ dużym stopniu wykorzystała możliwości przewidziane $w$ ramach na rzecz umocnienia praworządności w celu konstruktywnego dialogu $z$ polskimi władzami, po wymianie z nimi ponad 25 pism i odbyciu licznych spotkań (s. 3).

\section{Ocena dokumentów UE}

\section{- Ocena skutków społecznych, gospodarczych i finansowych dokumentów UE}

Projektowana decyzja nie wywołuje skutków społecznych, gospodarczych ani finansowych. W odniesieniu do skutków prawnych zob. uwagi zawarte w części Opinia prawna niniejszego opracowania. 


\section{- Ocena zgodności działań UE z zasadą pomocniczości}

Projektowana decyzja nie podlega ocenie pod względem zgodności z zasadą pomocniczości, ponieważ nie jest ona projektem aktu prawodawczego Unii Europejskiej ${ }^{6}$.

\section{- Ustosunkowanie się do projektu stanowiska Rady Ministrów na temat opiniowanych dokumentów UE}

Do momentu sporządzenia tej opinii Rada Ministrów nie przedstawiła projektu stanowiska RP w sprawie uzasadnionej opinii i projektu decyzji Rady.

\section{Opinia prawna}

\section{Podstawa prawna projektowanej decyzji Rady Unii Europejskiej}

Opiniowany dokument ma charakter szczególny, ponieważ zawiera pierwszy w historii procesu integracji europejskiej uzasadniony wniosek wszczynający procedurę, o której mowa w art. 7 TUE, stosowania środków wobec państw członkowskich w razie zagrożenia naruszenia lub naruszenia przez nie wartości, o których mowa w art. 2 TUE, obejmujący także projekt decyzji Rady Unii Europejskiej w sprawie stwierdzenia wyraźnego ryzyka poważnego naruszenia przez Rzeczpospolitą Polską zasady praworządności.

Określenia podstawy prawnej wymaga bez wątpienia decyzja Rady, której projekt został załączony do uzasadnionej opinii. Podstawa taka stanowi bowiem regułę wyrażającą kompetencję Unii do działania wobec państw członkowskich w szczególnym trybie. Jak wskazała Komisja w swoim projekcie, podstawą prawną przyszłej decyzji Rady w sprawie stwierdzenia wyraźnego ryzyka poważnego naruszenia przez Rzeczpospolitą Polską zasady praworządności ma być art. 7 ust. 1 TUE.

Projektowana decyzja składa się z preambuły, stanowiącej skrócone uzasadnienie przyjęcia decyzji, odwołujące się jednak do obszernego uzasadnionego wniosku (tak w części wstępnej, jak i w treści preambuły), i dwóch artykułów, z których pierwszy stwierdza istnienie wyraźnego ryzyka naruszenia przez Polskę zasady praworządności, a drugi zawiera pięć zaleceń skierowanych do Polski, które powinny być spełnione w terminie trzech miesięcy od daty notyfikacji decyzji.

W świetle art. 7 ust. 1 TUE projekt decyzji obarczony jest istotną wadą prawną. Polega ona na błędnej interpretacji tego postanowienia. W projektowanej decyzji doszło bowiem do połączenia dwóch aktów, jakie powinna przyjąć Rada. Artykuł 7 ust. 1 TUE stanowi bowiem, że: [n] a uzasadniony wniosek jednej trze-

6 O rozumieniu aktu prawodawczego zob. szerzej opinia C. Mika na temat pojmowania aktów ustawodawczych i znaczenia tego pojęcia dla pozycji parlamentów narodowych w Unii Europejskiej, „Zeszyty Prawnicze BAS” 2010, nr 2, s. 96 i n. 
ciej państw członkowskich, Parlamentu Europejskiego lub Komisji Europejskiej, Rada, stanowiąc większością czterech piątych swych członków po uzyskaniu zgody Parlamentu Europejskiego, może stwierdzić istnienie wyraźnego ryzyka poważnego naruszenia przez państwo członkowskie wartości, o których mowa w artykule 2. Przed dokonaniem takiego stwierdzenia Rada wysłuchuje dane państwo członkowskie $i$, stanowiąc zgodnie z ta sama procedura, może skierować do niego zalecenia.

Rada regularnie bada, czy powody dokonania takiego stwierdzenia pozostaja aktualne ${ }^{7}$.

Z zacytowanego postanowienia wynika określona sekwencja działania. Polega ona na tym, że stwierdzenie wyraźnego ryzyka ma poprzedzić wysłuchanie obwinianego o naruszenie art. 2 TUE państwa członkowskiego, po którym może (nie musi) dojść do sformułowania przez Radę zaleceń dla państwa członkowskiego ${ }^{8}$. Po wysłuchaniu państwa członkowskiego i ewentualnym (bezskutecznym) skierowaniu do niego zaleceń Rada może stwierdzić istnienie wyraźnego ryzyka. Stwierdzenie to powinno podawać powody, które do niego doprowadziły i które później będą mogły być (regularnie) weryfikowane co do tego, czy trwają nadal, czy też ustały. Cytowane postanowienie wymaga, aby zarówno przyjęcie zaleceń, jak i stwierdzenie wyraźnego ryzyka odbyło się „w tej samej procedurze”, opisanej w ust. 1. Jeżeli zatem Rada zamierzałaby przyjąć zalecenie, to najpierw

7 W wersjach w jęz. angielskim i francuskim brzmienie art. 7 ust. 1 TUE (zwłaszcza zdanie drugie) jest bardziej precyzyjne. Łączy się tutaj jednoznacznie uprzedniość wysłuchania i wydanie zaleceń, wymagając przeprowadzenia takiej samej procedury: 1) ang.: 1. On a reasoned proposal by one third of the Member States, by the European Parliament or by the European Commission, the Council, acting by a majority of four fifths of its members after obtaining the consent of the European Parliament, may determine that there is a clear risk of a serious breach by a Member State of the values referred to in Article 2. Before making such a determination, the Council shall hear the Member State in question and may address recommendations to it, acting in accordance with the same procedure.

The Council shall regularly verify that the grounds on which such a determination was made continue to apply.

2) fr.: 1. Sur proposition motivée d'un tiers des États membres, du Parlement européen ou de la Commission européenne, le Conseil, statuant à la majorité des quatre cinquièmes de ses membres après approbation du Parlement européen, peut constater qu'il existe un risque clair de violation grave par un État membre des valeurs visées à l'article 2. Avant de procéder à cette constatation, le Conseil entend l'État membre en question et peut lui adresser des recommandations, en statuant selon la même procédure.

Le Conseil vérifie régulièrement si les motifs qui ont conduit à une telle constatation restent valables.

8 W doktrynie niemieckiej zauważa się, że w zdaniu drugim art. 7 ust. 1 TUE przyjęto rozwiązanie w istocie dyplomatyczne, pozwalając Radzie przyjąć niewiążące zalecenia. Tak M. Ruffert w komentarzu do art. 7 [w:] E. Grabnitz, M. Hilf, M. Nettesheim, Das Recht der Europäischen Union, München 2012-2014, s. 9-10. 
uprawnione podmioty musiałyby jej przedłożyć uzasadniony wniosek, po czym Rada powinna wysłuchać państwo członkowskie, wreszcie podjąć uchwałę większością 4/5 członków Rady, uzyskując wcześniej zgodę Parlamentu Europejskiego. Procedura ta musiałaby zostać powtórzona w przypadku stwierdzenia istnienia wyraźnego ryzyka. Możliwe jest oczywiście nieformułowanie zaleceń, lecz od razu, aczkolwiek po wysłuchaniu państwa członkowskiego i uzyskaniu zgody Parlamentu Europejskiego, stwierdzenie istnienia wyraźnego ryzyka.

Artykuł 7 ust. 1 TUE nie precyzuje w pełni formy działania Rady. Wskazuje tylko, że Rada może udzielać zaleceń oraz stwierdzać istnienie wyraźnego ryzyka ${ }^{9}$. Należy jednak przyjąć, że udzielenie zalecenia nie może przybrać formy decyzji, ponieważ wzruszałoby to naturę zalecenia jako aktu prawnie niewiążącego. Zalecenie ma skłonić, a nie zobowiązywać, do działania. I jest tak nawet wtedy, gdy łączy się z określeniem terminu wykonania zaleceń (aczkolwiek w art. 7 ust. 1 TUE nie mówi się wyraźnie, że Rada ma kompetencję do udzielenia zalecenia, które ustalałoby termin zastosowania się państwa członkowskiego do zaleceń). Zalecenie zostaje także w art. 7 ust. 1 TUE nazwane (nie chodzi tutaj o zalecenie w postaci materialnej, lecz o formę zalecenia). Jest ono aktem formalnym w rozumieniu art. 288 Traktatu o funkcjonowaniu Unii Europejskiej (TFUE), różnym od decyzji (porównaj akapity 4 i 5 tego postanowienia).

Także w przypadku stwierdzenia wyraźnego TUE nie przesądza jego formy. W gruncie rzeczy sam akt również może się nazywać „stwierdzeniem wyraźnego ryzyka”, ewentualnie uchwałą w tej sprawie. W końcu procedura ma charakter szczególny, umiejscowiona jest w TUE, a nie TFUE, co skłaniałoby do korzystania z formalnych aktów, o których mowa w art. 288 TFUE. Ponadto inaczej niż np. w ust. 3 i 4 art. 7 TUE, gdzie wyraźnie mowa o decydowaniu, i inaczej niż w wielu innych postanowieniach TUE, nie wspomina się tutaj o decyzji jako formie aktu Rady. Do takiego wniosku prowadzi także lektura art. 269 TFUE ${ }^{10}$. Mówi się tutaj o skardze do Trybunału Sprawiedliwości, jaka przysługuje państwu członkow-

9 W doktrynie podkreśla się, że mechanizm nadzorczy, o którym mowa w art. 7 TUE, ma charakter polityczny, a nie prawny, a same ustalenia wyraźnego ryzyka i naruszenia mają naturę uznaniową. Zob. np. F.-X. Priollaud, D. Siritzky, Le Traité de Lisbonne. Texte et commentaire article par article des nouvaux traités européens (TUE-TFUE), Paris 2008, s. 49. W innym ujęciu mówi się, że jest to mechanizm wczesnego ostrzegania, odmienny od procedury sankcji, o którym mowa w art. 7 ust. 2 TUE. Zob. R. Geiger w komentarzu do art. 7 Traktatu o Unii Europejskiej [w:] European Union Treaties. A Commentary. Treaty on European Union. Treaty on the Functioning of the European Union. Charter of Fundamental Rights of the European Union, red. R. Geiger, D.-E. Khan, M. Kotzur, München-Oxford 2015, s. 60-61.

10 Art. 269 TFUE brzmi następująco:

1) pol.: Trybunał Sprawiedliwości jest właściwy do orzekania w sprawie legalności aktu przyjętego przez Rade Europejska lub Radę zgodnie z artykułem 7 Traktatu o Unii Europejskiej wyłącznie na wniosek Państwa Członkowskiego, którego dotyczy 
skiemu, wobec którego zastosowano art. 7 TUE. W postanowieniu tym używa się terminu „akt” jako równoważny określeniu „stwierdzenie” Rady Europejskiej lub Rady. Skarga może dotyczyć legalności aktu wyłącznie w zakresie procedury jego przyjęcia ${ }^{11}$, co sprawia, że natura samego aktu (prawna czy polityczna) pozostaje nierozstrzygnięta.

W przypadku stwierdzenia wyraźnego ryzyka należy oczekiwać, że Rada jednocześnie ustali termin, w którym dokona ponownej oceny co do tego, czy powody stwierdzenia uległy zmianie (skoro ma badać sprawę regularnie). Zarazem z ustalenia, że sprawa jest badana regularnie, wynika logiczny wniosek, że państwo członkowskie musi mieć pewien czas na usunięcie podstaw stwierdzenia wyraźnego ryzyka.

$\mathrm{Z}$ przedstawionego rozumowania wynika, że zalecenia i stwierdzenie wyraźnego ryzyka stanowią dwa odrębne akty Rady, z których zalecenia są aktem uprzednim wobec stwierdzenia wyraźnego ryzyka ${ }^{12}$. W konsekwencji zalecenia

stwierdzenie Rady Europejskiej lub Rady, oraz wyłacznie w odniesieniu do przestrzegania postanowień czysto proceduralnych przewidzianych $w$ tym artykule.

Wniosek taki musi być złożony w terminie miesiaca od daty tego stwierdzenia. Trybunat orzeka $w$ terminie miesiaca od daty wniosku.

2) ang.: The Court of Justice shall have jurisdiction to decide on the legality of an act adopted by the European Council or by the Council pursuant to Article 7 of the Treaty on European Union solely at the request of the Member State concerned by a determination of the European Council or of the Council and in respect solely of the procedural stipulations contained in that Article.

Such a request must be made within one month from the date of such determination. The Court shall rule within one month from the date of the request.

3) fr.: La Cour de justice n'est compétente pour se prononcer sur la légalité d'un acte adopté par le Conseil européen ou par le Conseil en vertu de l'article 7 du traité sur l'Union européenne que sur demande de l'État membre qui fait l'objet d'une constatation $d u$ Conseil européen ou du Conseil, et qu'en ce qui concerne le respect des seules prescriptions de procédure prévues par ledit article.

Cette demande doit être faite dans un délai d'un mois à compter de ladite constatation. La Cour statue dans un délai d'un mois à compter de la date de la demande.

11 Zob. też K. Scheuring w komentarzu do art. 269 TFUE [w:] Traktat o funkcjonowaniu Unii Europejskiej. Komentarz, red. A. Wróbel (całość), t. III (art. 223-358), red. D. Kornobis-Romanowska, J. Łacny, Warszawa 2012, s. 435-439.

12 Tak również F.-X. Priollaud, D. Siritzky, Le Traité de Lisbonne, op. cit., s. 50; a także S. Mangiameli, G. Saputelli, Article 7 [w:] The Treaty on European Union (TEU). A Commentary, red. H.-J. Blanke, S. Mangiameli, Heidelberg-New York 2013, s. 363. Podobnie L. Besselink, The Bite, the Bark and the Howl: Article 7 and the Rule of Law Initiatives [w:] The Enforcement of EU Law and Values: Ensuring Member States' Compliance, red. A. Jakab, D. Kochenov, Oxford 2017, s. 128 i n., według którego przed traktatem z Lizbony zalecenia mogły być wydawane także razem ze stwierdzeniem wyraźnego ryzyka. Rewizja lizbońska wprowadziła sekwencję czasową (The text since 
nie mogą stanowić części stwierdzenia wyraźnego ryzyka. Stwierdzenie wyraźnego ryzyka naruszenia art. 2 TUE powinno zawierać zatem jedynie samo stwierdzenie (ustalenie istnienia) wyraźnego ryzyka (zagrożenia) i jego uzasadnienie (powody ustalenia jego istnienia). Nie zawiera i nie może ono zawierać zaleceń. Odrębność zaleceń i stwierdzenia wyraźnego ryzyka jako odrębnych aktów Rady potwierdzają jednoznacznie inne wersje językowe art. 7 ust. 1 TUE, które nie pozostawiają wątpliwości, że gdyby Rada Unii Europejskiej zamierzała udzielić najpierw państwu członkowskiemu zaleceń, musi zastosować taką samą procedurę jak w przypadku stwierdzenia wyraźnego ryzyka. Nie byłoby potrzeby ponownego przeprowadzania procedury, gdyby chodziło o przyjęcie tylko jednego aktu. Tymczasem w opiniowanym projekcie doszło do jednoczesnego stwierdzenia wyraźnego ryzyka i sformułowania zaleceń, co stanowi istotne naruszenie art. 7 ust. 1 TUE zarówno z uwagi na uchybienia formalne (proceduralne), jak i materialne (powiązanie stwierdzenia wyraźnego ryzyka i zaleceń).

\section{Skutki prawne dokumentów UE}

Wadliwy charakter projektowanej decyzji Komisji utrudnia ocenę skutków. Sprzeczność projektowanej decyzji z TUE powinna być zakwestionowana przez Parlament Europejski w toku procedury wyrażania zgody, o której mowa w art. 7 ust. 1 TUE, albo podważona przez Trybunał Sprawiedliwości w toku procedury następczej, o której mowa w art. 269 TFUE.

Gdyby jednak doszło do przyjęcia decyzji (po bezskutecznym, zdaniem Rady, upływie wskazanego w niej terminu), to wówczas możliwe byłoby podjęcie dalszych kroków. W pierwszym rzędzie sprawa zostałaby przedłożona Radzie Europejskiej, która mogłaby, na wniosek $1 / 3$ państw członkowskich lub Komisji i za zgodą Parlamentu Europejskiego oraz po wysłuchaniu zainteresowanego państwa członkowskiego, stwierdzić jednomyślnie poważne i stałe naruszenie wartości, o których mowa w art. 2 TUE (art. 7 ust. 2 TUE). To z kolei otwierałoby drogę do ewentualnych dalszych decyzji (ponownie) Rady Unii Europejskiej (np. decyzji na podstawie art. 7 ust. 3 TUE).

Lisbon clearly suggests that recommendations can be made before the existence of such a risk has been determined, albeit under the same procedure as for that determination. This suggests the competence of the Union prior to the risk determination). Do takiego wniosku prowadzi również wykładnia historyczna, dotycząca brzmienia art. 7 TUE sprzed traktatu z Lizbony. Zalecenia i stwierdzenie wyraźnego ryzyka były tam powiązane. Zob. też C. Mik w komentarzu do art. 7 [w:] C. Mik, W. Czapliński, Traktat o Unii Europejskiej. Komentarz, Warszawa 2005, s. 93-100. Nie jest natomiast trafne stanowisko F. Schorkopfa, op. cit., s. 10, zgodnie z którym Radzie pozostawiono swobodę uznania, czy chce powiązać stwierdzenie wyraźnego ryzyka z zaleceniami. Nie bardzo jednak wiadomo, jak autor doszedł do takiego wniosku po lekturze art. 7 ust. 1. Warto przypomnieć, że postanowienia kompetencyjne, nawet te, które dają pewną władzę uznaniową, wymagają wykładni zwężającej, a nie rozszerzającej. 


\section{Kwestie proceduralne}

\section{- Procedura przyjmowania dokumentów UE}

Projektowana decyzja ma być przyjęta przez Radę Unii Europejskiej. W trakcie podejmowania decyzji Rada stanowi większością 4/5 członków Rady, bez udziału Polski (art. 354 ust. 1 TFUE).

Analizowany dokument UE został przyjęty przez Komisję 20 grudnia 2017 r. i tego samego dnia przekazany do Rady i Parlamentu Europejskiego. Następnego dnia, tj. 21 grudnia 2017 r., dokument ten został przesłany do Sejmu.

Projekt decyzji nie podlega ocenie z punktu widzenia zgodności z zasadą pomocniczości w trybie określonym w art. 6 protokołu (nr 2) w sprawie stosowania zasad pomocniczości i proporcjonalności, ponieważ nie jest projektem aktu prawodawczego UE.

\section{- Działania Komisji ds. Unii Europejskiej}

Komisja Europejska zakwalifikowała projektowany akt jako decyzję Rady. Zgodnie z art. 8 ust. 1 ustawy z 8 października 2010 r. o współpracy Rady Ministrów z Sejmem i Senatem w sprawach związanych z członkostwem Rzeczypospolitej Polskiej w Unii Europejskiej (Dz.U. nr 213, poz. 1395; dalej ustawa) Rada Ministrów ma obowiązek przekazać Sejmowi projekt aktu prawnego UE innego niż akt, o którym mowa w art. 7 ust. 1 i 2 ustawy (akt prawodawczy i akt wydawany na podstawie art. 352 TFUE). Dodatkowo, zgodnie z tym przepisem, na żądanie Komisji ds. Unii Europejskiej, w terminie 14 dni od dnia otrzymania żądania Rada Ministrów przedstawia projekt stanowiska RP dotyczący takiego projektu.

W dniu 12 stycznia 2018 r. Komisja ds. Unii Europejskiej wystąpiła o przedstawienie projektu stanowiska w tym trybie. Projekt stanowiska RP do projektowanej decyzji nie został do dnia sporządzenia niniejszej opinii przesłany do Sejmu.

Zgodnie $\mathrm{z}$ art. 8 ust. 2 ustawy po otrzymaniu projektu stanowiska RP Komisja ds. Unii Europejskiej może w terminie 21 dni od dnia przekazania Sejmowi projektu stanowiska do tego aktu wyrazić opinię o projekcie aktu prawnego UE. W związku z nieprzesłaniem przez Radę Ministrów projektu stanowiska RP dotyczącego projektowanej decyzji Rady termin ten nie zaczął jeszcze płynąć.

\section{Wnioski}

Sejm RP powinien zwrócić uwagę na wadliwość prawną projektowanej decyzji.

W razie jej przyjęcia Polska powinna zaskarżyć ją do Trybunału Sprawiedliwości UE. 


\section{Bibliografia}

Geiger R., Komentarz do art. 7 Traktatu o Unii Europejskiej [w:] European Union Treaties. A Commentary. Treaty on European Union. Treaty on the Functioning of the European Union. Charter of Fundamental Rights of the European Union, red. R. Geiger, D.-E. Khan, M. Kotzur, München-Oxford 2015.

M. Ruffert, Komentarz do art. 7 [w:] E. Grabnitz, M. Hilf, M. Nettesheim, Das Recht der Europäischen Union, München 2012-2014.

Mangiameli S., Saputelli G., Article 7 [w:] The Treaty on European Union (TEU). A Commentary, red. H.-J. Blanke, S. Mangiameli, Heidelberg-New York 2013, https://doi. org/10.1007/978-3-642-31706-4_8.

Mik C., Komentarz do art. 7 [w :] C. Mik, W. Czapliński, Traktat o Unii Europejskiej. Komentarz, Warszawa 2005.

Mik C., Opinia na temat pojmowania aktów ustawodawczych i znaczenia tego pojęcia dla pozycji parlamentów narodowych w Unii Europejskiej, „Zeszyty Prawnicze BAS” 2010, nr 2.

Priollaud F.-X., Siritzky D., Le Traité de Lisbonne. Texte et commentaire article par article des nouvaux traités européens (TUE-TFUE), Paris 2008.

Scheuring K., Komentarz do art. 269 TFUE [w:] Traktat o funkcjonowaniu Unii Europejskiej. Komentarz, red. A. Wróbel (całość), t. III (art. 223-358), red. D. Kornobis-Romanowska, J. Łacny, Warszawa 2012. 
2

OPINIE BAS

C

OPINIE LEGISLACYJNE 



\title{
Ocena rządowego projektu ustawy o dokumentach publicznych (druk sejmowy nr 2153) ${ }^{1}$
}

\begin{abstract}
Evaluation of the government bill on public documents (Sejm's paper no. 2153): In the aspect of compatibility with the UE law it has been pointed out that to the extent the project aims to exclude certain categories of prints and documents from the regulation of Directive 2014/24, it may be considered incompatible with this directive. It was recommended to suspend work on the bill until the CJEU delivers its judgment concerning case C-187/16. Furthermore in the aspect of compatibility with the rules of criminal procedure it was considered that the advantage of the proposed normative solution of Article 40 para. 3 is the pragmatic linking of access to evidence with the principles of procedural economy, i.e. the guarantee of access to material evidence is conditioned by the objectives of the criminal proceedings.
\end{abstract}

Keywords: documents | bill | EU law | public procurement | criminal procedure Słowa kluczowe: dokumenty | projekt ustawy | prawo UE | zamówienia publiczne | procedura karna

* Asystent w Instytucie Wymiaru Sprawiedliwości, ekspert ds. legislacji BAS; pawel.bachmat@sejm.gov.pl.

* Doktor nauk prawnych; adiunkt na Uniwersytecie Kardynała Stefana Wyszyńskiego, ekspert ds. prawa europejskiego i międzynarodowego BAS; marek.jaskowski@sejm.gov.pl.

\section{Przedmiot opinii}

Opinia dotyczy rządowego projektu ustawy o dokumentach publicznych (druk sejmowy nr 2153), a szczególnie:

- zgodności art. 17-21, art. 62, art. 64, art. 69 i art. 70 opiniowanego projektu ustawy z prawem Unii Europejskiej,

1 Opinia prawna dotyczaca rządowego projektu ustawy o dokumentach publicznych (druk sejmowy nr 2153) sporządzona 26 lutego 2018 r. na zlecenie przewodniczącego Komisji Administracji i Spraw Wewnętrznych; BAS-WAP/WAPM 284/18. 
- zgodności art. 40 ust. 3 i 4 opiniowanego projektu ustawy z regułami postępowania karnego.

Autorzy skoncentrowali się przede wszystkim na obszarach budzących wątpliwości co do zgodności z prawem UE oraz regułami postępowania karnego.

\section{Ocena projektu}

\section{Ocena dotycząca zgodności art. 17-21, art. 62, art. 64, art. 69 i art. 70 rządowego projektu ustawy o dokumentach publicznych (druk nr 2153) z prawem Unii Europejskiej}

\section{- Przedmiot opiniowanych przepisów}

Artykuł 17 projektu przewiduje, że blankiety dokumentów publicznych, o których mowa w art. 5 ust. 2 projektu, mają być wytwarzane przez jednoosobową spółkę Skarbu Państwa (dalej: Spółka), której przedmiotem działalności jest wytwarzanie blankietów dokumentów i druków zabezpieczonych, mającą siedzibę oraz zakład produkcyjny, w którym są wytwarzane blankiety dokumentów publicznych, na terytorium Rzeczypospolitej Polskiej. Artykuł 5 ust. 2 projektu zawiera wyliczenie dokumentów publicznych kategorii pierwszej, tj. w myśl ustawy dokumentów najistotniejszych z punktu widzenia bezpieczeństwa państwa. Jest to obszerny katalog obejmujący ponad 40 pozycji. Zgodnie z art. 17 ust. 6, jeżeli wytworzenie przez Spółkę blankietów dokumentu publicznego, o którym mowa $\mathrm{w}$ art. 5 ust. 2, zgodnie $\mathrm{z}$ warunkami określonymi przez emitenta dokumentu publicznego nie jest możliwe, blankiety tego dokumentu publicznego mogą być wytwarzane przez inny podmiot, mający świadectwo bezpieczeństwa przemysłowego pierwszego stopnia oraz zakład produkcyjny, w którym będzie wytwarzany blankiet tego dokumentu publicznego, na terytorium Rzeczypospolitej Polskiej.

Jednocześnie art. 64 projektu, przez zmianę art. 4 ust. 5c ustawy z 29 stycznia 2004 r. - Prawo zamówień publicznych (dalej: u.p.z.p.), zmierza do modyfikacji katalogu zamówień, do których nie stosuje się ustawy - Prawo zamówień publicznych. Zgodnie z obecnym brzmieniem tego przepisu ustawy - Prawo zamówień publicznych nie stosuje się do zamówień dotyczących wytwarzania i dystrybucji dokumentów publicznych (i ich personalizacji), druków o strategicznym znaczeniu dla bezpieczeństwa państwa oraz znaków akcyzy. Zgodnie z projektem przedmiotowe wyłączenie miałoby obejmować zamówienia dotyczące wytwarzania i personalizacji lub indywidualizacji dokumentów wymienionych w art. 5 ust. 2 opiniowanego projektu, a ponadto zamówienia dotyczące wytwarzania znaków akcyzy, znaków legalizacyjnych i nalepek kontrolnych, kart do głosowania, znaków holograficznych umieszczanych na zaświadczeniach o prawie do głosowania, a także układu mikroprocesorowego z oprogramowaniem służącym do zarządzania dokumentami publicznymi, systemów i baz informa- 
tycznych niezbędnych do zastosowania dokumentów publicznych, o których mowa w art. 5 ust. 2 projektu. Należy zaznaczyć, że zgodnie z obowiązującym stanem prawnym wykaz dokumentów publicznych i druków o strategicznym znaczeniu dla bezpieczeństwa państwa jest określany przez Radę Ministrów w drodze rozporządzenia (art. 4aa u.p.z.p. - przepis ten ma zostać uchylony na mocy art. 64 pkt 2 opiniowanego projektu). Obecnie wykaz taki jest zawarty w rozporządzeniu Rady Ministrów w sprawie wykazu dokumentów publicznych i druków o strategicznym znaczeniu dla bezpieczeństwa państwa z 20 lipca 2016 r. (Dz.U. poz. 1089; 2017, poz. 1996). Projektowana zmiana polega więc na przeniesieniu tej regulacji na poziom ustawowy, jak również na poszerzeniu jej zakresu o niektóre dokumenty. Modyfikacje przewidziane w art. 62, 69 i 70 projektu zmierzają do uchylenia przepisów przyznających określonym w nich ministrom kompetencję w zakresie wyboru dostawców druków i usług i stanowią konsekwencję wskazanych wyżej zmian.

\section{- Stan prawa Unii Europejskiej w materii objętej projektem ustawy}

Oceny wskazanych przepisów projektu należy dokonać z uwzględnieniem dyrektywy Parlamentu Europejskiego i Rady 2014/24/UE z 26 lutego 2014 r. w sprawie zamówień publicznych, uchylającej dyrektywę 2004/18/WE (Dz.Urz. UE L 94 z 28 marca 2014 r., s. 65).

W myśl art. 1 ust. 1 dyrektywa 2014/24 ustanawia przepisy dotyczące procedur udzielania zamówień przez instytucje zamawiające $\mathrm{w}$ odniesieniu do zamówień publicznych oraz konkursów, których wartość szacunkowa jest nie mniejsza niż kwoty progowe określone $\mathrm{w}$ art. 4 dyrektywy. Zgodnie $\mathrm{z}$ art. 15 ust. 2 akapit 1 dyrektywy 2014/24 nie ma ona jednak zastosowania do zamówień publicznych i konkursów w stopniu, w jakim ochrona podstawowych interesów danego państwa członkowskiego $\mathrm{w}$ zakresie bezpieczeństwa nie może zostać zagwarantowana przez mniej inwazyjne środki, na przykład przez nałożenie wymogów mających na celu ochronę poufnego charakteru informacji udostępnianych przez instytucję zamawiającą $\mathrm{w}$ trakcie trwania postępowania o udzielenie zamówienia zgodnie z dyrektywą. Ponadto art. 15 ust. 2 akapit 2 dyrektywy 2014/24 potwierdza, że zgodnie z art. 346 ust. 1 lit. a TFUE ${ }^{2}$ nie ma ona zastosowania do zamówień publicznych i konkursów w stopniu, w jakim stosowanie tej dyrektywy zobowiązywałoby państwo członkowskie do dostarczania informacji, których ujawnienie państwo to uważa za sprzeczne z jego podstawowymi interesami w zakresie bezpieczeństwa.

Trzeba podkreślić, że dyrektywa 2014/24, jako stosunkowo nowy akt prawny, nie doczekała się dotychczas orzecznictwa równie bogatego, co uchylona na

2 Zgodnie z tym przepisem: żadne Państwo Członkowskie nie ma obowiązu udzielania informacji, których ujawnienie uznaje za sprzeczne z podstawowymi interesami jego bezpieczeństwa. 
jej mocy dyrektywa 2004/18. Niemniej należy zauważyć, że również dyrektywa 2004/18 przewidywała wyłączenie jej stosowania do zamówień publicznych określonych jako tajne, jeżeli ich realizacji musiały towarzyszyć szczególne środki bezpieczeństwa albo jeżeli wymagała tego ochrona podstawowych interesów tego państwa. W związku z tym orzecznictwo dotyczące uchylonej dyrektywy może pomocniczo stanowić wskazówkę przy interpretacji dyrektywy 2014/24. Podobnie należy traktować orzecznictwo Trybunału Sprawiedliwości Unii Europejskiej (dalej: TSUE) dotyczące wyjątków uzasadnianych koniecznością ochrony bezpieczeństwa państwa członkowskiego, w szczególności zgodnie $\mathrm{z}$ art. 346 TFUE.

Jeżeli chodzi o podstawowe interesy państwa w zakresie bezpieczeństwa, to należy wskazać, że pojęcie bezpieczeństwa publicznego odnosi się jednocześnie do wewnętrznego bezpieczeństwa państwa członkowskiego i jego bezpieczeństwa zewnętrznego. Wśród zagrożeń dla bezpieczeństwa publicznego TSUE wymienia zagrożenie dla funkcjonowania głównych instytucji i służb publicznych oraz życia ludności, ryzyko poważnego zakłócenia stosunków zagranicznych lub pokojowego współistnienia narodów bądź zagrożenie interesów wojskowych ${ }^{3}$, ale również niektóre rodzaje przestępczości o szczególnym nasileniu (np. obrót środkami odurzającymi w zorganizowanej grupie przestępczej ${ }^{4}$ ).

W odniesieniu do marginesu uznania, jakim dysponują państwa członkowskie wprowadzające odstępstwo, orzecznictwo TSUE nie jest spójne. Z jednej bowiem strony TSUE stoi na stanowisku, że odstępstwa od podstawowych reguł rynku wewnętrznego - w tym z uwagi na konieczność ochrony bezpieczeństwa publicznego - muszą podlegać wykładni zwężającej (chociaż w literaturze wskazuje się, że w praktyce interpretacja tych wyjątków bywa jednak dość szeroka $^{6}$ ). Z drugiej strony TSUE stwierdza, że w przypadku powołania się na podstawowe interesy bezpieczeństwa państwa członkowskie dysponują szczególnie szerokim zakresem uznania przy ocenie potrzeb wymagających takiej ochrony ${ }^{7}$. W każdym razie środki, które przyjmują państwa członkowskie w ramach słusznych względów interesu narodowego, nie są wyjęte z zakresu stosowania prawa wspólnotowego z tego tylko powodu, że są podejmowane w interesie bezpieczeń-

3 Wyrok TSUE (Wielka Izba) z 23 listopada 2010 r. Land Baden-Württemberg v. Panagiotis Tsakouridis, sygn. akt C-145/09, ECLI:EU:C:2010:708, pkt 43-44.

$4 \quad$ Ibidem, pkt 47.

5 Wyrok TSUE z 7 czerwca 2012 r. Insinööritoimisto InsTiimi Oy, sygn. akt C-615/10, EU:C:2012:324, pkt 35; wyrok TSUE z 16 września 1999 r. Komisja Wspólnot Europejskich v. Królestwo Hiszpanii, sygn. akt C-414/97, EU:C:1999:417, pkt 22 i 24.

6 S. Arrowsmith, The Law of Public and Utilities Procurement, London 2014, s. 503.

7 Wyrok Sądu pierwszej instancji z 30 września 2003 r. Fiocchi munizioni SpA v. Komisja, sygn. akt T-26/01, ECLI:EU:T:2003:248, pkt 58 (w odniesieniu do obecnego art. 346 ust. 1 lit. b TFUE). 
stwa publicznego lub obrony narodowej ${ }^{8}$. Przepisów takich nie można więc interpretować w taki sposób, jakoby państwom członkowskim przyznano prawo do ustanowienia wyjątków poprzez samo tylko powołanie się na przedmiotowe interesy. Państwo członkowskie powinno bowiem w takiej sytuacji nie tylko wykazać konieczność zastosowania wyjątku w celu ochrony istotnych interesów swojego bezpieczeństwa ${ }^{9}$, ale również - że potrzeba ochrony tych podstawowych interesów nie mogła zostać osiągnięta w trakcie postępowania przetargowego przewidzianego $\mathrm{w}$ dyrektywie ${ }^{10}$ oraz że wyłączenia nie wykraczają poza granice przewidziane prawem UE ${ }^{11}$. Ponadto podkreślić należy konieczność poszanowania przez państwo członkowskie zasady proporcjonalności przy określaniu odstępstw od reguł prawa UE ${ }^{12}$. W przypadku art. 15 ust. 2 dyrektywy 2014/24 należy podkreślić, że odnosi się on do podstawowych interesów państwa w dziedzinie bezpieczeństwa, co ogranicza zakres swobody uznania przysługujący państwom członkowskim przy stosowaniu tego przepisu.

\section{- Analiza przepisów projektu pod kątem ustalonego stanu prawa Unii Europejskiej}

1. W zakresie, w jakim projekt zmierza do wyłączenia określonych kategorii druków i dokumentów spod regulacji dyrektywy 2014/24, wymaga się uzasadnienia zgodnie z orzecznictwem TSUE przedstawionym powyżej.

W uzasadnieniu projektu wskazuje się, że zlecenie produkcji wymienionych dokumentów poza systemem zamówień publicznych umożliwi skuteczne sprawowanie przez państwo kontroli nad ich produkcją, przejawiające się m.in. w wyborze podmiotu spełniającego warunki bezpieczeństwa produkcji, określone w ustawie. Ponieważ powierzenie takiemu podmiotowi produkcji dokumentów będzie stanowiło rękojmię, że nie dojdzie do osłabienia bezpieczeństwa wewnętrznego i zewnętrznego państwa, włączenie wymienionych dokumentów do kategorii pierwszej dokumentów publicznych jest działaniem adekwatnym (s. 8 uzasadnienia projektu). Ponadto, zgodnie z uzasadnieniem projektu, powierzenie, co do zasady, produkcji najistotniejszych dokumentów publicznych podmiotowi kontrolowanemu przez państwo daje gwarancje wpływu państwa na poziom bezpieczeństwa tych dokumentów. Regulacja ta wraz z wyłaczeniem dokumentów pierwszej

8 Wyrok TSUE (Wielka Izba) z 8 kwietnia 2008 r. Komisja v. Włochy, sygn. akt C-337/05, EU:C:2008:203, w szczególności pkt 42-43.

9 Wyrok TSUE z 4 września 2014 r. Schiebel Aircraft, sygn. akt C-474/12, EU:C:2014:2139, pkt 34.

10 Wyrok TSUE z 7 czerwca 2012 r. Insinööritoimisto InsTiimi Oy, sygn. akt C-615/10, EU:C:2012:324, pkt 45.

11 Wyrok TSUE (Wielka Izba) z 8 kwietnia 2008 r. Komisja v. Włochy, sygn. akt C-337/05, EU:C:2008:203, w szczególności pkt 44.

12 Wyrok TSUE z 2 października 2008 r. Komisja v. Włochy, sygn. akt C-157/06, EU:C:2008:530, pkt 31. 
kategorii spod stosowania przepisów o zamówieniach publicznych (art. 64 projektu) umożliwi ochrone podstawowych interesów bezpieczeństwa państwa i bezpieczeństwa publicznego. Ponadto powierzenie produkcji dokumentów identyfikacyjnych Spółce ma służyć ochronie danych osobowych oraz bezpieczeństwu transakcji, przy których wykorzystywane są zabezpieczone dokumenty (s. 11-12 uzasadnienia projektu). Ponadto projektodawca wskazuje, że: proces wywarzania dokumentów publicznych oraz druków, o których mowa $w$ zmienianym art. 4 pkt 5c PZP [ustawa - Prawo zamówień publicznych], wymaga stosowania szczególnych procedur bezpieczeństwa, nie jest [więc] możliwe udzielanie $w$ odniesieniu do nich zamówień publicznych w oparciu o przepisy ustawy, w tym w oparciu o przepisy rozdziału 4a PZP, co uzasadnia wyłaczenie ich wytwarzania spod obowiązku stosowania PZP i jest zgodne $z$ art. 15 ust. 2 dyrektywy 2014/24/UE, w tym $z$ art. 346 ust. 1 lit. a TFUE (s. 21 uzasadnienia projektu).

$\mathrm{W}$ związku z przedstawionym uzasadnieniem nasuwają się następujące wątpliwości. Po pierwsze, katalog dokumentów, których wytwarzanie miałoby zostać wyłączone z zakresu regulacji dotyczących zamówień publicznych, zawiera dokumenty, których znaczenie dla ochrony podstawowych interesów danego państwa członkowskiego w zakresie bezpieczeństwa jest wątpliwe. Przykładowo, wydaje się, że dokumenty takie jak legitymacja dokumentująca niepełnosprawność lub stopień niepełnosprawności, prawo wykonywania zawodu lekarza i lekarza dentysty czy karta pojazdu trudno uznać za kluczowe z punktu widzenia bezpieczeństwa państwa, czy to bezpieczeństwa zewnętrznego, czy wewnętrznego.

Po drugie, podobne wątpliwości budzi wskazanie w uzasadnieniu ochrony danych osobowych oraz bezpieczeństwa transakcji jako podstawy powołania się na odstępstwo przewidziane w art. 15 ust. 2 dyrektywy 2014/24. Dyskusyjne jest bowiem powiązanie ochrony danych osobowych ${ }^{13}$ oraz pewności obrotu handlowego $\mathrm{z}$ podstawowymi interesami państwa członkowskiego w zakresie bezpieczeństwa, a w każdym razie uzasadnienie nie wskazuje na taki związek.

Po trzecie, art. 15 ust. 2 dyrektywy 2014/24 wyłącza jej zastosowanie jedynie w stopniu, w jakim ochrona podstawowych interesów danego państwa członkowskiego w zakresie bezpieczeństwa nie może zostać zagwarantowana przez mniej inwazyjne środki, na przykład przez nałożenie wymogów mających na celu ochronę poufnego charakteru informacji udostępnianych przez instytucję zamawiającą w trakcie trwania postępowania o udzielenie zamówienia zgod-

13 Poza tym należy podkreślić, że zgodnie z wyrokiem TSUE z 5 grudnia 1989 r. Komisja v. Włochy, sygn. akt C-3/88, ECLI:EU:C:1989:606, pkt 23, ochrona danych jako taka może być zapewniona poprzez nałożenie obowiązku zachowania poufności i nie wymaga tak daleko idących środków jak wykluczenie przedsiębiorstw z innych państw członkowskich, nie zależy też od publicznej formy własności przedsiębiorstwa przetwarzającego dane. 
nie $\mathrm{z}$ tą dyrektywą. Tymczasem uzasadnienie projektu w zasadzie nie odnosi się do tego wymogu. Nie wyjaśnia ono, jakie „mniej inwazyjne” rozwiązania alternatywne były brane pod uwagę i dlaczego projektodawca uznał je za niecelowe (np. z uwagi na niedostateczną skuteczność, nadmierny koszt, nadmierny stopień skomplikowania). W szczególności projektodawca nie odniósł się do wyrażonej wprost przez art. 15 ust. 2 dyrektywy 2014/24 możliwości polegającej na nałożeniu wymogów mających na celu ochronę poufnego charakteru informacji udostępnianych przez instytucję zamawiającą. Ponadto spójność projektowanych rozwiązań może zostać zakwestionowana $\mathrm{w}$ związku $\mathrm{z}$ treścią art. 17 ust. 6 projektu, który przewiduje możliwość wytworzenia dokumentu publicznego, o którym mowa $\mathrm{w}$ art. 5 ust. 2 projektu, przez inny podmiot, o którym mówi art. 18 projektu (spełniający określone w projekcie wymogi), gdyby wytworzenie go przez Spółkę zgodnie z warunkami określonymi przez emitenta okazało się niemożliwe. Zgodnie z uzasadnieniem: sytuacja, w której Spółka może nie być w stanie wytworzyć blankietów dokumentów publicznych pierwszej kategorii zgodnie z warunkami określonymi przez emitenta dokumentu publicznego (lub Krajową Radę Notarialna w przypadku zamawiania dokumentów notarialnych), może zaistnieć np. w przypadku braku możliwości realizacji przez Spólkę zamówienia na wytworzenie dokumentu publicznego w określonym przez emitenta terminie, liczbie lub cenie (s. 11 uzasadnienia projektu). Niespójność polega na tym, że projektodawca z jednej strony uważa wytwarzanie dokumentów przez Spółkę za konieczne z uwagi na ochronę podstawowych interesów państwa w zakresie bezpieczeństwa, z drugiej - przewiduje możliwość odstąpienia od tego rzekomo koniecznego ograniczenia, co więcej - z tak banalnego w tym kontekście powodu jak choćby cena wytworzenia dokumentu. Wobec powyższego zasadna wydaje się wątpliwość, czy wszystkie dokumenty nie mogłyby być wytwarzane przez inne podmioty, o których mowa w art. 18 projektu.

Podsumowując, należy stwierdzić, że w zakresie, w jakim projekt zmierza do wyłączenia określonych kategorii druków i dokumentów spod regulacji dyrektywy 2014/24, może on zostać uznany za niezgodny z dyrektywą 2014/24, w szczególności z art. $1 \mathrm{w}$ związku $\mathrm{z}$ art. 15 ust. 2.

2. W dołączonej do projektu ocenie skutków regulacji wskazuje się, że rozwiązania podobne do zawartych w projekcie obowiązują również w innych państwach członkowskich, w tym w Austrii. W związku z tym należy zwrócić uwagę, że zgodność obowiązujących w Austrii przepisów z prawem UE stanowi przedmiot postępowania przed TSUE ${ }^{14}$. $\mathrm{Z}$ uwagi na istotne podobieństwo niektórych rozwiązań austriackich i rozwiązań zawartych w opiniowanym projekcie, a także na argumenty podnoszone przez Austrię, uzasadnione jest bardziej szczegółowe przedstawienie aktualnego stanu tej sprawy.

14 Sprawa Komisja v. Austria, sygn. akt C-187/16. 
W skardze wniesionej 13 maja 2016 r. Komisja Europejska (KE) zarzuca Austrii naruszenie m.in. art. 4 w związku z art. 11-37 dyrektywy 92/50/EWG ${ }^{15}$ oraz art. 14, 20 i $23-55$ dyrektywy $2004 / 18 / W^{16} \mathrm{z}$ tego powodu, że państwo to udzieliło zamówienia na usługi w zakresie wytwarzania określonych dokumentów (jak paszporty z chipem, paszporty tymczasowe, dokumenty pobytowe, dowody osobiste, legitymacje pirotechnika, dokumenty prawa jazdy $\mathrm{w}$ formacie karty bankowej i dowody rejestracyjne w formacie karty bankowej) bezpośrednio spółce Österreichische Staatsdruckerei GmbH oraz utrzymało w mocy przepisy krajowe przewidujące względem instytucji udzielających zamówień publicznych obowiązek udzielania zleceń na usługi wyłącznie spółce Österreichische Staatsdruckerei GmbH. Należy podkreślić, że w toku postępowania poprzedzającego wniesienie skargi Komisja stopniowo wycofywała swoje zarzuty dotyczące kart motorowerowych, dowodów rejestracyjnych $\mathrm{w}$ formacie papierowym, patentów żeglarskich, formularzy dokumentów bezpieczeństwa i banderol akcyzowych $\mathrm{z}$ uwagi na to, że dokumenty te zostały częściowo zniesione, a częściowo ich produkcja była przedmiotem $\operatorname{przetargu}^{17}$. W toku postępowania poprzedzającego wniesienie skargi Austria powołała się na ochronę podstawowych interesów bezpieczeństwa krajowego. Ochrona informacji tajnych, zabezpieczenie autentyczności i prawidłowości danych dokumentów, bezpieczeństwo dostaw i zapewnienie ochrony danych wrażliwych uzasadnia, w ocenie Austrii, udzielanie zamówień na druk wyłącznie Staatsdruckerei. Jedynie bowiem Staatsdruckerei charakteryzuje się odpowiednimi środkami bezpieczeństwa w zakresie organizacji, stanu technicznego i budynków, aby wykonać to zamówienie. Wobec przedsiębiorstw innych niż Staatsdruckerei dochowanie wymogów bezpieczeństwa może być egzekwowane tylko za pomocą środków prawa cywilnego, natomiast wobec Staatsdruckerei organom państwowym Austrii przysługują z mocy ustawy szczególne uprawnienia kontrolne. Z kolei KE podkreśliła, że możliwe jest zorganizowanie publicznego przetargu w ten sposób, że mogą zostać uwzględnieni wyłącznie przedsiębiorcy specjalizujący się w wytwarzaniu dokumentów spełniających szczególne wymogi w zakresie zabezpieczeń i podlegający odpowiedniej kontroli.

15 Dyrektywa Rady 92/50/EWG z 18 czerwca 1992 r. odnosząca się do koordynacji procedur udzielania zamówień publicznych na usługi (Dz.Urz. UE L 209 z 24 lipca 1992 r., s. 1), uchylona na mocy dyrektywy 204/18.

16 Dyrektywa 2004/18/WE Parlamentu Europejskiego i Rady z 31 marca 2004 r. w sprawie koordynacji procedur udzielania zamówień publicznych na roboty budowlane, dostawy i usługi (Dz.Urz. UE L 134 z 30 kwietnia 2004 r., s. 114), uchylona na mocy dyrektywy 2014/24.

17 Zgodnie $\mathrm{z}$ informacją przedstawioną w tej sprawie przez rzecznik generalną J. Kokott (opinia z 20 lipca 2017 r., ECLI:EU:C:2017:578). 
Na dzień sporządzenia niniejszej opinii sprawa nie została jeszcze rozstrzygnięta przez TSUE ${ }^{18}$, natomiast 20 lipca 2017 r. wydana została opinia rzecznik generalnej J. Kokott (dalej: rzecznik) ${ }^{19}$. Odnosi się ona do trzech zasadniczych argumentów przedstawionych przez Austrię.

Po pierwsze, w ocenie Austrii, wymóg scentralizowanego wykonywania zamówień na druk przez jedno przedsiębiorstwo znajduje uzasadnienie w konieczności sprawowania przez władze kontroli prawidłowego wykonania zamówień z zachowaniem koniecznych środków zapewnienia tajemnicy i bezpieczeństwa. Ponadto centralizacja realizacji zamówień zmniejsza ryzyko, że osoby nieuprawnione zdobędą wiedzę o tych środkach bezpieczeństwa lub że wrażliwy materiał (np. druki paszportów lub dokumentów pobytowych) wpadną w ręce osób nieuprawnionych. W ocenie rzecznik: centralizacja wykonywania zamówień przyczynia się do ochrony podstawowych interesów w zakresie bezpieczeństwa, a nawet przyczynia się do ochrony danych. Niemniej jednak argument centralizacji może ostatecznie wyjaśnić jedynie to, dlaczego sporne zamówienia na druk jest udzielane zawsze tylko jednemu przedsiębiorstwu (a nie kilku przedsiębiorstwom jednocześnie). Natomiast powołując się na argument wymogu centralizacji, nie da się przekonujaco uzasadnić, dlaczego do ochrony podstawowych interesów $w$ zakresie bezpieczeństwa niezbędne ma być udzielanie zamówienia zawsze tylko temu samemu przedsiębiorstwu (pkt 57 opinii).

Austria podnosi również, że w świetle prawa austriackiego jej organy dysponują władczymi uprawnieniami kontrolnymi tylko w stosunku do Staatsdruckerei, nie zaś w stosunku do innych przedsiębiorstw, w szczególności zagranicznych.

Rzecznik zgadza się ze stanowiskiem, że stosowanie władczych uprawnień kontrolnych może być konieczne w celu ochrony podstawowych interesów w zakresie bezpieczeństwa krajowego, ponieważ są one bardziej skuteczne w działaniu niż prawa kontrolne uzgodnione w umowie cywilnoprawnej. Niemniej, jej zdaniem, ta okoliczność sama w sobie nie uzasadnia całkowitego pomijania istniejących wymogów prawa Unii w odniesieniu do udzielania zamówień publicznych i a priori brania pod uwage jako wykonawcę zawsze tylko jednego określonego przedsiębiorstwa. Zdaniem rzecznik Austria powinna zapewnić równowagę między uprawnieniami kontrolnymi koniecznymi dla ochrony bezpieczeństwa z jednej strony i swoimi zobowiązaniami unijnymi z drugiej strony, przy czym do dopuszczalnych rozwiązań rzecznik zalicza:

- zamiast całkowitego wyłączenia z przetargu przedsiębiorstw z siedzibą w innych państwach stronach porozumienia EOG Austria mogłaby w razie potrzeby zobowiązać wszystkich zainteresowanych do zrealizowania spornego zamówienia na druk w razie jego udzielenia przez zakład położony w kraju,

18 Zgodnie z kalendarzem TSUE, https://curia.europa.eu/jcms/jcms/Jo1_6581/pl, wydanie wyroku zostało zaplanowane na 20 marca $2018 \mathrm{r}$.

19 Opinia z 20 lipca 2017 r., ECLI:EU:C:2017:578. 
przetwarzania gromadzonych przy tym danych osobowych wyłącznie w kraju oraz nieprzesyłania takich danych oraz informacji dotyczących bezpieczeństwa przez zagraniczne linie danych lub serwery lub nieprzekazywania ich do części przedsiębiorstwa położonych za granicą lub zagranicznym władzom,

- oraz zamiast przewidywać uprawnienia kontrolne z zakresu władzy publicznej [...] wyłacznie wobec Staatsdruckerei, ustawodawca austriacki mógłby ogólnie upoważnić odpowiedzialne organy państwowe do przeprowadzania takich kontroli we wszystkich przedsiębiorstwach majacych zakłady $w$ kraju, jeżeli wykonują one tam istotne pod względem bezpieczeństwa zamówienia na drukowanie.

Wynikające $\mathrm{z}$ powyższego rozwiązania ograniczenia swobody przepływu usług byłyby, zdaniem rzecznik, dopuszczalne w świetle orzecznictwa TSUE ${ }^{20}$ z uwagi na konieczność przeprowadzania kontroli administracyjnych.

W końcu rzecznik generalna odnosi się do argumentu jakoby spornego zamówienia udzielono konkretnie Staatsdruckerei, ponieważ między tym przedsiębiorstwem i odpowiedzialnym organem państwowym istnieje szczególny stosunek zaufania. Jej zdaniem: byłaby ewidentnie sprzeczna $z$ istota europejskiego rynku wewnętrznego w ogólności i prawem zamówień publicznych w szczególności sytuacja, w której państwo członkowskie niemal dowolnie uznaje wyłacznie jedno przedsiębiorstwo, zwłaszcza swojego poprzedniego państwowego i obecnie sprywatyzowanego "historycznego" usługodawcę $w$ określonej dziedzinie, zgodnie z mottem „znany i sprawdzony” za szczególnie niezawodne i godne zaufania, natomiast innym przedsiębiorstwom a priori odmawia niezawodności i wiarygodności lub $w$ każdym razie podaje je $w$ watpliwość. Opierając się na orzecznictwie TSUE, rzecznik generalna podkreśliła, że konieczność ustanowienia obowiązku dochowania poufności nie wyklucza w żaden sposób zastosowania postępowania przetargowego przy udzielaniu zamówienia ${ }^{21}$. Unijne zasady udzielania zamówień publicznych pozostawiają bowiem instytucjom zamawiającym wystarczający zakres swobody dla niezbędnych środków bezpieczeństwa i dochowania tajemnicy we wrażliwej dziedzinie, czy to w postępowaniu aż do wyboru najbardziej odpowiedniego wykonawcy, czy też później w stadium wykonywania zamówienia.

Podsumowując, rzecznik generalna stwierdza, że: nic nie ogranicza instytucji zamawiających przy udzielaniu wrażliwych zamówień publicznych, takich jak zamówienia na [...] wytwarzanie dokumentów urzędowych, w stawianiu szczególnie wysokich wymagań co do kwalifikacji i niezawodności wykonawcy zamówienia,

20 Wyrok TSUE z 4 grudnia 1986 r. Komisja v. Niemcy, sygn. akt 205/84, EU:C:1986:463, pkt 52 w związku z pkt 54.

21 Wyrok TSUE (Wielka Izba) z 8 kwietnia 2008 r. Komisja v. Włochy, sygn. akt C-337/05, EU:C:2008:203, pkt 52; wyrok TSUE z 2 października 2008 r. Komisja v. Włochy, sygn. akt C-157/06 EU:C:2008:530. 
ustalaniu odpowiednio warunków przetargu oraz żądaniu od ubiegających się o zamówienie potrzebnych dowodów. Ponadto wykonawcy moga zostać zobowiązani do spetnienia warunków dotyczacych wykonania zamówień na drukowanie, które moga obejmować również środki wakresie ochrony danych, dochowania tajemnicy $i$ bezpieczeństwa, $w$ tym kontrolę bezpieczeństwa wszystkich pracowników uczestniczących przy wykonaniu zamówienia. To wszystko nie powoduje jednakże tego, że wytwarzanie dokumentów urzędowych staje się zamówieniem intuitu personae, które powinno być wykonane wyłącnie przez konkretna osobę (pkt 68 opinii).

$\mathrm{Na}$ uwagę zasługuje również argument podniesiony przez Austrię na rozprawie: zagraniczne przedsiębiorstwa nie mogą całkowicie uchylić się od ingerencji władz swojego kraju pochodzenia i częściowo są nawet zobowiązane do współpracy z tamtejszymi tajnymi służbami, i to także wówczas, gdy wykonują zamówienia publiczne za pośrednictwem zagranicznego zakładu. Dlatego takie przedsiębiorstwa nie mogą być brane pod uwagę jako wykonawcy wrażliwych zamówień na druk, takich jak te sporne w niniejszej sprawie. Również ten argument nie przekonał rzecznik, warto jednak podkreślić jej uzasadnienie. Otóż $\mathrm{w}$ jej opinii: [z]godnie $z$ utrwalonym orzecznictwem przepisy krajowe sq odpowiednie do zapewnienia osiagnięcia zamierzonego celu jedynie wtedy, gdy rzeczywiście odzwierciedlają zamiar osiagnięcia tego celu w sposób spójny i systematyczny. W niniejszym wypadku Austria, o ile wiadomo, nie podjęła żadnych środków, które skutecznie mogłyby uniemożliwić, aby Staatsdruckerei dostała się pod kontrole zagranicznych wspólników lub stała się spótka zależna zagranicznej osoby prawnej. Państwo austriackie nie wynegocjowało sobie $w$ Staatsdruckerei motywowanych względami polityki bezpieczeństwa uprawnień do współdecydowania $w$ formie szczególnej akcji („złota akcja”), ani nie poddało zbywania udziałów w Staatsdruckerei żadnym ograniczeniom ze względów polityki bezpieczeństwa. Na podstawie tego stanowiska można wnioskować a contrario, że wprowadzenie tego rodzaju ograniczeń uniemożliwiających przejęcie kontroli nad spółką, o której mowa w art. 17 ust. 1 projektu, stanowiłoby argument przemawiający za zgodnością projektu z dyrektywą 2014/24.

Zważywszy na znaczenie rozstrzygnięcia w przedmiotowej sprawie dla oceny zgodności opiniowanego projektu z prawem UE, zaleca się zawieszenie prac nad projektem do czasu wydania wyroku przez TSUE (planowana data wydania wyroku: 20 marca 2018 r.).

\section{Ocena dotycząca zgodności art. 40 ust. 3 i 4 rządowego projektu ustawy o dokumentach publicznych (druk sejmowy nr 2153) $z$ regułami postępowania karnego}

\section{- Przedmiot opiniowanych przepisów}

Opiniowany projekt przewiduje uregulowanie dostępu upoważnionych członków Komisji do spraw dokumentów publicznych do dowodów rzeczowych w po- 
staci sfałszowanego dokumentu publicznego w trakcie trwającego postępowania karnego oraz po jego prawomocnym zakończeniu. Stosownie do art. 40 ust. 3 projektu organ dysponujący dowodem rzeczowym w postaci sfałszowanego dokumentu publicznego umożliwia upoważnionemu członkowi Komisji dostęp do tego dowodu rzeczowego, a po prawomocnym zakończeniu postępowania karnego przekazuje dowód rzeczowy na czas wskazany w upoważnieniu. Zgodnie $\mathrm{z}$ regułą ekonomii procesowej, przewidzianą w ust. 4 tego artykułu, dostęp do dowodu rzeczowego, o którym mowa w ust. 3, nie może utrudniać postępowania karnego ani wpływać na zmniejszenie wartości tego dowodu dla prowadzonego postępowania.

W ujęciu zaproponowanym w projekcie przy ministrze właściwym do spraw wewnętrznych (zob. art. 1 ust. 4 projektu) powstanie Komisja do spraw dokumentów publicznych (art. 49 ust. 1 projektu). Założona rola Komisji będzie sprowadzać się do pomocy ministrowi właściwemu ds. wewnętrznych przy realizacji zadań, o których mowa w art. 3 ust. 1 pkt 1-8 projektu (art. 3 ust. 2 projektu). Chodzi tu o udzielanie pomocy ministrowi w realizacji części zadań ministra nałożonych na niego przepisami projektowanej ustawy, do których należeć mają:

- branie udziału w procedurze opracowywania wzoru dokumentu publicznego,

- analizowanie przypadków fałszerstw dokumentów publicznych,

- inicjowanie zmian zabezpieczeń dokumentów publicznych przed fałszerstwem,

- ocena jakości wydawanych dokumentów publicznych, o których mowa w art. 5 ust. 2 pkt $1-28$ projektu,

- monitorowanie zmian zachodzących na świecie w dziedzinie zabezpieczeń dokumentów przed fałszerstwem,

- współpraca z międzynarodowymi instytucjami i organizacjami zajmującymi się ochroną i zabezpieczaniem dokumentów publicznych przed fałszerstwem,

- publikowanie w Rejestrze Dokumentów Publicznych informacji o wzorach dokumentów publicznych,

- podejmowanie działań mających na celu podnoszenie poziomu edukacji w zakresie wiedzy o możliwościach i sposobach rozpoznawania fałszywych dokumentów publicznych.

Zapewnienie dostępu do dowodów rzeczowych w postaci sfałszowanych dokumentów publicznych dla członków Komisji wydaje się niezbędne dla skutecznego wsparcia ministra właściwego do spraw wewnętrznych w realizacji obowiązków przewidzianych zwłaszcza w pkt $2-5$ oraz 8 art. 3 ust 1 projektu.

Zgodnie z art. 49 ust. 3 projektu w skład Komisji wejdą:

- siedmiu członków powołanych spośród osób wykonujących obowiązki służbowe w ministerstwie ds. wewnętrznych,

- do piętnastu członków powołanych spośród pracowników jednostek organizacyjnych nadzorowanych przez ministra, funkcjonariuszy lub pracowników 
delegowanych przez Komendanta Głównego Policji, Komendanta Głównego Straży Granicznej oraz Szefa Agencji Bezpieczeństwa Wewnętrznego na czas niezbędny do wykonywania zadań,

- do pięciu członków powołanych spośród ekspertów innych podmiotów zajmujących się dokumentami publicznymi.

Zakłada się, że przewodniczący i zastępca przewodniczącego Komisji będą mieć co najmniej 5-letnie, udokumentowane doświadczenie z zakresu technicznych badań dokumentów lub co najmniej 5-letnie, udokumentowane doświadczenie związane z projektowaniem systemów zabezpieczeń dokumentów (art. 49 ust. 4 projektu). Trzech członków Komisji, o których mowa w ust. 3 pkt 1, oraz członkowie, o których mowa w ust. 3 pkt 2, będą mieć co najmniej 2-letnie, udokumentowane doświadczenie, o którym mowa w ust. 4 . (art. 49 ust. 5 projektu). Z kolei wobec dwóch członków Komisji, o których mowa w ust. 3 pkt 1, wprowadza się wymóg posiadania wykształcenia wyższego oraz co najmniej 5-letniego doświadczenie zawodowego w administracji publicznej (art. 49 ust. 6 projektu).

$\mathrm{Z}$ kolei desygnaty pojęcia „organ dysponujący dowodem rzeczowym w postaci sfałszowanego dokumentu publicznego", o którym mowa w art. 40 ust. 3 projektu, będą zmieniać się w zależności od etapu, na którym będzie znajdować się prowadzone postępowanie karne. Na jego etapie przygotowawczym organem prowadzącym tzw. postępowanie przygotowawcze jest prokurator, a w zakresie przewidzianym w ustawie także Policja lub inny organ (art. $298 \$ 1$ Kodeksu postępowania karnego). Na etapie postępowania sądowego będzie nim sąd.

\section{- Analiza art. 40 ust. 3 i 4 przepisów projektu na gruncie prawnokarnych reguł dostępu do materiałów postępowania karnego}

W obowiązującym stanie prawnym dostęp do materiałów zebranych w aktach prowadzonego postępowania jest limitowany, zależy od etapu postępowania oraz roli procesowej uczestnika. Dla przykładu osoba podejrzana i jej pełnomocnik mogą zapoznać się - na ich wniosek - ze zgromadzonymi w śledztwie (dochodzeniu) materiałami $\mathrm{w}$ drodze przejrzenia akt dopiero $\mathrm{w}$ końcowej fazie postępowania przygotowawczego przed jego zamknięciem i skierowaniem aktu oskarżenia do sądu (art. $321 \$ 1$ Kodeksu postępowania karnego). Organ będący gospodarzem postępowania, zwłaszcza na etapie postępowania przygotowawczego, kierując się strategią prowadzonego postępowania, zazwyczaj niesłychanie oszczędnie dzieli się zebraną wiedzą procesową. Ustawodawca przewidział jednocześnie na gruncie Kodeksu karnego rozwiązania ukierunkowane na ochronę dostępu do informacji procesowych. Przy tej okazji należy zwrócić uwagę przede wszystkim na przepis art. $241 \$ 1$ Kodeksu karnego, według którego karane będzie publiczne rozpowszechnianie - bez zezwolenia - wiadomości $\mathrm{z}$ postępowania przygotowawczego, zanim zostały ujawnione $\mathrm{w}$ postępowaniu 
sądowym. Jest to przestępstwo powszechne, którego dopuścić może się każdy, a więc nie tylko uczestnik postępowania, ale każda osoba, która powzięła informacje na temat materiałów procesowych zebranych w takim postępowaniu. Za ten czyn przewidziano karę grzywny, ograniczenia wolności albo pozbawienia wolności do lat 2. Nie stanowi zatem przestępstwa rozpowszechnianie publicznie wiadomości z postępowania przygotowawczego w przypadku, gdy sprawca miał odpowiednie zezwolenie pochodzące od uprawnionego organu (np. prokuratora), a po wpłynięciu aktu oskarżenia do sądu - od sądu ${ }^{22}$. Jak zauważył Wojewódzki Sąd Administracyjny w Gdańsku w wyroku z 14 stycznia 2015 r., sygn. akt I SA/Gd 1250/14: Niezgodne z prawem jest takie działanie, które polega na nieuprawnionym ujawnieniu informacji z postępowania przygotowawczego tak, że stana się one dostępne dla bliżej nieokreślonego kręgu osób. Z taka sytuacją nie mamy do czynienia wówczas, gdy informacje z postępowania przygotowawczego sa przekazywane organom podatkowym, na potrzeby prowadzonego postępowania ${ }^{23}$.

Z kolei zgodnie $\mathrm{z}$ art. $241 \$ 2$ Kodeksu karnego tej samej karze podlega ten, kto rozpowszechnia publicznie wiadomości z rozprawy sądowej prowadzonej z wyłączeniem jawności. Odmiennie jednak niż w art. $241 \S 1$, na gruncie art. $241 \S 2$ nie użyto określenia „bez zezwolenia”, co należy interpretować w ten sposób, że tajemnica rozprawy niejawnej ma charakter bezwzględny i nie może być uchylona ${ }^{24}$.

Przewidziany w projekcie ustawy przepis art. 40 ust. 3 daje podstawę do tego, aby organ prowadzący postępowanie umożliwił upoważnionemu członkowi Komisji dostęp do dowodu rzeczowego w postaci sfałszowanego dokumentu. W konsekwencji realizacji tego uprawnienia członek Komisji uzyska w tym zakresie dostęp do materiałów procesowych. Będzie to jednak dostęp za zezwoleniem uprawnionego organu, co zasadniczo wyłącza bezprawność jego działania, czyniąc je legalnym. Przepis art. 40 ust. 3 projektu będzie pełnił tu rolę swoistego kontratypu dla działań członków Komisji, jako podmiotów trzecich na gruncie prowadzonego postępowania karnego, co do zasady legalizując je. Tym bardziej przepis ten powinien zostać ukształtowany precyzyjnie. Pewnym deficytem tego uregulowania, jaki może przynieść negatywne skutki w praktyce jego stosowania, jest brak określenia celu działania członka Komisji, jak również brak bliższego określenia na czym polegać ma „dostęp do dowodu” i co z pozyskaną informacją będzie mógł prawnie uczynić członek Komisji. Jeśli chodzi o identyfikację celu jego działania, można zapewne posiłkować się katalogiem zadań przypisanych pośrednio Komisji jako organowi wsparcia w realizacji obowiązków nałożonych przez

\footnotetext{
M. Mozgawa, Komentarz aktualizowany do art. 241 Kodeksu karnego, LEX.

LEX nr 16681210.

24 B. Kunicka-Michalska, Art. 241 KK [w:] A. Wąsek, R. Zawłocki, Kodeks karny. Część szczególna. Komentarz do artykułów 222-316, t. II, 2010, s. 318, Legalis; zob. też R.A. Stefański, Tajemnica przesłuchania $z$ wyłączeniem jawności, „Prokuratura i Prawo" 2003 , nr 11, s. 37.
} 
projekt ustawy na ministra (zob. zwłaszcza art. 3 ust. 1 pkt $2-5 \mathrm{w}$ związku z ust. 2 projektu). Natomiast pozostaje wątpliwość, czy dyspozycja art. 40 ust. 3 projektu nie została ujęta zbyt wąsko w zestawieniu z kryminalizacją zawartą w art. 241 Kodeksu karnego, gwarantując członkowi Komisji jedynie dostęp do dowodu, ale już bez, przynajmniej wprost, odniesienia się do tego, co z informacją zdobytą dzięki zrealizowaniu dostępu do dowodu, będzie mógł uczynić. Nie jest jasne w szczególności, czy członek Komisji będzie mógł podzielić się nią z innymi członkami Komisji. Na konieczność rozróżnienia między prawnymi konsekwencjami udostępnienia akt postępowania i rozpowszechnianiem uzyskanych na tej podstawie wiadomości zwrócił uwagę Sąd Najwyższy ${ }^{25}$, wskazując, że udostępnienie akt postępowania przez organ prowadzący postępowanie czy też udzielenie określonej informacji pochodzącej z takiego postępowania, niezależnie od trybu, w jakim zostało dokonane, i statusu podmiotu, któremu udostępniono akta lub udzielono informacji, nie jest równoznaczne z zezwoleniem na publiczne rozpowszechnianie uzyskanych w taki sposób wiadomości pochodzących z postępowania.

Warto jednocześnie zaznaczyć, że projektowany w art. 40 ust. 3 dostęp do materii prowadzonego postępowania karnego w postaci dowodu rzeczowego nie jest rozwiązaniem precedensowym na gruncie obowiązującego systemu prawa. Dla przykładu w postępowaniu immunitetowym, regulowanym przepisami ustawy z 9 maja 1996 r. o wykonywaniu mandatu posła i senatora (t.j. Dz.U. 2016, poz. 1510, ze zm.), przewiduje się nawet szerzej zakreślony instrument, polegający na udostępnieniu przez sąd lub prokuraturę całych akt postępowania na żądanie Marszałka Sejmu lub Marszałka Senatu, wyrażone w związku z postępowaniem sejmowym lub senackim o wyrażenie zgody na pociągnięcie do odpowiedzialności karnej odpowiednio posła lub senatora (art. 7c ust. 3), bądź też wyrażenie zgody na ich zatrzymanie lub aresztowanie (art. 10 ust. $6 \mathrm{w}$ związku $\mathrm{z}$ art. $7 \mathrm{c}$ ust. 3).

Zaletą omawianego rozwiązania normatywnego z art. 40 ust. 3 projektu, którą należy w tym miejscu wyeksponować, jest pragmatyczne powiązanie przyznania dostępu do dowodu z zasadami ekonomii procesowej. W przedstawionym ujęciu gwarancja dostępu do dowodu rzeczowego jest warunkowana celami prowadzonego postępowania karnego i nie może ich przesłaniać, $w$ tym sensie, że nie może utrudniać postępowania karnego ani wpływać na zmniejszenie wartości dowodu dla prowadzonego postępowania (art. 40 ust. 4 projektu).

\section{Wnioski}

- W zakresie, w jakim projekt zmierza do wyłączenia określonych kategorii druków i dokumentów spod regulacji dyrektywy 2014/24, może on zostać

25 Uchwała SN z 21 października 2003 r., sygn. akt I KZP 29/03. 
uznany za niezgodny z dyrektywą 2014/24, w szczególności z art. 1 w związku $\mathrm{Z}$ art. 15 ust. 2.

- Z uwagi na znaczenie rozstrzygnięcia przez TSUE sprawy Komisja v. Republika Austrii, sygn. akt C-187/16, dla oceny zgodności opiniowanego projektu z prawem UE zaleca się zawieszenie prac nad projektem do czasu wydania wyroku przez TSUE (planowana data wydania wyroku: 20 marca 2018 r.).

- Na gruncie ujęcia projektowanego art. 40 ust. 3 rodzi się wątpliwość, czy dyspozycja tego uregulowania nie została ujęta zbyt wąsko w zestawieniu z zakazem karnym zawartym w art. 241 Kodeksu karnego. Członkowi Komisji gwarantuje się dostęp do dowodu, ale już bez odniesienia się do tego, co będzie mógł uczynić z informacją zdobytą dzięki zrealizowaniu tego dostępu. Nie jest jasne w szczególności, czy członek Komisji będzie mógł podzielić się nią $\mathrm{z}$ innymi członkami Komisji.

- Zaletą projektowanego rozwiązania normatywnego z art. 40 ust. 3 jest pragmatyczne powiązanie przyznania dostępu do dowodu z zasadami ekonomii procesowej. Projekt zakłada, że gwarancja dostępu do dowodu rzeczowego jest warunkowana celami prowadzonego postępowania karnego i nie może ich przesłaniać, tzn. utrudniać postępowania karnego ani wpływać na zmniejszenie wartości dowodu dla prowadzonego postępowania (art. 40 ust. 4 projektu).

\section{Bibliografia}

Arrowsmith S., The Law of Public and Utilities Procurement, London 2014.

Kunicka-Michalska B., Art. 241 KK [w:] Kodeks karny. Część szczególna. Komentarz do artykułów 222-316, t. II, red. A. Wąsek, R. Zawłocki, Warszawa 2010.

Mozgawa M., Komentarz aktualizowany do art. 241 Kodeksu karnego, LEX.

Stefański R.A, Tajemnica przesłuchania z wyłączeniem jawności, „Prokuratura i Prawo” 2003, nr 11. 


\title{
Ocena rządowego projektu ustawy o szczególnych rozwiązaniach związanych z organizacją sesji Konferencji Stron Ramowej Konwencji Narodów Zjednoczonych w sprawie zmian klimatu w Rzeczypospolitej Polskiej (druk sejmowy nr 2120) ${ }^{1}$
}

\begin{abstract}
Evaluation of the government bill on specific solutions related to the organization of the sessions of the Conference of the Parties to the United Nations Framework Convention on Climate Change in Republic of Poland (Sejm's paper no. 2120): The bill can be qualified to the category of the so-called special acts that are passed due to the need for an extraordinary regulation regarding a given situation or event. It was found that although the legitimacy of accepting the submitted bill cannot be questioned, and regulations of this type have already been introduced into the Polish legal system, it is postulated that in the future reaching for the instrument in the form of a separate act for the organization of one event should be an exception, and it should not become a standard practice. It was assessed that Article 22 of the bill may be considered incompatible with Article 57 of the Constitution of the Republic of Poland due to the restriction that violates the essence of the right to participate in the assemblies.
\end{abstract}

Keywords: bill | climate | assemblies

Słowa kluczowe: projekt ustawy | klimat | zgromadzenia

* Doktor nauk prawnych, ekspert ds. legislacji BAS; tomasz.jaroszynski@sejm.gov.pl.

**Ekspert ds. ochrony środowiska BAS; miroslaw.sobolewski@sejm.gov.pl.

\section{Przedmiot opinii}

Opinia dotyczy oceny rządowego projektu ustawy o szczególnych rozwiązaniach związanych z organizacją sesji Konferencji stron Ramowej konwencji Narodów Zjednoczonych w sprawie zmian klimatu w Rzeczypospolitej Polskiej (druk sejmowy nr 2120); (dalej: projekt ustawy).

1 Opinia dotyczaca rządowego projektu ustawy o szczególnych rozwiązaniach związanych $z$ organizacja sesji Konferencji Stron Ramowej konwencji Narodów Zjednoczonych w sprawie zmian klimatu w Rzeczypospolitej Polskiej (druk nr 2120) sporządzona 8 stycznia $2018 \mathrm{r}$. na zlecenie przewodniczącego Komisji ds. Zagranicznych; BAS-WAP/WAPM 2617/17. 


\section{Przedmiot projektu ustawy}

Projektowana ustawa ma określać:

- zadania organów administracji publicznej oraz służb związane z organizacją Konferencji COP24, w szczególności w zakresie zapewnienia bezpieczeństwa i porządku publicznego, oraz pełnieniem przez Rzeczpospolitą Polską funkcji prezydencji konferencji stron,

- zasady udzielania i realizacji zamówień związanych z organizacją Konferencji COP24 oraz pełnieniem przez Rzeczpospolitą Polską funkcji prezydencji konferencji stron,

- zadania Zespołu do spraw organizacji Konferencji COP24,

- zasady finansowania organizacji Konferencji COP24 oraz wykonywania zadań związanych z pełnieniem przez Rzeczpospolitą Polską funkcji prezydencji konferencji stron,

- sposób finansowania wsparcia udzielanego państwom rozwijającym się w zakresie łagodzenia zmian klimatu i adaptacji do skutków tych zmian wykonywanego w ramach realizacji celów konwencji klimatycznej.

\section{Tło i kontekst projektu ustawy}

Decyzja o tym, że Polska zorganizuje szczyt klimatyczny COP24 w roku 2018 zapadła podczas konferencji klimatycznej w Marrakeszu (2016 r.). W czerwcu 2017 r. ogłoszono, że miastem-gospodarzem szczytu będą Katowice (o prawo do organizacji szczytu rywalizowały one z Gdańskiem). Szczyt COP24 odbędzie się w dniach od 3 do 14 grudnia 2018 r. Wydarzenie to będzie obejmować 24. sesję Konferencji stron Ramowej konwencji Narodów Zjednoczonych w sprawie zmian klimatu² (tzw. COP24), 14. spotkanie stron protokołu z Kioto (CMP 14) oraz wznowioną sesję konferencji sygnatariuszy porozumienia paryskiego (CMA 1.3).

Konferencje klimatyczne (COP, Conference of the Parties) odbywają się corocznie, począwszy od pierwszej sesji w Berlinie w 1995 r. Stanowią największe światowe forum negocjacyjne w sprawach związanych $\mathrm{z}$ ochroną klimatu, ograniczaniem emisji gazów cieplarnianych i transformacją światowych systemów energetycznych. W szczytach klimatycznych uczestniczą delegacje reprezentujące niemal wszystkie państwa świata, a także liczne organizacje międzynarodowe, przedstawiciele świata biznesu i nauki, ruchy ekologiczne i obywatelskie. Towarzyszy im liczne grono dziennikarzy i reporterów z całego świata zapewniających

2 Ramowa Konwencja Narodów Zjednoczonych w sprawie zmian klimatu, sporządzona w Nowym Jorku 9 maja 1992 r. (Dz.U. 1996, nr 53, poz. 238), dalej także: konwencja klimatyczna. 
obsługę medialną. Szacuje się, że w tegorocznej konferencji w Katowicach może wziąć udział nawet 30 tys. uczestników.

Szczyty klimatyczne organizowane są w porozumieniu z sekretariatem Konwencji Klimatycznej przez kraj sprawujący aktualnie prezydencję $\mathrm{w}$ ramach konwencji. Prezydencja ma charakter rotacyjny, co roku przypada krajowi reprezentującemu określony region geograficzny, zgodnie z algorytmem opracowanym przez ONZ. W 2018 r. Polska obejmie prezydencję po raz trzeci (będzie to pierwszy taki przypadek; dotychczas niewiele krajów ubiegało się o powtórną prezydencję, dwukrotnie sprawowały ją jedynie Argentyna, Maroko i Niemcy).

Przewodniczenie obradom COP przynosi korzyści w postaci podniesienia międzynarodowego prestiżu i osiągnięcia lepszej pozycji negocjacyjnej, ale wiąże się też $\mathrm{z}$ dużą odpowiedzialnością. Pełnienie funkcji prezydencji konferencji zakłada co do zasady pozostawanie bezstronnym moderatorem globalnej dyskusji, a jej wysiłki powinny skupiać się na wsparciu procesu toczonego zgodnie z mandatem Narodów Zjednoczonych. Prezydencja konferencji nie reprezentuje stanowiska swojego kraju. Działa na rzecz zbliżenia stanowisk stron, czyli państw, które podpisały konwencję klimatyczną. Praca kierowanego przezeń gremium ma na celu doprecyzowanie i formułowanie zagadnień w postaci projektów decyzji, które są przedstawiane do przyjęcia na sesjach plenarnych. W okresie między sesjami konferencji (pomiędzy COP-ami) zadaniem prezydencji jest monitorowanie postępów w realizacji zadań przyjętych na najbliższy rok przez konferencję stron, czyli do kolejnej sesji.

$\mathrm{Z}$ uwagi na dynamikę procesu negocjacyjnego poszczególne konferencje stron mają różny ciężar gatunkowy. Niektóre z nich koncentrują się głównie na kwestiach technicznych, inne związane są $\mathrm{z}$ negocjacjami o zasadniczym znaczeniu, w które angażują się bezpośrednio przywódcy państw (np. na konferencji w Paryżu obecnych było prawie 140 głów państw, w tym USA, Rosji, Chin i Indii). Choć szczyt w Katowicach nie będzie miał aż tak dużego znaczenia, to jego polityczna waga pozostaje istotna. Oczekuje się, że w Katowicach zapadną ustalenia, które pozwolą na praktyczne wdrożenie kluczowych elementów porozumienia paryskiego (zawartego na COP21 w 2015 r.). Porozumienie paryskie stworzyło ramy mające kształtować politykę rozwoju wszystkich państw świata po roku 2020 i w kolejnych dekadach. Najważniejszym celem polskiej prezydencji COP24 będzie doprowadzenie do przyjęcia pełnego pakietu implementacyjnego dla porozumienia paryskiego, tak by można było uruchomić wszystkie przewidziane $\mathrm{w}$ nim mechanizmy $\mathrm{i}$ instytucje.

Porozumienie paryskie miało w historii negocjacji klimatycznych charakter przełomowy, ponieważ zobowiązało do ograniczania emisji gazów cieplarnianych wszystkie kraje świata, a nie tylko gospodarki o wysokim poziomie rozwoju (jak było to w przypadku protokołu z Kioto). W efekcie stworzone zostały warunki umożliwiające prace nad osiągnięciem głównego celu politycznego konwencji klimatycznej, jakim jest utrzymanie wzrostu globalnej temperatury $\mathrm{w}$ granicach nie przekraczających +2 st. C. 
Powyższe uwagi odnoszące się do szerokiego kontekstu konferencji COP i ich roli w negocjacjach klimatycznych upoważniają do sformułowania kilku wniosków.

- Konwencja klimatyczna i porozumienie paryskie to umowy międzynarodowe o bardzo dużym znaczeniu politycznym i gospodarczym.

- Polska, występując w roli gospodarza konferencji COP24, zyska szansę na budowę pozytywnego wizerunku kraju zaangażowanego w rozwiazywanie problemów globalnych, a jednocześnie prowadzącego aktywną politykę klimatyczną.

- Potencjalne korzyści uzasadniają podjęcie wysiłku organizacyjnego i związanych z nim kosztów (o ile będą się one mieściły w racjonalnych granicach, a wydatki będą ponoszone $\mathrm{z}$ zachowaniem procedur gwarantujących przejrzystość i oszczędne gospodarowanie środkami publicznymi).

W analizowanym projekcie ustawy określono górny limit wydatków na organizację szczytu COP24 na $130 \mathrm{mln}$ zł. Nie przedstawiono jednak żadnego preliminarza kosztów w rozbiciu na poszczególne kategorie wydatków. Uniemożliwia to ocenę, czy zaproponowana kwota jest adekwatna do planowanych działań. Dla porównania można wskazać, że wydatki związane z organizacją szczytu COP14 w Poznaniu (2008 r.) wyniosły około 70 mln zł, zaś COP19 w Warszawie (2013 r.) około $100 \mathrm{mln}$ zł.

Zgodnie z projektem ustawy na finansowanie organizacji i obsługi szczytu klimatycznego przeznaczone będą głównie środki z Narodowego Funduszu Ochrony Środowiska i Gospodarki Wodnej (NFOŚiGW), ale dodatkowo organizacja COP24 może być także dofinansowana środkami pochodzącymi np. z dobrowolnych wpłat, zapisów, darowizn, wpływów pochodzących z fundacji, z budżetu UE oraz z budżetu państwa. W projekcie przewidziano też, że w 2018 r. Polska przekaże 8 mln dolarów US państwom rozwijającym się na działania mające na celu łagodzenie zmian klimatycznych i adaptację do nich. Realizację programu pomocy klimatycznej w tej wysokości zadeklarowała premier Beata Szydło na konferencji w Paryżu w 2015 r.

\section{Ocena zgodności projektu ustawy z prawem polskim}

\section{Uwagi ogólne}

Projektowaną ustawę można zakwalifikować do kategorii tzw. specustaw, które są uchwalane w związku z potrzebą nadzwyczajnej regulacji dotyczącej określonej sytuacji lub wydarzenia. Biorąc pod uwage przedmiot projektu ustawy, jako przykłady podobnych uregulowań można wskazać ustawę z 24 czerwca 2010 r. o szczególnych rozwiązaniach związanych z usuwaniem skutków powodzi z 2010 r. (Dz.U. nr 123, poz. 835, ze zm.), ustawę z 16 marca 2016 r. o szczególnych rozwiązaniach związanych z organizacją Szczytu Organizacji Traktatu 
Północnoatlantyckiego w Rzeczypospolitej Polskiej w Warszawie w 2016 roku (Dz.U. poz. 865, ze zm.) oraz ustawę z 18 marca 2016 r. o szczególnych rozwiązaniach związanych z organizacją wizyty Jego Świątobliwości Papieża Franciszka w Rzeczypospolitej Polskiej oraz Światowych Dni Młodzieży - Kraków 2016 (Dz.U. poz. 393, ze zm.).

Wymaga podkreślenia, że ostatnia z wymienionych ustaw zawiera przepisy, które odnoszą się do kwestii rodzajowo tożsamych z ujętymi w projekcie ustawy. Przedmiotem ustawy z 18 marca 2016 r. było bowiem określenie: a) szczególnych zadań organów administracji publicznej związanych z organizacją wizyty w Polsce papieża Franciszka oraz Światowych Dni Młodzieży, w szczególności w zakresie zapewnienia bezpieczeństwa i porządku publicznego oraz zabezpieczenia medycznego; b) zasad pokrywania kosztów realizacji tych zadań; c) zasad współpracy organów administracji publicznej, organizatora Światowych Dni Młodzieży i innych podmiotów, przy realizacji tych zadań. Należy zauważyć, że przepisy tej ustawy normujące opracowanie planu zapewnienia bezpieczeństwa i porządku publicznego, uprawnienia Policji w zakresie przetwarzania określonego rodzaju danych osobowych oraz wyłączenia stosowania przepisów ustawy z 29 stycznia 2004 r. - Prawo zamówień publicznych (Dz.U. 2015, poz. 2164) do zamówień na dostawy, usługi lub roboty budowlane zostały w projekcie ustawy sformułowane w bardzo zbliżony sposób. Natomiast w związku ze specyfiką i skalą wydarzenia, jakim jest szczyt klimatyczny COP24, w projekcie ustawy w większym stopniu uwzględniono współpracę organów administracji w skali międzynarodowej.

Przyjmowanie aktów normatywnych w rodzaju „specustaw” bywa poddawane krytyce z uwagi na postulat zachowania spójności systemu prawa. W doktrynie prawa podnoszone są głosy, że: zasadniczo tzw. specustawy reguluja materie związane z rzeczami publicznymi, z szeroko pojętym dobrem publicznym, służacym zaspokojeniu określonych potrzeb społecznych, dobru ogólnemu, korzystaniu z rzeczy publicznej lub kwestii związanych „wokót” rzeczy publicznych. Specustawy służa osiagnięciu zaplanowanego celu publicznego w niejako skróconym, niż zwykle terminie realizacji. Tego rodzaju ustawy dotycza spraw wymagajacych regulacji odrębnej od już obowiązującej w określonym przypadku. [...] Funkcjonowanie specustaw może i jest w jakiś sposób uzasadnione, biorąc pod uwage szczególne i pilne potrzeby państwa, ale tym samym powoduja one niejako "rozregulowanie” albo "przeregulowanie" materii prawnej już obowiązujacej. Tego rodzaju akty prawne moga także zawierać nowe, nieznane dotychczas zwroty terminologiczne albo instytucje prawne, a nawet modyfikuja instytucje już znane i utrwalone. Powyższe może także sprzyjać niejasności prawa $w$ tym zakresie oraz jego niewłaściwej wykładni.

3 L. Bielecki, Rzecz publiczna w specustawie o Euro 2012 a realizacja celu publicznego $w$ świetle pytań o jakość i inflację prawa [w:] Kryzys prawa administracyjnego?, t. II, Inflacja prawa administracyjnego, red. D.R. Kijowski, P.J. Suwaj, 2012, LEX. 
Przed podjęciem decyzji o przygotowaniu ustawy o charakterze szczególnym należy zatem dokładnie przeanalizować, czy w danym wypadku jest to niezbędne, czy może jednak wystarczające jest stosowanie przepisów obowiązujących lub ewentualnie ich punktowa korekta.

W odniesieniu do projektu ustawy w sposób oczywisty nasuwa się pytanie, dlaczego do organizacji szczytu klimatycznego COP24 w 2018 r. potrzebne jest uchwalenie ustawy, podczas gdy takie konferencje organizowane w 2008 r. w Poznaniu oraz w 2013 r. w Warszawie nie zostały poprzedzone przyjęciem odrębnych aktów ustawowych.

W uzasadnieniu opiniowanego projektu ustawy stosunkowo obszernie opisano zaproponowane w nim regulacje oraz argumentowano potrzebę jej uchwalenia, wskazując, że z uwagi na rozmiar i międzynarodowy charakter konferencji COP24 oraz wyzwania związane z jej organizacją i pełnieniem funkcji prezydencji konferencji stron, do ich realizacji nie są wystarczające przepisy obecnie obowiązujących ustaw. Pełna weryfikacja tych twierdzeń wykracza poza sferę ściśle prawną, wymaga bowiem m.in. oceny tego, czy względy organizacyjne, a przede wszystkim bezpieczeństwa publicznego nie przemawiają za wprowadzeniem przepisów szczególnych.

$\mathrm{Z}$ systemowego punktu widzenia wprowadzanie regulacji szczególnych (związanych z jednorazowym wydarzeniem), określających podział zadań oraz wzajemne relacje między organami administracji rządowej, wydaje się nie mieć uzasadnienia. Wystarczające w tym obszarze powinno być wykorzystanie instrumentów prawnych będących przedmiotem obowiązujących przepisów. Chodzi tutaj zwłaszcza o ustawę z 8 sierpnia 1996 r. o Radzie Ministrów (Dz.U. 2012, poz. 392, ze zm.), która przewiduje np. możliwość ustanowienia pełnomocnika rządu do określonych spraw (art. 10), a także ustawę z 23 stycznia 2009 r. o wojewodzie i administracji rządowej w województwie (Dz.U. 2017, poz. 2234, ze zm.), która upoważnia Prezesa Rady Ministrów do kierowania działalnością wojewody (art. 8 ust. 1). Z drugiej strony włączenie do zespołu do spraw organizacji konferencji COP24 organów samorządu terytorialnego, jak również konieczność prowadzenia współpracy o charakterze międzynarodowym, mogą być przywołane jako argumenty za ustawą szczególną.

Podsumowując, należy stwierdzić, że choć nie można podważyć zasadności przyjęcia przedłożonego projektu ustawy, a regulacje tego typu (zwłaszcza przywołana wyżej ustawa z 18 marca 2016 r.) były już wprowadzane do polskiego systemu prawa, to trzeba przychylić się do postulatu, aby w przyszłości sięganie do instrumentu w postaci odrębnej ustawy na okoliczność organizacji jednego wydarzenia było wyjątkiem, a nie stawało się regułą. Utrwalenie takiej praktyki nie służy bowiem utrzymywaniu spójności systemu prawa oraz może prowadzić do erozji traktowania ustawy jako aktu o charakterze generalnym i abstrakcyjnym. 


\section{Uwagi szczegółowe}

- Wydaje się, że skorygowania wymaga tytuł ustawy, którego brzmienie zawiera niezręczne sformułowanie „w sprawie zmian klimatu w Rzeczypospolitej Polskiej”. Zmodyfikowany tytuł ustawy mógłby brzmieć następująco: „o szczególnych rozwiązaniach związanych z organizacją w Rzeczypospolitej Polskiej sesji Konferencji stron Ramowej konwencji Narodów Zjednoczonych w sprawie zmian klimatu".

- Zastanowienia wymaga, w jaki sposób organ kolegialny, jakim będzie zespół do spraw organizacji konferencji COP24, ma wykonywać zadania polegające na koordynowaniu, a zwłaszcza nadzorowaniu realizacji zadań związanych z organizacją konferencji COP24 (art. 3 ust. 1). W kontekście podejmowania decyzji przez zespół problematyczne jest zwłaszcza postanowienie art. 4 ust. 2 projektu ustawy, według którego przewodniczący zespołu może zapraszać do udziału w pracach zespołu, na prawach członka, przedstawicieli innych organów lub służb zaangażowanych w organizację konferencji COP24.

- W trakcie prac legislacyjnych wymagałoby wyjaśnienia i skorygowania sformułowanie art. 8 ust. 1 pkt 6 projektu ustawy odnoszące się do działalności Championa do spraw Działań Klimatycznych, o którym mowa w przepisach wydanych przez Konferencje Stron Konwencji klimatycznej. Odwołanie się w ten sposób do bliżej nieokreślonych przepisów stoi w sprzeczności z wymogami prawidłowej legislacji.

- Wątpliwości budzi zamieszczenie w projekcie ustawy art. 8 ust. 1 pkt 9, zgodnie z którym minister właściwy do spraw środowiska udziela wsparcia finansowego państwom niewymienionym w załączniku I do konwencji klimatycznej w ramach współpracy międzynarodowej w zakresie spraw objętych tą konwencją. Po pierwsze, kwestia ta, choć mająca merytoryczny związek z przedmiotem projektu ustawy, nie jest jednak bezpośrednio związana $\mathrm{z}$ organizacją konferencji COP24 (uwaga ta dotyczy także art. 32 projektu ustawy). Po drugie, trzeba zwrócić uwagę, że w tym obszarze ustawodawca dokonał już określonych ustaleń. Jak stanowi bowiem art. 410e ust. 1 ustawy z 27 kwietnia 2001 r. Prawo ochrony środowiska (Dz.U. 2017, poz. 519, ze zm.), środki Narodowego Funduszu Ochrony Środowiska i Gospodarki Wodnej niebędące przychodami, o których mowa w art. 401 ust. 7, oraz niebędące wpływami pochodzącymi ze sprzedaży jednostek przyznanej emisji gromadzonymi na rachunku klimatycznym, o którym mowa w art. 23 ust. 1 ustawy z 17 lipca 2009 r. o systemie zarządzania emisjami gazów cieplarnianych i innych substancji (Dz.U. 2017, poz. 568), można także przeznaczać, za zgodą ministra właściwego do spraw środowiska, na: a) udzielanie pomocy w ramach międzynarodowej współpracy na rzecz rozwoju państwom niewymienionym w załączniku I do konwencji klimatycznej); b) dokonywanie wpłat na rzecz międzynarodowych organizacji, instytucji, programów i funduszy, zapewniających funkcjonowanie mechanizmów finansowych służących realizacji celów konwencji klimatycznej. 
- Zbędną regulacją jest art. 8 ust. 4 projektu ustawy, który przewiduje, że Instytut Ochrony Środowiska - Państwowy Instytut Badawczy, na wniosek ministra właściwego do spraw środowiska, ma sporządzać określone analizy, oceny i opinie. Zgodnie bowiem z rozporządzeniem Rady Ministrów z 13 września 2010 r. w sprawie nadania Instytutowi Ochrony Środowiska w Warszawie statusu państwowego instytutu badawczego (Dz.U. nr 172, poz. 1165) nadzór nad Instytutem sprawuje minister właściwy do spraw środowiska ( $\$ 1$ ust. 3), zaś do zadań Instytutu należy także wykonywanie innych zadań zleconych przez organ nadzorujący ( $\$ 2$ pkt 6$)$.

- Zbędną regulacją jest art. 16 ust. 3 projektu ustawy, zgodnie z którym Wojewoda Śląski może, w drodze aktu prawa miejscowego, wprowadzić w czasie trwania konferencji COP24 zakaz przewozu towarów niebezpiecznych oraz ruchu pojazdów o dopuszczalnej masie całkowitej przekraczającej 12 ton na drogach na obszarze województwa śląskiego. Trzeba zauważyć, że możliwość wprowadzenia tego typu zakazów daje wojewodom obowiązujący art. 60 ust. 1 ustawy z 23 stycznia 2009 r. o wojewodzie i administracji rządowej w województwie, stanowiący, że w zakresie nieuregulowanym w przepisach powszechnie obowiązujących wojewoda może wydawać rozporządzenia porządkowe, jeżeli jest to niezbędne do ochrony życia, zdrowia lub mienia oraz do zapewnienia porządku, spokoju i bezpieczeństwa publicznego. Na podstawie tego przepisu wydano np. rozporządzenie porządkowe nr 8 Wojewody Mazowieckiego z 4 lipca 2017 r. w sprawie wprowadzenia zakazu w przewozie drogowym towarów niebezpiecznych i ruchu pojazdów nienormatywnych na terenie m.st. Warszawy. W $\$ 1$ ust 1 tego rozporządzenia określono, że w związku ze spotkaniem przywódców państw Trójmorza na terenie m.st. Warszawy, w okresie od godziny 0.00 dnia 5 lipca 2017 r. do godziny 24.00 dnia 6 lipca 2017 r., wprowadza się zakaz przewozu towarów niebezpiecznych, o których mowa w ustawie z 19 sierpnia 2011 r. o przewozie towarów niebezpiecznych (Dz.U. 2016, poz. 1834; 2016, poz. 1948 i 1954) i ruchu pojazdów nienormatywnych, o których mowa w ustawie z 20 czerwca 1997 r. Prawo o ruchu drogowym (Dz.U. 2017, poz. 1260).

- Zastrzeżenia natury konstytucyjnej nasuwa art. 22 projektu ustawy, w myśl którego zabrania się od godz. 00.00 dnia 26 listopada 2018 r. do godz. 23.59 dnia 16 grudnia 2018 r. na terenie miasta Katowice uczestniczenia w zgromadzeniach spontanicznych, o których mowa w art. 3 ust. 2 ustawy z 24 lipca 2015 r. - Prawo o zgromadzeniach (Dz.U. poz. 1485; 2017, poz. 579). Przywołany przepis ustawy - Prawo o zgromadzeniach stanowi, że zgromadzeniem spontanicznym jest zgromadzenie, które odbywa się w związku z zaistniałym nagłym i niemożliwym do wcześniejszego przewidzenia wydarzeniem związanym ze sferą publiczną, którego odbycie w innym terminie byłoby niecelowe lub mało istotne $\mathrm{z}$ punktu widzenia debaty publicznej. Natomiast w art. 57 Konstytucji RP ustalono, iż: [k]ażdemu zapewnia się wolność organizowania 
pokojowych zgromadzeń i uczestniczenia w nich. Ograniczenie tej wolności może określać ustawa. Z kolei w art. 31 ust. 3 Konstytucji RP jest mowa o tym, że: [o]graniczenia $w$ zakresie korzystania $z$ konstytucyjnych wolności i praw moga być ustanawiane tylko w ustawie i tylko wtedy, gdy sa konieczne w demokratycznym państwie dla jego bezpieczeństwa lub porządku publicznego, bądź dla ochrony środowiska, zdrowia i moralności publicznej, albo wolności i praw innych osób. Ograniczenia te nie moga naruszać istoty wolności i praw.

Wprowadzenie $\mathrm{w}$ art. 22 projektowanej ustawy arbitralnego zakazu uczestniczenia w zgromadzeniach spontanicznych może zostać uznane za ograniczenie naruszające istotę prawa uczestniczenia w zgromadzeniach. Wprawdzie nie zostaje ograniczona możliwość zorganizowania i odbycia zgromadzenia (w rozumieniu art. 3 ust. 1 ustawy - Prawo o zgromadzeniach), jednakże w świetle orzecznictwa Trybunału Konstytucyjnego wydaje się to niewystarczającym argumentem za czasowym wykluczeniem drugiego rodzaju zgromadzenia, jakim jest zgromadzenie spontaniczne. W wyroku z 18 września 2014 r. w sprawie o sygn. akt K 44/12 Trybunał Konstytucyjny stwierdził, że: [z]gromadzenia spontaniczne obejmuja natomiast zgrupowania, które nie były wcześniej planowane $i$ przygotowywane. Sa one organizowane $w$ zwiazku $z$ jednorazowym, nagtym, a często też nieprzewidzianym wydarzeniem $w$ przestrzeni publicznej. $Z$ wydarzeniem tym wiąże się szybka reakcja określonej grupy osób chcacych przedstawić swoje stanowisko, wyrazić poparcie lub dezaprobatę, czy też wspólnie odnieść się do konkretnej sytuacji. Istotą tej formy jest możliwość gromadzenia się określonej grupy osób w ściśle wyznaczonym momencie, a niekiedy również i miejscu. Odbycie się zgromadzeń spontanicznych $w$ innym terminie byłoby nieistotne $z$ punktu widzenia ich celu, a więc zaprezentowania określonego stanowiska $w$ konkretnej sprawie. Gwarancje wolności zgromadzeń wynikajace $z$ art. 57 Konstytucji dotycza wszelkich form pokojowego zgromadzania się osób. Obejmuja one zatem zarówno zgromadzenia uprzednio zorganizowane i notyfikowane, jak i spontaniczne, stanowiace odpowiedź na bieżące wydarzenia w przestrzeni publicznej. Organy władzy publicznej powinny zapewnić warunki realizacji wolności pokojowego zgromadzania się niezależnie od tego, w jakiej formie jednostki chca z niej korzystać. Nie ma zatem podstaw, aby na gruncie art. 57 Konstytucji różnicować zgromadzenia z punktu widzenia zakresu ich ochrony, stosujac kryterium sposobu organizacji danego zgrupowania osób. Możliwość organizowania zgromadzeń spontanicznych ma swoje źródło $w$ art. 57 Konstytucji, a przy tym dotyczy istoty wolności wyrażonej w tym przepisie konstytucyjnym. Do przywołanego fragmentu wyroku TK nawiązał również w wyroku z 16 marca 2017 r. w sprawie o sygn. akt Kp 1/17.

W świetle powyższego należy uznać, że art. 22 projektu ustawy może zostać uznany za niezgodny $\mathrm{z}$ art. 57 Konstytucji RP z powodu naruszenia istoty prawa uczestniczenia w zgromadzeniach. 


\section{Ocena zgodności projektu ustawy z prawem Unii Europejskiej}

Przedmiot regulacji projektu ustawy jest w zasadniczej części nieobjęty zakresem prawa Unii Europejskiej, jednakże z uwagi na niektóre z proponowanych przepisów trzeba wziąć pod uwagę:

- dyrektywę Parlamentu Europejskiego i Rady 2016/680 z 27 kwietnia 2016 r. w sprawie ochrony osób fizycznych w związku z przetwarzaniem danych osobowych przez właściwe organy do celów zapobiegania przestępczości, prowadzenia postępowań przygotowawczych, wykrywania i ścigania czynów zabronionych i wykonywania kar, w sprawie swobodnego przepływu takich danych oraz uchylającej decyzję ramową Rady 2008/977/WSiSW (Dz.Urz. UE L 119 z 4 maja 2016 r., s. 89; dalej: dyrektywa 2016/680),

- dyrektywę 2014/24/UE Parlamentu Europejskiego i Rady z 26 lutego 2014 r. w sprawie zamówień publicznych, uchylającą dyrektywę 2004/18/WE (Dz.Urz. UE L 94 z 28 marca 2014 r., s. 65; dalej: dyrektywa 2014/24/UE).

1. Dyrektywa 2016/680 ustanawia przepisy o ochronie osób fizycznych w związku z przetwarzaniem danych osobowych przez właściwe organy do celów zapobiegania przestępczości, prowadzenia postępowań przygotowawczych, wykrywania i ścigania czynów zabronionych i wykonywania kar, w tym ochrony przed zagrożeniami dla bezpieczeństwa publicznego i zapobiegania takim zagrożeniom (art. 1 ust. 1). Jednocześnie w jej art. 2 ust. 3 przewiduje się, że nie znajduje ona zastosowania do przetwarzania danych osobowych w ramach działalności nieobjętej zakresem prawa Unii.

Na kanwie przywołanej dyrektywy 2016/680 powstają wątpliwości, czy odnosi się ona jedynie do działań określonych w jej art. 1 ust. 1, które są podejmowane przez państwa członkowskie w dziedzinie współpracy policyjnej, czy w pewnym stopniu może także objąć przetwarzanie przez służby danych na szczeblu tylko krajowym ${ }^{4}$. W związku z tym, że nie można w zupełności wykluczyć żadnej z tych możliwości, projekt ustawy powinien być oceniony pod kątem zgodności z dyrektywą 2016/680.

Zgodnie z art. 3 pkt 2 dyrektywy 2016/680 „przetwarzanie” oznacza operację lub zestaw operacji wykonywanych na danych osobowych lub zestawach danych osobowych w sposób zautomatyzowany lub niezautomatyzowany, takich jak zbieranie, utrwalanie, organizowanie, porządkowanie, przechowywanie, adaptowanie lub modyfikowanie, pobieranie, przeglądanie, wykorzystywanie, ujawnianie poprzez przesłanie, rozpowszechnianie lub innego rodzaju udostępnianie, dopasowywanie lub łączenie, ograniczanie, usuwanie lub niszczenie. Artykuł 13

4 Zob. opinia Biura Analiz Sejmowych z 8 marca 2017 r. w sprawie zgodności z prawem Unii Europejskiej poselskiego projektu ustawy o zmianie ustawy o Policji oraz niektórych innych ustaw, BAS-WAPEiM 404/17 (druk sejmowy nr 1373). 
dyrektywy 2016/680 określa zakres prawa do informacji osoby, której dane podlegają przetwarzaniu. Informacje, o których mowa w ust. 1 tego artykułu, mają charakter ogólny i mogą zostać udostępnione np. na stronie internetowej właściwego organu (motyw 42 dyrektywy 2016/680). Artykuł 13 ust. 2 przewiduje natomiast obowiązki informacyjne w konkretnych przypadkach. Poinformowanie osoby w konkretnych przypadkach może jednak zostać opóźnione, ograniczone lub wykluczone $\mathrm{w}$ takim zakresie i przez taki czas, w jakim odnośny środek jest działaniem koniecznym i proporcjonalnym $\mathrm{w}$ społeczeństwie demokratycznym, $\mathrm{z}$ należytym uwzględnieniem praw podstawowych i uzasadnionych interesów danej osoby fizycznej, aby m.in. uniemożliwić utrudnianie czynności postępowań urzędowych lub sądowych, postępowań przygotowawczych lub procedur, jak również aby uniemożliwić zakłócanie zapobiegania przestępczości, prowadzenia postępowań przygotowawczych, wykrywania i ścigania czynów zabronionych i wykonywania kar, a także aby chronić bezpieczeństwo publiczne oraz bezpieczeństwo narodowe (art. 13 ust. 3).

Zgodnie $\mathrm{z}$ art. 17 ust. 1 projektu ustawy $\mathrm{w}$ celu zapewnienia bezpieczeństwa i porządku publicznego podczas konferencji COP24, a także w celu zapobieżenia popełnianiu przestępstw i wykroczeń oraz wykrywania i ścigania ich sprawców, Policja może pobierać, uzyskiwać, gromadzić, sprawdzać, przetwarzać i wykorzystywać informacje, $w$ tym dane osobowe w zakresie określonym w tym przepisie, także bez wiedzy i zgody osób, których dotyczą te dane, w terminie do dnia 31 stycznia 2019 r. Informacje te przetwarza się przez okres niezbędny do realizacji zadań Policji wynikających z projektowanej ustawy, nie dłużej jednak niż do dnia 31 marca 2019 r. (art. 19 ust. 1 projektu ustawy).

Proponowane przepisy projektu ustawy można w świetle art. 13 ust. 3 dyrektywy 2016/680 uznać za zgodne z tą dyrektywą.

2. W myśl art. 25 ust. 1 projektu ustawy do zamówień na dostawy, usługi lub roboty budowlane, realizowanych w związku z organizacją konferencji COP24 oraz pełnieniem przez Rzeczpospolitą Polską funkcji prezydencji konferencji stron, nie stosuje się przepisów ustawy z 29 stycznia 2004 r. - Prawo zamówień publicznych (Dz.U. 2017, poz. 1579, ze zm.; dalej: u.p.z.p.), jeżeli: a) realizacja zamówienia wymaga zapewnienia bezpieczeństwa uczestnikom konferencji COP24 lub bezpieczeństwa publicznego przez podmioty realizujące to zamówienie lub b) wartość zamówienia jest mniejsza niż kwoty określone w przepisach wydanych na podstawie art. 11 ust. 8 u.p.z.p.

Ustawa - Prawo zamówień publicznych jest aktem, który wdraża do polskiego systemu prawa postanowienia dyrektywy 2014/24/UE, wobec czego należy zweryfikować, czy przytoczony przepis projektu ustawy można uznać za dopuszczalny w świetle tej dyrektywy5.

5 Zob. opinia Ministra Spraw Zagranicznych z 9 marca 2016 r. o zgodności z prawem Unii Europejskiej rządowego projektu ustawy o szczególnych rozwiązaniach związa- 
Zgodnie z art. 4 pkt 5 u.p.z.p. nie stosuje się do: zamówień lub konkursów: [...] b) jeżeli wymaga tego istotny interes bezpieczeństwa państwa, lub c) jeżeli wymaga tego ochrona bezpieczeństwa publicznego, lub d) którym musza towarzyszyć, na podstawie odrębnych przepisów, szczególne środki bezpieczeństwa - w zakresie, $w$ jakim ochrona istotnych interesów dotyczacych bezpieczeństwa państwa określonych $w$ lit. a-d nie może zostać zagwarantowana $w$ inny sposób niż udzielenie zamówienia bez zastosowania ustawy - Prawo zamówień publicznych.

Zgodnie $z$ art. 11 ust. 8 u.p.z.p. minister właściwy do spraw gospodarki określa, w drodze rozporządzenia, kwoty wartości zamówień oraz konkursów, od których jest uzależniony obowiązek przekazywania ogłoszeń Urzędowi Publikacji Unii Europejskiej, mając na względzie obowiązujące w tym zakresie przepisy prawa Unii Europejskiej. Na podstawie tego przepisu zostało wydane rozporządzenie Prezesa Rady Ministrów z 28 grudnia 2015 r. w sprawie kwot wartości zamówień oraz konkursów, od których jest uzależniony obowiązek przekazywania ogłoszeń Urzędowi Publikacji Unii Europejskiej (Dz.U. 2017, poz. 1880).

Jednocześnie należy podkreślić, że także zamówienia publiczne, których wartość zamówienia jest mniejsza niż kwoty określone w przepisach wydanych na podstawie art. 11 ust. 8 u.p.z.p., muszą być przeprowadzane zgodnie z zasadami wynikającymi z unijnych traktatów, w tym zasadami niedyskryminacji, równego traktowania, przejrzystości i proporcjonalności ${ }^{6}$.

W świetle przywołanych przepisów należy uznać, że projekt ustawy nie jest sprzeczny z dyrektywą 2014/24/UE.

\section{Wnioski}

- Potrzeba uchwalenia proponowanej ustawy o charakterze szczególnym jest w pewnej mierze uzasadniona, z zastrzeżeniem zachowania ostrożności przy wprowadzaniu odrębnych regulacji ustawowych z powodu organizacji jednorazowych wydarzeń.

- W trakcie dalszych prac legislacyjnych należałoby odnieść się do uwag podniesionych w podrozdziale Ocena zgodności projektu ustawy z prawem polskim niniejszej opinii. Wiążą się one przede wszystkim z koniecznością doprecyzowania niektórych przepisów lub usunięcia zbędnych regulacji. Zasadnicze znaczenie ma natomiast zastrzeżenie dotyczące art. 22 projektu ustawy, który

nych z organizacją Szczytu Organizacji Traktatu Północnoatlantyckiego w Rzeczypospolitej Polskiej w Warszawie w 2016 roku (druk sejmowy nr 515).

6 Zob. Komunikat wyjaśniający Komisji dotyczący prawa wspólnotowego obowiązującego w dziedzinie udzielania zamówień, które nie są lub są jedynie częściowo objęte dyrektywami w sprawie zamówień publicznych (2006/C 179/02), Dz.Urz. UE C 179 z 1 sierpnia 2006 r., s. 2. 
może zostać uznany za niezgodny z art. 57 Konstytucji RP z powodu ograniczenia naruszającego istotę prawa uczestniczenia w zgromadzeniach.

- Projekt ustawy obejmuje głównie materię nieobjętą prawem Unii Europejskiej, zaś w zakresie opisanym w podrozdziale Ocena zgodności projektu ustawy z prawem Unii Europejskiej niniejszej opinii może zostać uznany za zgodny z tym prawem.

\section{Bibliografia}

Bielecki L., Rzecz publiczna w specustawie o Euro 2012 a realizacja celu publicznego $w$ świetle pytań o jakość i inflacje prawa [w:] Kryzys prawa administracyjnego?, t. II, Inflacja prawa administracyjnego, red. D.R. Kijowski, P.J. Suwaj, 2012, LEX. 


\section{Przekroczenie granic obrony koniecznej - w sprawie propozycji nowelizacji art. 25 Kodeksu karnego ${ }^{1}$}

Exceeding the boundaries of necessary defense - regarding the petition concerning amendment of Article 25 of the Criminal Code: The author of the petition postulates the introduction of Article 25 para. 3a of the Criminal Code, in which the privilege of impunity for a person crossing the borders of necessary defense in a situation of defense against an unlawful, direct assault directed at legal rights set out in that regulation, would be guaranteed. It is concluded in the opinion that a more appropriate solution would be to link the non-subject to punishment of persons crossing the boundaries of the necessary defense with a more universal and capacious formula of "justifying the crossing of the limits of necessary defense by the circumstances accompanying the attack."Thus the petition does not seem to be justified. The mere fact that a person crossing the boundaries of defense necessary would not be subject of the penalty only due to the fact that he/she acts in defense of certain legal rights, made in isolation from other important elements of the incident, reduces the assessment of his/her behavior and may lead to mandatory release from penalties in socially unacceptable cases.

Keywords: Criminal Code | petition | necessary defense

Słowa kluczowe: Kodeks karny | petycja | obrona konieczna

Asystent w Instytucie Wymiaru Sprawiedliwości, ekspert ds. legislacji BAS; pawel.bachmat@sejm.gov.pl.

\section{Treść i cel petycji}

Przedmiotem petycji jest żądanie podjęcia inicjatywy ustawodawczej w zakresie nowelizacji art. $25 \$ 1-3$ ustawy z 6 czerwca 1997 r. - Kodeks karny (t.j. Dz.U. 2016, poz. 1137, ze zm.; dalej: k.k. lub Kodeks karny), w którym ustawodawca określił granice oraz prawne konsekwencje działania w ramach obrony koniecznej, jak również z przekroczeniem granic tego kontratypu. Stosownie do obowiązującego brzmienia art. 25 k.k.: $\$ 1$. Nie popetnia przestępstwa, kto w obronie koniecznej

1 Opinia w sprawie nowelizacji art. 25 Kodeksu karnego (przekroczenie granic obrony koniecznej) sporządzona 19 września 2017 r. na zlecenie przewodniczącego Komisji ds. Petycji; BAS-WAP 871/17. 
odpiera bezpośredni, bezprawny zamach na jakiekolwiek dobro chronione prawem. $\$ 2$. W razie przekroczenia granic obrony koniecznej, w szczególności gdy sprawca zastosowat sposób obrony niewspótmierny do niebezpieczeństwa zamachu, sąd może zastosować nadzwyczajne złagodzenie kary, a nawet odstąić od jej wymierzenia. \$3. Nie podlega karze, kto przekracza granice obrony koniecznej pod wplywem strachu lub wzburzenia usprawiedliwionych okolicznościami zamachu.

Autor petycji postuluje wprowadzenie dodatkowego przepisu art. $25 \$ 3$ a k.k., w którym zagwarantowany zostałby przywilej bezkarności osoby przekraczającej granice obrony koniecznej w sytuacji obrony przed bezprawnym, bezpośrednim zamachem skierowanym na wymienione $\mathrm{w}$ tym uregulowaniu dobra prawne człowieka. Artykuł $25 \$ 3$ a k.k. w zaproponowanym brzmieniu przybrałby następującą postać redakcyjną: Nie podlega karze ten, kto przekracza granice obrony koniecznej, jeżeli dobrem zagrożonym zamachem jest bezpieczeństwo powszechne, $\dot{z} y c i e$, zdrowie, wolność, wolność seksualna, lub mienie, gdy zamach na mienie połączony jest $z$ użyciem przemocy lub wdarciem się do cudzego domu, mieszkania, lokalu, pomieszczenia lub ogrodzonego terenu.

W uzasadnieniu wskazano m.in., że celem nowelizacji jest przesunięcie akcentu ze sfery emocjonalnej osoby odpierającej zamach na zobiektywizowany przedmiot zamachu. W przypadku zaproponowanej zmiany przełożyć się to ma na uwolnienie organów ścigania od konieczności ustalania stanu emocjonalnego osoby odpierającej zamach na gruncie niedookreślonych pojęć strachu i wzburzenia. Wedle przekonania wyrażonego przez autora petycji organy prowadzące postępowanie będą mogły wziąć pod uwagę jedynie fakt, czy zamach był bezprawny i czy godził $\mathrm{w}$ wyliczone w postulowanym art. $25 \$ 3 \mathrm{a}$ k.k. dobra prawne, a przy zamachu na mienie także, czy atak nastąpił w sposób i miejscu określonym $w$ tym przepisie.

Nowelizacja ma służyć osiągnięciu prewencji ogólnej. W ocenie składającego petycję jest ukierunkowana na osiągnięcie stanu, w którym napastnik będzie zmuszony liczyć się z prawem każdego obywatela do powstrzymania zamachu bez względu na wystąpienie strachu lub wzburzenia usprawiedliwionego okolicznościami zamachu. W następstwie zachęci to obywateli do przeciwdziałania aktom przemocy ze strony napastników - bez obawy przed poniesieniem z tego tytułu odpowiedzialności karnej.

\section{Czy petycja mieści się w zakresie zadań i kompetencji adresata petycji (art. 2 ust. 3 ustawy o petycjach)?}

Petycja dotyczy zmiany ustawy przez Sejm. Zgodnie z art. 95 ust. 1 Konstytucji RP władzę ustawodawczą w Rzeczypospolitej Polskiej sprawują Sejm i Senat. Natomiast stosownie do art. 118 ust. 1 Konstytucji RP inicjatywa ustawodawcza przysługuje m.in. posłom. Artykuł 32 ust. 2 regulaminu Sejmu, w związku 
Z art. 112 Konstytucji RP, precyzuje, że poselskie projekty ustaw mogą być wnoszone przez komisje sejmowe lub grupę co najmniej 15 posłów podpisujących projekt.

Uwzględniając powyższe, należy uznać, że petycja mieści się w zakresie zadań i kompetencji Sejmu.

\section{Wymogi formalne (art. 4 ust. 1 i 2 oraz ustawy o petycjach)}

Złożona petycja spełnia wymogi formalne określone w art. 4 ust. 1 i 2 ustawy z 11 lipca 2014 r. o petycjach (t.j. Dz.U. 2017, poz. 1123) - zawiera oznaczenie podmiotu wnoszącego petycję, wskazuje jego miejsce zamieszkania, adresata petycji oraz jej przedmiot.

\section{Kwestie, które ekspert uznaje za istotne w związku z petycją}

\section{Podstawowe informacje na temat instytucji obrony koniecznej}

Instytucja obrony koniecznej ma na celu nie tylko ochronę dobra bezprawnie i bezpośrednio zaatakowanego, ale również kształtowanie zasady, że prawo nie powinno ustępować przed bezprawiem ${ }^{2}$. Ten trafny pogląd Sądu Najwyższego, choć wyrażony na gruncie kodyfikacji karnej z 1969 r., zachowuje w pełni aktualność pod rządami obowiązującego Kodeksu karnego.

Obrona konieczna jest instytucją mającą ugruntowaną tradycję w polskim systemie prawa. Jako okoliczność wyłączającą bezprawność czynu zabronionego, a co za tym idzie jego przestępność, znały ją poprzednie kodyfikacje karne z lat $1932^{3}$ i $1969^{4}$. Zasadność jej obowiązywania nie budziła wątpliwości. Do tej tradycji nawiązał ustawodawca, wprowadzając obronę konieczną do obowiązującego Kodeksu karnego. Jest ona także uregulowana w Kodeksie cywilnym (art. 343 $\$ 1$, art. 423) $)^{5}$.

W prawie karnym przyjmuje się, że obrona konieczna należy do kategorii tzw. kontratypów. Według twórcy pojęcia kontratypu W. Woltera: [p]rzez kontratypy rozumiemy te i tylko te okoliczności, które, mimo że czyn wykazuje ustawowe znamiona czynu zabronionego przez ustawę pod groźba kary, jednak powoduja, że nie jest społecznie szkodliwy (ew. jest dodatni), a tym samym bezprawny; sa to więc oko-

2 Wyrok SN z 27 lipca 1973 r., sygn. akt IV KR 153/73, OSNKW 1974, nr 1, poz. 5, z glosą M. Szerera, OSPiKA 1974, nr 12, poz. 262,

3 Rozporządzenie Prezydenta Rzeczypospolitej z 11 lipca 1932 r. - Kodeks karny, Dz.U. nr 60, poz. 571, ze zm.

4 Ustawa z 19 kwietnia 1969 r. - Kodeks karny, Dz.U. nr 13, poz. 94, ze zm.

5 Ustawa z 23 kwietnia 1964 r. - Kodeks cywilny, t.j. Dz.U. 2017, poz. 459, ze zm. 
liczności legalizujące czyn, generalnie uznany za bezprawny ${ }^{6}$. Za ratio wszystkich kontratypów przyjmuje się wystąpienie kolizji dóbr, której nie można rozwiązać bez poświęcenia dobra mającego wartość społeczną przy założeniu, że uda się wykazać społeczną opłacalność poświęcenia określonego dobra dla ratowania innego 7 .

Zgodnie $\mathrm{z}$ art. $25 \$ 1$ i 2 k.k. obrona konieczna polega na odpieraniu bezpośredniego, bezprawnego zamachu (niektórzy autorzy dodają jeszcze wymóg, aby zamach był rzeczywisty ${ }^{8}$, skierowanego na jakiekolwiek dobro prawne, przy zachowaniu sposobu obrony współmiernego do niebezpieczeństwa zamachu. Faktycznym rezultatem obrony koniecznej jest poświęcenie dobra napastnika, które może zostać naruszone lub nawet zniweczone. Konsekwencją prawnomaterialną jest przyjęcie, że broniący się naruszył dobro prawne napastnika (realizując przy tym ustawowe znamiona typu czynu zabronionego), działając w sposób legalny. Innymi słowy, jego zachowanie nie było bezprawne, a zatem nie popełnił przestępstwa (zob. art. $25 \$ 1$ k.k., który rozpoczyna się od słów: Nie popetnia przestępstwa...). Konsekwencją formalnoprawną (procesową) będzie z kolei w takim wypadku: wyrok uniewinniający lub - na etapie postępowania przygotowawczego - umorzenie albo odmowa wszczęcia postępowania.

Sytuacją graniczącą z obroną konieczną jest działanie w warunkach przekroczenia granic obrony koniecznej. Od strony stanu faktycznego są to niejednokrotnie sytuacje bardzo zbliżone. Diametralnie odmienna jest jednak prawna ocena zachowania broniącego się z przekroczeniem granic obrony koniecznej, któremu przypisuje się działanie bezprawne, co może pociągać za sobą jego odpowiedzialność karną (gdy broniącemu się z przekroczeniem granic obrony koniecznej można dodatkowo przypisać winę oraz uznać, że jego zachowanie było społecznie szkodliwe w stopniu wyższym niż znikomy).

Przekroczenie granic obrony koniecznej może przybrać postać ekscesu intensywnego, kiedy zastosowano sposób obrony niewspółmierny do niebezpieczeństwa zamachu lub też ekscesu ekstensywnego, który zachodzi w dwojakiej sytuacji: obrony przedwczesnej - defensio antecedens, gdy zamach nie wszedł jeszcze w fazę bezpośredniości, lub też spóźnionej - defensio subsequens, gdy bezpośrednie zagrożenie zamachem już ustało". Jak wspomniano wyżej, konsekwencją przekroczenia granic obrony koniecznej jest bezprawność zachowania broniącego się, co może implikować jego odpowiedzialność karną. Sąd może jednak takiego sprawcę potraktować ulgowo, stosując - zgodnie z art. $25 \$ 2$ k.k. nadzwyczajne złagodzenie kary, a nawet odstąpienie od jej wymierzenia.

6 W. Wolter, Nauka o przestępstwie. Analiza prawnicza na podstawie części ogólnej kodeksu karnego z 1969 r., Warszawa 1973, s. 163.

7 A. Zoll, Okoliczności wyłączające bezprawność czynu. Zagadnienia ogólne, Warszawa 1982, s. 104.

8 M. Mozgawa, Komentarz aktualizowany do art. 25 Kodeksu karnego [w:] Kodeks karny. Komentarz aktualizowany, red. M. Mozgawa i in., 2017, LEX nr 534269.

9 M. Mozgawa, Komentarz aktualizowany do art. 25 Kodeksu karnego, op. cit. 
Z kolei na podstawie art. $25 \$ 3 \mathrm{k} . \mathrm{k}$. przekraczający granice obrony koniecznej (ustawodawca nie czyni tu rozróżnienia na eksces intensywny i ekstensywny) nie podlega karze, o ile działa pod wpływem strachu lub wzburzenia usprawiedliwionych okolicznościami zamachu. Przepis ten - z uwagi na liczne odwołania do niego, poczynione w treści petycji - wymaga szerszego omówienia.

Konsekwencja ekscesu wywołanego okolicznościami wskazanymi w art. 25 $\$ 3$ k.k. pierwotnie ujęta była mniej korzystnie dla występującego w obronie, jako obligatoryjne odstąpienie od wymierzenia kary. Ustawą z 5 listopada 2009 r. nowelizującą Kodeks karny (Dz.U. nr 206, poz. 1589, ze zm.), która weszła w życie z dniem 8 czerwca 2010 r., przepisowi temu - wychodząc naprzeciw postulatom doktryny i judykatury - nadano obecne brzmienie. Zmiana, polegająca na zastąpieniu „odstąpienia od wymierzenia kary” klauzulą „niepodlegania karze”, nie jest tylko zmianą redakcyjną, niesie ze sobą bardzo istotne konsekwencje czysto procesowe i prawnomaterialne.

$\mathrm{Z}$ procesowego punktu widzenia przypadki, w których ustawa stanowi, że sprawca nie podlega karze, prowadzą do prawnej niedopuszczalności postępowania karnego. Dlatego niepodleganie karze zaliczane jest do tzw. ujemnych przesłanek procesowych ${ }^{10}$. Stosownie do art. $17 \$ 1$ pkt 4 Kodeksu postępowania karnego ${ }^{11}$ zaistnienie ujemnej przesłanki procesowej przekłada się na obowiązek organu procesowego niewszczynania postępowania albo umorzenia postępowania już wszczętego. Ponieważ postępowanie karne nie może toczyć się bez ustalenia warunków jego dopuszczalności, organy prowadzące postępowanie zobligowane są na każdym etapie badać w pierwszej kolejności, czy postępowanie może się toczyć, a w razie stwierdzenia okoliczności wyłączającej postępowanie - podjąć w tym zakresie odpowiednią decyzję procesową ${ }^{12}$. Ustalenie niedopuszczalności postępowania $\mathrm{z}$ uwagi na przypadek niepodlegania karze, które miałoby miejsce jeszcze przed formalnym rozpoczęciem postępowania przygotowawczego (w drodze wydania postanowienia o wszczęciu śledztwa lub dochodzenia), prowadzić powinno do wydania postanowienia o odmowie jego wszczęcia. Późniejsze stwierdzenie zaistnienia tej okoliczności skutkuje natomiast: na etapie postępowania przygotowawczego - umorzeniem postępowania, zaś po rozpoczęciu przewodu sądowego - wydaniem wyroku umarzającego (art. $414 \$ 1$ k.p.k.).

$\mathrm{Na}$ gruncie procedury karnej niepodleganie karze z mocy ustawy (art. $17 \S 1$ pkt 4 k.p.k.) zaliczane jest także do tzw. materialnych przesłanek procesowych, podobnie jak niepopełnienie czynu, brak ustawowych znamion czynu zabronio-

10 M. Cieślak, O przesłankach procesowych w polskim postępowaniu karnym (podstawowe założenia i procesy metodologiczne), „Państwo i Prawo” 1969, z. 12, s. 953.

11 Ustawa z 6 czerwca 1997 r. - Kodeks postępowania karnego, t.j. Dz.U. 2016, poz. 1749, ze zm.; dalej: k.p.k.

12 Z. Gostyński, S. Zabłocki, Dział I. Przepisy wstępne [w:] J. Bratoszewski i in., Kodeks postępowania karnego. Komentarz, t. I, Warszawa 2003, s. 299. 
nego w zachowaniu sprawcy, wyłączenie przestępności czynu z mocy ustawy czy znikoma społeczna szkodliwość czynu (art. $17 \$ 1$ pkt 1, 2 i 3 k.p.k.). Wynika $\mathrm{z}$ tego, że znaczenie tej instytucji wykracza poza ramy prawa procesowego, gdzie postrzegana jest jako negatywny warunek dopuszczalności postępowania karnego. Niepodleganie karze stanowi jednocześnie negatywny warunek odpowiedzialności karnej w obszarze prawa materialnego ${ }^{13}$. Klauzulę bezkarności należy uznać za okoliczność uchylającą odpowiedzialność karną, gdyż prowadzi ona do zerwania normatywnego związku między przestępstwem a karą - związku, który jest konieczny dla pociągnięcia sprawcy do odpowiedzialności karnej ${ }^{14}$.

Sprawca nie ponosi odpowiedzialności karnej z powodu uchylenia przez ustawę karalności czynu, ale nie jego przestępności. Czyn sprawcy - ekscedenta nadal jest przestępstwem, jest bezprawny, zawiniony i w pewnym stopniu społecznie szkodliwy i tylko z uwagi na decyzję ustawodawcy pozostaje bezkarny. Wskazuje się przy tym, że w stwierdzeniu, iż sprawca nie podlega karze, zawarty jest mimo wszystko pewien element ujemnej oceny czynu, klauzula ta nie oznacza całkowitego jego usprawiedliwienia ${ }^{15}$.

Przepis art. $25 \$ 3 \mathrm{k} . \mathrm{k}$. spotkał się z niejednolitym odbiorem w doktrynie prawa karnego. Głosy aprobujące wskazują, że zmierza on do satysfakcjonującego społecznie rozwiązywania sytuacji konfliktowych, w których nastąpiło wprawdzie przekroczenie granic obrony koniecznej (a tym samym - popełnienie przestępstwa), ale sprawca ekscesu mimo to nie zasługuje na ukaranie ${ }^{16}$. Podkreśla się również, że w ten sposób uniknie się zbędnych procesów sądowych (a co za tym idzie - kosztów postępowania), jak również zaoszczędzi się ekscedentowi często niemiłych przeżyć związanych ze swoistą stygmatyzacją, wynikającą ze skierowania przeciwko niemu aktu oskarżenia i toczącego się procesu ${ }^{17}$. Głosy sceptyczne koncentrują się na różnorodnych aspektach tego uregulowania. I tak np. kwestionuje się zasadność posłużenia się formułą „nie podlega karze” w odniesieniu do sytuacji, o której mowa w art. $25 \$ 3$ k.k. Podnosi się, nie bez racji, że ocena zaistnienia przesłanek zastosowania tego przepisu - z uwagi na kwestie ustalania zawinienia - powinna być domeną sądu, a nie organów ścigania ${ }^{18}$. Nadto wskazuje się, że sytuacja, której dotyczy art. $25 \$ 3$ k.k., nie powinna być okolicznością wyłączającą karalność przestępstwa, lecz okolicznością wyłączają-

$13 \quad$ Ibidem, s. 298.

14 D. Gajdus, Czynny żal w polskim prawie karnym, Torun 1984, s. 181; K. Buchała, Prawo karne, Warszawa 1980, s. 608; A. Wąsek, Wspótsprawstwo w polskim prawie karnym, Warszawa 1977, s. 73.

15 L. Gardocki, Prawo karne, Warszawa 1998, s. 170.

16 J. Giezek, Komentarz do art. 25 Kodeksu karnego [w:] Kodeks karny. Część ogólna. Komentarz, red. J. Giezek, N. Kłączyńska, G. Łabuda, 2012, LEX nr 125523.

17 M. Mozgawa, Komentarz aktualizowany do art. 25 Kodeksu karnego, op. cit.

18 W. Wróbel, Opinia z 28 stycznia 2009 r. o zmianie ustawy - Kodeks karny i zmianie innych ustaw, druk sejmowy nr 1394/VI kad. 
cą przestępność czynu (z uwagi na brak winy) ${ }^{19}$. Inni autorzy podnoszą z kolei, że: nie przeżycia psychiczne ofiary zamachu, ale okoliczności zamachu sprawcy winny decydować o uznaniu przekroczenia granic obrony koniecznej za usprawiedliwione $^{20}$. Podnosi się także argument, że art. $25 \$ 3$ k.k.: zawiera swoista dyskryminację ludzi odpierających bezpośredni zamach przestępczy, którzy należą do kategorii osób bardzo odważnych i opanowanych. Dążac do realizacji skutecznej obrony, przekraczaja jednak jej granice ${ }^{21}$. Dlaczego: nie mieliby korzystać z obligatoryjnego odstapienia od wymierzenia kary? Dlatego, że nie bali się napastnika i bronili się bez wzburzenia? ${ }^{22}$.

Stawia się także pytanie: czy w jakiejkolwiek sytuacji możliwe jest stwierdzenie (udowodnienie), że przekroczenie granic obrony koniecznej nie zostało wywołane strachem lub wzburzeniem usprawiedliwionymi okolicznościami zamachu? Działającemu w obronie koniecznej także wówczas, gdy przekracza on jej granice, towarzysza emocje o wyraźnym zabarwieniu negatywnym, które $z$ natury rzeczy wywoływane sa przez sytuację zagrożenia. Można tutaj wymienić cała gamę uczuć, takich jak: strach, lęk, przerażenie, oburzenie, gniew, wściekłość itp. W zdecydowanej większości przypadków pojawiającym się uczuciem jest oczywiście strach. Własnymi siłami trzeba bowiem odeprzeć bezpośredni i bezprawny zamach zagrażajacy jakiemuś dobru chronionemu prawem (np. życiu, zdrowiu lub chociażby "tylko" mieniu), mając przy tym często do czynienia z profesjonalnie działającym napastnikiem. Gdyby jednak nawet uznać, że jest taka grupa przypadków, w których broniącemu się uczucie strachu nie towarzyszy (co, teoretycznie rzecz biorąc, jest oczywiście możliwe), to przecież zawsze będzie mógł on powołać się na wzburzenie (faktycznie występujące lub ex post jedynie deklarowane). Trudno zaś byłoby zaakceptować poglad, że okoliczności bezprawnego przecież zamachu $w$ jakiejkolwiek sytuacji mogłyby wzburzenia nie czynić zrozumiałym $i$ dającym się uzasadnić, zwłaszcza gdy mowa jedynie o jakości tego uczucia, nie zaś o jego natężeniu ${ }^{23}$.

\section{Ocena propozycji zgłoszonej w petycji}

Opiniowana propozycja zmian w zakresie przepisów Kodeksu karnego regulujących odpowiedzialność osoby przekraczającej granice obrony koniecznej dotyka niesłychanie istotnej społecznie kwestii sprawiedliwego potraktowania osoby, która, stając w obliczu bezprawnego zamachu, sama jest zmuszona

19 A. Zoll, Komentarz do art. 25 Kodeksu karnego [w:] Kodeks karny. Część ogólna, t. I, cz. I, Komentarz do art. 1-52, 2016, red. W. Wróbel, A. Zoll, LEX nr 510491, nb. 75. K. Daszkiewicz, Kodeks karny z 1997 roku. Uwagi krytyczne, Gdańsk 2001, s. 104 (rozdział Przekroczenie granic obrony koniecznej. Propozycja nowego ujęcia $\$ 3$ art. 25 k.k. O koniecznej obronie idei prawa. Błędne stosowanie przepisów o obronie koniecznej).

${ }^{21}$ Ibidem.

22 Ibidem.

23 J. Giezek, Komentarz do art. 25 Kodeksu karnego, op. cit., nb. 31. 
podjąć obronę lub decyduje się przyjść z pomocą innej osobie, i przy tej okazji wykracza poza granice przewidziane dla działań obronnych w przepisach prawa karnego. Sprawa jest tym bardziej delikatna, że prawnej oceny takiego zdarzenia dokona państwo w osobach umocowanych funkcjonariuszy wymiaru sprawiedliwości, działających ex post, bezpiecznie zasiadających w zaciszu gabinetów prokuratorskich czy sal sądowych - to samo państwo, którego zabrakło w krytycznym momencie zamachu. Waga zarysowanego tu zagadnienia nie powinna jednak przesłonić słabych stron przedłożonej propozycji nowelizacyjnej, o których poniżej.

Po pierwsze, należy odrzucić supozycję o nieoperatywnym charakterze kategorii „strachu lub wzburzenia usprawiedliwionych okolicznościami zamachu”, jako tej części normy zawartej w art. $25 \$ 3$ k.k., która - ze względu na nieokreśloność pojęć strachu i wzburzenia - nie daje organom wymiaru sprawiedliwości szansy na poprawne jej zastosowanie przy ocenie stanów faktycznych z przekroczenia granic obrony koniecznej. Jak pokazują wyniki badań $Ł$. Pohla i K. Burdziaka sądy stosują przepis art. $25 \$ 3$ k.k. w praktyce. Skutecznie poszukują w drodze wykładni odpowiedzi na pytanie, kiedy strach i wzburzenie usprawiedliwione są okolicznościami zamachu? Powołani wyżej autorzy wskazują, co warto podkreślić, że w zapadłych judykatach sądy nie tylko nie uchylały się od stosowania art. $25 \$ 3$ k.k., ale jednoznacznie wskazywały, że ocena działania sprawcy pod wpływem strachu lub wzburzenia jest wyłączną kompetencją sądu, a opinie biegłych (np. psychologa), choć odgrywają w tym zakresie niezwykle istotną rolę, nie mają decydującego znaczenia ${ }^{24}$.

Po drugie, nie można tracić z pola widzenia faktu, że raporty i opracowania dotyczące badań akt postępowań karnych z zakresu stosowania instytucji obrony koniecznej, jakie przywołano w treści uzasadnienia opiniowanej petycji, ograniczają swoje spektrum analityczne do postępowań zakończonych prawomocnym wyrokiem sądu. Jako autor jednego z przywołanych opracowań ${ }^{25}$ mam obowiązek zwrócić uwagę, że poza ich zakresem badawczym pozostały sprawy zakończone już na etapie postępowania przygotowawczego postanowieniem o umorzeniu postępowania lub odmowie jego wszczęcia z uwagi na okoliczność niepopełnienia przez sprawcę przestępstwa - działanie w granicach obrony koniecznej (art. $17 \$ 1$ pkt 2 k.p.k.) lub niepodlegania karze - przekroczenie granic obrony koniecznej w warunkach art. $25 \$ 3$ k.k. (art. $17 \$ 1$ pkt 4 k.p.k.). Ta kategoria spraw nie została dotychczas objęta badaniami - nie oznacza to, że w ogóle nie

24 Sygn. akt SA II AKa 29/17; SN IV sygn. akt KK 59/15 (zob. też: sygn. akt SO III K 82/15), cyt. za Ł. Pohl, K. Burdziak, Obraz i analiza wykładni sądowej przepisów Kodeksu karnego z 1997 r. o obronie koniecznej i przekroczeniu jej granic, Warszawa 2017 (raport w publikacji), s. 99-100.

25 P. Bachmat, Instytucja obrony koniecznej w praktyce prokuratorskiej i sądowej, „Prawo w Działaniu” 2008, nr 3, s. 39-117. 
występuje w praktyce organów wymiaru sprawiedliwości. Zważywszy na tę okoliczność, należy zdać sobie sprawę z faktu, iż przedstawiona w dotychczasowych raportach $\mathrm{z}$ badań generalnie niekorzystna ocena działań, zwłaszcza działań prokuratury, nie ma charakteru całościowego, a jedynie wycinkowy. Nie obejmuje bowiem tych przypadków (nie wiemy, czy są one liczne, czy nieliczne), w których prokuratura potraktowała działanie osoby odpierającej bezprawny, bezpośredni zamach na dobro prawne jako działanie legalne albo przynajmniej niezasługujące na ukaranie - to ostatnie mimo przekroczenia granic prawa do obrony.

Po trzecie, przechodząc do opiniowanej propozycji, została ona pomyślana jako kolejna (obok art. $25 \$ 3$ k.k.) prawna podstawa uwolnienia od kary sprawcy przekroczenia granic obrony koniecznej. Podstawą merytoryczną zagwarantowania ekscedentowi bezkarności byłaby sytuacja przekroczenia granic obrony koniecznej przy odpieraniu zamachu skierowanego przeciwko jednemu z dóbr prawnych wyegzemplifikowanych $\mathrm{w}$ treści proponowanego przepisu art. 25 $\S 3$ a k.k. Ich lista obejmuje: bezpieczeństwo powszechne, życie, zdrowie, wolność, wolność seksualną lub mienie, gdy zamach na mienie połączony jest z użyciem przemocy lub wdarciem się do cudzego domu, mieszkania, lokalu, pomieszczenia lub ogrodzonego terenu.

Przywołane rozwiązanie budzi następujące zastrzeżenia. Konstrukcja oparta na założeniu polegającym na premiowaniu ekscendenta tym, że niepodlega karze tylko z uwagi na fakt, że odpiera on zamach skierowany przeciwko określonemu dobru prawnemu, zdecydowanie zubaża perspektywę oceny jego zachowania, eliminując z niej nie tylko, jak chce tego autor petycji, sferę emocjonalną zachowania ekscendenta (strach i wzburzenie), ale również inne istotne elementy składające się na ocenę zdarzenia, jak np. rozkład sił między napastnikiem a broniącym się („osiłek” uzbrojony w niebezpieczne narzędzie versus starszy człowiek), konfiguracja interpersonalna (np. napastnicy versus pojedyncza osoba broniąca się, albo napastnik versus ojciec będący na spacerze z małymi dzieć$\mathrm{mi}$ ), konfiguracja sytuacyjna (zamach mający miejsce w nocy, na wyludnionej ulicy albo w nocy w mieszkaniu broniącego się), narzędzia i sposoby użyte przez napastnika i broniącego się czy zestawienie kolidujących w zdarzeniu kontratypowym dóbr prawnych, a także wiele innych elementów. Dobra regulacja tego zagadnienia powinna być też na tyle uniwersalna, aby okazała się przydatna do oceny zdarzeń, w których wektor oceny nie będzie już tak jednoznacznie skierowany na korzyć broniącego się, w sytuacji, w której to on ma zdecydowaną przewagę nad napastnikiem (siłową, liczbową, sytuacyjną itd.). Nowa regulacja powinna zawierać pewnego rodzaju wentyl bezpieczeństwa dla organów wymiaru sprawiedliwości, tj. powinna być w nią wpisana także możliwość zaniechania przez organy wymiar sprawiedliwości premiowania ekscendenta w sytuacji, w której wykorzystał swoją rażącą przewagę do obrony dobra stosunkowo niewielkiej wartości, przy poświęceniu dóbr o wartości najwyższej - jak życie czy zdrowie. Opiniowane rozwiązanie nie spełnia tego wymogu. 
W ocenie autora opinii zdecydowanie lepszym rozwiązaniem byłoby powiązanie niepodlegania karze ekscendenta z bardziej uniwersalną i pojemną zarazem formułą „usprawiedliwienia przekroczenia granic obrony koniecznej okolicznościami towarzyszącymi zamachowi”. Takie postulaty zostały nota bene zgłoszone w polskiej literaturze karnistycznej, jednak do tej pory nie zostały podjęte prace nad wdrożeniem tych propozycji w życie ${ }^{26}$.

Opiniowane uregulowanie zostało ujęte nazbyt szeroko, w sposób nie do końca przestający do przedstawionego uzasadnienia. Należy zwrócić uwagę, że propozycja nowego art. $25 \$ 3$ a k.k. została ujęta od strony redakcyjnej w taki sposób, że swoim zakresem obejmie nie tylko przypadki ekscesu intensywnego (sposób obrony niewspółmierny do niebezpieczeństwa zamachu), ale również sytuacje mieszczące się w ekscesie ekstensywnym (brak wskazanej w ustawie korelacji czasowej między zamachem a obroną, prowadzący do naruszenia zasady bezpośredniości zamachu, tzn. przypadki obrony przedwczesnej albo spóźnionej). Tymczasem cała warstwa argumentacyjna uzasadnienia dotyka kwestii ekscesu intensywnego. Autor nie podjął próby wykazania, czy proponowane rozwiązanie miałoby znaleźć zastosowanie także w przypadkach ekscesu ekstensywnego.

\section{Wnioski}

Zdaniem autora opinii przedłożona petycja nie wydaje się zasadna. Postulat ustanowienia art. $25 \$ 3$ a k.k., w brzmieniu zaproponowanym przez autora petycji, nie zasługuje na aprobatę. Niepodleganie karze ekscendenta tylko z uwagi na fakt, że ten występuje w obronie określonych dóbr prawnych, dokonane w oderwaniu od innych istotnych elementów zdarzenia kontratypowego, spłyca ocenę jego zachowania i może prowadzić do obligatoryjnego uwalniania od kary w przypadkach społecznie nieakceptowanych.

\section{Bibliografia}

Bachmat P., Instytucja obrony koniecznej w praktyce prokuratorskiej i sadowej, „Prawo w Działaniu" 2008, nr 3.

Buchała K., Prawo karne, Warszawa 1980.

Cieślak M., O przesłankach procesowych $w$ polskim postępowaniu karnym (podstawowe założenia i procesy metodologiczne), „Państwo i Prawo” 1969, z. 12.

Daszkiewicz K., Kodeks karny z 1997 roku. Uwagi krytyczne, Gdańsk 2001

Gajdus D., Czynny żal w polskim prawie karnym, Toruń 1984.

26 K. Daszkiewicz, Kodeks karny z 1997 roku, op. cit., s. 104; Ł. Pohl, K. Burdziak, Obraz i analiza wykładni sq̨dowej, op. cit., s. 98. 
Gardocki L., Prawo karne, Warszawa 1998.

Giezek J., Komentarz do art. 25 Kodeksu karnego [w:] Kodeks karny. Część ogólna. Komentarz, red. J. Giezek, N. Kłączyńska, G. Łabuda, 2012, LEX nr 125523.

Gostyński Z., Zabłocki S., Dział I. Przepisy wstępne [w:] J. Bratoszewski i in., Kodeks postępowania karnego. Komentarz, t. I, Warszawa 2003.

Mozgawa M., Komentarz aktualizowany do art. 25 Kodeksu karnego [w:] Kodeks karny. Komentarz aktualizowany, red. M. Mozgawa i in., 2017, LEX nr 534269.

Wąsek A., Wspótsprawstwo w polskim prawie karnym, Warszawa 1977.

Wolter W., Nauka o przestępstwie. Analiza prawnicza na podstawie części ogólnej kodeksu karnego z 1969 r., Warszawa 1973.

Zoll A., Komentarz do art. 25 Kodeksu karnego [w:] Kodeks karny. Część ogólna, t. I, część I, Komentarz do art. 1-52, 2016, red. W. Wróbel, A. Zoll, LEX nr 510491.

Zoll A., Okoliczności wyłączające bezprawność czynu. Zagadnienia ogólne, Warszawa 1982. 
\begin{tabular}{l|l}
2 & \\
& OPINIE BAS
\end{tabular}

\begin{tabular}{l|l} 
D & \\
SPRAWY POSELSKIE
\end{tabular} 



\title{
Znaczenie wyrażenia "obowiązki poselskie" - wykładnia art. 22 ust. 1 regulaminu Sejmu ${ }^{1}$
}

\begin{abstract}
The meaning of the term "Deputies' duties" - interpretation of Article 22 para. 1 of the Standing Orders of the Sejm: The concept of "non-performance of Deputies duties" covers all kinds of acts that violate legal norms determining the manner of exercising the parliamentary mandate. At the same time, this concept does not include acts leading to non-performance of such Deputies' duties, the violation of which is threatened by a legal sanction set out in other legal provisions. It is not possible to indicate a full catalog of duties, whose breach casuses a liability under Article 22 of the Standing Orders. "Non-performance of Deputies' duties" covers, among others, cases of violation of duties related to the participation in the composition of another state authority, related to the function of representing the Sejm in proceedings before other authorities and in interparliamentary relations.
\end{abstract}

Keywords: mandate | Deputy | Standing Orders of the Sejm

Słowa kluczowe: mandat | poseł | regulamin Sejmu

Ekspert ds. legislacji BAS; wojciech.sypniewski@sejm.gov.pl.

\section{Przedmiot opinii}

Przedmiotem opinii jest wykładnia art. 22 ust. 1 regulaminu Sejmu. Przepis ten przewiduje, że: [z]a niewykonywanie obowiązków poselskich Komisja Regulaminowa, Spraw Poselskich i Immunitetowych może, w drodze uchwały: 1) zwrócić posłowi uwage, 2) udzielić posłowi upomnienia, 3) udzielić postowi nagany. Kolejne ustępy tego artykułu określają tryb i zasady rozpatrywania przez Prezydium Sejmu odwołania od uchwały Komisji Regulaminowej, Spraw Poselskich i Immunitetowych. Celem opinii jest przybliżenie katalogu obowiązków poselskich

1 Opinia prawna w sprawie wykładni art. 22 ust. 1 regulaminu Sejmu (znaczenie wyrażenia „obowiązki poselskie”) sporządzona 10 października 2017 r. na zlecenie przewodniczącego Komisji Regulaminowej, Spraw Poselskich i Immunitetowych; BAS-WAKiU 2004/17. 
podlegających odpowiedzialności dyscyplinarnej na podstawie art. 22 ust. 1, które nie zostały wymienione w przepisach regulaminu Sejmu.

\section{Zakres odpowiedzialności dyscyplinarnej na podstawie art. 22 ust. 1 regulaminu Sejmu}

1. Ustalenie zakresu deliktów objętych odpowiedzialnością na podstawie art. 22 ust. 1 regulaminu Sejmu wymaga przybliżenia całokształtu zasad odpowiedzialności dyscyplinarnej posłów na podstawie regulaminu Sejmu. Punkt wyjścia dla tego rodzaju analizy wyznaczany jest przez podstawy ustrojowe odpowiedzialności regulaminowej posłów, które wiążą się z zagadnieniem immunitetu poselskiego. Norma zawarta w art. 105 ust. 1 Konstytucji RP - z jednej strony - wskazuje, że działalność wchodząca w zakres sprawowania mandatu poselskiego, która nie narusza praw osób trzecich, chroniona jest immunitetem materialnym (indemnitetem), z drugiej jednak zakłada, że czyny mieszące się w sferze wykonywania mandatu podlegają odpowiedzialności przed Sejmem. Ustawa zasadnicza ustanawia zatem wyraźną podstawę prawną dla określenia zasad odpowiedzialności dyscyplinarnej posłów za działalność wchodzącą w zakres sprawowania mandatu poselskiego.

2. Przewidziany w regulaminie Sejmu zakres odpowiedzialności dyscyplinarnej posłów obejmuje: a) odpowiedzialność za naruszenie lub niedopełnienie obowiązków poselskich określonych w art. 33-35 ustawy o wykonywaniu mandatu posła i senatora (art. 21); b) odpowiedzialność za niewykonywanie obowiązków poselskich (art. 22); c) odpowiedzialność za nieusprawiedliwioną nieobecność na posiedzeniu Sejmu (nieuczestniczenie w głosowaniach) lub komisji (art. 24); d) odpowiedzialność za uniemożliwianie przez posła pracy Sejmu lub jego organów (art. 23, art. 25 i art. 175) oraz e) odpowiedzialność za naruszenie zasad etyki poselskiej (art. 146-147). Procedura odpowiedzialności dyscyplinarnej nie została ujęta syntetycznie w jednym rozdziale regulaminu Sejmu. Zasady i tryb odpowiedzialności regulaminowej określa: rozdział 4 działu I „Zasady odpowiedzialności regulaminowej posłów” (art. 21-25), rozdział 11 działu II „Postępowanie w sprawach dyscyplinarnych posłów oraz w sprawach o pociągnięcie posłów do odpowiedzialności za przestępstwa lub wykroczenia albo o aresztowanie bądź zatrzymanie” (art. 131-136), rozdział 13 działu II „Komisja Etyki Poselskiej” (art. 143-148) oraz art. 155 i art. 175, które odpowiednio normują tryb postępowania wobec posła uniemożliwiającego prowadzenie obrad komisji i obrad plenarnych Sejmu.

Wyróżnienie w regulaminie Sejmu kilku materialnych podstaw odpowiedzialności wskazuje na to, że mają one odrębny (rozłączny) charakter. Poseł naruszający obowiązki, o których mowa w art. 33-35 ustawy o wykonywaniu mandatu, ponosi odpowiedzialność na podstawie art. 21 i nie może zostać ukarany za ten sam czyn na podstawie art. 22, który ustanawia sankcje za „niewykonywanie 
obowiązków poselskich". Podobnie czyn podlegający odpowiedzialności z tytułu uniemożliwiania pracy Sejmu, mimo że mógłby być kwalifikowany jako niewykonywanie obowiązku czynnego udziału w pracach izby, podlega odpowiedzialności na podstawie art. 23 lub art. 25. Zasada ne bis in idem, będąca jednym z fundamentów systemu prawa represyjnego, wyklucza podwójne (wielokrotne) karanie tej samej osoby za popełnienie tego samego czynu zabronionego. Trybunał Konstytucyjny, uznając tę zasadę za jeden z fundamentów demokratycznego państwa prawnego (art. 2 Konstytucji), wskazuje, że znajduje ona zastosowanie nie tylko w odniesieniu do wymierzania kar za przestępstwo, lecz także przy stosowaniu innych środków represyjnych².

Odpowiedzialność z tytułu naruszenia obowiązków poselskich (w tym również sankcje finansowe $\mathrm{z}$ tytułu wykluczenia $\mathrm{z}$ posiedzenia Sejmu lub uniemożliwiania jego pracy) nie wyłącza odpowiedzialności z tytułu naruszenia zasad etyki poselskiej. O ile ocena niedopełnienia lub niewykonywania obowiązków poselskich nawiązuje do norm prawnych wynikających z przepisów prawa, o tyle ocena naruszenia zasad etyki poselskiej zakłada wartościowanie odwołujące się do pozasystemowych dyrektyw etycznych. Kwalifikacja etyczna zachowania ocenianego w postępowaniu prowadzonym przez Komisję Etyki Poselskiej nie polega na ocenie, czy spełnia ono obowiązek poselski, lecz wiąże się z pytaniem, czy w rozpatrywanej sprawie poseł postąpił zgodnie $\mathrm{z}$ wzorcem etycznym wyznaczanym przez zasady etyki poselskiej ${ }^{3}$. Zasada ne bis in idem nie wyklucza zatem odpowiedzialności za ten sam czyn w ramach reżimów postępowania o odmiennym celu ${ }^{4}$.

3. Ustalanie zakresu odpowiedzialności z tytułu „niewykonywania obowiązków poselskich" na podstawie art. 22 ust. 1 wymaga przybliżenia historycznej ewolucji regulaminowych zasad odpowiedzialności dyscyplinarnej. Korzenie tych zasad tkwią bowiem w rozwiązaniach z okresu Polskiej Rzeczpospolitej Ludowej.

Regulamin Sejmu PRL z 1 marca 1957 r. powierzał Komisji Mandatowo-Regulaminowej rozpatrywanie - na wniosek Prezydium Sejmu - spraw posłów, którzy nie wykonują obowiązków poselskich, jak również posłów, którzy zachowują się w sposób nieodpowiadający godności posła. Od uchwały Komisji posłowi przysługiwało odwołanie do Sejmu (art. 9, M.P. 1957, nr 19, poz. 145). Regulamin Sejmu PRL z 17 lipca 1986 r. powielał wcześniejszy model odpowiedzialności dyscyplinarnej z tytułu niewykonywania obowiązków poselskich i zachowań nieodpowiadających godności posła. Tego rodzaju sprawy dyscyplinarne rozpatrywała Komisja Regulaminowa i Spraw Poselskich na wniosek Pre-

2 Zob. wyrok z 18 listopada 2010 r., sygn. akt P 29/09, a także wyroki TK z: 8 października 2002 r., sygn. akt K 36/00; 3 listopada 2004 r., sygn. akt K 18/03; 15 kwietnia 2008 r., sygn. akt P 26/06; 21 października 2014 r., sygn. akt P 50/13; 1 grudnia 2016 r. sygn. akt K 45/14.

3 Zob. Z. Czeszejko-Sochacki, Prawo parlamentarne w Polsce, Warszawa 1997, s. 115.

4 Zob. wyroki TK: z 8 października 2002 r., sygn. akt K 36/00, oraz z 1 grudnia 2016 r. sygn. akt K 45/14. 
zydium Sejmu. Wyraźnie określony został katalog kar dyscyplinarnych (zwrócenie uwagi i upomnienie), które mogła nałożyć Komisja Regulaminowa i Spraw Polskich po rozpatrzeniu sprawy z inicjatywy Prezydium Sejmu. W tym samym trybie rozpatrywane były sprawy posłów nieobecnych bez usprawiedliwienia na co najmniej dwóch posiedzeniach Sejmu lub komisji w okresie trwania danej sesji Sejmu (art. 4-5, art. 80, M.P. 1986, nr 21, poz. 151).

Regulamin Sejmu z 30 lipca 1992 r. przejął wcześniej obowiązujący model odpowiedzialności dyscyplinarnej. Pierwotne brzmienie omawianego przepisu obejmowało wyłącznie procedurę rozpatrywania spraw dotyczących niewykonywania obowiązków poselskich oraz zachowań nieodpowiadających godności posła (art. 72 według numeracji pierwotnej). Regulamin rozszerzył katalog kar o karę nagany oraz przyznał obwinionemu prawo ustanowienia obrońcy spośród posłów (art. 74 według numeracji pierwotnej). Nowela z 4 lipca 1996 r. (M.P. nr 43, poz. 419) wprowadziła odrębne podstawy odpowiedzialności dyscyplinarnej z tytułu naruszenia niektórych obowiązków o charakterze antykorupcyjnym, określonych w ustawie z 9 maja 1996 r. o wykonywaniu mandatu posła i senatora (obecnie art. 21 regulaminu Sejmu). Nowela z 28 października 1997 r. (M.P. nr 80, poz. 779) w miejsce odpowiedzialności z tytułu zachowania nieodpowiadającego godności posła ustanowiła odrębny reżim odpowiedzialności przed Komisją Etyki Polskiej z tytułu naruszenia Zasad etyki poselskiej (obecnie art. 143-148 regulaminu Sejmu). W konsekwencji odpowiedzialność za niewykonywanie obowiązków poselskich na podstawie art. 22 nie obejmuje dziś czynów nieodpowiadających godności posła (sfera kompetencji Komisji Etyki Poselskiej - art. 145 ust. 1 regulaminu Sejmu).

4. Pojęcie „obowiązków poselskich” nie występuje w przepisach ustawy zasadniczej. Wprawdzie zakres zobowiązań wynikających z mandatu poselskiego w sposób ogólny - wyznaczany jest przez ślubowanie poselskie (art. 104 ust. 2 Konstytucji), jednak jego istota powinna być rozpatrywana przede wszystkim w płaszczyźnie moralno-politycznej (pojęcia „obowiązków poselskich” nie można w szczególności utożsamiać z fragmentem roty ślubowania, eksponującym „obowiązki wobec Narodu”, ponieważ wyrażenie to określa wyłącznie jeden z elementów, które łącznie wyznaczają zakres zadań poselskich wiążących się z wykonywaniem mandatu). Ustalenie zakresu znaczeniowego omawianego pojęcia nie może jednak całkowicie abstrahować od treści ślubowania poselskiego, ponieważ wyznacza ono merytoryczne ramy swobodzie sprawowania „mandatu wolnego", a tym samym ma walor normatywny ${ }^{5}$.

Obowiązek poselski to powinność określonego zachowania się nałożona na posła przez normę prawną. Obowiązkom poselskim towarzyszą prawa poselskie (uprawnienia kompetencyjne), czyli przyznane przez normę prawną - w związku

L. Garlicki, Uwaga 16 do art. 104 [w:] Konstytucja Rzeczypospolitej Polskiej. Komentarz, t. II, red. L. Garlicki, Warszawa 2001. 
z realizowaniem zadań przedstawicielskich - możliwości określonego działania, które aktualizuje konkretny obowiązek organu państwa, w szczególności Sejmu ${ }^{6}$. Podział na prawa i obowiązki nie jest podziałem dychotomicznym. Prawa poselskie są korelatem obowiązków poselskich. Prawa i obowiązki stanowią pewne „oprzyrządowanie (instrumentarium) dla wykonywania mandatu”. Ustawa o wykonywaniu mandatu posła i senatora podkreśla immanentny związek między sferą obowiązków, wynikających z mandatu poselskiego, i uprawnieniami, które pozwalają na ich realizację. Przepis art. 14 tej ustawy przewiduje, że: $w w y$ konywaniu obowiązków poselskich poseł w szczególności ma prawo do określonych czynności w pracach Sejmu i jego organów.

Prawa i obowiązki poselskie mogą być podzielone na trzy grupy: a) związane z działalnością izby i jej organów (np. obowiązek złożenia ślubowania, prawo i obowiązek do czynnego uczestnictwa w posiedzeniach Sejmu i komisji); b) indywidualne formy wykonywania mandatu poselskiego (np. prawo do uzyskiwania informacji i wyjaśnień w sprawach wynikających z wykonywania obowiązków poselskich od członków Rady Ministrów oraz przedstawicieli innych instytucji i organów państwowych, prawo do interwencji w organie administracji rządowej i samorządu terytorialnego i innych wskazanych w ustawie podmiotach); c) prawa i obowiązki dotyczące warunków materialnych wykonywania mandatu (m.in. zasada incompatibilitas mandatu poselskiego, ograniczenia dotyczące prowadzenia działalności gospodarczej).

5. Zakres zastosowania art. 22 należy ustalać z uwzględnieniem innych reżimów odpowiedzialności dyscyplinarnej przewidzianych w regulaminie Sejmu. Przepis ten dotyczy kategorii czynów innych niż te, o których mowa w art. 21 (naruszenie lub niedopełnienie obowiązków określonych w art. 33-35 ustawy o wykonywaniu mandatu posła i senatora), art. 24 (nieprzestrzeganie obowiązku obecności na posiedzeniach Sejmu i jego organów) oraz art. 23 i art. 25 (uniemożliwianie pracy Sejmu i jego organów). Wyróżnienie w regulaminie Sejmu odrębnych podstaw odpowiedzialności dyscyplinarnej zakłada - jak już wspomniałem - rozłączny charakter tych reżimów.

Poza zakresem odpowiedzialności, o której mowa w art. 22, pozostają również czyny prowadzące do naruszenia zakazów, wynikających z zasady incompatibilitas (art. 103 Konstytucji i zakazy ustawowe). Skutki naruszenia tych zakazów określa ustawa z 5 stycznia 2011 r. - Kodeks wyborczy (t.j. Dz.U. 2017, poz. 15, ze zm.) oraz ustawa o wykonywaniu mandatu posła i senatora. Omawiany reżim odpowiedzialności nie dotyczy również naruszenia zakazów z art. 107 Konstytucji. Za naruszenie zakazu prowadzenia działalności gospodarczej z osiąganiem

$6 \quad$ M. Kudej, Status prawny posła i senatora w Rzeczypospolitej Polskiej [w:] Założenia ustrojowe, struktura i funkcjonowanie parlamentu, red. A. Gwiżdż, Warszawa 1997, s. $276-282$.

7 Z. Czeszejko-Sochacki, Prawo parlamentarne, op. cit., s. 100. 
korzyści z majątku Skarbu Państwa lub samorządu terytorialnego, a także zakazu nabywania tego majątku posłowie ponoszą odpowiedzialność przed Trybunałem Stanu. Zasady z art. 22 nie mają również zastosowania do niewykonania obowiązku złożenia ślubowania przed rozpoczęciem sprawowania mandatu, ponieważ odmowa złożenia ślubowania jest równoznaczna ze zrzeczeniem się mandatu (art. 104 ust. 2 i 3 Konstytucji).

Należy zatem przyjąć, że pojęcie „niewykonywania obowiązków poselskich” $\mathrm{z}$ art. 22 ust. 1 regulaminu Sejmu obejmuje wszelkiego rodzaju czyny (działania i zaniechania), które naruszają normy prawne wyznaczające sposób wykonywania mandatu poselskiego. Pojęcie to jednocześnie nie obejmuje czynów prowadzących do niewykonywania tych obowiązków poselskich, których naruszenie zagrożone jest sankcją prawną określoną w innych przepisach prawa (przepisach Konstytucji, ustawy lub regulaminu Sejmu).

$\mathrm{Z}$ natury rzeczy nie jest możliwe wyczerpujące wyliczenie wszystkich elementów zbioru deliktów objętych art. 22. Tytułem przykładu można wymienić delikty, które naruszają obowiązki dotyczące: a) funkcji i stanowisk w organach Sejmu, np. niewykonywanie obowiązków Marszałka Sejmu, wicemarszałka, członka Konwentu Seniorów, sekretarza Sejmu, przewodniczącego lub wiceprzewodniczącego komisji, posła sprawozdawcy, przedstawiciela wnioskodawcy projektu - w przypadku inicjatyw komisji sejmowych lub grupy posłów; b) organizacji zrzeszeń parlamentarnych, np. niewykonywanie obowiązku notyfikacji Marszałkowi Sejmu składu osobowego i regulaminu (statutu) wewnętrznego zrzeszenia (art. 8 ust. 7 regulaminu Sejmu), naruszenie zasad związanych z organizacją i finansowaniem biur zrzeszeń poselskich (art. 18 ustawy o wykonywaniu mandatu posła i senatora); c) indywidualnych form wykonywania mandatu poselskiego, $n p$. nierespektowanie ograniczeń związanych z prawem do informacji (art. 19), prawem do interwencji (art. 20), prawem do uczestnictwa w sesjach sejmików województw, rad powiatów i rad gmin (art. 22); d) nieprzestrzeganie obowiązków związanych z tworzeniem biur poselskich oraz korzystaniem ze wsparcia społecznych współpracowników (art. 23); e) indywidualnej sytuacji prawnej posła i jego zaopatrzenia socjalnego, np. naruszenie obowiązków związanych z: Rejestrem Korzyści (art. 35a), uprawnieniami do bezpłatnych przejazdów środkami publicznego transportu i komunikacji (art. 43), prawem prowadzenia korespondencji związanej z wykonywaniem mandatu bez uiszczania opłat pocztowych (art. 44).

Treść art. 22 rodzić może również pytanie, czy przewidziana w tym przepisie odpowiedzialność za niewykonywanie obowiązków poselskich obejmuje też swoim zakresem przypadki niewykonywania obowiązków związanych z uczestnictwem w składzie osobowym innego organu państwa. Chodzi przy tym o organy, których skład osobowy z mocy Konstytucji lub ustawy obejmuje jako element konieczny czynnik poselski. Innymi słowy, czy poseł, który nie wykonuje obowiązków członka organu kolegialnego, w skład którego został powołany z racji pełnienia mandatu poselskiego, może ponieść odpowiedzialność dyscyplinarną 
przed Sejmem z tytułu niewykonywania obowiązków wynikających z pełnienia takiej funkcji (obowiązki posłów - członków Krajowej Rady Sądownictwa, Krajowej Rady Prokuratorów, Rady Ochrony Pracy czy Rady Służby Cywilnej)? Zbliżona wątpliwość dotyczyć może wykonywania obowiązków związanych z funkcją reprezentowania Sejmu w postępowaniach przed innymi organami (obowiązki posła reprezentującego Sejm w postępowaniu przed Trybunałem Konstytucyjnym; obowiązki posła oskarżyciela w postępowaniu przed Trybunałem Stanu) czy w stosunkach międzynarodowych (np. obowiązki posła członka Zgromadzenia Parlamentarnego Rady Europy) oraz w stosunkach międzyparlamentarnych (m.in. obowiązki posłów członków tzw. grup międzyparlamentarnych). Naruszenie tych obowiązków, niezależnie od ewentualnych skutków wynikających z odrębnych przepisów, potencjalnie mogłoby być kwalifikowane jako niewykonywanie obowiązków poselskich.

W tym kontekście należy odnotować stanowisko, które odróżnia wykonywanie przez parlamentarzystę obowiązków publicznych (funkcji publicznej), pozostających w ścisłym związku z funkcjami Sejmu (Senatu), oraz takich, które plasują się poza tymi funkcjami ${ }^{8}$. W takim ujęciu warunkiem pozwalającym na zaliczenie określonej funkcji publicznej w poczet sprawowania mandatu poselskiego jest wymóg, by obowiązki z nią związane mieściły się w ramach funkcji izb parlamentarnych (w szczególności funkcji ustawodawczej i kontrolnej). W tych przypadkach jednak, w których ustawa (lub Konstytucja) przewiduje udział czynnika poselskiego w składzie osobowym organu kolegialnego niepowiązanego $\mathrm{z}$ realizacją funkcji izb parlamentarnych, obowiązki związane ze statusem członka takiego organu kolegialnego nie mogą być kwalifikowane jako wykonywanie obowiązków poselskich, lecz wiążą się ze sprawowaniem „innych funkcji publicznych”. Analiza statusu poszczególnych rad pozaparlamentarnych prowadzi powołanego autora do wniosku, że obowiązki posła członka Rady Ochrony Pracy należałoby kwalifikować jako „inne obowiązki poselskie”, a zarazem wykonywanie obowiązków członka Krajowej Rady Sądownictwa, Krajowej Rady Prokuratorów czy Rady Służby Cywilnej stanowi przykład sprawowania „innej funkcji publicznej” pozostającej poza zakresem sprawowania mandatu poselskiego?.

\section{Wnioski}

- Pojęcie „niewykonywania obowiązków poselskich” z art. 22 ust. 1 regulaminu Sejmu obejmuje wszelkiego rodzaju czyny (działania i zaniechania), które naruszają normy prawne wyznaczające sposób wykonywania mandatu posel-

8 P. Sarnecki, Immunitet posłów i senatorów w radach pozaparlamentarnych, „Przegląd Sejmowy" 2015, nr 6, s. 9-28.

$9 \quad$ Ibidem, s. 28. 
skiego. Pojęcie to jednocześnie nie obejmuje czynów prowadzących do niewykonywania tych obowiązków poselskich, których naruszenie zagrożone jest sankcją prawną określoną w innych przepisach prawa (przepisach Konstytucji, ustawy lub regulaminu Sejmu).

- Nie jest możliwe wskazanie pełnego katalogu obowiązków, których naruszenie stanowi delikt objęty odpowiedzialnością z art. 22 regulaminu Sejmu. Tytułem przykładu można wymienić delikty, które naruszają obowiązki dotyczące: a) funkcji i stanowisk w organach Sejmu (niewykonywanie obowiązków Marszałka Sejmu, wicemarszałka, członka Konwentu Seniorów, sekretarza Sejmu, przewodniczącego lub wiceprzewodniczącego komisji, posła sprawozdawcy, przedstawiciela wnioskodawcy projektu - w przypadku inicjatyw komisji sejmowych lub grupy posłów); b) organizacji zrzeszeń parlamentarnych, np. niewykonywanie obowiązku notyfikacji Marszałkowi Sejmu składu osobowego i regulaminu (statutu) wewnętrznego zrzeszenia (art. 8 ust. 7 regulaminu Sejmu); naruszenie zasad związanych z organizacją i finansowaniem biur zrzeszeń poselskich (art. 18 ustawy o wykonywaniu mandatu posła i senatora); c) indywidualnych form wykonywania mandatu poselskiego, np. nierespektowanie ograniczeń związanych z: prawem do informacji (art. 19), prawem do interwencji (art. 20 ustawy o wykonywaniu mandatu posła i senatora), prawem do uczestnictwa w sesjach sejmików województw, rad powiatów i rad gmin (art. 22 ustawy o wykonywaniu mandatu posła i senatora); d) tworzenia biur poselskich oraz korzystania ze wsparcia społecznych współpracowników (art. 23 ustawy o wykonywaniu mandatu posła i senatora); e) indywidualnej sytuacji prawnej posła i jego zaopatrzenia socjalnego (np. naruszenie obowiązków związanych z: Rejestrem Korzyści, art. 35a ustawy o wykonywaniu mandatu posła i senatora), uprawnieniami do bezpłatnych przejazdów środkami publicznego transportu i komunikacji (art. 43 ustawy o wykonywaniu mandatu posła i senatora), prawem prowadzenia korespondencji związanej z wykonywaniem mandatu bez uiszczania opłat pocztowych (art. 44 ustawy o wykonywaniu mandatu posła i senatora).

- „Niewykonywanie obowiązków poselskich” z art. 22 ust. 1 regulaminu Sejmu obejmuje również swoim zakresem przypadki naruszania obowiązków związanych z uczestnictwem w składzie osobowym innego organu państwa (w sytuacji, gdy skład osobowy z mocy Konstytucji RP lub ustawy obejmuje jako element konieczny czynnik poselski - Krajowa Rada Sądownictwa, Krajowa Rada Prokuratorów, Rada Ochrony Pracy, Rada Służby Cywilnej). Niewykonywanie obowiązków członka organu kolegialnego, w skład którego poseł został powołany $\mathrm{z}$ racji pełnienia mandatu poselskiego, może być kwalifikowane jako delikt z art. 22 regulaminu Sejmu. Podobnie należałoby ocenić niewykonywanie obowiązków związanych z funkcją reprezentowania Sejmu w postępowaniach przed innymi organami (obowiązki posła reprezentującego Sejm w postępowaniu przed Trybunałem Konstytucyjnym; obowiązki 
posła oskarżyciela w postępowaniu przed Trybunałem Stanu), w stosunkach międzynarodowych (np. obowiązki posła członka Zgromadzenia Parlamentarnego Rady Europy) oraz w stosunkach międzyparlamentarnych (m.in. obowiązki posłów członków tzw. grup międzyparlamentarnych). Należy jednak odnotować głos doktryny wskazujący, że warunkiem pozwalającym na zaliczenie określonej funkcji publicznej w poczet sprawowania mandatu poselskiego jest wymóg, by obowiązki z nią związane mieściły się w ramach funkcji izb parlamentarnych (w szczególności funkcji ustawodawczej i kontrolnej).

\section{Bibliografia}

Czeszejko-Sochacki Z., Prawo parlamentarne w Polsce, Warszawa 1997.

Garlicki L., Uwaga 16 do art. 104 [w:] Konstytucja Rzeczypospolitej Polskiej. Komentarz, t. II, red. L. Garlicki, Warszawa 2001.

Kudej M., Status prawny posła i senatora $w$ Rzeczypospolitej Polskiej [w:] Założenia ustrojowe, struktura i funkcjonowanie parlamentu, red. A. Gwiżdż, Warszawa 1997.

Sarnecki P., Immunitet posłów i senatorów w radach pozaparlamentarnych, „Przegląd Sejmowy" 2015, nr 6. 
Joanna M. Karolczak

\title{
Możliwość podjęcia interwencji poselskiej u komornika sądowego ${ }^{1}$
}

Possibility of taking Deputies' intervention in a court bailiff: The Act on the Exercise of the Mandate of Deputy or Senator does not provide for the right of a Deputy to intervene with a court bailiff. The intervention concerning bailiff's actions may be directed by a Deputy to the Minister of Justice, as an authority exercising supervision over the activity of bailiffs and their self-government.

\author{
Keywords: intervention | bailiff | Deputy \\ Słowa kluczowe: interwencja | komornik | poseł
}

Radca prawny, ekspert ds. legislacji BAS; joanna.karolczak@sejm.gov.pl.

\section{Przedmiot opinii}

Opinia zawiera odpowiedź na pytanie: czy poseł na Sejm RP, działając na podstawie ustawy o wykonywaniu mandatu posła i senatora, może podjąć interwencję poselską u komornika sądowego. Autorzy pytania doprecyzowali, że chodzi o interwencję poselską w przypadku zgłaszanych przez obywateli czynności komorniczych, które budzą wątpliwości, czy zostały podjęte zgodnie z obowiązującym prawem.

Opinia została przygotowana $\mathrm{z}$ uwzględnieniem następujących aktów prawnych, według stanu prawnego na dzień sporządzenia opinii:

- Konstytucji Rzeczypospolitej Polskiej z 2 kwietnia 1997 r., Dz.U. nr 78, poz. 483 , ze zm.,

- ustawy z 9 maja 1996 r. o wykonywaniu mandatu posła i senatora, Dz.U. 2016, poz. 1510, ze zm.; dalej: ustawa o wykonywaniu mandatu,

- ustawy z 29 sierpnia 1997 r. o komornikach sądowych i egzekucji, Dz.U. 2017, poz. 1277 , ze zm.; dalej: ustawa o komornikach,

1 Opinia prawna $w$ sprawie interpretacji art. 20 ustawy z 9 maja 1996 r. o wykonywaniu mandatu posła i senatora w kontekście możliwości podjęcia interwencji poselskiej u komornika sądowego sporządzona 16 stycznia 2018 r. na zlecenie Klubu Poselskiego Kukiz'15; BAS-WAP 18/18. 
- ustawy z 17 listopada 1964 r. - Kodeks postępowania cywilnego, Dz.U. 2016, poz. 1822, ze zm.; dalej: k.p.c.

\section{Interwencja poselska}

1. Prawo do interwencji poselskiej zostało uregulowane w art. 20 ustawy o wykonywaniu mandatu, który w ust. 1 stanowi: Poseł lub senator ma prawo podjać - w wykonywaniu swoich obowiązków poselskich lub senatorskich - interwencje $w$ organie administracji rządowej $i$ samorzadu terytorialnego, zakładzie lub przedsiębiorstwie państwowym oraz organizacji społecznej, a także w jednostkach gospodarki niepaństwowej dla załatwienia sprawy, która wnosi we własnym imieniu albo $w$ imieniu wyborcy lub wyborców, jak również zaznajamiać się z tokiem jej rozpatrywania.

Definiując pojęcie „interwencji”, autor Komentarza do ustawy o wykonywaniu mandatu ${ }^{2}$ odwołuje się do leksykalnego jej pojęcia rozumianego jako wtrącanie się w jakąś sprawę: wywieranie lub wywarcie [...] wpływu (przez jakieś podmioty) na bieg tych spraw, np. po to by komuś pomóc lub by zapobiec konfliktom i podkreśla, że nie ma żadnych przesłanek, by nadawać pojęciu „interwencja” odmiennego znaczenia niż to, jakie wynika z przytoczonego znaczenia słownikowego, a zatem: przyjać trzeba, że taka interwencja jest po prostu działaniem posła lub senatora, który ma zamiar uzyskania informacji o przebiegu sprawy rozpatrywanej przez dany podmiot, badź też doprowadzenia do jej ostatecznego rozstrzygnięcia. Podobnie M. Poślednik zauważa, że interwencja stanowi szczególny i wyjątkowy środek prawny przyznany posłom, której celem nie jest jednak wszczęcie określonego postępowania, załatwienie ani wpłynięcie na merytoryczny zakres sprawy, lecz ingerencja w tok toczącego się już postępowania ${ }^{3}$.

Zakres podmiotów, do których można wystąpić z interwencją, jest wskazany w omawianym przepisie. Może to być organ administracji rządowej i samorządu terytorialnego, zakład lub przedsiębiorstwo państwowe, organizacja społeczna, a także jednostka gospodarki niepaństwowej. Pomijając w tym miejscu rozważania na temat nieadekwatności pojęć użytych w tym przepisie ${ }^{4}$, można zauważyć, że nie wymieniono w tym przepisie komorników.

2 P. Uziębło [w:] Komentarz do ustawy o wykonywaniu mandatu posła i senatora, red. K. Grajewski, Warszawa 2014, s. 281 i n.

3 M. Poślednik, Interwencja poselska $z$ art. 20 ust. 1 ustawy o wykonywaniu mandatu posła i senatora, „Przegląd Sejmowy” 2010, nr 3, s. 201-202.

4 O czym w wielu opiniach BAS, w tym w szczególności w: P. Chybalski, I. Galińska-Rączy, E. Gierach, J.M. Karolczak, W. Odrowąż-Sypniewski, Opinia prawna w sprawie kierunków zmian ustawy z 9 maja 1996 r. o wykonywaniu mandatu posła i senato$r a$, BAS-WAUiP-WAL 116/15, BAS-WAUiP-WAL 1761/16. 
2. Z treści art. 1 ustawy o komornikach wynika, że komornik sądowy jest funkcjonariuszem publicznym działającym przy sądzie rejonowym. Komornik to organ egzekucji sądowej powiązany z władzą sądowniczą, lecz nie będący jej organem $^{5}$. Jest organem państwa powołanym do wykonywania orzeczeń sądowych w drodze przymusowej egzekucji świadczeń pieniężnych i niepieniężnych, a także wykonywania innych czynności określonych w ustawach ${ }^{6}$. Komornik działa przy sądzie rejonowym, nie jest jednak pracownikiem sądu ${ }^{7}$ Komornik jest powiązany organizacyjnie i funkcjonalnie $\mathrm{z}$ władzą sądowniczą, będącą wyodrębnioną konstytucyjnie postacią władzy publicznej. Nie jest jednak organem władzy sądowniczej, a przede wszystkim nie sprawuje wymiaru sprawiedliwości, powierzonego w art. 175 ust. 1 Konstytucji RP sądom ${ }^{8}$.

W myśl art. 3 ust. 1 ustawy o komornikach przy wykonywaniu czynności komornik podlega orzeczeniom sądu i prezesowi sądu rejonowego, przy którym działa. Natomiast zgodnie z art. 64 ust. 1 i 2 nadzór zwierzchni nad działalnością komorników i działalnością samorządu komorniczego sprawuje Minister Sprawiedliwości. Nadzór ten nie może wkraczać w działania podlegające nadzorowi sądu. Nadzór nad działalnością komorników sprawuje Minister Sprawiedliwości przez prezesów sądów okręgowych, sędziów wizytatorów, a w zakresie kontroli finansowej - przez osoby upoważnione.

3. Z powyższych przepisów należy wyprowadzić wniosek, że ewentualną interwencję poselską dotyczącą komornika należy skierować do podmiotu, który sprawuje zwierzchni nadzór nad komornikiem w zakresie niepodlegającym nadzorowi sądu, czyli do Ministra Sprawiedliwości. Jest on także organem, do którego - zgodnie z treścią art. 20 ust. 1 ustawy o wykonywaniu mandatu - interwencja poselska może być skierowana (organ administracji rządowej). Natomiast komornik sądowy nie jest podmiotem, do którego poseł może skierować interwencję w trybie przywołanego art. 20.

4. Należy zwrócić uwagę, że zgodnie z art. 3 ust. 2 ustawy o komornikach, prezes sądu rejonowego, przy którym działa komornik, sprawuje nadzór nad jego działalnością, a w szczególności:

1) ocenia szybkość, sprawność i rzetelność postępowania poprzez badanie, czy w konkretnych sprawach nie zachodzi nieuzasadniona przewlekłość w podejmowaniu czynności,

2) kontroluje prawidłowość prowadzenia biurowości i rachunkowości kancelarii komorniczej,

5 A. Machnikowska, Komentarz do art. 1 [w:] Ustawa o komornikach sadowych i egzekucji. Komentarz, red. J. Świeczkowski, 2012, LEX.

6 A. Barańska, Status prawny komornika sq̨dowego i mienia kancelarii komorniczej, „Przegląd Prawa Egzekucyjnego” 2008, nr 1-2.

7 M. Bieżuński, P. Bieżuński, Ustawa o komornikach sądowych i egzekucji. Komentarz, 2010, LEX, komentarz do art. 1.

8 W. Tomalak, Status ustrojowy i procesowy komornika sądowego, 2014, LEX. 
3) bada kulturę pracy, w tym przestrzeganie wyznaczonych terminów czynności i przyjmowania interesantów oraz utrzymywanie kancelarii komorniczej na poziomie odpowiednim do godności urzędu i posiadanych środków,

4) zawiadamia sąd o potrzebie wydania komornikowi zarządzeń $w$ trybie art. $759 \$ 2$ Kodeksu postępowania cywilnego.

Natomiast w myśl art. 3 ust. 4 ustawy o komornikach prezes sądu rejonowego, przy którym działa komornik, jest uprawniony tylko do rozpoznawania skarg i zażaleń niestanowiących przedmiotu rozpoznania sądu w trybie skargi na czynności komornika z art. 767 k.p.c. ${ }^{9}$. Nadzór prezesa sądu rejonowego nad działalnością komornika nie może więc wkraczać w działania komornika podlegające nadzorowi sądu, czyli w czynności egzekucyjne, innymi słowy, nie może polegać na weryfikacji zasadności tych czynności ani ich zgodności z prawem. Zakres nadzoru administracyjnego prezesa sądu rejonowego ograniczony został do oceny szybkości, sprawności i rzetelności postępowania, kontroli prawidło-

$9 \quad$ Art. 767. \$1. Na czynności komornika przysługuje skarga do sądu rejonowego, jeżeli ustawa nie stanowi inaczej. Dotyczy to także zaniechania przez komornika dokonania czynności. Do rozpoznania skargi na czynności komornika właściwy jest sąd, przy którym działa komornik. Jeżeli do prowadzenia egzekucji został wybrany komornik poza właściwościa ogólną, skarge rozpoznaje sąd, który byłby właściwy według ogólnych zasad.

$\$ 11$. Skarga nie przysługuje na zarzadzenie komornika o wezwaniu do usunięcia braków pisma, na zawiadomienie o terminie czynności oraz na uiszczenie przez komornika podatku od towarów i ustug.

$\$ 2$. Skargę może złożyć strona lub inna osoba, której prawa zostały przez czynności lub zaniechanie komornika naruszone bądź zagrożone.

$\$ 3$. Skarga na czynność komornika powinna czynić zadość wymaganiom pisma procesowego oraz określać zaskarżona czynność lub czynność, której zaniechano, jak również wniosek o zmianę, uchylenie lub dokonanie czynności wraz z uzasadnieniem.

$\$ 4$. Skarge wnosi się $w$ terminie tygodniowym od dnia dokonania czynności, gdy strona lub osoba, której prawo zostało przez czynność komornika naruszone bądź zagrożone, była przy czynności obecna lub była o jej terminie zawiadomiona; $w$ innych przypadkach - od dnia zawiadomienia o dokonaniu czynności strony lub osoby, której prawo zostało przez czynność komornika naruszone bądź zagrożone, a w braku zawiadomienia - od dnia powzięcia wiadomości przez skarżącego o dokonanej czynności. Skarge na zaniechanie przez komornika dokonania czynności wnosi się $w$ terminie tygodniowym od dnia, w którym skarżacy dowiedział się, że czynność miała być dokonana.

$\$ 5$. Skarge wnosi się do komornika, który dokonał zaskarżonej czynności lub zaniechał jej dokonania. Komornik $w$ terminie trzech dni od dnia otrzymania skargi sporzadza uzasadnienie zaskarżonej czynności, o ile nie zostało ono sporzadzone wcześniej, albo przyczyn jej zaniechania i przekazuje je wraz ze skarga i aktami sprawy do właściwego sąu, chyba że skarge w całości uwzględnia. O uwzględnieniu skargi komornik zawiadamia skarżącego oraz zainteresowanych, których uwzględnienie skargi dotyczy. 
wości prowadzenia biurowości i rachunkowości kancelarii komorniczej i kultury pracy komornika ${ }^{10}$.

Podstawowym środkiem zaskarżenia w postępowaniu egzekucyjnym jest skarga na czynności komornika, która zarazem stanowi środek nadzoru sądu nad komornikiem z art. 767 k.p.c. Służy ona, co do zasady, na wszelkie czynności komornika - rozstrzygające i faktyczne - oraz na zaniechanie dokonania przez niego czynności. Natomiast Minister Sprawiedliwości sprawuje nadzór administracyjny. Według A. Marciniaka ${ }^{11}$ nadzór zwierzchni Ministra Sprawiedliwości nad działalnością komorników sądowych i organów samorządu komorniczego nie jest jednolity i należy wyróżnić dwa rodzaje tegoż nadzoru - nadzór ogólny, którego przejawem są regulacje zawarte w art. 66 ust. 1 i $3^{12}$, art. 67 ust. 2 i $3^{13}$, art. 68 ust. $1^{14}$, art. $69^{15}$ ustawy o komornikach oraz nadzór szczególny na pod-

10 M. Dziewulska, Komentarz do art. 3 ustawy [w:] Ustawa o komornikach sadowych i egzekucji. Komentarz, red. J. Świeczkowski, 2012, LEX.

11 Idem, Nadzór nad komornikiem według ustawy o komornikach sądowych i egzekucji [w:] Analiza i ocena ustawy o komornikach sądowych i egzekucji, red. K. Lubiński, Sopot 2000, s. 164.

12 Art. 66 ust. 1. Komornik jest obowiązany złożyć przed dniem 1 lutego każdego roku roczne sprawozdanie ze swojej działalności. (...)

3. Minister Sprawiedliwości, po zasięgnięciu opinii Krajowej Rady Komorniczej, określi, $w$ drodze rozporządzenia, zakres sprawozdania, o którym mowa $w$ ust. 1, biorąc pod uwage, że dane wskazywane w sprawozdaniu powinny stworzyć odpowiednie warunki do oceny stanu egzekucji w obszarze właściwości sądu apelacyjnego, w szczególności pod kątem sprawności i skuteczności egzekucji oraz występujących tendencji w zakresie ruchu spraw egzekucyjnych.

13 Art. 67 ust. 2. Krajowa Rada Komornicza przedkłada Ministrowi Sprawiedliwości uchwały i protokoły walnych zgromadzeń izb komorniczych oraz Krajowego Zjazdu Komorników, a także własne sprawozdanie roczne wraz z bilansem, $w$ terminie dwóch tygodni od dnia ich otrzymania lub sporzadzenia.

3. Minister Sprawiedliwości może zażadać, w razie potrzeby, od Prezesa Krajowej Rady Komorniczej i rad izb komorniczych również innych dokumentów niż określone w ust. 2. 4. Rada izby komorniczej przekazuje prezesowi właściwego sąu okręowego odpisy protokołów wizytacji, wniosków i poleceń powizytacyjnych, o których mowa w ust. 1 .

14 Art. 68 ust. 1. Minister Sprawiedliwości może zwrócić się do Sądu Najwyższego z wnioskiem o uchylenie uchwały samorzadu komorniczego sprzecznej z prawem $w$ terminie 6 miesięcy od dnia jej otrzymania.

15 Art. 69. Minister Sprawiedliwości, po zasięgnięciu opinii Krajowej Rady Komorniczej określi, $w$ drodze rozporzadzenia, szczegółowe przepisy o biurowości i ewidencji operacji finansowych kancelarii komorniczych. W rozporządzeniu należy uwzględnić potrzeby szczegółowej ewidencji spraw prowadzonych $w$ kancelarii, uwidocznienia przebiegu czynności, zapewnienia przejrzystości wpisów oraz odzwierciedlenia wszystkich operacji finansowych dokonywanych przez komornika, a także stwarzania możliwości kontroli poprawności dokonywanych operacji finansowych. 
stawie art. 64 ust. $2^{16}$ ustawy o komornikach, a podział ten należy uzasadnić m.in. różnym charakterem czynności i środków w ramach nadzoru stosowanego przez Ministra Sprawiedliwości.

Minister Sprawiedliwości w ramach nadzoru nad działalnością komorników sądowych uprawniony jest również do oceny zgodności z prawem czynności podjętych przez komornika w zakresie niezbędnym do korzystania przez Ministra Sprawiedliwości z przyznanych mu uprawnień ustawowych, takich jak możliwość: odwołania komornika z zajmowanego stanowiska z powodu rażącego lub uporczywego naruszenia przepisów prawa, zawieszenia komornika w czynnościach czy wystąpienia $\mathrm{z}$ wnioskiem o wszczęcie postępowania dyscyplinarnego wobec komornika, opartego na zarzucie rażącej obrazy przepisów prawa.

Minister Sprawiedliwości nie jest natomiast uprawniony do zmiany, uchylenia lub nakazania komornikowi podjęcia wskazanych czynności egzekucyjnych, określonych w przepisach ustawy - Kodeks postępowania cywilnego. Tego rodzaju ingerencja w działalność komorników w postępowaniu egzekucyjnym jest możliwa jedynie przez sąd $\mathrm{w}$ ramach sprawowania nadzoru judykacyjnego, z wykorzystaniem prawem przewidzianych środków, w szczególności wskutek uwzględnienia przez sąd skargi na czynności komornika, wnoszonej i rozpatrywanej w trybie przepisów art. 767 k.p.c. Taką skargę może wnieść nie tylko strona postępowania egzekucyjnego, ale również inna osoba, której prawa zostały przez czynności lub zaniechanie komornika naruszone bądź zagrożone. Nadto, zgodnie $\mathrm{z}$ art. $759 \$ 2^{17}$ k.p.c., sąd może z urzędu wydawać komornikowi zarządzenia zmierzające do zapewnienia należytego wykonania egzekucji oraz usuwać spostrzeżone uchybienia. Czynności sądu na podstawie powyższego przepisu mogą być podejmowane na wniosek, a nawet $\mathrm{z}$ urzędu po zasygnalizowaniu sądowi potrzeby rozważenia wdrożenia nadzoru przewidzianego w tym przepisie.

5. Kwestie związane z problematyką podejmowania interwencji poselskich i senatorskich u komorników były przedmiotem następujących interpelacji i oświadczeń:

- interpelacja poselska nr 23121/VI kad. w sprawie uchylania się komorników sądowych od odpowiedzi na interwencję poselską, na przykładzie komornika sądowego w S., w odpowiedzi na którą skonstatowano, że z treści art. 20 ust. 1 i 2 ustawy o wykonywaniu mandatu niewątpliwie wynika prawo posła i senatora do podjęcia interwencji, ale wyłącznie we wskazanych w powołanym przepisie podmiotach, wśród których ustawodawca nie wymienił komornika; zgodnie z literalną wykładnią powyższego przepisu komornik nie ma zatem

16 Art. 64 ust. 2. Nadzór nad działalnościa komorników sprawuje Minister Sprawiedliwości przez prezesów sądów okręgowych, sędziów-wizytatorów, a w zakresie kontroli finansowej-przez osoby upoważnione.

17 Art. 759 \$2. Sąd może z urzędu wydawać komornikowi zarządzenia zmierzające do zapewnienia należytego wykonania egzekucji oraz usuwać spostrzeżone uchybienia. 
obowiązku udzielania odpowiedzi na interwencje składane przez parlamentarzystów,

- interpelacja nr 7910/VII kad. w sprawie zablokowania przez komornika sprzedaży gruntu należącego do petenta, gdzie z kolei w odpowiedzi wskazano, że z uwagi na charakter nadzoru nad działalnością komorników sądowych Minister Sprawiedliwości nie podejmie interwencji w sprawie egzekucyjnej wskazanej przez posła; zgodnie bowiem z art. 64 ust. 1 i 2 ustawy o komornikach sądowych i egzekucji Minister Sprawiedliwości sprawuje nad działalnością komorników sądowych nadzór administracyjny, który sprowadza się do badania szybkości i sprawności postępowania egzekucyjnego oraz kultury urzędowania i etycznych aspektów działalności komornika, a w szczególności do badania, czy nie zachodzi nieuzasadniona przewlekłość w podejmowaniu czynności; nadzór ten nie może wkraczać w działania podlegające nadzorowi sądu; Minister Sprawiedliwości nie jest uprawniony do uchylenia, zmiany lub nakazania komornikowi podjęcia określonych czynności egzekucyjnych; tego rodzaju działania wobec komornika może podjąć wyłącznie niezawisły sąd w drodze nadzoru judykacyjnego uregulowanego w przepisach Kodeksu postępowania cywilnego m.in. poprzez wydawanie komornikowi z urzędu zarządzeń zmierzających do zapewnienia należytego wykonania egzekucji oraz usuwanie spostrzeżonych uchybień (art. $759 \$ 2$ k.p.c.),

- oświadczenie senatora S.G. z 10 maja 2012 r. (VII kad.) w sprawie uchylania się przez komornika sądowego od odpowiedzi na interwencję senatora podjętą w trybie art. 20 ust. 1 i 2 ustawy; w odpowiedzi udzielonej przez podsekretarza stanu w Ministerstwie Sprawiedliwości zwrócono uwagę, że w przypadku skierowania do komornika interwencji posła lub senatora powinien on niezwłocznie przekazać ją sprawującemu zwierzchni nadzór nad komornikami Ministrowi Sprawiedliwości i o tym fakcie zawiadomić parlamentarzystę,

- interpelacja nr 15230/VIII kad. w sprawie nieudzielania odpowiedzi przez komorników sądowych na interwencje posłów i senatorów, gdzie wskazano, że komornicy sądowi określani w orzecznictwie Trybunału Konstytucyjnego jako „pomocniczy organ wymiaru sprawiedliwości” nie należą do żadnej z kategorii podmiotów obowiązanych, wymienionych w art. 20 ust. 1 ustawy o wykonywaniu mandatu; trzeba jednak zauważyć, że Minister Sprawiedliwości sprawujący w granicach art. 64 ust. 1 ustawy o komornikach zwierzchni administracyjny nadzór nad działalnością komorników sądowych, należy do organów wymienionych tak w art. 16 ust. 1, jak i w art. 20 ust. 1 ustawy o wykonywaniu mandatu. Korzystając z przysługujących mu kompetencji do żądania od komorników stosownych informacji, Minister Sprawiedliwości przeprowadza postępowanie wyjaśniające we własnym zakresie i udziela odpowiedzi na kierowane do niego interwencje parlamentarzystów również w zakresie dotyczącym postępowań egzekucyjnych. 


\section{Podsumowanie}

Poseł nie może podjąć interwencji u komornika sądowego, bowiem art. 20 ustawy o wykonywaniu mandatu posła i senatora nie przewiduje takiego uprawnienia.

Interwencja w sprawie działań komornika może być skierowana przez posła do Ministra Sprawiedliwości, jako organu sprawującego nadzór zwierzchni nad działalnością komorników i działalnością samorządu komorniczego.

\section{Bibliografia}

Barańska A., Status prawny komornika sądowego i mienia kancelarii komorniczej, „Przegląd Prawa Egzekucyjnego" 2008, nr 1-2.

Bieżuński M., Bieżuński P., Ustawa o komornikach sądowych i egzekucji. Komentarz, 2010, LEX, komentarz do art. 1.

Dziewulska M., Komentarz do art. 3 ustawy [w:] Ustawa o komornikach sadowych i egzekucji. Komentarz, red. J. Świeczkowski, 2012, LEX.

Dziewulska M., Nadzór nad komornikiem według ustawy o komornikach sadowych i egzekucji [w:] Analiza i ocena ustawy o komornikach sądowych i egzekucji, red. K. Lubiński, Sopot 2000.

Machnikowska A., Komentarz do art. 1 [w:] Ustawa o komornikach sadowych i egzekucji. Komentarz, red. J. Świeczkowski, 2012, LEX.

Poślednik M., Interwencja poselska $z$ art. 20 ust. 1 ustawy o wykonywaniu mandatu posła i senatora, „Przegląd Sejmowy”, 2010, nr 3.

Tomalak W., Status ustrojowy i procesowy komornika sądowego, 2014, LEX.

Uziębło P. [w:] Komentarz do ustawy o wykonywaniu mandatu posła i senatora, red. K. Grajewski, Warszawa 2014. 
Wojciech Odrowąż-Sypniewski

\section{Tryb zwoływania posiedzeń komisji sejmowych ${ }^{1}$}

The procedure for convening sittings of Sejm committees: The power of the presidium of the committee to determine the agenda of a committee sitting is limited only in two cases - a minority request to convene a sitting and an initiative of the Presidium of the Sejm. The chairperson of the committee establishes the agenda of the committee meeting only in the case in which he executes the minority's request. No provision of the Standing Orders of the Sejm I allows the chairman of the committee to set the agenda for a committee meeting without the involvement the presidium of the committee. Producing minutes documenting a sitting of the presidium is not required, nor there are any procedural requirements regarding the rules for convening these sittings.

Keywords: parliamentary committee | Standing Orders of the Sejm

Słowa kluczowe: komisja sejmowa | regulamin Sejmu

Ekspert ds. legislacji BAS; wojciech.sypniewski@sejm.gov.pl.

\section{Przedmiot opinii}

Przedmiotem opinii jest odpowiedź na pytania dotyczące trybu zwoływania posiedzeń komisji sejmowych. Sygnalizowane wątpliwości zostały wyrażone w następujących pytaniach:

- czy regulamin Sejmu (lub inne przepisy) wprowadzają wymóg sporządzania protokołu/sprawozdania z posiedzenia prezydium komisji?

- czy błędem jest zwołanie posiedzenia komisji przez przewodniczącego bez uprzedniego ustalenia $\mathrm{z}$ prezydium komisji?

1 Opinia prawna w sprawie trybu zwoływania posiedzeń komisji sejmowych sporządzona 25 lipca 2017 r. na zlecenie Klubu Parlamentarnego Prawo i Sprawiedliwość; BAS-WAKiU 1491/17. 


\section{Organizacja prac komisji sejmowej}

Organem kierowniczym komisji sejmowej - w sensie organizacyjnym - jest prezydium komisji. Stosownie do art. 150 ust. 1 regulaminu Sejmu: [p] rezydium komisji kolegialnie kieruje pracami komisji, a w szczególności: 1) opracowuje projekty planów pracy komisji, 2) ustala terminy i porządek dzienny posiedzeń, 3) czuwa nad przygotowaniem posiedzeń, 4) zapewnia członkom komisji otrzymywanie $w$ odpowiednim czasie należycie przygotowanych materiałów, 5) wyznacza sprawozdawców (referentów) na posiedzenia komisji.

W przyjętym w regulaminie Sejmu modelu normatywnym kompetencja prezydium komisji nie ogranicza się tylko do określenia terminów posiedzeń i ich porządków dziennych. Uprawnienie to koresponduje bowiem z innymi regulaminowymi zadaniami tego organu. Obowiązek określania planu pracy komisji stanowić ma gwarancję takiego trybu działania, w którym prace komisji prowadzone są w sposób uporządkowany i przemyślany. „Plan pracy” służy wyznaczeniu kolejnych etapów działań komisji oraz sposobu dochodzenia do zamierzonego rezultatu. Projekt przygotowany przez prezydium komisji winien uwzględniać sugestie tych członków, którzy nie zasiadają w prezydium (stosownie do art. 150 ust. 2 regulaminu Sejmu prezydium komisji, opracowując projekty planów pracy komisji oraz ustalając porządek dzienny posiedzenia, zobowiązane jest brać pod uwagę „wnioski klubów i kół poselskich oraz poszczególnych posłów”). Obowiązek przygotowania planu pracy komisji wiąże się z kompetencją do „wyznaczenia sprawozdawców (referentów) na posiedzenia komisji”. Prawo wyznaczenia referentów na poszczególne posiedzenia komisji widzieć należy w powiązaniu z planem pracy, zakładającym realizację celów cząstkowych. Innymi słowy, chodzi o to, że poszczególnym członkom komisji prezydium może powierzyć merytoryczne przygotowanie konkretnych zagadnień, które rozpatrywane są przez komisję. Działania prezydium w tym zakresie - z natury rzeczy - nie mają charakteru władczego. „Wyznaczenie referenta” dla swojej skuteczności musi zyskać zarówno akceptację osoby „wyznaczonej”, jak i aprobatę większości członków komisji.

Prezydium komisji odpowiada także za organizacyjno-techniczne przygotowanie pracy komisji. Domenę działań prezydium wyznacza nakaz czuwania nad przygotowaniem posiedzeń i obowiązek zapewnienia członkom komisji otrzymywania $w$ odpowiednim czasie należycie przygotowanych materiałów. Obok omówionych wyżej uprawnień wiążących się ściśle ze sprawami organizacyjnymi prezydium komisji przysługują również kompetencje zewnętrzne. Zgodnie $\mathrm{z}$ art. 150 ust. 4 regulaminu Sejmu prezydium komisji może zwrócić się do właściwych organów, instytucji i organizacji o przedstawienie stanowiska w sprawie wniosku lub uwagi wypowiedzianej przez posła w toku posiedzenia komisji. Ponadto na żądanie prezydium komisji ministrowie oraz kierownicy naczelnych organów administracji państwowej, a także kierownicy innych urzędów i instytucji 
państwowych są obowiązani przedstawiać sprawozdania i udzielać informacji oraz uczestniczyć w posiedzeniach komisji, na których rozpatrywane są sprawy dotyczące ich zakresu działania (art. 153 ust. 1 regulaminu Sejmu). Prezydium komisji zobowiązane jest również informować Prezydium Sejmu o przebiegu prac komisji (art. 150 ust. 3).

Istota wątpliwości wnioskodawcy wiąże się z uprawnieniem do ustalania przez prezydium komisji terminów i porządków dziennych posiedzeń komisji (art. 150 ust. 1 pkt 2 regulaminu Sejmu). Realizując tę kompetencję, prezydium powinno brać pod uwagę wnioski klubów i kół poselskich oraz poszczególnych posłów (art. 150 ust. 2). Od powyższych zasad regulamin przewiduje dwa wyjątki. Po pierwsze, Prezydium Sejmu może zwołać posiedzenie komisji w celu rozpatrzenia określonej sprawy, wyznaczając jego termin. Posiedzeniu zwołanemu w tym trybie może przewodniczyć Marszałek Sejmu (art. 152 ust. 3 regulaminu Sejmu). Po drugie, na pisemny wniosek co najmniej 1/3 ogólnej liczby członków komisji przewodniczący komisji obowiązany jest zwołać posiedzenie komisji w celu rozpatrzenia określonej sprawy. Zwołując posiedzenie w tym trybie, przewodniczący komisji wyznacza termin posiedzenia tak, aby odbyło się ono w terminie 30 dni od dnia złożenia wniosku (art. 152 ust. 2).

Od pojęcia „kierowania pracami” komisji odróżnić należy „kierowanie obradami komisji”. Uprawnienie to - w myśl art. 151 ust. 3 regulaminu Sejmu - przysługuje przewodniczącemu komisji, a w razie jego nieobecności - jego zastępcy. Przyjęty w regulaminie Sejmu model dystrybucji kompetencji kierowniczych w komisjach sejmowych wskazuje, że przewodniczącemu powierzone zostały wyłącznie obowiązki związane z prowadzeniem obrad komisji oraz zwoływaniem posiedzeń komisji. Przewodniczący komisji, obok prezydium i komisji in corpore, uczestniczy w ustalaniu terminów posiedzeń komisji (art. 152 ust. 1 i 2). Do obowiązków przewodniczącego należy również formalna czynność zwołania posiedzenia, z czym wiąże się obowiązek zawiadomienia jego uczestników o terminie i porządku dziennym posiedzenia. Zgodnie z art. 152 ust. 5 regulaminu Sejmu przewodniczący komisji zobowiązany jest zawiadomić w imieniu komisji o terminie i porządku dziennym posiedzenia wszystkich członków komisji, Prezydium Sejmu oraz właściwe (zainteresowane) organy państwowe. Zawiadomienie powinno nastąpić co najmniej na trzy dni przed posiedzeniem komisji na zasadach określonych przez Prezydium Sejmu i w trybie określonym przez ten organ. Ponadto przewodniczący komisji ma obowiązek zawiadomić Marszałka Sejmu o terminie i porządku dziennym planowanego posiedzenia, który może nie wyrazić zgody na jego odbycie (art. 152 ust. 4 regulaminu Sejmu).

Relacja między art. 150 ust. 1 pkt 2 oraz art. 152 ust. 1-3 wskazuje, że monopol prezydium komisji w zakresie ustalenia porządku dziennego posiedzenia komisji doznaje ograniczeń jedynie w dwóch omówionych wyżej sytuacjach (wniosek mniejszości o zwołanie posiedzenia oraz inicjatywa Prezydium Sejmu). Przewodniczący komisji samodzielnie ustala porządek dzienny posiedzenia ko- 
misji wyłącznie w przypadku, w którym realizuje wniosek mniejszości. Również w takim wypadku swoboda działań przewodniczącego związana jest obowiązkiem realizacji celu ujętego we wniosku mniejszości „rozpatrzenie określonej sprawy"). Żaden inny przepis regulaminu Sejmu nie pozwala przewodniczącemu komisji na określanie porządku dziennego posiedzenia komisji z pominięciem prezydium komisji.

Odpowiedź na drugie pytanie sformułowane we wstępie niniejszej opinii wiąże się z kwestią dokumentowania ustaleń podjętych przez prezydium komisji. Regulamin Sejmu nie wymaga w tym zakresie sporządzania protokołu z posiedzenia prezydium, jak również nie formułuje żadnych wymogów proceduralnych dotyczących zasad zwoływania tych posiedzeń poza ogólną zasadą odnoszącą się do trybu, w którym prezydium komisji dokonuje swoich rozstrzygnięć. W myśl art. 150 ust. 5 regulaminu Sejmu prezydium podejmuje uchwały większością głosów, a w razie równej liczby głosów decyduje głos przewodniczącego. Nie ma zatem formalnych przeszkód, aby rozstrzygnięcia prezydium komisji dokonywane były w trybie odformalizowanym przy założeniu zachowania wymogów wynikających $\mathrm{z}$ art. 150 ust. 5 .

Rekonstrukcja normatywnego modelu organizacji prac komisji sejmowych, który wyłania się z przepisów regulaminu Sejmu, nie byłaby pełna bez uwag odnoszących się do praktyki parlamentarnej. Trudno bowiem nie dostrzec, że na przestrzeni kilku ostatnich kadencji Sejmu zasada kolegialnego kierownictwa prac komisji podlegała istotnej deprecjacji. Rosnąca dynamika działań komisji sejmowych i konieczność sprawnego reagowania na wydarzenia parlamentarne powoduje, że przewodniczący komisji w praktyce odgrywają daleko większą rolę niż ta, która zarysowana została w przepisach regulaminu Sejmu. Przewodniczący komisji uczestniczą w realizacji obowiązku organizacji prac komisji w zakresie, który nie znajduje uzasadnienia normatywnego. W wielu wypadkach podejmowane przez nich ad hoc rozstrzygnięcia dopiero ex post zyskują aprobatę większości członków prezydium komisji. Rozbieżności między praktyką i modelem opisanym w regulaminie Sejmu nie stanowią jednak przesłanki, która uzasadniać może odstąpienie od jednoznacznych założeń normatywnych. Natomiast świadomość tej rozbieżności dać powinna impuls dla rozważenia celowości dokonania zmian w regulaminie Sejmu.

\section{Podsumowanie}

- Relacja między art. 150 ust. 1 pkt 2 oraz art. 152 ust. 1-3 regulaminu Sejmu wskazuje, że monopol prezydium komisji w zakresie ustalenia porządku dziennego posiedzenia komisji doznaje ograniczeń jedynie $\mathrm{w}$ dwóch wypadkach (wniosek mniejszości o zwołanie posiedzenia - art. 152 ust. 2 oraz inicjatywa prezydium Sejmu - art. 152 ust. 3). Przewodniczący komisji 
samodzielnie ustala porządek dzienny posiedzenia komisji wyłącznie wtedy, kiedy realizuje wniosek mniejszości. Również w takiej sytuacji jego swoboda związana jest obowiązkiem realizacji celu ujętego we wniosku mniejszości („rozpatrzenie określonej sprawy”). Żaden inny przepis regulaminu Sejmu nie pozwala przewodniczącemu komisji na określanie porządku dziennego posiedzenia komisji z pominięciem prezydium komisji.

- Regulamin Sejmu nie wymaga sporządzania protokołu z posiedzenia prezydium, jak również nie formułuje żadnych wymogów proceduralnych dotyczących zasad zwoływania tych posiedzeń, poza ogólną zasadą odnoszącą się do trybu, w którym prezydium komisji dokonuje swoich rozstrzygnięć (art. 150 ust. 5). Nie ma zatem formalnych przeszkód, aby rozstrzygnięcia prezydium komisji dokonywane były w trybie odformalizowanym przy założeniu zachowania wymogów wynikających z art. 150 ust. 5 regulaminu Sejmu. 
2

OPINIE BAS

E

VARIA 



\title{
Dopuszczalność uznania środków finansowych pobieranych przez wojewódzką stację sanitarno- -epidemiologiczną z tytułu zawartych umów z innymi wojewódzkimi stacjami sanitarno- -epidemiologicznymi na wykonywanie badań porównawczych za dochód budżetu państwa ${ }^{1}$
}

\begin{abstract}
Admissibility of recognizing, as an income of the state budget, financial resources charged by the Voivodship Sanitary and Epidemiological Station under contracts concluded with other Voivodship Sanitary and Epidemiological Stations (VSES) for conducting comparative tests: Sanitary and epidemiological stations collect fees from controlled entities within the jurisdiction of individual authorities of the State Sanitary Inspection. They can also raise funds from the sale of commissioned services. Funds from services provided by stations constitute state budget revenues. There are no obstacles to inclusion in the scope of these services of comparative tests performed for other VSES under cooperation agreements, in order to jointly implement the necessary research, provided that the execution of these tests can be considered as "sale of commissioned services".
\end{abstract}

Keywords: state budget | income | budgetary unit

Słowa kluczowe: budżet państwa | dochód | jednostka budżetowa

Doktor hab. nauk prawnych, profesor Uniwersytetu Łódzkiego; hdzwonkowski@poltax.pl.

\section{Przedmiot opinii}

Opinia dotyczy odpowiedzi na pytanie: czy pobierane przez wojewódzką stację sanitarno-epidemiologiczną środki finansowe z tytułu zawartych umów z innymi wojewódzkimi stacjami sanitarno-epidemiologicznymi na wykonywanie badań porównawczych stanowią dochód budżetu państwa?

1 Opinia prawna w przedmiocie dopuszczalności uznania środków finansowych pobieranych przez wojewódzka stację sanitarno-epidemiologiczna z tytułu zawartych umów $z$ innymi wojewódzkimi stacjami sanitarno-epidemiologicznymi na wykonywanie badań porównawczych za dochód budżetu państwa sporządzona 2 lutego 2018 r. na zlecenie Klubu Parlamentarnego Platforma Obywatelska; BAS-WASiE 98/18. 


\section{Analiza prawna zagadnienia}

Główny Inspektor Sanitarny, przy współdziałaniu z właściwymi jednostkami, opracowuje co roku „Plan pobierania próbek do badania żywności w ramach urzędowej kontroli i monitoringu". Plan ów obejmuje urzędową kontrolę i monitoring żywności pochodzenia niezwierzęcego, produkowanej i wprowadzanej do obrotu oraz produktów pochodzenia zwierzęcego znajdujących się w handlu detalicznym. Nadzór nad realizacją zadań określonych w rocznym planie pobierania próbek i badania żywności w województwie pełnią państwowi wojewódzcy inspektorzy sanitarni. Stosownie do postanowień art. 15 ust. 1 ustawy z 14 marca 1985 r. o Państwowej Inspekcji Sanitarnej (t.j. Dz.U. 2017, poz. 1261, ze zm.; dalej: u.p.i.s.), państwowy inspektor sanitarny wykonuje zadania przy pomocy podległej mu stacji sanitarno-epidemiologicznej. Stacje sanitarno-epidemiologiczne określone $\mathrm{w}$ wykazie ministra właściwego do spraw zdrowia wykonują badania laboratoryjne $\mathrm{w}$ zakresie nadzoru sanitarnego, działając $\mathrm{w}$ zintegrowanym systemie badań laboratoryjnych i pomiarów (art. 15a ust. 1 u.p.i.s.). Szeroki zakres badanych w żywności parametrów fizykochemicznych i mikrobiologicznych spowodował konieczność specjalizacji poszczególnych wojewódzkich stacji sanitarno-epidemiologicznych (dalej: WSSE) w wybranych dziedzinach badań, np. jedna z WSSE wykonuje badania żywności w zakresie obecności organizmów GMO dla kilku innych WSSE, które badań w tym zakresie nie wykonują. Podstawę zaś do takiego działania stanowią umowy, które poszczególne WSSE zawarły między sobą w ramach współpracy, w celu spójnej realizacji koniecznych badań. W rezultacie realizacji tych umów poszczególne WSSE uzyskują środki od innych WSSE, na rzecz których wykonują badania. W świetle powyższego pojawiła się wątpliwości w kwestii dotyczącej tego, czy środki pozyskane w opisany sposób przez WSSE stanowią dochód budżetu państwa.

W tym zakresie należy w pierwszej kolejności odnieść się do art. 36 u.p.i.s., regulującego zasady pobierania opłat w związku $\mathrm{z}$ działaniami podejmowanymi przez organy Państwowej Inspekcji Sanitarnej, w tym m.in. za badania laboratoryjne oraz inne czynności wykonywane przez organy Państwowej Inspekcji Sanitarnej w związku ze sprawowaniem bieżącego i zapobiegawczego nadzoru sanitarnego, za czynności związane ze sprawdzeniem danych podanych we wniosku o wydanie zezwolenia na prowadzenie zakładu inżynierii genetycznej, za czynności związane $\mathrm{z}$ wydaniem oceny o kosmetykach przywożonych $\mathrm{z}$ zagranicy $\mathrm{w}$ celu wprowadzenia do obrotu lub produkcji. Z kolei wysokość opłat za badania laboratoryjne i inne czynności, o których mowa w art. 36 ust. 1 u.p.i.s., związane z czynnościami wykonywanymi w ramach urzędowych kontroli żywności oraz materiałów i wyrobów przeznaczonych do kontaktu z żywnością określają przepisy o bezpieczeństwie żywności i żywienia (art. 75 ustawy z 25 sierpnia 2006 r. o bezpieczeństwie żywności i żywienia, t.j. Dz.U. 2017, poz. 149). We wskazanych przepisach mowa jest o opłatach pobieranych od podmiotów kontrolowanych w ramach właściwo- 
ści poszczególnych organów Państwowej Inspekcji Sanitarnej. Jednocześnie, niezależnie od opisanych wyżej opłat, o których mowa w art. 36 ust. 1-3a u.p.i.s., stacje sanitarno-epidemiologiczne mogą pozyskiwać środki finansowe z tytułu sprzedaży usług zleconych (art. 36 ust. 3b), w szczególności w zakresie:

- badań laboratoryjnych, badań i pomiarów środowiskowych i innych czynności dotyczących oceny jakości zdrowotnej i bezpieczeństwa zdrowotnego,

- prowadzenia szkoleń i egzaminów oraz wykonywania ocen zdrowotnych.

Zgodnie z treścią art. 36 ust. 3c u.p.i.s. środki pochodzące $\mathrm{z}$ wykonywanych przez stacje sanitarno-epidemiologiczne usług, o których mowa w ust. 3b, stanowią dochody budżetu państwa. Artykuł 36 ust. 3b u.p.i.s. dopuszcza zatem nie tylko możliwość wykonywania przez WSSE działań związanych z czynnościami kontrolnymi podejmowanymi wobec podmiotów kontrolowanych (art. 36 ust. 1-3a u.p.i.s.) przez właściwego wojewódzkiego państwowego inspektora sanitarnego, ale także sprzedaż usług innym podmiotom. Znajduje to potwierdzenie w uzasadnieniu do projektu nowelizacji ustawy o Państwowej Inspekcji Sanitarnej $^{2}$, mocą której - z dniem 1 stycznia 2011 r. - został dodany art. 26 ust. 3b. Jak wynika z owego uzasadnienia, wprowadzenie do ustawy o Państwowej Inspekcji Sanitarnej ust. 3b w art. 36 ma na celu umożliwienie: stacjom sanitarno-epidemiologicznym pozyskiwania dodatkowych środków finansowych z tytułu działalności usługowej na rzecz podmiotów zewnętrznych przeznaczonych na realizację zadań Państwowej Inspekcji Sanitarnej [...]. Jednocześnie, należy mieć na uwadze, że katalog usług zleconych, które mogą być przedmiotem sprzedaży, nie jest zamknięty. Jak trafnie wskazuje się w doktrynie: [w]yliczenie usług zleconych ma charakter przykładowy ${ }^{3}$ [...], a zatem w gre moga wchodzić jeszcze inne usługi mieszczace się $w$ zakresie kompetencji stacji sanitarno-epidemiologicznych ${ }^{4}$.

Jeżeli zatem nie byłoby możliwe zaliczenie środków otrzymywanych przez WSSE od innych WSSE do kategorii środków, o których mowa w art. 36 ust. 1-3a u.p.i.s., wówczas - wobec otwartego katalogu działań mogących być przedmiotem świadczonych usług, o których mowa w art. 36 ust. 3b u.p.i.s. - nie byłoby przeszkód, by w zakres tych usług wchodziły także badania porównawcze wykonywane na rzecz innych WSSE w ramach zawartych umów o współpracę, w celu wspólnej realizacji koniecznych badań, pod warunkiem że wykonywanie tych badań można uznać za „sprzedaż usług zleconych”.

Odnosząc się do pierwszego zagadnienia, a zatem możliwości kwalifikacji otrzymanych środków, jako opłat, o których mowa w art. 36 ust. 1-3a u.p.i.s., na-

2 Ustawa z 27 sierpnia 2009 r. - Przepisy wprowadzające ustawę o finansach publicznych, Dz.U. nr 157, poz. 1241, ze zm.

3 Zob. zwrot „W szczególności”.

4 M. Kaczocha, Ustawa o Państwowej Inspekcji Sanitarnej, 2017, LEX, komentarz do art. 36. 
leży mieć na uwadze, że badania wykonywane przez WSSE na rzecz innej WSSE nie są badaniami wykonywanymi przez konkretną WSSE w ramach kontroli prowadzonej przez państwowego wojewódzkiego inspektora sanitarnego (który wykonuje zadania w zakresie swojej właściwości przy pomocy podległej mu WSSE). WSSE działała bowiem w tym zakresie poza obszarem właściwości wojewódzkiego państwowego inspektora sanitarnego, którego aparat pomocniczy stanowi. Stosownie do postanowień art. 37 ust. 1 u.p.i.s. w postępowaniu przed organami Państwowej Inspekcji Sanitarnej stosuje się przepisy ustawy z 14 czerwca 1960 r. Kodeks postępowania administracyjnego (t.j. Dz.U. 2017, poz. 1257, ze zm.; dalej: k.p.a.), w tym przepisy dotyczące właściwości miejscowej, chyba że ustawy szczególne stanowią inaczej. W tym zakresie, ani przepisy ustawy o Państwowej Inspekcji Sanitarnej, ani ustawy z 25 sierpnia 2006 r. o bezpieczeństwie żywności i żywienia (t.j. Dz.U. 2017, poz. 149, ze zm.) nie przewidują szczególnych uregulowań w sprawie właściwości miejscowej, stąd zasadne jest odpowiednie stosowanie przepisów Kodeksu postępowania administracyjnego. Bezwzględny obowiązek przestrzegania przez organy administracji swojej właściwości w postępowaniu administracyjnym (w tym właściwości miejscowej) wynika wprost z treści art. 19 k.p.a. Właściwość miejscowa wskazuje, który organ właściwy rzeczowo jest władny do rozstrzygania określonej kategorii spraw na danym obszarze kraju. Do ustalenia właściwości miejscowej zastosowanie znajdują natomiast zasady zawarte w art. 21 k.p.a., który w $\$ 1$ pkt 3 wskazuje, że w sprawach innych niż dotyczące nieruchomości lub prowadzenia zakładu pracy, właściwość miejscową organu administracji publicznej ustala się według miejsca zamieszkania (siedziby) w kraju, a w braku zamieszkania w kraju - według miejsca pobytu strony lub jednej ze stron, a jeżeli żadna ze stron nie ma w kraju zamieszkania (siedziby) lub pobytu - według miejsca ostatniego ich zamieszkania (siedziby) lub pobytu w kraju. Reguły przewidziane w art. 21 k.p.a. znajdują przy tym bezpośrednie zastosowanie $\mathrm{w}$ postępowaniach administracyjnych, chyba że przepisy ustaw szczególnych zawierają regulacje określające inne kryteria ustalenia właściwości miejscowej lub na podstawie upoważnienia wynikającego $\mathrm{z}$ takich ustaw właściwość miejscowa organów zostanie inaczej określona w aktach wykonawczych.

Nie znajduje zatem uzasadnienia twierdzenie, że otrzymanie od innej WSSE środków w związku z wykonaniem na jej rzecz badań porównawczych następuje w ramach urzędowej kontroli i monitoringu żywności prowadzonej przez właściwego państwowego wojewódzkiego inspektora sanitarnego. Właściwym miejscowo organem w tym zakresie jest państwowy wojewódzki inspektor sanitarny, który wykonuje zadania w zakresie swojej właściwości przy pomocy podległej mu WSSE, zlecającej w opisywanym przypadku badania innej WSSE. Wykonywane przez WSSE badania na rzecz innej WSSE nie są zatem badaniami wykonywanymi przez konkretną WSSE w ramach realizacji zadań przez właściwego państwowego wojewódzkiego inspektora sanitarnego (którego aparat pomoc- 
niczy stanowi WSSE wykonująca badania), ale czynnościami zleconymi przez WSSE, przy pomocy której zadania w zakresie swojej właściwości wykonuje inny organ Państwowej Inspekcji Sanitarnej. Biorąc pod uwagę także aspekt podmiotowy zagadnienia, nie ulega wątpliwości, że WSSE, wykonująca badania na rzecz innej WSSE, nie pobiera należności bezpośrednio od podmiotów, wobec których inny właściwy organ Państwowej Inspekcji Sanitarnej prowadzi czynności. W konsekwencji, środków otrzymywanych przez WSSE od innego WSSE nie można zaliczać do należności, o których mowa w art. 36 ust. 1-3a u.p.i.s.

W dalszej kolejności należy zbadać, czy podejmowane na rzecz innej WSSE czynności można uznać za sprzedaż usług zleconych (art. 36 ust. 3b u.p.i.s.). Pomocne w stwierdzeniu, czy we wskazanym przypadku zachodzi sprzedaż usług zleconych, jest ustalenie, czy wykonywane działanie ma charakter odpłatny, czy zostało przekazane WSSE do wykonania przez podmiot zewnętrzny, a także czy jest realizowane na jego rzecz, a nie w ramach czynności kontrolnych prowadzonych przez WSSE wykonującą badania.

Odnosząc się do pierwszego z wymienionych warunków w kontekście postawionego problemu, trzeba stwierdzić, że niewątpliwie badania laboratoryjne wykonywane przez poszczególne WSSE dla innych tego rodzaju jednostek mają charakter czynności odpłatnych, ponieważ WSSE otrzymuje w zamian środki od innej WSSE, dla której (zgodnie z umową o współpracę) wykonują określone działania.

Należy też mieć na względzie, że poszczególne WSSE, jako jednostki budżetowe (art. 15 ust. 3 u.p.i.s.), stanowią odrębne, choć pozbawione osobowości prawnej, jednostki organizacyjne. Niewątpliwie, są to podmioty stanowiące aparat pomocniczy poszczególnych organów Państwowej Inspekcji Sanitarnej, działających w ramach jednego systemu. Jednocześnie jednak działania WSSE zostały przekazane do wykonania przez inną WSSE, na podstawie umowy o współpracę. Nie są to zatem, jak już zostało powiedziane, badania wykonywane przez konkretną WSSE w ramach kontroli prowadzonej przez właściwego państwowego wojewódzkiego inspektora sanitarnego (którego aparat pomocniczy stanowi WSSE wykonująca badania), ale czynności zlecone przez WSSE, przy pomocy której zadania w zakresie swojej właściwości wykonuje inny organ Państwowej Inspekcji Sanitarnej. Wobec powyższego zasadne jest przyjęcie, że podejmowane przez WSSE na rzecz innej WSSE czynności, zgodnie z zawartą umową o współpracę można uznać za sprzedaż usług zleconych, o której mowa w art. 36 ust. 3b u.p.i.s.

Niezależnie od powyższej argumentacji, zasadność kwalifikowania pozyskiwanych przez WSSE środków z tytułu wykonania na rzecz innej WSSE badań porównawczych do dochodów budżetu państwa znajduje uzasadnienie także w wykładni systemowej zewnętrznej, poprzez odniesienie się do przepisów ustawy z 27 sierpnia 2009 r. o finansach publicznych (t.j. Dz.U. 2017, poz. 2077, ze zm.; dalej: u.f.p.). W tym kontekście należy podkreślić, że WSSE są jednostkami 
budżetowymi. Stanowią one jednostki organizacyjne sektora finansów publicznych, które nie mają osobowości prawnej. Istota finansowo-organizacyjna jednostki budżetowej osadzona jest $w$ koncepcji, tzw. budżetowania brutto, będącej praktycznym wyrazem realizacji powszechności (zupetności) budżetu. ${ }^{5}$. Wszystkie swoje wydatki pokrywa ona bezpośrednio z budżetu, natomiast wszystkie dochody takiej jednostki odprowadzane są, odpowiednio, albo na rachunek budżetu państwa, albo na rachunek jednostki samorządu terytorialnego (rozliczenie brutto - pełnymi kwotami). Z kolei w art. 111 u.f.p. określony został enumeratywnie wykaz należności stanowiących dochody budżetu państwa. Stosownie do postanowień art. 111 pkt 7 u.f.p. dochodami podatkowymi i niepodatkowymi budżetu państwa są dochody pobierane przez państwowe jednostki budżetowe, o ile odrębne ustawy nie stanowią inaczej. W związku z tym należy przyjąć, że wobec braku postanowień szczególnych w zakresie wyłączenia określonej kategorii należności przypadających WSSE jako dochodów budżetu państwa, wszelkie dochody uzyskiwane przez WSSE, będącą jednostką budżetową, zarówno te, o których mowa w art. 36 ust. 1-3a, jak i w ust. 3b u.p.i.s., a także potencjalne inne dochody mają charakter dochodów budżetowych.

\section{Podsumowanie}

Środki finansowe pobierane przez wojewódzką stację sanitarno-epidemiologiczną z tytułu zawartych umów z innymi wojewódzkimi stacjami sanitarno-epidemiologicznymi na wykonywanie badań porównawczych stanowią dochód budżetu państwa.

\section{Bibliografia}

Kaczocha M., Ustawa o Państwowej Inspekcji Sanitarnej, 2017, LEX, komentarz do art. 36. Smoleń P. [w:] Ustawa o finansach publicznych. Komentarz, Warszawa 2014.

5 P. Smoleń [w:] Ustawa o finansach publicznych. Komentarz, Warszawa 2014, s. 205. 


\title{
Ocena petycji w sprawie zmiany ustawy o ujawnianiu informacji o dokumentach organów bezpieczeństwa państwa z lat 1944-1990 oraz treści tych dokumentów ${ }^{1}$
}

\begin{abstract}
Evaluation of the petition regarding the amendment of the act on disclosure of information on documents of state security autorities from 1944-1990 and the content of these documents: The petition contains a proposal to supplement the subjective catalogue of the lustration act in connection with the entry into force of the Act on the Metropolitan Union in the Śląskie Voivodeship, establishing the authorities forming the organizational structure of the union. The legal nature and scope of tasks of the metropolitan union means that in the doctrine this relationship was called a new institution of a local self-government. Pursuant to the provisions of the lustration act, individuals holding positions in local self-government authorities are subject to the provisions of that act, therefore they should be subject to its obligations. The lack of explicit specification of these individuals in the lustration act raises doubts as to the intentions of the lawgiver. An appropriate amendment to the act would clearly determine the lustration obligation of individuals sitting in the authorities of a metropolitan union.
\end{abstract}

Keywords: lustration | petition | local self-government

Słowa kluczowe: lustracja | petycja | samorząd terytorialny

Doktorant na Wydziale Prawa Kanonicznego UKSW, ekspert ds. oceny skutków regulacji BAS; wioleta.wasil@sejm.gov.pl.

\section{Treść i cel petycji}

Przedmiotem petycji nr 145-303/17 jest żądanie nowelizacji ustawy z 18 października 2006 r. o ujawnianiu informacji o dokumentach organów bezpieczeństwa państwa z lat 1944-1990 oraz treści tych dokumentów (Dz.U. 2017, poz. 2186;

1 Opinia prawna na temat petycji nr 145-303/17 w sprawie zmiany ustawy $z$ dnia 18 października 2006 r. o ujawnianiu informacji o dokumentach organów bezpieczeństwa państwa $z$ lat 1944-1990 oraz treści tych dokumentów sporządzona 30 stycznia $2018 \mathrm{r}$. na zlecenie przewodniczącego Komisji ds. Petycji; BAS-WAP 4/18. 
dalej: ustawa lustracyjna), w zakresie zobowiązania osób pełniących funkcje członków zarządów, skarbników i sekretarzy w związkach metropolitarnych do składania oświadczeń lustracyjnych. Uzupełnienie katalogu podmiotowego ustawy lustracyjnej (art. 4) jest spowodowane wejściem w życie ustawy z 9 maja 2017 r. o związku metropolitalnym w województwie śląskim (Dz.U. poz. 730; dalej: ustawa metropolitalna), ustanawiającej organy tworzące strukturę organizacyjną związku, piastowane przez osoby, które z racji pełnionej funkcji winny cieszyć się powszechnym zaufaniem obywateli.

Opiniowaną petycję wniosła Fundacja Centrum Analiz dla Rozwoju. Petycji towarzyszy propozycja legislacyjna nowelizacji ustawy lustracyjnej w następującym brzmieniu:

„Ustawa z dnia ... r. o zmianie ustawy o ujawnieniu informacji o dokumentach organów bezpieczeństwa państwa z lat 1944-1990 oraz treści tych dokumentów

Art. 1. W ustawie z dnia 18 października 2006 r. o ujawnianiu informacji o dokumentach organów bezpieczeństwa $z$ lat 1994-1990 oraz treści tych dokumentów (Dz. U. z 2016 r. poz. 1721, 2260, 2261 i 1948 oraz z 2017 r. poz. 1530, 1600 i 1909) wprowadza się następujące zmiany:

1) w art. 4:

a) pkt 17 otrzymuje brzmienie:

„17) organ i członek organu jednostki samorządu terytorialnego, organu związku jednostek samorządu terytorialnego, organu jednostki pomocniczej jednostki samorządu terytorialnego, organu jednostki pomocniczej jednostki samorządu terytorialnego, której obowiązek utworzenia wynika z ustawy oraz organu związku metropolitalnego;",

b) pkt 32 otrzymuje brzmienie:

„32) skarbnik województwa, powiatu, gminy lub związku metropolitalnego oraz sekretarz powiatu, gminy lub związku metropolitalnego;";

2) w art. 8 pkt 16 otrzymuje brzmienie:

„16) pkt 17:

a) w stosunku do osoby ubiegającej się o funkcję organu lub członka organu jednostki samorządu terytorialnego, której obowiązek utworzenia wynika z ustawy, pochodzącego z wyborów powszechnych - właściwa komisja wyborcza,

b) w stosunku do osoby ubiegającej się o funkcję organu lub członka organu

c) w stosunku do pozostałych osób - właściwy wojewoda";

3) w art. 22 w ust. 1 pkt 20 kropkę zastępuje się średnikiem i dodaje się pkt 21 w brzmieniu:

„21) organów lub członków organów związku metropolitalnego oraz skarbników i sekretarzy związku metropolitalnego.”.

Art. 2. Osoba pełniąca funkcję organu lub członek organu związku metropolitalnego, sekretarz związku metropolitalnego i skarbnik związku metropolitalnego - który objął funkcję przed dniem wejścia w życie niniejszej ustawy - składają 
oświadczenie, o którym mowa w art. 7 ust. 1 ustawy wymienionej w art. 1 w terminie 3 miesięcy od dnia wejścia w życie niniejszej ustawy. Przepis art. 7 ustawy wymienionej w art. 1 stosuje się odpowiednio.

Art. 3. Ustawa wchodzi w życie po upływie 14 od dnia ogłoszenia”.

\section{Czy petycja mieści się w zakresie zadań i kompetencji adresata petycji (art. 2 ust. 3 ustawy o petycjach)?}

Petycja dotyczy zmiany ustawy przez Sejm. Zgodnie z art. 95 ust. 1 Konstytucji RP władzę ustawodawczą w Rzeczypospolitej Polskiej sprawują Sejm i Senat. Natomiast stosownie do art. 118 ust. 1 Konstytucji inicjatywa ustawodawcza przysługuje m.in. posłom. Artykuł 32 ust. 2 regulaminu Sejmu, w związku z art. 112 Konstytucji, precyzuje, że poselskie projekty ustaw mogą być wnoszone przez komisje sejmowe lub grupę co najmniej 15 posłów podpisujących projekt.

Uwzględniając powyższe, należy uznać, że petycja mieści się w zakresie zadań i kompetencji Sejmu.

\section{Wymogi formalne (art. 4 ust. 1 i 2 ustawy o petycjach)}

Petycja spełnia wymogi formalne określone w art. 4 ust. 1 i 2 ustawy o petycjach.

\section{Kwestie, które ekspert uznaje za istotne w związku z petycją}

Ustawa lustracyjna w art. 4 zawiera zamknięty katalog osób pełniących funkcje publiczne, zobowiązanych do składania oświadczeń lustracyjnych. Wymienia wśród nich: organ i członka organu jednostki samorządu terytorialnego (dalej: j.s.t), organ związku j.s.t. oraz organ jednostki pomocniczej j.s.t. (art. 4 ust. 17 ustawy lustracyjnej). Z dniem 7 kwietnia 2017 r. zaczęła obowiązywać ustawa metropolitalna, ustanawiająca nową instytucję prawną, jaką jest związek metropolitalny (obecnie funkcjonuje jeden związek metropolitalny - Górnośląsko-Zagłębiowska Metropolia). Ustawodawca definiuje związek metropolitalny jako zrzeszenie gmin województwa śląskiego, charakteryzujących się istnieniem silnych powiązań funkcjonalnych oraz zaawansowaniem procesów urbanizacyjnych, położonych w obszarze spójnym pod względem przestrzennym, które zamieszkuje 2000000 mieszkańców (art. 1 ust. 1 ustawy metropolitalnej). Związek metropolitalny ma osobowość prawną, wykonuje zadania publiczne w imieniu własnym i na własną odpowiedzialność. W literaturze przedmiotu dostrzeżono wiele podobieństw pomiędzy konstrukcją związku metropolitalnego i związku 
komunalnego ${ }^{2}$, które uprawniały do twierdzenia, że związek metropolitalny mógł być klasyfikowany jako szczególny rodzaj związku jednostek samorządu terytorialnego. Przedstawiciele odmiennego poglądu doktryny, uwzględniając regulacje zawarte w ustawie metropolitalnej, utrzymują, że twierdzenie to straciło aktualność ${ }^{3}$. Związek metropolitalny zatem nie jest związkiem komunalnym w rozumieniu ustaw samorządowych. Przytoczeni autorzy podtrzymują, że niedopuszczalne jest odpowiednie stosowanie przepisów o związkach: międzygminnych, powiatowych czy powiatowo-gminnych w stosunku do związku metropolitalnego. Dokonując interpretacji charakteru prawnego związku, stwierdzili, że powstały twór należy uznać jako nową instytucję samorządu terytorialnego. O powiązaniu związku metropolitalnego z jednostkami samorządu terytorialnego świadczy także zakres zadań powierzonych mu przez ustawodawcę. Zgodnie z art. 12 ustawy metropolitalnej oprócz zadań własnych, które ówcześnie były zastrzeżone dla jednostek samorządu terytorialnego ${ }^{4}$, może on realizować lub koordynować zadania publiczne należące do zakresu działań tych jednostek oraz administracji rządowej. Na podstawie przytoczonych argumentów nie można wykluczyć, że związek metropolitalny mieści się w kategorii jednostki samorządu terytorialnego. Mając powyższe na względzie, umieszczenie organu związku metropolitalnego w katalogu (art. 4 ustawy lustracyjnej) podmiotów zobowiązanych do składania oświadczenia lustracyjnego mogłoby skutecznie ograniczyć stan niepewności prawnej, zwiększyć spójność prawa oraz wypełnić lukę prawną, jaka wystąpiła w ustawie lustracyjnej po wprowadzaniu ustawy metropolitalnej.

Nie można jednak wykluczyć, że w stosunku do organów związku metropolitalnego ustawodawca nie przewidział takiego obowiązku. W art. 26 ustawy metropolitalnej w stosunku do zgromadzenia związku metropolitalnego, w zakresie nieregulowanym przez ustawę, wskazał na odpowiednie stosowanie przepisów dotyczących sejmiku wojewódzkiego. Zgodnie z art. 15 ust. 1 ustawy z 5 czerwca 1998 r. o samorządzie województwa (Dz.U. 2017, poz. 2096) sejmik jest jednym z organów samorządu. Jak stanowi art. 4 ust. 17 ustawy lustracyjnej, organ i członek organu jednostki terytorialnej zobligowany jest do składania oświadczenia lustracyjnego. W stosunku do członków zarządu związku metropolitalnego,

2 T. Bąkowski [w:] Ustawa o związkach metropolitalnych. Komentarz, red. T. Bąkowski, Warszawa 2016, s. 17-18.

3 B. Dolnicki, R. Marchaj, Związek metropolitalny w województwie śląskim, „Samorząd Terytorialny" 2017, nr 7-8, s. 15-16.

4 Takie jak: kształtowanie ładu przestrzennego, rozwój społeczny i gospodarczy obszaru związku metropolitalnego, planowanie, koordynacja, integracja oraz rozwój publicznego transportu zbiorowego, w tym transportu drogowego, kolejowego oraz innego transportu szynowego, a także zrównoważona mobilność miejska, metropolitalne przewozy pasażerskie, współdziałanie w ustalaniu przebiegu dróg krajowych i wojewódzkich na obszarze związku metropolitalnego, promocja związku metropolitalnego i jego obszaru. 
a także skarbnika i sekretarza art. 39 ustawy metropolitalnej w zakresie nieuregulowanym ustawą nakazuje odpowiednio stosować przepisy dotyczące zarządu województwa, członków zarządu województwa, skarbnika województwa oraz sekretarza województwa. Zgodnie z art. 15 ust. 2 ustawy o samorządzie województwa zarząd województwa jest organem województwa jako jednostki samorządu terytorialnego i podlega dyspozycji art. 4 ust 17 ustawy lustracyjnej. Podobnie jak skarbnik województwa (sekretarz województwa nie występuje w przepisie), który zgodnie z art. 4 ust. 32 ustawy lustracyjnej także podlega powyższemu zobowiązaniu. Przedstawiona wykładnia przepisów budzi wątpliwości interpretacyjne, spowodowane nakazem odpowiedniego (a nie wprost) stosowania przepisów ustawy lustracyjnej.

Sformułowanie „odpowiednio” w technice prawodawczej stosowane jest jako pośrednik bądź odnośnik (w zależności od rodzaju przepisu) między różnymi aktami prawnymi czy przepisami tego samego aktu. Za wyrokiem Sądu Najwyższego z 15 lutego 2008 r., sygn. akt I CSK 357/07, uznać należy, że: [w] literaturze i orzecznictwie nie budzi wątpliwości, że odpowiednie stosowanie przepisów prawa oznacza bądź stosowanie odnośnych przepisów bez żadnych zmian do innego zakresu odniesienia, badź stosowanie ich z pewnymi zmianami, bądź też niestosowanie tych przepisów do innego zakresu odniesienia. Dyrektywa odpowiedniego stosowania przepisów, co do zasady, ułatwia dokonywanie wykładni przepisów oraz zapobiega inflacji prawa powodowanej tworzeniem nieustająco nowych przepisów. Jakkolwiek z racji specyfiki omawianej materii nie można wykluczyć, że odpowiednie stosowanie przepisów może wpływać na zmniejszenie stopnia pewności prawa oraz powodować trudności w prawidłowym stosowaniu przepisów.

Zgodnie z preambułą do ustawy lustracyjnej zasadność obowiązku składania oświadczeń lustracyjnych przez osoby urodzone przed dniem 1 sierpnia 1972 r. (art. 7 ust. 1), pełniące obecnie ważne funkcje publiczne, przejawia się w dbałości o transparentność zachowań oraz gwarancje prawości osób sprawujących te stanowiska. Przepisy ustawy lustracyjnej w stosunku do osób, które złożyły niezgodne z prawdą oświadczenia lustracyjne (bądź w ogóle ich nie złożyły), przewidują istotne konsekwencje, w tym także natury karnej (np. art. 21e, art. 29, art. 57). Ponadto w stosunku do osoby poddawanej postępowaniu lustracyjnemu zastosowanie znajdują przepisy dotyczące oskarżonego w postępowaniu karnym, natomiast w kwestiach nieuregulowanych ustawą lustracyjną odpowiednio stosuje się przepisy procedury karnej. Mając na względzie prawnokarny charakter niektórych postanowień ustawy lustracyjnej, zawarte w niej przepisy oraz wszelkie inne akty prawne odsyłające do niej, powinny być stanowione poprawnie, precyzyjnie i jasno. Cechy te odpowiadają zasadzie określoności prawa, która mieści się w nakazie przestrzegania reguł przyzwoitej legislacji. Nakaz ten jest jedną z form realizacji obowiązku państwa, jakim jest zapewnianie bezpieczeństwa obywatelowi. Powinność ta opiera się na wymogu pewności stanowionego 
prawa, które zapewni jednostce bezpieczeństwo prawne. Oznacza to, że jednostka ma możliwość określenia konsekwencji poszczególnych zachowań i zdarzeń na gruncie obowiązującego w danym momencie systemu, którego prawodawca bezwzględnie nie zmieni. U podstaw tego obowiązku leży zasada zaufania obywateli do państwa i stanowionego przez nie prawa, zajmująca nadrzędne miejsce w systemie wartości składających się na pojęcie demokratycznego państwa prawnego ${ }^{5}$. Istota tej zasady ujęta została w wyroku Trybunału Konstytucyjnego z 15 września 1998 r., sygn. akt K 10/98: wyraża się w takim stanowieniu $i$ stosowaniu prawa, by nie stawało się ono swoista pułapka dla obywatela $i$ aby mógł on układać swoje sprawy w zaufaniu, iż nie naraża się na prawne skutki, których nie mógł przewidzieć $w$ momencie podejmowania decyzji i działań, oraz w przekonaniu, iż jego działania podejmowane zgodnie z obowiązujacym prawem będa także w przyszłości uznawane przez porządek prawny. Podejmowane przez ustawodawce nowe unormowania nie moga zaskakiwać ich adresatów, którzy powinni mieć czas na dostosowanie się do zmienionych regulacji i spokojne podjęcie decyzji co do dalszego postępowania. Zasada zaufania obywateli do państwa i stanowionego przez nie prawa wchodzi w skład szerszej zasady wyrażonej w art. 2 Konstytucji, tj. zasady demokratycznego państwa prawa.

Tworzenie przepisów w zgodzie z zasadami demokratycznego państwa prawa oraz techniki legislacyjnej umożliwia realizację gwarancyjnej funkcji prawa karnego. Dochowanie wierności względom gwarancyjnym prawa karnego uniemożliwia samowolę w procesie stanowienia i stosowania prawa, a więc zabezpiecza wolności i prawa człowieka przed arbitralną ingerencją aparatu przymusu państwowego ${ }^{6}$. Postulat ten jest szczególnie doniosły w przypadku przepisów o charakterze prawnokarnym, które pociągają za sobą konkretne sankcje karne, jak jest to w przypadku ustawy lustracyjnej. Funkcja gwarancyjna prawa karnego ma swoje umocowanie w art. 42 ust. 1 Konstytucji, zgodnie z którym odpowiedzialności karnej podlega tylko ten, kto dopuścił się czynu zabronionego pod groźbą kary przez ustawę, obowiązującą w chwili jego popełnienia. W doktrynie i orzecznictwie wskazuje się, że art. 42 ust. 1 Konstytucji zawiera w sobie dwie podstawowe, fundamentalne dla prawa karnego zasady: nullum crimen sine lege i nulla poena sine lege, stanowiące aksjologiczne podstawy funkcjonowania odpowiedzialności karnej. Z uwagi na przedmiot omawianej materii, kluczową pozostaje zasada nullum crimen sine lege, zgodnie z którą czyn zabroniony pod groźbą kary musi być określony i przewidziany w ustawie obowiązującej w czasie jego popełnienia ${ }^{7}$. Prawnokarny charakter przepisów ustawy lustracyjnej rodzi konieczność

5 G. Koksanowicz, Zasada określoności przepisów w procesie stanowienia prawa, „Studia Iuridica Lublinensia" 2014, nr 22, s. 472-475.

6 J. Warylewski, Prawo karne. Część ogólna, Warszawa 2004, s. 61.

7 T. Sroka [w:] Konstytucja RP. Komentarz, t. I, Art. 1-86, red. M. Safian, L. Bosek, Warszawa 2016, s. 1027-1028. 
dochowania warunku jednoznaczności stanowionych przepisów, w taki sposób, aby proces odtwarzania zawartych w nich norm prawnych nie doprowadzał do wielu rozwiązań interpretacyjnych. Wymóg ten wyraża się w podstawowej zasadzie prawa karnego nullum crimen sine lege certa, która zastrzega precyzyjne ujmowanie znamion typu czynu zabronionego. Jest to naturalna konsekwencja wymagań stawianych każdej racjonalnie sformułowanej normie prawnej ${ }^{8}$.

\section{Wnioski}

Wejście w życie ustawy metropolitalnej zrodziło wątpliwości dotyczące obowiązku składania oświadczeń lustracyjnych przez osoby zajmujące stanowiska w organach związku metropolitalnego. Charakter prawny i zakres zadań związku metropolitalnego sprawia, że w doktrynie związek ten nazwany został nową instytucją samorządu terytorialnego. Zgodnie zaś z przepisami ustawy lustracyjnej piastuni organów samorządu terytorialnego podlegają dyspozycji ustawy lustracyjnej. W związku z tym wydawać by się mogło, że osoby piastujące organy związku metropolitalnego winny podlegać obowiązkowi wynikającemu z ustawy lustracyjnej. Ustawodawca, wprowadzając do porządku prawnego instytucję związku metropolitalnego, nie dokonał jednak nowelizacji ustawy lustracyjnej i nie dodał do zawartego w tej ustawie katalogu podmiotów objętych jej dyspozycją osób zasiadających w organach związku metropolitalnego. Brak wyszczególnienia wprost tych osób w ustawie lustracyjnej rodzi wątpliwości co do intencji ustawodawcy. Uznać należy zatem, że odpowiednia nowelizacja ustawy lustracyjnej jednoznacznie przesądziłaby o obowiązku lustracyjnym osób zasiadających w organach związku metropolitalnego.

\section{Bibliografia}

Bąkowski T. [w:] Ustawa o związkach metropolitalnych. Komentarz, red. T. Bąkowski, Warszawa 2016.

Dolnicki B., Marchaj R., Związek metropolitalny w województwie śląskim, „Samorząd Terytorialny" 2017, nr 7-8.

Koksanowicz G., Zasada określoności przepisów w procesie stanowienia prawa, „Studia Iuridica Lublinensia" 2014, nr 22, https://doi.org/10.17951/sil.2014.22.0.471.

Phol Ł. [w:] Kodeks karny. Komentarz, Warszawa 2015.

Sroka T. [w:] Konstytucja RP. Komentarz, t. I, Art. 1-86, red. M. Safian, L. Bosek, Warszawa 2016.

Warylewski J., Prawo karne. Część ogólna, Warszawa 2004.

8 Ł. Phol [w:] Kodeks karny. Komentarz, Warszawa 2015, s. 34-35. 


\title{
Piotr Czarny
}

\section{Ocena art. 25 ustawy o finansowaniu zadań oświatowych ${ }^{1}$}

Evaluation of Article 25 of the Act on Financing Educational Tasks: The opinion refers to the allegation that Article 25 of the act introduces different treatment of public schools run by local self-government units and public schools run by other entities. Running a public school is the most important feature in terms of entitlement to receive subsidies from the state budget and budgets of local self-government units. As to the amount of the subsidy (and the method of its calculation), the question of the legal status of the entity running a school is an important issue. Public schools run by local government units are budgetary units of the public finance sector. Budgetary units are subject to various restrictions, which do not apply to other entities. It cannot be a priori recognized that the financing schools in both cases must be based on absolutely the same - in formal terms - principles. Criterion provided by Article 25 para. 3 of the Act causes that a certain type of public post-secondary schools, in which there is no compulsory schooling or the obligation to learn, is treated like schools for adults, despite the fact that it belongs to other types of such institutions. The introduced diversity is therefore inadequate to the motive of its establishment indicated in the course of legislative works.

\author{
Keywords: subsidies | education | public finance | constitution | education | \\ local self-government | school \\ Słowa kluczowe: dotacje | edukacja | finanse publiczne | konstytucja | oświata | \\ samorząd terytorialny | szkoła
}

Doktor nauk prawnych, starszy wykładowca na Uniwersytecie Jagiellońskim, ekspert ds. legislacji BAS; piotr.czarny@neostrada.pl.

\section{Zagadnienia wstępne}

1. Przedmiotem niniejszej opinii prawnej jest analiza problemu wskazanego w skierowanym do Marszałka Sejmu piśmie dyrektor Publicznej Zaocznej Po-

1 Opinia prawna $w$ sprawie art. 25 ustawy o finansowaniu zadań oświatowych sporządzona 6 grudnia 2017 r. na zlecenie zastępcy Szefa Kancelarii Sejmu; BAS-WAKiU 2293/17. 
licealnej Szkoły Informatyki Cosinus w Łodzi z 27 października 2017 r. Podniesiono w nim, że art. 25 projektu ustawy o finansowaniu zadań oświatowych wprowadza różne traktowanie szkół publicznych prowadzonych przez jednostki samorządu terytorialnego i szkół publicznych prowadzonych przez inne podmioty. Wskazano w nim, że status prawny podmiotu prowadzącego dany typ szkoły nie ma znaczenia dla „kosztów organizacji nauki”. Co więcej, z przyczyn praktycznych koszty „utrzymania jednego słuchacza” są w szkołach publicznych prowadzonych przez jednostki samorządu terytorialnego $\mathrm{w}$ wielu przypadkach niższe niż w szkołach prowadzonych przez inne podmioty. Stąd też - w ocenie autorki pisma - proponowane rozwiązanie stanowi przejaw dyskryminacji szkół prowadzonych przez inne podmioty niż jednostki samorządu terytorialnego. Dodano też, że uzasadnienie projektu nie wskazuje, dlaczego zaproponowano zróżnicowanie zasad dotowania szkół publicznych w zależności od podmiotu, który jej prowadzi.

2. Kwestią wstępną o charakterze proceduralnym jest zagadnienie prawnej kwalifikacji pisma dyrektor Publicznej Zaocznej Policealnej Szkoły Informatyki Cosinus w Łodzi i sposobu ewentualnego rozpatrzenia sprawy w nim poruszonej. Pismo to trudno uznać za petycję, ponieważ zgodnie z art. 2 ust. 3 ustawy z 11 lipca 2014 r. o petycjach (t.j. Dz.U. 2017, poz. 1123): [p]rzedmiotem petycji może być żądanie, $w$ szczególności, zmiany przepisów prawa, podjęcia rozstrzygnięcia lub innego działania $w$ sprawie dotyczacej podmiotu wnoszącego petycje, życia zbiorowego lub wartości wymagających szczególnej ochrony w imię dobra wspólnego, mieszczacych się w zakresie zadań i kompetencji adresata petycji. Tymczasem w piśmie dyrektor Publicznej Zaocznej Policealnej Szkoły Informatyki Cosinus w Łodzi nie sformułowano wprost żadnych „żądań” pod adresem władz publicznych.

Jego treść sugeruje raczej, że mamy tu do czynienia ze skargą, której przedmiotem jest (potencjalne) naruszenie praworządności (a konkretnie naruszenie Konstytucji RP) i interesów skarżącego. Zgodnie z art. 240 Kodeksu postępowania administracyjnego, gdy skarga dotyczy sprawy, która nie podlega rozpatrzeniu według przepisów Kodeksu (art. $3 \$ 1$ i 2 ) albo nie należy do właściwości organów administracji publicznej (a taki charakter ma sprawa podniesiona w piśmie z 27 października 2017 r.), przepisy art. 233-239 stosuje się odpowiednio, z zastrzeżeniem, że w miejsce pozostałych przepisów Kodeksu stosuje się przepisy postępowania właściwego dla danej sprawy. Jednak przepisy Konstytucji RP, ustaw i regulaminu Sejmu dotyczące postępowania ustawodawczego nie regulują w żaden sposób kwestii składania i rozpatrywania skarg.

3. Poza tym zauważyć należy, że od momentu złożenia wskazanego pisma $\mathrm{w}$ istotny sposób zmienił się stan faktyczny sprawy w nim podniesionej. Po pierwsze, rządowy projekt ustawy o finansowaniu zadań oświatowych został uchwalony przez Sejm 27 października 2017 r. Ponieważ Senat nie wniósł poprawek, ustawa została 13 listopada 2017 r. przekazana Prezydentowi do pod- 
pisu $^{2}$. Prezydent podpisał tę ustawę i została ona 29 listopada 2017 r. ogłoszona w Dzienniku Ustaw pod poz. 22033.

W tej sytuacji czynnością, którą ewentualnie mógłby podjąć Marszałek Sejmu, wydaje się przekazanie pisma, o którym mowa wyżej, Komisji Edukacji, Nauki i Młodzieży w celu rozważenia zasadności podniesionych w nim argumentów i możliwości wystąpienia z inicjatywą nowelizacji ustawy o finansowaniu zadań oświatowych. Marszałek Sejmu ma jednak również uprawnienie do wystąpienia do Trybunału Konstytucyjnego z wnioskiem o stwierdzenie niezgodności ustawy z Konstytucją.

Po drugie, w toku prac ustawodawczych treść art. 25 ustawy o finansowaniu zadań oświatowych - a konkretnie jego ust. 3 - uległa istotnym zmianom. Stąd też analizowanie i ocena treści samego projektu tej ustawy w tym zakresie nie ma w chwili obecnej praktycznego znaczenia w odniesieniu do szkół publicznych, w których nie jest realizowany obowiązek szkolny lub obowiązek nauki, które nie są szkołami specjalnymi.

4. Niezależnie od powyższych uwag proceduralnych w dalszej części pisma przedstawiono merytoryczną stronę podniesionego w piśmie dyrektor Publicznej Zaocznej Policealnej Szkoły Informatyki Cosinus w Łodzi problemu, przy założeniu, że analiza ta ma skrócony charakter. Z uwagi na to, że szkoła ta jest publiczną szkołą policealną, badanie ograniczono w zasadzie do tego typu szkół. Z góry zastrzec należy, że rozważania te nie mają charakteru wyczerpującego, co wiąże się z tym, że ocena zgodności określonej regulacji ustawowej z konstytucyjną zasadą równości i zakazem dyskryminacji wymagałaby w tym przypadku analizy finansowych konsekwencji art. 25 ustawy o finansowaniu zadań oświatowych, co - wobec skomplikowania problematyki - wymaga specjalistycznej wiedzy z zakresu prawa oświatowego i prawa finansowego, jak również z zakresu praktyki funkcjonowania szkół publicznych.

\section{Uzasadnienie i ustalenia szczegółowe}

1. Punktem wyjścia dla dalszych rozważań jest treść art. 25 ust. 3 rządowego projektu ustawy o finansowaniu zadań oświatowych (druk sejmowy nr 1837). Zgodnie z nim: prowadzone przez osoby prawne niebędace jednostkami samorzadu terytorialnego oraz osoby fizyczne publiczne szkoły, w których nie jest realizowany obowiązek szkolny lub obowiązek nauki, niebędace szkołami specjalnymi otrzymują na każdego ucznia dotację z budżetu jednostki samorządu terytorialnego będacej dla tych szkół organem rejestrującym, w wysokości stanowiącej iloczyn kwoty

2 Http://www.sejm.gov.pl/Sejm8.nsf/PrzebiegProc.xsp?id=56F5B3373F0E5251C12581 A200460E8E [dostęp 21 listopada 2017 r.].

3 Http://dziennikustaw.gov.pl/du/2017/2203/1. 
przewidzianej na takiego ucznia w części oświatowej subwencji ogólnej dla jednostki samorządu terytorialnego oraz wskaźnika zwiększającego dla szkół danego typu niebędacych szkołami specjalnymi. Szkoły publiczne prowadzone przez osoby prawne niebędące jednostkami samorządu terytorialnego oraz osoby fizyczne określane są skrótowo mianem niesamorządowych szkół publicznych. Nie wnikając w szczegóły, wskazać trzeba, że podobne zasady w zakresie finansowania dotyczyć miały również niesamorządowych szkół publicznych innych typów. Przypomnieć też należy, że niesamorządowe szkoły publiczne to inna instytucja niż szkoły prywatne o uprawnieniach szkół publicznych. Podstawowa różnica polega na tym, że w tych pierwszych nauka jest bezpłatna, a w drugich nie.

Idea ogólna przytoczonego rozwiązania polegała na tym, że niesamorządowe szkoły publiczne otrzymują dotację zależną od dwóch elementów. Pierwszym jest kwota „na ucznia” przewidziana w części oświatowej subwencji z budżetu państwa dla jednostek samorządu terytorialnego. Ten element powinien być równy dla wszystkich typów szkół publicznych. Drugi element, tj. współczynnik zwiększający, uwzględnia to, że jednostki samorządu terytorialnego finansują działalność prowadzonych przez siebie szkół również „ze środków własnych”, tj. ponad kwoty wynikające z subwencji z budżetu państwa. Chodzi więc w założeniu o to, żeby wszystkie szkoły publiczne były traktowane równo, a szkoły prowadzone przez jednostki samorządu terytorialnego nie były z założenia w lepszej sytuacji finansowej z uwagi na otrzymywanie środków publicznych od prowadzących je jednostek ponad kwoty wynikające z wysokości kwot przekazywanych z budżetu państwa.

Istota proponowanej zmiany widoczna jest w zestawieniu $\mathrm{z}$ jeszcze obowiązującym art. 80 ust. 3ae ustawy z 7 września 1991 r. o systemie oświaty (t.j. Dz.U. 2016, poz. 1943, ze zm.), zgodnie z którym: [p]rowadzone przez osoby prawne niebędace jednostkami samorzadu terytorialnego lub osoby fizyczne publiczne szkoły niewymienione $w$ ust. 3 otrzymuja na każdego ucznia dotacje $z$ budzetu jednostki samorządu terytorialnego obowiązanej do prowadzenia danego typu i rodzaju szkół w wysokości równej podstawowej kwocie dotacji dla szkót danego typu i rodzaju, nie niższej jednak niż kwota przewidziana na takiego ucznia w części oświatowej subwencji ogólnej dla jednostki samorządu terytorialnego.

W projekcie założono więc faktycznie zmianę systemu finansowania szkół publicznych prowadzonych przez osoby niebędące jednostkami samorządu terytorialnego. W uzasadnieniu projektu i dołączonych do niego materiałach wyjaśniono cel proponowanej zmiany. Wskazano tam, że: [z] miany $w$ zakresie dotowania niepublicznych, jak i publicznych placówek wychowania przedszkolnego, szkót i placówek prowadzonych przez ministrów, osoby prawne niebędące jednostkami samorzadu terytorialnego oraz osoby fizyczne polegaja głównie na odejściu od pojęcia rodzaju szkoły przy wyliczaniu dotacji dla szkół (s. 8). Wyjaśniono też, że w projekcie: [w]prowadzono definicję wskaźnika zwiększającego dla szkót danego typu, niebędących szkołami specjalnymi (art. 14 ust. 1 projektu ustawy) 
oraz wskaźnika zwiększającego dla szkół danego typu będących szkołami specjalnymi (art. 14 ust. 2 projektu ustawy). Wprowadzenie powyższego wskaźnika jest konieczne, aby w przypadku dotowanych szkół publicznych odpowiednio zwiększyć kwote przeznaczona w części oświatowej subwencji ogólnej dla jednostki samorzadu terytorialnego na ucznia, uwzględniając wszystkie wydatki ponoszone przez ten samorząd na szkoły danego typu (ponad kwotę naliczana w części oświatowej subwencji ogólnej) (s. 10).

Dodatkowo przytoczyć należy dwa fragmenty z dołączonego do uzasadnienia raportu z konsultacji, w którym za wyjaśnione uznano uwagi polegające na tym, że: przepisy dotyczace dotacji z JST [jednostek samorządu terytorialnego dopisek P.C.] dla szkół i placówek prowadzonych przez inne podmioty niż JST sq skomplikowane i moga spowodować obniżenie dotacji dla tych podmiotów. Wskazano, iż: w przypadku szkót publicznych kwota w subwencji oświatowej zostanie odpowiednio zwiększona przez przemnożenie jej przez tzw. wskaźnik zwiększający. Wskaźnik zwiększający uwzględnia rzeczywiste wydatki danego samorzadu na dany typ szkoły przez określenie, jaki procent dany samorzad wydaje ponad subwencje (tj. iloraz rzeczywistych poniesionych wydatków $w$ danym samorządzie na dany typ szkoły do kwoty subwencji otrzymanej na te szkoły). Przemnożenie kwoty subwencji przez wskaźnik zwiększający umożliwi więc odniesienie kwoty dotacji do rzeczywistych wydatków ponoszonych przez samorzad na dany typ szkoły. Intencja ustawodawcy jest dotowanie szkó publicznych niesamorządowych $w$ takiej samej kwocie na ucznia jak wydatki na ucznia ponoszone przez samorzad w szkołach samorządowych (raport z konsultacji, s. 45).

Mówiąc najkrócej, proponowana zmiana nie polegała na tym, aby niesamorządowe szkoły publiczne finansowane były wyłącznie w wysokości wynikającej z subwencji „na ucznia” pochodzącej z budżetu państwa, ale na przyjęciu innej metody określenia swego rodzaju „dodatku”, wynikającego z założenia, że samorząd terytorialny winien w równym stopniu przyczyniać się do zapewnienia „środków pieniężnych” na działalność wszystkich szkół publicznych należących do określonego typu placówek bez względu na podmiot je prowadzący.

2. Oceniając całe zagadnienie z konstytucyjnego punktu widzenia, stwierdzić należy, że w świetle orzecznictwa Trybunału Konstytucyjnego zasada równości nie oznacza, że istnienie odmiennego traktowania adresatów norm prawnych charakteryzujących się wspólną cechą istotną jest zawsze jej naruszeniem czy też dyskryminacją. Konieczna w takiej sytuacji jest ocena kryterium, na podstawie którego dokonano zróżnicowania. Jak stwierdził TK w wyroku z 6 maja 1998 r., sygn. akt K 37/97: [z]asada równości zakłada jednocześnie różne traktowanie podmiotów różnych, tj. podmiotów, które nie posiadaja wspólnej cechy istotnej. Równość wobec prawa to zasadność wyboru takiego, a nie innego kryterium różnicowania. Aby odpowiedzieć na pytanie, czy dane kryterium może stanowić podstawę różnicowania podmiotów prawa, należy rozstrzygnać: czy kryterium to pozostaje $w$ racjonalnym związku z celem i treścia danej regulacji; czy waga in- 
teresu, któremu różnicowanie ma służyć pozostaje $w$ odpowiedniej proporcji do wagi interesów, które zostana naruszone w wyniku wprowadzonego różnicowania; czy kryterium różnicowania pozostaje w związku z innymi wartościami, zasadami, czy normami konstytucyjnymi, uzasadniajacymi odmienne traktowanie podmiotów podobnych (orzeczenia: z 3 września 1996 r., K. 10/96, OTK ZU Nr 4(7)/1996, s. 280-281, z 16 grudnia 1996 r., U. 1/96, OTK ZU Nr 6(9)/1996, s. 530 i n.). $\mathrm{W}$ analizowanej w niniejszej opinii sprawie stwierdzić można, że prowadzenie (utrzymywanie) szkoły publicznej jest najważniejszą cechą istotną w zakresie uprawnienia do otrzymywania dotacji ze środków z budżetu państwa i budżetów jednostek samorządu terytorialnego. Jednakże, jeśli chodzi o wysokość dotacji (i sposób jej obliczenia), to kwestia statusu prawnego podmiotu prowadzącego nie jest zagadnieniem nieistotnym. W tym kontekście zauważyć należy, że szkoły publiczne prowadzone przez jednostki samorządu terytorialnego są jednostkami budżetowymi sektora finansów publicznych, a szkoły publiczne prowadzone przez inne podmioty nie. Jednostki budżetowe podlegają różnego rodzaju ograniczeniom, które nie dotyczą innych podmiotów. Utrzymywanie szkół stanowi realizację ustawowych zadań jednostek samorządu terytorialnego w zakresie edukacji publicznej, a w przypadku innych podmiotów jest to konkretyzacja prawa do zakładania szkół podstawowych i ponadpodstawowych (art. 70 ust. 3 Konstytucji). Stąd też nie można a priori uznać, że finansowanie szkół w obu tych przypadkach musi być oparte na absolutnie takich samych - pod względem formalnym - zasadach. Zwrócić należy też uwagę, że wielkość kwot, jakie jednostki samorządu przeznaczają na funkcjonowanie prowadzonych przez siebie szkół, nie jest określona w sposób absolutnie „sztywny”. W ramach przysługującej im samodzielności (art. 165 ust. 2 Konstytucji) mogą one przeznaczać na funkcjonowanie placówek oświatowych kwoty wyższe niż minimum wynikające z przepisów ustawowych. Realizacja zasady równego traktowania szkół publicznych musi uwzględniać w tym wypadku samodzielność samorządu terytorialnego, co oznacza wręcz konieczność wprowadzenia odrębnych reguł dla szkół niesamorządowych. Reguły te z formalnego punktu widzenia tworzą zróżnicowanie, ale ma ono charakter tzw. zróżnicowania wyrównawczego. To zaś jest realizacją zasady równości, a nie jej naruszeniem.

Poza tym zauważyć należy, że najistotniejszym aspektem realizacji zasady równości w zakresie prawa oświatowego powinno być dążenie do równego traktowania uczniów jako osób, które korzystają z prawa do nauki, w szczególności zaś zapewnienia im „równego dostępu do wykształcenia” (art. 70 ust. 4 Konstytucji).

Co do konstytucyjnoprawnego uzasadnienia zmian proponowanych w art. 25 ust. 3 projektu ustawy o finansowaniu zadań oświatowych dodać należy, że zgodnie z orzecznictwem Trybunału Konstytucyjnego kryterium, które stanowi podstawę zróżnicowania, powinno być tzw. kryterium operatywnym. Chodzi o to, aby organ posługujący się tym kryterium, dokonujący m.in. na jego podstawie subsumpcji i podejmujący następnie rozstrzygnięcie, nie miał trudności z odpo- 
wiedzią na pytanie, czy w danym przypadku podmiot spełnia ustawowe kryterium, czy też go nie spełnia.

Jak wynika z orzeczenia TK z 27 czerwca 1995 r., sygn. akt K 4/94: [w] procesie tworzenia prawa występuje prawidłowość polegająca na tym, że im bardziej próbuje się sprecyzować kryterium, w oparciu o które dokonujemy zróżnicowania, tym trudniejsze może być ustalenie, kto spełnia wymogi przewidziane w przepisie. Tak więc dążenie do zachowania w jak największym stopniu równości i sprawiedliwości na płaszczyźnie generalno-abstrakcyjnej może w praktyce spowodować niemożność posługiwania się danym kryterium na płaszczyźnie konkretno-indywidualnej. Wymagać ono będzie bowiem ustalenia elementów sytuacji faktycznej o takim stopniu szczegółowości, któremu organ nie będzie w stanie sprostać. Przyjęcie tego rodzaju kryterium godzi w konstytucyjna zasadę równości $w$ ten sposób, iz uniemożliwia w praktyce zachowanie równości na płaszczyźnie stosowania prawa. $Z$ powyższego wynika, iż możliwość doboru kryteriów i ich precyzowania w ustawie podlega praktycznym ograniczeniom.

Stwierdzenia powyższe pasują do analizowanego tu problemu w tym sensie, że zarysowane wcześniej obowiązujące uregulowania nie spełniały - jak wynika z uzasadnienia projektu - kryterium operatywności, mimo podejmowanych wiele razy prób ich doprecyzowania. Powodowały cały czas wątpliwości interpretacyjne, związane głównie z wykładnią pojęcia „rodzaj szkoły”. Stąd też uzasadniona w świetle Konstytucji RP była ich zmiana i oparcie systemu obliczania dotacji na innej metodzie.

Wcześniejsze rozważania dotyczyły wyłącznie „strony formalnej” całego zagadnienia, tj. samej dopuszczalności wprowadzenia nowych metod obliczania dotacji dla niesamorządowych szkół publicznych. Ocena, czy nie powoduje to faktycznych skutków finansowych niekorzystnych dla tej grupy podmiotów w porównaniu ze szkołami samorządowymi, i to skutków nieproporcjonalnych do zarysowanych wcześniej różnic w ich statusie prawnym, wymagałaby szczegółowej analizy art. 14 projektu ustawy o finansowaniu zadań oświatowych i metod obliczania tzw. wskaźników zwiększających. Z uwagi na to, że zasadniczy wskaźnik zwiększający uzależniony jest od aż 10 czynników, konieczne byłoby przygotowanie odrębnego opracowania z wykorzystaniem szczegółowej wiedzy z zakresu prawa oświatowego i prawa finansowego. Dopiero ustalenia takie mogłyby stać się podstawą pełnej oceny pod względem zgodności z Konstytucją RP.

3. W ostatecznie przyjętym przez Sejm brzmieniu art. 25 ust. 3 przewiduje, że: [p] rowadzone przez osoby prawne niebędace jednostkami samorzadu terytorialnego oraz osoby fizyczne publiczne szkoły, w których nie jest realizowany obowiązek szkolny lub obowiązek nauki, niebędące szkołami specjalnymi otrzymuja na każdego ucznia dotacje z budżetu jednostki samorządu terytorialnego będacej dla tych szkół organem rejestrującym, w wysokości równej kwocie przewidzianej na takiego ucznia w części oświatowej subwencji ogólnej dla jednostki samorządu terytorialnego. 
Jak łatwo zauważyć, różnica w stosunku do proponowanej przez rząd metody obliczania dotacji polega na zniesieniu zastosowania w tym wypadku tzw. wskaźnika zwiększającego. Nowe brzmienie art. 25 ust. 3 wprowadzone zostało $\mathrm{w}$ wyniku poprawki poselskiej zgłoszonej w trakcie drugiego czytania projektu. Jak wskazano na wspólnym posiedzeniu Komisji Edukacji, Nauki i Młodzieży oraz Komisji Samorządu Terytorialnego i Polityki Regionalnej w dniu 26 października 2017 r., propozycja autorów poprawki w ustawie o finansowaniu zadań oświatowych polegała na tym, aby: $w$ poprawce $n r 6-w$ art. $25 w$ ust. 3 wyrazy „w wysokości stanowiącej iloczyn kwoty przewidzianej na takiego ucznia w czesści oświatowej subwencji ogólnej dla jednostki samorządu terytorialnego oraz wskaźnika zwiększającego, o którym mowa $w$ art. 14 ust. 1” zastąić wyrazami „w wysokości równej kwocie przewidzianej na takiego ucznia w części oświatowej subwencji ogólnej dla jednostki samorząu terytorialnego. Intencję poprawki lapidarnie wyjaśniła obecna na posiedzeniu minister edukacji, stwierdzając, że: [c]hodzi o to, że mówimy o tym, aby przy wyliczaniu dotacji w szkołach publicznych dla dorostych niebędacych szkołami specjalnymi odnosić się jedynie do kwoty przewidzianej w subwencji oświatowej, tj. bez uwzględnienia wskaźnika zwiększajacego ${ }^{4}$.

Nawiązując do wcześniejszych rozważań, należy stwierdzić, że przyjęta poprawka oznacza, iż niesamorządowe szkoły publiczne, w których nie jest realizowany obowiązek szkolny lub obowiązek nauki, będą finansowane ze środków publicznych wyłącznie w wysokości określonej przez kwotę przewidzianą na ucznia w części oświatowej subwencji ogólnej. Natomiast nie będzie dopuszczalne uwzględnienie w kwocie dotacji dla nich rzeczywistych wydatków ponoszonych przez samorząd na prowadzenie przez siebie szkół tego „rodzaju”. Mamy tu do czynienia z „podwójnym” zróżnicowaniem. Po pierwsze, opisane wcześniej szkoły prowadzone przez jednostki samorządu terytorialnego będą (mogą być) „faworyzowane”. Jednostki samorządu terytorialnego będą mogły przeznaczać na ich utrzymanie środki finansowe bez konieczności uwzględnienia, że powodować to będzie - poprzez zastosowanie wskaźnika zwiększającego obowiązek zwiększenia dotacji dla szkół publicznych prowadzonych przez inne podmioty. Po drugie, w samej kategorii niesamorządowych szkół publicznych dochodzi do zróżnicowania. Tego rodzaju placówki, w których jest realizowany obowiązek szkolny lub obowiązek nauki albo są szkołami specjalnymi, będą bowiem otrzymywały dotację z uwzględnieniem wskaźników zwiększających, a pozostałe - bez uwzględnienia tych wskaźników. Trudno wskazać racjonalne uzasadnienie tak daleko idącego zróżnicowania, tym bardziej że oddziałuje ono pośrednio na realizację konstytucyjnej gwarancji dla zapewnienia równego dostępu do wykształcenia (art. 70 ust. 4 Konstytucji). Tej gwarancji nie można rozumieć wyłącznie w sposób formalny, jako „dostępu do instytucji oświatowych”.

4 Zob. zapis przebiegu posiedzenia komisji, 26 października 2017 r., http://www.sejm. gov.pl/Sejm8.nsf/biuletyn.xsp?skrnr=ENM-113 [dostęp 20 listopada 2017 r.]. 
Wykształcenie oznacza bowiem: wiadomości i umiejętności zdobyte w szkole lub na studiach, umożliwiajace wykonywanie jakiegoś zawodu. Wysokość dotacji na działalność placówki oświatowej z natury rzeczy oddziałuje na zakres i sposób przekazywania w niej „wiadomości i umiejętności”. Obniżenie dotacji na działalność pewnego typu placówek nie jest oczywiście niedopuszczalne, ale jednym z warunków jest zachowanie zasady, zgodnie z którą nie prowadzi to w konsekwencji do odmiennego traktowania przez władze publiczne uczniów szkół analogicznych typów.

Poza tym przyjęta regulacja zrównuje właściwie w zakresie finansowania ze środków publicznych niesamorządowe szkoły publiczne, w których nie jest realizowany obowiązek szkolny lub obowiązek nauki, i analogiczne typy szkół prywatnych o uprawnieniach szkół publicznych. Zgodnie bowiem z art. 26 ust. 2 ustawy o finansowaniu zadań oświatowych: [s]zkoły niepubliczne, w których nie jest realizowany obowiązek szkolny lub obowiązek nauki, otrzymuja na każdego ucznia uczestniczacego w co najmniej 50\% obowiązkowych zajęć edukacyjnych $w$ danym miesiacu dotacje $z$ budżetu jednostki samorzadu terytorialnego [...] $w$ wysokości równej kwocie przewidzianej na takiego ucznia w części oświatowej subwencji ogólnej dla jednostki samorząu terytorialnego. Przyjęta regulacja zaciera więc dodatkowo podstawową różnicę w systemie finansowania obu tych typów szkół, jaką jest bezpłatny lub odpłatny charakter nauki.

Jak już wspomniano, konstytucyjna zasada równości nie zakłada zakazu zróżnicowania podmiotów stosunków prawnych, nawet jeżeli legitymują się określoną wspólną cechą. Wówczas jednak wykazać należy, że - ujmując rzecz krótko - zróżnicowanie jest racjonalnie uzasadnione, ma swoje oparcie w normach, zasadach i wartościach konstytucyjnych i „sprawiedliwe” (tj. głównie proporcjonalne do występujących różnic).

$\mathrm{Z}$ tego punktu widzenia zauważyć należy, że trudno w ogóle ustalić, jaki był cel uregulowania przyjętego w art. 25 ust. 3, a zatem i podstawa faktyczna kryterium zróżnicowania. O kryterium tym można powiedzieć, że jest merytorycznie związane z przedmiotem regulacji i ma charakter operatywny (jednoznaczny). Na podstawie powszechnie dostępnych źródeł nie można ustalić, jakie dokładnie były podstawy (motywy) wprowadzonego (i, jak podkreślono wcześniej, wieloaspektowego) zróżnicowania. Stąd też nie można uznać, że spełniają one konstytucyjne standardy, w szczególności zaś, że odpowiadają zasadom sprawiedliwości społecznej i zasadzie proporcjonalności.

Co do celu regulacji, to wątpliwości pogłębia dodatkowo ich motywacja, przy czym problematyczna jest nie tylko jej lakoniczność. Przede wszystkim chodzi o to, że pojęcie szkół dla dorosłych, do których - zgodnie z wcześniej przytoczoną wypowiedzią - odnosić się miała zgłoszona w toku prac w Sejmie poprawka nie pokrywa się z określeniem: szkoły publiczne, w których nie jest realizowany

5 Słownik języka polskiego, t. VI, Warszawa 2007, s. 158. 
obowiązek szkolny lub obowiązek nauki. Szkoła dla dorosłych jest bowiem szkołą, o której mowa w art. 18 ust. 1 pkt 1 i 2 lit. a i f ustawy z 14 grudnia 2016 r. Prawo oświatowe (Dz.U. 2017, poz. 59, ze zm.), a więc taką, w której stosuje się odrębną organizację kształcenia i do której są przyjmowane osoby mające 18 lat, a także kończące 18 lat w roku kalendarzowym, w którym są przyjmowane do szkoły. Istotne dla statusu szkół dla dorosłych jest to, że kształcenie odbywać się może (ale nie musi) w formie zaocznej (art. 98 ust. 1 pkt 15 ustawy - Prawo oświatowe). Szkoły dla dorosłych nie są poza tym zobowiązane do prowadzenia zajęć wychowania fizycznego (art. 28 ust. 2 ustawy - Prawo oświatowe). Nie wnikając w szczegóły, wskazać też należy, że zajęcia ze słuchaczami w szkole dla dorosłych kształcącej w formie stacjonarnej odbywają się przez 3 lub 4 dni w tygodniu, a w formie zaocznej konsultacje zbiorowe odbywają się zasadniczo we wszystkich semestrach co 2 tygodnie przez 2 dni (zob. $\$ 20$ rozporządzenia Ministra Edukacji Narodowej z 17 marca 2017 r. w sprawie szczegółowej organizacji publicznych szkół i publicznych przedszkoli, Dz.U. poz. 649). Wobec tych różnic w porównaniu z innymi szkołami można byłoby ewentualnie zastanawiać się, czy istotnie wobec szkół dla dorosłych uzasadnione jest stosowanie nieco innych zasad finansowania, szczególnie dla placówek kształcących w formie zaocznej, ale trudno wskazać powody, dla których w daleko idący sposób zasadne jest różnicować szkoły samorządowe i niesamorządowe.

Na marginesie należy wskazać, że formułowane często oceny, dotyczące różnego rodzaju nieprawidłowości w dotowaniu szkół dla dorosłych, odnoszą się głównie do szkół niepublicznych. Jak stwierdziła Najwyższa Izba Kontroli: [w] obowiązującym systemie organizacji kształcenia osób dorostych nie funkcjonuja mechanizmy, które zapewniałyby wysoka jakość, skuteczność i efektywność ksztatcenia. Przyjęte rozwiąania nie zapobiegaja zjawiskom patologicznym, w tym wyłudzaniu dotacji przez część szkół niepublicznych ${ }^{6}$. Trudno więc uzasadnić wprowadzoną zmianę potrzebą eliminacji zjawisk patologicznych.

4. Dodatkowy problem polega na tym, że w świetle uchwalonej przez Sejm ustawy o finansowaniu zadań oświatowych szkołą, w której nie jest realizowany obowiązek szkolny lub obowiązek nauki, jest szkoła podstawowa dla dorosłych, liceum ogólnokształcące dla dorosłych i szkoła policealna (art. 2 pkt 30). Jak $\mathrm{z}$ tego wynika, wszystkie szkoły policealne należą zatem do tej kategorii, jednak mogą mieć one status szkół dla dorosłych, jak również istnieć mogą takie placówki tego typu, w których proces nauczania zorganizowany jest analogicznie jak w szkołach (tj. przez 5 dni tygodniu) realizujących obowiązek szkolny. Nazywane są one potocznie szkołami policealnymi dla młodzieży. Przyjęte w art. 25 ust. 3 ustawy kryterium powoduje, że ten rodzaj publicznych szkół policealnych potraktowany został tak jak szkoły dla dorosłych, mimo że należy do placówek

6 Najwyższa Izba Kontroli, Kształcenie $w$ szkołach dla dorostych $w$ latach szkolnych 2013/2014-2015/2016, Warszawa 2017, s. 16. 
innego typu. Wprowadzone zróżnicowanie jest więc nieadekwatne do wskazanego w toku prac ustawodawczych motywu jego ustanowienia.

\section{Podsumowanie}

- Rozwiązania zawarte w art. 25 rządowego projektu ustawy o finansowaniu zadań oświatowych dotyczące dotowania szkół publicznych prowadzonych przez podmioty niebędące jednostkami samorządu terytorialnego (tzw. niesamorządowych szkół publicznych) wprowadzały pewne ich zróżnicowanie w porównaniu ze szkołami prowadzonymi przez jednostki samorządu terytorialnego. Zróżnicowanie to trudno byłoby uznać za naruszenie zasady równości wobec prawa (art. 32 Konstytucji). Szkoły publiczne prowadzone przez jednostki samorządu terytorialnego są bowiem jednostkami budżetowymi sektora finansów publicznych, a szkoły publiczne prowadzone przez inne podmioty - nie. Wobec różnego statusu prawnego sposób ustalania dotacji dla obu typów szkół nie musi być bezwzględnie taki sam. Ponadto projekt wprowadzał instytucję współczynnika zwiększającego, który uwzględniać miał przy obliczaniu dotacji dla publicznych szkół niesamorządowych wydatki ponoszone przez samorząd terytorialny na szkoły danego typu ponad kwotę naliczaną w części oświatowej subwencji ogólnej. Zróżnicowanie dotyczyło więc sposobu określania wielkości dotacji i było próbą realizacji założenia, zgodnie z którym „budżetowe” środki finansowe przeznaczone na nauczanie we wszystkich szkołach publicznych określonych typów są w przeliczeniu „na ucznia” równe bądź zbliżone. Kompleksowe wyjaśnienie kwestii zachowania w tym wypadku zasady równego traktowania wymagałoby przeprowadzenia dokładnej analizy skutków finansowych proponowanych regulacji w odniesieniu do szkół publicznych prowadzonych przez osoby fizyczne i prawne niebędące jednostkami samorządu terytorialnego, a konkretnie zastosowania współczynnika zwiększającego dotację dla tego typu szkół. To wykracza poza regulację zawartą w art. 25 projektu.

- Analiza postanowień zawartych w art. 25 opisanego wyżej projektu pod kątem zgodności z Konstytucją RP jest o tyle bezprzedmiotowa, że został on już uchwalony i ogłoszony w dniu 29 listopada 2017 r. w Dzienniku Ustaw, a istotnej zmianie uległ w toku prac ustawodawczych art. 25 ust. 3 ustawy.

- Marszałek Sejmu nie jest organem właściwym do rozpatrzenia „skargi” Publicznej Zaocznej Policealnej Szkoły Informatyki Cosinus w Łodzi. Działaniem, które może w zaistniałej sytuacji podjąć, byłoby przekazanie jej sejmowej Komisji Edukacji, Nauki i Młodzieży.

- Artykuł 25 ust. 3 ustawy o finansowaniu zadań oświatowych zawiera regulację, która może być traktowana jako naruszenie zasady równości wobec prawa oraz zakazu dyskryminacji. Przepis ten wyłącza bowiem w odniesieniu do 
szkół publicznych prowadzonych przez osoby fizyczne i prawne niebędące jednostkami samorządu terytorialnego, w których nie jest realizowany obowiązek szkolny lub obowiązek nauki, zastosowanie wspomnianego wcześniej współczynnika zwiększającego. Oznacza to, że szkoły tego rodzaju prowadzone przez jednostki samorządu terytorialnego mają jednoznacznie korzystniejszy status prawny, ponieważ dotacja na ich działalność ponad kwotę wynikającą z części oświatowej subwencji ogólnej z budżetu państwa dla jednostki samorządu terytorialnego nie będzie znajdowała żadnego „odpowiednika" w dotacji dla podobnych typów szkół prowadzonych przez inne podmioty. Oddziałuje to na realizację konstytucyjnego prawa do nauki i równego dostępu do wykształcenia. W toku prac ustawodawczych nie wskazano bliżej motywów, które uzasadniałyby wprowadzone zróżnicowanie, co przemawia za uznaniem je za niekonstytucyjne.

- Regulacja przyjęta w art. 25 ust. 3 wyżej opisanej ustawy dotyczy nie tylko szkół dla dorosłych (w rozumieniu ustawowym), co wskazywano w toku prac ustawodawczych jako podłoże wprowadzonych zmian w stosunku do projektu rządowego.

\section{Bibliografia}

Najwyższa Izba Kontroli, Kształcenie $w$ szkołach dla dorostych $w$ latach szkolnych 2013/2014-2015/2016, Warszawa 2017.

Słownik języka polskiego, t. VI, Warszawa 2007. 
Henryk Dzwonkowski

\title{
Prawnofinansowa ocena art. 25 ustawy o finansowaniu zadań oświatowych ${ }^{1}$
}

\begin{abstract}
Legal and financial evaluation of Article 25 of the Act on Financing of Educational Tasks: As a consequence of the solution provided by Article. 25 of the Act and solutions planned at the level of the Regulation on the manner of dividing the educational part of the general subsidy for local government units in 2018, the previous subsidy calculated with consideration of the number students of particular types of schools (including general secondary schools for adults, post-secondary schools) has been divided into two parts: "for participation in classes", which is unconditional and "for passed exam", which is conditional and depends on the effectiveness of education. This solution implements a postulate of the Supreme Chamber of Control. As a result of the adopted solutions in case of schools with low level of passing of exams, a subsidy applied to them will be lower than before. Finally, there may be a significant reduction in the amounts of subsidies concerning to adult students in relation to the current level. If the new solution is not neutral for subsidized institutions, violations of the rule of equal treatment of entities running educational institutions may occur.
\end{abstract}

\author{
Keywords: $\quad$ subsidies | education | public finance | constitution | education | \\ local self-government | school \\ Słowa kluczowe: dotacje | edukacja | finanse publiczne | konstytucja | oświata | \\ samorząd terytorialny | szkoła
}

Doktor hab. nauk prawnych, profesor Uniwersytetu Łódzkiego; hdzwonkowski@poltax.pl.

\section{Przedmiot opinii}

Do Marszałka Sejmu RP wpłynęło pismo dyrektor Publicznej Zaocznej Policealnej Szkoły Informatyki Cosinus w Łodzi z 27 października 2017 r., w którym

1 Opinia prawna w przedmiocie prawnofinansowej oceny przepisów art. 25 ustawy o finansowaniu zadań oświatowych wyznaczających zasady otrzymywania dotacji przez podmioty prowadzace szkołe publiczna niebędace jednostka samorzadu terytorialnego sporządzona 30 listopada 2017 r. na zlecenie zastępcy Szefa Kancelarii Sejmu; BAS-WASiE 2293/17. 
zwrócono uwagę, że zaproponowane w projekcie ustawy o finansowaniu zadań oświatowych regulacje wprowadzają różne traktowanie szkół publicznych w zależności od tego, kto jest organem prowadzącym placówki oświatowej. Autorka pisma argumentuje, że nieuzasadnione jest wprowadzanie odmiennych zasad dotowania szkół w zależności od tego, czy organem prowadzącym jest jednostka samorządu terytorialnego czy też inny podmiot, bowiem nie ma to znaczenia dla wysokości kosztów organizacji nauki w szkołach. Dodatkowo wskazała, że koszty utrzymania jednego słuchacza w szkole prowadzonej przez jednostki samorządu terytorialnego czy przez inne podmioty nie różnią się od siebie. Stąd - zdaniem autorki pisma - przewidziane w art. 25 projektu zasady dotowania szkół prowadzonych przez podmioty niebędące jednostkami samorządu terytorialnego wprowadzają dyskryminację tych podmiotów. Uzasadnienie projektu ustawy nie wyjaśnia, dlaczego zaproponowane zostało takie rozróżnienie.

\section{Analiza prawna zagadnienia}

Przystępując do analizy przedstawionego zagadnienia, w pierwszej kolejności należy poczynić kilka uwag natury ogólnej, które warunkują prawidłowe ustalenia co do oceny prawnofinansowej wskazanych przepisów ustawy o finansowaniu zadań oświatowych ${ }^{2}$.

Finansowanie oświaty stanowi, zgodnie z obowiązującym systemem prawnym $^{3}$, zadanie własne jednostek samorządu terytorialnego i jest realizowane ze środków własnych samorządów oraz z subwencji oświatowej przekazywanej z budżetu państwa. Algorytm podziału łącznej kwoty części oświatowej subwencji ogólnej (pomniejszonej o kwotę rezerwy), zawartej w ustawie budżetowej, między poszczególne jednostki samorządu terytorialnego wszystkich szczebli jest ustalany corocznie w postaci określonego wzoru matematycznego i publikowany w rozporządzeniu ministra właściwego do spraw oświaty i wychowania (Minister Edukacji Narodowej) $)^{4}$. Według ogólnej dyrektywy podziału zawartej w art. 28 ust. 5 ustawy o dochodach jednostek samorządu terytorialnego dokonuje się, biorąc pod uwagę zakres realizowanych przez jednostki samorządu terytorialnego zadań oświatowych, z wyłączeniem zadań związanych z dowozem uczniów oraz zapewnieniem kształcenia, wychowania i opieki uczniom, którzy

2 Ustawa z 27 października 2017 r., która w dniu 13 listopada 2017 r. została przekazana Prezydentowi RP do podpisu.

3 Ustawa z 7 września 1991 r. o systemie oświaty (t.j. Dz.U. 2016, poz. 1943, ze zm.); ustawa z 14 grudnia 2016 r. - Prawo oświatowe (Dz.U. 2017, poz. 59, ze zm.); ustawa z 13 listopada 2003 r. o dochodach jednostek samorządu terytorialnego (t.j. Dz.U. 2017, poz. 1453).

4 Zob. art. 28 ust. 6 ustawy z 13 listopada 2003 r. o dochodach jednostek samorządu terytorialnego, Dz.U. 2017, poz. 1453, ze zm. 
kończą 5 lat lub mniej w roku bazowym, w przedszkolach, oddziałach przedszkolnych w szkołach podstawowych i innych formach wychowania przedszkolnego, niezwiązanych $z$ wychowaniem i kształceniem specjalnym albo zajęciami rewalidacyjno-wychowawczymi. Sposób podziału określony przez ministra powinien uwzględniać w szczególności:

- typ i rodzaj szkół i placówek prowadzonych przez te jednostki,

- stopień awansu zawodowego nauczycieli,

- liczbę uczniów w szkołach i placówkach,

- liczbę dzieci, które ukończyły 6 lat lub więcej w roku bazowym, objętych wychowaniem przedszkolnym w przedszkolach, oddziałach przedszkolnych w szkołach podstawowych i innych formach wychowania przedszkolnego,

- zróżnicowania kwot ustalanych na dzieci objęte wychowaniem przedszkolnym i dzieci realizujące obowiązek szkolny i obowiązek nauki z uwzględnieniem wyższej kwoty na dziecko objęte wychowaniem przedszkolnym w przedszkolach oraz wyższej kwoty w przedszkolach, oddziałach przedszkolnych w szkołach podstawowych i innych formach wychowania przedszkolnego zlokalizowanych na terenach wiejskich i w miastach do 5000 mieszkańców.

Warto zauważyć, że w świetle obowiązujących regulacji nie ma jednak bezpośredniego związku między naliczaną częścią oświatową subwencji ogólnej a wydatkami samorządowymi na oświatę, a kwestia adekwatności środków otrzymywanych w formie subwencji oświatowej w stosunku do realizowanych zadań oświatowych bywa oceniana krytycznie przez jednostki samorządu terytorialnego.

Należy również zwrócić uwagę, że szkoły oraz placówki oświatowe mogą być zakładane i prowadzone zarówno przez ministrów i jednostki samorządu terytorialnego, jak i przez osoby prawne niebędące jednostkami samorządu terytorialnego lub osoby fizyczne (art. 8 ust. 2 ustawy - Prawo oświatowe). Przedszkola, szkoły i placówki publiczne zakładane i prowadzone przez ministrów i jednostki samorządu terytorialnego są jednostkami budżetowymi. Zasady gospodarki finansowej tych placówek określają odrębne przepisy (art. 79 ustawy o systemie oświaty), w tym przede wszystkim ustawa z 27 sierpnia 2009 r. o finansach publicznych (t.j. Dz.U. 2017, poz. 2077, ze zm.) oraz rozporządzenie Ministra Finansów z 7 grudnia 2010 r. w sprawie sposobu prowadzenia gospodarki finansowej jednostek budżetowych i samorządowych zakładów budżetowych (t.j. Dz.U. 2015, poz. 1542). Fakt, że szkoły i placówki prowadzone przez podmioty prawa publicznego mają obligatoryjnie formę organizacyjno-prawną tzw. jednostek budżetowych (art. 11 ustawy o finansach publicznych), skutkuje tym, że prowadzą one najmniej samodzielną formę gospodarki. Zarówno bowiem z prawnofinansowego, jak i z ekonomicznego punktu widzenia jednostka budżetowa jest nierozerwalnie powiązana $\mathrm{z}$ budżetem państwa lub budżetem jednostki samorządowej. Jako jednostki budżetowe placówki te są zatem utrzymywane w zasadzie wyłącz- 
nie ze środków budżetowych. Ograniczenie ich samodzielności wyraża się w tzw. zasadzie budżetowania brutto, w myśl której całość dochodów jednostki budżetowej jest pokrywana bezpośrednio z budżetu macierzystego, a całość pobranych dochodów jest odprowadzana na rachunek dochodów budżetu.

Obowiązek finansowania szkół i placówek oświatowych prowadzonych przez jednostki samorządu terytorialnego spoczywa na tych jednostkach. W finansowaniu tym ma swój udział całość dochodów uzyskiwanych przez jednostki samorządu terytorialnego, tj. obok części oświatowej subwencji ogólnej również pozostałe dochody. Część oświatowa nie może być tym samym wyłącznym punktem odniesienia dla wysokości nakładów przeznaczanych przez jednostki samorządu terytorialnego na konkretne zadania oświatowe. Co więcej, jakkolwiek część oświatowa jest naliczana na podstawie m.in. typu i rodzaju szkół i placówek oświatowych prowadzonych przez jednostki samorządu terytorialnego oraz liczby uczniów w tych szkołach i placówkach, to w praktyce środki naliczone na uczniów określonej jednostki oświatowej nie muszą być przeznaczone na realizację zadań oświatowych przez tę jednostkę adekwatnie do przeprowadzonych wyliczeń. W myśl bowiem art. 7 ustawy o dochodach jednostek samorządu terytorialnego o przeznaczeniu środków otrzymanych z tytułu subwencji ogólnej decyduje organ stanowiący jednostki samorządu terytorialnego. Innymi słowy, źródłem pochodzenia środków, z których finansowane są szkoły i placówki oświatowe prowadzone przez jednostkę samorządu terytorialnego, jest m.in. część oświatowa subwencji ogólnej, jednak kwota środków wydatkowana z budżetu tej jednostki na poszczególne jednostki oświatowe nie musi być równa kwocie subwencji oświatowej naliczonej na uczniów tej jednostki oświatowej.

Z oczywistych względów pozostałe placówki oświatowe, tj. te, które nie są zakładane i prowadzone przez ministrów i jednostki samorządu terytorialnego (zarówno mające charakter publiczny, jak i niepubliczny), nie są jednostkami budżetowymi, a zatem również i forma finansowania ich działalności musi być odmienna. Jak wskazuje art. 80 ust. 1 ustawy o systemie oświaty, przedszkola, szkoły i placówki publiczne niewymienione w art. 79 (a więc niebędące jednostkami budżetowymi) prowadzą gospodarkę finansową według zasad określonych przez organ lub podmiot prowadzący szkołę.

Biorąc zatem pod uwagę fakt, że w przeciwieństwie do jednostek prowadzonych przez samorząd placówki oświatowe publiczne niebędące jednostkami budżetowymi (takie jak Publiczna Zaoczna Policealna Szkoła Informatyki Cosinus z Łodzi, której dyrekcja zgłosiła zastrzeżenia do projektu ustawy o finansowaniu zadań oświatowych), nie są wprost powiązane z budżetem samorządu terytorialnego, funkcjonuje obecnie system dotacji, który służy dofinansowaniu realizacji zadań szkół lub placówek oświatowych prowadzonych przez osoby prawne

Zob. Z. Pirożyński, Budżetowanie brutto [w:] Leksykon finansowo-bankowy, red. W. Jaworski, Warszawa 1991, s. 59. 
niebędące jednostkami samorządu terytorialnego lub osoby fizyczne w zakresie kształcenia, wychowania i opieki, w tym kształcenia specjalnego i profilaktyki społecznej. U podstaw przyznawania tych dotacji leży założenie, że działalność oświatowa, jako mająca charakter niegospodarczy, jest z założenia deficytowa i, aby była prowadzona, wymaga wsparcia ze środków publicznych. Przyznanie dotacji następuje więc nie ze względu na doraźne zaspokojenie potrzeb finansowych podmiotu, ale aby systematycznie wyrównać bilans przychodów i kosztów działalności ${ }^{6}$. Dotacje te mogą być jednak wykorzystane wyłącznie na:

- pokrycie wydatków bieżących, obejmujących każdy wydatek poniesiony na cele działalności szkoły lub placówki oświatowej, w tym na: wynagrodzenie osoby fizycznej prowadzącej szkołę lub placówkę, jeżeli pełni funkcję jej dyrektora, sfinansowanie wydatków związanych z realizacją zadań organu prowadzącego ( $\mathrm{z}$ wyjątkiem wydatków na inwestycje i zakupy inwestycyjne, zakup i objęcie akcji i udziałów lub wniesienie wkładów do spółek prawa handlowego),

- zakup środków trwałych oraz wartości niematerialnych i prawnych, obejmujących: książki i inne zbiory biblioteczne, środki dydaktyczne służące procesowi dydaktyczno-wychowawczemu realizowanemu w szkołach, przedszkolach i placówkach, sprzęt rekreacyjny i sportowy, meble oraz pozostałe środki trwałe, wartości niematerialne i prawne o wartości nieprzekraczającej wielkości ustalonej w przepisach o podatku dochodowym od osób prawnych, dla których odpisy amortyzacyjne są uznawane za koszt uzyskania przychodu w 100\% ich wartości, w momencie oddania do używania.

W przypadku placówek publicznych, w których nie jest realizowany obowiązek szkolny lub obowiązek nauki (takich jak szkoły policealne), zastosowanie ma norma $\mathrm{z}$ art. 80 ust. 3ae ustawy o systemie oświaty, zgodnie z którą prowadzone przez osoby prawne niebędące jednostkami samorządu terytorialnego lub osoby fizyczne publiczne szkoły otrzymują na każdego ucznia dotację z budżetu jednostki samorządu terytorialnego obowiązanej do prowadzenia danego typu i rodzaju szkół w wysokości równej podstawowej kwocie dotacji dla szkół danego typu i rodzaju, nie niższej jednak niż kwota przewidziana na takiego ucznia w części oświatowej subwencji ogólnej dla jednostki samorządu terytorialnego. W przypadku braku na terenie odpowiednio gminy lub powiatu szkoły danego typu i rodzaju prowadzonej odpowiednio przez gminę lub powiat kwotę dotacji określa się w wysokości nie niższej niż kwota przewidziana na takiego ucznia w części oświatowej subwencji ogólnej odpowiednio dla gminy lub powiatu.

Biorąc pod uwagę powyższe uwarunkowania prawne, łatwo zauważyć, że obowiązujący dotąd system finansowania realizacji zadań oświatowych, w tym

6 Zob. M. Pilich, Ustawa o systemie oświaty. Komentarz, 2015, LEX, komentarz do art. 80 . 
w odniesieniu do placówek publicznych prowadzonych przez podmiot niebędący jednostką samorządu terytorialnego, z uwagi na swoje skomplikowanie oraz niejasność sformułowań budził wiele problemów związanych z jego stosowaniem (w tym m.in. dotyczących „poszukiwania” zbliżonej co do typu i rodzaju placówki oświatowej celem określenia prawidłowej wysokości dotacji). Warto przy tym podkreślić, że dotychczasowy sposób przyznawania dotacji doprowadził również do wytworzenia się niejednolitych praktyk w skali kraju oraz stanowił zarzewie sporów między organami właściwymi do udzielania dotacji a podmiotami dotowanymi.

Stąd wynikające $\mathrm{z}$ treści nowego aktu prawnego, jakim jest projekt ustawy o finansowaniu zadań oświatowych, założenie dotyczące stworzenia spójnego i uporządkowanego, a przede wszystkim uproszczonego zbioru przepisów obejmującego system dotacji zasługuje na aprobatę, jednakże szczegółowe rozwiązanie przewidziane $\mathrm{w}$ art. 25 ustawy może budzić pewne wątpliwości.

Przechodząc do szczegółowej analizy proponowanych rozwiązań ustawowych, warto w pierwszej kolejności pochylić się nad przepisem nowej ustawy o finansowaniu zadań oświatowych, który budzi największe obiekcje autorki pisma z 27 października 2017 r., kierowanego do Marszałka Sejmu RP, tj. art. 25.

Zgodnie z uchwalonym brzmieniem normy art. 25 ust. 3 o finansowaniu zadań oświatowych, znajdującej się w polu szczególnego zainteresowania podmiotu kierującego policealną szkołą publiczną Cosinus, prowadzone przez osoby prawne niebędące jednostkami samorządu terytorialnego oraz osoby fizyczne publiczne szkoły, w których nie jest realizowany obowiązek szkolny lub obowiązek nauki (obejmujące również szkoły policealne na podstawie art. 2 pkt $30 \mathrm{o}$ finansowaniu zadań oświatowych), niebędące szkołami specjalnymi, otrzymują na każdego ucznia dotację z budżetu jednostki samorządu terytorialnego będącej dla tych szkół organem rejestrującym, w wysokości równej kwocie przewidzianej na takiego ucznia w części oświatowej subwencji ogólnej dla jednostki samorządu terytorialnego.

Jednocześnie, jak stanowi art. 25 ust. 5 o finansowaniu zadań oświatowych, prowadzone przez osoby prawne niebędące jednostkami samorządu terytorialnego oraz osoby fizyczne publiczne licea ogólnokształcące dla dorosłych i szkoły policealne niebędące szkołami specjalnymi otrzymują, niezależnie od dotacji, o której mowa w ust. 3, na każdego ucznia, niebędącego uczniem niepełnosprawnym, który uzyskał odpowiednio świadectwo dojrzałości lub dyplom potwierdzający kwalifikacje zawodowe, dotację z budżetu jednostki samorządu terytorialnego będącej dla tych szkół organem rejestrującym, w wysokości równej kwocie przewidzianej na takiego ucznia w części oświatowej subwencji ogólnej dla jednostki samorządu terytorialnego, pod warunkiem że organ prowadzący tę szkołę przedstawi zaświadczenie o uzyskaniu przez ucznia tej szkoły odpowiednio świadectwa dojrzałości lub dyplomu potwierdzającego kwalifikacje zawodowe w terminie 12 miesięcy od dnia, w którym uczeń ukończył tę szkołę (za- 
świadczenie wydaje niezwłocznie okręgowa komisja egzaminacyjna na wniosek organu prowadzącego szkołę).

Jak wynika z treści wskazanych unormowań, system dotacji z budżetu jednostki samorządu terytorialnego w przypadku podmiotów prowadzących publiczne szkoły policealne (takie jak Publiczna Zaoczna Policealna Szkoła Informatyki Cosinus w Łodzi), składał się będzie z dwóch odrębnych elementów (części):

- części „bezwarunkowej”, „obligatoryjnej” dotacji - należnej w każdym przypadku, w wysokości równej kwocie przewidzianej na ucznia w części oświatowej subwencji ogólnej,

- części „dodatkowej” dotacji - przyznawanej w zależności od spełnienia kryteriów ustawowych związanych z rezultatami (skutecznością) prowadzonej przez daną placówkę edukacji, również w wysokości równej kwocie przewidzianej na ucznia w części oświatowej subwencji ogólnej.

Nowe rozwiązanie polegające na przyznaniu części dotacji w powiązaniu z efektem w postaci uzyskania przez ucznia świadectwa dojrzałości lub dyplomu potwierdzającego kwalifikacje zawodowe wpłynie na zmianę w algorytmie podziału subwencji oświatowej. Innymi słowy, oznacza to, że część subwencji na ucznia szkoły dla dorosłych będzie naliczana tak jak obecnie (tj. na każdego ucznia), a część subwencji będzie naliczana po zdanym egzaminie (tj. na uczniów, którzy zdali egzamin). Jednocześnie warto zauważyć, że twórcy projektu ustawy uwzględnili założenia oparte na danych według Systemu Informacji Oświatowej (SIO) na dzień 30 września 2016 r. oraz przyjęli, że wskaźnik zdawalności w szkołach dla dorosłych w liceach ogólnokształcących wyniesie 15\%, a w szkołach policealnych dla dorosłych $50 \%$.

Uwzględnienie w algorytmie podziału części oświatowej subwencji ogólnej między poszczególne jednostki samorządu terytorialnego liczby uczniów, którzy zdali odpowiednio egzamin maturalny lub egzamin potwierdzający kwalifikacje w zawodzie w liceach ogólnokształcących dla dorosłych, szkołach policealnych oraz w szkołach lub placówkach prowadzących kwalifikacyjne kursy zawodowe, wprowadza zmiana do art. 28 ust. 5 ustawy o dochodach jednostek samorządu terytorialnego ujęta w art. 81 nowej ustawy o finansowaniu zadań oświatowych.

W ślad za zmianami regulacji w zakresie finansowania kształcenia dorosłych przyjętymi w ustawie o finansowaniu zadań oświatowych odpowiednie zmiany zostały zaproponowane w projekcie rozporządzenia w sprawie sposobu podziału czę-

7 W dokumentach źródłowych można się spotkać z określeniem tej części jako części "za uczestnictwo w zajęciach".

8 W dokumentach źródłowych można się spotkać z określeniem tej części jako części „za efekt”.

9 Zob. Projekt ustawy o finasowaniu zadań oświatowych. Ocena skutków regulacji, s. 5, https://legislacja.rcl.gov.pl/docs//2/12298908/12436004/12436005/dokument307704. pdf. 
ści oświatowej subwencji ogólnej dla jednostek samorządu terytorialnego w roku $2018^{10}$. W konsekwencji podziału dotychczasowej subwencji oświatowej naliczanej na uczniów poszczególnych rodzajów szkół kształcących dorosłych na dwie części: „za uczestnictwo w zajęciach” oraz „za zdany egzamin”, do algorytmu podziału części oświatowej proponuje się dodać nową wagę „za zdany egzamin” dla:

- uczniów w liceach ogólnokształcących dla dorosłych, którzy zdali egzamin maturalny,

- uczniów w szkołach policealnych (wszystkie kategorie uczniów, bez szkół specjalnych), którzy zdali egzaminy potwierdzające wszystkie kwalifikacje w danym zawodzie,

- uczestników kwalifikacyjnych kursów zawodowych, którzy zdali egzamin potwierdzający kwalifikacje w zawodzie w zakresie danej kwalifikacji.

Wartość wagi kształtuje się na poziomie 0,165 , co wyniesie w przybliżeniu około 890 zł na ucznia. Wagą „za zdany egzamin” zostaną przeliczeni uczniowie, którzy zdali egzamin w ubiegłym roku szkolnym (czyli waga będzie uwzględniać zdawalność z rocznym opóźnieniem).

Należy zauważyć, że finansowanie „za efekt” nie zostało ograniczone tylko do szkół „niesamorządowych”, ale również objęło szkoły prowadzone przez jednostki samorządu terytorialnego, dotyczy bowiem m.in. uczniów liceów ogólnokształcących dla dorosłych, którzy uzyskali świadectwo dojrzałości, oraz uczniów szkół policealnych niebędących szkołami specjalnymi, którzy uzyskali dyplom potwierdzający kwalifikacje zawodowe (z wyłączeniem uczniów niepełnosprawnych) bez względu na organ prowadzący te szkoły ${ }^{11}$.

Konsekwencją podziału dotacji na dwie części są również planowane w projekcie rozporządzenia w sprawie sposobu podziału części oświatowej w roku 2018 zmiany poziomu subwencji „za uczestnictwo w zajęciach”, polegające m.in. na zmniejszeniu wraz ze zróżnicowaniem wskaźników do wyliczenia kwot subwencji dla liceów ogólnokształcących dla dorosłych oraz szkół policealnych w czę-

10 Zob. https://legislacja.rcl.gov.pl/projekt/12304953/katalog/12469922\#12469922.

11 Zob. definicja wagi $\mathrm{P}_{11}=0,165 \mathrm{w}$ Projekcie rozporzadzenia Ministra Edukacji Narodowej w sprawie sposobu podziału części oświatowej subwencji ogólnej dla jednostek samorządu terytorialnego $w$ roku 2018, https://legislacja.rcl.gov.pl/projekt/12304953/ katalog/12469916\#124699160:

$P_{11}=0,165$ - dla uczniów liceów ogólnokształcących dla dorosłych, którzy uzyskali świadectwo dojrzałości, dla uczniów szkół policealnych niebędących szkołami specjalnymi, którzy uzyskali dyplom potwierdzający kwalifikacje zawodowe (z wyłaczeniem uczniów niepetnosprawnych), dla uczestników kwalifikacyjnych kursów zawodowych prowadzonych przez szkoły lub placówki (z wyłączeniem uczestników kwalifikacyjnych kursów zawodowych prowadzonych przez placówki prowadzone przez osoby prawne inne niż jednostki samorzadu terytorialnego lub przez osoby fizyczne), którzy zdali egzamin potwierdzający kwalifikacje w zawodzie w zakresie danej kwalifikacji. 
ści SOA ${ }^{12}$. Ministerstwo Edukacji Narodowej szacuje, że w rezultacie przyjętych zmian wiążących się ze zmniejszeniem wskaźników w części SOA dla liceów ogólnokształcących dla dorosłych oraz szkół policealnych skutek finansowy wyniesie około 228,5 mln zł (zmiana dotyczy 332 tys. uczniów). Porównanie średnich kwot subwencji na ucznia naliczanych poszczególnymi wskaźnikami prowadzi do wniosku, że w stosunku do roku 2017 relatywnie największy spadek kwot subwencji na ucznia dotyczyć będzie niepublicznych szkół dla dorosłych (zob. tabela 1$)^{13}$.

Tabela 1. Zróżnicowanie wskaźników do wyliczenia kwot subwencji dla liceów ogólnokształcących dla dorosłych oraz szkół policealnych w części SOA

\begin{tabular}{|c|c|c|c|c|c|c|}
\hline \multirow[t]{2}{*}{ Wskaźnik } & \multirow[t]{2}{*}{ Kategorie uczniów } & \multicolumn{2}{|c|}{$\begin{array}{l}\text { Wskaźniki do części } \\
\text { SOA }\end{array}$} & \multicolumn{2}{|c|}{$\begin{array}{l}\text { Średnia kwota } \\
\text { subwencji na } \\
\text { ucznia naliczana } \\
\text { poszczególnymi } \\
\text { wskaźnikami w zł }\end{array}$} & \multirow[t]{2}{*}{$\begin{array}{l}\text { Zmiana } \\
\text { w \% }\end{array}$} \\
\hline & & 2017 r. & $\begin{array}{c}\text { projekt } \\
\text { na } \\
2018 \mathrm{r} .\end{array}$ & 2017 r. & $\begin{array}{c}\text { projekt } \\
\text { na } \\
2018 \mathrm{r} .\end{array}$ & \\
\hline Sf & $\begin{array}{l}\text { Uczniowie publicznych LO i szkół policeal- } \\
\text { nych dla dorosłych (tryb stacjonarny) }\end{array}$ & 0,700 & 0,600 & 3844 & 3295 & 14 \\
\hline $\mathrm{Sg}$ & $\begin{array}{l}\text { Uczniowie niepublicznych szkół policeal- } \\
\text { nych dla dorosłych (tryb zaoczny) }\end{array}$ & 0,180 & 0,06 & 989 & 330 & 67 \\
\hline Sh & $\begin{array}{l}\text { Uczniowie niepublicznych LO dla dorosłych } \\
\text { (tryb zaoczny) }\end{array}$ & 0,180 & 0,1 & 987 & 548 & 44 \\
\hline $\mathrm{Si}$ & $\begin{array}{l}\text { Uczniowie publicznych LO i szkół policeal- } \\
\text { nych dla dorosłych (tryb zaoczny) }\end{array}$ & 0,420 & 0,330 & 2312 & 1816 & 21 \\
\hline Sj & $\begin{array}{l}\text { Uczniowie niepublicznych LO i policeal- } \\
\text { nych szkół dla dorosłych (tryb stacjonarny) }\end{array}$ & 0,350 & 0,250 & 1914 & 1367 & 29 \\
\hline Sk & $\begin{array}{l}\text { Uczniowie publicznych szkół policealnych } \\
\text { dla dzieci i młodzieży }\end{array}$ & 1,000 & 0,900 & 5458 & 4912 & 10 \\
\hline SI & $\begin{array}{l}\text { Uczniowie niepublicznych szkół policeal- } \\
\text { nych dla dzieci i młodzieży }\end{array}$ & 1,000 & 0,450 & 5511 & 2480 & 55 \\
\hline
\end{tabular}

Źródło: Projekt rozporzadzenia Ministra Edukacji Narodowej w sprawie sposobu podziału części oświatowej subwencji ogólnej dla jednostek samorzqdu terytorialnego w roku 2018. Ocena skutków regulacji, https:// legislacja.rcl.gov.pl/projekt/12304953/katalog/12469922\#12469922, s. 5.

W ocenie Ministerstwa Edukacji Narodowej w rezultacie przyjętych rozwiązań w przypadku szkól, które charakteryzują się wysoką zdawalnością, subwencja światowa zostanie naliczona na uczniów tych szkół w wysokości tak jak dotychczas lub nawet wyższej niż do tej pory, natomiast w przypadku uczniów szkół z niską zdawalnością zostanie naliczona subwencja niższa niż do tej pory ${ }^{14}$.

12 Kwota bazowa części oświatowej według finansowego standardu A podziału części oświatowej na realizację zadań szkolnych.

13 Zob. Projekt rozporządzenia Ministra Edukacji Narodowej w sprawie sposobu podziatu części oświatowej subwencji ogólnej dla jednostek samorządu terytorialnego $w$ roku 2018. Uzasadnienie, op. cit., s. 3.

14 Zob. Projekt rozporzadzenia Ministra Edukacji Narodowej w sprawie sposobu podziału części oświatowej subwencji ogólnej dla jednostek samorządu terytorialnego $w$ roku 2018. Uzasadnienie, op. cit., s. 3. 
W kontekście zagadnienia kształcenia w szkołach dla dorosłych należy zwrócić uwagę na wnioski płynące z kontroli przeprowadzonej przez Najwyższą Izbę Kontroli (NIK) w zakresie prawidłowości, skuteczności i efektywności kształcenia w szkołach dla dorosłych ${ }^{15}$. NIK wielokrotnie zwracała uwagę na problem niskiej skuteczności kształcenia dorosłych. Już w 2008 r. negatywnie oceniła funkcjonowanie szkół niepublicznych o uprawnieniach szkół publicznych dla dorosłych w związku ze stwierdzeniem istotnych nieprawidłowości w organizacji tych szkół, skutkujących niską efektywnością kształcenia, którą wyrażał niewielki odsetek słuchaczy promowanych i kończących wspomniane szkoły. Wskazywano wówczas m.in., że w celu wyeliminowania stwierdzonych nieprawidłowości Minister Edukacji Narodowej powinien opracować mechanizmy prawne, uniemożliwiające uzyskiwanie dotacji przez szkoły niepubliczne w nadmiernej wysokości, a także uzyskiwanie uprawnień szkół publicznych przez szkoły, których efektywność kształcenia jest niezadowalająca. Z kolei w 2012 r. NIK proponowała podjęcie działań w celu wprowadzenia zmiany ustawowego sposobu obliczania dotacji dla niepublicznych szkół, w których nie jest realizowany obowiązek szkolny lub obowiązek nauki (czyli m.in. szkół dla dorosłych). Uwagi i wnioski sformułowane dotychczas przez NIK w kontrolowanym zakresie nadal pozostają aktualne. Mimo wprowadzenia pewnych zmian, które miały wyeliminować lub ograniczyć występujące patologie w zakresie m.in. pozyskiwania dotacji z budżetu jednostek samorządu terytorialnego, kształcenie dorosłych pozostaje wciąż obszarem w znacznym stopniu obciążonym nieprawidłowościami. Zdaniem NIK główne zmiany, które należy zastosować, powinny doprowadzić do uzależnienia udzielania lub ustalania wysokości wypłacanej dotacji od efektu kształcenia. Rozwiązania te mogłyby być oparte na zasadach, jakie funkcjonują w przypadku finansowania kwalifikacyjnych kursów zawodowych - w tym wypadku wypłata dotacji następuje dopiero po zdaniu przez słuchacza egzaminu potwierdzającego kwalifikacje w zawodzie ${ }^{16}$. NIK w rezultacie przeprowadzonej kontroli wniosła o rozważenie przez Ministra Edukacji Narodowej przygotowania zmian obowiązujących przepisów w zakresie dotowania szkół niepublicznych. Pożądaną jakość kształcenia można byłoby osiągnąć, uzależniając udzielanie dotacji lub jej wysokość od skuteczności i uzyskiwanych efektów kształcenia. NIK zaproponowała również, aby podstawę obliczania dotacji stanowiły odpowiednie kwoty przewidziane na jednego ucznia danego typu i rodzaju szkoły w części oświatowej subwencji ogólnej otrzymywanej przez jednostki samorządu terytorialnego ${ }^{17}$.

15 Zob. Najwyższa Izba Kontroli, Informacja o wynikach kontroli. Kształcenie w szkołach dla dorostych, 2017, https://www.nik.gov.pl.

16 Ibidem, s. 17.

17 Ibidem, s. 18. Informacja NIK o wynikach kontroli w sprawie kształcenia w szkołach dla dorosłych jest datowana na 16 sierpnia 2017 r., tj. przed wpłynięciem do Sejmu projektu ustawy o finansowaniu zadań oświatowych, który uwzględnia powyższy postulat. 
Omawiając finansowanie szkół dla dorosłych, NIK stwierdza, że: Minister Edukacji Narodowej poinformowat, że w rozporzadzeniu z 22 grudnia 2016 r. w sprawie sposobu podziału części oświatowej subwencji ogólnej dla jednostek samorzadu terytorialnego $w$ roku 2017 dokonano zmiany zasad subwencjonowania słuchaczy szkół dla dorosłych kształcacych się w trybie zaocznym. Zmiana ta jest kontynuacja rozwiazania zaproponowanego na rok 2015, kiedy to dla stuchaczy szkół dla dorosłych kształcących się $w$ trybie zaocznym obniżono wartości wskaźników z 0,7 na 0,5 (szkoły publiczne) i z 0,35 na 0,25 (szkoły niepubliczne). Planowano wtedy, że w kolejnym roku wartość wskaźników powinna ulec dalszemu obniżeniu. Na rok 2017 wprowadzono niższe wskaźniki, tj. w przypadku publicznych szkół dla dorosłych kształcacych $w$ trybie zaocznym obniżono wskaźniki $z$ 0,5 do 0,42, a dla niepublicznych z 0,25 na 0,18. W piśmie wskazano też: warto zauważyć dysproporcję pomiędzy środkami naliczonymi w subwencji oświatowej na uczniów szkół prowadzonych przez podmioty inne niż jst [jednostki samorządu terytorialnego - dopisek H.D.] (liceów ogólnokształcących oraz szkół zawodowych) a wysokościa dotacji udzielonych tym szkołom. W 2015 r. dotacje udzielone przez powiaty liceom ogólnokształcącym stanowiły 85,5\% naliczonej na uczniów tych szkół kwoty subwencji, a w przypadku szkół zawodowych było to tylko $60,1 \%{ }^{18}$.

W ramach ustaleń poczynionych przez NIK w toku kontroli w sprawie kształcenia w szkołach dla dorosłych zwraca uwagę opinia dyrektorów szkół dla dorosłych odnośnie do obniżenia kwoty dotacji. Część z nich, negatywnie oceniając te obniżenia, wskazywała na liczne konsekwencje tego zjawiska. Najczęściej ankietowani dyrektorzy podnosili, że taki stan rzeczy skutkował przede wszystkim brakiem zakupu pomocy naukowych i dydaktycznych, podwyżek dla nauczycieli (ewentualnie zmniejszeniem ich wynagrodzeń). Ponadto wskazywano na ograniczenie liczby zajęć dodatkowych, wynajmowanych pomieszczeń czy oferty nauczania ${ }^{19}$.

Dokonując analizy prawnofinansowej wprowadzanych rozwiązań w odniesieniu do publicznych szkół policealnych (oraz innych szkół dla dorosłych) prowadzonych przez podmioty inne niż jednostki samorządu terytorialnego, należy stwierdzić, że przewidują one faktycznie znaczne obniżenie wysokości otrzymywanych przez te podmioty kwot dotacji, w stosunku do dotychczasowego poziomu, co może istotnie wpływać na działalność przynajmniej części szkół policealnych (dla dorosłych).

Uzasadniając powyższe, trzeba zwrócić uwagę na następujące uwarunkowania:

- Nowy system dotacji zakłada uzależnienie przyznania jej części „dodatkowej” od wskaźnika zdawalności w danej placówce, przy czym do oceny skutków regulacji przyjęto arbitralnie i bez szczegółowego uzasadnienia, że wskaźniki te będą w poszczególnych kategoriach szkół dla dorosłych istotnie wzra-

\footnotetext{
$18 \quad$ Ibidem, s. 36.

19 Ibidem, s. 41.
} 
stać, co z kolei ma spowodować brak odczuwalnego zmniejszenia wysokości dotacji. I tak w przypadku liceów ogólnokształcących dla dorosłych wzrost zdawalności ma wynieść ponad 50\% (z 9,5\% do 15\% zdających), natomiast w szkołach policealnych o blisko $20 \%$ (z $42 \%$ do $50 \%$ zdających) ${ }^{20}$. Zatem z uwagi na powiązanie wysokości części dotacji z podwyższonymi wskaźnikami zdawalności, które mogą być niesłychanie trudne do zrealizowania przez placówki oświatowe prowadzone przez osoby prawne niebędące jednostkami samorządu terytorialnego lub osoby fizyczne, można oczekiwać, że przynajmniej dla części placówek faktyczna wysokość części „dodatkowej”/ „za efekt” dotacji może być poważnie niższa od zakładanej przez twórców nowelizacji, co z kolei może wpłynąć negatywnie na możliwość realizacji przez niesamorządowe placówki oświatowe działalności edukacyjnej.

- Również sami twórcy ustawy o finansowaniu zadań oświatowych wprost wskazali, że zmiany w systemie finansowania publicznych szkół dla dorosłych będą skutkować oszczędnościami, sięgającymi w roku 2018 kwoty $48580200 \mathrm{zl}$, w roku 2019 kwoty 51311223 zł, natomiast w roku 2020 i latach następnych kwoty $56773269 \mathrm{zł}^{21}$. Jednocześnie przyjęto, że kwota subwencji oświatowej na jednego ucznia w odniesieniu do publicznych szkół policealnych (takich jak Publiczna Zaoczna Policealna Szkoła Informatyki Cosinus) po zmianie systemu ulegnie zmniejszeniu o 19\% - z kwoty 5892 zł do kwoty $4787 \mathrm{zł}^{22}$. Projektodawca przewidział również, że środki uzyskane $\mathrm{z}$ wprowadzenia zmian $\mathrm{w}$ zakresie dotacji: zostana przeznaczone na sfinansowanie zwiększonej liczby godzin wynikających z nowych ramowych planów nauczania [oraz] będa adresowane dla małych szkót podstawowych ${ }^{23}$.

Jak zatem wynika z powyższego, istotną intencją projektodawców związaną z wdrożeniem nowego systemu dotacji dla publicznych szkół dla dorosłych (w tym szkół policealnych) było uzyskanie oszczędności, które z kolei po stronie owych szkół oznaczają istotne ograniczenie uzyskiwanych sum dotacji, które z całą pewnością mogą przynajmniej częściowo ujemnie wpływać na funkcjonowanie tego typu placówek.

W kontekście nakreślonych wyżej celów projektodawców ustawy o finansowaniu zadań oświatowych oraz projektu rozporządzenia Ministra Edukacji Narodowej w sprawie sposobu podziału części oświatowej subwencji ogólnej dla jednostek samorządu terytorialnego w roku 2018 związanych z ograniczeniem wydatków na dotacje, należy odnotować, że: [i]ntencja ustawodawcy jest dotowa-

20 Projekt ustawy o finansowaniu zadań oświatowych. Ocena skutków regulacji, op. cit., s. 5-6.

$21 \quad$ Ibidem, s. 5.

22 Ibidem, s. 6.

23 Ibidem, s. 6-7. 
nie szkół publicznych niesamorządowych w takiej samej kwocie na ucznia jak wydatki na ucznia ponoszone przez samorzad w szkołach samorzadowych. Natomiast szkół niepublicznych w kwocie niższej ${ }^{24}$.

Urzeczywistnienie tego zamiaru zależeć jednak będzie w dużej mierze od skuteczności kształcenia w szkołach dla dorosłych prowadzonych przez osoby prawne niebędące jednostkami samorządu terytorialnego lub osoby fizyczne. Warto w tym miejscu zwrócić uwagę, że NIK ustaliła, że wskaźniki zdawalności zarówno egzaminu maturalnego, jak i egzaminów potwierdzających kwalifikacje w zawodzie w publicznych szkołach dla dorosłych były znacznie wyższe niż w szkołach niepublicznych ${ }^{25}$. Jak zauważa NIK w syntezie wyników kontroli poświęconej kształceniu w szkołach dla dorosłych: [w] MEN nie prowadzono pogłębionych analiz dotyczących skuteczności kształcenia w szkołach dla dorosłych. Analiz zdawalności egzaminów zewnętrznych $w$ szkołach dla dorosłych nie prowadziła także CKE oraz okregowe komisje egzaminacyjne. Przeprowadzone przez NIK, na podstawie danych uzyskanych ze wszystkich OKE $w$ kraju badanie wskazuje, że zdawalność egzaminów potwierdzajacych kwalifikacje w zawodzie $w$ szkołach dla dorosłych jest istotnie (o kilka punktów procentowych) gorsza, niż ogólna zdawalność tych egzaminów we wszystkich typach szkót. Zdawalność egzaminów zewnętrznych jest wyższa w szkołach publicznych. Różnica w poziomie zdawalności egzaminów kwalifikacyjnych w publicznych i niepublicznych szkołach policealnych wynosiła w latach 2014, 2015 i 2016 odpowiednio: 12,6; 13,5 oraz 10,8 punktu procentowego. W liceach ogólnokształcących dla dorosłych różnica między $z$ dawalnościa $w$ szkołach publicznych $i$ niepublicznych wynosiła $w$ tym okresie średnio 4,3 punktu procentowego dla języka polskiego, 3 punkty procentowe dla matematyki oraz 4,5 punktu procentowego dla języka angielskiego na korzyść szkót publicznych ${ }^{26}$.

Zgodnie z obowiązującymi regulacjami ustawy o systemie oświaty prowadzone przez osoby prawne niebędące jednostkami samorządu terytorialnego lub osoby fizyczne publiczne szkoły, w których nie jest realizowany obowiązek szkolny lub obowiązek nauki, otrzymują na każdego ucznia dotację z budżetu jednostki samorządu terytorialnego obowiązanej do prowadzenia danego typu i rodzaju szkół w wysokości równej podstawowej kwocie dotacji dla szkół danego typu i rodzaju, nie niższej jednak niż kwota przewidziana na takiego ucznia w części oświatowej subwencji ogólnej dla jednostki samorządu terytorialnego. Przy tym przez podstawową kwotę dotacji dla szkół danego typu i rodzaju należy

24 Zob. Raport z konsultacji dotyczący projektu ustawy o finansowaniu zadań oświatowych, sporzadzony $w$ dniu 11 sierpnia 2017 r., https://legislacja.rcl.gov.pl/docs//2/122 98908/12436004/12436005/dokument307709.pdf.

25 Zob. Najwyższa Izba Kontroli, Informacja o wynikach kontroli. Kształcenie w szkołach dla dorostych, op. cit., s. 11.

26 Ibidem, s. 13. 
rozumieć kwotę wydatków bieżących zaplanowanych na prowadzenie przez jednostkę samorządu terytorialnego szkół danego typu i rodzaju, z uwzględnieniem ewentualnie określonych pomniejszeń wskazanych w przepisach (art. 78b ust. 3 ustawy o systemie oświaty). W razie braku na terenie odpowiednio gminy lub powiatu szkoły danego typu i rodzaju prowadzonej odpowiednio przez gminę lub powiat kwotę dotacji określa się w wysokości nie niższej niż kwota przewidziana na takiego ucznia w części oświatowej subwencji ogólnej odpowiednio dla gminy lub powiatu.

Mankamentem obowiązujących dotychczas regulacji jest odniesienie do rodzaju szkoły. Z uwagi na brak definicji rodzaju szkoły samorząd musi samodzielnie określić rodzaj dotowanej szkoły, biorąc pod uwagę różne czynniki (przykładowo: położenie szkoły na terenie wsi lub miasta, tryb nauki, realizację obowiązku szkolnego lub nauki, kategorię uczniów, czy szkoła jest szkołą specjalną, procentowy udział oddziałów: integracyjnych, sportowych, mistrzostwa sportowego, dwujęzycznych, dla mniejszości, międzynarodowych, terapeutycznych, czy szkoła jest szkołą zawodową, czy jest szkołą artystyczną itp.). W praktyce określenie rodzaju szkoły polega na wyznaczeniu odpowiedniej kombinacji powyższych czynników dla każdej dotowanej szkoły, a przy braku jednoznacznej definicji stwarza istotne problemy. Następnie jednostka samorządu terytorialnego określa, czy prowadzi dokładnie taki typ i rodzaj szkoły jak szkoła dotowana. Jeżeli tak, to, aby obliczyć wysokość dotacji, samorząd musi dla każdego typu i rodzaju dotowanej szkoły oddzielnie określić wysokość zaplanowanych w budżecie wydatków bieżących na prowadzenie dokładnie takiego typu i rodzaju szkoły. Natomiast jeżeli samorząd nie prowadzi szkoły takiego typu i rodzaju jak szkoła dotowana, to musi wyznaczyć najbliższą jednostkę samorządu terytorialnego prowadzącą taki typ i rodzaj szkoły - najpierw wśród samorządów graniczących, potem $\mathrm{w}$ powiecie, $\mathrm{w}$ województwie, a na końcu na terenie całego $\mathrm{kraju}^{27}$.

Procedura taka stwarza jednak istotne problemy przy ustalaniu kwot dotacji dla szkół danego typu i rodzaju, stąd w projekcie ustawy o finansowaniu zadań oświatowych zaproponowano zmiany polegające na tym, aby w przypadku szkół publicznych, w których nie jest realizowany obowiązek szkolny lub obowiązek nauki, dotacja określana była na każdego ucznia w wysokości równej kwocie przewidzianej w części oświatowej subwencji ogólnej dla jednostki samorządu terytorialnego na takiego ucznia i przemnażana dodatkowo przez wskaźnik zwiększający dla szkół danego typu. Ostatecznie przyjęte przez Sejm oraz przez Senat brzmienie art. 25 ust. 3 ustawy o finansowaniu zadań oświatowych w sposób istotny różni się od tego, które zostało przewidziane w pierwotnym projekcie ustawy (i do którego przygotowano uzasadnienie oraz ocenę skutków regulacji, a także raport z konsultacji). W przyjętej przez Sejm RP i Senat RP wersji ustawy

${ }_{27}$ Zob. Projekt ustawy o finansowaniu zadań oświatowych. Uzasadnienie, op. cit., s. 8. 
z 27 października 2017 r. w treści art. 25 ust. 3 usunięto zapis mówiący o stosowaniu wskaźnika zwiększającego, co oznacza, że kwota dotacji ograniczona jest jedynie do kwoty przewidzianej na ucznia w części oświatowej subwencji ogólnej dla jednostki samorządu terytorialnego.

Tymczasem w uzasadnieniu do projektu ustawy wskazywano, że: [w]prowadzenie powyższego wskaźnika jest konieczne, aby w przypadku dotowanych szkót publicznych, odpowiednio zwiększyć kwotę przeznaczona w części oświatowej subwencji ogólnej dla jednostki samorządu terytorialnego na ucznia, uwzględniając wszystkie wydatki ponoszone przez ten samorzad na szkoły danego typu ${ }^{28}$.

Zatem na podstawie pierwotnego brzmienia przepisu dotacja przeznaczona dla publicznej szkoły niesamorządowej miała ulegać faktycznemu podwyższeniu według wskaźnika zwiększającego. Na istotną funkcję owego wskaźnika zwrócono również uwagę na s. 10 Raportu z konsultacji dotyczacego projektu ustawy, wydanego w dniu 11 sierpnia 2017 r., w którym podkreślono, że: [n]atomiast w przypadku szkół publicznych kwota w subwencji oświatowej zostanie odpowiednio zwiększona przez przemnożenie jej przez tzw. wskaźnik zwiększajacy. Wskaźnik zwiększający uwzględnia rzeczywiste wydatki danego samorzadu na dany typ szkoły poprzez określenie, jaki procent dany samorzad wydaje ponad subwencje (tj. iloraz rzeczywistych poniesionych wydatków $w$ danym samorządzie na dany typ szkoły do kwoty subwencji otrzymanej na te szkoły). Przemnożenie kwoty subwencji przez wskaźnik zwiększający umożliwi więc odniesienie kwoty dotacji do rzeczywistych wydatków ponoszonych przez samorząd na dany typ szkoły ${ }^{29}$.

Z powyższych ustaleń wynika zatem, że uwzględnianie wskaźnika zwiększającego, uregulowanego $\mathrm{w}$ art. 14 ust. 1 i 2 projektu ustawy (a pominiętego w samej ustawie), biorącego pod uwagę rzeczywiste wydatki samorządu, miało stanowić swoisty wentyl bezpieczeństwa systemu, który gwarantował równe zasady finansowania oświatowych jednostek samorządowych oraz pozostałych publicznych placówek otrzymujących dotacje.

Usunięcie w treści art. 25 ust. 3 zapisu mówiącego o stosowaniu wskaźnika zwiększającego oznacza, że kwota dotacji ograniczona jest jedynie do kwoty przewidzianej na ucznia w części oświatowej subwencji ogólnej dla jednostki samorządu terytorialnego. Tym samym w obecnych uwarunkowaniach prawnych nie zostały uwzględnione postulaty samego projektodawcy, który uznawał za konieczne wprowadzenie owego wskaźnika zwiększającego. Rezygnacja z pierwotnej wersji przepisu art. 25 ust. 3 ustawy może zatem skutkować tym, że faktycznie uzyskane przez publiczne szkoły niesamorządowe kwoty dotacji będą inne niż zakładane w projekcie ustawy, jego uzasadnieniu oraz w przyjętej ocenie

28 Zob. Uzasadnienie do projektu ustawy o finansowaniu zadań oświatowych, s. 8, https:// legislacja.rcl.gov.pl/docs//2/12298908/12436004/12436005/dokument307702.pdf.

29 Https://legislacja.rcl.gov.pl/docs//2/12298908/12436004/12436005/dokument307709.pdf. 
skutków regulacji. Nie ma pewności, czy w skutek uchwalonych przez parlament przepisów art. 25 ustawy o finansowaniu zadań oświatowych publiczne szkoły prowadzone przez osoby prawne niebędące jednostkami samorządu terytorialnego oraz osoby fizyczne, w których nie jest realizowany obowiązek szkolny lub obowiązek nauki, otrzymują na każdego ucznia dotację z budżetu w kwocie równej wysokości tej dotacji, którą otrzymałyby zgodnie z dotychczas obowiązującymi rozwiązaniami. Wydaje się, że uzależnione to jest od tego, na ile subwencja oświatowa odwzorowuje specyfikę ekonomiczną szkół.

\section{Podsumowanie}

- W konsekwencji rozwiązania przewidzianego w art. 25 ustawy o finansowaniu zadań oświatowych oraz rozwiązań planowanych na poziomie rozporządzenia w sprawie sposobu podziału części oświatowej subwencji ogólnej dla jednostek samorządu terytorialnego w roku 2018 dotychczasowa subwencja naliczana na uczniów poszczególnych rodzajów szkół (w tym licea ogólnokształcące dla dorosłych, szkoły policealne) została podzielona na dwie części: „za uczestnictwo w zajęciach”, która ma charakter bezwarunkowy, i „za zdany egzamin", która ma charakter warunkowy i zależy od efektywności kształcenia. W rezultacie tych zmian kwota dotacji udzielanej szkołom dla dorosłych prowadzonym przez osoby prawne niebędące jednostkami samorządu terytorialnego oraz osoby fizyczne w części będzie uzależniona od skuteczności i uzyskiwanych efektów kształcenia. O taką zmianę przepisów w zakresie dotowania szkół niepublicznych wnioskowała Najwyższa Izba Kontroli. Według projektowanego algorytmu podziału części oświatowej subwencji ogólnej dla jednostek samorządu terytorialnego na rok 2018 finansowanie „za efekt" dotyczy w takim samym stopniu szkół niesamorządowych co szkół prowadzonych przez jednostki samorządu terytorialnego.

Zakłada się, że w rezultacie przyjętych rozwiązań w szkołach, które charakteryzują się wysoką zdawalnością, subwencja zostanie naliczona na uczniów tych szkół w wysokości tak jak dotychczas lub nawet wyższej, natomiast w szkołach z niską zdawalnością zostanie naliczona subwencja niższa niż do tej pory.

Konsekwencją wydzielenia w subwencji oświatowej części „za zdany egzamin” są zmiany poziomu subwencji „za uczestnictwo w zajęciach”. Udział subwencji w części „za uczestnictwo w zajęciach” do dotychczasowej subwencji został ustalony w zależności od trybu kształcenia i kategorii uczestników tego kształcenia, a nie ze względu na organ prowadzący. Ze zmianami w subwencji oświatowej w części „za uczestnictwo w zajęciach” wiąże się przyjęte w projekcie rozporządzenia w sprawie sposobu podziału części oświatowej subwencji ogólnej dla jednostek samorządu terytorialnego w roku 2018 zmniejszenie 
wskaźników do wyliczenia kwot subwencji dla liceów ogólnokształcących dla dorosłych oraz szkół policealnych, które dotyczą w tym samym stopniu szkół niesamorządowych co szkół prowadzonych przez jednostki samorządu terytorialnego.

$\mathrm{W}$ świetle powyższego można stwierdzić, że z prawnofinansowego punktu widzenia faktycznie może dojść do nawet znacznego obniżenia kwot subwencji naliczanych na uczniów szkół dla dorosłych w stosunku do dotychczasowego poziomu, co może w sposób istotny wpływać na funkcjonowanie szkół dla dorosłych.

- Dotychczas funkcjonujące zasady dotowania publicznych szkół dla dorosłych prowadzonych przez osoby prawne niebędące jednostkami samorządu terytorialnego lub osoby fizyczne przewidują dotację z budżetu jednostki samorządu terytorialnego obowiązanej do prowadzenia danego typu i rodzaju szkół w wysokości równej podstawowej kwocie dotacji dla szkół danego typu i rodzaju, nie niższej jednak niż kwota przewidziana na takiego ucznia w części oświatowej subwencji ogólnej dla jednostki samorządu terytorialnego. Dotychczas funkcjonujący system zakładał więc konieczność równego traktowania szkół niesamorządowych oraz szkół prowadzonych przez jednostki samorządu terytorialnego ${ }^{30}$.

Przyjęte nowe przepisy w tym zakresie (art. 25 ustawy o finansowaniu zadań oświatowych) wprowadzają zmiany powodujące, że w szkołach prowadzonych przez osoby prawne niebędące jednostkami samorządu terytorialnego oraz osoby fizyczne publiczne szkoły, w których nie jest realizowany obowiązek szkolny lub obowiązek nauki, niebędące szkołami specjalnymi, dotacja określana będzie na każdego ucznia w wysokości równej kwocie przewidzianej na takiego ucznia w części oświatowej subwencji ogólnej dla jednostki samorządu terytorialnego. W przeciwieństwie do prowadzonych przez osoby prawne niebędące jednostkami samorządu terytorialnego oraz osoby fizyczne publicznych szkół, w których jest realizowany obowiązek szkolny lub obowiązek nauki, dotacje dla szkół, w których nie jest realizowany obowiązek szkolny lub obowiązek nauki, nie będą przemnażane dodatkowo przez wskaźnik zwiększający dla szkół danego typu. Jakkolwiek w projekcie ustawy o finansowaniu zadań oświatowych zasadę przemnażania dotacji o wskaźnik zwiększający przyjęto również w stosunku do szkół, w których nie jest realizowany obowiązek szkolny lub obowiązek nauki, a w uzasadnieniu do tego projektu argumentowano, że wprowadzenie wskaźnika jest konieczne, aby w przypadku dotowanych szkół publicznych odpowiednio zwiększyć kwotę przeznaczoną w części oświatowej subwencji ogólnej dla jednostki samorzą-

30 Zob. również wyroki: NSA z 8 lutego 2013 r., sygn. akt II GSK 2095/11, LEX nr 1358351, oraz WSA w Kielcach z 25 kwietnia 2013 r., sygn. akt II SA/Ke 215/13, LEX nr 1325744. 
du terytorialnego na ucznia, uwzględniając wszystkie wydatki ponoszone przez ten samorząd na szkoły danego typu (ponad kwotę naliczaną w części oświatowej subwencji ogólnej). Nie ma jasności co do tego, czy brak przemnożenia dotacji wskaźnikiem zwiększającym wpłynie na odwzorowanie w kwocie dotacji kosztów utrzymania szkół prowadzonych przez jednostki samorządu terytorialnego. W tym kontekście może budzić wątpliwości, czy niezastosowanie wskaźnika zwiększającego kwoty części oświatowej subwencji ogólnej w przypadku prowadzonych przez osoby prawne niebędące jednostkami samorządu terytorialnego oraz osoby fizyczne szkół publicznych, w których nie jest realizowany obowiązek szkolny lub obowiązek nauki, nie spowoduje istotnych różnic $\mathrm{w}$ wysokości dotacji w stosunku do obecnych kwot dotacji. Jeśli nowe rozwiązanie nie byłoby neutralne dla dotowanych placówek, to może dochodzić do naruszenia reguły równego traktowania podmiotów prowadzących placówki oświatowe.

\section{Bibliografia}

Najwyższa Izba Kontroli, Informacja o wynikach kontroli. Kształcenie w szkołach dla dorostych, 2017, https://www.nik.gov.pl.

Pilich M., Ustawa o systemie oświaty. Komentarz, 2015, LEX, komentarz do art. 80.

Pirożyński Z., Budżetowanie brutto [w:] Leksykon finansowo-bankowy, red. W. Jaworski, Warszawa 1991. 



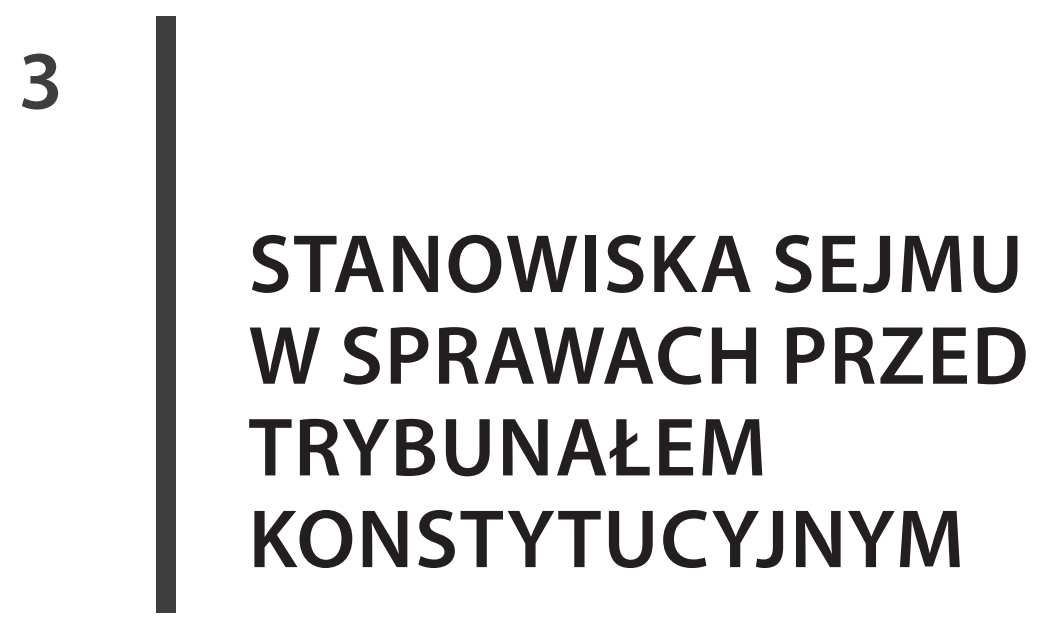





\section{Dopuszczalność dowodów - wniosek Rzecznika Praw Obywatelskich (sygn. akt K 27/16) dotyczący ustawy - Kodeks postępowania karnego ${ }^{1}$}

Admissibility of evidence - request of the Ombudsman (K 27/16) regarding the Act Code of Criminal Procedure: The object of the Constitutional Tribunal's review is Article 168a of the Code indicating the reasons of inadmissibility of evidence. The draft Sejm's position contains a conclusion that the above provision is consistent with the Constitution of the Republic of Poland. The applicant (the Commissioner for Citizens' Rights) claims that the challenged provision expresses an absolute obligation to include any evidence in the Polish criminal trial, regardless of how it was collected, including evidence obtained in violation of the prohibitions on collecting evidence. In the justification of the Sejm's draft position it was stated that the purpose of the amendment was to ensure that the offender would be held criminally responsible and that any innocent person would be released from this liability in any situation where material evidence could be subject to exclusion only due to a defect in the procedure for obtaining it.

\footnotetext{
Keywords: Code of Criminal Procedure | Constitutional Tribunal |"fruit of the poisonous tree" | material truth

Słowa kluczowe: Kodeks postępowania karnego | Trybunał Konstytucyjny |„owoce zatrutego drzewa"| prawda materialna
}

Doktor nauk prawnych, Uniwersytet Kardynała Stefana Wyszyńskiego w Warszawie, ekspert ds. legislacji BAS; a.poglodek@uksw.edu.pl.

\section{Trybunał Konstytucyjny}

Na podstawie art. 69 ust. 2 w związku z art. 42 pkt 3 ustawy z dnia 30 listopada 2016 r. o organizacji i trybie postępowania przed Trybunałem Konstytucyjnym (Dz. U. poz. 2072), w imieniu Sejmu Rzeczypospolitej Polskiej przedkładam wyjaśnienia w sprawie wniosku Rzecznika Praw Obywatelskich z 6 maja

1 Sprawa dotyczaca wniosku Rzecznika Praw Obywatelskich z dnia 6 maja 2016 r. (K 27/16), dotyczacego ustawy - Kodeks postępowania karnego sporządzona 23 lutego 2018 r.; BAS-WPTK 1037/16. 
2016 r. (sygn. akt K 27/16), jednocześnie wnosząc o stwierdzenie, że art. 168a ustawy z dnia 6 czerwca 1997 r. - Kodeks postępowania karnego (tj. Dz. U. 2017, poz. 1904) jest zgodny $\mathrm{z}$ art. 45 ust. $1 \mathrm{w}$ związku $\mathrm{z}$ art. 51 ust. $4 \mathrm{w}$ związku $\mathrm{z}$ art. 31 ust. 3 Konstytucji w związku z art. 6 Konwencji o ochronie praw człowieka i podstawowych wolności sporządzonej w Rzymie dnia 4 listopada $1950 \mathrm{r}$. (Dz. U. 1993, Nr 61, poz. 284, ze zm.), a także z art. 2, art. 7 i art. 47 Konstytucji, oraz nie jest niezgody $z$ art. 40 Konstytucji w związku z art. 3 Konwencji o ochronie praw człowieka i podstawowych wolności sporządzonej w Rzymie dnia 4 listopada 1950 r. (Dz. U. 1993, Nr 61, poz. 284, ze zm.).

Ponadto wnoszę o umorzenie postępowania w pozostałym zakresie na podstawie art. 59 ust. 1 pkt 2 ustawy o organizacji i trybie postępowania przed Trybunałem Konstytucyjnym ze względu na niedopuszczalność wydania orzeczenia.

\section{Uzasadnienie}

\section{Przedmiot kontroli}

Do Kancelarii Sejmu wpłynęło zawiadomienie Prezesa Trybunału Konstytucyjnego o wszczęciu postępowania przed Trybunałem Konstytucyjnym w sprawie z wniosku Rzecznika Praw Obywatelskich z dnia 6 maja 2016 r., sygn. akt K 27/16.

Przedmiotem kontroli jest art. 168a ustawy z dnia 6 czerwca 1997 r. - Kodeks postępowania karnego (tj. Dz. U. 2017, poz. 1904; dalej: k.p.k.): „Dowodu nie można uznać za niedopuszczalny wyłącznie na tej podstawie, że został uzyskany z naruszeniem przepisów postępowania lub za pomocą czynu zabronionego, o którym mowa w art. $1 \$ 1$ Kodeksu karnego, chyba że dowód został uzyskany w związku z pełnieniem przez funkcjonariusza publicznego obowiązków służbowych, w wyniku: zabójstwa, umyślnego spowodowania uszczerbku na zdrowiu lub pozbawienia wolności”.

Zaskarżony przepis w obecnym brzmieniu został wprowadzony do Kodeksu postępowania karnego ustawą z dnia 11 marca 2016 r. o zmianie ustawy - Kodeks postępowania karnego oraz niektórych innych ustaw (Dz. U. poz. 437; dalej: ustawa nowelizująca). Projekt tej ustawy wpłynął do Sejmu z propozycją usunięcia art. 168a k.p.k. w brzmieniu nadanym mu ustawą z dnia 27 września 2013 r., która weszła w życie z dniem 1 lipca 2015 r., a ustanowiła następującą treść tego przepisu: „Niedopuszczalne jest przeprowadzenie i wykorzystanie dowodu uzyskanego do celów postępowania karnego za pomocą czynu zabronionego, o którym mowa w art. $1 \$ 1$ Kodeksu karnego".

Pierwotnie projekt ustawy wniesiony przez rząd do Sejmu w dniu 27 stycznia 2016 r. (druk sejmowy nr 207/VIII kad.), ograniczał się do uchylenia art. 168a k.p.k. W uzasadnieniu do ustawy nowelizującej wskazano: „W ocenie projektodawcy zbędna jest regulacja art. 168a k.p.k., gdyż przepis ten wprowadza bardzo szeroki zakres zakazu dowodowego, niezależnie od okoliczności jego uzyskania. 
W tym stanie rzeczy celowe jest ocenianie każdej sytuacji in casu, z uwzględnieniem wszystkich aspektów sprawy, w oparciu o ogólnie przyjęte zasady w dorobku orzecznictwa i doktryny w perspektywie ostatnich kilkudziesięciu lat. Jak wskazuje się w doktrynie, «przepis art. 168a k.p.k., dyskwalifikujący dowody uzyskane za pomocą czynu zabronionego, znacznie rozszerza i tak szeroki obecnie system zakazów dowodowych w postępowaniu karnym. Dyskwalifikacja dowodów ocenianych nie tyle według kryteriów prawnoprocesowych wyznaczanych przez zakazy dowodowe, ile według kryteriów prawnokarnomaterialnych dotyczących przestępnych (a nawet jedynie zabronionych przez prawo karne) działań zarówno uczestników postępowania, jak i osób nieuczestniczących w procesie, może prowadzić do rezultatów chyba niezamierzonych przez ustawodawcę.

Z orzecznictwa Europejskiego Trybunału Praw Człowieka nie wynika również zakaz korzystania $\mathrm{z}$ dowodów pośrednio nielegalnych, pomimo dostrzeżenia nielegalnego źródła ich pochodzenia. [...]»" (uzasadnienie rządowego projektu ustawy o zmianie ustawy - Kodeks postępowania karnego oraz niektórych innych ustaw, druk sejmowy nr 207/VIII kad.).

Zmiana dalej idąca została wprowadzona $\mathrm{w}$ formie poprawki na etapie prac sejmowych. Dodano wówczas do ustawy nowelizującej art. 168a k.p.k. w obecnym brzmieniu podczas posiedzenia Komisji nadzwyczajnej do spraw zmian w kodyfikacjach. Przedstawiciele Ministerstwa Sprawiedliwości stwierdzili, że nowa regulacja jest przejawem samoograniczenia się ustawodawcy, który wprowadza przepis bardziej ograniczający w kwestii postępowania dowodowego, niż miało to miejsce przed 1 lipca $2015 \mathrm{r}$. Jednocześnie doprecyzowuje zakres stosowania przepisu, bowiem brzmienie art. 168a przed wykreśleniem w 2015 r. nie wyznaczało ani zakresu przedmiotowego czynów, ani zakresu podmiotowego osób popełniających czyny zabronione przez prawo karne. Wskazano, że nie sposób przyjąć, aby przepis art. 168a k.p.k. w obecnym brzmieniu zachęcał organy państwa, by za wszelką cenę zdobywały dowody niezbędne do dowiedzenia winy oskarżonego. Podkreślono, że celem wprowadzenia przepisu jest uniknięcie wątpliwości dotyczących sytuacji, w której z uwagi na nieznaczne uchybienia proceduralne byłyby eliminowane $z$ procesu dowody o fundamentalnym znaczeniu dla stwierdzenia winy bądź niewinności oskarżonego, podając jako przykład przeszukanie, $\mathrm{w}$ rezultacie którego ujawniono dowody popełnienia przestępstwa nieobjęte zakresem postanowienia o przeszukaniu. Projektodawca podkreślił, że nie do zaakceptowania jest sytuacja, w której ujawnienie dowodu zabójstwa $\mathrm{w}$ toku dokonywania przestępstwa, np. kradzieży $\mathrm{z}$ włamaniem, mogłoby skutkować uznaniem takiego dowodu przez sąd za niedopuszczalny. Zauważono też, że niedopuszczalna jest również sytuacja, w której zdobycie w nielegalny sposób dowodu przesądzającego o niewinności oskarżonego, powodowałoby konieczność uznania takiego dowodu za niedopuszczalny, a na taką wykładnię art. 168a k.p.k. w poprzednim brzmieniu pozwalała treść tego przepisu. Projektodawca wskazał też, że przecinek pomiędzy sformułowaniami „obowiązków służbowych” 
i „W wyniku” w obecnym brzmieniu art. 168a k.p.k. jest elementem koniunkcji między obiema frazami, tj. musi zaistnieć związek pomiędzy pełnieniem przez funkcjonariusza publicznego obowiązków służbowych i zabójstwem, spowodowaniem uszczerbku na zdrowiu lub pozbawieniem wolności, aby aktualizował się zakaz dowodowy, przewidziany w art. 168a k.p.k. in fine (stenogram z posiedzenia Komisji nadzwyczajnej do spraw zmian w kodyfikacjach z dnia 25 lutego 2016 r., http://orka.sejm.gov.pl/Zapisy8.nsf/wgskrnr/NKK-9).

Jak można wywodzić z treści wniosku Rzecznika Praw Obywatelskich (dalej: Rzecznik), przyjął on, że art. 168a k.p.k. wyraża bezwzględny nakaz uwzględnienia w polskim procesie karnym każdego dowodu, niezależnie od sposobu jego uzyskania, w tym dowodów uzyskanych z naruszeniem zakazów dowodowych, m.in. art. $171 \S 7$ k.p.k. Rzecznik podnosi bowiem przykładowo, że art. 168a k.p.k. nakłada na sąd obowiązek uwzględnienia dowodu uzyskanego wskutek tortur lub okrutnego, nieludzkiego albo poniżającego traktowania. Takie rozumienie kwestionowanego przepisu nie może jednak zostać uznane za prawidłowe, uwzględniając poza wykładnią językową także wykładnię autentyczną, systemową i funkcjonalną.

Na podstawie przebiegu prac ustawodawczych można stwierdzić, że: „celem znowelizowania art. 168a k.p.k. było ograniczenie dowolności organów procesowych w zakresie uznawania dowodów za niedopuszczalne a priori, bez przeprowadzenia ich oceny stosownie do treści art. 4 i art. 7 k.p.k., oraz wskazanie wyjątków od zasady swobodnego dowodzenia poprzez precyzyjne ujęcie w treści komentowanego przepisu in fine bezwzględnych zakazów dowodowych mających zapewnić respektowanie standardu konwencyjnego, a także jednoznaczne odrzucenie przez ustawodawcę koncepcji „owoców zatrutego drzewa” jako sprzecznej z fundamentalnymi zasadami polskiej procedury karnej, w szczególności zasadą prawdy materialnej, oraz celami postępowania karnego, mającymi uzasadnienie w normach konstytucyjnych, w szczególności z koniecznością dążenia do takiego ukształtowania procedury karnej, aby sprawca przestępstwa został wykryty i pociągnięty do odpowiedzialności karnej, a osoba niewinna nie poniosła tej odpowiedzialności” (stanowisko Prokuratora Generalnego, s. 63). Ustawodawca odwołał się w ten sposób do: „tych orzeczeń sądowych w których odrzucono doktrynę „owoców zatrutego drzewa” (tak m.in. w orzeczeniach Sądu Apelacyjnego w Katowicach z dn. 27 maja 2004, sygn. II AKa 160/04, LEX nr 149706; Sądu Najwyższego z dn. 14 listopada 2006 r., sygn. V KK 52/06, LEX nr 202271; z dn. 22 lutego 2007 r., sygn. V KK 183/06, LEX nr 274709; z dn. 5 lutego 2008 r., sygn. SNO 2/08, LEX nr 432189; z dn. 3 grudnia 2008 r., sygn. V KK 195/08, LEX nr 482213; z dn. 25 marca 2010 r., sygn. I KZP 2/10, LEX nr 564518; Sądu Apelacyjnego w Lublinie z dn. 22 stycznia 2013 r., sygn. II AKa 301/12, LEX nr 1289474; Sądu Najwyższego z dn. 30 października 2013 r., sygn. II KK 139/13, LEX nr 1391587, oraz z dn. 2 lutego 2016 r., sygn. IV KK 346/15, LEX nr 1976252)” (ibidem). Artykuł 168a k.p.k.: „stanowi lex generalis i podlega 
ograniczeniu przez leges speciales, w szczególności inne zakazy dowodowe. Należy go rozumieć w ten sposób, że w obecnym stanie prawnym nie można uznać za niedopuszczalny dowodu z powodu uzyskania go bezpośrednio lub pośrednio z powodu jedynie jakiegokolwiek, choćby porządkowego, naruszenia przepisów postępowania lub za pomocą czynu zabronionego, każdy taki dowód musi natomiast podlegać swobodnej ocenie sądu, dokonanej na zasadach przewidzianych w art. 4 i art. 7 k.p.k., a więc w zgodzie z zasadami obiektywizmu oraz swobodnej oceny dowodów. Stwierdzenie, że dowód został pozyskany nie w drodze czynu zabronionego, o którym mowa w art. $1 \S 1$ k.k., ale w drodze czynu sprzecznego z prawem cywilnym lub stanowiącego wykroczenie, przestępstwo skarbowe bądź wykroczenie skarbowe, nie jest przesłanką wystarczającą do wyeliminowania go z procesu karnego. Dowód nie może zostać uznany za niedopuszczalny nie tylko wyłącznie na tej podstawie, że został uzyskany za pomocą przestępstwa, lecz także przy stwierdzeniu jedynie realizacji znamion danego typu czynu zabronionego, w oderwaniu od stopnia społecznej szkodliwości i winy. Jednakże, w żadnych okolicznościach nie może zostać uznany za dopuszczalny dowód, uzyskany bezpośrednio lub pośrednio $\mathrm{w}$ związku $\mathrm{z}$ pełnieniem przez funkcjonariusza publicznego obowiązków służbowych w wyniku zabójstwa, umyślnego spowodowania uszczerbku na zdrowiu lub pozbawienia wolności. Wydaje się, że, wprowadzając ten zakaz dowodowy, ustawodawca chciał sprostać wymaganiom konwencyjnym dotyczącym zakazu wykorzystywania dowodów uzyskanych wskutek tortur, szczegółowo precyzując zakres niedopuszczalnych dowodów nielegalnych, zarówno bezpośrednio, jak i pośrednio" (ibidem, s. 64). Stąd też na gruncie art. 168a k.p.k. za niedopuszczalny powinien zostać uznany dowód, który: „1) został bezpośrednio lub pośrednio uzyskany w wyniku czynu zabronionego realizującego znamiona zabójstwa, umyślnego spowodowania uszczerbku na zdrowiu lub pozbawienia wolności popełnionego przez funkcjonariusza publicznego w związku z pełnieniem obowiązków służbowych lub 2) został bezpośrednio uzyskany wskutek złamania istniejącego już w prawie procesowym zakazu dowodowego” (ibidem, s. 65). „Ustalić również należy istnienie związku funkcjonalnego pomiędzy pozyskaniem dowodu a działaniami podejmowanymi przez funkcjonariusza publicznego w związku z pełnieniem obowiązków. Niezbędne jest także ustalenie, że osoba pozyskująca dowód działała w intencji jego uzyskania przy wykorzystaniu jednej z metod określonych w art. 168a k.p.k. in fine" (ibidem).

\section{Zarzuty wnioskodawcy}

1. Rzecznik podnosi, że: „już przed 2013 r. w orzecznictwie wykształciła się koncepcja nawiązująca do teorii owoców zatrutego drzewa, wedle której niedopuszczalne jest przeprowadzenie przed sądem dowodu, który został zdobyty w sposób niezgodny z prawem. [...]. Wprowadzenie do Kodeksu postępowania karnego art. 168a w brzmieniu ustalonym w nowelizacji z dnia 27 września 2013 r. nie 
tylko potwierdzało linię orzeczniczą Sądu Najwyższego, ale też konweniowało z dopuszczonymi do procesu karnego dowodami prywatnymi" (wniosek Rzecznika, s. 5). W 2016 r. ustawą nowelizującą zmieniono brzmienie art. 168a k.p.k., nadając mu brzmienie w ocenie Rzecznika niezgodne z Konstytucją. Rzecznik wskazuje, że: „ustawodawca, nie tylko uchylając - jak planowano pierwotnie art. 168a k.p.k., ale zmieniając jego treść w taki sposób, aby zobligować sądy do uwzględniania dowodów, nawet - z nielicznymi wyjątkami - zdobytych nielegalnie, wyeksplikował swoje intencje. Niewątpliwie celem zmiany było zaprzeczenie koncepcji niedopuszczalności niektórych dowodów, wypracowanej przez Sąd Najwyższy dzięki odwołaniu się do metody wykładni prawa w zgodzie z Konstytucją RP. Ustawodawca - twierdząc, że tego wymaga zasada prawdy materialnej - miał na celu możliwie daleko idące ograniczenie dyskrecjonalności sądu w ustalaniu możliwości dopuszczenia danego dowodu” (ibidem).

Rzecznik podkreśla, że: „konstruowanie implikacji między prawdą materialną i nakazem przeprowadzania wszystkich dowodów jest błędne. Organy państwa, w tym zwłaszcza prokuratura odpowiadająca za prowadzenie postępowania przygotowawczego i popieranie oskarżenia dysponują licznymi środkami umożliwiającymi pozyskiwanie materiału dowodowego w sposób legalny. Ograniczenie możliwości przeprowadzania dowodów zdobytych w sposób wypełniający znamiona czynu zabronionego nie uniemożliwia dotarcia do prawdy materialnej. Nie można także zapominać, że zasada prawdy materialnej jest bardzo ważną ale nie jedyną zasadą którą należy uwzględnić w ramach procesu karnego. Państwo nie powinno dążyć do prawdy «za wszelką cenę», nie zważając na naruszanie podstawowych praw i wolności człowieka. Najważniejszą a także jedną z niewielu, szansą na ochronę dóbr człowieka - pokrzywdzonego, sprawcy, innych uczestników postępowania - jest zapewnienie właściwych standardów postępowania, dających jednostce szansę na uzyskanie pomocy państwa i gwarancję zaniechania naruszania jej praw. W przeciwnym razie organy państwa, $\mathrm{z}$ istoty wykazujące tendencje ku omnipotencji, będą mogły dowolnie ingerować w esencjalne dobra jednostki, nie dając jej szansy na skuteczną obronę" (ibidem, s. 6).

Dalej Rzecznik podnosi, że: „zobowiązanie sądu do uwzględnienia dowodu, który został pozyskany z naruszeniem przepisów postępowania lub za pomocą czynu zabronionego narusza prawo do sprawiedliwego rozpatrzenia sprawy. Nie zmienia tego wprowadzenie do przepisu wyjątków, które uniemożliwiają przeprowadzenia dowodu pozyskanego $\mathrm{w}$ związku z pełnieniem przez funkcjonariusza publicznego obowiązków służbowych, w wyniku: zabójstwa, umyślnego spowodowania uszczerbku na zdrowiu lub pozbawienia wolności” (ibidem, s. 8). Wciąż bowiem, w ocenie Rzecznika pozostawia się: „szeroką możliwość dowodzenia w oparciu o materiał zdobyty z naruszeniem postępowania lub za pomocą czynu zabronionego [...]” (ibidem). Następnie Rzecznik wywodzi, że: „naruszenia prawa do sprawiedliwego procesu nie sanuje także zasada swobodnej oceny 
dowodów. Sprawiedliwość procesu narusza już samo dopuszczenie dowodu pozyskanego nielegalnie i włączenie go do materiału będącego podstawą rozstrzygnięcia sprawy” (ibidem). Rzecznik dostrzega, że: „możliwa być może byłaby taka wykładnia prokonstytucyjna, która pozwalałaby jednak sądowi na nie uwzględnienie dowodu w ustaleniach faktycznych będących podstawą wyroku, po jego uprzednim dopuszczeniu, tylko $\mathrm{z}$ uwagi na sposób jego pozyskania. W materii tak ważnej, kiedy waży się sprawiedliwość procesu, nie należy jednak wprowadzać rozstrzygnięć normatywnych, które powodowałyby tak liczne wątpliwości interpretacyjne" (ibidem, s. 8-9).

2. Rzecznik wywodzi również, że art. 168 k.p.k. stanowi zakwestionowanie wyrażonej w art. 7 Konstytucji zasady praworządności pro futuro, z tego względu, że ustawodawca: „nie tylko zauważa, że organy władzy publicznej - skądinąd odpowiadające za praworządne postępowanie - mogą postępować w sposób niezgodny z prawem, ale z góry to akceptuje. Co więcej, nakazuje wymiarowi sprawiedliwości opieranie swojej działalności na niepraworządnym działaniu organów władzy publicznej i ich funkcjonariuszy" (ibidem, s. 11). Podkreśla także, że: „taki wymóg nałożony na sądy może nawet zachęcać organy państwa do pozyskania materiału dowodowego bez względu na ograniczenia prawne. W niektórych, skomplikowanych postępowaniach, może to okazać się łatwiejsze - biorąc pod uwagę nawet ryzyko odpowiedzialności karnej - niż pozyskiwanie dowodu w sposób legalny" (ibidem).

Naruszona jest także, w ocenie Rzecznika, zasada przewidywalności procesu karnego. Artykuł 168a k.p.k.: „dekonstruuje możliwość przewidywania sposobu działania organów władzy publicznej, ponieważ legitymizuje działania niezgodne z prawem, pozwalając na budowanie strategii procesowej prokuratury także w oparciu o tzw. owoce zatrutego drzewa. Ten stan rzeczy wydaje się niezgodny nie tylko $\mathrm{z}$ art. 45 , ale także $\mathrm{z}$ art. 42 ust. 2 Konstytucji RP statuującym prawo do obrony we wszystkich stadiach postępowania" (ibidem, s. 13).

Rzecznik podnosi, że skutkiem bezpośrednim art. 168a k.p.k. jest więc: „samo dopuszczenie do przeprowadzenia dowodów pozyskanych z naruszeniem przepisów postępowania lub za pomocą czynu zabronionego" (ibidem). Oprócz tego pośrednio przepis ten: „legitymizuje bezprawne działania organów władzy publicznej, niejako skłaniając nawet te podmioty do zdobywania materiału dowodowego z naruszeniem przepisów prawa" (ibidem, s. 14). Rzecznik wskazuje, że: „niewątpliwie bezprawne pozyskiwanie dowodów przez organy władzy publicznej może naruszać art. 47 Konstytucji RP” (ibidem). Jak dalej wywodzi Rzecznik: „jeżeli zatem można zrekonstruować zakaz uchwalania przepisów, które pozwalałyby na zarządzanie kontroli operacyjnej w sposób arbitralny, to tym bardziej naruszać standardy konstytucyjne i konwencyjne musi przepis, który pozwala na wykorzystywanie w postępowaniu karnym materiałów zdobytych nawet nie na podstawie przepisów arbitralnych, ale nielegalnie, a więc wbrew zasadom kierującym realizowaniem czynności operacyjno-rozpoznawczych. $\mathrm{W}$ tym kontek- 
ście należy także przywołać normy rekonstruowane w oparciu o art. 51 ust. 2 i 4 Konstytucji RP. Po pierwsze, władze publiczne nie mogą pozyskiwać, gromadzić i udostępniać innych informacji o obywatelach niż niezbędne w demokratycznym państwie prawnym. Po drugie, każdy ma prawo do żądania sprostowania oraz usunięcia informacji nieprawdziwych, niepełnych lub zebranych w sposób sprzeczny z ustawą. Konstytucja wskazuje zatem wprost, że dane zebrane w sposób sprzeczny z ustawą powinny być usunięte na żądanie osoby, której dotyczą. Tym samym, przepis, który nie tylko nie nakazuje usunięcia takich danych, ale przeciwnie - wymaga od sądu uwzględnienia ich w procesie orzekania, jest niewątpliwie niezgodny z art. 54 ust. 4 Konstytucji RP” (ibidem, s. 16-17). Rzecznik, odwołując się do zasady a minori ad maius, podnosi, że: „jeżeli ustawodawca zabrania przetwarzania danych zebranych niezgodnie z prawem, a także nakazuje ich usunięcie, to tym bardziej zabronione jest wykorzystywanie tych danych w procedurze karnej, która w swojej naturze może skutkować istotnymi konsekwencjami dla jednostki” (ibidem, s. 17-18).

3. W ocenie Rzecznika art. 168a k.p.k. budzi także poważne wątpliwości: „dotyczącego [jego - dopisek A.P.] celowości i proporcjonalności sensu stricto. Aparat państwa wyposażony jest $\mathrm{w}$ bardzo szerokie instrumentarium pozwalające mu na legalne pozyskiwanie dowodów, które mogą być później przedmiotem oceny w postępowaniu karnym. Trudno jest znaleźć uzasadnienie dla przepisu nakładającego na sąd nie tylko możliwość, ale aż obowiązek uwzględnienia dowodów pozyskanych nielegalnie” (ibidem, s. 19). Podnosi też, że: „nie trudno zauważyć także jego niezgodność z art. 40 Konstytucji RP w związku z art. 3 Konwencji o ochronie praw człowieka i podstawowych wolności. Nałożenie na sąd obowiązku uwzględnienia dowodu pozyskanego w sposób niezgodny z przepisami lub za pomocą czynu zabronionego daje organom prowadzącym postępowanie możliwość wnioskowania o włączenie do sprawy także tych dowodów, które zostały pozyskane w sposób wypełniający znamiona tortur lub okrutnego, nieludzkiego albo poniżającego traktowania” (ibidem). Taka możliwości: „nie tylko jest niezgodna ze standardem konstytucyjnym i konwencyjnym, ale narusza także absolutny zakaz tortur oraz okrutnego, poniżającego i nieludzkiego zachowania, rozpoznany jako norma o charakterze ius cogens" (ibidem, s. 20). Proces, w którym zostaną wykorzystane takie dowody: „staje się nierzetelny, a więc prowadzony jest $\mathrm{z}$ naruszeniem art. $6 \mathrm{EKPC}$, a więc narusza także standard wynikający z art. 45 Konstytucji RP” (ibidem, s. 21).

4. Ostatecznie pozwala to Rzecznikowi także na stwierdzenie, że art. 168 k.p.k.: „jest niezgodny również z art. 2 Konstytucji RP, w tym zwłaszcza z zasadą zaufania obywateli do państwa i stanowionego przez nie prawa. [...] Nie da się mówić o przewidywalności, obliczalności, a tym bardziej o lojalności państwa wobec adresatów norm prawnych w sytuacji, gdy nielegalne działania organów władzy publicznej mogą stać się podstawą podejmowania czynności działających na niekorzyść jednostki. [...]” (ibidem). 


\section{Analiza formalnoprawna}

1. Trybunał Konstytucyjny na każdym etapie postępowania jest obowiązany do badania, czy nie zachodzi ujemna przesłanka wydania wyroku, skutkująca obligatoryjnym umorzeniem postępowania (postanowienia TK z: 6 lipca 2004 r., sygn. akt SK 47/03; 14 listopada 2007 r., sygn. akt SK 52/06; 10 listopada 2009 r., sygn. akt SK 45/08; 14 grudnia 2011 r., sygn. akt SK 29/09; 28 lutego 2012 r., sygn. akt SK 32/10; 18 czerwca 2013 r., sygn. akt SK 1/12; 28 października 2015 r., sygn. akt P 6/13).

Wniosek Rzecznika został wniesiony w dniu 6 maja 2016 r., a więc przed wejściem w życie ustawy z dnia 30 listopada 2016 r. o organizacji i trybie postępowania przed Trybunałem Konstytucyjnym (dalej: u.o.t.p.TK). Zgodnie z art. 1 ustawy z dnia 13 grudnia 2016 r. - Przepisy wprowadzające ustawę o organizacji i trybie postępowania przed Trybunałem Konstytucyjnym oraz ustawę o statusie sędziów Trybunału Konstytucyjnego (Dz. U. poz. 2074; dalej: p.w.u.o.t.p.TK): „Ustawa z dnia 30 listopada 2016 r. o organizacji i trybie postępowania przed Trybunałem Konstytucyjnym (Dz. U. poz. 2072) wchodzi w życie po upływie 14 dni od dnia ogłoszenia niniejszej ustawy, z wyjątkiem: 1) art. 1-6, które wchodzą w życie z dniem następującym po dniu ogłoszenia niniejszej ustawy; 2) art. 1632, które wchodzą w życie z dniem 1 stycznia 2018 r.". Ogłoszenie przepisów wprowadzających ustawę o organizacji i trybie postępowania przed Trybunałem Konstytucyjnym miało miejsce w dniu 19 grudnia 2016 r. Zgodnie z art. 3 p.w.u.o.t.p.TK: „, [t]raci moc ustawa z dnia 22 lipca 2016 r. o Trybunale Konstytucyjnym (Dz. U. poz. 1157), z wyjątkiem art. 18 ust. 1, 4 i 5, które tracą moc obowiązującą z dniem 1 stycznia 2018 r.” Zgodnie z regulacją art. 9 p.w.u.o.t.p.TK: „1. Do postępowań przed Trybunałem Konstytucyjnym, zwanym dalej „Trybunałem", wszczętych i niezakończonych przed dniem wejścia w życie ustawy, o której mowa w art. 1, stosuje się przepisy tej ustawy. 2. Czynności procesowe dokonane w postępowaniach, o których mowa w ust. 1, pozostają w mocy”.

Do wniosku Rzecznika mają zatem zastosowanie przepisy ustawy o organizacji i trybie postępowania przed Trybunałem Konstytucyjnym, a w szczególności art. 46 oraz art. 47 . Zgodnie $\mathrm{z}$ art. 46 u.o.t.p.TK: „[p]ismami procesowymi są wnioski, pytania prawne i skargi konstytucyjne, a także inne wnioski i oświadczenia uczestników postępowania, wnoszone do Trybunału w toku postępowania poza rozprawą". Artykuł 47 u.o.t.p.TK stanowi: „1. Wniosek złożony przez podmiot, o którym mowa w art. 191 ust. 1 pkt 1-5 Konstytucji, zawiera: 1) oznaczenie podmiotu uprawnionego do złożenia wniosku; 2) podanie podstawy prawnej działania podmiotu uprawnionego do złożenia wniosku; 3) oznaczenie rodzaju pisma procesowego; 4) określenie kwestionowanego aktu normatywnego lub jego części; 5) wskazanie wzorca kontroli; 6) uzasadnienie. 2. Uzasadnienie, o którym mowa w ust. 1 pkt 6 , zawiera: 1) przywołanie treści kwestionowanego wnioskiem przepisu wraz z jego wykładnią; 2) przywołanie treści wzorców kontroli wraz z ich wykładnią; 3) określenie problemu konstytucyjnego i zarzutu niekonstytu- 
cyjności; 4) wskazanie argumentów lub dowodów na poparcie zarzutu niekonstytucyjności. [...]”. Należy ponadto przypomnieć, że Trybunał Konstytucyjny związany jest zarzutami sformułowanymi w piśmie procesowym (wniosku, pytaniu prawnym, skardze konstytucyjnej), pochodzącym od podmiotu uprawnionego do inicjowania postępowania. Niemniej zarzuty te mogą podlegać rozpatrzeniu tylko wtedy, jeżeli zostały należycie uzasadnione. Jak podkreślił Trybunał Konstytucyjny: „przesłanka odpowiedniego uzasadnienia zarzutów nie powinna być traktowana powierzchownie i instrumentalnie. Przytaczane w piśmie procesowym argumenty mogą być mniej lub bardziej przekonujące [...], lecz zawsze muszą być argumentami „nadającymi się” do rozpoznania przez Trybunał Konstytucyjny" (wyrok TK z 19 października 2010 r., sygn. akt P 10/10). Konieczność uzasadnienia zarzutu sformułowanego w piśmie inicjującym postępowanie przed Trybunałem Konstytucyjnym wynika z domniemania konstytucyjności norm prawnych oraz z zasady kontradyktoryjności. W związku z tym wniosek Rzecznika nie spełnia wymogów uzasadnienia wniosku przewidzianych w art. 47 ust. 2 pkt 1 i 2 u.o.t.p.TK, Rzecznik nie dokonał bowiem wykładni kwestionowanego przepisu ani wskazanych wzorców kontroli.

Jednak, mając na uwadze okoliczność, że wnioskodawca w dniu składania wniosku nie mógł wiedzieć o konieczności spełnienia warunków formalnych, przewidzianych w art. 47 ust. 1 i 2 u.o.t.p.TK, należy uznać, że powyższe uchybienia nie powinny spowodować umorzenia postępowania w całości.

2. Zgodnie $\mathrm{z}$ wypowiedziami Trybunału Konstytucyjnego: „kontrola konstytucyjności ustaw przebiega w oparciu o domniemanie, że badane normy są zgodne z konstytucją. Ciężar dowodu spoczywa na podmiocie kwestionującym zgodność ustawy z konstytucją i dopóki nie powoła on konkretnych i przekonywających argumentów prawnych na rzecz swojej tezy, dopóty Trybunał Konstytucyjny uznawać będzie kontrolowane przepisy za konstytucyjne. W przeciwnym razie naruszeniu uległaby zasada kontradyktoryjności postępowania przed Trybunałem Konstytucyjnym, a Trybunał przekształciłby się w organ orzekający z inicjatywy własnej" (zob. orzeczenie TK z 24 lutego 1997 r., sygn. akt K 19/96, oraz orzeczenia TK z: 26 kwietnia 1995 r., sygn. akt K 11/94; 31 stycznia 1996 r., sygn. akt K 9/95; wyroki TK z: 27 czerwca 2008 r., sygn. akt K 51/07; 15 lipca 2009 r., sygn. akt K 64/07; 12 stycznia 2012 r., sygn. akt Kp 10/09). Jak wskazuje się w literaturze, wymóg uzasadnienia powołanych zarzutów oznacza konieczność przedstawienia argumentów, które przemawiają za stwierdzeniem niezgodności zaskarżonych norm prawnych z normami powołanymi jako podstawa kontroli. Wymóg ten odnosi się do każdego z podniesionych zarzutów niezgodności danej normy (zob. K. Wojtyczek, Ciężar dowodu i argumentacji w procedurze kontroli norm przez Trybunał Konstytucyjny, „Przegląd Sejmowy” 2004, nr 1, s. 17; L. Jamróz, Skarga konstytucyjna. Wstępne rozpoznanie, Białystok 2011, s. 191).

3. Jak wskazuje Trybunał: „przesłanka odpowiedniego uzasadnienia zarzutów w kontekście każdego wzorca kontroli nie powinna być traktowana powierz- 
chownie i instrumentalnie" (wyroki TK z: 19 października 2010 r., sygn. akt P 10/10; 23 października 2012 r., sygn. akt SK 11/12). Powyższe oznacza, że nie wystarczy sformułowanie samej tezy o niekonstytucyjności zaskarżonego przepisu. Uzasadnienie musi wskazywać precyzyjnie co najmniej jeden argument przemawiający za naruszeniem danego wzorca kontroli. Wymogu tego nie spełniają uwagi nazbyt ogólne, niejasne czy też czynione jedynie na marginesie innych rozważań (zob. np. wyrok TK z 5 czerwca 2014 r., sygn. akt K 35/11; postanowienie TK z 13 stycznia 2015 r., sygn. akt K 44/13). W opinii Trybunału: „wobec respektowania generalnej zasady, jaką jest domniemanie konstytucyjności aktu normatywnego, samo wskazanie w petitum wzorca kontroli, bez szczegółowego odniesienia się w uzasadnieniu do kwestionowanej regulacji prawnej lub lakoniczne sformułowanie zarzutu niekonstytucyjności nie może zostać uznane za „uzasadnienie postawionego zarzutu, z powołaniem dowodów na jego poparcie” w rozumieniu przepisów regulujących postępowanie przed Trybunałem Konstytucyjnym. W świetle utrwalonej praktyki orzeczniczej wymóg ten należy rozumieć jako nakaz odpowiedniego udowodnienia zarzutów stawianych w kontekście każdego wskazanego wzorca kontroli" (postanowienie TK z 21 stycznia 2015 r., sygn. akt K 13/13). W tym względzie należy wskazać, że Rzecznik wbrew wyrażonemu w orzecznictwie Trybunału Konstytucyjnego obowiązkowi rzetelnej i szczegółowej analizy zaskarżonego przepisu (postanowienie TK z 12 maja 2015 r., sygn. akt K 7/14) poprzestał jedynie na ustaleniu jego znaczenia zgodnie z dyrektywami wykładni językowej. Poważne wątpliwości budzi także spełnienie wymogów dotyczących uzasadnienia przedstawianych zarzutów. Przykładowo Rzecznik mimo wskazania jako wzorca kontroli art. 51 ust. 3 Konstytucji nie uzasadnił swojego stanowiska w tym zakresie - w uzasadnieniu wniosku nie umieszczono ani tej jednostki redakcyjnej wprost, ani żadnego zdania, które mogłoby się odnosić bezpośrednio do tego wzorca kontroli. Wobec jednak istotności problemu podniesionego przez Rzecznika w ocenie Sejmu wniosek powinien zostać rozpoznany merytorycznie.

\section{Analiza merytoryczna}

\section{- Wzorce kontroli}

1. Zgodnie z art. 42 ust. 2 Konstytucji: „Każdy, przeciw komu prowadzone jest postępowanie karne, ma prawo do obrony we wszystkich stadiach postępowania. Może on w szczególności wybrać obrońcę lub na zasadach określonych w ustawie korzystać z obrońcy z urzędu”. Przepis ten ustanawia konstytucyjną zasadę prawa do obrony (ius defensionis). W ujęciu konstytucyjnym prawo to oznacza: „możność podejmowania wszelkich działań niesprzecznych z prawem, które w przekonaniu osoby poddanej temu postępowaniu mogą potwierdzić jego wersje zdarzeń [...] oraz jego niewinności lub występowanie określonego rodzaju winy” (P. Sarnecki, Komentarz do art. 42 [w:] Konstytucja Rzeczypospolitej 
Polskiej. Komentarz, t. III, red. L. Garlicki, Warszawa 2003, s. 2). Konstytucyjne prawo do obrony należy rozumieć szeroko, jest ono bowiem nie tylko fundamentalną zasadą procesu karnego, ale też elementarnym standardem demokratycznego państwa prawnego (zob. wyrok TK z 3 listopada 2004 r., sygn. akt K 18/03). Istotą prawa do obrony jest: „podejmowanie działań zmierzających do odparcia stawianych oskarżonemu zarzutów za pomocą przyznanych mu uprawnień procesowych. Nie obejmują one zaś blokowania możliwości prowadzenia postępowania karnego wobec innych osób, także wtedy gdy to postępowanie związane jest przedmiotowo z postępowaniem karnym oskarżonego. Korzystanie z prawa do obrony nie może polegać na działaniach, które prowadzą do ochrony własnych interesów kosztem realizacji prawa do obrony innych współoskarżonych" (P. Karlik, T. Sroka, P. Wiliński, Komentarz do art. 42 [w:] Konstytucja RP. Komentarz, t. I, Art. 1-86, red. M. Safjan, L. Bosek, Warszawa 2016, nb. 186). Konstytucyjne prawo do obrony ma wymiar materialny i formalny (zob. wyroki TK z: 7 października 2008 r., sygn. akt P 30/07; 19 lutego 2008 r., sygn. akt P 48/06). Obrona materialna to możliwość bronienia przez oskarżonego jego interesów osobiście (np. możność odmowy składania wyjaśnień, prawo wglądu w akta i składania wniosków dowodowych). Obrona formalna to prawo do korzystania z pomocy obrońcy z wyboru lub z urzędu (zob. wyrok TK z 17 lutego 2004 r., sygn. akt SK 39/02). Prawo do obrony: „przysługuje od momentu rozpoczęcia postępowania do jego zakończenia). Tak szerokie ujęcie prawa do obrony wynika z podziału postępowania karnego i innych postępowań, których przedmiotem jest odpowiedzialność o zbliżonym charakterze (dyscyplinarna, karnoskarbowa, wykroczeniowa) na kilka stadiów. W ich ramach można wyróżnić tzw. postępowanie przygotowawcze (postępowanie wyjaśniające), postępowanie rozpoznawcze sądowe oraz postępowanie odwoławcze, co z kolei jest konsekwencją obowiązywania konstytucyjnej zasady prawa do sądu (art. 45 ust. 1 Konstytucji RP) oraz dwuinstancyjności postępowania sądowego (art. 176 ust. 1 Konstytucji RP). Nie ulega wątpliwości, że prawo do obrony musi przysługiwać jednostce w każdej z tych faz postępowania. Jednocześnie zakres uprawnień wchodzących w skład prawa do obrony może się różnić na poszczególnych etapach i być adekwatny do ich istoty" (P. Karlik, T. Sroka, P. Wiliński, Komentarz do art. 42, op. cit., nb. 225). Na prawo do obrony składa się wiele szczególnych praw, do których zaliczyć można:

- prawo do wyboru sposobu i środków obrony, zgodnie z orzecznictwem Trybunału Konstytucyjnego zawiera w sobie dwa zasadnicze elementy: „prawo wyboru sposobów obrony oraz prawo wyboru służących do ich realizacji środków” (zob. wyrok TK z 28 kwietnia 2009 r., sygn. akt P 22/07),

- prawo do znajomości stawianych zarzutów „obejmuje zarówno prawo do informacji o istocie zarzutów, jak i ich przyczynie, a także kwalifikacji prawnej stawianych zarzutów. Jest niezbędnym warunkiem skutecznego prowadzenia obrony w toku każdego postępowania o charakterze represyjnym. Prawo to 
ma na celu niedopuszczenie do oskarżenia i skazania osoby za czyn, który nie jest jej oficjalnie przedstawiony w formie zarzutu, ani też za czyn zakwalifikowany z surowszego przepisu niż było to wcześniej zakomunikowanie" (P. Karlik, T. Sroka, P. Wiliński, Konstytucja RP, Komentarz do art. 42, op. cit., nb. 212),

- prawo do odpowiedniego czasu i możliwości przygotowania obrony „zawiera w sobie dwa podstawowe elementy: prawo do dysponowania odpowiednim czasem do przygotowania obrony oraz prawo do możliwości jej przygotowania, tj. prawo do zapewnienia odpowiednich warunków przygotowania obrony. Prawo do zapewnienia odpowiedniego czasu do przygotowania obrony jednocześnie nakłada na ustawodawcę obowiązek adekwatnego wyznaczenia terminów dokonywania działań przez jednostkę" (P. Karlik, T. Sroka, P. Wiliński, Komentarz do art. 42, op. cit., nb. 213),

- prawo do obrony osobistej „przysługuje w każdym stadium postępowania, nie jest ono jednak nieograniczone" (zob. wyrok TK z 28 kwietnia 2009 r., sygn. akt P 22/07, „Prokuratura i Prawo” 2009, nr 68, poz. 585). Ustawodawca przewiduje sytuacje, w których ciężar obrony przejąć musi obrońca. Ograniczenie tego prawa związane jest z przekonaniem, iż istnieją sytuacje, w których jednostka nie jest w stanie skutecznie prowadzić osobiście swojej obrony bądź też wykonać określonych czynności procesowych. Jest więc ono paradoksalnie wyrazem dążenia do zapewnienia prawa do obrony tam, gdzie nie można w pełni świadomie bądź efektywnie z niego skorzystać” (P. Karlik, T. Sroka, P. Wiliński, Komentarz do art. 42, op. cit., nb. 214),

- prawo do posiadania i korzystania z pomocy obrońcy „mieści w sobie zarówno prawo do powołania obrońcy, jak i prawo do korzystania z jego pomocy, a więc działania obrońcy na rzecz oskarżonego (zob. wyroki TK z: 7 października 2008 r., sygn. akt P 30/07; 11 grudnia 2008 r., sygn. akt K 33/07)” (ibidem, nb. 215),

- prawo do swobody wypowiedzi, które obejmuje także: „prawo do składania wyjaśnień i ewentualnej odmowy ich składania. Dodatkowo z faktu skorzystania przez jednostkę z tzw. prawa do milczenia, nie można wyciągać negatywnych konsekwencji. Powyższe wynika $\mathrm{z}$ obowiązywania w polskim porządku prawnym zasady nemo se ipsum accusare tenetur" (ibidem, nb. 217),

- prawo dostępu do materiału dowodowego: „jest podstawowym warunkiem realnego udziału w toczącym się postępowaniu. Skuteczna obrona jest bowiem niemożliwa albo co najmniej niezwykle utrudniona, jeśli jednostka pozbawiona zostanie możliwości dostępu do zgromadzonego w sprawie materiału dowodowego. W procesie karnym prawo do dostępu do materiału dowodowego nie zostało ukształtowane jednolicie. Najpełniej uprawnienie to realizowane jest na etapie postępowania jurysdykcyjnego, gdzie strony mają niczym nieskrępowaną możliwość zapoznawania się z materiałami dowodowymi” (J. Skorupka, Udostępnienie akt sprawy podejrzanemu, „Proku- 
ratura i Prawo" 2007, nr 5, s. 65 i n.). Zupełnie inaczej ukształtowana jest kwestia dostępu do materiału dowodowego na etapie postępowania przygotowawczego. Wynika to oczywiście $\mathrm{z}$ samej istoty i charakteru tej fazy procesu karnego, gdzie z uwagi na dobro prowadzonego postępowania lub ważny interes państwa organ prowadzący śledztwo lub dochodzenie może odmówić udostępnienia materiału dowodowego. Obowiązująca tradycyjnie reguła ograniczonej jawności materiału dowodowego na etapie postępowania przygotowawczego doznała jednak bardzo istotnego ograniczenia. Zgodnie z - wielokrotnie nowelizowanym - art. $156 \$ 5$ a k.p.k. „nie można odmówić dostępu do materiału dowodowego, który stanowi podstawę wniosku o zastosowanie albo przedłużenie tymczasowego aresztowania. Wszelkie decyzje zapadłe w tym zakresie muszą być poczynione w oparciu o materiał dowodowy jawny dla oskarżonego (art. 249a KPK; zob. wyr. TK z: 3.6.2008 r., K 42/07, OTK-A 2008, Nr 5, poz. 77; 20.5.2014 r., SK 13/13, OTK-A 2014, Nr 5, poz. 54; P. Kardas, Standard rzetelnego procesu, s. 89)" (P. Karlik, T. Sroka, P. Wiliński, Komentarz do art. 42, op. cit., nb. 218). Prawo dostępu do materiału dowodowego „uznać można za uprawnienie do korzystania $\mathrm{z}$ tej samej wiedzy procesowej i tych samych materiałów procesowych (dowodów), jakie posiada organ prowadzący postępowanie" (ibidem, nb. 219),

- prawo do inicjatywy dowodowej: „to uprawnienie, zgodnie z którym strona może wystąpić do organu prowadzącego postępowanie z żądaniem przeprowadzenia wskazanego dowodu. Istota tego uprawnienia polega na możliwości wpływania na kierunek prowadzonego postępowania dowodowego, uzupełniania ustaleń organów procesowych" (ibidem, nb. 220),

- prawo do udziału w czynnościach dowodowych: „to uprawnienie, zgodnie z którym oskarżony ma zapewnioną możliwość uczestnictwa w przeprowadzaniu dowodów, w toku postępowania karnego. Prawo udziału w czynnościach dowodowych może być pojmowane jako element szerszego uprawnienia - do udziału w czynnościach procesowych, obejmujących: 1) udział w czynnościach dowodowych; 2) udział w posiedzeniach sądu; 3) udział w rozprawie" (ibidem, nb. 221).

„ «Naruszeniem prawa do obrony nazwać należy bezprawne utrudnienie lub pozbawienie oskarżonego wykonywania przysługujących mu uprawnień procesowych, służących ochronie jego interesów w postępowaniu karnym» (P. Wiliń$s k i$, Zasada prawa do obrony, s. 549). [...]. Na podstawie analizy zakresu prawa do obrony stwierdzić możemy, iż naruszenie prawa do obrony polegać może na: «1) niedopuszczalnym ograniczeniu uprawnień niepodlegających ograniczeniu; 2) nadmiernym ograniczeniu któregokolwiek z pozostałych uprawnień; 3) pozbawieniu oskarżonego jednego lub więcej uprawnień»” (ibidem, nb. 226).

Przyjmuje się, że zakres stosowania art. 42 Konstytucji obejmuje nie tylko odpowiedzialność karną sensu stricto, a więc za przestępstwa, ale również odpo- 
wiedzialność za wykroczenia (wyrok TK z 3 czerwca 2014 r., sygn. akt K 19/11), a także: „inne formy odpowiedzialności prawnej związane z wymierzaniem kar wobec jednostki” (zob. np. wyroki TK z: 8 lipca 2003 r., sygn. akt P 10/02; 26 listopada 2003 r., sygn. akt SK 22/02; 28 października 2015 r., sygn. akt SK 59/13). Do tych ostatnich Trybunał Konstytucyjny zaliczył m.in. postępowanie karnoskarbowe (wyrok TK z 9 lipca 2002 r., sygn. akt P 4/01) oraz postępowanie dyscyplinarne (wyrok TK z 28 listopada 2007 r., sygn. akt K 39/07).

2. Konstytucja w art. 45 ust. 1 przewiduje, że: „[k]ażdy ma prawo do sprawiedliwego i jawnego rozpatrzenia sprawy bez nieuzasadnionej zwłoki przez właściwy, niezależny, bezstronny i niezawisły sąd”. Zgodnie z art. 45 ust. 1 Konstytucji każdy ma prawo do sprawiedliwego i jawnego rozpatrzenia sprawy bez nieuzasadnionej zwłoki przez właściwy, niezależny, bezstronny i niezawisły sąd. Wobec czego istota prawa do sądu sprowadza się więc do zapewnienia ochrony sądowej w sprawach dotyczących sfery praw lub wolności danego podmiotu (postanowienie TK z 13 kwietnia 1999 r., sygn. akt Ts 24/99). Prawo do sądu wedle utrwalonego orzecznictwa Trybunału Konstytucyjnego obejmuje:

- „prawo dostępu do sądu, tj. prawo uruchomienia postępowania przed sądem - organem o określonej charakterystyce (właściwym, niezależnym, bezstronnym i niezawisłym);

- prawo do właściwej procedury przed sądem;

- prawo do wiążącego rozstrzygnięcia sprawy" (wyroki TK z: 9 czerwca 1998 r., sygn. akt K 28/97; 10 lipca 2000 r., sygn. akt SK 12/99; stanowisko to zostało wielokrotnie powtórzone w późniejszym orzecznictwie).

W 2007 r. Trybunał uzupełnił te elementy prawa do sądu o „prawo do odpowiedniego kształtowania ustroju i pozycji organów rozpoznających sprawy” (wyrok z 24 października 2007 r., sygn. akt SK 7/06). Stanowisko to pojawia się również w nowszej judykaturze, w której wyodrębnia się cztery elementy prawa do sądu (np. wyroki TK z: 13 stycznia 2015 r., sygn. akt SK 34/12; 30 września 2014 r., sygn. akt SK 22/13; 15 kwietnia 2014 r., sygn. akt SK 12/13; 6 listopada 2012 r., sygn. akt K 21/11). Trybunał podkreślił również, że: „W państwie prawnym prawo do sądu nie może być rozumiane jedynie formalnie, jako dostępność drogi sądowej w ogóle, lecz i materialnie, jako możliwość prawnie skutecznej ochrony praw na drodze sądowej [...]”. Podobne stanowisko zajął Sąd Najwyższy, według którego prawo do sądu nie wygasa w momencie złożenia powództwa i podjęcia na tej podstawie procesu, ale chodzi w nim o to, aby sąd rozpoznał sprawę co do jej istoty (postanowienie SN z 19 lipca 2006 r., sygn. akt I CSK 112/06). Ponadto TK zwraca uwagę na znaczenie prawa do wysłuchania, stwierdzając, że naruszenie prawa do sądu: „przejawia się w pozbawieniu [...] tzw. prawa do wysłuchania, które wprawdzie nie zostało wyrażone w Konstytucji, jednak jest powszechnie uznane za składową prawa do sądu” (wyrok TK z 12 marca 2002 r., sygn. akt P 9/01). Prawo do sądu istnieje nawet wówczas, gdy jakaś ustawa regulująca pra- 
wa i obowiązki jednostki nie przewiduje możliwości wystąpienia na drogę sądową (zob. wyrok SN z 7 kwietnia 1999 r., sygn. akt I PKN 648/98; uchwała SN z 18 stycznia 2001 r., sygn. akt III ZP 28/00).

Konstytucyjne prawo do sądu ma aspekt pozytywny, zawiera bowiem dyrektywy, zobowiązujące ustawodawcę do należytego ukształtowania systemu wymiaru sprawiedliwości w wymiarze instytucjonalnym i proceduralnym oraz zapewnienia jego efektywnego funkcjonowania. W tym aspekcie można mówić o obowiązku ustawodawcy ustanowienia regulacji prawnej, która zapewnia rozpatrzenie sprawy przez sąd, na żądanie zainteresowanego. Negatywny aspekt prawa do sądu wyraża się w zakazie zamykania lub nadmiernego ograniczania dostępu do wymiaru sprawiedliwości (art. 45 ust. 1 w związku z art. 77 ust. 2 Konstytucji). Fundamentalnym założeniem Konstytucji jest jej aksjologiczna i teleologiczna spójność, dlatego też dyrektywa zakazująca zamykania drogi sądowej musi być uwzględniania w procesie wykładni ogólnej zasady prawa do sądu (wyroki TK z: 9 czerwca 1998 r., sygn. akt K 28/97; 15 października 2001 r., sygn. akt K 12/01; 7 września 2004 r., sygn. akt P 4/04; 29 stycznia 2013 r., sygn. akt SK 28/11).

Trybunał Konstytucyjny w swoim orzecznictwie podkreślił, że z prawa do sądu wynika prawo do zastosowania sprawiedliwej procedury, tj. takiej, która: „powinna zapewniać stronom uprawnienia procesowe stosowne do przedmiotu prowadzonego postępowania. Wymóg sprawiedliwego postępowania zakłada bowiem dostosowanie jego zasad do specyfiki rozpoznawanych spraw" (wyrok TK z 16 listopada 2011 r., sygn. akt SK 45/09). Prawo do odpowiedniego ukształtowania postępowania ma charakter uniwersalny w tym sensie, że dotyczy każdego rodzaju postępowania sądowego, które objęte jest gwarancjami składającymi się na prawo do sądu (zob. wyrok TK z 12 lipca 2011 r., sygn. akt SK 49/08). Prawo to obowiązuje więc niezależnie od rodzaju załatwianej sprawy, jeżeli tylko ustawodawca powierza jej rozpoznanie sądowi przedmiotu sprawy (praw lub obowiązków, których dotyczy), sposobu jej wszczęcia (na żądanie zainteresowanego podmiotu, organu publicznego albo z urzędu) oraz etapu, na którym znajduje się rozstrzygana sprawa (zob. wyroki TK z: 12 stycznia 2010 r., sygn. akt SK 2/09; 11 maja 2011 r., sygn. akt SK 11/09; 12 lipca 2011 r., sygn. akt SK 49/08). Ustawodawca zwykły jest uprawniony do różnicowania postępowań sądowych w zależności od ich charakteru, przedmiotu rozpoznawanych w nich spraw, znaczenia dochodzonych w nich praw, i obowiązków dla zainteresowanych podmiotów, celów realizowanych w ramach tych postępowań, zakresu kognicji sądu, a także etapu, na którym znajduje się rozstrzygana sprawa (zob. wyroki TK z: 13 stycznia 2004 r., sygn. akt SK 10/03; 28 lipca 2004 r., sygn. akt P 2/04; 26 stycznia 2005 r., sygn. akt P 10/04; 16 listopada 2011 r., sygn. akt SK 45/09; zob. też wyroki TK z: 28 lipca 2004 r., sygn. akt P 2/04; 26 stycznia 2005 r., sygn. akt P 10/04; 20 października 2010 r., sygn. akt P 37/09; 16 listopada 2011 r., sygn. akt SK 45/09). Ocena konstytucyjności tych szczegółowych rozwiązań i wyłaniającego się z nich kształtu określonego rodzaju postępowania sądowego wymaga odniesienia tego 
kształtu do wymagań konstytucyjnych w ujęciu całościowym (zob. wyroki TK z: 28 lipca 2004 r., sygn. akt P 2/04; 26 stycznia 2005 r., sygn. akt P 10/04; 20 października 2010 r., sygn. akt P 37/09; 16 listopada 2011 r., sygn. akt SK 45/09). Takie prawo ustawodawcy nie oznacza arbitralności w stanowieniu przepisów proceduralnych, przykładowo takich, które ponad miarę, a więc bez wystąpienia istotnych racji, ograniczają prawa procesowe strony (zob. wyroki TK z: 20 października 2010 r., sygn. akt P 37/09; 16 listopada 2011 r., sygn. akt SK 45/09). Wymagane jest choćby zapewnienie sprawiedliwości proceduralnej, która, jak wskazuje TK, stanowi gwarancję tego, aby prawo do sądu nie było prawem fasadowym (zob. wyroki TK z: 26 lutego 2008 r., sygn. akt SK 89/06; 29 kwietnia 2008 r., sygn. akt SK 11/07; 20 października 2010 r., sygn. akt P 37/09).

Wreszcie konstytucyjny nakaz sprawiedliwego rozpatrzenia sprawy zawiera w sobie trzy podstawowe gwarancje (zob. wyroki TK z: 31 marca 2005 r., sygn. akt SK 26/02; 16 stycznia 2006 r., sygn. akt SK 30/05; 2 października 2006 r., sygn. akt SK 34/06; 20 listopada 2007 r., sygn. akt SK 57/05; 26 lutego 2008 r., sygn. akt SK 89/06; 12 stycznia 2010 r., sygn. akt SK 2/09; 18 października 2011 r., sygn. akt SK 39/09; 8 kwietnia 2014 r., sygn. akt SK 22/11):

- możność bycia wysłuchanym (prawo do wysłuchania),

- ujawnienie w czytelny sposób motywów rozstrzygnięcia (prawo do uzasadnienia lub szerzej - prawo do informowania),

- zapewnienie przewidywalności postępowania (prawo do przewidywalności postępowania; we wcześniejszym orzecznictwie wskazywano także na prawo do przewidywalności rozstrzygnięcia - zob. wyrok TK z 17 października 2000 r., sygn. akt SK 5/99).

3. Zgodnie $\mathrm{z}$ art. 47 Konstytucji: ,[k]ażdy ma prawo do ochrony prawnej życia prywatnego, rodzinnego, czci i dobrego imienia oraz do decydowania o swoim życiu osobistym". Przepis ten, po pierwsze, wyraża prawo jednostki do ochrony prawnej życia prywatnego, rodzinnego, czci, dobrego imienia i wiąże się ze stosownymi pozytywnymi obowiązkami władzy państwowej. Po drugie, w zakresie prawa do decydowania o swoim życiu osobistym, ma w istocie charakter „wolności” i polega "na wykluczeniu wszelkiej postronnej ingerencji w sferę życia osobistego jednostki" (P. Sarnecki, Komentarz do art. 47 [w:] Konstytucja Rzeczypospolitej Polskiej. Komentarz, t. III, red. L. Garlicki, Warszawa 2003, s. 1; zob. również wyroki TK z: 2 kwietnia 2001 r., sygn. akt SK 10/00; 9 lipca 2009 r., sygn. akt SK 48/05).

Jak wskazuje Trybunał Konstytucyjny: „[k]oncepcja prawa do prywatności zaczęła stosunkowo niedawno odgrywać poważniejszą rolę w regulacjach konstytucyjnych i orzecznictwie sądowym. Zdołała już jednak zyskać sobie trwałe miejsce we współczesnych państwach demokratycznych. Stanowią ją zasady i reguły odnoszące się do różnych sfer życia jednostki, a ich wspólnym mianownikiem jest przyznanie jednostce prawa „do życia własnym życiem układanym 
według własnej woli z ograniczeniem do niezbędnego minimum wszelkiej ingerencji zewnętrznej” (A. Kopff, Koncepcje prawa do intymności i do prywatności życia. Zagadnienia konstrukcyjne, „Studia Cywilistyczne” 1972, t. XX). Tak rozumiana prywatność odnosi się przede wszystkim do życia osobistego, rodzinnego, towarzyskiego i czasem jest określana jako „prawo do pozostawienia w spokoju” (zob. W. Sokolewicz, Prawo do prywatności [w:] Prawa człowieka w Stanach Zjednoczonych, Warszawa 1985, s. 252). Na ogół przyjmuje się, że prywatność odnosi się też do ochrony informacji dotyczących danej osoby i gwarantuje m.in. pewien stan niezależności, w ramach którego jednostka może decydować o zakresie i zasięgu udostępniania i komunikowania innym osobom informacji o swoim życiu” (orzeczenie TK z 24 czerwca 1997 r., sygn. akt K 21/96).

Prawo do prywatności nie ma charakteru absolutnego i jako takie może być limitowane. Podlega to jednak ocenie przez pryzmat art. 31 ust. 3 Konstytucji (zob. np. P. Sarnecki, Komentarz do art. 47, op. cit., s. 4; wyroki TK z: 21 października 1998 r., sygn. akt K 24/98; 11 kwietnia 2000 r., sygn. akt K 15/98; 20 listopada 2002 r., sygn. akt K 41/02; 20 marca 2006 r., sygn. akt K 17/05), który formułuje kumulatywnie ujęte przesłanki dopuszczalności ograniczeń w korzystaniu z konstytucyjnych praw i wolności. Są to: 1) ustawowa forma ograniczenia; 2) istnienie w państwie demokratycznym konieczności wprowadzenia ograniczenia; 3) funkcjonalny związek ograniczenia $\mathrm{z}$ realizacją wskazanych w art. 31 ust. 3 Konstytucji wartości (bezpieczeństwo państwa, porządek publiczny, ochrona środowiska, zdrowia i moralności publicznej, wolności i praw innych osób); 4) zakaz naruszania istoty danego prawa lub wolności (zob. np. wyrok TK z 30 maja 2007 r., sygn. akt SK 68/06; zob. również L. Garlicki, Komentarz do art. 31 [w:] Konstytucja Rzeczypospolitej Polskiej. Komentarz, t. III, red. L. Garlicki, Warszawa 2003, s. 14 i n.; J. Zakolska, Zasada proporcjonalności w orzecznictwie Trybunału Konstytucyjnego, Warszawa 2008, s. 115-141).

4. Zgodnie $\mathrm{z}$ art. 51 ust. 2 Konstytucji: „[w]ładze publiczne nie mogą pozyskiwać, gromadzić i udostępniać innych informacji o obywatelach niż niezbędne w demokratycznym państwie prawnym". Z tego, adresowanego do władz publicznych, przepisu wynika jednoznacznie, że dopuszczalne jest pozyskiwanie, gromadzenie i udostępnianie tylko takich informacji o obywatelach, które są niezbędne w demokratycznym państwie prawnym. Nie do końca jasne jest natomiast to, jakie informacje o obywatelach mogą być uznane za niezbędne w demokratycznym państwie prawnym. W doktrynie przyjmuje się, że chodzi tu o takie dane, które: „umożliwiają normalne funkcjonowanie jednostki w zorganizowanym w państwo społeczeństwie" i bez posiadania których władze publiczne nie są: „zdolne do podjęcia (czy zakończenia) działań w ramach przyznanych im kompetencji”. Nie będą więc niezbędne w demokratycznym państwie prawnym takie informacje o obywatelach, których pozyskiwanie, gromadzenie i udostępnianie służy jedynie „wygodzie” organów władzy publicznej, czy też, które są potrzebne tym organom „na wszelki wypadek”, np. gdyby dana osoba w przyszłości do- 
puściła się przestępstwa (zob. B. Banaszak, Konstytucja Rzeczypospolitej Polskiej. Komentarz, Warszawa 2012, komentarz do art. 51, nb. 6; I. Lipowicz, Komentarz do art. 51 [w:] Konstytucje Rzeczypospolitej oraz komentarz do Konstytucji RP z 1997 roku, red. J. Boć, Wrocław 1998, s. 99).

Jak podnosi Trybunał Konstytucyjny, art. 51 ust. 2 ustawy zasadniczej: „po pierwsze legalizuje - nieuchronne we współczesnym społeczeństwie - działania władz publicznych polegające na pozyskiwaniu, gromadzeniu i udostępnianiu informacji o jednostkach w sposób inny niż w drodze zgłoszenia takich danych przez samego obywatela, zobligowanego w trybie określonym w art. 51 ust. 1 Konstytucji. Po drugie [...] w sposób częściowo autonomiczny określa przesłanki legalności (granice) takich działań. Konstytucja realizuje jednak w ten sposób najbardziej zasadnicze elementy składające się na treść prawa do ochrony życia prywatnego: respekt dla autonomii informacyjnej jednostki, a więc sam obowiązek udostępnienia danych ograniczony do ściśle określonych ustawowo sytuacji; ograniczenie arbitralności ustawodawcy - ustawa nie może bowiem zakresu obowiązku kształtować dowolnie [...]. Zakres autonomii informacyjnej obejmuje zarówno dane o charakterze stricte personalnym (osobowym), jak i te dotyczące majątku i sfery ekonomicznej jednostki. W tym ostatnim zakresie Trybunał dopuszcza jednak łagodniejsze kryteria jej ograniczania niż w wypadku sfery czysto osobistej [...]" (wyrok TK z 17 czerwca 2008 r., sygn. akt K 8/04, i przywołane tam inne orzeczenia TK). Jednocześnie w art. 51 ust. 2 Konstytucji mowa jedynie o obywatelach w związku z czym władze publiczne mogą przetwarzać informacje dotyczące innych osób i dane poddane przetworzeniu nie muszą spełniać jednocześnie warunku niezbędności w demokratycznym państwie prawnym.

Zgodnie z art. 51 ust. 3 Konstytucji: „[k]ażdy ma prawo dostępu do dotyczących go urzędowych dokumentów i zbiorów danych. Ograniczenie tego prawa może określić ustawa”. Uprawnienie to jego ograniczone do „urzędowych” dokumentów oraz „urzędowych” zbiorów danych. W przypadku podmiotów niepublicznych podstawą uzyskania dostępu jest prawo do ochrony życia prywatnego (art. 47 Konstytucji). Przepis ten gwarantuje, że podstawą decydowania o statusie prawnym danej osoby nie mogą być jakiekolwiek dokumenty i informacje, które pozostawałyby niedostępne, jako tajne, dla samej osoby zainteresowanej czy dla sądu kontrolującego wydanie decyzji (wyroki TK z: 26 października 2005 r., sygn. akt K 31/04; 11 maja 2007 r., sygn. akt K 2/07; 27 czerwca 2008 r., sygn. akt K 51/07). Dostęp do akt sprawy przez strony postępowań oraz prawo żądania sprostowania lub usunięcia informacji nieprawdziwych, niepełnych lub zebranych w sposób sprzeczny z ustawą, zamieszczonych w aktach sprawy, w celu wydania indywidualnego rozstrzygnięcia, jest uznawany przez TK za jeden ze standardów sprawiedliwego postępowania administracyjnego (wyrok TK z 27 czerwca 2008 r., sygn. akt K 51/07). Zgodnie z orzecznictwem TK ograniczenie tego prawa (tj. odmowa dostępu) musi być uzasadniona doniosłym in- 
teresem publicznym, a ograniczenia tego prawa muszą czynić zadość zasadom proporcjonalności (wyrok TK z 26 października 2005 r., sygn. akt K 31/04).

Zgodnie $\mathrm{z}$ art. 51 ust. 4 Konstytucji: „[k]ażdy ma prawo do żądania sprostowania oraz usunięcia informacji nieprawdziwych, niepełnych lub zebranych w sposób sprzeczny z ustawą". Przyjmuje się, że przewiduje on uprawnienie każdej osoby do: „przedstawiania/kształtowania swego publicznego obrazu, rysującego się na tle danych zebranych przez władzę” i „obejmuje żądanie sprostowań oraz usunięcia informacji niepełnych, nieprawdziwych lub zebranych w sposób sprzeczny z ustawą" (wyrok TK z 12 grudnia 2005 r., sygn. akt K 32/04; zob. też wyrok TK z 23 czerwca 2009 r., sygn. akt K 54/07). Uwagę zwraca rygoryzm unormowania zawartego w art. 51 ust. 4 Konstytucji, gdyż nie przewiduje ono możliwości ograniczeń wprowadzanych w drodze ustawy zwykłej (zob. np. postanowienie TK z 25 stycznia 2006 r., sygn. akt S 2/06). Stąd wynika z niego obowiązek władzy publicznej, aby na poziomie ustawodawstwa zwykłego zagwarantować realizację unormowanego w tym przepisie aspektu prawa do prywatności, a tym bardziej nie naruszać go ani nie narażać na szkodę (np. wyrok TK z 26 października 2005 r., sygn. akt K 31/04). Nie są z niego wyłączone informacje zebrane $\mathrm{w}$ drodze działalności operacyjnej. Jednakże $\mathrm{z}$ uwagi na to, że: „dane pochodzące $z$ kontroli operacyjnej nie są ujawniane wobec zainteresowanego przy rozpoczęciu i w czasie trwania kontroli operacyjnej, przeto możliwość skorzystania z uprawnienia, o którym mowa w art. 51 ust. 4 Konstytucji de facto jest ograniczona" (wyrok TK z 12 grudnia 2005 r., sygn. akt K 32/04; zob. też wyrok TK z 23 czerwca 2009 r., sygn. akt K 54/07). W orzecznictwie TK zasadnie podnosi się, że żaden interes państwa nie może sankcjonować i usprawiedliwiać zachowywania w urzędowych dokumentach i zbiorach danych informacji nieprawdziwych, niepełnych czy zebranych w sposób sprzeczny z ustawą (wyroki TK z: 11 maja 2007 r., sygn. akt K 2/07; 20 października 2010 r., sygn. akt P 37/09), bowiem w interesie państwa - dla ochrony wartości konstytucyjnych - jest posiadanie informacji prawdziwych i możliwie pełnych. Jednocześnie w orzecznictwie wskazuje się, że istnieje pewien zakres informacji, które mogą nie rościć sobie prawa do kompletności, a jednak uwzględnienie żądania o ich sprostowanie bądź usunięcie stanowiłoby zakłócenie równowagi między interesem publicznym a interesem indywidualnym (postanowienie TK z 4 grudnia 2000 r., sygn. akt SK 10/99). Z informacjami zebranymi w sposób sprzeczny z ustawą zgodnie z orzecznictwem TK mamy do czynienia nie tylko wówczas, gdy uzyskiwanie danego rodzaju informacji jest w ogóle niedopuszczalne, ale również wtedy, gdy informacji nie pozyskano na podstawie i w granicach przewidzianych wyraźnie w ustawie lub gdy ich pozyskanie nastąpiło niezgodnie z określoną procedurą (wyrok TK z 30 lipca 2014 r., sygn. akt K 23/11). Należy także mieć na względzie - szczególnie w przypadku oceny konstytucyjności - że: „literalne brzmienie tego przepisu umieszczonego w samej Konstytucji wskazuje, że nacisk położono tu na sposób, w jaki zbierano materiały (a nie na kwestię ich 
wykorzystania w ewentualnym innym procesie, czemu ma służyć zachowanie zbioru)" (wyrok TK z 12 grudnia 2005 r., sygn. akt K 32/04).

5. Zgodnie z art. 31 ust. 3 Konstytucji: „[o]graniczenia w zakresie korzystania z konstytucyjnych wolności i praw mogą być ustanawiane tylko w ustawie i tylko wtedy, gdy są konieczne w demokratycznym państwie dla jego bezpieczeństwa lub porządku publicznego, bądź dla ochrony środowiska, zdrowia i moralności publicznej, albo wolności i praw innych osób. Ograniczenia te nie mogą naruszać istoty wolności i praw". Zasada proporcjonalności jest ściśle związana z założeniem racjonalnego działania prawodawcy, które stanowi punkt wyjścia podczas oceny zgodności kwestionowanych przepisów z Konstytucją. Cel podjęcia działania przez prawodawcę nie ogranicza się jedynie do wskazania pożądanego stanu faktycznego, ale wymaga odwołania się do wartości, które prawodawca obowiązany jest chronić, a zatem do systemu wartości wyrażonego w Konstytucji. Racjonalny prawodawca wybiera zatem cele służące najpełniejszej realizacji wyrażonego w Konstytucji systemu wartości, a następnie dobiera środki najbardziej adekwatne do realizacji tych celów. Za środki najbardziej adekwatne należy uznać te, które są, po pierwsze, skuteczne w realizacji pożądanego stanu faktycznego, a po drugie, zgodne z przyjętym systemem wartości. Tak rozumiany model racjonalności prawodawcy pozwala uznać, że funkcja prawa polega na realizacji wartości o podstawowym znaczeniu dla jednostki i społeczeństwa i nie sprowadza się do skutecznego sterowania procesami społecznymi (zob. K. Wojtyczek, Granice ingerencji ustawodawczej w sferę praw człowieka w Konstytucji RP, Kraków 1999, s. 137-139). Prawodawca, którego działania mieszczą się w takim ujęciu racjonalności, unika także zarzutu arbitralności swych działań (wyrok TK z 12 lutego 2014 r., sygn. akt K 23/10). W związku z tym wprowadza się trzy kryteria: przydatności, konieczności i proporcjonalności przyjmowanych ograniczeń (zob. K. Wojtyczek, Granice ingerencji, op. cit., s. 150 i n.).

$\mathrm{Z}$ zasady proporcjonalności Trybunał Konstytucyjny wyprowadził trzy powiązane między sobą obowiązki prawodawcy:

- przyjmowanie danej regulacji tylko wówczas, gdy jest niezbędna dla ochrony interesu publicznego, z którym jest związana,

- kształtowanie danej regulacji w sposób zapewniający osiągnięcie zamierzonych celów (skutków),

- zachowanie proporcji między efektami wprowadzonej regulacji a ciężarami bądź niedogodnościami wynikającymi z niej dla obywateli. Zasada ta kładzie szczególny nacisk na adekwatność celu i środka użytego do jego osiągnięcia. To znaczy, że spośród możliwych środków oddziaływania należałoby wybierać środki skuteczne dla osiągnięcia założonych celów, a zarazem jak najmniej uciążliwe dla podmiotów, wobec których mają być zastosowane, lub dolegliwe w stopniu nie większym niż jest to niezbędne dla osiągnięcia założonego celu (wyroki TK z: 18 października 2011 r., sygn. akt SK 2/10; 12 stycznia 2012 r., sygn. akt Kp 10/09; 23 maja 2012 r., sygn. akt P 11/10). 
Artykuł 31 ust. 3 Konstytucji: „wyznacza granice ingerencji władzy publicznej w sferę praw człowieka, nie udziela natomiast sam przez się ogólnego upoważnienia do ograniczania praw konstytucyjnych. [...] znajduje zastosowanie wtedy, gdy Konstytucja wyznacza zakres ochrony danego prawa, a jednocześnie w sposób wyraźny lub dorozumiany - dopuszcza ingerencję władz publicznych w sferę danego prawa chronioną konstytucyjnie. [...] nie znajduje natomiast zastosowania w tych wypadkach, gdy Konstytucja ogranicza się do wyznaczenia minimalnego zakresu ochrony danego prawa, który wiąże władze publiczne, a jednocześnie pozostawia ustawodawcy bardzo dużą swobodę przy urzeczywistnieniu tego prawa pod warunkiem poszanowania minimalnego zakresu danego prawa wynikającego z Konstytucji. W takim wypadku ustawodawca jest w praktyce związany przede wszystkim bezwzględnym zakazem naruszania istoty danego prawa” (wyrok TK z 23 lutego 2010 r., sygn. akt P 20/09).

6. Zgodnie $z$ art. 2 Konstytucji: „Rzeczpospolita Polska jest demokratycznym państwem prawnym, urzeczywistniającym zasady sprawiedliwości społecznej”. Wskazany przepis ustanawia zasadę demokratycznego państwa prawnego, której treść jest bardzo bogata. Założeniem państwa prawnego jest wykonywanie władzy państwowej jedynie wtedy, gdy zezwala na to Konstytucja oraz ustawy, zgodne $\mathrm{z}$ nią pod względem formalnym i materialnym, a celem wykonywania tej władzy jest ochrona ludzkiej godności, sprawiedliwości i pewności prawa (E. Morawska, Klauzula państwa prawnego w Konstytucji RP na tle orzecznictwa Trybunału Konstytucyjnego, Toruń 2003, s. 60). Klauzula ta stanowi podstawę do wyprowadzenia z niej katalogu zasad konstytucyjnych niesformułowanych wprost w przepisach. Zasady te dotyczą przede wszystkim stanowienia prawa. Istnieje stały katalog tych zasad wywodzony przede wszystkim z zasady zaufania osoby do państwa i stanowionego przez nie prawa. W doktrynie wskazuje się, że katalog ten ma charakter otwarty, tj. istnieje możliwość wyprowadzenia przez Trybunał Konstytucyjny $\mathrm{z}$ art. 2 Konstytucji nowej zasady pochodnej.

$\mathrm{Z}$ art. 2 Konstytucji wywodzone są w orzecznictwie Trybunału zasady pochodne, w tym jest on źródłem zasady zaufania obywatela do państwa. Zgodnie z orzecznictwem TK: „[z]asada ochrony zaufania wyznacza sytuację prawną nie tylko obywateli, lecz także chroni przed ingerencją władzy państwowej inne podmioty stosunków prawnych" (wyrok TK z 31 stycznia 2001 r., sygn. akt P 4/99). Nazywana jest ona także zasadą lojalności państwa względem obywateli, jest jedną z najważniejszych zasad pochodnych, wynikających z zasady demokratycznego państwa prawnego (zob. np. wyrok TK z 20 grudnia 1999 r., sygn. akt K 4/99; W. Sokolewicz, M. Zubik, Komentarz do art. 2 [w:] Konstytucja Rzeczypospolitej Polskiej. Komentarz, t. I, red. L. Garlicki, M. Zubik, Warszawa 2016, s. 127 i n.). „W dotychczasowym orzecznictwie TK ugruntowane zostało stanowisko, iż art. 2 Konstytucji obejmuje również zasadę ochrony zaufania do państwa i stanowionego przez nie prawa. Jest ona - jak podkreślano we wcześniejszych orzeczeniach - oczywistą cechą demokratycznego państwa prawnego, 
bowiem „demokratyczne państwo prawne oznacza państwo, w którym chroni się zaufanie do państwa i stanowionego przez nie prawa". Zasada ta oznacza przede wszystkim konieczność ochrony i respektowania praw słusznie nabytych i ochrony interesów w toku (por. m.in. orzeczenie TK z 2 marca 1993 r., sygn. akt K 9/92), ale obejmuje jednocześnie zakaz tworzenia przez ustawodawcę takich konstrukcji normatywnych, które są niewykonalne, stanowią złudzenie prawa i w konsekwencji jedynie pozór ochrony tych interesów majątkowych, które są funkcjonalnie związane z treścią ustanowionego prawa podmiotowego" (wyroki TK z: 19 grudnia 2002 r., sygn. akt K 33/02; 25 listopada 1997 r., sygn. akt K 26/97; 13 kwietnia 1999 r., sygn. akt K 36/98). Zasada ta nie ma charakteru bezwzględnego, bowiem są od niej dopuszczalne wyjątki (wyrok TK z 12 maja 2015 r., sygn. akt P 46/13).

7. Zgodnie z art. 7 Konstytucji: „[o]rgany władzy publicznej działają na podstawie i w granicach prawa”. Przywołany przepis wyraża zarówno zasadę legalizmu w wąskim znaczeniu, nakaz działania na podstawie prawa, jak i obowiązek przestrzegania prawa (zob. W. Sokolewicz, Komentarz do art. 7 [w:] Konstytucja Rzeczypospolitej Polskiej. Komentarz, t. V, red. L. Garlicki, Warszawa 2007, s. 3). Nakaz wyrażony w art. 7 Konstytucji adresowany jest do organów władzy publicznej. Zgodnie z orzecznictwem Trybunału Konstytucyjnego „pojęcie „władzy publicznej” w rozumieniu art. 77 ust. 1 Konstytucji obejmuje wszystkie władze w sensie konstytucyjnym - ustawodawczą, wykonawczą i sądowniczą. Należy podkreślić, że pojęcia organu państwa oraz organu władzy publicznej nie są tożsame. W pojęciu „władzy publicznej” mieszczą się bowiem także inne instytucje niż państwowe lub samorządowe, o ile wykonują funkcje władzy publicznej w wyniku powierzenia czy przekazania im tych funkcji przez organ władzy państwowej lub samorządowej. Wykonywanie władzy publicznej dotyczy wszelkich form działalności państwa, samorządu terytorialnego i innych instytucji publicznych, które obejmują bardzo zróżnicowane formy aktywności. Wykonywanie takich funkcji łączy się z reguły, chociaż nie zawsze, z możliwością władczego kształtowania sytuacji jednostki. Dotyczy to obszaru, na którym może dojść do naruszenia praw i wolności jednostki ze strony władzy publicznej. Nazwa „organ” władzy publicznej użyta w art. 77 ust. 1 Konstytucji oznacza instytucję, strukturę organizacyjną, jednostkę władzy publicznej, z której działalnością wiąże się wyrządzenie szkody, nie zaś organ osoby prawnej w kategoriach prawa cywilnego. Odpowiedzialność oparta na tym przepisie obciąża strukturę (instytucję), a nie osoby z nią związane (jej funkcjonariuszy). Podstawowe znaczenie ma ustalenie, czy działanie organu władzy publicznej związane jest $\mathrm{z}$ realizacją jego prerogatyw. Formalny charakter powiązań pomiędzy bezpośrednim sprawcą szkody a władzą publiczną jest mniej istotny. Ustalenie statusu osoby, która jest bezpośrednim sprawcą szkody, ułatwia jednak przypisanie danego działania organowi władzy publicznej" (wyrok TK z 4 grudnia 2001 r., sygn. akt SK 18/00). 
Podobnie Trybunał Konstytucyjny wskazał, że: „pojęcie «działania» organu władzy publicznej nie zostało konstytucyjnie zdefiniowane. W pojęciu tym mieszczą się zarówno zachowania czynne tego organu, jak i zaniechania. W zakresie działań czynnych organu władzy publicznej mieszczą się indywidualne rozstrzygnięcia, np. decyzje, orzeczenia i zarządzenia. Pojęcie «zaniechania» władzy publicznej dotyczy tych sytuacji, w których obowiązek określonego działania władzy publicznej jest skonkretyzowany w przepisie prawa i można ustalić, na czym konkretnie miałoby polegać zachowanie organu władzy publicznej” (wyrok TK z 4 grudnia 2001 r., sygn. akt SK 18/00).

Jak wskazał Trybunał Konstytucyjny: „stosownie do art. 7 Konstytucji, organy władzy publicznej działają na podstawie i w granicach prawa. Oznacza to m.in., że kompetencje organów władzy publicznej powinny zostać jednoznacznie i precyzyjnie określone w przepisach prawa, wszelkie działania tych organów powinny mieć podstawę $\mathrm{w}$ takich przepisach, a - w razie wątpliwości interpretacyjnych - kompetencji organów władzy publicznej nie można domniemywać" (wyrok TK z 14 czerwca 2006 r., sygn. akt K 53/05). Podobnie w postanowieniu z 4 października 2011 r., sygn. akt P 9/11, Trybunał Konstytucyjny stwierdził, że: „zgodnie z art. 7 Konstytucji, organy władzy publicznej działają na podstawie i w granicach prawa. Oznacza to powinność organu władzy publicznej przestrzegania wszystkich przepisów, niezależnie od usytuowania ich w systemie źródeł prawa, które określają jego uprawnienia lub obowiązki. Organy muszą zatem znać przepisy regulujące ich kompetencje i stosować się do wynikających z nich nakazów i zakazów. Z konstytucyjnej zasady legalizmu wynika zatem, że nie mogą podejmować działań bez podstawy prawnej czy unikać wykonania kompetencji, jeżeli wiążące normy prawne nakładają na te organy określone obowiązki (por. wyrok TK z 21.02.2001 r., sygn. P 12/00)”. Wreszcie z art. 7 Konstytucji wynika domniemanie, że organy władzy publicznej działają na podstawie i w granicach prawa. Domniemanie to może zostać obalone w przewidzianych przez prawo formach, w szczególności poprzez stwierdzenie przez Trybunał Konstytucyjny naruszenia przez organ władzy publicznej art. 7 Konstytucji.

8. Zgodnie z art. 40 Konstytucji: „[n]ikt nie może być poddany torturom ani okrutnemu, nieludzkiemu lub poniżającemu traktowaniu i karaniu. Zakazuje się stosowania kar cielesnych". W przepisie tym występuje pewien ciąg określeń, wykluczających wiele zachowań ludzkich, określeń bliskoznacznych, z wyraźną intencją uczynienia nielegalnymi działań wymierzonych przeciwko samej naturze człowieka i tym samym jego godności (zob. P. Sarnecki, Komentarz do art. 40 [w:] Konstytucja Rzeczypospolitej Polskiej. Komentarz, t. III, red. L. Garlicki, Warszawa 2003, s. 1).

Przy definiowaniu pojęć, którymi posłużył się ustrojodawca w art. 40 Konstytucji, oraz zakresu i głębokości ustanowionego w tym przepisie zakazu warto odwołać się do właściwych aktów prawa międzynarodowego, a także ustaleń orzecznictwa i doktryny poczynionych na ich gruncie (zob. B. Banaszak, Konsty- 
tucja Rzeczypospolitej Polskiej. Komentarz, Warszawa 2009, komentarz do art. 40, s. 219; M. Królikowski, K. Szczucki, Komentarz do art. 40 [w:] Konstytucja RP. Komentarz, t. I, Art. 1-86, red. M. Safjan, L. Bosek, Warszawa 2016, nb. 25; P. Sarnecki, Komentarz do art. 40, op. cit., s. 1-3; J. Sobczak, Komentarz do art. 4 [w:] Karta praw podstawowych Unii Europejskiej. Komentarz, red. A. Wróbel, Warszawa 2013, nb. 9).

Zgodnie $\mathrm{z}$ art. 1 ust. 1 Konwencji w sprawie zakazu stosowania tortur oraz innego okrutnego, nieludzkiego lub poniżającego traktowania albo karania $\mathrm{z}$ dnia 10 grudnia 1984 r. (Dz.U. 1989, Nr 63, poz. 378) „tortury” oznaczają każde działanie, którym jakiejkolwiek osobie umyślnie zadaje się ostry ból lub cierpienie, fizyczne bądź psychiczne, w celu uzyskania od niej lub od osoby trzeciej informacji lub wyznania, w celu ukarania jej za czyn popełniony przez nią lub osobę trzecią albo o którego dokonanie jest ona podejrzana, a także w celu zastraszenia lub wywarcia nacisku na nią lub trzecią osobę albo w jakimkolwiek innym celu wynikającym z wszelkiej formy dyskryminacji, gdy taki ból lub cierpienie powodowane są przez funkcjonariusza państwowego lub inną osobę występującą $\mathrm{w}$ charakterze urzędowym lub $\mathrm{z}$ ich polecenia albo za wyraźną lub milczącą zgodą. Określenie to nie obejmuje bólu lub cierpienia wynikających jedynie ze zgodnych z prawem sankcji, nieodłącznie związanych z tymi sankcjami lub wywołanych przez nie przypadkowo.

Wymienione w art. 40 Konstytucji okrutne, nieludzkie traktowanie i karanie obejmuje: „oprócz zadawania bólu fizycznego czy psychicznego stwarzanie sytuacji dolegliwych także z innych względów, np. moralnych, religijnych czy obyczajowych", traktowanie i karanie poniżające zaś: „polega na zamachach, wymierzonych w godność człowieka, na zmuszaniu go do zachowań ośmieszających, upadlających, czy w ogóle sprawiających wrażenie wyrzekania się człowieczeństwa" (zob. P. Sarnecki, Komentarz do art. 40, op. cit., s. 2; B. Banaszak, Konstytucja, op. cit., s. 220).

Zwraca się również uwagę, że ustalenie tego, w czym się wyraża na przykład okrutność traktowania, może być w konkretnym wypadku kwestią ocen, które to oceny nie będą jednak całkowicie dowolne, ponieważ w kręgu kulturowym, do którego należy Polska, poglądy na ten temat są dość sprecyzowane i ustabilizowane (P. Winczorek, Komentarz do Konstytucji Rzeczypospolitej Polskiej z dnia 2 kwietnia 1997 roku, Warszawa 2008, s. 100-101).

9. Artykuł 3 Konwencji o ochronie praw człowieka i podstawowych wolności sporządzonej w Rzymie dnia 4 listopada 1950 r. (Dz. U. 1993, Nr 61, poz. 284, ze zm., dalej: EKPC) stanowi natomiast, że: „[n]ikt nie może być poddany torturom ani nieludzkiemu lub poniżającemu traktowaniu albo karaniu”. Treścią art. 3 EKPC jest wprowadzenie zakazu poddawania człowieka traktowaniu sprzecznemu z naturą godności ludzkiej, w szczególności powodującego cierpienia fizyczne i (lub) psychiczne, co można określić ogólnie jako zakaz maltretowania. Zakaz ten odnosi się zarówno do karania (rozumianego jako nakładanie sankcji 
przewidzianych przez prawo), jak i do wszelkich form faktycznego traktowania, powodujących - bezpośrednio lub pośrednio - takie skutki i pozostających w sferze odpowiedzialności państwa (władz publicznych) - (zob. L. Garlicki, Komentarz do art. 3 [w:] Konwencja o ochronie praw człowieka i podstawowych wolności, t. I, Komentarz do artykułów 1-18, red. L. Garlicki, Warszawa 2010, nb. 1).

Nieludzkie traktowanie w rozumieniu art. 3 EKPC polega na takim wkroczeniu w sferę integralności fizycznej i psychicznej człowieka, które - nie sięgając swoją drastycznością poziomu tortury - przekracza dolegliwości w sposób nieunikniony związane ze zgodną z prawem realizacją przez funkcjonariuszy zadań i obowiązków o legitymowanym charakterze. Obecne orzecznictwo orientuje się nie tylko na kryterium intensywności cierpienia, ale także na kryterium konieczności zastosowania siły fizycznej. Rozszerzyło to zakres sytuacji, które wobec braku tej konieczności kwalifikuje się jako nieludzkie traktowanie.

Tak rozumiane nieludzkie traktowanie pojawia się, przede wszystkim, w sytuacji zatrzymań policyjnych. Niepotrzebne i ekscesywne użycie siły zawsze może zostać uznane za nieludzkie traktowanie: „[a]rt. 3 nie zakazuje użycia siły w celu dokonania zatrzymania. Niemniej, użycie siły jest dopuszczalne tylko, gdy jest nieodzowne i nie może mieć nadmiernego charakteru" (wyrok ETPC z 3 listopada 2009 r., Staszewska v. Polska, skarga nr 10049/04).

$\mathrm{O}$ nieludzkim traktowaniu można mówić ponadto w szczególności w wypadkach użycia siły w związku z tłumieniem zamieszek czy innych, związanych z użyciem przemocy, zachowań grup ludzi, przejawami brutalności wobec osób już zatrzymanych oraz w odniesieniu do traktowania więźniów w tym bezzasadnego używania siły. Traktowanie poniżające polega natomiast na takim wkroczeniu w sferę integralności fizycznej i/lub psychicznej człowieka, które wywołuje u ofiary odczucia strachu, stresu i podporządkowania, zdolne do jej upokorzenia i upodlenia/zniewolenia. Znaczenie zasadnicze ma element subiektywny, tzn. sposób recepcji działań przez osobę im poddawaną. Odczucia poniżenia mogą ulec wzmocnieniu, gdy działania wobec ofiary podejmowane są w sposób pozwalający publiczności (środkom masowego przekazu) ich obserwację i relacjonowanie (zob. szerzej L. Garlicki, Komentarz do art. 3, op. cit., nb. 17 i n., wraz z przywołanym tam orzecznictwem).

Należy zwrócić uwagę, że w toku ewolucyjnej wykładni poszerzono zakres obowiązków wynikających z art. 3 EKPC. Obok, podstawowego (materialnego), obowiązku o charakterze negatywnym (zakazującego władzom i ich funkcjonariuszom dopuszczania się działań o maltretującym charakterze), orzecznictwo zaczęło wydobywać obowiązki proceduralne, nakazujące władzom przeprowadzenie „efektywnego badania” wszelkich zarzutów maltretowania (L. Garlicki, Komentarz do art. 3, op. cit., nb. 9). Każde pojawienie się zarzutu maltretowania zobowiązuje władze krajowe do przeprowadzenia dochodzenia mającego na celu ustalenie faktów i ukaranie ewentualnych sprawców. Obowiązek ten dotyczy przede wszystkim sytuacji, gdy ofiara maltretowania złożyła stosowną skargę lub 
zawiadomienie. Także jednak, gdy władza publiczna powzięła z urzędu wiadomość o fakcie maltretowania, jest obowiązana do wdrożenia dochodzenia lub przekazania sprawy właściwemu organowi.

10. Zgodnie z art. 6 EKPC: „1. Każdy ma prawo do sprawiedliwego i publicznego rozpatrzenia jego sprawy $\mathrm{w}$ rozsądnym terminie przez niezawisły i bezstronny sąd ustanowiony ustawą przy rozstrzyganiu o jego prawach i obowiązkach o charakterze cywilnym albo o zasadności każdego oskarżenia w wytoczonej przeciwko niemu sprawie karnej. Postępowanie przed sądem jest jawne, jednak prasa i publiczność mogą być wyłączone z całości lub części rozprawy sądowej ze względów obyczajowych, z uwagi na porządek publiczny lub bezpieczeństwo państwowe $\mathrm{w}$ społeczeństwie demokratycznym, gdy wymaga tego dobro małoletnich lub gdy służy to ochronie życia prywatnego stron albo też w okolicznościach szczególnych, w granicach uznanych przez sąd za bezwzględnie konieczne, kiedy jawność mogłaby przynieść szkodę interesom wymiaru sprawiedliwości. 2. Każdego oskarżonego o popełnienie czynu zagrożonego karą uważa się za niewinnego do czasu udowodnienia mu winy zgodnie z ustawą. 3. Każdy oskarżony o popełnienie czynu zagrożonego karą ma co najmniej prawo do: a) niezwłocznego otrzymania szczegółowej informacji w języku dla niego zrozumiałym o istocie i przyczynie skierowanego przeciwko niemu oskarżenia; b) posiadania odpowiedniego czasu i możliwości do przygotowania obrony; c) bronienia się osobiście lub przez ustanowionego przez siebie obrońcę, a jeśli nie ma wystarczających środków na pokrycie kosztów obrony - do bezpłatnego korzystania z pomocy obrońcy wyznaczonego z urzędu, gdy wymaga tego dobro wymiaru sprawiedliwości; d) przesłuchania lub spowodowania przesłuchania świadków oskarżenia oraz żądania obecności i przesłuchania świadków obrony na takich samych warunkach jak świadków oskarżenia; e) korzystania z bezpłatnej pomocy tłumacza, jeżeli nie rozumie lub nie mówi językiem używanym w sądzie". W związku z tym przepis ten gwarantuje: „1) sprawiedliwość proceduralną (procedural fairness) w postępowaniach w sprawach cywilnych i karnych, 2) prawo dostępu do sądu celem dochodzenia praw i obowiązków cywilnoprawnych, 3) prawo do wykonania wyroku w sprawie cywilnej (Human Rights Practice, Londyn 2006, Article 6 Right to a Fair Trial, M. Purchase, E. Schutzer-Weismann, s. 6.001-6.002). Według innego poglądu, gwarancje zawarte $\mathrm{w}$ art. 6 to: 1) gwarancje organizacyjne (niezawisły i bezstronny sąd ustanowiony ustawą), 2) prawo dostępu do sądu, 3) gwarancje rzetelnego postępowania w węższym znaczeniu (Ch. Grabenwarter, Europäische Menschenrechtskonvention, München-Basel-Wien 2008, s. 660)" (P. Hofmański, A. Wróbel, Komentarz do art. 6 [w:] Konwencja o ochronie praw człowieka $i$ podstawowych wolności, t. I, Komentarz do artykułów 1-18, red. L. Garlicki, Warszawa 2010, nb. 5). Uprawnienia zawarte w tym przepisie tworzą tzw. minimalny standard praw oskarżonego. „[... Prawo do obrony, w zakresie gwarantowanym przez przepisy EKPC nie jest jednak prawem absolutnym. Wskazuje 
na to również ETPC, podkreślając, że zakres realizacji także i tego prawa musi być oceniany w kontekście wszystkich okoliczności sprawy, w szczególności zaś nakazuje uwzględnienie innych prawnie chronionych wartości, oraz realizację praw wszystkich jego uczestników” (P. Karlik, T. Sroka, P. Wiliński, Komentarz do art. 42, op. cit., nb. 201-203).

\section{- Analiza zgodności}

1. Oceniając zaskarżony przez Rzecznika przepis, należy mieć na względzie zarówno dobro wymiaru sprawiedliwości, jak też to, że z każdym przestępstwem wiąże się krzywda lub szkoda innej osoby lub zbiorowości. Stąd ustawodawca zwykły ma obowiązek takiego ukształtowania procesu karnego, by sprawca przestępstwa mógł zostać pociągnięty do odpowiedzialności i poniósł zasłużoną karę. Taka jest też ratio legis art. 168a k.p.k., który ma na celu zagwarantowanie, że każdy dowód zostanie poddany ocenie przez sąd rozpoznający sprawę karną odnośnie do jego treści i wiarygodności. Stanowi to jedną z gwarancji rzetelnego procesu sądowego i wydania sprawiedliwego wyroku. Odnosząc się do doktryny owoców zatrutego drzewa, do której odwołuje się Rzecznik, wskazać należy, że praktyka krajów, w których jest ona przyjęta, dowodzi, że nie przyniosła ona realizacji celów, którymi uzasadniano jej wprowadzenie (por. stanowisko Prokuratora Generalnego, s. 92 i n. oraz powoływana tam literatura przedmiotu). D. Osborn wskazuje, że poza Stanami Zjednoczonymi, także w Australii, Kanadzie i Wielkiej Brytanii: „wykluczanie istotnych dowodów uzyskanych nielegalnie nie gwarantuje sprawiedliwego procesu, lecz wypacza wymiar sprawiedliwości. Ponadto, konieczność wykluczania nielegalnie uzyskanych dowodów burzy stabilność orzecznictwa oraz wywołuje niezrozumienie wśród opinii publicznej (D. Osborn, Suppressing the Truth: Judicial Exclusion of Illegally Obtained Evidence in the United States, Canada, England and Australia, Murdoch University Electronic Journal of Law, http://www.austlii.edu.au/au/joumals/MurUEJL/2000/44.html, teza 70-86)" (ibidem, s. 93). Negatywne skutki procesowe stosowania doktryny owoców zatrutego drzewa spowodowały ograniczenie zakresu jej stosowania w amerykańskim procesie karnym. Uczynił tak Sąd Najwyższy Stanów Zjednoczonych „w wyrokach z dnia 15 czerwca 2006 r. w sprawie Hudson v. Michigan (https://www.supremecourt.gov/opinions/05pdf/04-1360. pdf), z dnia 14 stycznia 2009 w sprawie Herring v. United States (https://wvvw. law.comell.edu/supct/pdf/07-513P.ZO) oraz z dnia 20 czerwca 2016 r. w sprawie Utah v. Strieff (https://www. supremecourt.gov/opinions/15pdf/14-1373_83i7. pdf)" (ibidem). Przy ocenie art. 168a k.p.k. te negatywne doświadczenia państw anglosaskich, wskazujące, że wskutek stosowania doktryny owoców zatrutego drzewa wymiar sprawiedliwości niejednokrotnie pozbawia się możliwości wymierzania sprawiedliwości, muszą być wzięte pod uwagę. Podobnie jak to, że zarówno tamtejsza doktryna, jak i orzecznictwo odchodzą od takiego rozumienia tej doktryny, która jest obecna we wniosku Rzecznika. 
Rozważenia wymaga także, czy w kwestionowanych przez Rzecznika przepisach mamy do czynienia z kolizją praw czy wartości uznawanych przez Konstytucję, czy też nie. Pojęcie kolizji praw rozumiane jest przy tym w orzecznictwie TK szerzej i obejmuje również sytuacje, gdy urzeczywistnienie prawa określonego podmiotu w danej sytuacji faktycznej powoduje jedynie niebezpieczeństwo naruszenia prawa innego podmiotu (zob. m.in. wyroki TK z: 5 maja 2004 r., sygn. akt P 2/03; 12 maja 2008 r., sygn. akt SK 43/05). W każdym takim wypadku konieczne jest dokonanie oceny z punktu widzenia kompromisu między wszystkimi konstytucyjnymi wartościami pozostającymi w konflikcie. Konstytucja przez konstrukcję proporcjonalności dopuszcza bowiem redukcję zakresu konkurencyjnych praw i wolności, ale nie zniweczenie ochrony któregoś z nich (wyrok TK z 25 listopada 2008 r., sygn. akt K 5/08). Trybunał Konstytucyjny wskazał, że w sytuacji kolizji konstytucyjnych wartości, praw i wolności zasadnicze znaczenie ma wyznaczenie proporcji ochrony i gwarancji każdego z chronionych dóbr, wolności i praw (wyrok TK z 9 listopada 2010 r., sygn. akt K 13/07). Gwarancje praw oskarżonego w procesie karnym jako ratio legis nie mają na celu ułatwienia sprawcy przestępstwa uniknięcia odpowiedzialności karnej, lecz zagwarantowanie osobie niewinnej, że nie zostanie skazana. Uwzględniając spójność aksjologiczną Konstytucji, nie można wyprowadzić z niej - jak wskazuje Rzecznik - normy prawnej nakazującej ułatwienie sprawcy przestępstwa skutecznej obrony, rozumianej jako zapewnienie przez państwo takich warunków obrony, żeby sprawca przestępstwa mógł uwolnić się od odpowiedzialności karnej za jego dokonanie. Taka wykładnia przywoływanych przez Rzecznika wzorców kontroli stanowiłaby nadużycie praw i wolności, które na poparcie swojego stanowiska przywołał on we wniosku. Wskazuje się w literaturze, że pojęcie „nadużycia prawa” oznacza zastosowanie (użycie) danego narzędzia prawnego sprzecznie z celem, dla którego zostało ono utworzone, sprzecznie z jego przeznaczeniem (M. Warchoł, Pojęcie „nadużycia prawa” w prawie procesowym, „Prokuratura i Prawo” 2007, nr 11, s. 48-67). Wobec czego z przypadkiem nadużycia prawa będziemy mieć do czynienia w razie, gdy prawo: „nie jest wykorzystywane do zadośćuczynienia interesom pożądanym przez ustawę, lecz do osiągnięcia celu nie godnego aprobaty" (U. Weber, Der MißbrauchprozessualerRechte im Strafverfahren, GA 1975, s. 289 [za:] M. Warchoł, Pojęcie "nadużycia prawa”, op. cit., s. 48). Niektórzy autorzy słusznie stwierdzają, że o nadużyciu możemy mówić zawsze wtedy, gdy dane uprawnienie jest wykonywane w sposób, który narusza ratio normy prawnej, które ustawodawca w niej zamieścił celem przestrzegania go, oraz takie użycie danego prawa, które ma wpływ na sferę interesów innych podmiotów (F. Cordopatri, L'abuso del processo. Diritto positivo, Padova 2000, s. 90; C. Conti, L'imputato nel procedimento connesso. Diritto al silenzio e obbligo di verità, Cedam 2003, s. 152 [za:] M. Warchoł, Pojęcie „nadużycia prawa”, op. cit., s. 48). Inaczej rzecz ujmując, w tym wypadku nadużyciem prawa i wolności przywoływanych przez Rzecznika na poparcie swojego wniosku jest rozciągnięcie ich na obszary nimi nie obję- 
te, do stopnia sprzeciwiającego się sensowi i uzasadnieniu aksjologicznemu tych prawa i wolności. Wykładnia praw i wolności konstytucyjnych, którą proponuje Rzecznik, prowadzi w praktyce do celu niegodnego aprobaty z punktu widzenia wartości i celów wyrażonych przez ustrojodawcę, dlatego musi być uznana za niedopuszczalną. W praktyce wykładnia ta w wielu wypadkach utrudniałaby lub uniemożliwiałaby pociągnięcie do odpowiedzialności sprawcy przestępstwa i wydanie sprawiedliwego wyroku. Należy bowiem pamiętać, że dowód stanowi jedynie nośnik informacji. Wady istniejące przy jego pozyskaniu nie wpływają na rzeczywisty przebieg zdarzeń, który miał miejsce, i nie muszą wpływać na wiarygodność dowodu. Stąd też zasadne jest dla rzetelności procesu sądowego i wydania sprawiedliwego wyroku poddanie takiego dowodu ocenie sądu.

Kwestionowane przez Rzecznika rozwiązanie stanowi także realizację konstytucyjnego obowiązku państwa, by: „działaniu instytucji publicznych zapewnić rzetelność i sprawność”. Oceniając art. 168a k.p.k., należy mieć na względzie zasadę dobra wspólnego. Zgodnie z art. 1 Konstytucji: „Rzeczpospolita Polska jest dobrem wspólnym wszystkich obywateli”. W orzecznictwie TK dobro wspólne jest wprost przywoływane jako racja lub jedna $\mathrm{z}$ racji uzasadniających ograniczenie wolności i praw konstytucyjnych czy jako aksjologiczna podstawa - wskazywanych w klauzulach limitacyjnych - racji ograniczania konstytucyjnych wolności i praw. Trybunał Konstytucyjny stwierdził, że: „uważa za fakt niewątpliwy, że pierwszą przyczyną, dla której prawa jednostki mogą być ograniczane jest ochrona dobra wspólnego [...]. W świetle tego przepisu, któremu - zważywszy na systematykę konstytucji - została nadana najwyższa ranga, nie może budzić wątpliwości, że zapewnienie bezpieczeństwa państwa jest celem usprawiedliwiającym ograniczenia wszelkich praw i wolności obywatelskich" (wyrok TK z 3 lipca 2001 r., sygn. akt K 3/01; zob. także wyroki TK z: 25 listopada 2003 r., sygn. akt K 37/02; 16 kwietnia 2002 r., sygn. akt SK 23/01). W tym samym orzeczeniu uznał też, że ochrona dobra wspólnego może stanowić rację wprowadzenia uregulowań: „które niewątpliwie ograniczają prawa jednostek i całych społeczności”. Tymczasem w argumentacji Rzecznika zawartej we wniosku wyraźnie widać przeciwstawianie praw człowieka dobru wspólnemu. Takie rozumienie praw i wolności jest nieuprawnione na gruncie Konstytucji. W praktyce Rzecznik neguje uznany przez TK obowiązek „dostatecznej ochrony określonych wartości konstytucyjnych”, który to obowiązek: „obliguje ustawodawcę zwykłego do wprowadzenia określonych środków służących ochronie tych wartości” (wyrok TK z 25 maja 1996 r., sygn. akt K 26/96). Trybunał Konstytucyjny w swoim orzecznictwie wskazał również, że powiązane z dobrem wspólnym poczucie sprawiedliwości wymaga karania przestępców i odpowiedzialności za czyny naruszające przepisy prawa karnego (wyroki TK z: 25 maja 2004 r., sygn. akt SK 44/03; 15 października 2008 r., sygn. akt P 32/06).

2. Rzecznik wywodzi, że art. 168a k.p.k. jest niezgodny $z$ art. 2, w tym zwłaszcza z zasadą zaufania obywateli do państwa i stanowionego przez nie prawa. 
Stanowić ma bowiem podstawę do: „podejmowania czynności działających na niekorzyść jednostki” (wniosek Rzecznika, s. 21). Uwzględniając poczynione już uprzednio w poprzednim punkcie rozważania, Sejm pragnie podkreślić, że stosowanie w procesie karnym exclusionary rule (zasady wykluczania) i doktryny „owoców zatrutego drzewa”, za czym opowiada się Rzecznik, podważałoby zaufanie obywateli do państwa i stanowionego przez nie prawa, w szczególności kryzys zaufania dotknąłby władzę sądowniczą. Trudno bowiem przyjąć, że zaufanie praworządnego obywatela miałoby budować uniknięcie odpowiedzialności przez sprawcę przestępstwa tylko ze względów formalnych. Nie jest to jedynie zagrożenie potencjalne, gdyż stosowanie tych zasad: „doprowadziło do kryzysu wiary opinii publicznej w system wymiaru sprawiedliwości [w Stanach Zjednoczonych - dopisek A.P.] (vide D. Osborn, Suppressing the Truth: Judicial Exclusion of Illegally Obtained Evidence in the United States, Canada, England and Australia, Murdoch University Electronic Journal of Law, http://www.austlii. edu.au/au/journals/MurUEJL/2000/44.html, teza 68)" (stanowisko Prokuratora Generalnego, s. 111).

Przypomnieć należy, że państwo stanowi wynik umowy społecznej, poprzez którą: „obywatele zrzekli się części prerogatyw osobistych na rzecz Państwa, w tym prawa do samodzielnego wymierzania sprawiedliwości. Trudno jest mówić o lojalności państwa względem obywatela, jeśli państwo zabrania obywatelowi samodzielnego wymierzenia sprawiedliwości sprawcy przestępstwa popełnionego na szkodę tegoż obywatela, a jednocześnie samo odmawia ukarania owego sprawcy, ponieważ w toku zbierania materiału dowodowego uchybiono np. prawu do ochrony autonomii informacyjnej oskarżonego" (ibidem). Taki stan rzeczy stanowiłby niezgodną z konstytucyjną zasadą ochrony zaufania obywateli do państwa i stanowionego przez nie prawa pułapkę zastawioną na praworządnych obywateli pokrzywdzonych przez sprawców przestępstw. Pokrzywdzony obywatel owszem - na wzór Stanów Zjednoczonych - mógłby dochodzić swoich praw w procesie cywilnym, jednakże droga taka jest kosztowna oraz powoduje wtórną wiktymizację pokrzywdzonego. Co więcej, w większości przypadków byłaby także nieskuteczna, bowiem z dużym prawdopodobieństwem można przyjąć, że sąd cywilny oparłby się na ustaleniach sądu karnego. Prokurator Generalny w swoim stanowisku słusznie wykazuje, że państwo ma obowiązek zachowywania zawartej z obywatelami umowy społecznej, a więc m.in. wykrywania i pociągania do odpowiedzialności karnej sprawców przestępstw oraz zapewniania, że nie poniesie tej odpowiedzialności osoba niewinna. Przyjęcie doktryny owoców zatrutego drzewa godzi w realizację tego celu, co jest niebezpiecznie dla porządku społecznego, bowiem: „w skrajnych przypadkach może prowadzić do samosądów, które w istocie są skrajną emanacją braku zaufania obywateli do wymiaru sprawiedliwości, stanowią klęskę systemu zwalczania przestępczości oraz mogą skutkować drastycznymi naruszeniami najistotniejszych praw obywateli wskutek działań innych obywateli” (ibidem, s. 112). Oprócz tego pamiętać na- 
leży, że zgodnie z preambułą Konstytucji Rzeczypospolita Polska jest państwem opartym „na poszanowaniu [...] sprawiedliwości [...]”. W art. 2 Konstytucji wyrażono nakaz urzeczywistniania zasad sprawiedliwości społecznej. Wydaje się zasadne, że przyjęcie, iż jednym z elementów zasady sprawiedliwości jest możliwość skutecznego karania sprawców przestępstw. Skoro bowiem: „nie jest demokratycznym państwem prawnym państwo, które nie realizuje idei sprawiedliwości, przynajmniej pojmowanej jako dążenie do zachowania równowagi w stosunkach społecznych i powstrzymywanie się od kreowania nieusprawiedliwionych, niepopartych obiektywnymi wymogami i kryteriami przywilejów dla wybranych grup obywateli" (P. Tuleja, Komentarz do art. 2 [w:] Konstytucja RP. Komentarz, t. I, Art. 1-86, red. M. Safjan, L. Bosek, Warszawa 2016, nb. 85), to państwem takim nie będzie również państwo, które tworzy w procedurze karnej mechanizmy pozwalające na uniknięcie przez sprawcę przestępstwa sprawiedliwej kary z powodów formalnych. Przyjmowanie tego typu rozwiązań godzi w zasadę sprawiedliwości. Doktryna owoców zatrutego drzewa prowadzi bowiem do „skrajnych wypaczeń w funkcjonowaniu wymiaru sprawiedliwości, godzi w zasadę prawdy materialnej [...] oraz [...] prawa innych [niż oskarżony - dopisek A.P.] uczestników postępowania, w szczególności oskarżyciela posiłkowego (pokrzywdzonego)" (stanowisko Prokuratora Generalnego, s. 112-113). Z tych względów art. 168a k.p.k. jest zgody z art. 2 Konstytucji, choć przypomnieć należy, że: „[w] razie zakwestionowania zgodności aktu normatywnego ze standardami demokratycznego państwa prawnego, skonkretyzowanymi i rozwiniętymi w odrębnych postanowieniach ustawy zasadniczej, podstawę kontroli konstytucyjności powinny stanowić przede wszystkim szczegółowe przepisy konstytucyjne. $\mathrm{W}$ takich sytuacjach nie ma natomiast potrzeby powoływania - jako podstawy kontroli - zasady demokratycznego państwa prawnego, wyrażonej w art. 2 Konstytucji. Zasada ta pełni wówczas przede wszystkim funkcję wskazówki dla interpretacji wymienionych, szczegółowych przepisów ustawy zasadniczej” (wyrok TK z 9 czerwca 1998 r., sygn. akt K 28/97; zob. także wyrok TK z 9 października 2012 r., sygn. akt P 27/11).

3. Rzecznik postawił zarzut naruszenia przez art. 168a k.p.k. art. 42 Konstytucji, nie spełnił jednak wymogu formalnego obejmującego przedstawienie argumentów uzasadniających zarzut niezgodności przedmiotu kontroli ze wskazanym wzorcem kontroli. Dlatego w tym zakresie postępowanie na podstawie art. 59 ust. 1 pkt 2 u.o.t.p.TK podlega umorzeniu wobec niedopuszczalności wydania orzeczenia. Sejm pragnie w związku z tym zauważyć jedynie, że na prawo do obrony składają się: prawo do wyboru sposobu obrony, prawo do znajomości stawianych zarzutów, prawo do odpowiedniego czasu i możliwości przygotowania obrony, prawo do obrony osobistej, prawo do posiadania i korzystania z pomocy obrońcy, prawo do swobody wypowiedzi, prawo do dostępu do materiału dowodowego, prawo do inicjatywy dowodowej, prawo do udziału w czynnościach procesowych, prawo do zaskarżania decyzji procesowych i czynności orga- 
nów procesowych (T. Sroka, Komentarz do art. 42 [w:] Konstytucja RP. Komentarz, t. I, Art. 1-86, red. M. Safjan, L. Bosek, Warszawa 2016). Kwestionowany przez Rzecznika przepis nie uniemożliwia przedstawiania dowodów na swoją korzyść oraz kwestionowania dowodów świadczących przeciw niemu. Treść art. 168a k.p.k. nie podważa uprawnienia kwestionowania uzyskanych dowodów ani podważania ich wiarygodności. Zagwarantowanego w Konstytucji prawa do obrony nie można utożsamiać z prawem do uniknięcia odpowiedzialności przez sprawcę przestępstwa.

4. Sejm nie podziela także stanowiska Rzecznika, że art. 168a k.p.k. kwestionuje domniemanie praworządności działania organów państwa pro futuro. Istnieje bowiem fundamentalna różnica między wyrażeniem akceptacji dla naruszania prawa przez funkcjonariuszy - ze wszystkimi tego konsekwencjami a dostrzeżeniem, że naruszenia w praktyce się zdarzają i niesprawiedliwe jest obarczanie ich skutkami pokrzywdzonego. Tymczasem ma to miejsce w przypadku apriorycznego uniemożliwiania oceny uzyskanego w ten sposób materiału dowodowego przez sąd. Przepis ten nie powoduje wyłączenia odpowiedzialności osób winnych takich naruszeń. Tworzy jednak gwarancję, że orzeczenie sądu będzie wydane na podstawie całości ujawnionych $\mathrm{w}$ toku postępowania dowodowego okoliczności. Znajduje to oparcie w orzecznictwie TK, w którym podkreślono, że: „zasada art. 7 Konstytucji nie rodzi wprawdzie po stronie jednostek jej podlegających prawa podmiotowego «do władzy publicznej działającej tylko zgodnie z prawem (byłoby to nierealne, ponieważ musi istnieć zawsze margines ryzyka błędów, pomyłek)». Jednakże pojawienie się w Konstytucji art. 77 ust. 1 wprowadziło gwarancję, że ekonomiczny skutek tych ryzyk, błędów czy pomyłek nie będzie obciążał poszkodowanego" (wyrok TK z 23 września 2003 r., sygn. akt K 20/02). Ponownie trzeba podkreślić, że art. 168a k.p.k.: „nie nakazuje, nie umożliwia ani nie ułatwia organom władzy publicznej zachowania sprzecznego z prawem, w szczególności nie obejmuje zakresem unormowania zalegalizowania czynności nielegalnych. Przepis ten nie upoważnia w żadnej mierze organów państwa do działania poza prawem ani nie uwalnia funkcjonariuszy organów państwa od odpowiedzialności dyscyplinarnej, karnej i cywilnej związanej z niedopełnieniem obowiązków bądź przekroczeniem uprawnień. Innymi słowy, norma zawarta w tym przepisie nie ma wpływu na stwierdzenie naruszenia przez funkcjonariusza publicznego procedury postępowania, dokonania czynu zabronionego czy na uchylenie odpowiedzialności odszkodowawczej Państwa dochodzonej na gruncie art. 77 ust. 1 Konstytucji. Podkreślić należy, że naruszenie reguł postępowania przez funkcjonariuszy organów ścigania, jak również popełnienie czynu zabronionego, nadal podlega odpowiednim sankcjom w postępowaniu dyscyplinarnym, karnym i cywilnym. Przepis art. 168a k.p.k. stanowi jedynie, że orzekający sąd karny nie może pozostawić materiału dowodowego uzyskanego wskutek naruszenia przepisów postępowania przez funkcjonariuszy publicznych poza zakresem swojej oceny" (stanowisko Proku- 
ratora Generalnego, s. 119). Z tego względu art. 168a k.p.k. jest zgodny z art. 7 Konstytucji.

5. W ocenie Sejmu art. 168a k.p.k. nie pozostaje w koniecznym merytorycznym związku z art. 40 Konstytucji w związku art. 3 EKPC i dlatego nie stanowią one adekwatnych wzorców kontroli. Sejm pragnie podkreślić, że art. 168a k.p.k. w żaden sposób nie reguluje materii objętej treścią art. 40 Konstytucji w związku z art. 3 EKPC, w szczególności nie podważa doniosłości norm prawnych zawartych w tych przepisach. Z art. 168a k.p.k. nie można - co zostało już uprzednio wykazane - wywieść normy prawnej, która dopuszczałaby w jakiejkolwiek formie stosowanie tortur, okrutnego, nieludzkiego lub poniżającego traktowania i karania. Z tego względu należy uznać, że art. 168a k.p.k. nie jest niezgodny $\mathrm{z}$ art. 40 Konstytucji w związku z art. 3 EKPC.

6. Co do art. 45 ust. 1 Konstytucji i art. 6 EKPC wniosek Rzecznika dotyczy zasady sprawiedliwości (rzetelności) proceduralnej. Istota sprawiedliwości (rzetelności) proceduralnej zawiera się w zapewnieniu stronom możliwości korzystania z praw i gwarancji procesowych oraz zagwarantowaniu rzetelnego i merytorycznego rozpatrzenia sprawy. Ze względu na zbieżny zakres treściowy konstytucyjnej i konwencyjnej zasady sprawiedliwości (rzetelności proceduralnej), nie zachodzi potrzeba odrębnego rozważania zarzutu niezgodności kwestionowanej regulacji z art. 6 EKPC. Sprawiedliwość proceduralna należy do istoty konstytucyjnego prawa do sądu, albowiem prawo do sądu bez zachowania standardu rzetelności postępowania byłoby prawem fasadowym (wyroki TK z: 21 lipca 2009 r., sygn. akt K 7/09; 14 stycznia 2014 r., sygn. akt SK 25/11). Trybunał Konstytucyjny wyjaśnił, że istota sprawiedliwości proceduralnej zawiera się w stworzeniu stronom możliwości korzystania z praw i gwarancji procesowych oraz zapewnieniu rzetelnego i merytorycznego rozpatrzenia sprawy, które determinują takie elementy, jak: prawo strony do bycia wysłuchanym, prawo do informowania, przewidywalność rozstrzygnięć, sprawne rozstrzygnięcie sprawy w rozsądnym terminie, umożliwienie wszechstronnego zbadania okoliczności sprawy przez sąd. Zasada sprawiedliwości proceduralnej ma przy tym charakter uniwersalny, gdyż dotyczy wszystkich etapów i rodzajów postępowań, ale powinna być stosowana $\mathrm{z}$ uwzględnieniem funkcji i charakteru prawnego danej procedury (zob. wyroki TK z: 31 stycznia 2005 r., sygn. akt SK 27/03; 14 czerwca 2006 r., sygn. akt 53/05; 30 maja 2007 r., sygn. akt SK 68/06; 26 lutego 2008 r., sygn. akt SK 89/06; 9 lutego 2010 r., sygn. akt SK 10/09; 12 lipca 2011 r., sygn. akt SK 49/08). Dlatego też: „[s]prawiedliwość proceduralna nie może być oceniana w kategoriach abstrakcyjnych, niezależnie od kategorii spraw, które są przedmiotem rozpoznania sądowego, konfiguracji podmiotowych, znaczenia poszczególnych kategorii praw dla ochrony interesów jednostki itd. Ustawodawca zachowuje w tym zakresie dość znaczne pole swobody, które umożliwia kształtowanie procedur sądowych z uwzględnieniem tych zróżnicowanych czynników i zarazem w sposób stanowiący próbę wyważenia interesów pozostających w pewnym 
konflikcie" (wyrok TK z 1 lipca 2008 r., sygn. akt SK 40/07). Zasada sprawiedliwości proceduralnej nie ma bowiem charakteru absolutnego, gdyż jej realizacja może być ograniczana przez inne wartości, jeśli ograniczenia te spełniają przesłanki określone w art. 31 ust. 3 Konstytucji i nie naruszają istoty prawa do sądu (zob. wyroki TK z: 28 lipca 2004 r., sygn. akt P 2/04; 14 czerwca 2006 r., sygn. akt K 53/05; 20 maja 2008 r., sygn. akt P 18/07; 12 lipca 2011 r., sygn. akt SK 49/08). Wymogi związane ze sprawiedliwością proceduralną wymagają dostosowania kryteriów oceny rzetelności badanej procedury do jej funkcji i charakteru prawnego (wyroki TK z: 14 marca 2006 r., sygn. akt SK 4/05; 3 lipca 2007 r., sygn. akt SK 1/06; 12 lipca 2011 r., sygn. akt SK 49/08).

Do obecnych w orzecznictwie TK elementów składowych zasady sprawiedliwości proceduralnej w doktrynie dodaje się: „konieczność zapewnienia równości broni (P. Grzegorczyk, K. Weitz, Komentarz do art. 45 [w:] Konstytucja RP. Komentarz, t. I, Art. 1-86, M. Safjan, L. Bosek, 2017, Legalis). Jak podnoszą ci autorzy, «[w] związku z prawem do wysłuchania pozostaje prawo do dowodu (Recht auf Beweis), które obejmuje zespół uprawnień stron i uczestników oraz reguł wiążących sąd w kontekście postępowania dowodowego. [...] Podstawowe znaczenie ma tu prawo do tego, aby przedmiotem dowodu uczynić każdą sporną okoliczność, relewantną dla rozstrzygnięcia sprawy. Ponadto w tym kontekście należy rozpatrywać problematykę obecności stron i uczestników postępowania, w szczególności oskarżonego, w czasie przeprowadzania dowodów, prawo do zadawania pytań świadkom i biegłym, problematykę dopuszczalności dowodów nielegalnych, uwzględniania przytoczeń stron $\mathrm{w}$ ramach oceny dowodów, jak również ich prawa do roztrząsania wyników postępowania dowodowego, ograniczeń co do powinności składania zeznań w charakterze świadka (prawo do odmowy zeznań) i prezentacji dowodu w sądzie» (ibidem)" (stanowisko Prokuratora Generalnego, s. 83).

W orzecznictwie ETPC dostrzega się potrzebę ochrony prawa innych poza oskarżonym uczestników procesu karnego, co: „może [...] czasem wymagać pewnej restryktywności w wykładni art. 6, w szczególności wówczas, gdy prawa oskarżonego $\mathrm{w}$ procesie karnym pozostają $\mathrm{w}$ konflikcie $\mathrm{z}$ gwarancjami ofiary przestępstwa (zob. wyr. ETPCz 26.3.1985 r. w sprawie X. i Y. p. Niderlandom, par. 63 i nast.)" (P. Hofmański, A. Wróbel Komentarz do art. 6, op. cit.). ETPC: „podkreślał wielokrotnie w swoim orzecznictwie, że zagadnienie oceny dowodów w konkretnych sprawach leży poza zakresem jego kognicji i należy bez reszty do kompetencji organów krajowych. [...] Także zagadnienie dopuszczalności poszczególnych dowodów pozostawione jest wyłącznie sądom krajowym, albowiem Konwencja nie zawiera katalogu dopuszczalnych środków dowodowych, czy metod dowodzenia. Co więcej, nawet uzyskanie (i wykorzystanie) dowodu uzyskanego $\mathrm{z}$ naruszeniem tych standardów nie prowadzi automatycznie do stwierdzenia, że wyrok skazujący narusza art. 6 ust. 1. Innymi słowy, orzecznictwo strasburskie nigdy nie było skłonne do prostego przejęcia amerykań- 
skiej doktryny "owoców zatrutego drzewa»" (ibidem). Stąd nieuprawniony jest pogląd Rzecznika, iż EKPC oraz powstałe na jej gruncie orzecznictwo ETPC przesądza o potrzebie przyjęcia w procesie karnym doktryny owoców zatrutego drzewa. Wręcz przeciwnie w orzecznictwie ETPC powstała „doktryna pozytywnych zobowiązań" (positive obligations) państw, które ratyfikowały ETPC, która wyraża nakaz ochrony praw pokrzywdzonych i świadków (stanowisko Prokuratora Generalnego, s. 85-87). W ocenie Sejmu trudno znaleźć bardziej drastyczny sposób pogwałcenia praw pokrzywdzonego, jak odmówienie ukarania sprawcy przestępstwa mimo istnienia dowodów świadczących o jego winie.

Powoduje to, że nie można podzielić oceny Rzecznika co do niezgodności art. 168a k.p.k. z art. 45 ust. 1 Konstytucji w związku z art. 6 EKPC. Po pierwsze: „oparcie wyroku na wadliwie uzyskanym materiale dowodowym nie może być uznane samo w sobie za naruszające uprawnienie oskarżonego do rzetelnego procesu, co potwierdza dominująca linia orzecznicza sądów powszechnych oraz Sądu Najwyższego, jednoznacznie odrzucająca doktrynę «owoców zatrutego drzewa» (por. m.in. wyroki: Sądu Apelacyjnego w Katowicach - z dn. 27 maja 2004, sygn. II AKa 160/04, LEX nr 149706; Sądu Najwyższego - z dn. 14 listopada 2006 r., sygn. V KK 52/06, LEX nr 202271; z dn. 22 lutego 2007 r., sygn. V KK 183/06, LEX nr 274709; z dn. 5 lutego 2008 r., sygn. SNO 2/08, LEX nr 432189; z dn. 3 grudnia 2008 r., sygn. V KK 195/08, LEX nr 482213 oraz z dn. 25 marca 2010 r., sygn. I KZP 2/10, LEX nr 564518; Sądu Apelacyjnego w Lublinie - z dn. 22 stycznia 2013 r., sygn. II AKa 301/12, LEX nr 1289474; Sądu Najwyższego - z dn. 30 października 2013 r., sygn. II KK 139/13, LEX nr 1391587, i z dn. 2 lutego 2016 r., sygn. IV KK 346/15, LEX nr 1976252). Wbrew bowiem stanowisku Wnioskodawcy, jak trafnie wskazał Sąd Najwyższy w wyroku z dnia 2 lutego 2016 r., sygn. IV KK 346/15, «nie budzi wątpliwości, że w polskiej procedurze karnej nie obowiązuje reguła zakazu wykorzystywania w procesie 'owoców zatrutego drzewa'» (LEX 2017)" (ibidem, s. 87-88).

Nie można zasadnie twierdzić, że art. 168a k.p.k. ogranicza którekolwiek z uprawnień stron składających się na zasadę sprawiedliwości (rzetelności) proceduralnej. Inaczej niż przyjmuje Rzecznik, art. 168a k.p.k. nie oznacza nakazu wydania wyroku na podstawie dowodów uzyskanych z uchybieniem wymogom formalnym. Przepis ten nakazuje jedynie poddać taki dowód ocenie sądu, która odbywa się z wykorzystaniem wszystkich reguł oceny dowodów. W tym zakresie art. 168a k.p.k. pozwala na realizację zasady prawdy materialnej, która także jest jednym z elementów zasady sprawiedliwości proceduralnej wynikającej z art. 45 ust. 1 Konstytucji (J. Grajewski, S. Steinborn, Zasada prawdy materialnej jako granica upraszczania procesu karnego [w:] Zasada prawdy materialnej. Materiały z konferencji. Krasiczyn, 15-16 października 2005 r., red. Z. Sobolewski, G. Artymiak, Kraków 2006, s. 209; S. Waltoś, Naczelne zasady procesu karnego, Warszawa 1999, s. 18; J. Skorupka, Zasada prawdy materialnej w projekcie noweli Kodeksu postępowania karnego opracowanym przez Komisje Kodyfikacyjna Pra- 
wa Karnego [w:] P. Kardas, T. Sroka, W. Wróbel, Państwo prawa i prawo karne. Ksiega Jubileuszowa Profesora Andrzeja Zolla, t. II, Warszawa 2012, s. 1745-1746; B. Nita, A. Światłowski, Kontradyktoryjny proces karny (między prawda materialna a szybkością postępowania), „Państwo i Prawo” 2012, z. 1, s. 33-49). Zasada prawdy materialnej ma dwa aspekty - pragmatyczny i optymalizacyjny. W Konstytucji przyjmuje postać: „kierowanej do prawodawcy dyrektywy odpowiedniego ukształtowania modelu procesowego, a w szczególności postępowania dowodowego, tak by stwarzał największe z możliwych prawdopodobieństwo zgodności twierdzeń organu procesowego o pozajęzykowej rzeczywistości z tą rzeczywistością. Na poziomie stosowania prawa kierowany do organu procesowego nakaz takiego przeprowadzenia określonych w procedurze czynności dowodowych, by ich rezultaty w postaci twierdzenia dotyczącego zdarzenia faktycznego w największym stopniu były zgodne z rzeczywistym jego przebiegiem, a więc z pozajęzykową rzeczywistością, w tym sensie nawiązuje do korespondencyjnej teorii prawdy, wskazując, że celem postępowania dowodowego jest maksymalna wierność (adekwatność, zgodność) twierdzenia o zdarzeniu faktycznym z rzeczywistym przebiegiem tego zdarzenia w pozajęzykowej rzeczywistości” (P. Kardas, Zasada prawdy materialnej w perspektywie korespondencyjnej, koherencyjnej, pragmatycznej i konsensualnej teorii prawdy (kilka uwag na tle propozycji nowego ujęcia przepisów dotyczących postępowania dowodowego przed sądem pierwszej instancji oraz postępowania dowodowego w toku postępowania przygotowawczego) [w:] Kontradyktoryjność w polskim procesie karnym, red. P. Wiliński, 2013, LEX). Potrzeba poszanowania w procesie karnym zasady prawdy materialnej wynika także ze skutków, jakie niesie poddanie jedynie formalizmowi procesowemu rozstrzygnięcie, które może oznaczać uwolnienie sprawcy przestępstwa od odpowiedzialności, skazanie osoby niewinnej, a wreszcie poprzez niezgodny ze stanem faktycznym wyrok także naruszenie prawa osoby pokrzywdzonej przestępstwem do ukarania sprawcy jej krzywd.

Artykuł 168a k.p.k. nie narusza także zasady równości broni w postępowaniu sądowym, bowiem jedynie reguluje zakres materiału dowodowego, jaki powinien podlegać ocenie sądu, pozostawiając stronom procesu sądowego równe prawa $\mathrm{w}$ zakresie kwestionowania owego materiału. Zasada równości broni $\mathrm{w}$ procesie karnym nie może być utożsamiana $\mathrm{z}$ uprawnieniem do eliminowania rzeczywistych dowodów popełnienia przestępstwa przez oskarżonego z wyjątkiem dowodów naruszających obowiązujące zakazy dowodowe. Podobnie wynikająca z art. 45 ust. 1 Konstytucji zasada przewidywalności postępowania zgodnie $z$ orzecznictwem TK oznacza zapewnienie stronom i innym uczestnikom postępowania przewidywalności przebiegu postępowania sądowego przez odpowiednią spójność i logikę mechanizmów, którym podmioty te są poddawane $\mathrm{w}$ toku rozpoznawania ich sprawy (wyroki TK z: 31 marca 2005 r., sygn. akt SK 26/02; 2 października 2006 r., sygn. akt SK 34/06; 30 maja 2007 r., sygn. akt SK 68/06), a nie z możnością przewidywania korzystnego dla siebie 
rozstrzygnięcia sądowego. Zasada przewidywalności wymaga więc, by istniały jasne, z góry określone i mające zastosowanie w poszczególnych postępowaniach, reguły ich prowadzenia od początku aż do ich zakończenia (wyroki TK Z: 14 listopada 2007 r., sygn. akt SK 16/05; 29 kwietnia 2008 r., sygn. akt SK 11/07; 30 października 2012 r., sygn. akt SK 8/12). Stąd też w ocenie Sejmu nie można zgodzić się z poglądem Rzecznika, że przepis art. 168a k.p.k. narusza zasadę przewidywalności postępowania. Przeciwnie, obecne brzmienie art. 168a k.p.k. stanowi doprecyzowanie reguł postępowania dowodowego w postępowaniu karnym. Przesądza, że faktyczną podstawę rozstrzygnięcia w procesie karnym stanowią wszelkie okoliczności ujawnione w toku postępowania, z wyjątkami wynikającymi z zawartych w treści przepisów procesowych zakazów dowodowych. W obowiązującym uprzednio stanie prawnym niektóre dowody mogły być uwzględnione lub wyłączone zależnie od składu orzekającego. Obecne brzmienie art. 168a k.p.k. powinno powodować ukształtowanie się jednolitej linii orzeczniczej, co zwiększa przewidywalność postępowania. Z przytoczonych wyżej powodów art. 168a k.p.k. jest zgodny z art. 45 ust. 1 Konstytucji w związku z art. 6 EKPC.

7. Rzecznik postawił także zarzut niezgodności art. 168a k.p.k. z art. 47 oraz z art. 51 ust. 2, 3 i 4 Konstytucji. Przy czym w zakresie art. 51 ust. 2 Konstytucji Rzecznik nie wykazał, na czym miałoby polegać naruszenie tego przepisu przez art. 168a k.p.k. Podobnie, mimo wskazania jako wzorca kontroli art. 51 ust. 3 Konstytucji, Rzecznik nie uzasadnił swojego stanowiska. W tym zakresie w uzasadnieniu wniosku nie umieszczono ani tej jednostki redakcyjnej wprost, ani żadnego zdania, które mogłoby się odnosić bezpośrednio do tego wzorca kontroli. W związku z czym Sejm wnosi o umorzenie postępowania w zakresie art. 51 ust. 2 i 3 Konstytucji na podstawie art. 59 ust. 1 pkt 2 u.o.t.p.TK ze względu na niedopuszczalność wydania orzeczenia. Odnośnie do art. 47 i art. 54 ust. 1 Konstytucji odwołać się można do uwag poczynionych w pkt 1. Należy też zwrócić uwagę, że wykładnia tego przepisu zawarta we wniosku Rzecznika mogłaby prowadzić do wniosku, że jakiekolwiek, nawet nieznaczące, naruszenie przepisu ustawy w toku pozyskiwania materiału dowodowego (który można uznać za informację w rozumieniu tego przepisu) powinno prowadzić do niezwłocznego usunięcia i wykluczenia na żądanie oskarżonego tak uzyskanego materiału dowodowego z podstawy orzekania. Przyjęcie jednak takiej wykładni godziłoby w inne, gwarantowane przez ustawę zasadniczą, prawa i wolności, a także w stanowiącą podstawę ustroju Rzeczypospolitej Polskiej zasadę sprawiedliwości. Wymaga zastanowienia to, czy działalność przestępcza w ogóle korzysta z ochrony prywatności przewidzianej w art. 47 i art. 51 Konstytucji. M. Wild wskazuje, że: „można stwierdzić, że sferą życia prywatnego objęte są takie okoliczności, w stosunku do których można przyjąć prymat interesu jednostki nad interesem publicznym, domniemanie przewagi prawa jednostki do bycia pozostawioną samej sobie nad interesem publicznym bądź interesem innych podmiotów. [...] Należy 
zatem ustalić sytuacje, w których jednostce nie przysługuje roszczenie o poszanowanie tak rozumianej prywatności, oraz objąć pozostałe przypadki ochroną wyprowadzaną z art. 47 Konstytucji RP” (M. Wild, Komentarz do art. 47 [w:] Konstytucja RP. Komentarz, t. I, Art. 1-86, red. M. Safjan, L. Bosek, 2017, Legalis, teza 55-58). Uznać można, że działalność przestępcza jako naruszająca wolności i prawa innych osób, do których poszanowania każdy jest zobowiązany zgodnie $\mathrm{z}$ art. 31 ust. 2 Konstytucji, pozostaje poza obszarem konstytucyjnego prawa do prywatności. Jednostka, popełniając przestępstwo, wykracza bowiem poza sferę objętą swoim prawem do prywatności. Czyn zabroniony trudno bowiem objąć pojęciem „życia intymnego”, „życia rodzinnego” czy „̇̇ycia prywatnego”. Stąd też działalność przestępcza nie może być uznana za uprawnioną do korzystania z gwarancji przewidzianych w art. 47 i art. 51 ust. 4 Konstytucji. Z powyższych względów należy stwierdzić, że art. 168a k.p.k. jest zgodny z art. 47 oraz z art. 51 ust. 4 Konstytucji.

8. W ocenie Sejmu art. 168a k.p.k. jest zgodny z art. 31 ust. 3 Konstytucji. Po pierwsze, jest przydatny, bowiem umożliwia realizację celu założonego przez ustawodawcę, tj. uczynienie podstawą orzeczenia sądu karnego wszystkich okoliczności sprawy, w tym materiału dowodowego uzyskanego z naruszeniem przepisów postępowania lub za pomocą czynu zabronionego z wyjątkami wynikającymi z art. 168a k.p.k. Po drugie, jego wprowadzenie było „konieczne”, tj. niezbędne dla ochrony bezpieczeństwa państwa i porządku publicznego oraz wolności i praw innych osób, a więc wartości wymienionych w art. 31 ust. 3 Konstytucji. Konieczność taka powstała w związku z pojawieniem się w doktrynie oraz judykaturze tendencji do wprowadzania do polskiego procesu karnego doktryny owoców zatrutego drzewa. W związku z tym ustawodawca postanowił nie ograniczać się jedynie do uchylenia poprzedniego brzmienia art. 168a k.p.k. wprowadzonego w 2013 r., ale ustawą nowelizującą nadał mu nowe brzmienie, przełamujące tendencje, które zaczęły się pojawiać już wcześniej. W ten sposób ustawodawcy udało się zagwarantować pociągnięcie do odpowiedzialności karnej sprawcy przestępstwa oraz uwolnienie od tej odpowiedzialności osoby niewinnej w każdej sytuacji, w której istotny materiał dowodowy mógłby podlegać wykluczeniu wyłącznie z uwagi na wadliwość w procedurze jego uzyskania. Wreszcie, art. 168a k.p.k. spełnia wymóg proporcjonalności sensu stricto, tj. cel jego wprowadzenia i jego efekty pozostają w proporcji do nałożonych przez nią na obywatela (tu: podejrzanego/oskarżonego) ograniczeń. Przewidziany w art. 168a k.p.k. zakaz stosowania doktryny owoców zatrutego drzewa nie ogranicza bowiem prawa oskarżonego do obrony, uniemożliwia mu jedynie powoływanie się na uchybienia formalne w celu wyłączenia spod oceny sądu dowodów świadczących przeciw niemu. Jednocześnie jednak gwarantuje mu, że materiał dowodowy przesądzający o jego niewinności nie zostanie wyeliminowany z zakresu oceny sądu jedynie na gruncie formalnych uchybień w jego zdobyciu. Za pomocą kwestionowanego przez Rzecznika rozwiązania ustawodawca osiąga konstytucyjnie 
legitymowany cel. Spełniony jest więc test proporcjonalności. Z tego względu art. 168a k.p.k. jest zgodny z art. 31 ust. 3 Konstytucji.

9. Podsumowując, celem procesu karnego jest: „ochrona interesów państwa i los człowieka, którego czyny stanowią przedmiot badania w sprawie karnej, są uzależnione od tego czy została ustalona prawda w tejże sprawie czy też nie dało się jej ustalić. Rozstrzygane są tu bowiem kwestie winy albo niewinności osoby pociągniętej do odpowiedzialności karnej. Dlatego też problem prawdy w procesie karnym jest nierozerwalnie związany z problemem gwarancji, zapewniających zarówno jej wykrycie, jak i chroniących osobę pociągniętą do odpowiedzialności przed bezpodstawnym oddaniem pod sąd i skazaniem (M.S. Strogowicz, Prawda obiektywna i dowody sadowe $w$ radzieckim procesie karnym, Warszawa 1959, s. 21)" (M. Warchoł, Ciężar dowodu w procesie karnym. Studium prawnoporównawcze, Warszawa 2017, s. 289). Artykuł 168a k.p.k. stanowi gwarancję ustalenia w sprawie karnej faktycznego (prawdziwego) przebiegu zdarzenia, co zapewnia gwarancję prawa zarówno pokrzywdzonego, jak też oskarżonego, w tym w szczególności osoby niewinnej. Uwzględniając podstawowe wartości konstytucyjne, ustawodawca nie może zrezygnować w procesie karnym z poszukiwania prawdy na rzecz formalizmu, którego jedynym z wyrazów jest doktryna owoców zatrutego drzewa.

Mając na uwadze przedstawione argumenty, należy uznać, że art. 168a k.p.k. jest zgodny $\mathrm{z}$ art. 45 ust. $1 \mathrm{w}$ związku $\mathrm{z}$ art. 51 ust. $4 \mathrm{w}$ związku $\mathrm{z}$ art. 31 ust. 3 Konstytucji w związku z art. 6 EKPC, a także z art. 2, art. 7 i art. 47 Konstytucji oraz nie jest niezgody $z$ art. 40 Konstytucji w związku $z$ art. 3 EKPC.

Ponadto wnoszę o umorzenie postępowania w pozostałym zakresie na podstawie art. 59 ust. 1 pkt 2 u.o.t.p.TK, ze względu na niedopuszczalność wydania orzeczenia.

\section{Bibliografia}

Banaszak B., Konstytucja Rzeczypospolitej Polskiej. Komentarz, Warszawa 2012, komentarz do art. 51.

Banaszak B., Konstytucja Rzeczypospolitej Polskiej. Komentarz, Warszawa 2009, komentarz do art. 40.

Conti C., L'imputato nel procedimento connesso. Diritto al silenzio e obbligo di verità, Cedam 2003.

Cordopatri F., L'abuso del processo. Diritto positivo, Padova 2000.

Garlicki L., Komentarz do art. 3 [w:] Konwencja o ochronie praw człowieka i podstawowych wolności, t. I, Komentarz do artykułów 1-18, red. L. Garlicki, Warszawa 2010.

Garlicki L., Komentarz do art. 31 [w:] Konstytucja Rzeczypospolitej Polskiej. Komentarz, t. III, red. L. Garlicki, Warszawa 2003.

Grabenwarter Ch., Europäische Menschenrechtskonvention, München-Basel-Wien 2008. 
Grajewski J., Steinborn S., Zasada prawdy materialnej jako granica upraszczania procesu karnego [w:] Zasada prawdy materialnej. Materiały z konferencji. Krasiczyn, 1516 października 2005 r., red. Z. Sobolewski, G. Artymiak, Kraków 2006.

Grzegorczyk P., Weitz K., Komentarz do art. 45 [w:] Konstytucja RP. Komentarz, t. I, Art. 1-86, red. M. Safjan, L. Bosek, 2017, Legalis.

Hofmański P., Wróbel A., Komentarz do art. 6 [w:] Konwencja o ochronie praw człowieka i podstawowych wolności, t. I, Komentarz do artykułów 1-18, red. L. Garlicki, Warszawa 2010.

Human Rights Practice, Londyn 2006, Article 6 Right to a Fair Trial, M. Purchase, E. Schutzer-Weismann.

Jamróz L. , Skarga konstytucyjna. Wstępne rozpoznanie, Białystok 2011.

Kardas P., Zasada prawdy materialnej w perspektywie korespondencyjnej, koherencyjnej, pragmatycznej $i$ konsensualnej teorii prawdy (kilka uwag na tle propozycji nowego ujecia przepisów dotyczących postępowania dowodowego przed sądem pierwszej instancji oraz postępowania dowodowego $w$ toku postępowania przygotowawczego) [w:] Kontradyktoryjność $w$ polskim procesie karnym, red. P. Wiliński, 2013, LEX.

Karlik P., Sroka T., Wiliński P., Komentarz do art. 42 [w:] Konstytucja RP. Komentarz, t. I, Art. 1-86, red. M. Safjan, L. Bosek, Warszawa 2016.

Kopff A. , Koncepcje prawa do intymności i do prywatności życia. Zagadnienia konstrukcyjne, „Studia Cywilistyczne” 1972, t. XX.

Królikowski M., Szczucki K., Komentarz do art. 40 [w:] Konstytucja RP. Komentarz, t. I, Art. 1-86, red. M. Safjan, L. Bosek, Warszawa 2016.

Lipowicz I., Komentarz do art. 51 [w:] Konstytucje Rzeczypospolitej oraz komentarz do Konstytucji RP z 1997 roku, red. J. Boć, Wrocław 1998.

Morawska E., Klauzula państwa prawnego w Konstytucji RP na tle orzecznictwa TrybunaŁu Konstytucyjnego, Toruń 2003.

Nita B., Światłowski A., Kontradyktoryjny proces karny (między prawda materialna a szybkościa postępowania), „Państwo i Prawo” 2012, z. 1.

Osborn D., Suppressing the Truth: Judicial Exclusion of Illegally Obtained Evidence in the United States, Canada, England and Australia, Murdoch University Electronic Journal of Law, http://www.austlii.edu.au/au/joumals/MurUEJL/2000/44.html.

Sarnecki P., Komentarz do art. 40 [w:] Konstytucja Rzeczypospolitej Polskiej. Komentarz, t. III, red. L. Garlicki, Warszawa 2003.

Sarnecki P., Komentarz do art. 42 [w:] Konstytucja Rzeczypospolitej Polskiej. Komentarz, t. III, red. L. Garlicki, Warszawa 2003.

Sarnecki P., Komentarz do art. 47 [w:] Konstytucja Rzeczypospolitej Polskiej. Komentarz, t. III, red. L. Garlicki, Warszawa 2003.

Skorupka J., Udostępnienie akt sprawy podejrzanemu, „Prokuratura i Prawo” 2007, nr 5. Skorupka J., Zasada prawdy materialnej w projekcie noweli Kodeksu postępowania karnego opracowanym przez Komisje Kodyfikacyjna Prawa Karnego [w:] P. Kardas, Sroka T., Wróbel W., Państwo prawa i prawo karne. Księa Jubileuszowa Profesora Andrzeja Zolla, t. II, Warszawa 2012. 
Sobczak J., Komentarz do art. 4 [w:] Karta praw podstawowych Unii Europejskiej. Komentarz, red. A. Wróbel, Warszawa 2013.

Sokolewicz W., Prawo do prywatności [w:] Prawa człowieka w Stanach Zjednoczonych, Warszawa 1985.

Sokolewicz W., Komentarz do art. 7 [w:] Konstytucja Rzeczypospolitej Polskiej. Komentarz, t. V, red. L. Garlicki, Warszawa 2007.

Sroka T., Komentarz do art. 42 [w:] Konstytucja RP. Komentarz, t. I, Art. 1-86, red. M. Safjan, L. Bosek, Warszawa 2016.

Strogowicz M.S., Prawda obiektywna i dowody sadowe $w$ radzieckim procesie karnym, Warszawa 1959.

Tuleja P., Komentarz do art. 2 [w:] Konstytucja RP. Komentarz, t. I, Art. 1-86, red. M. Safjan, L. Bosek, Warszawa 2016.

W. Sokolewicz, M. Zubik, Komentarz do art. 2 [w:] Konstytucja Rzeczypospolitej Polskiej. Komentarz, t. I, red. L. Garlicki, M. Zubik, Warszawa 2016.

Waltoś S., Naczelne zasady procesu karnego, Warszawa 1999.

Warchoł M., Ciężar dowodu w procesie karnym. Studium prawnoporównawcze, Warszawa 2017.

Warchoł M., Pojęcie „nadużycia prawa” w prawie procesowym, „Prokuratura i Prawo” 2007, nr 11.

Weber U., Der Mißbrauchprozessualer Rechte im Strafverfahren, GA 1975.

Wild M., Komentarz do art. 47 [w:] Konstytucja RP. Komentarz, t. I, Art. 1-86, red. M. Safjan, L. Bosek, 2017, Legalis.

Winczorek P. , Komentarz do Konstytucji Rzeczypospolitej Polskiej z dnia 2 kwietnia 1997 roku, Warszawa 2008.

Wojtyczek K., Ciężar dowodu i argumentacji w procedurze kontroli norm przez Trybunat Konstytucyjny, „Przegląd Sejmowy” 2004, nr 1.

Wojtyczek K., Granice ingerencji ustawodawczej w sferę praw człowieka w Konstytucji RP, Kraków 1999.

Zakolska J., Zasada proporcjonalności w orzecznictwie Trybunału Konstytucyjnego, Warszawa 2008. 


\title{
Zgodność z Konstytucją niektórych przepisów ustawy o planowaniu rodziny, ochronie płodu ludzkiego i warunkach dopuszczalności przerywania ciąży'
}

\begin{abstract}
Compliance with the Constitution of some provisions of the Act on Family Planning, Protection of the Human Fetus and Conditions of Acceptability of Termination of Pregnancy: In the draft position of the Sejm it was stated that some provisions of the Act, questioned by a group of Deputies before the Constitutional Tribunal, are inconsistent with the Constitution of the Republic of Poland. The challenged provisions state that removal of pregnancy may occur when prenatal tests or other medical premises indicate a high probability of severe and irreversible impairment of the fetus or an incurable disease threatening his life. The complainant's provision, according to the applicants, allows selection and deprivation of life due to the alleged defects of people, and thus leads to the negation of the value of human life and denies human dignity. The justification of the Sejm's position stated that the principle of equal protection of all human beings, regardless of their degree of physical or intellectual fitness, is a fundamental standard of the contemporary legal system.
\end{abstract}

Keywords: Constitutional Tribunal | protection of life

Słowa kluczowe: Trybunał Konstytucyjny | ochrona życia

Doktor nauk prawnych, ekspert ds. legislacji BAS; jolanta.bucinska@sejm.gov.pl.

Na podstawie art. 69 ust. 2 w związku z art. 42 pkt 3 ustawy z dnia 30 listopada 2016 r. o organizacji i trybie postępowania przed Trybunałem Konstytucyjnym (Dz. U. poz. 2072), w imieniu Sejmu Rzeczypospolitej Polskiej przedkładam stanowisko w sprawie wniosku grupy posłów z 22 czerwca 2017 r., sygn. akt K 13/17, jednocześnie wnosząc o stwierdzenie, że art. 4a ust. 1 pkt 2 oraz art. $4 a$ ust. 2 zdanie pierwsze ustawy z dnia 7 stycznia $1993 \mathrm{r}$. o planowaniu rodziny, ochronie płodu ludzkiego i warunkach dopuszczalności przerywania ciąży (Dz. U. Nr 17,

Sprawa dot. zgodności z Konstytucją RP projektu ustawy o świadomej prokreacji sporządzona 23 lutego 2018 r.; BAS-WAKU 2322/17. 
poz. 78 ze zm.) jest niezgodny $\mathrm{z}$ art. $30 \mathrm{w}$ związku $\mathrm{z}$ art. 38 Konstytucji oraz $\mathrm{z}$ art. $38 \mathrm{w}$ związku z art. 31 ust. 3 Konstytucji.

Na podstawie art. 59 ust. 1 pkt 2 ustawy z dnia 30 listopada 2016 r. o organizacji i trybie postępowania przed Trybunałem Konstytucyjnym postępowanie należy umorzyć w pozostałym zakresie ze względu na niedopuszczalność wydania wyroku.

\section{Uzasadnienie}

\section{Przedmiot kontroli}

1. Postępowanie przed Trybunałem Konstytucyjnym zostało wszczęte wnioskiem z 22 czerwca 2017 r., w którym grupa posłów reprezentowanych przez posła Bartłomieja Wróblewskiego (dalej: wnioskodawcy) zakwestionowała konstytucyjność art. 4a ust. 1 pkt 2 oraz art. 4a ust. 2 zdanie pierwsze ustawy z dnia 7 stycznia 1993 r. o planowaniu rodziny, ochronie płodu ludzkiego i warunkach dopuszczalności przerywania ciąży (Dz. U. Nr 17, poz. 78, ze zm.; dalej: ustawa o planowaniu rodziny, u.p.r.), określające eugeniczne przesłanki dopuszczalności przerywania ciąży.

2. Przedmiotem kontroli jest art. 4 a ust. 1 pkt 2 oraz art. $4 a$ ust. 2 zdanie pierwsze ustawy o planowaniu rodziny.

Zgodnie $z$ art. 4 a ust. 1 pkt 2 u.p.r.: „Przerwanie ciąży może być dokonane wyłącznie przez lekarza, w przypadku gdy badania prenatalne lub inne przesłanki medyczne wskazują na duże prawdopodobieństwo ciężkiego i nieodwracalnego upośledzenia płodu albo nieuleczalnej choroby zagrażającej jego życiu”. Natomiast zgodnie z 4a ust. 2 zdanie pierwsze u.p.r.: „W przypadkach określonych w ust. 1 pkt 2 przerwanie ciąży jest dopuszczalne do chwili osiągnięcia przez płód zdolności do samodzielnego życia poza organizmem kobiety ciężarnej [...]”.

Zaskarżone przepisy określają tzw. przesłankę eugeniczną, czyli stan, w którym badania prenatalne lub inne przesłanki medyczne wskazują na duże prawdopodobieństwo ciężkiego i nieodwracalnego upośledzenia płodu albo nieuleczalnej choroby zagrażającej jego życiu. Przesłanka ta została wprowadzona przez art. 1 pkt 5 ustawy z 30 sierpnia 1996 r. o zmianie ustawy o planowaniu rodziny, ochronie płodu ludzkiego i warunkach dopuszczalności przerywania ciąży oraz zmianie niektórych innych ustaw (Dz. U. Nr 139, poz. 646). Stanowi jedno ze znamion negatywnych współtworzących typ czynu zabronionego przerwania ciąży za zgodą kobiety, określony w art. 152 Kodeksu karnego (ustawa z 6 czerwca 1997 r. - Kodeks karny, tj. Dz. U. 2017, poz. 2204, ze zm.; dalej także: k.k.), który chroni życie człowieka w prenatalnej fazie rozwoju. Zgodnie z jego brzmieniem: „\$1. Kto za zgodą kobiety przerywa jej ciążę z naruszeniem przepisów ustawy, podlega karze pozbawienia wolności do lat 3 . $\$ 2$. Tej samej karze podlega, kto udziela kobiecie ciężarnej pomocy w przerwaniu ciąży z naru- 
szeniem przepisów ustawy lub ją do tego nakłania. \$3. Kto dopuszcza się czynu określonego w $\$ 1$ lub 2, gdy dziecko poczęte osiągnęło zdolność do samodzielnego życia poza organizmem kobiety ciężarnej, podlega karze pozbawienia wolności od 6 miesięcy do lat 8”.

\section{Zarzuty wnioskodawców}

Wnioskodawcy wnoszą o stwierdzenie niezgodności art. 4a ust. 1 pkt 2 oraz art. 4a ust. 2 zdanie pierwsze ustawy o planowaniu rodziny $z$ art. 30 Konstytucji ze względu na to, że w ich ocenie przepisy te legalizują praktyki eugeniczne w stosunku do dziecka jeszcze nienarodzonego, odmawiając mu tym samym poszanowania i ochrony godności człowieka. Skarżony przepis, zdaniem wnioskodawców, dopuszcza selekcję i pozbawianie życia ze względu na domniemane defekty ludzi, a tym samym prowadzi do negacji wartości życia ludzkiego i zaprzecza godności człowieka (wniosek, s. 16). Praktyki eugeniczne mające na celu przeprowadzanie genetycznej selekcji przed urodzeniem są sprzeczne z godnością człowieka, zasadą niedyskryminacji z powodu dziedzictwa genetycznego, prawem do życia oraz stanowią zagrożenie dla innych praw jednostki (wniosek, s. 15). Legalizacja zabiegu przerywania ciąży wyłącznie z uwagi na duże prawdopodobieństwo ciężkiego i nieodwracalnego upośledzenia płodu albo nieuleczalnej choroby zagrażającej jego życiu nie znajduje dostatecznego usprawiedliwienia w sposobie rozstrzygnięcia konfliktu między obowiązkiem ochrony życia dziecka poczętego a realizacją wolności kobiety i ochroną jej komfortu psychicznego (wniosek, s. 17). W ocenie wnioskodawców kwestionowany przepis służy wspieraniu postaw eugenicznych, a nie ochronie kobiety ciężarnej, ze względu na aksjologiczną nieracjonalność w ustaleniu terminu dopuszczalności przerwania ciąży. Terminacja w przypadku wystąpienia prawdopodobieństwa upośledzenia bądź choroby dziecka poczętego jest bowiem dopuszczalna aż do chwili osiągnięcia przez nie zdolności do samodzielnego życia poza organizmem kobiety ciężarnej, natomiast w sytuacji poczęcia dziecka w wyniku czynu zabronionego - jedynie do 12 tygodnia ciąży. Ochrona przed negatywnymi stanami emocjonalnymi, jakich doświadczałaby matka w pierwszej sytuacji, uznana została zatem za wartość wyższą niż ochrona przed negatywnymi stanami emocjonalnymi doświadczanymi przez matkę w drugiej sytuacji (wniosek, s. 17). Jak wynika z uzasadnienia wnioskodawców, skarżony przepis art. 4a ust. 1 pkt 2 u.p.r. dopuszcza stosowanie niedozwolonego różnicowania wartości życia ludzkiego, bezwzględnie i zupełnie uchyla ochronę prawną płodu. W powiązaniu $\mathrm{z}$ innymi przepisami ustawy o planowaniu rodziny tworzy system nacisku na przerwanie podejrzanej o defekt ciąży (choćby realizowanego groźbą rażąco wygórowanej odpowiedzialności deliktowej) oraz wspierania i finansowania ze środków publicznych czynności nakierowanych na unicestwienie płodu (wniosek, s. 17).

W przypadku nieuwzględnienia wyżej przedstawionego zarzutu, wnioskodawcy formułują zarzut niezgodności zaskarżonych przepisów z art. 38 w związ- 
ku z art. 30 i art. 31 ust. 3 oraz z art. 38 w związku z 32 ust. 1 i 2 Konstytucji przez to, że legalizują one praktyki eugeniczne w zakresie prawa do życia dziecka jeszcze nieurodzonego oraz uzależniają ochronę prawa do życia dziecka jeszcze nieurodzonego od jego stanu zdrowia, co stanowi zakazaną bezpośrednią dyskryminację. Jak podnoszą wnioskodawcy, przepis art. 4a ust. 2 u.p.r. dokonuje zasadniczego zróżnicowania płodów ludzkich pod względem ich ochrony. W przypadkach występowania dużego prawdopodobieństwa ciężkiego i nieodwracalnego upośledzenia płodu albo nieuleczalnej choroby zagrażającej jego życiu następuje całkowite uchylenie ochrony życia płodu ludzkiego w stosunku do płodów pozbawionych cech embriopatologicznych, co stanowi wspieraną finansowo przez państwo legalizację zamachów umyślnych na życie dziecka (wniosek, s. 24). Ponadto, wskazane w przepisach ustawy o planowaniu rodziny przesłanki dopuszczalności przerwania ciąży istotnie różnicują zakres ochrony życia ludzkiego przed urodzeniem w aspekcie temporalnym. W zależności od tego, czy człowiek w fazie prenatalnej postrzegany jest jako zdrowy, czy też dotknięty upośledzeniem albo chorobą, wskazana została inna długość okresu, w którym możliwe jest dokonanie przerwania ciąży. Skarżony przepis dokonuje legalizacji selektywnego i umyślnego pozbawiania życia człowieka bez dostatecznego usprawiedliwienia koniecznością ochrony innej wartości konstytucyjnej. Nie można uzasadniać aborcji eugenicznej ani względami poprawy jakości przekazywanej informacji genetycznej, ani też powodami społecznymi lub osobistymi, leżącymi po stronie rodziców dziecka (wniosek, s. 25).

Skarżone przepisy zdaniem wnioskodawców naruszają nadto art. 38 w związku z art. 31 ust. 3 i w związku z art. 2 i art. 42 Konstytucji przez to, że legalizują przerwanie ciąży bez dostatecznego usprawiedliwienia koniecznością ochrony innej wartości, prawa lub wolności konstytucyjnej oraz posługują się nieokreślonymi kryteriami tej legalizacji, naruszając w ten sposób gwarancje konstytucyjne dla życia ludzkiego. W ocenie wnioskodawców analiza uzasadnień aborcji eugenicznej nie pozwala na ich przyporządkowanie do żadnej z wartości, zasad i praw konstytucyjnych w stopniu uniemożliwiającym przyjęcie, że plasują się one wyżej w konstytucyjnej hierarchii dóbr niż wartość życia ludzkiego (wniosek, s. 27). Ponadto, zdaniem wnioskodawców, art. 4a ust. 1 pkt 2 u.p.r. nie określa adekwatnie i precyzyjnie znamion przestępstwa przerwania ciąży ustanowionego w art. 152 Kodeksu karnego. Termin „duże prawdopodobieństwo ciężkiego i nieodwracalnego upośledzenia płodu albo nieuleczalnej choroby zagrażającej jego życiu” nie jest wystarczająco precyzyjnie określony w ustawie. Tak określone materialne znamiona przestępstwa są, w ocenie wnioskodawców, w wysokim stopniu niejasne, ponieważ umożliwiają przerwanie ciąży także w sytuacji braku spełnienia przesłanek, wyłącznie na podstawie błędnej diagnozy (prawdopodobieństwa), a przede wszystkim tworzą szerokie pole do subiektywnej interpretacji, czy stopień prawdopodobieństwa jest „duży” a upośledzenie może być „znaczne” i „nieodwracalne”. „Zaskarżone przepisy z uwagi na ich subiektywne 
uzasadnienie i obiektywną nieokreśloność zagrażają nie tylko dziecku, ale także lekarzowi narażając go na nieuzasadnione ryzyko odpowiedzialności karnej, dyscyplinarnej, cywilnej i pracowniczej" (wniosek, s. 29).

\section{Analiza formalnoprawna}

1. Na wstępie przeprowadzania analizy formalnoprawnej należy zauważyć, że ustawa o planowaniu rodziny była już przedmiotem oceny ze strony Trybunału Konstytucyjnego. W orzeczeniu z 28 maja 1997 r., sygn. akt K 26/96, Trybunał formalnie orzekał w sprawie zgodności ustawy z 30 sierpnia $1996 \mathrm{r}$. o zmianie ustawy o planowaniu rodziny, ochronie płodu ludzkiego i warunkach dopuszczalności przerywania ciąży oraz zmianie niektórych innych ustaw (Dz. U. Nr 139, poz. 646, dalej: ustawa o zmianie ustawy o planowaniu rodziny) z przepisami konstytucyjnymi pozostawionymi w mocy na podstawie art. 77 ustawy konstytucyjnej z dnia 17 października 1992 r. o wzajemnych stosunkach między władzą ustawodawczą i wykonawczą Rzeczypospolitej Polskiej oraz o samorządzie terytorialnym (Dz. U. Nr 84, poz. 426; ze zm.). Przedmiotem kontroli były przepisy art. 1 pkt 2, pkt 4 lit. b i c, pkt 5 ustawy o zmianie ustawy o planowaniu rodziny w zakresie dotyczącym art. 4 a ust. 1 pkt 4 , art. 2 pkt 1 i 2 oraz art. 3 pkt 1, 2 i 4 ustawy o planowaniu rodziny. Zaznaczyć należy, iż Trybunał nie oceniał wszystkich ustawowych przesłanek dopuszczalności przerwania ciąży. Stosownie do przedstawionego mu wniosku orzekał w sprawie przesłanki dopuszczalności przerwania ciąży ze względu na ciężkie warunki życiowe oraz trudną sytuację osobistą kobiety ciężarnej (art. 4a ust. 1 pkt 4 ustawy o zmianie ustawy o planowaniu rodziny). Skarżony przepis Trybunał uznał za niezgodny z przepisami konstytucyjnymi, gdyż w podjętym przez ustawodawcę rozstrzygnięciu kolizji wartości konstytucyjnych naruszona została zasada proporcjonalności oraz niespełniony wymóg adekwatnego określenia kryteriów dopuszczalności naruszenia wartości konstytucyjnej. Trybunał wypowiedział się za istnieniem $\mathrm{w}$ tych okolicznościach ochrony prawnej nienarodzonego dziecka, mimo że obowiązujące w czasie orzekania przepisy konstytucyjne nie zawierały przepisu odnoszącego się bezpośrednio do ochrony życia człowieka. W uzasadnieniu orzeczenia powołał się na zasadę państwa prawa, wywodząc, że życie ludzkie, również w fazie prenatalnej, ma charakter wartości konstytucyjnej podlegającej ochronie. W konsekwencji zapadłego orzeczenia art. 4a ust. 1 pkt 4 został uchylony. Związany granicami wniosku inicjatorów postępowania Trybunał Konstytucyjny nie wypowiadał się natomiast w kwestii pozostałych przesłanek. Brak jest zatem podstaw do stawiania tezy o „potwierdzeniu” czy "uznaniu” zgodności z przepisami konstytucyjnymi tych przepisów ustawowych, które dopuszczają przerwanie ciąży ze wskazań medycznych, eugenicznych czy kryminalnoprawnych. Przepisy te nie były bowiem przedmiotem zaskarżenia. W związku z powyższym należy stwierdzić, że ocena konstytucyjności przesłanki eugenicznej jest dopuszczalna. 
2. Zgodnie z petitum wniosku przedmiot zaskarżenia został ujęty w następujące grupy ze względu na rodzaj stawianych zarzutów:

- art. 4a ust. 1 pkt 2 oraz art. 4a ust. 2 zdanie pierwsze u.p.r. jest niezgodny $\mathrm{z}$ art. 30 Konstytucji przez to, że w ich ocenie przepisy te legalizują praktyki eugeniczne w stosunku do dziecka jeszcze nienarodzonego, odmawiając mu tym samym poszanowania i ochrony godności człowieka,

- art. 4 a ust. 1 pkt 2 oraz art. 4a ust. 2 zdanie pierwsze u.p.r. jest niezgodny $\mathrm{z}$ art. $38 \mathrm{w}$ związku z art. 30, z art. 31 ust. 3 oraz z art. 32 ust. 1 i 2 Konstytucji przez to, że legalizują one praktyki eugeniczne w zakresie prawa do życia dziecka jeszcze nieurodzonego oraz uzależniają ochronę prawa do życia dziecka jeszcze nieurodzonego od jego stanu zdrowia, co stanowi zakazaną bezpośrednią dyskryminację,

- art. $4 a$ ust. 1 pkt 2 oraz art. 4a ust. 2 zdanie pierwsze u.p.r. jest niezgodny $\mathrm{z}$ art. $38 \mathrm{w}$ związku $\mathrm{z}$ art. 31 ust. 3 oraz w związku z art. 2 i art. 42 Konstytucji przez to, że legalizują przerwanie ciąży bez dostatecznego usprawiedliwienia koniecznością ochrony innej wartości, prawa lub wolności konstytucyjnej oraz posługują się nieokreślonymi kryteriami tej legalizacji, naruszając w ten sposób gwarancje konstytucyjne dla życia ludzkiego.

3. W odniesieniu do drugiego ze stawianych w piśmie procesowym zarzutu należy zwrócić uwagę, że został sformułowany alternatywnie. Zgodnie z intencją wnioskodawców powinien być rozpatrzony w razie nieuwzględnienia zarzutu niezgodności z art. 30 Konstytucji (wniosek, s. 1).

Ponadto, w przypadku drugiego zarzutu, wzorcem kontroli wnioskodawcy uczynili art. 30 Konstytucji jako przepis związkowy względem art. 38 Konstytucji. W uzasadnieniu brak jest jednak argumentacji na poparcie stawianego zarzutu. Wnioskodawcy koncentrują się jedynie na umotywowaniu zarzutów w zakresie art. 38 Konstytucji. W związku z tym, że zarzut ma charakter alternatywny, nie będą mogły zostać uwzględnione dowody na poparcie niezgodności kwestionowanych przepisów $\mathrm{z}$ art. 30 Konstytucji, które przedstawiono w odniesieniu do pierwszego zarzutu.

Podobnie w uzasadnieniu trzeciej grupy zarzutów wnioskodawcy wskazali w konkluzji na naruszenie art. 38 w związku z art. 30 Konstytucji. Natomiast przytoczony wzorzec kontroli nie występuje w petitum wniosku i nie przedstawiono w stosunku do niego odpowiedniej argumentacjj na poparcie zarzutów. Z uwagi na brak stosownego uzasadnienia wyłączona zostaje możliwość zastosowania w tym wypadku zasady falsa demonstratio non nocet.

Należy zauważyć, że w petitum pisma procesowego wnioskodawcy stawiają zarzut niezgodności z art. 42 Konstytucji. Natomiast przedstawione w uzasadnieniu argumenty pozwalają przyjąć, że wnioskodawcy uznają art. 4a ust. 1 pkt 2 oraz art. 4 a ust. 2 zdanie pierwsze u.p.r. za niezgodne jedynie $z$ art. 42 ust. 1 Konstytucji, wyrażającym zasadę nullum crimen sine lege, nulla poena sine lege. 
W ten sposób określony wzorzec kontroli będzie przedmiotem dalszej analizy przeprowadzonej w stanowisku Sejmu. W związku z poczynionymi ustaleniami, należy przyjąć, że wnioskodawcy wskazują na naruszenie wymogu dostatecznej określoności przepisów represyjnych (art. 38 w związku z art. 2 i w związku $\mathrm{z}$ art. 42 ust. 1 Konstytucji). Stawiany zarzut odnoszą do użytych w art. 4a ust. 1 pkt 2 u.p.r. terminów: „duże” w odniesieniu do prawdopodobieństwa, „prawdopodobieństwo”, jako brak pewności, oraz „ciężkie” i „nieodwracalne” upośledzenie, co czyni, w ich ocenie, opisane w nim znamiona przestępstwa $\mathrm{z}$ art. $152 \mathrm{k} . \mathrm{k}$. w wysokim stopniu niejasne, dające szerokie pole do subiektywnej interpretacji. Natomiast nie przedstawiają przykładów orzecznictwa, z którego wynikałby problem w interpretacji wskazanych przesłanek. Analiza dorobku orzeczniczego wskazuje, że wykładnia przepisów kwestionowanych przez wnioskodawców nie budzi zasadniczych wątpliwości sądów (zob. wyroki SN z: 12 czerwca 2008 r., sygn. akt III CSK 16/08; 6 maja 2010 r., sygn. akt II CSK 580/09; wyrok Sądu Apelacyjnego w Białymstoku z 4 lipca 2008 r., sygn. akt I ACa 278/08). W konsekwencji powyższych ustaleń należy uznać stawiany zarzut za nienależycie uzasadniony.

Sąd konstytucyjny związany jest z zarzutami sformułowanymi w piśmie procesowym, pochodzącym od podmiotu uprawnionego do inicjowania postępowania. Niemniej zarzuty te podlegają rozpatrzeniu tylko wtedy, gdy zostały należycie uzasadnione. Zgodnie z art. 47 ust. 2 pkt 4 ustawy z dnia 30 listopada 2016 r. o organizacji i trybie postępowania przed Trybunałem Konstytucyjnym (Dz. U. poz. 2072; dalej: ustawa o TK) wniosek powinien zawierać uzasadnienie postawionego zarzutu, ze wskazaniem argumentów lub dowodów na jego poparcie. Jak konsekwentnie podkreśla w swym orzecznictwie Trybunał Konstytucyjny, prawidłowe pismo inicjujące postępowanie przed Trybunałem powinno zawierać szczegółową i precyzyjną jurydyczną argumentację uprawdopodabniającą stawiane zarzuty (zob. np. postanowienia TK z: 17 listopada 2011 r., sygn. akt Ts 40/11; 2 lutego 2012 r., sygn. akt Ts 93/11). „Wobec respektowania generalnej zasady, jaką jest domniemanie konstytucyjności aktu normatywnego, samo wskazanie w petitum wzorca kontroli, bez szczegółowego odniesienia się w uzasadnieniu do kwestionowanej regulacji prawnej lub lakoniczne sformułowanie zarzutu niekonstytucyjności nie może zostać uznane za «uzasadnienie postawionego zarzutu, z powołaniem dowodów na jego poparcie» w rozumieniu przepisów regulujących postępowanie przed Trybunałem Konstytucyjnym. W świetle utrwalonej praktyki orzeczniczej wymóg ten należy rozumieć jako nakaz odpowiedniego udowodnienia zarzutów stawianych w kontekście każdego wskazanego wzorca kontroli” (postanowienie TK z 21 stycznia 2015 r., sygn. akt K 13/13).

Brak realizacji przez wnioskodawcę powyższego obowiązku skutkuje koniecznością umorzenia postępowania ze względu na niedopuszczalność wydania wyroku na podstawie art. 59 ust. 1 pkt 2 ustawy o TK w odniesieniu do zarzutów, które nie zostały dostatecznie uzasadnione. 
4. W orzecznictwie Trybunału Konstytucyjnego art. 30 ustawy zasadniczej wielokrotnie był przywoływany jako samodzielny wzorzec kontroli (zob. przykładowo wyroki TK z: 4 kwietnia 2001 r., sygn. akt K 11/00; 15 października 2002 r., sygn. akt SK 6/02; 5 marca 2003 r., sygn. akt SK 56/04; 7 lutego 2006 r., sygn. akt SK 45/04). Stwierdzenie niezgodności z art. 30 Konstytucji następuje jednak w sytuacjach ewidentnego wkroczenia przez ustawodawcę w sferę najbardziej podstawowych atrybutów osobowych człowieka (zob. wyroki TK z: 8 listopada 2001 r., sygn. akt P 6/01; 30 września 2008 r., sygn. akt K 44/07). Jak stwierdził Trybunał w wyroku z 15 października 2002 r., sygn. akt SK 6/02, co do samej zasady, godność ludzka może być traktowana jako samoistny wzorzec konstytucyjny. „Na tle art. 30 Konstytucji sytuacja, w której człowiek stawałby się wyłącznie przedmiotem działań podejmowanych przez władzę, byłby «zastępowalną wielkością», a jego rola sprowadzałaby się do czysto instrumentalnej postaci, lub zarzut «ustawowego odpodmiotowienia-urzeczowienia» - mogą być uznane co do zasady za naruszenie godności”. Wnioskodawcy w odniesieniu do pierwszego zarzutu wskazali art. 30 Konstytucji w charakterze samodzielnego wzorca kontroli. Jednak z uzasadnienia wniosku wynika, że zarzut naruszenia ochrony godności człowieka jest wiązany z naruszeniem prawa do ochrony życia, dlatego w przeprowadzonej analizie zgodności uwzględniony został zmodyfikowany wzorzec kontroli w postaci art. $30 \mathrm{w}$ związku z art. 38 Konstytucji.

\section{Wzorce kontroli}

1. Wnioskodawcy w charakterze wzorca kontroli wskazują zasadę poszanowania godności człowieka wyrażonej w art. 30 Konstytucji. Zgodnie z jego treścią: „Przyrodzona i niezbywalna godność człowieka stanowi źródło wolności i praw człowieka i obywatela. Jest ona nienaruszalna, a jej poszanowanie i ochrona jest obowiązkiem władz publicznych".

Godność człowieka należy do pojęć aksjologicznych, a tym samym definiowana jest różnie, w zależności od ogólnego systemu religijnego bądź filozoficznego, w ramach którego występuje. Pluralizm tych systemów powoduje wielorakość ujmowania pojęcia godności (zob. L. Garlicki, Komentarz do art. 30 [w:] Konstytucja Rzeczypospolitej Polskiej. Komentarz, t. II, red. L. Garlicki, M. Zubik, Warszawa 2016, s. 32). Nie zostało ono zdefiniowane zarówno w samej Konstytucji, jak i w orzecznictwie sądowym oraz nauce prawa. Godność traktowana jest w ustawie zasadniczej jako dobro przyrodzone i niezbywalne, stanowiące źródło wolności i praw człowieka i obywatela. Uznanie godności za dobro przyrodzone oznacza akceptację dla jej prawnonaturalnego charakteru i nadrzędności w stosunku do woli ustawodawcy (zob. wyroki TK z: 15 listopada 2000 r., sygn. akt P 12/99; 15 października 2002 r., sygn. akt SK 6/02) oraz przynależności każdej osobie ludzkiej niezależnie od etapu rozwoju jej życia (zob. orzeczenie TK z 28 maja 1997 r., sygn. akt K 26/96). Trybunał Konstytucyjny wskazywał, że: „Konstytucja w całokształcie swych postanowień daje wyraz pewnemu obiektywnemu syste- 
mowi wartości, którego urzeczywistnianiu służyć powinien proces interpretacji i stosowania poszczególnych przepisów konstytucyjnych. Dla określenia tego systemu wartości centralną rolę odgrywają postanowienia o prawach i wolnościach jednostki, usytuowane przede wszystkim w rozdziale II Konstytucji. Wśród tych postanowień centralne $\mathrm{z}$ kolei miejsce zajmuje zasada przyrodzonej i niezbywalnej godności człowieka" (wyrok TK z 23 marca 1999 r., sygn. akt K 2/98). Zasada godności orientuje całą Konstytucję na osobę człowieka i stanowi podstawę całego porządku konstytucyjnego, jest źródłem, fundamentem i zasadą tego porządku (zob. wyrok TK z 23 lutego 2010 r., sygn. akt P 20/09).

Nadanie przez ustrojodawcę godności charakteru niezbywalnego oznacza, że nie można człowieka jej pozbawić, a on sam nie może się jej zrzec (zob. wyrok TK z 5 marca 2003 r., sygn. akt K 7/01). Zgodnie z treścią art. 30 Konstytucji z zasady godności wywodzą się wszelkie prawa i wolności konstytucyjne jednostki. Twierdzenie to pozwala uznać, że prawa i wolności przysługują istocie ludzkiej nie z faktu przyznania ich przez organ państwowy ani nie opierają się na nienazwanej abstrakcyjnej podstawie, ale wywodzą się z określonej, właściwej każdemu człowiekowi cechy, którą jest godność (B. Banaszak, Konstytucja Rzeczypospolitej Polskiej. Komentarz, Warszawa 2012, s. 214).

Ustrojodawca formułuje zasadę nienaruszalności godności, z której wynika zakaz podejmowania działań mogących ją naruszyć lub choćby tylko ograniczyć. Władze publiczne są nie tylko zobligowane do poszanowania godności, tj. nienaruszania swoimi działaniami, lecz także do jej ochrony, a więc do stworzenia systemu procedur, prawnych nakazów i zakazów zapobiegających wszelkim jej naruszeniom i zagrożeniom. Trybunał Konstytucyjny, analizując zasadę nienaruszalności godności, stwierdził: „Będąc źródłem praw i wolności jednostki, pojęcie godności determinuje sposób ich rozumienia i urzeczywistniania przez państwo. Zakaz naruszania godności człowieka ma charakter bezwzględny i dotyczy wszystkich. Natomiast obowiązek poszanowania i ochrony godności nałożony został na władze publiczne państwa. W konsekwencji wszelkie działania władz publicznych powinny z jednej strony uwzględniać istnienie pewnej sfery autonomii, w ramach której człowiek może się w pełni realizować społecznie, a $\mathrm{z}$ drugiej działania te nie mogą prowadzić do tworzenia sytuacji prawnych lub faktycznych odbierających jednostce poczucie godności" (wyrok TK z 4 kwietnia 2001 r., sygn. akt K 11/00).

Przedmiotem prawa do godności jest stworzenie (zagwarantowanie) każdemu człowiekowi takiej sytuacji, by miał możliwość autonomicznego realizowania swojej osobowości, ale - przede wszystkim - by nie stawał się przedmiotem działań ze strony innych (zwłaszcza władzy publicznej) i nie stanowił tylko instrumentu w urzeczywistnianiu ich celów. Zauważyć trzeba, że ani orzecznictwo Trybunału Konstytucyjnego, ani doktryna prawa konstytucyjnego nie wypowiedziały ostatecznego zdania co do znaczenia formuły godności człowieka (zob. K. Działocha, Idee przewodnie wolności i praw jednostki w procesie uchwa- 
lania Konstytucji RP [w:] Wolności i prawa jednostki w Konstytucji RP, t. I, Idee $i$ zasady przewodnie konstytucyjnej regulacji wolności i praw jednostki $w R P$, red. M. Jabłoński, Warszawa 2010, s. 17). Sam Trybunał przyznaje, że potrzebna jest „znaczna powściągliwość w treściowym precyzowaniu godności” (wyrok TK z 9 lipca 2009 r., sygn. akt SK 48/05). Możliwe jest jednak wyodrębnienie pewnych dziedzin, gdzie związek godności człowieka ze szczegółowymi prawami czy wolnościami rysuje się z wyrazistością (zob. M. Granat, Godność człowieka $z$ art. 30 Konstytucji RP jako wartość i norma prawna, „Państwo i Prawo” 2014, z. 8, s. 4). Będą to takie dziedziny, jak: ochrona życia ludzkiego, materialne warunki bytowania człowieka, integralność fizyczna i integralność intelektualna człowieka, prywatności człowieka.

2. Wnioskodawcy wskazują na możliwość naruszenia przez przepisy stanowiące przedmiot kontroli art. $38 \mathrm{w}$ związku z art. 31 ust. 3 Konstytucji. A zatem kolejnym wzorcem kontroli jest prawo do ochrony życia w kontekście zasady proporcjonalności.

Zgodnie z art. 38 Konstytucji: „Rzeczpospolita Polska zapewnia każdemu człowiekowi prawną ochronę życia”. Życie ludzkie potwierdzone jest w przytoczonym przepisie i stanowi zasadniczą wartość konstytucyjną, a państwo w sposób bezpośredni powołane zostaje do jego ochrony. Jedną z obszerniejszych wypowiedzi Trybunału Konstytucyjnego odnoszących się explicite do art. 38 Konstytucji był wyrok z 30 września 2008 r., sygn. akt K 44/07. Trybunał podkreślił wówczas, iż; „[ż]ycie ludzkie stanowi wartość o randze najwyższej w naszej cywilizacji i kulturze prawnej. Wartość dobra prawnego, jakim jest życie ludzkie, nie podlega przy tym, na gruncie Konstytucji, różnicowaniu. W polskim i zagranicznym orzecznictwie konstytucyjnym podkreśla się rangę prawa do prawnej ochrony życia jako podstawowego prawa jednostki, warunkującego posiadanie i realizację wszelkich innych praw i wolności. Znaczenie prawa do życia wykracza jednak poza tak rozumiany kontekst indywidualno-podmiotowy”. Należy go w pierwszym rzędzie rozumieć jako zakaz pozbawiania człowieka życia (wyrok TK z 23 marca 1999 r., sygn. akt K 2/98).

Z przedstawionego ujęcia przepisu art. 38 Konstytucji wynika, że ustrojodawca nie tyle formułuje prawo podmiotowe jednostki w postaci prawa do życia - co jest raczej kategorią filozoficzną lub teologiczną - lecz prawo do prawnej ochrony życia. Wykracza poza rozumienie go jako wyłącznie obowiązek zapewnienia jednostce określonego zakresu zdolności do działania i prywatnej sfery życia, w którą państwo nie może ingerować. Przeciwnie, jego odpowiednikiem powinny być wszelkie pozytywne działania państwa, dokonywane w określonych formach prawnych, a stwarzające zarówno prawne, jak i faktyczne instytucje i stany, zmniejszające lub eliminujące zagrożenia życia ludzkiego. Na ten aspekt znaczenia ochrony prawnej życia zwraca także uwagę Trybunał Konstytucyjny w wyroku z 23 marca 1999 r., sygn. akt K 2/98, w którym wywiódł, że niezależnie od „obronnej” treści prawa do życia, z art. 38 Konstytucji wynika również 
zobowiązanie władz publicznych do podejmowania działań służących ochronie życia. Zgodnie ze stanowiskiem zaprezentowanym przez sąd konstytucyjny w wyroku z 30 września 2008 r., sygn. akt K 44/07, we wskazanym, pozytywnym aspekcie prawa do ochrony życia mieszczą się - uznawane także w orzecznictwie Europejskiego Trybunału Praw Człowieka oraz innych europejskich sądów konstytucyjnych - pozytywne obowiązki państwa. Z kolei w orzeczeniu z 28 maja 1997 r., sygn. akt K 26/96, Trybunał stwierdził, że ochrona życia ludzkiego nie może być rozumiana wyłącznie jako ochrona minimum funkcji biologicznych niezbędnych do egzystencji, ale jako gwarancje prawidłowego rozwoju, a także uzyskania i zachowania normalnej kondycji psychofizycznej, właściwej dla danego wieku rozwojowego (etapu życia). Podkreśla również, że ochrona życia ludzkiego pozostaje też w ścisłym związku z klauzulą demokratycznego państwa prawnego, którą - co należy podkreślić - zawiera także obecnie obowiązująca Konstytucja. Trybunał dodaje, że: „[p]aństwo takie realizuje się bowiem wyłącznie jako wspólnota ludzi, i tylko ludzie mogą być właściwymi podmiotami praw i obowiązków stanowionych w takim państwie. Podstawowym przymiotem człowieka jest jego życie. Pozbawienie życia unicestwia więc równocześnie człowieka, jako podstawowych dyrektyw wyprowadzanych $\mathrm{z}$ istoty demokratycznie stanowionego prawa, a gwarantujących minimum jego sprawiedliwości, to pierwszą taką dyrektywą musi być respektowanie w państwie prawa wartości, bez której wykluczona jest wszelka podmiotowość prawna, tj. życia ludzkiego od początku jego powstania".

Wprowadzanie jakichkolwiek ograniczeń analizowanego prawa, niezależnie od tego, że musi być dokonywane zgodnie z ogólnymi regułami z art. 31 ust. 3 , wymaga jednak - z uwagi na szczególny charakter wartości, o której traktuje równie szczególnej rozwagi (P. Sarnecki, Komentarz do art. 38 [w:] Konstytucja Rzeczypospolitej Polskiej. Komentarz, t. I, red. L. Garlicki, M. Zubik, Warszawa 2016, s. 200). Zdaniem Trybunału dotyczy to, po pierwsze, przesłanki „konieczności" tam występującej, która musi być interpretowana szczególnie restryktywnie, w kierunku zbieżnym z kryterium „absolutnej konieczności”, a po drugie, względy na ochronę dóbr, usprawiedliwiających ograniczenie analizowanego prawa musiałyby spełniać wymóg „symetrii dóbr: poświęcanego i ratowanego" (wyrok TK z 30 września 2008 r., sygn. akt K 44/07).

3. Zgodnie z art. 31 ust. 3 Konstytucji: „[o]graniczenia w zakresie korzystania z konstytucyjnych wolności i praw mogą być ustanawiane tylko w ustawie i tylko wtedy, gdy są konieczne w demokratycznym państwie dla jego bezpieczeństwa lub porządku publicznego, bądź dla ochrony środowiska, zdrowia i moralności publicznej, albo wolności i praw innych osób. Ograniczenia te nie mogą naruszać istoty wolności i praw".

Istotą unormowania zawartego $\mathrm{w}$ cytowanym przepisie konstytucyjnym jest wyznaczenie granic ingerencji władzy publicznej w sferę wolności i praw konstytucyjnych (tzw. granic ograniczeń) poprzez ogólne określenie przesłanek, 
których spełnienie jest konieczne do wprowadzenia ograniczeń praw i wolności jednostki. Został on skonstruowany z trzech części, z których pierwsza to ustalenie przesłanki formalnej (wymóg ustawowej formy ograniczeń); druga określenie przesłanek materialnych (poprzez specyfikację pojęcia „interesu publicznego") oraz trzecia - wskazanie maksymalnych granic dla wprowadzania ograniczeń (nakaz szanowania zasady proporcjonalności oraz zakaz naruszania „istoty” praw i wolności (L. Garlicki, K. Wojtyczek, Komentarz do art. 31 [w:] Konstytucja Rzeczypospolitej Polskiej. Komentarz, t. II, red. L. Garlicki, M. Zubik, Warszawa 2016, s. 72). Jest to przepis zawężający zakres zastosowania wolności i praw konstytucyjnie zagwarantowanych i tym samym musi być interpretowany zgodnie z zasadami wykładni wyjątków, w szczególności przy uwzględnieniu zakazu rozszerzającej interpretacji jego postanowień.

Granicą dla wprowadzenia ograniczeń konstytucyjnych praw i wolności są zatem przesłanki „konieczności”, dopuszczalności w „demokratycznym państwie” oraz zakazu naruszania „istoty wolności i praw”.

Z uzasadnienia wnioskodawców wynika, że z treści art. 31 ust. 3 Konstytucji wyprowadza on zasadę proporcjonalności. W orzecznictwie sądu konstytucyjnego nie budzi wątpliwości, że wspomniany przepis statuuje w sposób w pełni samodzielny i całościowy zasadę proporcjonalności (wyrok TK z 12 stycznia 1999 r., sygn. akt P 2/98). Świadczy o tym jego treść, która wskazuje, że ograniczenia konstytucyjnych praw i wolności mogą być ustanawiane tylko wtedy: „gdy są konieczne w demokratycznym państwie”. W ocenie TK zasada proporcjonalności: „[z] jednej strony stawia [...] przed prawodawcą każdorazowo wymóg stwierdzenia rzeczywistej potrzeby dokonania w danym stanie faktycznym ingerencji w zakres prawa bądź wolności jednostki. Z drugiej zaś winna być ona rozumiana jako wymóg stosowania takich środków prawnych, które będą skuteczne, a więc rzeczywiście służące realizacji zamierzonych przez prawodawcę celów. Ponadto chodzi tu o środki niezbędne, w tym sensie, że chronić będą określone wartości w sposób, bądź w stopniu, który nie mógłby być osiągnięty przy zastosowaniu innych środków. Niezbędność to również skorzystanie ze środków jak najmniej uciążliwych dla podmiotów, których prawa lub wolności ulegną ograniczeniu. Ingerencja w sferę statusu jednostki musi więc pozostawać w racjonalnej i odpowiedniej proporcji do celów, których ochrona uzasadnia dokonane ograniczenie. [...] «Konieczność», którą wyraża art. 31 ust. 3 Konstytucji mieści więc w sobie postulat niezbędności, przydatności i proporcjonalności sensu stricto wprowadzanych ograniczeń" (wyrok TK z 12 stycznia 1998 r., sygn. akt P 2/98).

Z powyższego orzeczenia wynika, że dla oceny, czy doszło do naruszenia zasady proporcjonalności, konieczne jest udzielenie odpowiedzi na pytanie, czy kwestionowana norma spełnia trzy wymagania: przydatności, konieczności i proporcjonalności sensu stricto. Te trzy kryteria stosowane powinny być do konkretnych unormowań odnoszących się do poszczególnych typów wolności i praw jednostki. Trybunał wskazuje tym samym, że zasada proporcjonalności 
ma charakter relatywny, bo różnicuje zakres dopuszczalnej ingerencji w zależności od tego, jakie wolności bądź prawa stają się przedmiotem tej ingerencji (orzeczenie TK z 26 kwietnia 1995 r., sygn. akt K 11/94). W orzecznictwie konstytucyjnym przyjmuje się, że im cenniejsze jest dobro ograniczane i wyższy jest stopień tego ograniczenia, tym cenniejsza musi być wartość uzasadniająca ograniczenia (wyrok TK z 25 lipca 2013 r., sygn. akt P 56/11).

Zakaz naruszania istoty konstytucyjnych wolności i praw opiera się na założeniu, że każda wolność bądź prawo ma pewien podstawowy czy minimalny zakres treściowy, którego usunięcie zniweczy faktyczne jej istnienie. Nie może prowadzić do całkowitego wydrążenia ich z rzeczywistej treści i pozostawienia tylko pozoru ich obowiązywania (L. Garlicki, K. Wojtyczek, Komentarz do art. 31, op. cit., s. 96). Należy zauważyć, że w swoim orzecznictwie TK zajmował się koncepcją „istoty wolności i praw”, wskazując, iż: „[w] treści każdego z konstytucyjnych praw i wolności zawierają się pewne elementy podstawowe, istnienie których jest konieczną przesłanką zachowania przez to prawo lub wolność swej konstytucyjnej tożsamości” (orzeczenie TK z 17 lipca 1996 r., sygn. akt K 8/96).

4. Artykuł 32 ust. 1 Konstytucji statuuje fundamentalną w demokratycznym państwie prawnym zasadę równości. Zgodnie z jego brzmieniem: „[w]szyscy są wobec prawa równi. Wszyscy mają prawo do równego traktowania przez władze publiczne”. Konstytucyjna zasada równości wobec prawa ujęta w art. 32 ust. 1 wyraża nakaz, aby wszystkie podmioty prawa (adresaci norm prawnych), charakteryzujące się daną cechą istotną w równym stopniu, były traktowane równo, a więc według jednakowej miary, bez zróżnicowań zarówno dyskryminujących, jak i faworyzujących. W orzecznictwie TK przyjmuje się, że: „[r]ówność oznacza akceptację różnego traktowania przez prawo różnych podmiotów (adresatów norm prawnych), bo równe traktowanie przez prawo tych samych podmiotów pod pewnym względem oznacza $z$ reguły różne traktowanie tych samych podmiotów pod innym względem. [...] różne traktowanie przez prawo określonych grup (klas) podmiotów powinno być jednak uzasadnione w tym sensie, że musi być oparte na uznanych kryteriach oceny klasyfikacji różnicującej podmioty prawa" (orzeczenie TK z 9 marca 1988 r., sygn. akt U 7/87; wyrok TK z 6 maja 1998 r., sygn. akt K 37/97).

W orzecznictwie konstytucyjnym podkreśla się konieczność badania kontekstu zastosowania zasady równości. „Równość w rozumieniu konstytucyjnym nie ma charakteru abstrakcyjnego i absolutnego, funkcjonuje zawsze w pewnym kontekście sytuacyjnym i musi odnosić się do nakazów (zakazów) lub uprawnień przynależnych określonym jednostkom (ich grupom) w porównaniu ze statusem innych jednostek (grup). Postulat równości nie może być utożsamiany z nakazem identyczności praw wszystkich jednostek nie tylko z tego względu, że każda regulacja prawna w istocie wprowadza zróżnicowanie między podmiotami. Nakaz identycznego ukształtowania uprawnień czy obowiązków wszystkich jednostek w warunkach obiektywnie istniejących zróżnicowań o charakterze naturalnym 
(np. cech osobowościowych jednostek) czy faktycznym (sytuacyjnym, np. miejsce jednostki w społeczeństwie) kolidowałby niejednokrotnie z zasadą sprawiedliwości społecznej, a także z zasadą racjonalnego ustawodawcy. A zatem dopóki zróżnicowania odpowiadają obiektywnie istniejącym różnicom między adresatami norm prawnych, dopóty nie mamy do czynienia z naruszeniem zasady równości. Problem naruszenia tej zasady powstaje wówczas, gdy wprowadzone do systemu prawnego zróżnicowania dotyczą podmiotów podobnych. Kluczowe dla oceny, czy doszło do naruszenia konstytucyjnej zasady równości, jest więc zawsze ustalenie cechy istotnej, która przesądzałaby o uznaniu określonych (porównywanych) podmiotów za podobne lub odmienne. Jeśli wynik tego ustalenia prowadzi do wniosku, że porównywane podmioty są podobne, wówczas konieczne staje się zbadanie, czy wprowadzenie zróżnicowania jest uzasadnione. Zróżnicowanie podmiotów prawa charakteryzujących się wspólną cechą istotną jest bowiem dopuszczalne (i nie narusza zasady równości) pod warunkiem sine qua non jasno sformułowanego kryterium (stanowiącego podstawę zróżnicowania), które można w świetle zasad i wartości konstytucyjnych uzasadnić odpowiednio przekonującymi argumentami” (wyrok TK z 23 marca 2010 r., sygn. akt SK 47/08).

W orzecznictwie Trybunału Konstytucyjnego został ustalony katalog warunków, które w świetle zasady równości musi spełniać kryterium stanowiące podstawę zróżnicowania. Po pierwsze, musi mieć ono charakter relewantny, a zatem musi pozostawać $\mathrm{w}$ bezpośrednim związku $\mathrm{z}$ celem i zasadniczą treścią przepisów, w których zawarta jest kontrolowana norma, i służyć realizacji tego celu i treści. Kryterium to musi mieć zatem charakter racjonalnie uzasadniony, a nie arbitralny (zob. orzeczenie TK z 12 grudnia 1994 r., sygn. akt K 3/94). Po drugie, kryterium to musi mieć charakter proporcjonalny. Waga interesu, któremu ma służyć zróżnicowanie sytuacji adresatów normy, musi więc pozostawać w odpowiedniej proporcji do wagi interesów, które zostaną naruszone w wyniku nierównego potraktowania podmiotów podobnych. Po trzecie, kryterium to musi pozostawać w związku z zasadami, wartościami i normami konstytucyjnymi uzasadniającymi odmienne traktowanie podmiotów podobnych (zob. np. wyrok TK z 23 października 1995 r., sygn. akt K 4/95). Niespełnienie tych warunków świadczy o tym, że dokonane przez prawodawcę zróżnicowanie jest niedopuszczalne (wyrok TK z 23 marca 2010 r., sygn. akt SK 47/08).

Artykuł 32 ust. 2 Konstytucji wprowadza zakaz dyskryminacji. Nie określa jednak cech, ze względu na które można dokonać różnicowania sytuacji prawnej podmiotów. Ale wskazuje, że nikt nie może być dyskryminowany w życiu politycznym, społecznym lub gospodarczym z jakiejkolwiek przyczyny. Jak wskazał Trybunał Konstytucyjny w wyroku z 23 października 2001 r., sygn. akt K 22/01: „[a]rt. 32 stanowi całość normatywną. Ust. 1 wymienionego artykułu formułuje w sposób ogólny zasadę równości jako normę konstytucyjną adresowaną do wszelkich organów władzy publicznej - zarówno do organów stosujących prawo jak i do organów stanowiących prawo. Ust. 2 precyzuje bliżej znaczenie konsty- 
tucyjnej zasady równości. Po pierwsze, art. 32 ust. 2 wyraża uniwersalny charakter równości, nakazujący jej przestrzeganie we wszystkich sferach życia - zarówno w życiu politycznym, społecznym jak i gospodarczym. Po drugie, art. 32 ust. 2 określa granice dopuszczalnych różnicowań podmiotów prawa. W myśl tego przepisu żadne kryterium nie może stanowić podstawy dla różnicowań niesprawiedliwych, dyskryminujących określone podmioty". Trybunał Konstytucyjny podtrzymał powyższe tezy w wyroku z 25 listopada 2010 r., sygn. akt K 27/09, oraz podkreślił, że: „[p]rawo do równego traktowania wyrażone w art. 32 ust. 1 Konstytucji oraz zakaz dyskryminacji wyrażony w art. 32 ust. 2 ustawy zasadniczej stanowią "dwie strony medalu», czyli pozytywny oraz negatywny aspekt konstytucyjnej zasady równości. Orzeczenie stwierdzające zgodność pewnych treści normatywnych z prawem do równego traktowania oznacza więc automatycznie zgodność tychże treści z konstytucyjnym zakazem dyskryminacji”.

5. Wskazany jako wzorzec kontroli art. 2 Konstytucji stanowi: „Rzeczpospolita Polska jest demokratycznym państwem prawnym, urzeczywistniającym zasady sprawiedliwości społecznej". Zasada demokratycznego państwa prawnego ma charakter klauzuli generalnej o wielopłaszczyznowej treści i dopiero w procesie wykładni art. 2 Konstytucji judykatura i doktryna wyodrębniły zasady pochodne, które w wypadku kontroli konstytucyjności stanowią samodzielne wzorce kontroli. W rozpatrywanej sprawie sąd pytający precyzuje w uzasadnieniu pytania prawnego, że art. 2 Konstytucji stanowi wzorzec kontroli w zakresie, w jakim wynika z niego zasada określoności przepisów prawa.

Zasada określoności prawa stanowi dyrektywę prawidłowej legislacji oraz jeden $\mathrm{z}$ elementów zasady ochrony zaufania do państwa i stanowionego przez nie prawa (wyroki TK z: 28 października 2009 r., sygn. akt K 32/08; 29 maja 2012 r., sygn. akt SK 17/09; 29 lipca 2014 r., sygn. akt P 49/13). Wynika z niej spoczywający na prawodawcy obowiązek formułowania przepisów prawnych, zwłaszcza dotyczących wolności i praw jednostki lub przewidujący możliwość stosowania wobec niej sankcji, w sposób poprawny, jasny i precyzyjny, tym samym zapewniający przewidywalność skutków jego zastosowania (zob. wyroki TK z: 11 stycznia 2000 r., sygn. akt K 7/99; 12 czerwca 2002 r., sygn. akt P 13/01). $\mathrm{Z}$ tak ujętej zasady określoności wynika, że każdy przepis prawny powinien być skonstruowany poprawnie z punktu widzenia językowego i logicznego. Przepis powinien być klarowny i zrozumiały dla adresata, niebudzący wątpliwości co do treści nakładanych obowiązków i przyznawanych praw. Związana z jasnością precyzja przepisu powinna przejawiać się również w konkretności nakładanych obowiązków i przyznawanych praw, tak aby pozwalała ona na ich egzekwowanie (zob. wyrok TK z 21 marca 2001 r., sygn. akt K 24/00). Konkretyzując ten obowiązek, Trybunał Konstytucyjny wskazał, że wymóg jasności oznacza nakaz tworzenia przepisów w sposób kompletny, precyzyjny i jednoznacznie definiujący wszystkie, $\mathrm{w}$ tym podmiotowe, znamiona czynów zagrożonych karą (zob. wyrok TK z 26 kwietnia 1995 r., sygn. akt K 11/94). 
Niemniej nie każde naruszenie zasad techniki legislacyjnej stanowi jednocześnie złamanie konstytucyjnej zasady prawidłowej legislacji, a jedynie takie, które jest istotne. Do naruszenia wymogu określoności przepisów prawa dochodzi w sytuacji, gdy przepis jest sformułowany w sposób niejasny i nieprecyzyjny w stopniu powodującym istotne wątpliwości prawne, a także gdy posługuje się niezdefiniowanymi pojęciami albo mającymi niezrozumiałą treść (zob. wyroki TK z: 30 października 2001 r., sygn. akt K 33/00; 28 października 2009 r., sygn. akt Kp 3/09). Rygor stosowania tej zasady zależy także od rodzaju zagadnień będących przedmiotem regulacji prawnej. Niewątpliwie i w sposób kategoryczny odnosi się on do relacji między państwem a obywatelami jako adresatami przepisu prawnego. Stąd wszystkie przepisy ograniczające realizację wolności i praw jednostki muszą być dostatecznie określone (wyrok TK z 10 listopada 1998 r., sygn. akt K 39/97, zob. W. Sokolewicz, M. Zubik, Komentarz do art. 2 [w:] Konstytucja Rzeczypospolitej Polskiej. Komentarz, t. I, red. L. Garlicki, M. Zubik, Warszawa 2016, s. 147-148).

Wymóg określoności nie wyklucza posługiwania się przez ustawodawcę pojęciami pozaprawnymi, nawet nieostrymi, odwołującymi się do funkcjonujących w społeczeństwie przekonań i ocen, jeśli mają ugruntowaną w świadomości prawnej jednostek podstawę aksjologiczną, z której wynika konkretny imperatyw normatywny (zob. wyrok TK z 15 września 1999 r., sygn. akt K 11/99). Dopuszcza się również używanie pojęć, które ze swej istoty wymagają wykładni lub odwołują się do regulacji zawartych w innych gałęziach prawa (zob. wyrok TK z 12 września 2005 r., sygn. akt SK 13/05). Z brzmienia art. 2 Konstytucji nie można też wyprowadzać zakazu posługiwania się odesłaniem do innych aktów prawnych (postanowienie TK z 23 listopada 2004 r., sygn. akt Tw 25/04). Natomiast będzie sprzeczne z zasadą określoności odesłanie, które zawiera sformułowanie niedookreślone, prowadząc do niedających się usunąć wątpliwości co do zakresu naruszenia wolności człowieka (wyrok TK z 7 października 2015 r., sygn. akt K 12/14).

W wyroku z 6 października 2015 r., sygn. akt SK 54/13, Trybunał Konstytucyjny sformułował swoisty test określoności prawa, który wymaga odpowiedzi na trzy problemy dotyczące: po pierwsze, precyzyjności regulacji prawnej (konkretność regulacji praw i obowiązków, tak by ich treść pozwalała na wyegzekwowanie); po drugie, jasności przepisu (zrozumiałość dla adresatów) oraz po trzecie, legislacyjnej poprawności (spełnienie wymogów co do technicznej strony legislacyjnej).

6. Przywołany w charakterze wzorca kontroli art. 42 ust. 1 Konstytucji wyraża zasadę nullum crimen sine lege, nulla poena sine lege. Stanowi on, że: „[o]dpowiedzialności karnej podlega ten tylko, kto dopuścił się czynu zabronionego pod groźbą kary przez ustawę obowiązującą w czasie jego popełnienia. Zasada ta nie stoi na przeszkodzie ukaraniu za czyn, który w czasie jego popełnienia stanowi przestępstwo w myśl prawa międzynarodowego". 
Z ogólnej zasady nullum crimen sine lege, nulla poena sine lege wyprowadzone są następujące zasady szczegółowe:

- nullum crimen, nulla poena sine lege scripta, zgodnie z którą źródłem określenia przestępstwa i kary kryminalnej może być tylko ustawa bądź akty równe ustawie, dosł. tylko prawo pisane,

- nullum crimen, nulla poena sine lege stricta, zgodnie z którą w prawie karnym zabronione jest stosowanie analogii mającej na celu poszerzenie zakresu kryminalizacji lub penalizacji, jak również dokonywanie wykładni rozszerzającej przepisu prawa karnego na niekorzyść sprawcy,

- nullum crimen, nulla poena sine lege certa, zgodnie z którą określenie przestępstwa i kary powinny charakteryzować się dostateczną precyzyjnością,

- nullum crimen, nulla poena sine lege praevia, zgodnie z którą zabronione jest wsteczne działanie ustawy karnej w takim zakresie, w jakim pogarsza to sytuację sprawcy (zob. R. Dębski, Pozaustawowe znamiona przestępstwa. O ustawowym charakterze norm prawa karnego i znamionach typu czynu zabronionego nie określonych w ustawie, Łódź 1995, s. 19-20; A Wąsek, Kodeks karny. Komentarz, t. I, Gdańsk 1999, s. 16-20).

Kwestia określoności norm karnych była podejmowana w dotychczasowym orzecznictwie Trybunału Konstytucyjnego. Jak wskazano w uzasadnieniu postanowienia z 25 września 1991 r., sygn. akt S 6/91, „[w] demokratycznym państwie prawa funkcją prawa karnego nie jest tylko ochrona państwa i jego instytucji, nie jest także tylko ochrona społeczeństwa lub poszczególnych jednostek przed przestępstwami, ale także, $w$ nie mniejszym stopniu, ochrona jednostki przed samowolą państwa. Prawo karne stwarza dla władzy w demokratycznym państwie prawa barierę, poza którą obywatel powinien czuć się bezpieczny w tym sensie, że bez przekroczenia pola zabronionego pod groźbą kary nie może być pociągnięty do odpowiedzialności karnej. Prawo karne ma wyznaczyć wyraźne granice między tym, co jest dozwolone, a tym, co jest zabronione. Bariera, o której tu mowa, nie powinna być usuwana dla żadnych celów politycznych lub innych. Prawo karne nie jest bowiem instrumentem mającym służyć zachowaniu władzy, lecz jest właśnie tej władzy ograniczeniem”. Jak dalej wskazano: „z powyższych założeń wynika, że w demokratycznym państwie prawa prawo karne musi być oparte przynajmniej na dwóch podstawowych zasadach: określoności czynów zabronionych pod groźbą kary (nullum crimen, nulla poena sine lege) oraz na zakazie wstecznego działania ustawy wprowadzającej lub zaostrzającej odpowiedzialność karną (lex severior retro non agit)".

W myśl przytoczonych reguł warunkiem odpowiedzialności karnej jest określona ustawowo karalność czynu podlegającego ocenie w momencie jego popełnienia. Odpowiedzialność karna nie może być więc przewidziana w akcie podustawowym. Ustawa powinna przy tym być sformułowana w sposób precyzyjny, niebudzący jakichkolwiek wątpliwości, pozwolić na wskazanie czynu 
zabronionego i definiować wszystkie jego znamiona wyznaczające cechy tworzące zarys typu przestępstwa. W nauce prawa wskazuje się, że zasada nullum crimen sine lege, nulla poena sine lege wywiera wpływ na prawo karne na trzech płaszczyznach: stanowienia prawa, jako skierowany do prawodawcy postulat ustawowego określenia zagrożenia sankcją karną, jego stosowania - w postaci adresowanego do sądu nakazu wymierzenia tylko takiej kary, jaka została ustawowo przewidziana, oraz wykonywania - jako postulat ścisłego określania sposobu egzekwowania kary i wykonania jedynie kary oznaczonej przez orzekający w sprawie sąd (zob. B. Banaszak, Konstytucja Rzeczypospolitej Polskiej, op. cit., komentarz do art. 42, s. 275). Na podobnym stanowisku stoi Trybunał Konstytucyjny, stwierdzając: „Zasada nullum crimen, nulla poena sine lege kreuje jedno z podstawowych praw człowieka. Wynikają z niej postulaty skierowane zarówno do ustawodawcy, jak i do podmiotów stosujących prawo" (wyrok TK z 16 marca 2011 r., sygn. akt K 35/08).

Ponadto art. 42 ust. 1 Konstytucji formułuje dyrektywę określoności przepisów karnych. Zakaz lub nakaz obwarowany sankcją karną musi być sformułowany ściśle, zgodnie z zasadą nullum delictum sine lege certa (zob. J. Warylewski, Zasady techniki prawodawczej. Komentarz do rozporządzenia, Warszawa 2003, s. 326). Brak precyzji ustawodawcy stwarza szerokie pole dla dowolności działania organów stosujących prawo, a to istotnie zwiększa ryzyko bezpodstawnego stosowania sankcji. Podobny pogląd wyraził Trybunał Konstytucyjny, głosząc, że należy wykluczyć niedoprecyzowanie jakiegokolwiek elementu normy karnej, które pozwalałoby na dowolność jej stosowania przez właściwe organy władzy publicznej czy na zawłaszczenie przez te organy pewnych sfer życia i penalizowanie zachowań, które nie zostały expressis verbis określone jako zabronione w przepisie prawa karnego (zob. wyrok TK z 5 maja 2004 r., sygn. akt P 2/03). Jeżeli na skutek braku precyzji ustawodawcy pojawią się wątpliwości dotyczące treści normy prawa karnego, nie można stosować takiej wykładni przepisów, która byłaby na niekorzyść sprawcy czynu. Wiąże się z tym zakaz stosowania analogii i wykładni rozszerzającej (zob. wyrok TK z 6 lipca 1999 r., sygn. akt P 2/99). Konstytucja w art. 42 ust. 1 stanowi o czynie zabronionym. Jak zauważa Trybunał Konstytucyjny: „chodzi zatem o konkretne (skonkretyzowane) zachowanie, jakie można przypisać pewnej jednostce. Jakkolwiek zachowanie to może polegać na różnych aktach (działaniu, zaniechaniu), nie budzi wątpliwości, iż na gruncie wspomnianego przepisu konieczne jest precyzyjne jego wskazanie (dookreślenie). W konsekwencji jakiekolwiek wskazanie ogólnikowe, umożliwiające daleko idącą swobodę interpretacji co do zakresu znamion czynu zabronionego czy pewnego typu kategorii zachowań, nie może być traktowane jako spełniające wymóg określoności na gruncie art. 42 ust. 1 Konstytucji”.

Z kolei w postanowieniu Trybunału Konstytucyjnego z 13 czerwca 1994 r., sygn. akt S 1/94, podkreślono, iż: „każda regulacja prawna, nawet o charakte- 
rze ustawowym, dająca organowi państwowemu uprawnienie do wkraczania w sferę praw i wolności obywatelskich, musi spełniać warunek dostatecznej określoności. Należy przez to rozumieć precyzyjne wyznaczenie dopuszczalnego zakresu ingerencji oraz trybu, w jakim podmiot ograniczony w swoich prawach i wolnościach może bronić się przed nieuzasadnionym naruszeniem jego dóbr osobistych”. „W demokratycznym państwie prawa każda forma naruszenia przez organ państwowy dobra osobistego musi łączyć się z możliwością kontroli zasadności działania organu państwowego" (orzeczenie TK z 19 czerwca 1992 r., sygn. akt U 6/92). Podkreślono przy tym, że w demokratycznym państwie prawa: „wymaganie określoności dotyczyć musi zarówno materialnych elementów czynu, jak i elementów kary, tak by czyniło to zadość wymaganiu przewidywalności. Przepisy prawne muszą bowiem stwarzać obywatelowi (podmiotowi odpowiedzialności karnej) możliwość uprzedniego i dokładnego rozeznania, jakie mogą być prawnokarne konsekwencje jego postępowania. Materialne elementy czynu, uznanego za przestępny, muszą więc być zdefiniowane w ustawie (zgodnie z konstytucyjną zasadą wyłączności ustawy) w sposób kompletny, precyzyjny i jednoznaczny". Wymóg określoności został również wyeksponowany w orzeczeniu z 1 marca 1994 r., sygn. akt U 7/93, w którym wskazano, że niesporne jest, iż w państwie prawnym przepisy karne winny precyzyjnie określać zarówno czyn, jak i karę. Niesporne jest też, w świetle konstytucyjnego podziału materii między ustawy a akty wykonawcze, że podstawowe elementy zarówno czynu, jak i kary muszą być określone w samej ustawie, a nie mogą być - w sposób blankietowy - pozostawione do unormowania w akcie wykonawczym. Trybunał Konstytucyjny jest zdania, że powyższe konstytucyjne wymagania pod adresem przepisów karnych należy odnosić do wszystkich przepisów o charakterze represyjnym (sankcjonująco-dyscyplinującym), a więc do wszystkich przepisów, których celem jest poddanie obywatela jakiejś formie ukarania czy jakiejś sankcji.

„Nie oznacza to jednak, że ustawodawca nie może określać pewnych zachowań stanowiących czyn zabroniony w sposób na tyle ogólny, aby w ich zakresie mieściły się różne działania, które są zabronione np. ze względu na cel, jaki ma być osiągnięty przez ich realizację. Wniosek przeciwny należałoby uznać za absurdalny, w krańcowym bowiem ujęciu prowadziłby do konieczności zaprzeczenia abstrakcyjnego i ogólnego charakteru normy prawnej. Nie może jednak budzić wątpliwości, że jednostka w konkretnych okolicznościach narażona jest na odpowiedzialność karną" (wyrok TK z 26 listopada 2003 r., sygn. akt SK 22/02). Ponadto Trybunał Konstytucyjny stwierdził: „rozważana zasada wyklucza odpowiedzialność karną na podstawie aktów normatywnych, nawet o mocy ustawy, ustanowionych przez organy bez odpowiednich kompetencji lub ustanowionych z naruszeniem przepisów proceduralnych" (wyrok TK z 16 marca 2011 r., sygn. akt K 35/08). 


\section{Analiza zgodności}

- Zgodność art. 4a ust. 1 pkt 2 oraz art. 4a ust. 2 zdanie pierwsze u.p.r. $z$ art. 30 w związku z art. 38 Konstytucji (zarzut naruszenia ochrony godności człowieka)

Konstytucja bez wątpienia gwarantuje każdemu człowiekowi ochronę jego godności. Ustrojodawca nadając godności człowieka znaczenie konstytucyjne, uczynił z niej płaszczyznę odniesienia dla systemu wartości, wokół którego zbudowano Konstytucję, a zarazem fundament całego porządku prawnego (zob. wyrok TK z 4 kwietnia 2001 r., sygn. akt K 11/00). Czyni to nie ze względu na cechy fizyczne człowieka, zachowanie czy inne jego przymioty, ale ze względu na godność, która jest wartością samą w sobie, wrodzoną człowiekowi z racji jego natury. Jest ona immanentnie związana z człowiekiem i jest komponentem jego człowieczeństwa $\mathrm{z}$ tej racji, iż człowiek $\mathrm{z}$ natury swej jest istotą rozumną, wolną i wyposażoną w sumienie (zob. F.J. Mazurek, Godność człowieka a prawa człowieka, „Roczniki Nauk Społecznych” 1980, nr 8, s. 29; A. Krąpiec, Człowiek i prawo naturalne, Lublin 1993, s. 133-142; A. Rodziński, Osoba, moralność, kultura, Lublin 1989, s. 32). Elementów tych nie może się wyzbyć ani zostać pozbawionym przez inny podmiot. Pojęcie człowieka oznacza zatem każdą istotę ludzką obdarzoną godnością.

Powstaje pytanie o to, kiedy mamy do czynienia z fenomenem człowieka, czyli istoty obdarzonej godnością. Nie można tracić z pola widzenia, że wiodącym zadaniem prawa jest ochrona życia człowieka, nie zaś definiowanie jego granic. Ustrojodawca ani na poziomie konstytucyjnym, ani ustawowym nie precyzuje, jaki moment możemy uważać za początek istnienia człowieka. Pośrednio jednak wyjaśnia tę kwestię, na co wskazuje chociażby zapis art. 71 ust. 2 Konstytucji, gdzie termin „dziecko” został użyty zarówno do okresu prenatalnego, jak i postnatalnego. Również analiza przebiegu prac nad przepisem art. 38 Konstytucji wskazuje, że intencją ustrojodawcy było to: „aby konstytucja maksymalnie chroniła człowieka, a przede wszystkim [...] dziecko poczęte" (zob. Biuletyn Komisji Konstytucyjnej Zgromadzenia Narodowego 1997, nr 45, s. 47). Warto także przywołać stanowisko zajęte w tej kwestii przez Sąd Najwyższy, który dla uzasadnienia twierdzenia, że dziecko nienarodzone podlega ochronie prawnej, odwołuje się do treści przepisu art. 38 Konstytucji, zapewniającego prawną ochronę życia „każdego człowieka”, który obejmuje również dziecko nienarodzone (wyrok SN z 26 listopada 2014 r., sygn. akt III CSK 307/13; wyrok Sądu Okręgowego w Piotrkowie Trybunalskim z 27 listopada 2014 r., sygn. akt I C 1760/13).

Udzielając odpowiedzi na postawione pytanie tylko z perspektywy nauk przyrodniczych, należy zauważyć, że dynamika rozwoju człowieka rozpoczyna się już w okresie życia prenatalnego. Okres ten jest jedną z faz życia człowieka i wywołuje określone konsekwencje po jego urodzeniu. Przy takim ujęciu początkiem życia jest chwila połączenia się plemnika z komórką jajową. W tej niezwykle istotnej chwili utworzona bowiem zostaje określona struktura kodu ge- 
netycznego, z którego wynikają w przyszłości określone konsekwencje w postaci cech genetycznych danej jednostki (zob. J. Giezek, R. Kokot, Granice ludzkiego życia a jego prawna ochrona [w:] Prawa $i$ wolności obywatelskie w Konstytucji $R P$, red. B. Banaszak, A. Preisner, Warszawa 2002, s. 106). Stwierdzone także zostało, że płód jest istotą samoistną biologicznie, tzn. że ma wszystko, co pozwala mu rozwijać się poza organizmem matki. W tym sensie nie jest on częścią organizmu matki, aczkolwiek fizjologicznie zależną od organizmu matki do czasu nabycia zdolności do życia poza jej organizmem. Jak słusznie wskazują wnioskodawcy, w doktrynie prawa stwierdza się, że istota człowieczeństwa nie wyczerpuje się w posiadaniu przez organizm pewnych cech morfologicznych i właściwej dla gatunku ludzkiego budowy i kształtu tego organizmu, ale w posiadaniu przez organizm genotypu ludzkiego, który decyduje, że dana istota jest człowiekiem (zob. M. Szydło, Opinia prawna na temat petycji w sprawie ustawy o świadomym rodzicielstwie, z 8 marca 2017 r., http://orka.sejm.gov.pl/petycje. nsf/nazwa/141/\$file/141.pdf, s. 10-11). W literaturze podkreśla się, że istota posiadająca genom ludzki jest człowiekiem, niezależnie od etapu jego rozwoju czy stanu zdrowia (zob. M. Żelichowski, Podmiotowość prawna człowieka w okresie życia embrionalno-płodowego, „Czasopismo Prawa Karnego i Nauk Penalnych” 1997, nr 1, s. 108-109; T. Sroka, Komentarz do art. 38 [w:] Konstytucja RP. Komentarz, t. I, Art. 1-86, red. M. Safjan, L. Bosek, Warszawa 2016, s. 941; L. Bosek, Gwarancje godności ludzkiej i ich wpływ na polskie prawo cywilne, Warszawa 2012, s. 165-166; J. Hajerko, Cywilnoprawna ochrona dziecka poczętego a stosowanie procedur medycznych, Warszawa 2010, s. 44; M. Królikowski, Problem interpretacji tzw. przesłanki eugenicznej stanowiącej o dopuszczalności zabiegu przerywania ciąży [w:] Współczesne wyzwania bioetyczne, red. L. Bosek, M. Królikowski, Warszawa 2010, s. 177). Życie zarodka i płodu jest od początku poczęcia życiem ludzkim, ponieważ ma ludzki kod genetyczny otrzymany od ludzkich rodziców. Wynika z tego, że zarodek rozwijający się w łonie matki jest postacią życia ludzkiego (zob. T. Smyczyński, Opinia prawna o poselskim projekcie zmiany (art. 38) Konstytucji Rzeczypospolitej Polskiej [w:] Konstytucyjna formuła ochrony żcia, druk sejmowy nr 993, seria „Przed Pierwszym Czytaniem” nr 3, Warszawa 2007, s. 16).

Argumenty biologiczne, które nota bene mogą stale ulegać zmianie wraz z rozwojem poziomu wiedzy, stanowią bardzo ważną, ale nie jedyną płaszczyznę dla rozważania początków życia człowieka. Człowieczeństwo ma bowiem poza biologicznym również swój wymiar ontyczny (odnoszący się do jego istoty). Nie odmawia się człowieczeństwa, a tym samym godności ludziom chorym, zniekształconym fizycznie, dotkniętymi defektami konstrukcji psychicznej czy obciążonym wadami genetycznymi. Nikt nie kwestionuje także statusu moralnego i prawnego noworodka, które nie ma cech charakteryzujących dorosłego człowieka, świadomie i rozumnie uczestniczącego w życiu społecznym. Wspólna jest bowiem dla nich wszystkich ta sama natura (rozum, wolna wola i sumie- 
nie), także w odniesieniu do noworodka. Nie inaczej jest w przypadku dziecka nienarodzonego. Bez względu na to, jak zostanie nazwane, w kontekście godności jego natura pozostaje niezmienna. Życia ludzkiego nie można wartościować według tego, w jakiej fazie rozwoju się znajduje (zob. ibidem, s. 17). Przy czym pojęcia typu „embrion”, „płód” czy „zarodek” właściwe są dla nauk biomedycznych i mają charakter techniczny, służący określeniu etapu rozwoju życia (nie zawsze ludzkiego). Powodują one jednak uprzedmiotowienie opisywanego zjawiska oraz w nieadekwatny sposób oddają istotę samej osoby, której natura jest przecież stała. Zarówno człowiek narodzony, jak i pozostający na prenatalnym etapie rozwoju ma taką samą naturę, której komponentem jest godność.

Nie tracąc z pola widzenia przedstawionych trudności w temacie ujmowania życia ludzkiego w kategoriach ochrony prawnej, należy wskazać na, będącą wyrazem określonego poziomu kulturowego społeczeństwa, zasadę rozstrzygania wszelkich wątpliwości na korzyść życia ludzkiego. Pośrednio daje temu wyraz Trybunał Konstytucyjny w orzeczeniu z 28 maja 1997 r., sygn. akt K 26/96, w którym wyraźnie stwierdza, że: „[w]artość konstytucyjnie chronionego dobra prawnego, jakim jest życie ludzkie, w tym życie rozwijające się w fazie prenatalnej, nie może być różnicowana. Brak jest bowiem dostatecznie precyzyjnych i uzasadnionych kryteriów pozwalających na dokonanie takiego zróżnicowania w zależności od fazy rozwojowej ludzkiego życia. Od momentu powstania życie ludzkie staje się więc wartością chronioną konstytucyjnie. Dotyczy to także fazy prenatalnej”. Trybunał Konstytucyjny stoi na stanowisku, że w pojęciu życia ludzkiego mieści się również życie rozwijające się w fazie prenatalnej i że życie ludzkie - będące w demokratycznym państwie prawnym dobrem najcenniejszym - pozostaje pod ochroną konstytucyjną w każdym stadium jego rozwoju, w tym w fazie prenatalnej. Trybunał pojęciem „życia człowieka” czy też „życia ludzkiego” obejmuje również „życie dziecka poczętego” (ibidem). Orzeczenie to, mimo iż zostało wydane przed wejściem w życie obowiązującej Konstytucji, zachowuje nadal aktualność, gdyż jego podstawą była - obowiązująca również obecnie - zasada demokratycznego państwa prawnego (obowiązujące w czasie orzekania regulacje konstytucyjne nie zawierały przepisu odnoszącego się bezpośrednio do ochrony życia człowieka); (zob. J. Kondratiewa-Bryzik, Początek prawnej ochrony życia ludzkiego $w$ świetle standardów międzynarodowych, Warszawa 2009, s. 245). Odnosząc się do przedstawionego orzeczenia w literaturze przedmiotu, wskazuje się, że Trybunał opowiada się w ten sposób za brakiem precyzyjnych i uzasadnionych kryteriów pozwalających zidentyfikować konkretny moment, późniejszy niż moment poczęcia, w którym istota, która została już poczęta w wyniku połączenia się ludzkiej męskiej i żeńskiej komórki rozrodczej, uzyskuje przymiot (godność) człowieka. Każdy ustalony dla tego celu moment późniejszy niż moment poczęcia będzie arbitralny i dowolny oraz będzie musiał być traktowany jako dyskrecjonalne przesądzenie o tym, od kiedy przysługuje człowiekowi ochrona właściwa przedstawicielowi rodzaju ludzkiego. Deklara- 
tywne uznanie, że człowiek powstaje w chwili poczęcia, jest najbardziej czytelnym, jednoznacznym i „proludzkim” stanowiskiem (M. Szydło, Opinia prawna, op. cit., s. 10).

Omawiana zasada została wyrażona jako dyrektywa interpretacyjna w wyroku Trybunału Konstytucyjnego z 7 stycznia 2004 r., sygn. akt K 14/03. Trybunał podkreślił ścisły związek między konstytucyjną gwarancją ochrony życia każdego człowieka oraz konstytucyjną gwarancją nienaruszalności przyrodzonej i niezbywalnej godności człowieka, której poszanowanie i ochrona jest obowiązkiem władz publicznych. Uznaje, że skoro prawo do życia jest prawem wobec państwa pierwotnym i w zasadzie nienaruszalnym, to wszelkie wątpliwości co do ochrony życia ludzkiego winny być rozstrzygane na rzecz tej ochrony (in dubio pro vita humana). (Zob. J. Boć [w:] Konstytucje Rzeczypospolitej oraz komentarz do Konstytucji RP z 1997 r., red. J. Boć, Wrocław 1998, s. 78; P. Winczorek, Komentarz do Konstytucji Rzeczypospolitej Polskiej, Warszawa 2000, s. 58).

W ten sam sposób wypowiedział się Trybunał w wyroku z 30 września 2008 r., sygn. akt K 44/07, w którym wskazuje, że: „[n] a gruncie art. 30 Konstytucji pojęciu godności ludzkiej należy przypisać charakter wartości konstytucyjnej o centralnym znaczeniu dla zbudowania aksjologii obecnych rozwiązań konstytucyjnych. Demokratyczne państwo prawne to państwo oparte na poszanowaniu człowieka, a w szczególności na poszanowaniu i ochronie życia oraz godności ludzkiej. Te dwa dobra są zresztą sprzężone w bezpośredni sposób. Art. 30 Konstytucji jest postanowieniem wiodącym dla wykładni i stosowania wszystkich pozostałych postanowień o prawach, wolnościach i obowiązkach jednostki. Podkreśla to także preambuła do Konstytucji, która wzywa wszystkich stosujących konstytucję do tego, aby czynili to, dbając o zachowanie przyrodzonej godności człowieka [...]”. Odwołując się do wcześniejszego orzecznictwa, w szczególności orzeczenia w sprawie o sygn. akt K 26/96, Trybunał przypomina, że pierwszą dyrektywą wyprowadzaną $\mathrm{z}$ istoty demokratycznie stanowionego prawa, a gwarantującą minimum jego sprawiedliwości, musi być respektowanie w państwie prawa wartości, bez której wykluczona jest wszelka podmiotowość prawna, tj. życia ludzkiego od początków jego powstania (ibidem). Dotychczasowe orzecznictwo Trybunału Konstytucyjnego wskazuje zatem, że życie człowieka, także w fazie prenatalnej, podlega ochronie z mocy samej Konstytucji (zob. J. Lipski, Opinia prawna na temat rzadowego projektu leczenia niepłodności, „Zeszyty Prawnicze BAS” 2015, nr 4(48), s. 135).

Na konieczność ochrony godności na każdym etapie życia wskazuje również doktryna prawa. Podkreśla się, że: „[a]rt. 30 Konstytucji stanowiący o przyrodzonej i niezbywalnej godności człowieka: odnosi się do człowieka jako gatunku i do każdego człowieka jako niepowtarzalnej indywidualności. Przepis ten odnosi się do człowieka w każdej fazie jego życia, a więc od poczęcia do śmierci. Życie człowieka jako przedstawiciela gatunku, ale przede wszystkim jako odrębnej istoty posiadającej zdeterminowane cechy jednostkowe, jest procesem i ten pro- 
ces niewątpliwie rozpoczyna się z chwilą poczęcia. $\mathrm{Z}$ tą chwilą możemy mówić o człowieku z jego przyrodzoną i niezbywalną godnością i z wszystkimi wynikającymi z tego konsekwencjami, także dla obowiązków władz publicznych, w tym ustawodawczych" (A. Zoll, Opinia prawna w sprawie oceny konstrukcji i skutków prawnych projektu zmiany art. 30 i 38 Konstytucji RP [w:] Konstytucyjna formuła ochrony życia, druk sejmowy nr 993, seria „Przed Pierwszym Czytaniem”, nr 3, Warszawa 2007, s. 104).

Stwierdza się również, że pojęcie „przyrodzona godność” nie oznacza objęcia ochroną jedynie człowieka urodzonego. W języku polskim bowiem „słowo „przyrodzony” jest synonimem takich słów i pojęć, jak naturalny, wrodzony, własny, wsobny, immanentny, inherentny, nieodłączny, samorodny, wewnętrzny, właściwy sobie, dany przez naturę. Termin „przyrodzona” odnosi zatem godność człowieka do ludzkiej tożsamości (określonej przez przynależność gatunkową), a nie wskazuje na czasową lub przestrzenną cezurę zawężającą godność do określonej fazy rozwojowej istoty ludzkiej (okres postnatalny) lub miejsca rozwoju (poza łonem kobiety) [...]. Przyrodzona godność człowieka nie pojawia się „przy-rodzeniu”, ale jest cechą należną człowiekowi przed, w trakcie i po urodzeniu, a także w sytuacjach, gdy w ogóle nie dochodzi do porodu fizjologicznego [...]. Konstytucyjne pojęcia „człowiek” i „przyrodzona godność” odnoszą się więc również do człowieka w prenatalnej fazie rozwoju” (F. Ciepły, Status prawny płodu upośledzonego, „Roczniki Nauk Prawnych” 2014, nr 4, t. XXIV, s. 6-7).

Godność nie jest cechą nadawaną przez państwo i ma wobec niego charakter pierwotny (zob. B. Banaszak, Komentarz do art. 30 Konstytucji RP, op. cit., teza 3-5). Potwierdzenie niezbywalnej godności człowieka jako zasady konstytucyjnej oraz prawa podmiotowego każdej jednostki ludzkiej - niezależnie od jej kwalifikacji, stanu psychiczno-fizycznego czy aktualnej sytuacji życiowej stanowi podstawę uznania jego podmiotowości (zob. wyrok TK z 30 września 2008 r., sygn. akt K 44/07). Zatem od momentu, kiedy uznajemy, że dana istota jest człowiekiem, powstaje konstytucyjny obowiązek prawnej ochrony jego godności. Zauważyć trzeba, że przyjęta w Konstytucji nienaruszalność godności oznacza zakaz podejmowania działań mogących ją naruszyć czy choćby tylko ograniczyć. Zakaz naruszania godności człowieka ma charakter bezwzględny i dotyczy wszystkich. Nie ma tutaj zastosowania art. 31 ust. 3 Konstytucji określający warunki dopuszczalności ograniczeń konstytucyjnie gwarantowanych praw jednostki, których źródłem jest godność człowieka. Uzasadnienie przesłanki dopuszczalności przerwania ciąży w kontekście ochrony godności ludzkiej może być rozważane jedynie ze względu na kolizję dóbr paralelnych, czyli dóbr tego samego rodzaju. Ochrona godności wymaga zatem, aby desygnat konstytucyjnego pojęcia „człowiek” był określony najszerzej jak to możliwe, bez żadnych wyłączeń, w sposób pełny i kompletny. Interpretacja pojęcia „człowiek” przez organy władzy publicznej nie może bowiem prowadzić do wykluczenia z kategorii podmiotów praw człowieka żadnej istoty ludzkiej, bez względu na fazę jej rozwoju, wady 
rozwojowe, stan zdrowia i jakiekolwiek cechy wtórnie ją dookreślające. Godność człowieka ze swej istoty nie dopuszcza żadnych wyłączeń, gdyż powiązana jest z przynależnością do gatunku ludzkiego. Poprzez akceptację możliwości zastosowania wyłączeń podmiotowych godność zostałaby pozbawiona swojego metaprawnego charakteru i utraciłaby swoje aksjologiczne uzasadnienie. Nie byłaby wiązana z istotą człowieczeństwa, lecz uzależniona od arbitralnej decyzji władzy („człowieczeństwo” normatywne), (zob. F. Ciepły, Aborcja eugeniczna a dyskryminacja osób niepetnosprawnych, „Czasopismo Prawa Karnego i Nauk Penalnych” 2014, nr 2, s. 79). Różnicowanie ochrony prawnej człowieka ze względu na uprawdopodobniony zły stan zdrowia lub występowanie wad genetycznych płodu prowadzi do różnicowania wartości człowieka. Wyrażenie zgody na wyłączenie z zakresu podmiotowego art. 30 Konstytucji człowieka w prenatalnej fazie rozwoju ze względu na duże prawdopodobieństwo wad rozwojowych płodu w postaci ciężkiego i nieodwracalnego upośledzenia lub nieuleczalnej choroby zagrażającej życiu płodu stanowi uznanie wyjątku od zasady ochrony godności. Tworzy tym samym niebezpieczeństwo rozszerzania zakresu wyłączeń, których kryteria zależałyby od obecnie najsilniej oddziałujących tendencji ideologicznych. Dopuszczalność aborcji ze względów eugenicznych może budować błędne przekonanie społeczne o niższej wartości osób dotkniętych niepełnosprawnością, skoro już na etapie prenatalnym ich życie objęte zostało mniejszą ochroną prawną w porównaniu z dziećmi zdrowymi. Choroba, kalectwo czy każda inna forma ułomności stają się wówczas społecznie nieakceptowane, nie tylko w odniesieniu do etapu prenatalnego. Istnieje jednak konstytucyjny obowiązek zapewnienia szczególnej opieki zdrowotnej osobom z niepełnosprawnością (art. 68 ust. 3 Konstytucji) oraz pomocy osobom z niepełnosprawnością (art. 69 Konstytucji), w związku z którym państwo nie może wspierać działań eugenicznych, mających na celu eliminację dziecka upośledzonego czy nieuleczalnie chorego.

Stosowanie zakwestionowanego przepisu prowadzi zatem do selekcyjnego podejścia do wartości człowieka i nie znajduje uzasadnienia w perspektywie konstytucyjnego obowiązku ochrony godności ludzkiej, naruszając tym samym art. $30 \mathrm{w}$ związku z art. 38 Konstytucji.

\section{- Zgodność art. 4a ust. 1 pkt 2 oraz art. 4a ust. 2 zdanie pierwsze u.p.r. z art. 38 w związku z art. 31 ust. 3 Konstytucji (zarzut naruszenia zasady proporcjonalności w zakresie ochrony życia)}

Zasada jednakowej ochrony wszystkich istot ludzkich bez względu na stopień sprawności fizycznej czy intelektualnej stanowi fundamentalny standard współczesnego systemu prawnego. Jak zauważył Trybunał Konstytucyjny w wyroku z 30 września 2008 r., sygn. akt K 44/07, wartość dobra prawnego, jakim jest życie ludzkie, nie podlega, na gruncie Konstytucji, różnicowaniu. W polskim i zagranicznym orzecznictwie konstytucyjnym podkreśla się rangę prawa do prawnej ochrony życia jako podstawowego prawa jednostki, warunkującego 
posiadanie i realizację wszelkich innych praw i wolności. Znaczenie prawa do życia wykracza jednak poza tak rozumiany kontekst indywidualno-podmiotowy. W dotychczasowym orzecznictwie Trybunału Konstytucyjnego oraz w wypowiedziach doktryny za ugruntowany można uznać pogląd, wedle którego konstytucyjny nakaz ochrony życia, czy też - ujmując rzecz z drugiej strony - prawo do prawnej ochrony życia ludzkiego, ma dwojakie znaczenie. Prawną ochronę życia, gwarantowaną przez art. 38 Konstytucji, należy rozumieć przede wszystkim jako zakaz pozbawiania człowieka życia. W tym „obronnym” kontekście prawna ochrona życia jest konsekwencją przysługującego każdemu człowiekowi „prawa do życia”. W opinii Trybunału zapewniana każdemu człowiekowi przez art. 38 Konstytucji prawna ochrona życia implikuje także zobowiązania władz publicznych do podejmowania pozytywnych działań służących ochronie życia (zob. wyroki TK z: 23 marca 1999 r., sygn. akt K 2/98; 8 października 2002 r., sygn. akt K 36/00). Z kolei w przywołanej wcześniej sprawie o sygn. K 26/96 Trybunał stwierdził, że: „[o]chrona życia ludzkiego nie może być rozumiana wyłącznie jako ochrona minimum funkcji biologicznych niezbędnych do egzystencji, ale jako gwarancje prawidłowego rozwoju, a także uzyskania i zachowania normalnej kondycji psychofizycznej, właściwej dla danego wieku rozwojowego (etapu życia)". Z Konstytucji wynika bowiem pewien obiektywny system wartości, obejmujący w szczególności życie ludzkie, i na ustawodawcy ciąży w związku z tym obowiązek stanowienia prawa o takiej treści, by możliwa była ochrona i realizacja tych wartości, w tym przede wszystkim życia ludzkiego, w możliwie najszerszym zakresie (zob. wyrok TK z 23 marca 1999 r., sygn. akt K 2/98).

Konstytucyjny obowiązek ochrony życia człowieka obejmuje zatem również troskę o jego życie w fazie prenatalnej (zob. orzeczenie TK z 28 maja 1997 r., sygn. akt K 26/96; wyrok TK z 7 stycznia 2004 r., sygn. akt K 14/03). Na wartość życia ludzkiego w tej fazie rozwoju zwraca uwagę w swoim orzecznictwie Trybunał, stwierdzając, że: „[p]odstawowym przymiotem człowieka jest jego życie. Pozbawienie życia unicestwia więc równocześnie człowieka, jako podmiot praw i obowiązków. Jeżeli treścią zasady państwa prawa jest zespół podstawowych dyrektyw wyprowadzanych $\mathrm{z}$ istoty demokratycznie stanowionego prawa, a gwarantujących minimum jego sprawiedliwości, to pierwszą taką dyrektywą musi być respektowanie w państwie prawa wartości, bez której wykluczona jest wszelka podmiotowość prawna, tj. życia ludzkiego od początków jego powstania” (orzeczenie TK z 28 maja 1997 r., sygn. akt K 26/96).

We wskazanym, pozytywnym aspekcie prawa do prawnej ochrony życia mieszczą się zatem pozytywne obowiązki państwa, polegające na faktycznej ochronie życia dziecka poczętego. Na troskę o życie i zdrowie człowieka w fazie prenatalnej wskazują również przepisy art. 68 ust. 1 Konstytucji, a także przepisy ustawowe, jak np. art. 26 ustawy z dnia 5 grudnia 1996 r. o zawodach lekarza i lekarza dentysty (t.j. Dz. U. 2017, poz. 125), art. 2 ust. 1 pkt 1 u.p.r., art. 2 i art. 3 ustawy z 6 stycznia 2000 r. o Rzeczniku Praw Dziecka (tj. Dz. U. 2017, 
poz. 922). Co więcej, na poziomie przepisów ustawowych - poza kwestionowanym przepisem - nie można doszukać się podstaw do obniżania wartości życia ludzkiego czy zmniejszania jego ochrony prawnej ze względu na zły stan zdrowia, niepełnosprawność lub chorobę. Przeciwnie, istnieje wiele norm gwarantujących osobom upośledzonym, niepełnosprawnym czy nieuleczalnie chorym poszanowanie godności, równe traktowanie, a nawet szczególną ochronę (zob. F. Ciepły, Aborcja, op. cit., s. 81). Wskazują na to przykładowo: art. 2 i kolejne ustawy z dnia 19 sierpnia 1994 r. o ochronie zdrowia psychicznego (t.j. Dz. U. 2017, poz. 882, ze zm.), art. 15, art. 27, art. 33 ustawy z dnia 27 sierpnia 2004 r. o świadczeniach opieki zdrowotnej finansowanych ze środków publicznych (t.j. Dz. U. 2017, poz. 1938, ze zm.), art. 20 ust. 2 ustawy z dnia 6 listopada 2008 r. o prawach pacjenta i Rzeczniku Praw Pacjenta (t.j. Dz. U. 2017, poz. 1318, ze zm.), art. 9 ust. 1 pkt 4 ustawy z dnia 15 kwietnia 2011 r. o działalności leczniczej (t.j. Dz. U. 2018, poz. 160). W sytuacji, kiedy prawodawca w całym systemie prawa zapewnia ochronę dziecka poczętego i obejmuje szczególną ochroną osoby niepełnosprawne, nie można doszukać się uzasadnienia dla pozbawienia, poprzez stosowanie przesłanek eugenicznych, ochrony płodu aż do momentu osiągnięcia zdolności do samodzielnego życia ze względu na duże prawdopodobieństwo ciężkiego i nieodwracalnego upośledzenia albo nieuleczalnej choroby zagrażającej jego życiu.

Na gruncie przyjętej przez Trybunał interpretacji art. 38 Konstytucji ochrona życia nie jest absolutna i nie wyklucza ona pewnych ograniczeń, w tym także życia w fazie prenatalnej. Jak zauważył TK w sprawie z 28 maja 1997 r., sygn. akt K. 26/96: „[s]twierdzenie, że życie człowieka w każdej fazie jego rozwoju stanowi wartość konstytucyjną podlegającą ochronie, nie oznacza, że intensywność tej ochrony w każdej fazie życia i w każdych okolicznościach ma być taka sama. Intensywność ochrony prawnej i jej rodzaj nie jest prostą konsekwencją wartości chronionego dobra. Na intensywność i rodzaj ochrony prawnej, obok wartości chronionego dobra, wpływa cały szereg czynników różnorodnej natury, które musi brać pod uwagę ustawodawca zwykły, decydując się na wybór rodzaju ochrony prawnej i jej intensywności. Ochrona ta jednak powinna być zawsze dostateczna z punktu widzenia chronionego dobra" (podobnie TK w wyroku z 23 marca 1999 r., sygn. akt K 2/98). W pewnych sytuacjach, zwłaszcza po uwzględnieniu określonego kontekstu sytuacyjnego, związanego z nierozwiązywalną w inny sposób kolizją prawa do życia dwóch osób, prawo może depenalizować czyny polegające na odebraniu życia innemu człowiekowi (np. kontratyp obrony koniecznej). Powyższe stwierdzenie nie oznacza akceptacji swoiście rozumianego relatywizmu aksjologicznego. Przywołując ponownie wywody Trybunału z orzeczenia z 28 maja 1997 r., sygn. akt K 26/96, należy zacytować, że: „[u]stawodawca zwykły władny jest [...] do określenia ewentualnych wyjątków, przy zaistnieniu których - ze względu na kolizję dóbr stanowiących wartości konstytucyjne, praw lub wolności konstytucyjnych - konieczne jest poświęcenie 
jednego z kolidujących ze sobą dóbr. Wynikająca z kolizji dobra konstytucyjnego $\mathrm{z}$ innym dobrem, prawem lub wolnością konstytucyjną zgoda ustawodawcy na poświęcenie jednego z kolidujących dóbr nie odbiera mu przymiotu dobra konstytucyjnego podlegającego ochronie".

W tym samym orzeczeniu Trybunał Konstytucyjny dopuścił ograniczenie prawnej ochrony życia, jeżeli jest to konieczne ze względu na konieczność ochrony lub realizacji innych wartości, praw czy wolności konstytucyjnych. Zgodnie z tym założeniem Trybunał wskazał także generalne kryteria, które mogą uzasadniać legalizację pozbawienia życia, wskazując, że konieczne jest ustalenie: „a) czy dobro, którego naruszenie ustawodawca legalizuje, stanowi wartość konstytucyjną; b) czy legalizacja naruszeń tego dobra znajduje usprawiedliwienie na gruncie wartości konstytucyjnych [...]; c) czy ustawodawca dochował konstytucyjnych kryteriów rozstrzygania takiej kolizji, w szczególności, czy przestrzegał [...] wymogu zachowania proporcjonalności" (orzeczenie TK z 28 maja 1997 r., sygn. akt K 26/96; zob. także wyrok TK z 30 września 2008 r., sygn. akt K 44/07).

Ustabilizowane orzecznictwo Trybunału Konstytucyjnego określa przesłanki i model oceny konstytucyjności przepisów prawnych, wskazując sposoby rozwiązania kolizji konstytucyjnie chronionych dóbr, w odwołaniu do postanowienia art. 31 ust. 3 Konstytucji. Przepis ten formułuje kumulatywnie ujęte przesłanki dopuszczalności ograniczeń korzystania z konstytucyjnych praw i wolności. „Wypracowana na podstawie art. 31 ust. 3 Konstytucji metodologia oceny znajduje zastosowanie także w odniesieniu do rozwiązań ograniczających prawną ochronę życia, wszakże z dwoma istotnymi zastrzeżeniami. Po pierwsze - przesłanka konieczności musi być interpretowana szczególnie restryktywnie, w kierunku zbieżnym z kryterium «absolutnej konieczności», wypracowanym w orzecznictwie ETPC na gruncie art. 2 konwencji o ochronie praw człowieka [...]. Każdy wypadek ograniczenia prawnej ochrony życia ludzkiego w stosunku do standardów ogólnych - musi być traktowany jako środek o charakterze ultima ratio. Po drugie $-z$ uwagi na fundamentalny charakter prawa do życia w aksjologii konstytucyjnej, nie każde $\mathrm{z}$ dóbr wskazanych w art. 31 ust. 3 Konstytucji może uzasadniać godzące w nie rozwiązania. Bez potrzeby dalszego poszerzania argumentacji można stwierdzić, że zdecydowanie nieakceptowane w demokratycznym państwie prawnym, realizującym zasady sprawiedliwości społecznej i chroniącym życie oraz niezbywalną godność człowieka, byłoby ograniczenie prawnej ochrony życia człowieka w celu ochrony dóbr lokujących się niżej w hierarchii konstytucyjnej, np. własności i innych praw majątkowych, moralności publicznej, ochrony środowiska czy nawet zdrowia innych ludzi. Warunkiem ograniczenia prawa do prawnej ochrony życia jest więc zaistnienie sytuacji, w której jest niewątpliwe, że nie da się ono pogodzić $\mathrm{z}$ analogicznymi prawami innych osób. Przesłankę tę można określić ogólnie jako wymaganie symetrii dóbr: poświęcanego i ratowanego" (wyrok TK z 30 września 2008 r., sygn. akt K 44/07). 
W analizowanej sprawie kontekst kolizyjny różnych dóbr jest oczywisty. Dziecko poczęte jest odrębną od matki istotą ludzką i odrębnym dobrem prawnie chronionym. Jest jednak od organizmu matki fizjologicznie uzależnione i dlatego może niekiedy dochodzić do kolizji dóbr chronionych (dziecka i matki). Dopuszczalność przesłanek eugenicznych nie może być rozważana jedynie z płaszczyzny ochrony życia dziecka poczętego (na co zwraca uwagę E. Zielińska, Opinia prawna o poselskim projekcie zmiany (art. 38) Konstytucji Rzeczypospolitej Polskiej [w:] Konstytucyjna formuła ochrony życia, druk sejmowy nr 993, seria „Przed Pierwszym Czytaniem”, nr 3, Warszawa 2007, s. 11-15). Prawna ochrona życia na gruncie art. 38 Konstytucji oraz gwarancja poszanowania godności zawarta $\mathrm{w}$ art. 30 Konstytucji obejmuje przecież kobietę, w tym także kobietę ciężarną. Ponadto Konstytucja gwarantuje każdemu prawo do ochrony prawnej życia prywatnego, rodzinnego oraz decydowania o swoim życiu osobistym (art. 47). Gwarantuje także każdemu prawo do ochrony zdrowia (art. 68), a ponadto zobowiązuje władze publiczne do zapewnienia szczególnej opieki zdrowotnej kobietom ciężarnym. Obejmuje ochroną i opieką macierzyństwo i rodzicielstwo (art. 18). Konstytucja nakłada również obowiązek zapewnienia ochrony każdemu człowiekowi, w tym także kobietom, przed poniżającym traktowaniem (art. 40) i dyskryminacją (art. 32).

W przedstawionym wyżej orzecznictwie Trybunału wskazuje się jednak na bardzo rygorystyczne przesłanki dopuszczające ograniczenie prawa do życia, a $\mathrm{w}$ analizowanym przypadku dopuszczające przerwanie ciąży. Wynika z nich, że działania pozwalające na przerwanie ciąży muszą być absolutnie i bezwzględnie konieczne dla ochrony równorzędnych wartości, tj. dla ochrony życia matki. Analiza zgodności z Konstytucją kwestionowanego przepisu ustawy o planowaniu rodziny wymaga zatem przeprowadzenia rozważań na płaszczyźnie kolizji dóbr paralelnych. Należy zbadać, jakiego rodzaju wartość jest chroniona art. 4a ust. 1 pkt 2 u.p.r., dopuszczającym przerwanie ciąży ze względu na stan zdrowia dziecka, tj. kiedy występuje duże prawdopodobieństwo ciężkiego i nieodwracalnego upośledzenia płodu lub nieuleczalnej choroby zagrażającej jego życiu.

Selekcyjnego charakteru przesłanek eugenicznych nie można uzasadniać wolnością kobiety czy jej komfortu psychicznego (zob. W. Wróbel, Konstytucyjne gwarancje ochrony życia a przesłanki dopuszczalności aborcji [w:] Konstytucyjna formuła ochrony życia, druk sejmowy nr 993, seria „Przed Pierwszym Czytaniem”, nr 3, Warszawa 2007, s. 32). Wolność kobiety, choć jest to jedna z podstawowych wartości chronionych konstytucyjnie, nie może przesądzać o pozbawieniu życia dziecka poczętego, u którego stwierdzono prawdopodobieństwo upośledzenia lub choroby zagrażającej jego życiu. Podobnie należy ocenić komfort psychiczny kobiety, który może doznać uszczerbku na skutek świadomości prawdopodobieństwa urodzenia upośledzonego dziecka. Na gruncie przesłanki eugenicznej życie niepełnosprawnego dziecka poczętego konkuruje z bliżej nieokreślonym dobrem kobiety, które w istocie stanowi wartość niższą niż życie ludzkie. Tego 
typu uzasadnienie dla aborcji eugenicznej zbliża się do typu znaczeniowego przesłanki społecznej, wyraźnie uznanej przez Trybunał za niezgodną z Konstytucją (zob. orzeczenie TK z 28 maja 1997 r., sygn. akt K 26/96). Uzasadnianie przesłanki eugenicznej faktem naruszenia równowagi psychicznej matki w ten sposób, że prowadziłoby to do zakłócenia jej zdrowia psychicznego, jest dlatego nietrafne, ponieważ w takiej sytuacji należy mówić o zagrożeniu dla zdrowia kobiety, którego ochronę uwzględnia pierwsza z przesłanek (medyczna) dopuszczających przerwanie ciąży. Przesłanka eugeniczna natomiast w ogóle nie odnosi się do zdrowia kobiety ciężarnej i nie może być odczytywana jako domniemanie zagrożenia dla zdrowia psychicznego kobiety.

Za niedopuszczalne należy uznać usprawiedliwianie eugenicznej aborcji troską o jakość przekazywanej informacji genetycznej, którą zawiera płód. Przyjęcie tego argumentu sprowadzałoby się do ustawowej akceptacji eugeniki negatywnej, postulującej kontrolę genetyczną polegającą na ograniczeniu poprzez selekcję przedurodzeniową występowania w populacji ludzkiej niekorzystnych genów. Prowadziłoby to dyskryminacji ze względu na cechy genetyczne, której zakaz można wywodzić z ogólnego zakazu dyskryminacji zawartego w art. 32 ust. 2 Konstytucji. Zakaz praktyk eugenicznych, w szczególności tych, których celem jest selekcja osób, expressis verbis wyraża w art. 3 pkt 2 Karta praw podstawowych Unii Europejskiej, dodając również zakaz dyskryminacji ze względu na cechy genetyczne w art. 21 ust. 1 (Dz. Urz. UE C 326/391).

Przesłanka eugeniczna nie może być również uzasadniana błędnie określanym prawem kobiety do przerwania ciąży. Takie ujęcie prawnej dopuszczalności przerwania ciąży pozostaje w sprzeczności z art. $38 \mathrm{w}$ związku z art. 31 ust. 3 Konstytucji, z których wynika generalny zakaz dokonywania aborcji, który jedynie w bardzo wyjątkowych przypadkach (i przy założeniu zaistnienia w zawężający sposób interpretowanych przesłanek) może zostać uchylony. Nie istnieje wolność kobiety do przerywania ciąży, która mogłaby być wyprowadzana $\mathrm{z}$ wolności człowieka gwarantowanej art. 31 ust. 1 Konstytucji. Przeciwnie, z punktu widzenia Konstytucji prawna dopuszczalność przerwania ciąży jest kwalifikowana jako kontratyp, który może być ustawowo dopuszczalny tylko w bardzo ściśle i wąsko zakreślonych przypadkach (zob. M. Szydło, Opinia prawna, op. cit., s. 16). Pogląd ten jest ugruntowany w orzecznictwie sądowym zarówno Trybunału Konstytucyjnego, jak Sądu Najwyższego. W przywoływanym wielokrotnie orzeczeniu z 28 maja 1997 r., sygn. akt K 26/96, Trybunał wyraźnie zanegował konstytucyjność koncepcji istnienia jakiegokolwiek prawa kobiety do przerwania ciąży. Zdaniem Trybunału kobieta oraz mężczyzna mają prawo do podjęcia decyzji o poczęciu dziecka, ale nie mają prawa do przerwania ciąży, zaś w szczególności kobieta nie ma „prawa do nieurodzenia dziecka”. Nie można bowiem decydować o posiadaniu dziecka, gdy dziecko to już rozwija się w fazie prenatalnej i w tym sensie jest już „posiadane” przez rodziców. Jak dodaje dalej: „[p]rawo do posiadania dziecka może być więc interpretowane wyłącznie 
w aspekcie pozytywnym, a nie jako prawo do unicestwienia rozwijającego się płodu ludzkiego" (orzeczenie TK z 28 maja 1997 r., sygn. akt K 26/96). Pogląd ten podzielił Sąd Najwyższy w uchwale z 22 lutego 2006 r., sygn. akt III CZP 8/06, w której opowiedział się za ujmowaniem przesłanek dopuszczalności przerwania ciąży w charakterze kontratypu. Zdaniem Sądu Najwyższego art. 4a ust. 1 u.p.r. legalizuje działania zmierzające do przerwania ciąży, z zasady zabronione także na gruncie innych regulacji odnoszących się do dziecka poczętego. Jego życie pozostaje pod ochroną prawa od chwili poczęcia, wszelkie zaś czyny zmierzające do pozbawienia do życia, w tym w szczególności przerwanie ciąży, są generalnie zakazane. Okoliczności wskazane w art. 4a ust. 1 u.p.r. mają charakter zbliżony do kontratypu, a więc wiążą się z wyłączeniem bezprawności. „Nie jest to jednak równoznaczne $z$ uznaniem „prawa do aborcji” za dobro osobiste, wskazać bowiem należy, że właściwa dla kontratypu kolizja dóbr wyłącza możliwość konstruowania prawa podmiotowego, którego przedmiotem byłoby dobro osobiste, polegające na możliwości naruszenia dóbr osobistych innych osób" (uchwała SN z 22 lutego 2006 r., sygn. akt III CZP 8/06).

Zgodnie z przyjętym $\mathrm{w}$ polskim systemie prawnym modelem regulacji kwestii przerywania ciąży uznaje się społeczną szkodliwość aborcji oraz karalność jej przeprowadzania. Skarżone przepisy określają znamiona przestępstwa przerwania ciąży ustanowionego w art. 152 Kodeksu karnego. Na zasadzie wyjątku dopuszczają przerwanie ciąży w określonych sytuacjach, uzasadnionych względami ochrony życia matki, zdrowia matki, względami kryminalnymi lub eugenicznymi, gdy badania prenatalne lub inne przesłanki medyczne wskazują na duże prawdopodobieństwo ciężkiego i nieodwracalnego upośledzenia płodu albo nieuleczalnej choroby zagrażającej jego życiu. Na tle przepisów ustawy o planowaniu rodziny art. 152 k.k. wyznacza granicę karalności przerwania ciąży, wskazując wyraźnie, że bezpośrednim przedmiotem ochrony jest trwanie ciąży (art. 152 $\$ 1$ i $\$ 2$ k.k.) oraz dziecko poczęte (art. $153 \$ 3$ i art. $153 \$ 2$ k.k.), dalszym zaś kobieta ciężarna (jej życie, zdrowie, wolność od przymusu, groźby i podstępu), (zob. A. Marek, Prawo karne, Warszawa 2007, s. 440-441).

Zakaz naruszania życia ludzkiego, w tym życia dziecka poczętego, wynika z norm o charakterze konstytucyjnym. Ustawodawca zwykły nie może być więc uprawniony do decydowania o warunkach obowiązywania takiego zakazu, gdyż prowadziłoby to do jedynie warunkowego obowiązywania gwarancji konstytucyjnych. Ustawodawca władny jest jedynie do określenia ewentualnych wyjątków ochrony życia w fazie prenatalnej, przy zaistnieniu których - ze względu na kolizję dóbr stanowiących wartości konstytucyjne, praw lub wolności konstytucyjnych - konieczne jest poświęcenie jednego z kolidujących ze sobą dóbr. Wynikająca $\mathrm{z}$ kolizji dobra konstytucyjnego z innym dobrem, prawem lub wolnością konstytucyjną zgoda ustawodawcy na poświęcenie jednego z kolidujących dóbr nie odbiera mu przymiotu dobra konstytucyjnego podlegającego ochronie (zob. orzeczenie TK z 28 maja 1997 r., sygn. akt K 26/96). Kwestionowane prze- 
pisy ustawy o planowaniu rodziny nie wskazują na paralelne do życia ludzkiego dobro, którego konieczność ochrony uzasadniałaby dopuszczalność przerwania ciąży. W istocie uchylają całkowicie prawną ochronę dziecka poczętego z uwagi na duże prawdopodobieństwo jego ciężkiego i nieodwracalnego upośledzenia albo nieuleczalnej choroby zagrażającej jego życiu. Negują tym samym walor wartości życia dziecka poczętego tylko z powodu podejrzeń występowania choroby lub upośledzenia, naruszając konstytucyjny obowiązek ochrony życia.

Reasumując, należy stwierdzić, że nie ulega wątpliwości, iż art. 4a ust. 1 pkt 2 oraz art. 4a ust. 2 legalizują przerwanie ciąży bez dostatecznego usprawiedliwienia wartościami, zasadami i prawami konstytucyjnymi. Kwestionowany przepis dopuszcza bowiem przerwanie ciąży ze względu na inne wartości niż konieczność ochrony życia matki. Legalizacja praktyk eugenicznych w stosunku do jeszcze nieurodzonego dziecka stanowi nieproporcjonalne ograniczenia konstytucyjnego prawa do ochrony życia. Należy zatem uznać, że kwestionowane przepisy naruszają art. $38 \mathrm{w}$ związku $\mathrm{z}$ art. 31 ust. 3 Konstytucji.

- Zgodność 4a ust. 1 pkt 2 oraz art. 4a ust. 2 zdanie pierwsze u.p.r. z art. 38 w związku z art. 32 ust. 1 i ust. 2 Konstytucji (zarzut naruszenia zasady równości i zakazu dyskryminacji w zakresie ochrony życia)

Zarzut naruszenia zasady równości i zakazu dyskryminacji w zakresie ochrony życia został postawiony alternatywnie, tj. w przypadku nieuwzględnienia zarzutu naruszenia ochrony godności człowieka. Z uwagi na uznanie kwestionowanych przepisów za niezgodne $\mathrm{z}$ art. 30 Konstytucji zbędne jest przeprowadzanie analizy zgodności we wskazanym zakresie.

Mając na uwadze powyższe, Sejm wnosi jak na wstępie.

\section{Dodatkowe uwagi Sejmu}

Obecnie w Sejmie trwają prace nad prawem aborcyjnym. W dniu 30 listopada 2017 r. został zgłoszony poselski projekt ustawy o zmianie ustawy dnia z 7 stycznia 1993 r. o planowaniu rodziny, ochronie płodu ludzkiego i warunkach dopuszczalności przerwania ciąży (druk nr 2146), uchylający dopuszczalność przerwania ciąży z powodów eugenicznych. Został on skierowany do dalszych prac w Komisji Polityki Społecznej i Rodziny, z zaleceniem zasięgnięcia opinii Komisji Sprawiedliwości i Praw Człowieka. Liberalizację dotychczas obowiązujących przepisów zakłada, zgłoszony do Sejmu 7 lutego 2018 r., poselski projekt ustawy o prawach kobiet i świadomym rodzicielstwie. Przewiduje on bezwarunkowe prawo kobiety do przerwania ciąży do 12. tygodnia, a po upływie tego czasu, po spełnieniu jednej z trzech przesłanek. Przeprowadzenie aborcji eugenicznej jest dopuszczalne do 24. tygodnia ciąży, a gdy ciężkie i nieodwracalne upośledzenie lub nieuleczalna choroba uniemożliwia płodowi samodzielne życie, przerwanie ciąży jest dopuszczalne bez ograniczeń. Projekt został skierowany do opinii Biu- 
ra Legislacyjnego oraz do opinii Biura Analiz Sejmowych w kwestii zgodności z prawem Unii Europejskiej. Katalog sytuacji umożliwiających przerwanie ciąży podobnie poszerza poselski projekt ustawy o świadomej prokreacji zgłoszony 18 stycznia 2018 r., który został skierowany do zaopiniowania przez Biuro Legislacyjne, Biuro Analiz Sejmowych oraz do licznych konsultacji.

\section{Bibliografia}

Banaszak B., Konstytucja Rzeczypospolitej Polskiej. Komentarz, Warszawa 2012.

Boć J. [w:] Konstytucje Rzeczypospolitej oraz komentarz do Konstytucji RP z 1997 r., red. J. Boć, Wrocław 1998.

Bosek L., Gwarancje godności ludzkiej i ich wpływ na polskie prawo cywilne, Warszawa 2012.

Ciepły F., Aborcja eugeniczna a dyskryminacja osób niepetnosprawnych, „Czasopismo Prawa Karnego i Nauk Penalnych" 2014, nr 2.

Ciepły F., Status prawny płodu upośledzonego, „Roczniki Nauk Prawnych” 2014, nr 4, t. XXIV.

Działocha K., Idee przewodnie wolności i praw jednostki w procesie uchwalania Konstytucji $R P$ [w:] Wolności i prawa jednostki w Konstytucji RP, t. I, Idee i zasady przewodnie konstytucyjnej regulacji wolności i praw jednostki w RP, red. M. Jabłoński, Warszawa 2010.

Garlicki L., Komentarz do art. 30 [w:] Konstytucja Rzeczypospolitej Polskiej. Komentarz, t. II, red. L. Garlicki, M. Zubik, Warszawa 2016.

Garlicki L., Wojtyczek K., Komentarz do art. 31 [w:] Konstytucja Rzeczypospolitej Polskiej. Komentarz, t. II, red. L. Garlicki, M. Zubik, Warszawa 2016.

Giezek J., Kokot R., Granice ludzkiego życia a jego prawna ochrona [w:] Prawa $i$ wolności obywatelskie w Konstytucji RP, red. B. Banaszak, A. Preisner, Warszawa 2002.

Granat M., Godność człowieka $z$ art. 30 Konstytucji RP jako wartość $i$ norma prawna, „Państwo i Prawo” 2014, z. 8.

Hajerko J., Cywilnoprawna ochrona dziecka poczętego a stosowanie procedur medycznych, Warszawa 2010.

Kondratiewa-Bryzik J., Początek prawnej ochrony życia ludzkiego w świetle standardów międzynarodowych, Warszawa 2009.

Krąpiec A., Człowiek i prawo naturalne, Lublin 1993.

Królikowski M., Problem interpretacji tzw. przesłanki eugenicznej stanowiacej o dopuszczalności zabiegu przerywania ciąży [w:] Współczesne wyzwania bioetyczne, red. L. Bosek, M. Królikowski, Warszawa 2010.

Lipski J., Opinia prawna na temat rządowego projektu leczenia niepłodności, „Zeszyty Prawnicze BAS” 2015, nr 4(48).

Marek A., Prawo karne, Warszawa 2007.

Mazurek F.J., Godność człowieka a prawa człowieka, „Roczniki Nauk Społecznych” 1980, nr 8.

Rodziński A., Osoba, moralność, kultura, Lublin 1989. 
Sarnecki P., Komentarz do art. 38 [w:] Konstytucja Rzeczypospolitej Polskiej. Komentarz, t. I, red. L. Garlicki, M. Zubik, Warszawa 2016.

Smyczyński T., Opinia prawna o poselskim projekcie zmiany (art. 38) Konstytucji Rzeczypospolitej Polskiej [w:] Konstytucyjna formuła ochrony życia, druk sejmowy nr 993, seria „Przed Pierwszym Czytaniem” nr 3, Warszawa 2007.

Sokolewicz W., Zubik M., Komentarz do art. 2 [w:] Konstytucja Rzeczypospolitej Polskiej. Komentarz, t. I, red. L. Garlicki, M. Zubik, Warszawa 2016.

Sroka T., Komentarz do art. 38 [w:] Konstytucja RP. Komentarz, t. I, Art. 1-86, red. M. Safjan, L. Bosek, Warszawa 2016.

Warylewski J., Zasady techniki prawodawczej. Komentarz do rozporzadzenia, Warszawa 2003.

Wąsek A., Kodeks karny. Komentarz, t. I, Gdańsk 1999.

Winczorek P., Komentarz do Konstytucji Rzeczypospolitej Polskiej, Warszawa 2000.

Wróbel W., Konstytucyjne gwarancje ochrony życia a przesłanki dopuszczalności aborcji [w:] Konstytucyjna formuła ochrony życia, druk sejmowy nr 993, seria „Przed Pierwszym Czytaniem", nr 3, Warszawa 2007.

Zielińska E., Opinia prawna o poselskim projekcie zmiany (art. 38) Konstytucji Rzeczypospolitej Polskiej [w:] Konstytucyjna formuła ochrony życia, druk sejmowy nr 993, seria „Przed Pierwszym Czytaniem”, nr 3, Warszawa 2007.

Zoll A., Opinia prawna w sprawie oceny konstrukcji i skutków prawnych projektu zmiany art. 30 i 38 Konstytucji RP [w:] Konstytucyjna formuła ochrony życia, druk sejmowy nr 993, seria „Przed Pierwszym Czytaniem”, nr 3, Warszawa 2007.

Żelichowski M., Podmiotowość prawna człowieka w okresie życia embrionalno-płodowego, „Czasopismo Prawa Karnego i Nauk Penalnych” 1997, nr 1. 